University of Louisville

ThinkIR: The University of Louisville's Institutional Repository

Electronic Theses and Dissertations

8-2016

\title{
Putting Christians on the map : topographic mosaics from late antique Jordan as representations of authority and status.
}

Tracey Elizabeth Eckersley

University of Louisville

Follow this and additional works at: https://ir.library.louisville.edu/etd

Part of the Ancient, Medieval, Renaissance and Baroque Art and Architecture Commons

\section{Recommended Citation}

Eckersley, Tracey Elizabeth, "Putting Christians on the map : topographic mosaics from late antique Jordan as representations of authority and status." (2016). Electronic Theses and Dissertations. Paper 2484.

https://doi.org/10.18297/etd/2484

This Doctoral Dissertation is brought to you for free and open access by ThinkIR: The University of Louisville's Institutional Repository. It has been accepted for inclusion in Electronic Theses and Dissertations by an authorized administrator of ThinkIR: The University of Louisville's Institutional Repository. This title appears here courtesy of the author, who has retained all other copyrights. For more information, please contact thinkir@louisville.edu. 
PUTTING CHRISTIANS ON THE MAP:

TOPOGRAPHIC MOSAICS FROM LATE ANTIQUE JORDAN

AS REPRESENTATIONS OF AUTHORITY AND STATUS

\author{
By \\ Tracey Elizabeth Eckersley \\ B.A., Wilfrid Laurier University, 1993 \\ M.A., McMaster University, 1996 \\ M.M.St., University of Toronto, 1999
}

\begin{abstract}
A Dissertation
Submitted to the Faculty of the

College of Arts and Sciences of the University of Louisville in Partial Fulfillment of the Requirements

for the Degree of
\end{abstract}

Doctor of Philosophy

in Art History

Department of Fine Arts

University of Louisville

Louisville, KY

August 2016 
Copyright 2016 by Tracey Elizabeth Eckersley

All rights reserved 

PUTTING CHRISTIANS ON THE MAP:

TOPOGRAPHIC MOSAICS FROM LATE ANTIQUE JORDAN

AS REPRESENTATIONS OF AUTHORITY AND STATUS

\section{By}

Tracey Elizabeth Eckersley

B.A., Wilfrid Laurier University, 1993

M.A., McMaster University, 1996

M.M.St., University of Toronto, 1999

\section{A Dissertation Approved on}

April 11, 2016

by the following Dissertation Committee:

Dr. Jennifer Westerfeld

Dr. Christopher Fulton

Dr. Debra Foran

Dr. Sheila Campbell 


\section{DEDICATION}

This dissertation is dedicated to my parents

Bill and Dianne Eckersley

for always encouraging me to follow my passion

and to my husband

David MacInnis

for his unfailing love and support over the last two decades. 


\section{ACKNOWLEDGEMENTS}

I am deeply indebted to my committee chair, Dr. Jennifer Westerfeld, for her wisdom, encouragement, and patience. Her motivation and humor have helped me though what has sometimes felt like an impossible task. I am similarly grateful to my other committee members, Dr. Christopher Fulton, Dr. Debra Foran, and Dr. Sheila Campbell; their expertise has helped to shape this dissertation for the better. Dr. Stephanie Maloney and Dr. Linda Safran were also instrumental to my success in this process, as was Dr. Wendy Pfeffer, to whom I am greatly obliged for her assistance in navigating the labyrinth of university administration.

I am extremely thankful for the generous funding provided by the University of Louisville's Department of Fine Arts, especially the Frederic Lindley Morgan Travel Scholarship, which allowed me to conduct my initial research in Jordan in 2012. I am equally thankful to the American Center of Oriental Research (ACOR) in Amman, as well as to Dr. Burton MacDonald and Dr. Rosemarie Sampson, for the eponymous fellowship that allowed me to return to Jordan for an extended period in 2014. My time at ACOR was illuminating and Dr. Barbara Porter and her staff were most accommodating in helping me navigate the complexities of living and working abroad.

Many scholars have been extremely generous with their time and research, including Dr. Rina Avner of the Israeli Antiquities Authority, who shared unpublished information about the newly discovered mosaic at Kiryat Gat. Dr. William D. Pearson, Professor of Biology at the University of Louisville, was kind enough to identify the 
various species of fish depicted in the topographic mosaics, while Dr. Lisa Brody and her staff at the Yale University Art Gallery took time out of their busy schedules to conduct a tesserae density count for the topographic mosaic in their collection. Dr. Brenda Llewellyn-Ihssen was extremely generous in answering my unending questions concerning the Byzantine liturgy, patristics, and the subtleties of Late Antique Greek inscriptions.

I am thankful for the beer and sympathy provided by friends worldwide, and the comradery of my colleagues from art history and other departments, student government, and $\mathrm{O} \Delta \mathrm{K}$. Meeting "y'all" has been one of the greatest benefits of the time I have spent at the University of Louisville. Special thanks are owed to my excellent editors, Harley Ferris and Lisa Higgins Shugoll. Lastly, I am forever grateful for my husband Dave, who deserves an honorary doctorate for his emotional support and his assistance in assembling this dissertation. 


\title{
ABSTRACT \\ PUTTING CHRISTIANS ON THE MAP: TOPOGRAPHIC MOSAICS FROM LATE ANTIQUE JORDAN AS REPRESENTATIONS OF AUTHORITY AND STATUS
}

\author{
Tracey Elizabeth Eckersley
}

April 11, 2016

In this dissertation, I examine nine ecclesiastic floor mosaics from Late Antique Palaestina and Arabia that contain topographic motifs - images of cities set in realistic or stylized landscapes. Previous interpretations of the pavements have been limited by two assumptions: that artists or bishops were solely responsible for determining the compositions, and that only religious interpretations were intended for church pavements. Inscriptions indicating that patrons were generally lay people and iconography that encourages secular interpretations complicates both assumptions. This study investigates the mosaics in light of Late Antique euergetism in order to determine why donors included architectonic elements in the pavements.

This objective is realized using an interdisciplinary approach designed to gain an understanding of the ways in which patrons interpreted topographic imagery. An examination of Late Antique Neo-Platonist philosophy and ekphrases is utilized in ascertaining perceptions of ecclesiastic space. Spatial analyses of the topographic pavements within their architectural contexts recreate the original viewer experience as closely as possible. Comparisons to topographic mosaics from Israel, Syria, and the West 
provide identifications for some of the motifs and indicate that architectonic imagery was often used to signify the purpose of individual buildings, including funerary, reliquary, or pilgrimage churches.

Patrons of the church mosaics strategically combined topographic motifs with iconography that had traditionally been used in domestic mosaics to denote elite status and economic prosperity, including images of leisure activities and agricultural production. Donors also incorporated images of local natural resources, as well as depictions of pilgrimage and trade routes, in order to illustrate the source of their personal and/or communal wealth. The socio-economic importance of the depicted resources and sites is well attested in archaeological and textural sources, including pilgrim itineraria, saints' vitae, and documents related to agricultural production and trade. The inclusion of this iconography in topographic mosaics complicates conventional religious interpretations.

This dissertation expands our understanding of the ways in which topographic motifs functioned as elements of Late Antique iconography, their roll in identifying various types of ecclesiastic buildings, and the motivations that led donors to contribute resources to the construction and decoration of churches. 
TABLE OF CONTENTS

PAGE

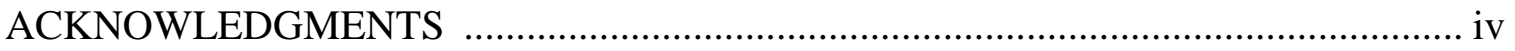

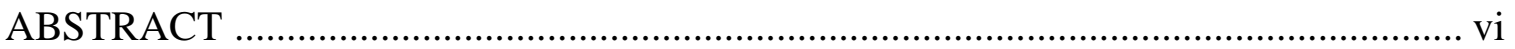

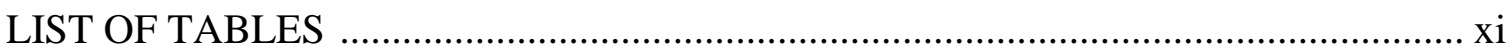

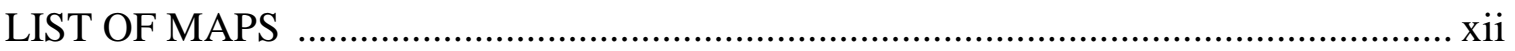

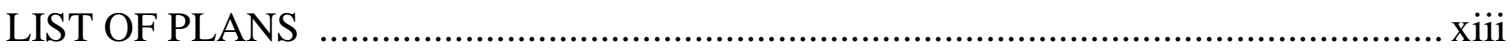

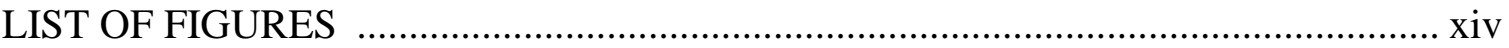

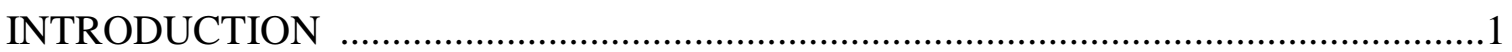

I. Parameters of the Study ….....................................................................

CHAPTER 1: PRIOR SCHOLARSHIP AND THE METHODOLOGICAL

FRAMEWORK OF THE CURRENT STUDY ...................................................

I. Prior Studies of the Topographic Mosaics ...................................................10

i. Studies Including Multiple Topographic Pavements ...................................11

ii. $\quad$ Studies of Individual Topographic Mosaics ................................................19

a. The Mosaic of the Church of the Map, Madaba ....................................19

b. The Church of the Acropolis, Ma' in .....................................................30

c. The Church of St. Stephen, Umm al-Rasas ........................................... 31

d. Studies of Individual Topographic Mosaics: Conclusions .......................32

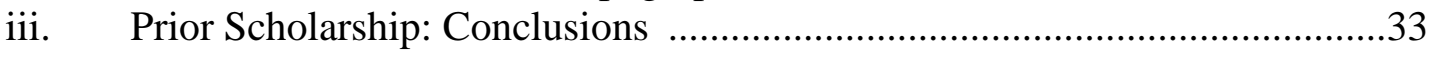

II. Methodology of the Current Study ............................................................34

CHAPTER 2: THE TOPOGRAPHIC MOSAICS, PATRONAGE, AND SHIFTING PATTERNS OF EUERGETISM AND PUBLIC DISPLAY IN LATE ANTIQUE

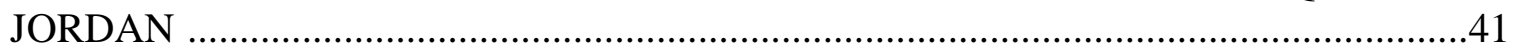

I. Shifting Patterns of Euergetism and Public Display in Late Antique Jerash ....43

II. Patrons of the Topographic Mosaics and Their Churches ................................56

III. Mosaic Elements and Their Architectural Contexts in Light of Church

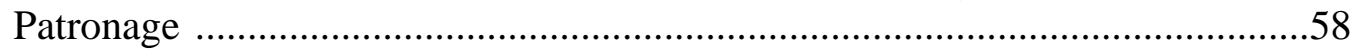

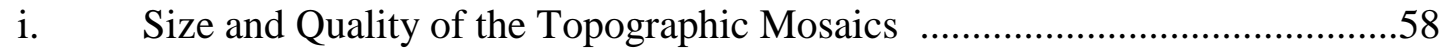

ii. Location of the Topographical Motifs within the Churches ........................65

iii. Iconography Associated with the Topographic Motifs ...............................71

iv. Donor Inscriptions Associated with the Topographic Mosaics ......................74

v. Donor Portraits Connected to the Topographic Mosaics ..............................84 
IV. Conclusions

\section{CHAPTER 3: THE TOPOGRAPHIC MOSAICS IN THEIR ARCHITECTURAL AND ICONOGRAPHIC CONTEXTS}

I. Late Antique Visual Reception and Perception ........................................93

II. The Topographic Mosaics in Their Architectural Contexts ..........................106

i. Umm al- Manabi ${ }^{\prime}$, Unidentified Church .....................................................107

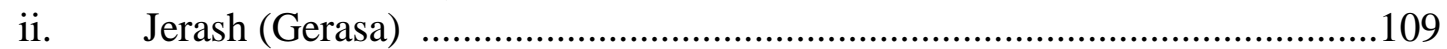

a. Jerash, Church of St. John the Baptist ..............................................111

b. Jerash, Church of Sts. Peter and Paul .................................................120

iii. Khirbat al-Samra, Church of St. John ...................................................123

iv. Madaba, Church of the Map ....................................................................... 128

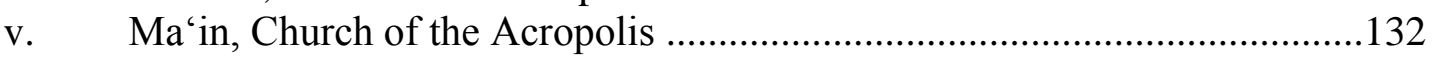

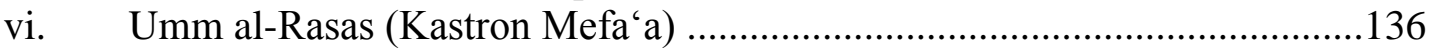

a. Umm al-Rasas, Church of the Lions ...............................................137

b. Umm al-Rasas, Church of the Priest Wa'il ........................................139

c. Umm al-Rasas, Church of St. Stephen ...............................................145

III. Examinations of Iconographic Groups Related to the Topographic Mosaics .150

i. An Examination of Topographic Imagery in Nilotic Representations from Palestinian and Arabian Buildings ..............................................................151

ii. Route-like Topographic Mosaics and Regional Comparanda ......................158

IV. Route-like Topographic Mosaics in Light of Late Antique Map ...................167

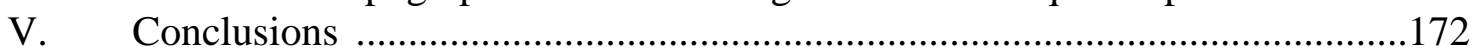

CHAPTER 4: THE TOPOGRAPHIC MOSAICS IN THEIR SOCIO-ECONOMIC

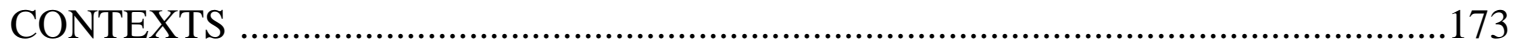

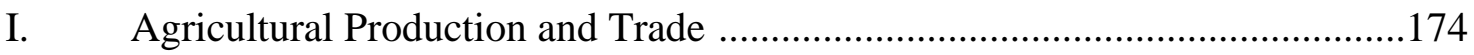

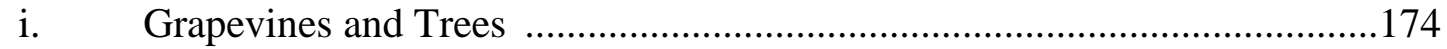

ii. Other Economic Products Featured on the Madaba Mosaic .....................183

II. Routes, Roadways and Pilgrimage ..........................................................185

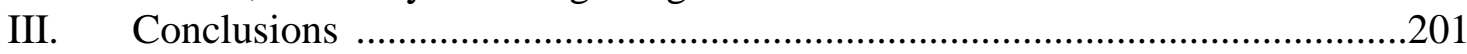

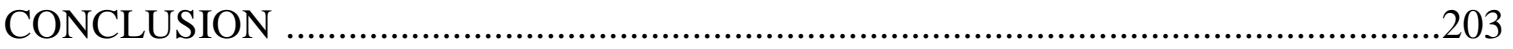

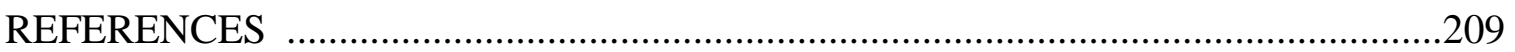

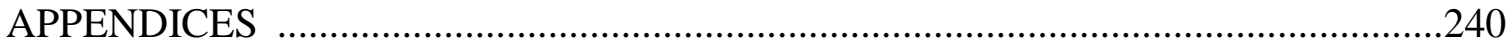

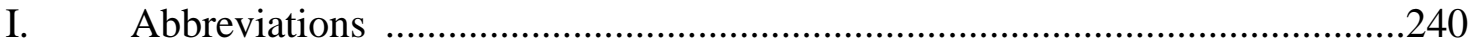

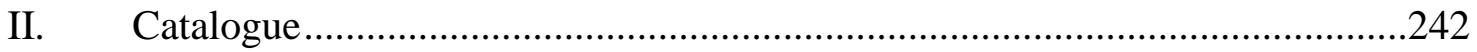

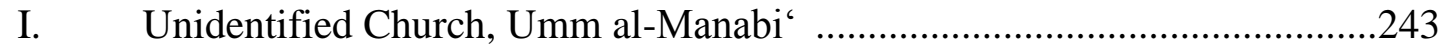

II. Church of St. John the Baptist, Jerash ...................................................247

III. Church of Sts. Peter and Paul, Jerash ....................................................255

IV. Church of the Map, Madaba .................................................................263 
V. Church of the Lions, Umm al-Rasas .....................................................22

VI. Church of the Priest Wa'il, Umm al-Rasas ..............................................278

VII. Church of St. John, Khirbat al-Samra .....................................................283

VIII. Church of St. Stephen, Umm al-Rasas ..................................................289

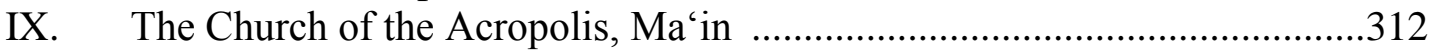

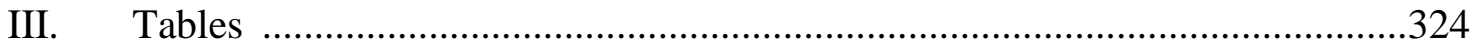

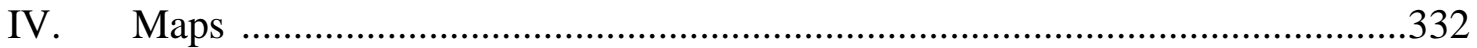

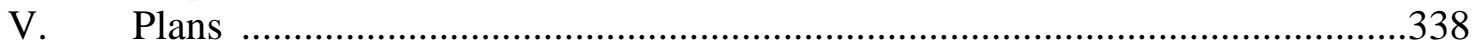

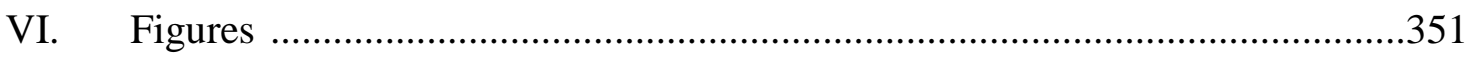

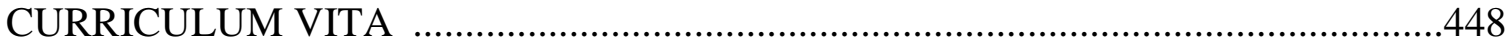




\section{LIST OF TABLES}

TABLE

PAGE

1a. Distribution of Holy Land Topographic Motifs in Jordanian Churches

.324

1b. Distribution of Egyptian Topographic Motifs in Jordanian Churches

2 Estimation of Time Required to Lay the Nave Mosaics in Churches Containing

Topographic Images .326

3. Donors of the Topographic Mosaics

4. Distribution of Representational and Geometric Mosaics in Churches with Topographical Motifs 328

5. Representational Motifs in Churches with Topographical Motifs

6. Types of Inscriptions in the Churches with Topographic Mosaics

7. Donor Portraits in the Churches with Topographic Mosaics 


\section{LIST OF MAPS}

1. Late Antique Sites in Jordan 332

2. Late Antique Sites in Egypt

3. The Order of Holy Land Sites Depicted on the St. Stephen Intercolumnar Mosaics .334

4. The Order of Egyptian Sites Depicted on the St. Stephen Border Mosaic .335

5. The Order of Holy Land Sites Depicted on the Ma'in Border Mosaic .336

6. Routes Depicted Using Walled City Motifs on the Madaba Mosaic .337 


\section{LIST OF PLANS}

$\begin{array}{ll}\text { PLAN PAGE } & \text { PAN }\end{array}$

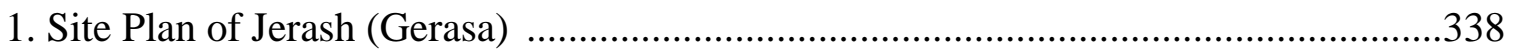

2. Churches of Sts. Cosmas and Damian, St. John the Baptist, and St. George, Jerash

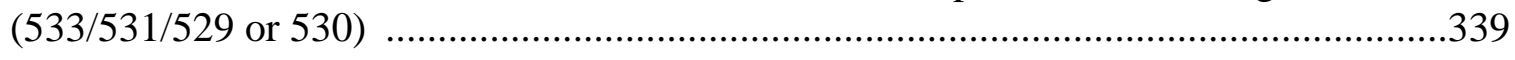

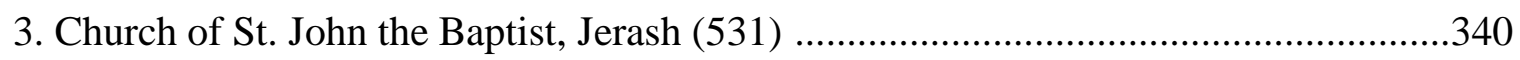

4. Church of Sts. Peter and Paul, Jerash (Mid-Sixth Century) …...............................341

5. Proposed Plan of the Church of the Map, Madaba (Mid-sixth Century) ....................342

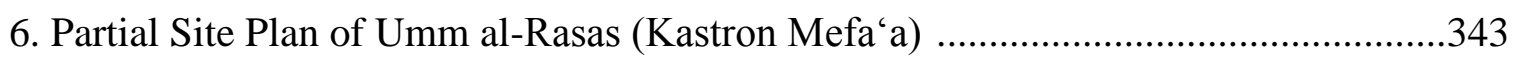

7. Church of the Lions, Umm al-Rasas (573 or 588) …............................................344

8. Church of the Priest Wa'il, Umm al-Rasas (586) ................................................345

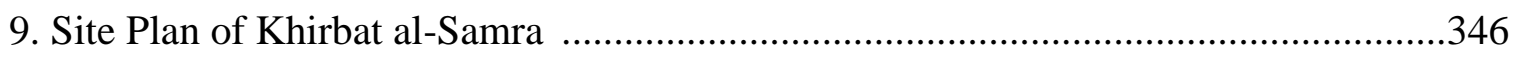

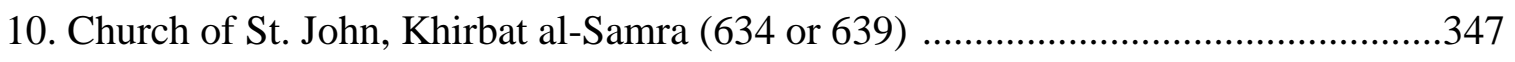

11. Church Complex Including St. Stephen, Umm al-Rasas .....................................348

12. Church of St. Stephen, Umm al-Rasas (718/719) ..............................................349

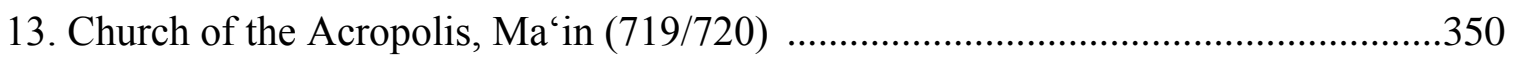




\section{LIST OF FIGURES}

\section{FIGURE}

PAGE

1. Drawing of the Topographic Mosaic from Umm al-Manabi‘

.351

2. Aerial View of the Churches of Sts. Cosmas and Damian, St. John the Baptist, and St. George, Jerash (Gerasa)

3. Depiction of a Religious Shrine (Sts. Cyrus and John at Menouthis?), St. John the

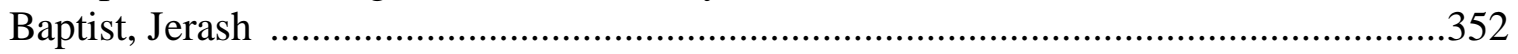

4. Depiction of a City (Canopus or Menouthis?), St. John the Baptist, Jerash ...............353

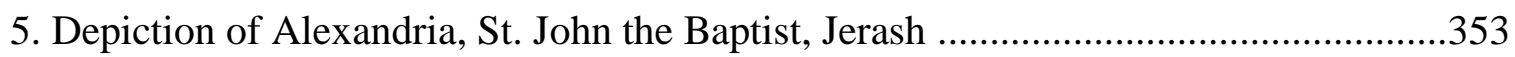

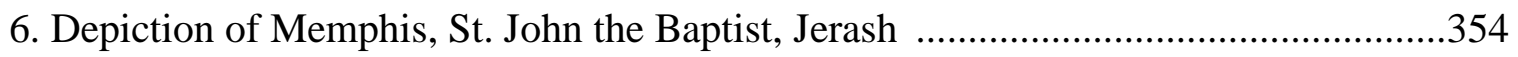

7. Depiction of a Servant Leading a Camel, St. John the Baptist, Jerash .......................354

8. Depiction of an Unidentified City (Peluseion?), St. John the Baptist, Jerash ............355

9. Inhabited Acanthus Scroll Border, St. John the Baptist, Jerash ................................355

10. Exedra Mosaic, St. John the Baptist, Jerash ......................................................356

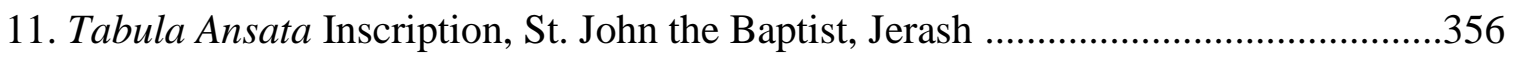

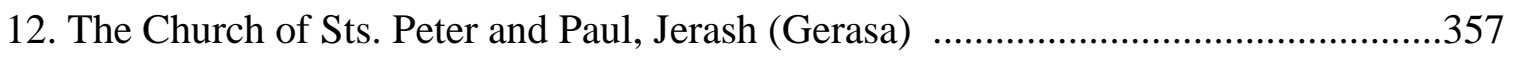

13. Topographic Panel with Depictions of Alexandria and Memphis, Sts. Peter and Paul, Jerash 357

14. Depiction of Alexandria, Sts. Peter and Paul, Jerash ..........................................358

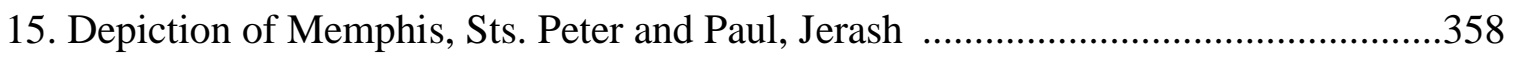

16. Tabula Ansata Inscription, Sts. Peter and Paul, Jerash ........................................359

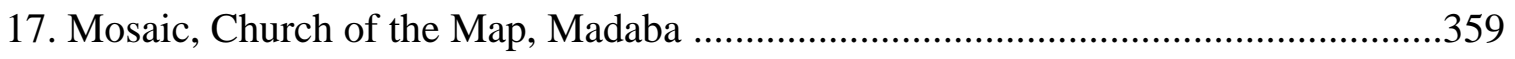


18. Depiction of Charach Moba (al-Karak), Madaba Mosaic .360

19. Depiction of Neapolis (Nablus), Madaba Mosaic .360

20. Depiction of Jerusalem, Madaba Mosaic .361

21. Depiction of Diospolis (Lod), Madaba Mosaic .361

22. Depiction of Iamnia (Yavne), Madaba Mosaic .362

23. Depiction of Eleutheropolis (Beit Guvrin), Madaba Mosaic .362

24. Depiction of Azotos Paralos (Ashdod), Madaba Mosaic .363

25. Depiction of Askalon (Ashkelon), Madaba Mosaic .363

26. Depiction of Gaza, Madaba Mosaic .364

27. Depiction of Peluseion, Madaba Mosaic .364

28. Aerial View of the Church of the Lions, Umm al-Rasas, Kastron Mefa'a .365

29. Depiction of Kastron Mefa'a (Umm al-Rasas), Church of the Lions .366

30a. Border Mosaic with Alternating Depictions of People and Fruit Trees, Church of the Lions, Umm al-Rasas 367

30b. Border Mosaic with Alternating Depictions of People and Fruit Trees, Church of the Lions, Umm al-Rasas .367

31. Inhabited Vine Scroll with Inscription, Church of the Lions, Umm al-Rasas 367

32. South Apse Mosaic, Church of the Lions, Umm al-Rasas .368

33. Sanctuary and Central Apse Mosaic, Church of the Lions, Umm al-Rasas .368

34. Depiction of a Beribboned Bird, Sanctuary Mosaic, Church of the Lions, Umm alRasas .369

35. Aerial View of the Church of the Priest Wa'il, Umm al-Rasas (Kastron Mefa'a) ...369 36. Depictions of Cities and Personifications of Rivers, Church of the Priest Wa'il, Umm al-Rasas .370

37. Nave Mosaic, Church of the Priest Wa'il, Umm al-Rasas .370 
38. Depiction of Jonah, Church of the Priest Wa'il, Umm al-Rasas

39. The Church of St. John, Khirbat al-Samra, Jordan .372

40. Reliquary and Glass Bottle, Church of St. John, Khirbat al-Samra .372

41. Depiction of Jerusalem, Church of St. John, Khirbat al-Samra .373

42. Depiction of Bethlehem, Church of St. John, Khirbat al-Samra .373

43 Aerial View of Church of St. Stephen, Umm al-Rasas (Kastron Mefa'a) .374

44. Depiction of Jerusalem, St. Stephen Mosaic, Umm al-Rasas .375

45. Depiction of Neapolis, (Nablus), St. Stephen Mosaic, Umm al-Rasas .376

46. Depiction of Sebastis (Sebastia), St. Stephen Mosaic, Umm al-Rasas .377

47. Depiction of Caesarea (Maritima), St. Stephen Mosaic, Umm al-Rasas .378

48. Depiction of Diospolis (Lod), St. Stephen Mosaic, Umm al-Rasas .379

49. Eleutheropolis (Beit Guvrin), St. Stephen Mosaic, Umm al-Rasas .380

50. Depiction of Askalon (Ashkelon), St. Stephen Mosaic, Umm al-Rasas .381

51 Depiction of Gaza, St. Stephen Mosaic, Umm al-Rasas .382

52. Depiction of Kastron Mefa'a (Umm al-Rasas), St. Stephen Mosaic, Umm al-Rasas

53. Depiction of Philadelphia (Amman), St. Stephen Mosaic, Umm al-Rasas .384

54. Depiction of Madaba, St. Stephen Mosaic, Umm al-Rasas .385

55. Depiction of Esbounta (Heshbon), St. Stephen Mosaic, Umm al-Rasas .386

56. Belemounta (Ma'in), St. Stephen Mosaic, Umm al-Rasas .387

57. Depiction of Areopolis (Rabba), St. Stephen Mosaic, Umm al-Rasas .388

58. Charach Moba (al-Karak), St. Stephen Mosaic, Umm al-Rasas . .389

59. Depiction of Tamiathis (Damietta), St. Stephen Mosaic, Umm al-Rasas .390

60. Depiction of Panau (Busiris), St. Stephen Mosaic, Umm al-Rasas .391 
61. Depiction of Peluseion, St. Stephen Mosaic, Umm al-Rasas

62. Antinoë (Sheikh Ibada), St. Stephen Mosaic, Umm al-Rasas

63. Depiction of Heraklion, St. Stephen Mosaic, Umm al-Rasas .394

64. Depiction of Alexandria, St. Stephen Mosaic, Umm al-Rasas 395

65. Depiction of Kasion (Mt. Kasios), St. Stephen Mosaic, Umm al-Rasas 396

66. Depiction of Thenesos, St. Stephen, Umm al-Rasas .397

67. Depiction of Kynopolis, St. Stephen Mosaic, Umm al-Rasas 398

68. Depiction of Pseudostomon, St. Stephen Mosaic, Umm al-Rasas .399

69. Inhabited Vine Scroll, Nave Pavement St. Stephen, Umm al-Rasas .400

70. Depiction of Diblaton and Donor Portraits, North Aisle, St. Stephen, Umm al-Rasas

71. Depiction of Limbon and Donor Portrait, South Aisle, St. Stephen Mosaic, Umm al-

Rasas .401

72. Donor Portraits Amongst Fruit Trees, Eastern Portion of the Nave, St. Stephen, Umm al-Rasas .402

73. Aerial View of the Sanctuary, St. Stephen, Umm al-Rasas .402

74. Depiction of Nikopolis, Church of the Acropolis, Ma'in 403

75. Depiction of a Fruit Tree, Church of the Acropolis, Ma'in .403

76. Depiction of Eleutheropolis (Beit Guvrin), Church of the Acropolis, Ma'in .404

77. Drawing of the Depiction of Askalon (Ashkelon), Church of the Acropolis, Ma'in

78. Drawing of the Depiction of Maiumas, Church of the Acropolis, Ma'in .405

79. Drawing of the Depiction of Gaza, Church of the Acropolis, Ma'in .405

80. Drawing of the Depiction of Odra, Church of the Acropolis, Ma'in .406

81. Depiction of Charach Moba (al-Karak), Church of the Acropolis, Ma'in .406 
82. Depiction of Gadoron (Gadara or Gadora), Church of the Acropolis, Ma'in .407

83. Depiction of Esbounta (Heshbon), Church of the Acropolis, Ma'in .407

84. Drawing of the Depiction of Belemounta (Ma'in), Church of the Acropolis, Ma'in

85. Side Chapel Mosaic with Iconoclastic Repair, Church of the Acropolis, Ma'in ......408

86. The Magerius Mosaic, El Djem (Smirat), Tunisia, Mid-third Century ...................409

87. The Dominus Julius Mosaic, Carthage, Tunisia, Late-fourth Century

88. The Lady Silthous Mosaic, Church of St. Elias, Kissufim, Israel, Late-sixth Century

89. Justinian Presenting a Model of the Church and Constantine Presenting a Model of

the City to the Theotokos and Child, Hagia Sophia, Istanbul, Turkey, Tenth Century ..410

90. Viewing Patterns, Nave Mosaic, Umm al-Manabi`

91. Nilotic Mosaic with Depictions of a Hut and a Country Villa, El Alia, Tunisia, Second Century

92. Nilotic Mosaic, House of Leontis, Beth She'an, Israel, Fifth Century

93a. Nilotic Mosaic, The Nile Festival Building, Sepphoris, Israel, Early Fifth Century

93b. Depiction of Alexandria, Nilotic Mosaic, The Nile Festival Building, Sepphoris .413

94a. Nilotic Border, Haditha Chapel, Haditha, Israel, Second Half of the Sixth Century

94b. Depiction of Egypt, Nilotic Border, Haditha Chapel .........................................414

95. Odysseus Mosaic, House of Leontis, Beth She'an, Israel, Fifth Century

96. Intercolumnar Panel, Church of Sts. Lot and Procopios, Khirbat al-Mukhayyat, Jordan, Mid-sixth Century

97. Depiction of Salt and Bitumen Harvesting on the Dead Sea, Madaba Mosaic, Midsixth Century 416

98. Patron Portrait of Theodore, Church of Sts. Cosmas and Damian, Jerash 
99. Patron Portrait of Georgina, Church of Sts. Cosmas and Damian, Jerash

100. Patterns of Movement/Vision, Central Mosaic, St. John the Baptist, Jerash .418

101. Pilgrim Ampulla with a Lamp over a Shrine, St. Menas, and a Censer, Abu Mena,

Egypt (Louvre Museum) .419

102. Intercolumnar Panel Featuring Orbikon, Church of St. Elias, Kissufim, Israel, 576

103. Nave Pavement with Image of a Camel-Driver, Church of St. George, Deir el-Ádas, Syria, 722 420

104. Image of Pope Pelagius II Presenting a Model of the Church to Christ, San Lorenzo fuori la mura, Rome, Sixth Century .421

105. Patterns of Movement/Vision, Church of Sts. Peter and Paul, Jerash .422

106. Patterns of Movement/Vision, Church of St. John, Khirbat al-Samra .423

107. Heavenly Jerusalem, Apse Mosaic, Santa Pudenziana, Rome, Late Fourth Century

108. “City Gates” Sarcophagus, Late Fourth Century (Louvre Museum)

109. Mosaic with Jerusalem and Bethlehem, Church of the Holy Martyrs, Tayyibat alImam, Syria, 447 425

110a. Depiction of Jerusalem, Church of the Holy Martyrs, Tayyibat al-Imam, Syria ..426 110b. Depiction of Bethlehem, Church of the Holy Martyrs, Tayyibat al-Imam, Syria 426

111. Patterns of Movement/Vision, Church of the Map, Madaba

112. Mediterranean Sea Mosaic, Ammaedara (Haïdra), Tunisia, Late Third or Early Fourth Century .428

113. Patterns of Movement/Vision, Church of the Acropolis, Ma'in .429

114. Patterns of Movement/Vision, Church of the Lions, Umm al-Rasas .430

115. Patterns of Movement/Vision, Church of the Priest Wa'il, Umm al-Rasas 431

116. Depiction of Jonah, Beth Guvrin, Israel, Mid-sixth Century .432 
117. Depiction of a Horse Transporting Relics, North Church, Huarte, Syria, Late Fifth/Early Sixth Century

118. Depiction of Horses Transporting Relics, Church of the Holy Martyrs, Tayyibat al-

Imam, Syria, 447 .433

119. Patterns of Movement/Vision, Church of St. Stephen, Umm al-Rasas .434

120. Detail of a Border Mosaic from a Villa, Beth Guvrin, Israel (Fifth Century?) .435

121. Kalo Keria Mosaic, Winter Bathhouse, Caesarea Maritima, Israel, (Fifth Century?)

122. Depictions of Named Horses, Maison des Chevaux, Carthage, Tunisia, (Fourth or

Fifth Century) .437

123. Megalopsychia Mosaic, Yakto Complex, Daphne, Syria (Mid-fifth Century) .......437

124. Depiction of Chortaso, Kiryat Gat, Israel (Sixth Century) ...................................438

125. Depiction of Egyptian Sites in Lower Egypt, Madaba Mosaic .............................439

126a. Mosaics of the North Aisle Wall, Sant'Apollinare Nuovo, Ravenna, Italy (c. 504)

126b. Depiction of Classe on the North Aisle Wall, Sant'Apollinare Nuovo, Ravenna, Italy (c. 504) .440

127a. Mosaics of the South Aisle Wall, Sant'Apollinare Nuovo, Ravenna, Italy (c. 504, revised c. 561)

127b Depiction of Ravenna and the Palace on the South Aisle Wall, Sant' Apollinare Nuovo, Ravenna, Italy (c. 504, revised c. 561)

128. Depiction of a City, Church of the Holy Martyrs, Tayyibat al-Imam, Syria (447) 441

129. Depiction of a Building with a Stylite (?) Tower, Church of the Holy Martyrs, Tayyibat al-Imam, Syria (447)

130. Depiction of Camels Leaving a City, Church of the Holy Martyrs, Tayyibat alImam, Syria (447)

131. Geometric Panel with Architectonic Motifs, Church of the Holy Martyrs, Tayyibat al-Imam, Syria (447) 
133. Reproduction of the Peutinger Table, Fourth Century (?) .....................................444

134. Vintaging Scene, Nave Mosaic, St. Stephen, Umm-al Rasas ..............................445

135. Depiction of Fruit Trees and Facing Animals, Church of the Apostles, Madaba (578)

136. Depiction of Zoara, Madaba Mosaic ...........................................................446

137. Drawing of Commiphora gileadensis (Gilead Balm or Gilead Balsam) ...............447

138. Depiction of Opobalsam Plants, Madaba Mosaic ..............................................447 


\section{INTRODUCTION}

The sixth century ushered in an explosion of church-building in the Byzantine provinces of Palaestina Secunda and Arabia, roughly the area of modern Jordan. More than 150 churches have been uncovered and the majority have floors decorated in mosaics. Topographic motifs depicting various scenes with roofed and domed buildings within polygonal fortifications are popular inclusions in these pavements. In this dissertation, I examine nine examples of this genre to identify the depicted sites and determine why patrons chose to include these specific cities in their compositions. Their selections were not random; the motifs were often chosen to emphasize the specific purpose of the building, such as a mortuary or pilgrimage church, while in other cases they were combined with agrarian or other topographic motifs to promote the patron's or community's status.

This is not the first time the mosaics have been studied. In addition to iconographic descriptions in excavation reports, Michele Piccirillo includes a brief discussion of the group in his seminal book, The Mosaics of Jordan. This publication introduced the country's early Christian pavements, and the topographic mosaics, to a much wider academic audience. ${ }^{1}$ The primary purpose of the book is to document Jordan's mosaics and present illustrations of them as they appear within their architectural contexts, but Piccirillo briefly comments on the popularity of architectonic

\footnotetext{
${ }^{1}$ Michele Piccirillo, The Mosaics of Jordan (Amman: American Center of Oriental Research, 1993).
} 
images, which he terms "walled city" motifs. He does not present an in-depth analysis, but instead provides a list of examples and identifies much of the accompanying imagery as "Nilotic," or representations of flora and fauna from Egypt. Piccirillo questions why such combinations were included on church floors, but does no more than suggest a possible connection between the depictions of these cities, their ecclesiastic settings, and the Nile's identification as one of the four Rivers of Paradise. ${ }^{2}$

Since the publication of Piccirillo's work, numerous scholars have examined select examples of the topographic motifs in order to investigate their meaning; however, these analyses have been problematized by their supposition of two commonly held beliefs: first, that Piccirillo's iconographic identifications are correct, and second, that Late Antique church mosaics must somehow reflect Christian ideologies. The current study rejects both assumptions and instead reexamines the topographic motifs and accompanying imagery in light of comparanda from Israel, Syria, and other parts of the Mediterranean in order to provide new identifications for the unlabeled cities. While an unusually large number of topographic mosaics have been discovered in Jordan, copious examples from both domestic and ecclesiastic buildings in other regions demonstrate that topographic motifs were common and malleable images in the Late Antique visual communication system.

In order to interpret the mosaics, it is vital to understand that they were more than Christian compositions; Late Antique mosaics reflect active choices made by the individuals who commissioned them. Spatial analyses of Late Antique buildings have demonstrated that patrons, architects, and artisans carefully considered the ways in which various architectural and decorative features could be combined to affect the viewers'

${ }^{2}$ Ibid., 37. 
understanding of, and experience with, the spaces they inhabited. ${ }^{3}$ Moreover, Late Antique descriptions of architectural decoration indicate that the ancient viewer analyzed visual material much differently than today's spectator. ${ }^{4}$ To replicate the Late Antique experience in this study, each mosaic is examined within its architectural context, relating it to what is known about the church's decoration and liturgical furnishings.

The reasons behind the topographic mosaics' construction are grounded in the longstanding Greco-Roman tradition of euergetism, the donation of buildings and public works in exchange for official accolades. In the Late Antique period, this practice shifted to the construction and adornment of churches. The benefits of such donations were great; patrons had the opportunity to publically display their piety and reify their generosity through inscriptions and portraits placed within the hierarchical social and sacred space of the churches' interiors. Donors took advantage of the mosaics' visual medium and demonstrated their wealth and status through the size and quality of the pavement, its prominent placement in the church, and the combination of images they selected.

We know little about individual patrons of the topographic mosaics, and our information about the patron-artist relationship is similarity incomplete. Nevertheless, the popularity of architectonic motifs in Jordan should not be dismissed as a byproduct of a

\footnotetext{
${ }^{3}$ Simon Ellis, "Power, Architecture, and Décor: How the Late Roman Aristocrat Appeared to His Guests," in Roman Art and the Private Sphere: New Perspectives, ed. Elaine Gazda (Ann Arbor, MI: University of Michigan Press, 1994), 117-134; David Chatford Clark, "Viewing the Liturgy: A Space Syntax Study of Changing Visibility and Accessibility in the Development of the Byzantine Church in Jordan," WorldArch 39, no. 1 (March 2007): 84-104; Ann Marie Yasin, Saints and Church Spaces in the Late Antique Mediterranean: Architecture, Cult, and Community (Cambridge: Cambridge University Press, 2009), 129150.

${ }^{4}$ John Onians, “Abstraction and Imagination in Late Antiquity," Art History 3, no. 1 (March 1980): 12-13; Jan Deręgowski and Denis Parker, "The Perception of Spatial Structure with Oblique Viewing: An Explanation for Byzantine Perspective?," Perception 23, no. 1 (January 1994): 5-13; Ruth Webb, Ekphrasis, Imagination, and Persuasion in Ancient Rhetorical Theory and Practice (Farnham, UK: Ashgate, 2009), 4-5.
} 
local workshop tradition. While patrons were limited to some extent by the skill and repertoire of local mosaicists, images could be modified and combined to create an endless number of compositions. The cities depicted in the Jordanian mosaics are a testament to this, as twenty-four different towns from the Holy Land are incorporated into church pavements, along with twelve sites from Egypt (Tables 1a-b). Identical combinations of cities only occur when they represent a specific concept. For example, Jerusalem and Bethlehem are commonly displayed in western churches as apocalyptic/savlific imagery, and this combination appears in two of the mosaics examined in this study. ${ }^{5}$ In Jordan, these selections were chosen to reflect the individual building's purpose as a funerary or martyr church.

Patrons also drew from the iconographic traditions of the elite. Hunting and vintaging scenes are commonly combined with architectonic motifs to illustrate landholdings, crops, and leisure activities. Such compositions originated in third-century North African villa decoration and began to appear in Jordan during the fifth century, at a time when the Vandal invasions caused artistic production to decline in the African provinces. It is possible that the images were brought east by itinerant craftsmen, though transmission could also have occurred through pattern books or other media. ${ }^{6}$ Agrarian motifs were used in eastern villas just as they were in the west, as a means of denoting status and wealth provided by agricultural production. In an ecclesiastic setting, one may construe these images in a Christian framework, but it is unlikely that a Late Antique

\footnotetext{
${ }^{5}$ Raffaella Farioli Campanati, "Jerusalem and Bethlehem in the Iconography of Church Sanctuary Mosaics," in The Madaba Map Centenary, 1897-1997: Travelling through the Byzantine Umayyad Period; Proceedings of the International Conference held in Amman, 7-9 April 1997, ed. Michele Piccirillo and Eugenio Alliata (Jerusalem: Studium Biblicum Franciscanum, 1999), 173.

${ }^{6}$ Katherine M.D. Dunbabin, Mosaics of the Greek and Roman World (Cambridge: Cambridge University Press, 1999), 300-303.
} 
patron would completely divorce the motifs from their original meaning. In a region made rich through agriculture, this practice allows for a polyvalent reading. ${ }^{7}$ While the compositions are generally highly stylized, artists took great care to depict specific species of trees and plants, reinforcing their economic value in these communities.

Four of the topographic mosaics are laid out in such a fashion as to mimic natural topography, and three of these simulate routes between the depicted cities. During the liturgy, the mosaic's composition would guide the congregation's movement toward the altar along these visual pathways. Patrons took advantage of this and included cities from known pilgrimage routes, visually reinforcing the purpose of the church in which the viewer stood. Such inclusions also strategically marked the community's importance in the Christian world through the hierarchical placement of their city's motif in a privileged location within the church. Archaeological evidence from the depicted sites, as well as textual sources such as pilgrim itineraria and saint's vitae, illustrate the connections a Late Antique patron would have made between the topographic images and their socioeconomic importance.

By tracing the use of similar imagery in Late Antique art and examining the pavements in their architectural contexts, this study expands our comprehension of topographic iconography while addressing the purpose and function of the mosaics and the buildings in which they are found. More importantly, it revises our conceptions of ecclesiastic pavements, which are often interpreted solely within the constraints of religious or liturgical parameters. Late Antique churches were social spaces and patrons

\footnotetext{
${ }^{7}$ Basema Hamarneh, "Dynamics and Transformation of the Rural Settlements in Provincia Arabia and Palaestina Tertia in the Omayyad and Early Abbasid Periods," in Proceedings of the 6th International Congress of the Archaeology of the Ancient Near East, 5 May-10 May 2009, ed. Paolo Matthiae, et al. (Wiesbaden: Harrassowitz, 2010), 96-98.
} 
exploited the opportunity to demonstrate wealth and status, both their own and that of their communities.

\section{Parameters of the Study}

The current study expands upon Piccirillo's inquiry on the topographic imagery's purpose, while narrowing the number of mosaics under investigation. Despite his "walled city" label, Piccirillo includes a number of images of individual churches and temple-like buildings in his discussion. ${ }^{8}$ These have been excluded in the present study because it is impossible to determine if the patrons intended for these to be interpreted as specific sites or merely components of generic landscapes. ${ }^{9}$ This study shifts its focus from architectonic motifs to those that can be considered topographic. The modern geographical definition of the term "topographic" is most generally accepted as, "of or relating to the arrangement or accurate representation of the physical features of an area." However, a more appropriate description, both in light of Late Antique criteria for a realistic copy and for the purpose of this dissertation, is "the representation of one or

\footnotetext{
${ }^{8}$ Piccirillo, Mosaics of Jordan, 34. Piccirillo describes not only the mosaics included in this study but also the mosaics from the Chapel of the Priest John and the Church of the Holy Martyrs Lot and Procopius in Khirbat al-Mukhayyat, the Theotokos Chapel at the Memorial of Moses at Mt. Nebo, the Church of Bishop Sergios at Umm-al-Rasas, and the Lower Church at al-Quwaysmah.

${ }^{9}$ Piccirillo, Mosaics of Jordan, 34-37. Though he does not mention it in this category, I have also excluded the mosaic from the church at Zay al-Gharby, which also included a (now destroyed) image of a single church. In the case of the Theotokos Chapel pavement, it is not the contemporary city of Jerusalem depicted but a historical representation of the Temple, suggesting Christianity's triumphant succession of the Jewish faith. For further discussion of the religious meaning behind this motif, see Rina Talgam, "Constructing Identity through Art: Jewish Art as Minority Culture in Byzantium," in Jews in Byzantium, Dialectics of Minority and Majority Cultures, ed. Robert Bodfil, et al. (Leiden: Brill, 2011), 432-436; Joan R. Branham, "Mapping Sacrifice on Bodies and Spaces in Late-Antique Judaism and Early Christianity," in Architecture of the Sacred: Space, Ritual, and Experience from Classical Greece to Byzantium, ed. Bonna D. Wescoat and Robert G. Ousterhout (Cambridge: Cambridge University Press, 2012), 209-213.
} 
more cities or sites, though the depiction of identifiable features and/or toponyms, set within a real or imagined landscape."10

Nine mosaics from Jordan fit this definition: from Umm al-Manabi ${ }^{\circ}$, an unidentified church (Figure 1); from Jerash, St. John the Baptist (Figures 2-11, Plans 1-3) and Sts. Peter and Paul (Figures 12-16, Plans 1, 4); from Madaba, the Church of the Map (Figures 17-27, Plan 5); from Khirbat al-Samra, the Church of St. John (Figures 39-42, Plans 9-10); from Umm al-Rasas, the Church of the Lions (Figures 28-34, Plans 6-7), the Church of the Priest Wa'il (Figures 35-38, Plans 6, 8), and the Church of St. Stephen (Figures 43-73, Plans 6, 11-12); and from Ma'in, the Church of the Acropolis (Figures 74-85, Plan 13). For the sake of brevity, each topographic mosaics is referred to by its city name; in examples where there is more than one topographic mosaic per city, the pavement is referenced by the name of the church in which it was found. While the corpus of topographic pavements appears small, it represents a significant trend in regional church decoration during the Late Antique period.

In 2001, Anne Michel published the most complete inventory of Late Antique churches in modern Jordan, which includes 151 extant structures. ${ }^{11}$ Landscape scenes represent $9 \%$ of this inventory and the nine mosaics featured in this study (those with clearly identifiable topographic imagery) represent $6 \%$. However, if one excludes the forty-one churches with no evidence of mosaic decoration and another thirty-three paved

\footnotetext{
${ }^{10}$ Oxford Dictionaries, “Topographic," accessed June 15, 2013, http://oxforddictionaries.com/definition/english/topographic. The second definition is my own. Henry Maguire provides an excellent overview and bibliography concerning the issue of "realism" in the case of Byzantine art, especially in relation to the concept of an acceptable likeness of a prototype in The Icons of their Bodies: Saints and their Images in Byzantium (Princeton, NJ: Princeton University Press, 1996), 1547. For a discussion of the criteria for copies specific to architecture in the Late Antique period and Middle Ages, see Richard Krautheimer, "Introduction to an 'Iconography of Medieval Architecture," JWarb 5 (1942): 1-33.

${ }^{11}$ Anne Michel, Les églises d'époque byzantine et umayyade de Jordanie: Ve-VIIIe siècle; Typologie architecturale et amménagements liturgiques (Turnhout: Brepols, 2001).
} 
only with geometric designs, these percentages rise to $18 \%$ and $11.5 \%$, respectively. Additionally, while pavements featuring topographic motifs are found throughout the Mediterranean in both secular and ecclesiastical contexts, in no other region has such a large concentration been discovered.

The nine mosaics were created between the fifth and the eighth centuries CE. ${ }^{12}$ Art historians categorize this date range as part of the early Byzantine period. However, scholars working in the Near East utilize "late Byzantine" for dates between 491 and either 630, the start of the Muslim Conquest, or 641, when Muslim forces captured Caesarea and completed their domination of the region. Near Eastern specialists consider the period from 630/641 until 1099, when the Crusaders captured Jerusalem, as "early Islamic." 13 To avoid confusion, I use "Byzantine" and "Islamic" only in reference to administrative and religious authorities, substituting the more ambivalent designation of "Late Antique" in general contexts. This term is also problematic, as a clear chronological framework has not been established and many scholars propose an end date at or before the Islamic Conquest. However, "Late Antique" is especially appropriate in discussions concerning the diverse cultures of the Eastern Mediterranean that continued to coexist beyond 630. For the purpose of this study, I adopt the parameters established by Peter Brown, who helped popularize the term amongst English-speaking scholars and has most recently proposed an end-date of 800 for Late Antiquity, a time frame based on cultural attitudes instead of historical events. ${ }^{14}$

\footnotetext{
${ }^{12}$ All dates presented in this study are CE, unless otherwise noted.

${ }^{13}$ For a further description of these chronological categories, see Michele Piccirillo, "The Mosaics at Umm er-Rasas in Jordan," The Biblical Archaeologist, 51, no. 4 (December 1988): 227; Thomas S. Parker, "An Empire's New Holy Land: The Byzantine Period.” NEA 62, no. 3 (1999): 139.

${ }^{14}$ See, for example, Glen Bowersock, Peter Brown, and Oleg Grabar, introduction to Interpreting Late Antiquity: Essays on the Postclassical World, ed. Glen Bowersock, Peter Brown, and Oleg Grabar (Cambridge, MA: Belknap Press of Harvard University Press, 2001), vii-x.
} 


\section{CHAPTER 1:}

\section{PRIOR SCHOLARSHIP AND \\ THE METHODOLOGICAL FRAMEWORK OF THE CURRENT STUDY}

Prior to the publication of Michele Piccirillo's Mosaics of Jordan in 1993, examinations of the topographic mosaics of Byzantine Palaestina and Arabia generally focused on single pavements and took the form of excavation reports, in which description is favored over analysis. There are few iconological enquiries discussing the intended symbolism of the motifs. In contrast, publications after 1993 have focused more on interpreting the mosaics' iconography, albeit within extremely limited frameworks. These analyses generally consist of short articles and conference papers, and rarely examine more than two or three of the topographic mosaics. The conclusions of these studies are surprisingly similar, proposing that the topographic pavements served as illustrations of urban pride, religious philosophies, or the prosperity provided to Christians by Christ and the Church.

Although these findings are not inaccurate, the present study demonstrates that this commonly held view of the mosaics' meaning is too general. Scholars' singular focus on the topographic motifs, at the expense of entire compositions, has limited the interpretations. The current investigation of the topographic mosaics' iconography, analyzed both in relationship to their architectural contexts and in comparison to similar pavements from Israel, Syria, and other regions of the Late Antique Mediterranean, 
reveals that the compositions illustrated the purpose of the church and/or information about the patron or community.

Patrons often demonstrated their wealth and status to their communities through the pavements' compositions, but a Late Antique audience would also have been acutely aware of the financial value of the mosaics, and few scholars have considered the implications of this fact. Likewise, the accompanying inscriptions and donor portraits, superficially examined in more recent studies, provide important information about the ways in which patrons used these decorations as proxies, granting them access to privileged space inaccessible to most laypeople. Understanding the mosaics' more complex functions requires consideration of both their architectural contexts and their connection to the Late Antique practice of euergetism.

\section{Prior Studies of the Topographic Mosaics}

Previous investigations of the topographic mosaics can be divided into two categories: those considering multiple pavements simultaneously, and those focusing on individual mosaics. These analyses have yielded valuable insights into the general messages the topographic pavements conveyed in the Late Antique period, and their conclusions are summarized below. Some theories associate the topographic imagery with general messages of prosperity, while others suggest that the mosaics are connected to specific cultural practices such as pilgrimage. The current study expands upon these hypotheses with particular interest in how the imagery might be connected to the mosaics' patrons or the type of church in which the pavements were installed. Examinations of archaeological evidence and textual sources including pilgrimage accounts and records of trade from Jordan and Egypt determines that patrons drew 
specifically from iconography that reflected the agro-economic situation of Late Antique Jordan.

\section{I.i. Studies Including Multiple Topographic Pavements}

Drawing primarily from Piccirillo's catalogue, several scholars have studied select groups of topographic mosaics. These analyses take three forms: examinations of the architectonic motifs as historical records, iconographic studies of the images in connection to the landscape genre, and analyses of the religious contexts of the pavements. The first of these is extremely limited in scope and the work of previous scholars has exhausted the need for further investigation. The present study builds on scholarship from the latter two categories, which suggests that the mosaics served as general expressions of urban pride and prosperity, but it reframes these subjects within the context of patronage to demonstrate that more specific statements of affluence or status relating to the individual or community were often intended.

Given the poor state of preservation of most Late Antique churches in the Near East, the architectonic motifs have been used as models to enhance our understanding of the period's architectural styles and building techniques. This work has been largely undertaken by Noël Duval, who has used some of the Jordanian topographic motifs to describe the depicted cities' Late Antique layouts, as well as the building types of individual structures. ${ }^{1}$ However, the stylized nature of the motifs, which are often

\footnotetext{
${ }^{1}$ Noël Duval, "Les representations architecturales sur les mosaïques chrétiennes de Jordanie," in Actes de la journée d'études sur les églises de Jordanie et leurs mosaïques: organisée à l'occasion de l'inauguration de l'exposition "Mosaïques Byzantines de Jordanie" au museée de la civilization galloromaine à Lyon en avril 1989, ed. Noël Duval (Beirut: Institut français d'archéologie du Proche-Orient, 2003), 211-281; Noël Duval, "Rappresentazioni architettoniche," in Umm al-Rasas Mayfa 'ah I: Gli scavi del complesso di Santo Stefano, ed. Michele Piccirillo and Eugenio Alliata (Jerusalem: Studium Biblicum Franciscanum, 1994), 165-230; Noël Duval, "Essai sur la signification des vignettes topographiques," in Madaba Map Centenary, 134-145.
} 
presented in unusual perspectives, limits the usefulness of this type of study. Duval admits the depictions are not always realistic or accurate reproductions, but he nonetheless notes that key features of certain depicted cities are often repeated. ${ }^{2}$ The current study attempts to identify unlabeled cities by examining their attributes and comparing them to toponymic examples. Additionally, the use of formulaic motifs lends credence to the supposition that local audiences were able to recognize the cities even without labels.

While architectural studies like Duval's focus on the ways topographic motifs help the modern viewer understand Late Antique architecture and city planning, iconographic approaches center on the interpretation of individual motifs. As cityscapes, the Jordanian topographic motifs can be considered a subset of the landscape genre: compositions that include animals or people engaged in hunting, fishing, or other activities in an outdoor setting. These compositions were popular in both the Roman and Late Antique periods, and examples exist throughout the Mediterranean. In domestic contexts, these scenes typically have been interpreted as symbols of the patrons' prosperity, tied to agricultural production and the status of wealthy landowners. ${ }^{3}$ With this in mind, art historians Lucy-Anne Hunt and Henry Maguire have explored possible interpretations of the topographic motifs within the semiotics of this genre.

In a paper presented in conjunction with an exhibition of Jordanian mosaics, Hunt briefly examines the topographic scenes from St. John the Baptist (Figures 3-8) and

\footnotetext{
${ }^{2}$ Noël Duval, "Les representations architecturales," 212. Duval's typology closely follows that of Michael Avi-Yonah in The Madaba Mosaic Map with Introduction and Commentary (Jerusalem: Israel Exploration Society, 1954), 21-23. Avi-Yonah determines that a semiotic system was used to depict the size of cities, towns, and villages on the Madaba mosaic. In addition to these stylistic depictions, he notes that ten cities were portrayed with individualized buildings which, in some cases, can be identified as historical structures ${ }^{3}$ Christine Kondoleon, "Signs of Privilege and Pleasure," in Roman Art and the Private Sphere, 105-116; Dunbabin, Mosaics Greek and Roman, 116-119.
} 
Madaba (Figures 18-27) within the context of the landscape genre in order to understand why the motif was especially popular in Jordan. She concludes that the inclusion of major centers like Alexandria and Jerusalem represent "civilization," and that Jordanian cities visually linked their growing communities to the "great centers of Antiquity" as expressions of urban pride. ${ }^{4}$ While a general reading of urban pride is easily accepted, it is not a sufficient explanation for the combination of smaller, less important cities found on several of the pavements in this study. Information about such sites is often limited; however, archaeological remains and textual evidence, such as references to the cities in pilgrim interaria, provide clues as to why these sites might be significant to mosaic patrons.

Piccirillo identifies Nilotic elements in many of the motifs displayed in, or in conjunction with, the topographic pavements. Several scholars have examined the topographic mosaics within the context of this subgenre of landscapes, which are believed to symbolize (agricultural) prosperity. The focus of these studies has been on how the topographic motifs reflect a change in the acceptance of Nilotic imagery rather than on the ways in which the Egyptian material influences the interpretation of the topographic depictions. ${ }^{5}$ The most thorough and nuanced study of Nilotic compositions is presented by Maguire, who analyzes the imagery of St. John the Baptist and St. Stephen (Figures 44-75) within the context of shifting opinions regarding Late Antique Nilotic

\footnotetext{
${ }^{4}$ Lucy-Anne Hunt, "The Byzantine Mosaics in Jordan in Context: Remarks on Imagery, Donors, and Mosaicists," in Byzantium, Eastern Christendom and Islam: Art at the Crossroads of the Medieval Mediterranean v. 1, ed. Lucy-Anne Hunt (London: Pindar Press, 1998), 13-14. Hunt connects the use of Nilotic imagery in the mosaics to "classical" cities. This is a tenuous link, especially in light of Maguire's findings in "The Nile and the Rivers of Paradise," in Madaba Map Centenary, 179-184.

${ }^{5}$ See, for example, Janine Balty, "Thèmes nilotiques dans la mosaïque tardive du proche-orient" in Alessandria e il mondo ellenistico: Studi in onore di Achille Adriani, ed. Nicola Bonacasa et al. (Rome: L'Erma di Bretschnider, 1984), 827-834; Basema Hamarneh, "The River Nile and Egypt in the Mosaics of the Middle East," in Madaba Map Centenary, 185-189; Rachel Hachlili, Ancient Mosaic Pavements: Themes, Issues, and Trends (Leiden: Brill, 2009), 101-103.
} 
motifs. ${ }^{6}$ His work is especially important because it draws from a variety of contemporaneous textual sources instead of relying on suppositions about the iconography, a common occurrence in other analyses of both Nilotic pavements and ancient mosaics in general. $^{7}$

In light of the Nile's inclusion as one of the four Rivers of Paradise, Piccirillo suggests a religious interpretation of the pavements is possible, but I believe that he overstates the connection between the topographic mosaics and Nilotic imagery. ${ }^{8}$ In the pavements from Khirbat al-Samra (Figures 41-42) and the Church of the Priest Wa'il (Figures 36-38), I argue that the unlabeled sites are not Alexandria and Memphis, as posited by Piccirillo and others, but the apocalyptic/salvific cities of Jerusalem and Bethlehem. These identifications are secured in Chapter 3 through comparisons to contemporaneous mosaics with labeled motifs. ${ }^{9}$ Furthermore, the topographic mosaics from St. John the Baptist, Madaba, and St. Stephen incorporate specific Egyptian cities in depictions of Late Antique topography and are not generic Nilotic landscapes. As such, the Egyptian cities, and their Holy Land counterparts, must be examined for the significance they could hold for the people who included them in church pavements. Archaeological evidence from these sites, while limited, suggests that many of the

\footnotetext{
${ }^{6}$ Maguire, "Nile," 179-184.

${ }^{7}$ Maguire, "Nile," 181-183. Maguire refers to a number of sixth-century texts that demonstrate the Christian appropriation of the Nile's fecundity as a symbol of God's munificence, including Egyptian hymns, a wedding speech given by Dioskoros of Aphrodito, and a poem by Romanos the Melodist, as well a number of liturgies in which the Nile was blessed. In contrast, the fourth-century Christian apologist Firmicius Maternus contrasts the Nile to the purity of baptismal water. In his eighth-century encomium of St. Patapios, Andrew of Crete amplifies this juxtaposition between the "corruptible land of Egypt," represented by a number of Nilotic features, and the riches of heaven. Maguire has few late examples to support his argument and does not acknowledge that, with the exception of Firmicius Maternus, his texts linking the Nile to Christ originate in Egypt. As I argue with the topographic mosaics, Late Antique Egyptians used important local sites to emphasize their status within the Christian community.

${ }^{8}$ Piccirillo, Mosaics of Jordan, 37. Despite suggesting that a religious interpretation is possible, Piccirillo does not elaborate but leaves the meaning behind the combination of architectonic and Nilotic imagery as an open-ended question.

${ }^{9}$ See Chapter 3 below, pp. 125-127.
} 
included cities were part of important pilgrimage and trade routes. These conclusions are supported by descriptions from fourth to eighth-century pilgrim itineraria and papyri that outline well-traveled roadways in Late Antique Jordan.

In contrast to inspecting topographic motifs as part of landscape or Nilotic traditions in mosaic art, some scholars have examined the more direct religious messages that might have been intended in these compositions. Such studies are important because they take into account the buildings' purpose, at least at the basic level, as all nine topographic mosaics decorated church naves. At the heart of these investigations is the analysis of the mosaics within the context of Late Antique religious philosophies. In his foreword to The Mosaics of Jordan, Ernst Kitzinger briefly mentions that the topographic mosaics reflect a conscious shift from generalized representations of the natural world to depictions of regional geography dominated by the physical domain of humankind. $\mathrm{He}$ suggests that this illustrates the Christian reevaluation of the cosmos as reflected in the Neo-Platonist writings of Pseudo-Dionysios. ${ }^{10}$ Kitzinger does not specify which texts or provide further explanation to justify his reasoning, yet it is easy to identify PseudoDionysios' hierarchies of angels and men, as outlined in The Celestial Hierarchy and Ecclesiastical Hierarchy, reflected in the spatial organization of Late Antique church decoration. ${ }^{11}$

\footnotetext{
${ }^{10}$ Kitzinger, foreword to The Mosaics of Jordan, by Michele Piccirillo (Amman: American Center of Oriental Research, 1993), 10.

${ }^{11}$ For a discussion of hierarchical displays of church decoration, see Chapter 3 below, p. 101-103, as well as Jean-Michel Spieser, "The Representation of Christ in the Apses of Early Christian Churches," Gesta, 37, no. 1 (1998): 63-73; Raymond van Dam, Saints and their Miracles in Late Antique Gaul (Princeton, NJ: Princeton University Press, 1993), 134; Ann Marie Yasin, "Sacred Space and Visual Art," in The Oxford Handbook of Late Antiquity, ed. Scott Fitzgerald Johnson (Oxford: Oxford University Press, 2012), 949953. Van Dam perhaps describes the visitor experience best, as "a horizontal pilgrimage through the church [towards the altar] and the vertical journey to heaven [represented by the church's dome]."
} 
It is likely that the clergy, whom Kitzinger suggests worked in collaboration with the laity as patrons of these pavements, would have been familiar with PseudoDionysios' texts. ${ }^{12}$ Moreover, educated elite viewers would also have been able to relate the naves' decoration to these popular philosophical beliefs, requiring further investigation of the relation between Late Antique ideologies and the topographic mosaics. ${ }^{13}$ However, Roman and Late Antique mosaics often had multiple layers of meaning and it is likely that the combinations of cities on each mosaic were also read in a less abstract manner, as realistic depictions of regional geography dominated by contemporary cities. Individual interpretations would depend on viewers' knowledge of the depicted sites. Connections to Neo-Platonist cosmologies does not preclude the idea that the images were individualized in order to make more specific claims about the status of the patrons and/or their communities.

Using a socio-religious framework similar to Kitzinger's, Pauline Donceel-Voûte analyzes the spatial relationship between topographic motifs in the Madaba and St. Stephen mosaics, and offers interpretations based on early Christian ideologies and Late Antique Church politics. In the case of the Madaba mosaic, she suggests that the composition creates a "cosmographical" scene, with Jerusalem at the center of the world as per Late Antique beliefs. ${ }^{14}$ The depiction of Madaba is now lost, but Donceel-Voûte rightly suggests that it must originally have been located in close proximity to the Holy

\footnotetext{
${ }^{12}$ Names of the clergy are recorded in the inscriptions at the Church of Sts. Peter and Paul, the Church of the Priest Wa'il, and the Church of St. John.

${ }^{13}$ For a short but comprehensive overview of Byzantine education, see Athanasios Markopoulos, "Education," in The Oxford Handbook of Byzantine Studies, ed. Elizabeth Jeffreys, John Haldon, and Robin Cormack (Oxford: Oxford University Press, 2008), 785-795.

${ }^{14}$ On the concept of the centrality of Jerusalem as the omphalos of the Christian world, see Philip S. Alexander, "Jerusalem as the Omphalos of the World: on the History of a Geographical Concept," in Jerusalem: Its Sanctity and Centrality to Judaism, Christianity, and Islam, ed. Lee Levine (New York: Continuum, 1999), 104-119.
} 
City at the eastern end of the church. She believes that by including Madaba in axial alignment with Jerusalem, the community was aligning itself with Jerusalem's Orthodox patriarch. She cites the same reason for the mirrored position of Jerusalem on the northeast end and Kastron Mefa'a (Umm al-Rasas) on the southeast end of St. Stephen's nave. ${ }^{15}$ However, she does not address the allegiance of the other cities depicted in these compositions, nor does she discuss the religious organization of Byzantine Arabia in the sixth to the eighth centuries. Donceel-Voûte ignores the fact that St. Stephen's two rows of cities are depicted in contrast to each other, in two distinct rows. Moreover, Kastron Mefa'a and the toponyms on the south aisle include a depiction of a small palm or olive branch, while the ones with Jerusalem bear no such mark. How might this be explained? While Donceel-Voûte considers the mosaic's architectural context, she does not take into the account the alternative explanation made possible by the building's use as a pilgrimage church. The south row of cities displays a pilgrimage route to Umm al-Rasas and should not be interpreted as a symbol of allegiance to Jerusalem but as a visual form of competition with it as a rival sacred site. It is important to remember that religious politics played a key role in the regional pilgrimage trade; as the power of the Church in Jerusalem grew, it asserted its authority over the Holy Land sites to which pilgrims traveled. ${ }^{16}$ Umm al-Rasas' topographic mosaic is a visual response to Jerusalem's claims of authority, and it is possible the Ma'in pavement (Figures 74-84), similar in composition and date, carries a comparable message.

\footnotetext{
${ }^{15}$ Pauline Donceel-Voûte, "La carte de Madaba: cosmographie, anachronisme, et propogande," RBibl 95, no. 4 (1988): 522-525.

${ }^{16}$ On the part that pilgrimage played in ecclesial politics in the region, see A. Kofsky, "Peter the Iberian: Pilgrimage, Monasticism, and Ecclesiastical Politics in Byzantine Palestine," Liber Annuus 47 (1997): 209 22; Lorenzo Perrone, "Christian Holy Places and Pilgrimage in an Age of Dogmatic Conflicts," ProcheOrient chrétien 48, no. 1/2 (1998): 5-37; Brouria Bitton-Ashkelony, "Territory, Anti-Intellectual Attitude, and Identity Formation in Late Antique Palestinian Monastic Communities," Religion and Theology 17, no. 3-4 (2010): 244-267.
} 
While interpretations reflecting Late Antique Christian philosophy should be considered in light of the topographic mosaics' locations within churches, none of the studies presented above account for the inclusion of less important cities, whose appearance might have inspired more literal interpretations of the topographic motifs. The specific cities included, from both Egypt and the Holy Land (Tables 1a-1b), would have held significance at the time of the mosaics' construction. Moreover, the fact that they are labeled and sometimes include key features to help identify specific cities lends credence to the supposition that patrons who commissioned these compositions might have intended, or that viewers might have inferred, more explicit messages.

The studies of multiple topographic pavements presented in this section typify the two major streams of mosaic analysis. The first includes Duval's work, which is reflective of an earlier trend scholarship, in which the compositions are used to explain physical elements (such as city plans and building elevations) of a society that no longer exists. This work helps in the reconstruction of archaeological material but is hampered by the hieratic style popular in Late Antique art and the limited realism that all but the finest mosaics exhibit. The second type of scholarship focuses on iconographic interpretations of the pavements and reflects a shift in mosaic studies that began in the 1980s, when mosaics were emphasized as illustrations of cultural beliefs and declarations of the patron's status. The work of Maguire and Donceel-Voûte represents the most insightful of these studies, and analyzes the iconography in relation to contemporaneous textual sources or architectural contexts in order to ground their interpretations within the framework of Late Antique societal norms. The present study draws from this second stream of scholarship and focuses on the architectural and social contexts in which the 
mosaics were constructed. Moreover, this study utilizes a combination of in situ spatial analysis coupled with the examination of archaeological and textual materials that clarify the significance of the chosen city motifs, in order to identify the various ways Late Antique viewers might interpret the mosaics.

\section{I.ii. Studies of Individual Topographic Mosaics}

Much of the previous scholarship on individual mosaics has been limited to iconographic descriptions published in excavation reports, but iconological analysis has also been used to conduct more in-depth studies examining the possible messages conveyed by the topographic pavements from Madaba, Ma'in, and St. Stephen. The Madaba mosaic has received the most attention, with over a dozen studies dedicated to it. Scholars have privileged it to such an extent that they have created an artificial distinction between it and the rest of the topographic pavements. This study redefines the Madaba mosaic, eliminating its privileged status and recontextualizing it alongside the other examples so the topographic mosaics can be examined both individually and as a group in their socio-cultural and architectural contexts.

I.ii.a. The Mosaic of the Church of the Map, Madaba

The pavement from the Church of the Map in Madaba, commonly referred to as the Madaba Map, is a complex composition depicting over 150 historical and biblical sites in a large landscape scene. The mosaic's detailed content has long intrigued scholars, and more than a dozen studies of its iconography and the sources of its composition have been published. Unlike the other Jordanian mosaics, for which questions of purpose and function have been largely ignored, a select number of scholars 
have questioned why the Madaba pavement was constructed and how viewers were expected to experience it within its architectural setting.

The mosaic's topographical accuracy is discussed below; although its artist and/or patron most certainly drew from a variety of sources to complete the composition, the Madaba mosaic clearly served as more than an illustration of ancient texts. The suggestion that topographic mosaics conveyed messages of urban pride has been previously discussed and accepted; however, the idea that their function was also connected to local cultural practices such as pilgrimage, as has been proposed for the Madaba mosaic, must also be considered. ${ }^{17}$

Connecting the term "map" to the Madaba mosaic has problematized its study in relation to other topographic mosaics. The use of this term for the mosaic, as well as labeling it a "unique" pavement, has encouraged the belief that its purpose and function are distinct from the other examples. However, the present study argues that the similar architectural contexts, dates, and motifs suggest the Madaba mosaic, despite its stylistic differences, can be interpreted using the same methodologies that have been applied to the other topographic mosaics.

The pavement was unearthed in 1896, during the construction of a new church over the ruins of the Byzantine structure. The Jerusalem Patriarchate dispatched Father Kleopas Koikylides to report on the discovery, and the priest published sketches and a short description in $1897 .{ }^{18}$ Drawing from this source, a variety of scholars produced several brief publications over the next decade and, except for the minutest details, they

\footnotetext{
${ }^{17}$ Eugenio Alliata, "The Pilgrimage Routes during the Byzantine Period in Transjordan," in Madaba Map Centenary, 124. In his investigation of Late Antique pilgrimage routes in Jordan, Alliata suggests that the Madaba mosaic was created to display local pride in Madaba's place in the Holy Land.

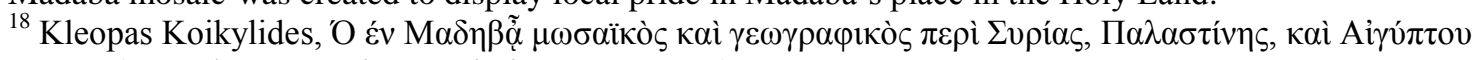

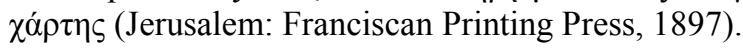


are extremely similar in nature. Each publication posits dates between the fourth and seventh centuries for the mosaic's construction, uses the labeled motifs to identify archaeological sites in the Holy Land, and suggests possible literary and documentary sources used to create the composition. ${ }^{19}$

The study of the Madaba mosaic in relation to the other topographic mosaics has been hindered by scholars' determination to differentiate it from the rest. The word "unique" is incorporated in almost every publication dedicated to the Madaba pavement. ${ }^{20}$ The continued use of this term in reference to the mosaic is incorrect in some respects and only serves to distance the Madaba pavement from others in the topographic group. While the Madaba pavement is composed in a more naturalistic style and contains more sites than the other examples, the compositions of Ma'in and St. Stephen (and possibly St. John the Baptist) also reflect geographic realities and therefore could be called stylized "maps." Additionally, examining the Madaba mosaic in reference to the

\footnotetext{
${ }^{19}$ Eugène Germer-Durand, La carte mosaïque de Madaba; Découverte importante (Paris: Maison de la bonne presse, 1897); Marie-Joseph Lagrange, "La mosaïque géographique de Mâdabâ" RBibl 6 (1897): 165-184; Caspar René Gregory, "The Mâdaba Map," The Biblical World 12, no. 4 (October 1898): 244250; Adolf Schulten, Die Mosaikkarte von Madaba und ihr Verhaltnis zu den altesten Karten und Beschi'eibungen des heiligen Landes (Berlin: Weidmann, 1900); Charles Raymond Beazley, "Madaba Map," The Geographical Journal 17, no. 5 (1901): 516-520; W. Bacher, "Zur Mosaikkarte von Madaba," $J Q R, 13$, no. 2 (January 1901): 322-323; Lucius H. Bugbee, "The Mosaic Map of Medeba: A Contribution to the Topography of Ancient Palestine" (M.A. thesis, University of Chicago, 1901); Charles ClermontGanneau, "The Land of Promise, Mapped in Mosaic in Madaba," PEFQ (1901): 235-246; H. Guthe, "Das Stadtbild Jerusalems auf der Mosaikkarte von Madaba," ZDPV 28 (1905): 120-130; Adolf Jacoby, Das geographische Mosaik von Madaba: Die älteste Karte des Heiligen Landes (Leipzig: Dieterich, 1905); M. Gisler, "Jerusalem auf der Mosaikkarte von Madaba," Das Heilige Land 56 (1912): 214-227. In every one of these sources, it is assumed that the artist made all compositional choices for the Madaba mosaic, as the concept of patron-driven mosaics was not generally considered before Katherine Dunbabin's 1978 publication The Mosaics of Roman North Africa: Studies in Iconography and Patronage (Oxford: Clarendon Press, 1978).

${ }^{20}$ In Mosaics of Jordan, 26-34, Piccirillo is one of the few authors who does not label the Madaba pavement "unique" and thus does not distinguish it from the other mosaics containing topographic representations. However, he discusses it in a discrete section in his category of "Architectural Representations" and provides a more thorough description and examination of this pavement than he does for the other topographic examples.
} 
definition of "topographic" utilized in this study determines that the pavement is only a more elaborate variation of this genre. ${ }^{21}$

Koikylides was the first to label the Madaba mosaic a "map," and all subsequent scholars have followed this practice whether or not they believe this is the pavement's purpose. ${ }^{22}$ Some go so far as to suggest that a geographer or cartographer was behind its design. ${ }^{23}$ Few of these authors attempt to explain how a Late Antique audience might have used this "map." While most archaeologists and art historians in recent years acknowledge that the Madaba pavement does not meet the modern criteria for consideration as a "map," they continue to describe it using that term. The complications of this appellation are reflected in recent studies that use the Madaba mosaic as an accurate source in investigations of Late Antique geography, which serves as false evidence in this scholarship. ${ }^{24}$

Late Antique populations, for whom maps were often used to express ideological concepts or propagandistic messages, did not necessarily share our contemporary definition of "map." J.B. Harley and David Woodward provide an excellent overview of the distinction between ancient and modern perceptions of maps and cartography, and offer their own definition, which reflects ancient perceptions of this type of document: "Graphic representations that facilitate a spatial understanding of things, concepts,

\footnotetext{
${ }^{21}$ See my definition of "topographic" above, pp. 6-7.

${ }^{22}$ Lagrange, "Mosaïque géographique," 182-183; Gregory, "Mâdaba Map," 246. While several early authors do not provide a reason for the mosaic's creation, Marie-Joseph Lagrange and Caspar René Gregory suggest that it was a map of the Late Antique Holy Land.

${ }^{23}$ Gregory, "Mâdaba Map,"246; Bugbee, "Mosaic Map," 31.

${ }^{24}$ See, for example, David H.K. Amiran, "The Madaba Map as a Climate Indicator for the Sixth Century," IEJ 47, no. 1/2 (1997): 98-99; Frank Nigel Hepper and Joan E. Taylor, "Date Palms and Opobalsam in the Madaba Mosaic Map," PEFQ 136, no. 1 (2004): 41, 43. Amiran suggests that the shoreline depicted in the Madaba mosaic is an exact replication of the sixth-century topography and that its contracted state illustrates a period of drought. Similarly, Hepper and Taylor assume that the placement of plants, which they identify as opobalsam, on the mosaic depict the precise location of plantations, and attest to a flourishing industry in this region in the sixth century.
} 
conditions, processes, or events in the human world." 25 This definition can be applied to all the Jordanian topographic pavements and reduces the differentiation between the Madaba mosaic and the others. Applying Harley and Woodward's definition also permits one to study the mosaics as a group, even if the concepts they illustrate are not the same because, in this sense, all the topographic mosaics could be termed "maps."

In addition, this definition erases the artificial distinction between the more topographically accurate motifs in the Madaba mosaic and the stylized topographic imagery found in the other examples from Jordanian churches. ${ }^{26}$ Late Antique viewers did not necessarily share our modern bias favoring realistic depictions, and required only key elements of the prototype to consider the image an acceptable likeness of a person or building. ${ }^{27}$ The fact that several cities are depicted in different mosaics using the same key features suggests they were standardized to help viewers recognize them. ${ }^{28}$ Moreover, toponyms like those found on many of the topographic mosaics, helped alleviate any ambiguity about what was depicted while also serving as markers of status. $^{29}$

\footnotetext{
${ }^{25}$ J.B. Harley and David Woodward, preface to The History of Cartography, ed. J.B. Harley and David Woodward (Chicago: University of Chicago Press, 1987), xv-xviii.

${ }^{26}$ For an early discussion of artistic license at the expense of geographical accuracy, see Bugbee, "Mosaic Map," 6-7.

${ }^{27}$ Richard Krautheimer, "Introduction,"1-33. Krautheimer discusses the concept of copies of buildings in the Late Antique period and the Middle Ages and concludes that only key elements, ones that could be related symbolically to the prototype's purpose or to general Christian beliefs (especially numerological symbols), were necessary for the building to be considered a reproduction until the thirteenth century.

${ }^{28}$ Hendrik Dey, "Urban Armatures, Urban Vignettes: The Interpretation of the Reality and the Ideal of the Late Antique Metropolis," in Using Images in Late Antiquity, ed. Stine Birk, Troels Myrup Kristensen, and Birte Poulsen. (Oxford: Oxbow Books, 2014), 190-208. In his examination of the representation of the city of Jerusalem on the Madaba mosaic and Alexandria on the pavement in St. John at Jerash, Dey explains that these motifs "capture the most salient details of both places, the parts of the city designed to be the most visible and the most frequented," in order to illustrate the characteristics of a "great" city.

${ }^{29}$ Robin Lane Fox, "Literacy and Power in Early Christianity," in Literacy and Power in The Ancient World, ed. Alan K. Bowman and Greg Woolf (Cambridge: Cambridge University Press, 1994), 126-148, especially pp. 138-148. Fox discusses the perception and realities about the power obtained through literacy in the early Christian period. While much of his essay focuses on Church leaders, the prestige of literacy for "ordinary Christians" is also discussed.
} 
The patron and/or artist of the Madaba mosaic chose to highlight ten cities with detailed, "bird's eye" depictions similar to those found on the other topographic pavements. ${ }^{30}$ However, these selections do not necessarily represent the largest populations in the region at the time of the mosaic's creation, and not all the depicted cities held particular importance in Late Antiquity. The possible reasons for their selection, like the choice of cities on the other topographic mosaics, are examined in this study. More specific messages intended by the mosaics' patrons are proposed for all nine topographic pavements following an investigation of the depicted cities' economic, religious, and political histories.

Unlike many of the other topographic mosaics from Jordan, scholars have sought to explain the Madaba pavement's purpose, or the reason for its creation. Some suggestions are that it was a depiction of biblical topography, a representation of Moses' journey from Egypt to the Holy Land, and/or a didactic tool for pilgrims. There has been less interest in the mosaic's function, or how viewers interacted with the mosaic within the church, though one scholar has investigated this in order to support his proposed connection between the composition and the cultural practice of pilgrimage.

There is a distinct difference in approaches to the study of the Madaba mosaic taken by scholars before and after World War II. Most early scholars, influenced by questions regarding the literary prototypes of the composition, support the idea that it served as a visual representation of biblical topography. Many believe it was influenced

\footnotetext{
${ }^{30}$ The ten cities are Jerusalem, Neapolis, Lod-Diospolis, Iamnia, Charach Moba, Azotos Paralios, Askalon, Eleutheropolis, Gaza, and Peluseion.
} 
by, or even an illustration of, biblical gazetteers like Eusebius' Onomasticon, while others suggest it served to educate viewers about biblical history. ${ }^{31}$

Others focus on the composition's formal elements in order to explain its purpose from an art historical viewpoint. The "bird's eye" perspective used to depict the ten large city motifs in the Madaba pavement led Charles Clermont-Ganneau to suggest that the composition represents Moses' view of the Holy Land from nearby Mt. Nebo, as well as his journey though the region. ${ }^{32}$ Henri Leclercq and R.T. O'Callaghan champion this idea, and more recent scholars have suggested similar theories. ${ }^{33}$ In truth, the atypical perspective incorporated in the mosaic merely reflects a stylistic convention used in both Roman and Byzantine art, and this same perspective is evident in portrayals of city motifs on the other topographic mosaics in the region. ${ }^{34}$ The depiction of walls within the composition provided Late Antique artists with the semiotic identifier of "city," while depictions of individual buildings inside the walls often allowed viewers to identify the specific city the patron intended to represent.

While the present study questions Clermont-Ganneau's reliance on stylistic features in forming his theory, the idea that the Madaba pavement includes depictions of

\footnotetext{
${ }^{31}$ Schulten, Mosaikkarte, 114; Charles Raymond Beazley, The Dawn of Modern Geography: A History of Exploration and Geographical Science v. 2 (London: John Murray, 1901), 581; Bugbee, "Mosaic Map," 7; Avi-Yonah, Madaba Mosaic, 27, 34. Avi-Yonah also suggests that there was a didactic function for the topographic motifs on both the Ma in pavement and the Megalopsychia mosaic in Daphne, Syria, though he does not specify what message was intended in either composition.

${ }^{32}$ Clermont-Ganneau, "Land of Promise," 243-244.

${ }^{33}$ Henri Leclercq, "Madaba," in Dictionnaire d'archéologie chrétienne et de liturgie X, no. 1, ed. Fernand Cabrol and Henri Leclercq (Paris: Letouzey et Ané, 1930), 807; R. T. O'Callaghan. "Madaba," in Dictionnaire de la Bible, Supplément 5, ed. L. Pirot and H. Cazelles (Paris: Letouzey et Ané 1957), 704; Irfan Shahid, "The Madaba Mosaic Map Revisited: Some New Observations on its Purpose and Meaning," in Madaba Map Centenary, 148-149. Irfan Shahid suggests that Madaba appropriated the figure of Moses, through an illustration of his vision, to enhance its status, a religiously themed variation of urban pride.

${ }^{34}$ Jocelyn Mary Catherine Toynbee "Ara Pacis Reconsidered and Historical Art in Roman Italy," ProcBritAc 39 (1959): 92-93; Diane Favro, "The Iconicity of Ancient Rome," Urban History 33, no. 1 (2006): 21; Lucy Grig and Gavin Kelly, eds., Two Romes: Rome and Constantinople in Late Antiquity (Oxford: Oxford University Press), 34-36.
} 
the Promised Land only strengthens this study's proposal that some topographic mosaics were used to connect their communities to the more important pilgrimage sites included in the compositions. In the case of the Madaba mosaic, this conceptual association with Moses provides a visual link between Madaba and the popular Shrine of Moses at Mt. Nebo, about $8.5 \mathrm{~km}$ away. But the composition also links Madaba to a number of other important sites along Late Antique pilgrimage routes, including Jerusalem and those highlighted in the composition through hierarchy of scale. In a similar manner, patrons of other topographic mosaics could appropriate the depicted cities' religious, political, and economic importance for their own communities.

After World War II, there was greater interest in linking the topographic compositions to the local practice of pilgrimage and in understanding the ways that viewers interacted with the mosaic inside the church nave. The first time the Madaba mosaic was linked to religious travel was in 1910, when Adolf Schulten suggested that a pilgrim commissioned it as a votive offering at the end of a successful pilgrimage. ${ }^{35}$ Although his contemporaries summarily dismissed Schulten's suggestion, it has been revived several times since the 1950 s.

Some authors suggest multiple purposes for the mosaic, accepting the more traditional interpretations while proposing that it served as an educational tool for pilgrims. Piccirillo proposes that the Madaba mosaic served as a "revision and correction of [Eusebius'] Onomasticon," which is a variation of the pre-war scholars' suggestion that the pavement illustrates or was influenced by the same literature. Piccirillo takes it one step further, however, when he posits that the mosaic was used by pilgrims visiting

\footnotetext{
${ }^{35}$ Schulten, Mosaikkarte, 114.
} 
the Holy Land. ${ }^{36}$ Herbert Donner proposes that the pavement served as a didactic guide for local and eastern pilgrims, and that its depiction of Old and New Testament sites illustrates "God's salvation history." 37 Donner also believes that the mosaic's central feature, the city of Jerusalem, served a liturgical function. ${ }^{38}$ Unfortunately, neither Piccirillo nor Donner elaborates on how pilgrims would have interacted with the mosaic. Victor Roland Gold addresses the issue of function and posits that as a viewer faced the altar, he or she would use the mosaic to prepare for an actual visit to the pilgrimage sites or perhaps to experience a form of virtual pilgrimage. ${ }^{39}$

The hypothesis that the Madaba pavement was created as a pilgrimage aid has not been widely accepted. Irfan Shahid rejects the notion outright, questioning the usability of both the medium and its composition. Since the Madaba pavement is not portable, Shahid sees no benefit to Christian travelers. Because he assumes the local population was illiterate, Shahid questions the mosaic's function as a didactic tool. ${ }^{40}$ Like Shahid, more recent publications examine the pavements from other viewpoints and suggest purposes for the mosaics that are unrelated to pilgrimage. ${ }^{41}$

\footnotetext{
${ }^{36}$ Piccirillo, Mosaics of Jordan, 29.

${ }^{37}$ Herbert Donner, The Mosaic Map of Madaba: An Introductory Guide (Kampen: Kok Pharos, 1992), 30. ${ }^{38}$ Ibid.

${ }^{39}$ Victor Roland Gold, "The Mosaic Map of Madeba," The Biblical Archaeologist 21, no. 3 (1958): 50.

${ }^{40}$ Irfan Shahid, "Madaba Mosaic," 147.

${ }^{41}$ Donner, Mosaic Map, 30; Hunt, "Byzantine Mosaics," 13-14; Hachlili, Ancient Mosaic, 103-104; Hendrik Dey, "Urban Armatures," 190-208; Rina Talgam, Mosaics of Faith: Floors of Pagans, Jews, Samaritans, Christians, and Muslims in the Holy Land (University Park, PA: Penn State University Press, 2014), 387-395; Glen Bowersock, Mosaics as History: The Near East from Late Antiquity to Islam (Cambridge, MA: Belknap Press of Harvard University Press, 2006), 24. Hachlili describes the city motifs within the context of Nilotic scenes and concentrates on their iconography. Hendrik Dey compares the extent to which the cities of Jerusalem and Alexandria are realistically depicted in the Madaba mosaic and at Jerash. In a discussion that recalls Lucy-Anne Hunt's work, he concludes that images were included to reflect the importance of the great Late Antique Christian urban centers. Rina Talgam discusses the Madaba mosaic within a section entitled "Unique Mosaics" and concludes that the mosaic promoted the "sacred identity" of Madaba through its depiction of the biblical past, while also accepting Herbert Donner's recommendation that it was linked to the Late Antique practice of pilgrimage. In contrast, she suggests that the topographic mosaics from Ma'in and St. Stephen promote the Christian identity of their
} 
The potential connection between pilgrimage and the Madaba and other topographic mosaics should not be easily dismissed. In light of the economic importance of religious travel in Late Antique Jordan, the present study investigates what is known about the depicted cities in relation to pilgrimage in the Holy Land and Egypt. Visits to some sites are recorded by locals and foreigners in itineraria and saints'vitae. Like Madaba, some of the cities were part of the pilgrimage route even if they did not contain sacred sites, and information about these more tenuous connections can be gleaned from textual sources and also from sources providing information about the region's Late Antique roadways.

The Madaba composition could be used to orient viewers, both literally and figuratively, to their place in the world. In one respect, it could be used as a guide for pilgrims by providing a visual overview of the region in which they traveled, but it could also be used to identify both the viewer's and Madaba's locus within the Christian world. Richard Talbert has argued that the Peutinger Table's original prototype decorated the apse behind a Roman emperor's throne and emphasized the capital's status through its central location in the composition. ${ }^{42}$ A similar interpretation can be made for the Madaba mosaic. Although the pavement is damaged where the depiction of Madaba would have been, we know that the representation was originally situated adjacent to the Holy City motif and in close proximity to the church's sanctuary, a position that conveys both sanctity and status.

cities at a time when they came under Muslim control. Similarly, Glen Bowersock believes that the topographic mosaics were used by communities to show their place in the Christian world.

${ }^{42}$ Richard J.A. Talbert, "Urbs Roma to Orbis Romanis: Roman Mapping on a Grand Scale," in Ancient Perspectives: Maps and Their Place in Mesopotamia, Egypt, Greece, and Rome, ed. Richard J.A. Talbert (Chicago: University of Chicago Press, 2012), 184. 
Although Piccirillo, Gold, and Donner link the mosaic to Late Antique pilgrimage, the majority of scholars focus on identifying either the geographic sites of the 150 depicted locations or the literary sources used to create the mosaic. The representation of similar cities in other Jordanian mosaics suggests that an examination of the entire corpus within the context of the cultural practice of pilgrimage would be beneficial, especially at St. John the Baptist, St. Stephen, and Ma'in, in which the architectonic motifs are organized to mimic real topography. In each of these mosaics, the city motifs depict sites that are found along known trade or pilgrimage routes.

Unlike the Madaba mosaic, other topographic pavements have received little individual attention; only the architectonic motifs from Ma'in and St. Stephen have been analyzed. However, this research, which links the mosaics to both ecclesiastical politics and roadways, shows that there is merit in investigating the topographic mosaics in sociocultural contexts beyond pilgrimage. The scholarship in these areas has been cursory and is expanded in the current study through an examination of textual sources that refer to Late Antique ecclesial networks and trade, as well as an investigation of the archaeological remains of travel routes in this period.

Many studies of the topographic genre in Jordan have focused on religious interpretations of the mosaics, but it is possible that Late Antique viewers construed the depicted sites in secular contexts as well. Non-spiritual interpretations would have been influenced by both the viewer's knowledge of the region and the combination of motifs in the composition. The present study accepts the idea that the mosaics contain polyvalent messages and focuses on how the topographic mosaics functioned within their architectural space. Its objective is to broaden our understanding of the mosaics' expected 
viewership and the ways in which these observers might have interacted with, and interpreted, the pavements. In Chapter 2, I conduct a spatial analysis of the potential sightlines and patterns of movement over the topographic mosaics within their architectural spaces. This method of investigation allows one to determine the order in which the motifs might have been viewed, and therefore the connections that could be made between them.

\section{I.ii.b. The Church of the Acropolis, Ma'in}

In 1938, Father Roland de Vaux examined the extant depictions of eleven walled cities in the nave pavement of the Church of the Acropolis at Ma'in (Figures 74-84). He proposes that they represented the bishoprics under the authority of the Jerusalem patriarch. ${ }^{43}$ Piccirillo rightly calls this theory into question, as he notes that two of the sites were not bishoprics. Moreover, two of the depicted sites, Belemounta (Ma'in) and Esbounta (Heshbon), were located in Arabia, and thus were under the authority of the Antiochene patriarch. ${ }^{44}$ Despite the fact that bishops and priests are mentioned in several inscriptions linked to the topographic mosaics, their involvement was often limited to a supervisory position and there is no evidence that the mosaics were used as explicit demonstrations of ecclesial politics. ${ }^{45}$

\footnotetext{
${ }^{43}$ Roland de Vaux, "Une mosaïque byzantine à Ma 'in (Transjordanie)." RBibl 47 (1938): 251-252. For more information about the organization of the Church in Late Antique Jordan, see Yiannis E. Meimaris, Sacred Names, Saints, Martyrs, and Church Officials in the Greek Inscriptions and Papyri Pertaining to the Christian Church of Palestine (Athens: National Hellenic Research Foundation, 1986), 5-13.

${ }^{44}$ de Vaux, "Une mosaïque," 257; Piccirillo, Mosaics of Jordan, 36. de Vaux dates the mosaic to the sixth century and suggests that the damage to the mosaic was inflicted during the Muslim conquest, requiring the later repairs to which he ascribes the 719/20 inscription. In contrast, Piccirillo sees no stylistic difference between the mosaic and inscription panel and dates the whole pavement to the later date.

${ }^{45}$ Bishops' names are mentioned in the inscriptions at St. John the Baptist, Sts. Peter and Paul and Khirbat al-Samra, while St. Stephen includes the name of a superior from the monastery at Mt. Nebo. A priest is listed as the donor for the Church of the Priest Wa'il.
} 
I.ii.c. The Church of St. Stephen, Umm al-Rasas

Unlike recent studies of the individual mosaics discussed above, research on the topographic motifs at St. Stephen (Figures 44-71) has been largely iconographic in nature. Piccirillo, one of the principal investigators, brings up some important points that should be considered when examining the rest of the corpus. In his investigation of the topographic mosaic, which contains an outer border of fifteen cities from Palaestina and Arabia and an inner border depicting ten Nile Delta cities, Piccirillo focuses on identifying Umm al-Rasas as Kastron Mefa a, a Roman frontier site known only from textual sources. ${ }^{46} \mathrm{He}$ also notes that the division of the walled-city motifs follows an actual topographic pattern, placing those from the west bank of the Jordan River in the north intercolumnar panels and those from the east bank in the south. Despite this revelation, Piccirillo makes no attempt to determine why cities other than Kastron Mefa'a were chosen. ${ }^{47}$

The idea of visually following the motifs as if moving along a roadway is intriguing. If the cities are plotted on a map in the order they are represented in the mosaic, they form two circular routes, one on each side of the river. Although there are images missing from the $\mathrm{Ma}^{\text {'in }}$ pavement, those that remain are also laid out in a way that reflects the actual topography of the area. In order to look closely at the motifs, one

\footnotetext{
${ }^{46}$ Michele Piccirillo, "Mosaics at Umm er-Rasas," 230.

${ }^{47}$ Ibid., 227. It is also important to note that, while incorporating the traditional Nilotic motifs, the water here clearly is meant to represent the Jordan River. In this light, all other so-called depictions of Nilotic imagery should be reconsidered, as this could significantly alter their interpretations. In terms of viewers being able to read the toponyms on the Madaba mosaic, it is difficult to determine Late Antique literacy rates but one must remember that someone who cannot read a book might be able to read simple words. Priests or other local figures could have provided interpretations for visitors. Additionally, it has been discussed above that certain city motifs were standardized to the point that viewers could possibly identify the depicted sites by their features, depending on their familiarity with either the images or their prototypes. Moreover, the extensive use of text in the Madaba mosaic is in itself a statement of status, as it reflects the assumed literacy of the patron.
} 
must walk along the mosaics as if walking along a roadway, which recalls the function of virtual pilgrimage that Gold suggested for the Madaba mosaic. ${ }^{48}$ Given that many of the depicted cities had connections to pilgrimage and trade, the idea of mimetic movement is investigated further in the present study. Both Umm al-Rasas and Ma'in are known Late Antique pilgrimage sites, which lends credence to my proposal that these mosaics illustrate pilgrimage routes leading to these two churches.

\section{I.ii.d. Studies of Individual Topographic Mosaics: Conclusions}

The previous scholarship on individual topographic mosaics serves as an important foundation for the current study. Many investigations of the Madaba mosaic suggest that the pavement's purpose and function was linked to pilgrimage. Since it has been shown above that the distinction between the Madaba pavement and other topographic mosaics is mainly a question of style rather than content, an inquiry into the possible connection between pilgrimage practices and at least three of the topographic mosaics examined in the present study- Madaba, Ma‘in, and St. Stephen- is justified.

The pavements' connection to Late Antique trade systems is an additional aspect worthy of examination. Piccirillo does not expressly mention trade in his study of the St. Stephen mosaic, though he does note similarities between the layout of the motifs and actual topography. If one plots the depicted cities on a map, it is evident that they follow Late Antique roadways used for travel and trade. The Ma'in motifs can be mapped out in a similar fashion, and the mosaic prominently displays one source of the town's economic wealth, fruit production, between the building motifs. Similarly, the Madaba mosaic highlights agricultural production of important trade materials including salt,

\footnotetext{
${ }^{48}$ Gold, "Mosaic Map,” 50.
} 
bitumen, balsam, and dates. I identify the trees on the St. John the Baptist mosaic as a second type of balsam, which was an economically important crop in Late Antique Egypt.

\section{I.iii. Prior Scholarship: Conclusions}

There have been numerous articles and conference papers examining the topographic motifs of Late Antique Jordan, but the various pavements have been given uneven attention. A few, like the Madaba mosaic, have been the subject of numerous studies, while most of the others merely have been described in archaeological reports or catalogues. Nonetheless, previous scholarship has demonstrated the merit of investigating the topographic pavements as tools for conveying the patron's status through visual associations with centers of pilgrimage and trade. While the brevity of previous studies has limited their focus to select features of the compositions, the current study provides a more in-depth analysis and uses comparanda, textual sources, and archeological information to examine all of the motifs within their cultural contexts. Previous studies have also provided the impetus to open new lines of inquiry and examine both the layout of the city motifs and depictions of accompanying flora as representations of economic success through agricultural production and trade.

Few prior studies have considered the topographic mosaics within their architectural contexts, which limits information about both patronage and viewer reception. The latter is especially important because Late Antique viewers made associations between the depicted cities, and these associations varied depending upon the viewer's knowledge of the sites. The messages the viewers inferred could differ from those the patron intended. The current study provides a spatial analysis for each of the 
nine topographic pavements in order to determine how visitors could have viewed and interacted with the mosaics as the pavements existed within their architectural spaces. It then postulates how this experience might have influenced audience interpretation of the compositions.

\section{Methodology of the Current Study}

The current study adopts a multi-disciplinary approach, utilizing textual sources, iconographic comparisons, and archaeological material to interpret the topographic mosaics. The material is analyzed within a non-Marxist social art historical framework. This methodology is especially important when considering ancient imagery, as it has changed the way scholars have approached visual material culture. In the 1970s, Timothy J. Clark and other scholars of modern art critiqued the continued focus on formalism and iconography and instead championed the examination of art within its cultural contexts. ${ }^{49}$

In some respects, this has been a less important issue for those who study ancient art. Tangentially linked with the field of archaeology, specialists of ancient art commonly use its imagery to explain various social practices of the cultures in question. ${ }^{50}$ However,

\footnotetext{
${ }^{49}$ Timothy J. Clark, Image of the People: Gustave Courbet and the Second French Republic 1848-1851 (Greenwich, CT: New York Graphic Society, Ltd., 1973), 9. Clark's work is centered on a Marxist perspective and, as such, focuses more on class and the economic aspects of artistic production than other cultural considerations. For this reason, many subsequent scholars have broadened the Marxist approach to consider other socio-cultural influences on art, including politics and religion. See, for example, Francis Haskell, History and Its Images: Art and the Interpretation of the Past (New Haven, CT: Yale University Press, 1993); Norman Bryson, Michael Ann Holly, and Keith Moxey, introduction to Visual Culture: Images \& Interpretations, ed. Norman Bryson, Michael Ann Holly, and Keith Moxey (Hanover, NH: University Press of New England (for) Wesleyan, 1994), xv-xxii; Peter Burke, Eyewitnessing: The Use of Images as Historical Evidence (Ithaca, NY: Cornell University Press, 2001), 178-187.

${ }^{50}$ While the field of archaeology has always been concerned with cultural contexts to some extent, a parallel methodology of social archaeology developed in the 1960s, guided by similar Marxist principles. For an overview, see, Michael S. Nassaney, "Social Archaeology," in Archaeology: Encyclopedia of Life Support Systems v. 1, ed. Donald L. Hardesty (Oxford: EOLSS Publishers, 2000), 258-272; Christopher Chippendale, "“'Social Archaeology” in the Nineteenth Century: Is It Right to Look for Modern Ideas in Old Places?" in Tracing Archaeology's Past: The Historiography of Archaeology, ed. Andrew Christenson (Carbondale, IL: Southern Illinois University Press, 1989), 21-33.
} 
these scholars largely use this material to illustrate the history of ancient cultures without considering the objects' roles as cultural artifacts within their particular societies. This is especially true of Roman and Byzantine mosaics, whose iconography has commonly been interpreted as illustrations of Roman-Byzantine daily life. Such studies often disregard the mosaics' architectural context and do not investigate potential meanings held by the original patrons and viewers.

In contrast, social art historians focus on the images' purpose and function. Adherents do not believe that art develops against a cultural "backdrop," but that cultural practices such as religion, politics, and economics actively condition the production of art. Moreover, opposing the Kantian claims of the universal reception of the aesthetic value of art, social art historians believe that imagery is grounded in the socio-cultural roots of the specific culture and period in which it was created. As such, one of the main goals of this methodology is to determine the nature of the relationship between art and the society in which it was created.

This relationship is illustrated in the architectural arrangement of Late Antique churches, the structures and liturgical furnishings of which were modified as needed to reflect regional changes in both early Christian practice and belief. ${ }^{51}$ But it is also true of church mosaics, the patronage of which has come under less scrutiny than the patronage of those from domestic buildings. Social art history dictates that art is embedded in the social processes of the time and place in which it is made. This concept is especially

\footnotetext{
${ }^{51}$ There are many studies on this subject but for ones germane to the Near East, see Lihi Habas' examination of the function and symbolic meaning of the church bema in "The Bema and Chancel Screen in Synagogues and their Origins," in From Dura to Sepphoris: Studies in Jewish Art Society in Late Antiquity, JRA Supplementary Series 40), ed. Lee I. Levine and Zeev Weis (Portsmouth, RI: 2000), 115 120; Marica Cassis, Mensa, Thysiasterion, and Madebha: The Evolution of the Permanent Altar in the Early Christian Church (PhD diss., University of Toronto 2006); Susan Balderstone, Early Church Architectural Forms: A Theologically Contextual Typology for the Eastern Churches of the $4^{\text {th }}-6^{\text {th }}$ Centuries (Melbourne: Australian Institute of Archaeology, 2007); Clark, "Viewing the Liturgy."
} 
relevant to the practice of artistic patronage, as it questions the motivation behind the commission. Drawing from modern concepts of artistic creation, early scholars believed that artists were solely responsible for the choice of motifs in mosaic compositions. However, in the 1970s there was an increased interest in the role of the patron in this process, an idea that has been supported by both textual evidence and closer investigation of Late Antique compositions. ${ }^{52}$ The current study acknowledges the importance of the patron's role in the creation of the topographic mosaics, but with the understanding that motifs were used to delineate different purposes and functions of architectural space. ${ }^{53}$

A growing interest in moving away from a strictly iconographical method for investigating Late Antique mosaics has led to the development of socio-economic approaches, including analyses of their materials and construction techniques, with the goal of identifying patronage patterns as well as macro-economic trends. ${ }^{54}$ This methodology is useful for examining ways in which patrons demonstrated their status to a Late Antique audience that are perhaps less obvious to the modern viewer.

Mosaic patronage is well-attested in Late Antique Jordan, and donors of five of the nine topographic mosaics are named in inscriptions and their portraits were possibly included in four (Tables 6-7). ${ }^{55}$ Inscriptions and portraits were two of many ways that

\footnotetext{
${ }^{52}$ The investigation of mosaic patronage was brought to the forefront of mosaic studies in Dunbabin, Mosaics of Roman North Africa.

${ }^{53}$ Yves Thébert, "Private Life and Domestic Architecture in Roman Africa," in A History of Private Lifefrom Pagan Rome to Byzantium, ed. Paul Veyne (Cambridge, MA: Harvard University Press, 1987), 313409; William Tronzo, "Mimesis in Byzantium: Notes towards the History of the Function of an Image," RES: Anthropology and Aesthetics 25 (Spring 1994): 61-76. Research on the use of specific mosaic motifs to denote the function of architectural space is still quite limited, though these two studies illustrate the merit of such investigations.

${ }^{54}$ Mark Merrony, Socio-Economic Aspects of Late Roman Mosaic Pavements in Phoenicia and Northern Palestine, BAR International Series 2530 (Oxford: Archaeopress, 2013).

${ }^{55}$ For general information about donors in Late Antique Jordan, see Lihi Habas, "Donations and Donors as Reflected in the Mosaic Pavements of Transjordan's Churches in the Byzantine and Umayyad Periods," in Between Judaism and Christianity: Art Historical Essays in Honor of Elisheva (Elizabeth) Revel-Neher, ed. Katrin Kogmann-Appel and Mati Meyer (Leiden: Brill, 2009), 73-90. Donor information is recorded at the
} 
patrons could demonstrate their wealth while permanently reifying their presence within the sacred space of the church. The financial costs of large, high-quality mosaics, such as those examined in this study, would have been immediately recognizable to a Late Antique viewer. Moreover, the location of the mosaic, highly visible in the nave and in axial alignment with the altar, ensured constant attention while emphasizing the privileged ecclesiastical space this donation occupied. These less obvious but equally important aspects of the mosaics and their reflection of the patrons' status are examined in Chapter 2.

While not all of the topographic mosaics' patrons were members of the elite class, evidence suggests that patrons in elevated social positions commissioned the sixthcentury pavements from Jerash. The language used in the churches' dedicatory inscriptions indicates that these individuals received some form of advanced education. In the Late Antique period, this included training in ekphrasis, the description of images, and synkrisis, the comparison of objects within a composition. These exercises would have informed both the way patrons envisioned their compositions and the messages of status they wished to project. Examples of these rhetorical devices, used in the description of Late Antique churches, their decoration, and praise of their patrons are scrutinized in Chapter 2 in order to highlight the reception the donors might expect for their contributions.

Church of St. John the Baptist, the Church of the Priest Wa'il, the Church of the Lions, and the Church of St. Stephen, while the names of clergy who oversaw the building projects are documented at the Church of Sts. Peter and Paul and at Khirbat al-Samra. The mosaic from St. Stephen contains labeled donor portraits of both individuals and communities, while a portrait of Wa'il was possibly the central feature of the composition at the church of the same name. Similarly, donor portraits might have been included in the mosaic from Khirbat al-Samra. The possible identity of the surviving figure in the mosaic from St. John the Baptist at Jerash is discussed below in Chapter 3, pp. 115-118. 
Chapter 3 contains an examination of the pavements within their architectural

contexts in order to determine how patrons intended their mosaics to be read. This

process not only draws from aspects of social art history but also from the related fields

of spatial analysis, phenomenology, and hierotopy. All four are founded on the belief that

space is a social construct and that the objects inhabiting a space play an active role in its

construction. ${ }^{56}$ Spatial analysis is a practical process that allows one to recreate Late

Antique visitors' movements through the churches, as well as to examine how viewers

would have interacted with the topographic mosaics and what they would have seen as

they did so. ${ }^{57}$ Recent studies in Late Antique hierotopy and phenomenology have shown

that patrons and architects gave great consideration to all aspects of church design and

decoration in order to heighten the visitors' awareness of, and interaction with, the

divine. ${ }^{58}$ Most germane to this investigation of the topographic pavements is the work of

Liz James, who examines the apse mosaic in Hagia Sophia and concludes, "The interplay

\footnotetext{
${ }^{56}$ For the theoretical background of the social construction of space, see Henri Lefebvre, La production de l'éspace (Paris: Editions Anthropos, 1974); Bill Hillier and Julienne Hanson, The Social Logic of Space (Cambridge: Cambridge University Press, 1984).

${ }^{57}$ For parallel studies that have helped to inform this dissertation, see Clark, "Viewing the Liturgy"; Ann Marie Yasin, "Sight Lines of Sanctity at Late Antique Martyria," in Architecture of the Sacred, 248-280; Eleftheria Paliou, "Visibility Analysis in 3D Built Spaces: A New Dimension to the Understanding of Social Space," in Spatial Analysis and Social Spaces: Interdisciplinary Approaches to the Interpretation Prehistoric and Historic Built Environments, ed. Eleftheria Paliou, Undine Lieberwirth, and Silvia Polla (Berlin: De Gruyter, 2014), 91-114.

${ }^{58}$ Alexei Lidov, "Hierotopy: The Creation of Sacred Spaces as a form of Creativity and Subject of Cultural History," in Hierotopy: The Creation of Sacred Spaces in Byzantium and Medieval Russia, ed. Alexei Lidov (Moscow: Progress-tradition, 2006), 32-58; Bissera V. Pentcheva, "The Performative Icon," ArtB 88, no. 4 (December 2006): 631-655; The Sensual Icon: Space, Ritual, and the Senses in Byzantium (University Park, PA: Penn State University Press, 2010); "Icons of Sound," Stanford University, accessed June 18, 2014, http://iconsofsound.stanford.edu/index.html; Amy Papalexandrou, "Echoes of Orality in the Monumental Inscriptions of Byzantium," in Art and Text in Byzantine Culture, ed. Liz James (Cambridge: Cambridge University Press, 2006), 161-186. Lidov presents a detailed discussion of hierotopy in the medieval east and west. Pentcheva is one of the most influential scholars in the area of phenomenology. She examines the viewer's interaction with icons in light of other sensory stimuli including touch, smell, and sound, and is currently involved with Stanford University's "Icons of Sound" project, a collaboration between its Department of Art and Art History and its Center for Computer Research in Music and Acoustics that investigates the role that acoustics had in the architectural and aesthetic program of Hagia Sophia. Similarly, sense of sound is the focus of Papalexandrou's work. She is interested not only in building acoustics but also the interactive and multisensory nature of inscriptions.
} 
of the five senses around the object opened its audience to a fuller perception of its meaning and purpose. ${ }^{, 59}$ Analyzed in conjunction with the archaeological evidence of liturgical furnishings and Late Antique texts discussing contemporary concepts of hierarchical space, the visibility analysis conducted in Chapter 3 provides insight into the topographic mosaics' intended and inferred socio-symbolic meanings. It is my assertion that some patrons carefully chose the individual topographic motifs and placed them in such a way within both the compositions and the church that they conveyed more specific messages about the building's purpose.

The topographic mosaics' setting within ecclesial spaces does not preclude nonreligious interpretations of the compositions. Church patrons commonly drew from secular iconography to illustrate their status, including the use of hunting scenes, which had a long tradition as representations of elite leisure activities. ${ }^{60}$ Likewise, choosing specific cities for the topographical compositions expressed another form of status and conveyed messages beyond generic urban pride. One might expect to see visual references to the most politically and religiously influential cities in this area during the Late Antique period: Jerusalem, Antioch, Bosra, and Constantinople. Of these, only Jerusalem appears and then only twice, on the mosaics from Madaba and St. Stephen. Instead, Egyptian cities are highlighted, as are a number of lesser cities from Palaestina and Arabia. While the Egyptian cities have been connected to Nilotic imagery, they were also important religious, political, and economic centers. Such cultural interpretations

\footnotetext{
${ }^{59}$ Liz James, "Senses and Sensibility in Byzantium," Art History 27, no. 4 (September 2004): 531.

${ }^{60}$ For a discussion of the meaning behind the hunting images, see Dunbabin, Mosaics Greek and Roman, 44-48. For a description of the hunting mosaics found in Jordan, refer to Mohammad Nassar, "The Art of Decorative Mosaics (Hunting Scenes) from the Madaba Area during the Byzantine Period (5 $5^{\text {th }}-6^{\text {th }}$ c. AD)" Mediterranean Archaeology and Archaeometry 13, no. 1 (2013): 67-76.
} 
would have been apparent to viewers, with the nature of those interpretations dependent upon the viewer's level of familiarity with the depicted sites.

In contrast with the presence of Egyptian motifs, the representation of local cities seldom occurs in Late Antique mosaics. The Jordanian examples make up the majority of this rare theme which, unlike Nilotic scenes, have no connection to established iconographic and ideological traditions. Instead, visitors would have interpreted these motifs solely on the basis of what they knew about the chosen cities' economic, political, and religious history. In this way, the images are a reflection of "common sense geography." Unlike scientific geography, common sense geography explores the shared and intuitive information about a place that a general population has access to. This information can come from direct experience, accounts from others, textual sources (both "scientific" and "intuitive"), and images. ${ }^{61}$ To better understand how Late Antique viewers might have interpreted the topographic images in the Late Antique period, Chapter 4 includes an examination of textual sources containing references to the sites in question. These sources are diverse and include mention of the cities, with various degrees of specificity, in vitae of religious figures, pilgrim intineraria, and other travel literature. This textual information is supplemented by the archaeological evidence of the cities, and by information pertaining to activities like pilgrimage and trade in order to understand what was commonly known about the sites and how this information might affect interpretation of the topographic mosaics.

\footnotetext{
${ }^{61}$ Klaus Geus and Martin Therin, "Common Sense Geography and Mental Modelling: Setting the Stage," in Features of Common Sense Geography: Implicit Knowledge Structures in Ancient Geographical Texts, ed. Klaus Geus and Martin Therin (Münster: LIT Verlag, 2014), 56; Anca Dan, Klaus Geus, and Kurt Guckelsberger, "What is Common Sense Geography?: Some Preliminary Thoughts from a Historical Perspective," in Features of Common Sense, 20.
} 


\section{CHAPTER 2:}

\section{THE TOPOGRAPHIC MOSAICS, PATRONAGE, AND SHIFTING PATTERNS OF EUERGETISM AND PUBLIC DISPLAY IN LATE ANTIQUE JORDAN}

The rise of the Church in Late Antique Jordan presented new opportunities for euergetism, especially within small communities like Umm al-Manabi ${ }^{‘}$, Khirbat alSamra, and Ma'in, all of which previously lacked monumental buildings. In both the East and the Roman West, there had been a longstanding tradition of donating public works in exchange for commemoration, usually in the form of a statue or inscription. While the history of this practice cannot be traced at the majority of the sites investigated in this study, Jerash provides an excellent opportunity to examine the shifting patterns of euergetism as Roman control dissipated and the Church's authority grew in the Late Antique period. In the first part of this chapter, the two topographic mosaics from Jerash are used to demonstrate the ways in which patrons in larger, Greco-Roman influenced centers adapted both donations and commemorations within this changing social climate. While the Near East had its own traditions of euergetism, the topographic mosaics and inscriptions from the other sites examined in this study suggest that it was the Church that initiated and/or encouraged this practice in smaller centers that had been less influenced by Greco-Roman customs.

Church mosaics provided Late Antique donors with a number of highly visual methods of proclaiming their elevated position within the community. The size and quality of the pavement, its location within the church, and the inclusion of certain 
motifs, inscriptions, and patron portraits all provided affirmation of the donor's wealth and status. An analysis of these aspects in the second portion of this chapter demonstrates the various ways in which the topographic mosaics were carefully designed to emphasize the patron's prominence within the community, while still portraying compositions appropriate to the specific types of church they decorated.

In most mosaic studies, church pavements are examined separately from those found in domestic or secular public buildings. What differentiates the analyses between secular and religious mosaics is that in the former, the patrons' consideration of both their audience and the function of the specific spaces the pavements decorate are taken into consideration. In previous investigations of the topographic mosaics, scholars have not taken the functions of the individual buildings into account. Instead of reading the topographic compositions within the context of "funerary church" or "pilgrimage church," and so forth, scholars have instead tried to provide generic religious interpretations. These have included suggestions that the city motifs are symbols of Late Antique ecclesiastical affiliations or representations of Christian philosophical beliefs. I do not wish to argue that these postulations are completely incorrect; however, evidence from both the inscriptions and the iconography suggests that more specific meanings were intended in some mosaics, while others provided opportunities for polyvalence.

Previous scholars' interpretations are based on the undeclared assumption that church officials had the sole decision in selecting the compositions and individual motifs. However, the language used in the dedicatory inscriptions indicates that, despite the common inclusion of clergy's names, the majority of topographic mosaics were donated by laypeople. Moreover, the subjects they chose, including hunting and vintaging scenes, 
had been used for hundreds of years in domestic settings to proclaim personal wealth and status. Shifting the focus to the mosaics' patrons allows one to consider new socioeconomic interpretations of the topographic motifs.

The prior focus on the topographic mosaics' Christian settings has led scholars to ignore other possible cultural influences that affected their creation. One of the goals of employing the term "Late Antique" in the current study is to lessen the artificial dichotomy that has developed between the interpretations of Roman and Byzantine cultures. In the latter, the religious aspect is often overemphasized to suggest a complete break from an earlier and distinct culture. However, it is now generally accepted that, even though the majority of the population changed its religious beliefs, many cultural practices remained the same or were altered subtly over time. Christian principles were not responsible for all cultural transitions; some were part of the natural evolution of Greco-Roman culture toward the end of the Imperial period. In the case of Jerash, archaeological and textual evidence shows that the Greco-Roman system of euergetism did not disappear. However, modifications occurred in the Late Antique period, both in regards to what people donated and how these gifts were recorded. By the time topographic motifs appeared in the sixth century, the practice of euergetism had been absorbed into the now mostly Christian culture and had spread to smaller communities in Palaestina and Arabia.

I. Shifting Patterns of Euergetism and Public Display in Late Antique Jerash

Few Jordanian sites have been excavated as completely as Jerash, which makes it an excellent candidate for the investigation of shifting patterns of euergetism in eastern cities in the Late Antique period. The Romanization of this cultural practice has been 
well-documented in Egypt and Israel but less so in Jordan. ${ }^{1}$ The understanding of euergetism at Jerash has been complicated by the chronological separation between the "Roman" and "Byzantine" city; studies of the latter have ignored questions of patronage in favor of formal analyses of the Christian buildings. The following case study is relevant to this dissertation in that it demonstrates the specific way in which elite members of Jerash's community continued the practice of euergetism in the Late Antique period, subtlety adapting the Greco-Roman aspects of commemoration to Christian use. Jerash is atypical of the sites examined in this study, the rest of which had indigenous populations that were largely uninfluenced by Greco-Roman traditions. Nonetheless, the evidence at Jerash indicates that it was less the practice of euergetism that changed over time than the individuals who practiced it. In the Late Antique period, bishops (who largely came from elite families) assumed the role of civic administrators in centers like Jerash, and continued the practice of public works. These individuals brought the practice to smaller centers, where they encouraged the local population to contribute to the construction and dedication of churches such as those investigated in this study.

The more than 150 extant Late Antique churches in Jordan serve as strong illustrations of Late Antique patronage practices. Almost seventy of these buildings contain dedicatory inscriptions naming benefactors and indicating that both individuals

\footnotetext{
${ }^{1}$ Peter van Minnen, "Hermopolis in the Crisis of the Roman Empire," in After the Past: Essays in Ancient History in Honor of H. W. Pleket, ed. W. Jongman and M. Kleijwegt (Leiden: Brill, 2002), 285-304; Jane Draycott. "Who is Performing What, and for Whom? The Dedication, Construction, and Maintenance of a Healing Shrine in Roman Egypt," in Medicine, Healing, and Performance, ed. Effie Gemi-Iordanu, et al. (Oxford: Oxbow Books, 2014), 42-54; Seth Schwartz, "Euergetism in Josephus and the Epigraphic Culture of First-Century Jerusalem," in From Hellenism to Islam: Cultural and Linguistic Change in the Roman Near East, ed. Hannah M. Cotton, et al. (Cambridge: Cambridge University Press, 2009), 75-92; Steven Fine, "Between Liturgy and Social History: Priestly Power in Late Antique Palestinian Synagogues?" in Art, History, and Historiography of Judaism in Roman Antiquity, ed. Steven Fine (Leiden: Brill, 2013), 181-193. Studies in Egypt center on cities like Hermopolis, while several sites, including Caesarea, Jerusalem, and Sepphoris are investigated in Israel.
} 
and groups contributed to the projects. The churches decorated with topographic mosaics contain numerous inscriptions, many of which directly reference contributions toward the buildings and pavements. Such patronage echoes Greco-Roman and local traditions of civic euergetism in the Hellenistic and Imperial periods. From the first century BCE to the third century CE, members of the elite class demonstrated their status through the construction and decoration of both public and domestic structures. In addition to their lavish villas, the wealthy contributed to public works and organized a variety of spectacles for the local population. $^{2}$

Evidence of these earlier civic contributions is rare in Jordan. It is difficult to determine if this lacuna is due to different cultural practices amongst the indigenous populations or to less complete textual and archaeological records. It is challenging to make comparisons between regions and periods, as the thoroughness of archaeological investigations have varied. In Jordan, members of the Franciscan and Dominican orders have undertaken many of the excavations, and this work has often focused on Christian churches at the expense of other buildings. In some areas, like Madaba, the modern city's density has restricted excavations and only select structures have been uncovered. For these reasons, our understanding of the Late Antique ancient urban landscape is limited at many of the sites investigated in the current study, and these factors also create

\footnotetext{
${ }^{2}$ Benjamin W. Porter, "Authority, Polity, and Tenuous Elites in Iron Age Edom (Jordan)," OJA 23, no. 4 (2004): 373-395; Samuel Rocca, Herod's Judea: A Mediterranean State in the Classic World (Eugene, OR: Wipf and Stock Publishers, 2015), 37-52; Schwartz, "Euergetism in Josephus," 75-92; Jérôme Yon, "Euergetism and Urbanism in Palmyra," in Recent Research in Late Antique Urbanism, JRA Supplementary Series 42, ed. Luke Lavan (Portsmouth, RI: Journal of Roman Archaeology, 2001): 173181. Evidence exists for indigenous customs of euergetism in Iron Age Jordan; however, there is no evidence to suggest that it was continuously practiced in the area. In the first century BCE, the client King Herod I was an enthusiastic adopter of Hellenistic traditions, including the provision of grain for the poor, patronage of the arts, and the construction of buildings in Caesarea and other cities. In some instances, his donations are preserved through inscriptions, while others are recorded by Josephus. In the Roman period, other cities benefited from extensive civic donations, especially the trade city of Palmyra in the province of Syria.
} 
challenges when assessing patterns of euergetism in Late Antique Jordan. Nonetheless, surviving evidence suggests shifts in the civic patronage system beginning in the fourth century.

While scholars have examined both Greco-Roman and early Christian euergetism in the East, little work has been done to document changes to the practice that occurred between these two time periods. Jerash's monuments and inscriptions bridge this gap, clearly illustrating the shifting patterns of civic donation in the Late Antique period. This important city on one of the major eastern Roman trade routes was large enough to warrant numerous monumental structures, including a forum, baths, an amphitheater, and two theaters from the Imperial period, as well as at least fourteen early Christian churches. Its excavated structures and inscriptions are well documented, which allows for a thorough chronological investigation of civic donations and their commemoration. While Jerash is not typical of all cities housing topographic mosaics, it is indicative of the larger Late Antique centers in the region that directly or indirectly influenced smaller Christian communities.

Jerash came under control of the newly formed Roman province of Syria in 63 BCE, but the settlement did not flourish until the Nabateans expanded their trade network into this area during the first century CE. At this time Jerash became one of the major stations on the King's Highway trade route running between Memphis and Syria. ${ }^{3}$ Between the first and third quarters of the first century, the people of Jerash reorganized their city on a Roman plan with paved and colonnaded streets, and also built a large temple complex dedicated to Zeus. The first dedicatory inscriptions appear at this time, and commemorate both public and private patronage of these projects.

\footnotetext{
${ }^{3}$ Graeme Donnan, The King's Highway (Amman: Al Kutbah, 1994), 94.
} 


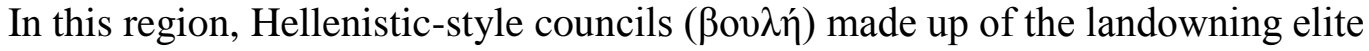
oversaw municipal affairs in larger metropoleis during the Roman period. ${ }^{4}$ The earliest reference to a civic council in Jerash is found in first-century CE inscriptions that

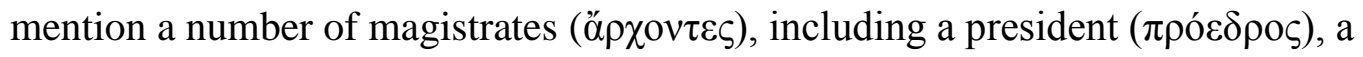
secretary $(\gamma \rho \alpha \mu \mu \alpha \tau \varepsilon v ́ \varsigma)$, and fiscal officials $(\delta \varepsilon \kappa \alpha \pi \rho \tilde{\omega} \tau о \varsigma) .{ }^{5}$ Between at least the first century and the late third century $\mathrm{CE}$, these magistrates were responsible for the erection of temples, stoae, altars, and honorific statues. While it is clear that many of these operations were undertaken at public expense, the language in select inscriptions suggests that perhaps some contributions were made by private citizens. ${ }^{6}$ Other officials were responsible for overseeing athletic games, public events, and civic institutions. ${ }^{7}$ These

${ }^{4}$ Fergus Millar, The Roman Empire and Its Neighbours (New York: Holmes \& Meier, 1981), 60.

${ }^{5}$ Charles Bradford Welles, "The Inscriptions," in Gerasa: City of the Decapolis, ed. Carl Hermann Kraeling (New Haven, CT: Yale University Press, 1936), 395-396, inscription nos. 45-46. Unfortunately, the inscriptions are damaged and do not record the type of buildings that the assembly constructed. For a description of the council and other civic positions, see Julian Bowsher, "Civic Organization of the Decapolis," ARAM 4 (1992): 272-275.

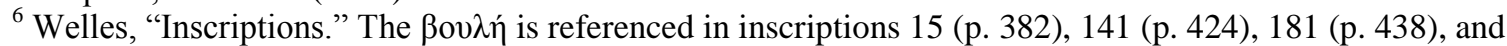
189 (p. 441). The first three date to the second century, while the fourth dates to the middle of the third. In addition to nos. 45 and 46, an ö $\rho \chi \omega v$ is mentioned in inscription no. 47 (p. 409), dated to the mid-third century. Nos. 73 (p. 408) and 190 mention the $\pi \rho \varepsilon_{\varepsilon} \delta \rho o \varsigma$. The latter is dated to the mid-third century. Welles dates the former to the late third century based on the wording (and the inclusion of the title " $\pi \rho$ ó $\delta \rho \rho \varsigma$ "); however, he notes that the individual's name, Symmachos, is common in the Byzantine period and that the letter forms could also indicate a later date. A $\gamma \rho \alpha \mu \mu \alpha \tau \varepsilon v ́ \varsigma$ was possibly mentioned in inscription no. 181 (p. 438), dated to 117, but there is no conclusive proof. Individual councilors

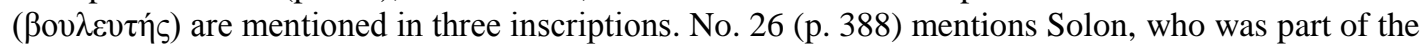

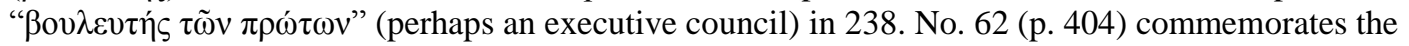
donation of a mosaic by the councilor Flavius Mounatius, a member of the equestrian rank who also served as a senior magistrate ( $\sigma \tau \rho \alpha \tau \eta \gamma o ́ \varsigma)$ in Jerash in the mid-third century. No. 170 (p. 434) marks the dedication of a statue in the second quarter of the third century by a Syrian councilor and president of an athletic

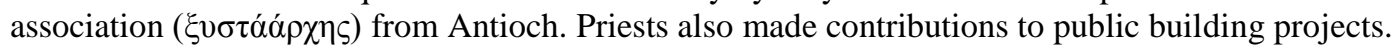
Zabdion, an imperial priest of Tiberius, contributed towards a temple, likely the Temple of Zeus, in 22/23 CE (no. 2, pp. 373-374).

${ }^{7}$ Welles, "Inscriptions." Such contributions are recorded in both inscriptions and in rabbinic sources. Gymnasiarchs ( $\gamma v \mu v \alpha \sigma i \alpha \rho \chi 0 \varsigma)$ were responsible for overseeing the gymnasiums and their adjoining baths. Three are mentioned at Jerash, two in relation to first-century dedications at the Temple of Zeus (inscriptions nos. 42-43, pp. 374-376), and a third from the second century, inscription no. 192 (p. 442444). Bowsher suggests that this position was only held for six months at a time, given the great expenses incurred by the official ("Civic Organization," 274). Similarly, a "judge of the contests" or "president of the

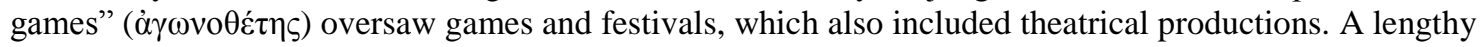
inscription from the southern theater in Jerash (Welles, "Inscriptions," no. 192, p, 442-444) mentions that a group of actors dedicated a statue in honor of the city's first à $\gamma \omega v o \theta \dot{\varepsilon} \tau \eta \varsigma$, Titus Flavius Gerrenus, during 
officials were often required to pay summae honorariae, mandatory contributions that helped fund events and activities. ${ }^{8}$ There are also many inscriptions memorializing donors who did not have civic titles. It is possible that these benefactors contributed large sums to building projects and events in the hope of being considered for prestigious and culturally important civic positions. ${ }^{9}$ In other instances it is obvious that donors with limited sums of money, as well as guilds of craftsmen and merchants, purchased smaller objects. ${ }^{10}$ The munificence of both elites and non-elites was commemorated through inscriptions that adorned their donations. These buildings and objects were in some of Jerash's most-visited locales: the theater, the odeion (which also served as the council assembly space), the hippodrome, the temples, and the forum. In addition, wealthy individuals or important officials who made larger contributions had their status further

Trajan's reign. In addition to "providing the requirements" of all the festivals, he hosted lavish banquets during these events. A more detailed explanation of the ả $\gamma \omega v 0 \theta \varepsilon \dot{\tau} \tau\rceil \varsigma$ position is provided by Daniel Sperber, The City in Roman Palestine (Oxford: Oxford University Press, 1998), 86-88.

${ }^{8}$ Zeev Weiss in "Theaters, Hippodromes, Amphitheaters, and Performances," in The Oxford Handbook of Jewish Life in Roman Palestine, ed. Catherine Hezser (Oxford: Oxford University Press, 2010), 625-626; Zeev Weiss, Public Spectacles in Roman and Late Antique Palestine (Cambridge, MA: Harvard University Press, 2014), 172-174; Maurice Satre, The Middle East Under Rome, trans. Catherine Porter and Elizabeth Rawlings (Cambridge, MA: Belknap Press, 2005), 156-158. Both authors provide a brief summary of regional civic and public benefactors, and Weiss includes specific examples of such donations recorded in inscriptions and rabbinic sources.

${ }^{9}$ Bowsher, "Civic Organization," 273; Alexandra Retzleff and Abdel Majeed Mjely, "Seat Inscriptions in the Odeum at Gerasa (Jerash)," BASOR 336 (November 2004): 40; Arjan Zuiderhoek, "Oligarchs and Benefactors: Elite Demography and Euergetism in the Greek East of the Roman Empire," in Political Culture in the Greek City after the Classical Age, ed. Onno M. van Nijf and Richard Alston (Leuven:

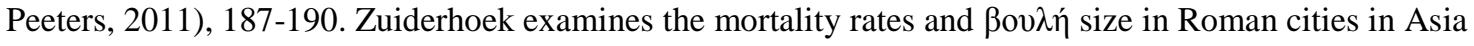
Minor. He argues convincingly that most cities would be required to offer council membership to wealthy but non-elite males in order to meets the numbers required for the assembly, and he provides textual evidence that this was put into practice. At Jerash, it has been estimated that the Council contained up to 600 men, based on the seating capacity of the North Theater. It is not inconceivable to think that wealthy men would engage in civic patronage to prove their wealth and gain the notice of the elite in order to be

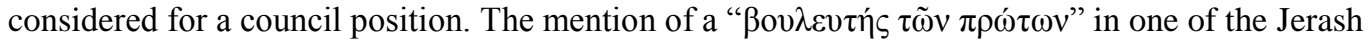
inscriptions might refer to an executive council made up of elite males, separated by title from their nonelite counterparts (Welles, "Inscriptions," no. 26, p. 388). Retzleff and Mjely suggest that Jerash's ßovגí might have been as large as 275 men, occupying one portion of the North Theater. Bowsher posits that the

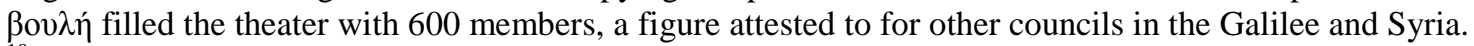

${ }^{10}$ Welles, "Inscriptions," nos. 75-104 (pp. 409-414); Emilio Olvarri Goicoechea, Excavaciones en el agora de Gerasa en 1983 (Madrid: Dirrección General della Bella Artes y Archivos, 1986), 19-26, 33-38. Individual craftsmen, merchants, and professional guilds were responsible for donating individual columns in the Oval Forum. 
proclaimed by the dedication of honorific statues in prominent locations within the city. ${ }^{11}$

In this way, the portraits and inscriptions (and, to some extent, the objects and buildings on which they were found) memorialized in perpetuity the patrons as well as their wealth and status, a function similarly served by the funerary monuments that lined Jerash's North Gate road.

At Jerash, the inscriptions mentioning acts of euergetism by individuals holding civic titles have been dated between the first and the mid-third centuries CE, and the honorific statues between the second and the late-third centuries. ${ }^{12}$ The rise of dedicatory inscriptions referencing civic titles in the second century, and the decline of such inscriptions in the late third century follows a widespread trend in cities throughout the Roman Empire. Scholars have adopted two opposing positions in an effort to explain the apparent modifications in civic patronage and its commemoration. The traditional view is that an empire-wide financial crisis in the third century forced the end of public building programs, and several scholars posit that this economic depression also caused a breakdown in the imperial administration of Roman cities. ${ }^{13}$

\footnotetext{
${ }^{11}$ Elise Friedland, "Marble Sculptures from the North Hall of the East Baths at Gerasa," AJA 107, no. 3 (July 2003): 414-415. In 1984, excavations of the East Baths uncovered two portrait statues of local citizens, one belonging to the equestrian class, both dated to the mid-second century. With the exception of these, few dedicatory statues have survived in Jerash; however, of the 319 inscriptions described in the 1930s excavation report, nine belonged to statues of emperors (Welles, "Inscriptions," nos. 141, 142, 143, $145,147,155,157,158,160, \mathrm{pp} .424-430$ ), three of provincial governors (nos. 165, 168, 170, pp.433-434), and one of a military tribune (174, pp. 435-436). One statue belonged to a local official, an ó $\gamma \omega v 0 \theta \dot{\varepsilon} \tau\rceil \varsigma$ (no. 192, pp.442-444). Another five commemorate men without titles (nos. 182, 183, 186, 188, 190, pp.439-442).

${ }^{12}$ Welles, "Inscriptions," 373-494. Of the 319 inscriptions published by Welles, he dates twenty-seven to the first century, two to the late second/early third century, 105 to the second century, twenty-seven to the late second/early third century, fifty to the third century, and five to the late third/early fourth century. ${ }^{13}$ Wolfgang Liebeschuetz, "The End of the Ancient City," in The City in Late Antiquity, ed. John Rich (London: Routledge, 1992), 1-49; Andrew Wilson, "Cyrenaica and the Late Antique Economy," in Ancient West and East v. 3, no. 1, ed. Gocha Tsetskhladze (Leiden: Brill, 2004),143-153; Veronika ScheibelreiterGail, "Inscriptions in the Late Antique Private House: Some Thoughts about their Function and Distribution," in Patrons and Viewers in Late Antiquity, ed. Stine Birk and Birte Poulsen (Aarhus: Aarhus University Press, 2012), 136-137, especially note 8. Liebeschuetz provides a generalized outline of the suggested economic decline in the Late Antique period, while Wilson and Scheibelreiter-Gail present more
} 
Perhaps the greatest problem with these theories is that many scholars use the decreasing number of dedicatory inscriptions, and the corresponding decline in the appearance of civic titles in these inscriptions, as primary evidence of the Empire's thirdcentury economic and political decline. ${ }^{14}$ In turn, they cite these "disruptions" to explain the paucity of new buildings and inscriptions in the late third and fourth centuries.

Recognizing the lack of persuasive evidence indicating significant economic or political disruption, some scholars have suggested that the changes in the material record reflect shifting cultural attitudes toward both urban planning and civic patronage. ${ }^{15}$

Christian Witschel rejects the idea of an empire-wide crisis in the third century and reevaluates several forms of evidence that previous scholars have used to support the theory of recession. In terms of dedicatory statues, he notes that one must treat the apparent decline cautiously, as the phenomenon occurs even in areas where the thirdcentury archaeological record suggests prosperity. ${ }^{16}$ A similar case could be made for Jerash, for which there is no evidence of an economic decline in this period. The use of spolia in Jerash's Late Antique churches is often used as an indication of an economic

recent and specific studies. Wilson examines the proposed economic decline in light of the production of building materials, trade goods, and public euergetism in Cyrenaica, but also includes general suppositions about the Late Antique Mediterranean. Scheibelreiter-Gail studies the rising number of inscriptions within domestic structures in the East from the mid-third century onward and attributes this phenomenon to both an economic crisis and the diminishing number of public offices available under the Byzantine emperors.

${ }^{14}$ For the decrease in civic titles in Late Antique prosopography, see T.D. Barnes, "Latin Epigraphy and the History of the Western Roman Empire after Constantine," in XI congresso internazionale di epigrafia Greca e Latina, 18-24 settembre 1997, v. II (Rome: Edizioni Quasar, 1999), 565-576.

${ }^{15}$ Hugh Kennedy, "Gerasa and Scythopolis: Power and Patronage in the Byzantine Cities of Bilad alSham," BÉO 52 (2000): 199-204; Ine Jacobs, “'Encroachment' in the Eastern Mediterranean between the Fourth and Seventh Century AD," Ancient Society (2009): 203-244. Parallels are found in the revaluation of the economic situation in fourteenth-century Jordan under Mamluk patronage. See Bethany Walker, "Mamluk Investment in Transjordan: a "Boom and Bust" Economy," Mamluk Studies Review 8, no. 2 (2004): 119-147.

${ }^{16}$ Christian Witschel, "Re-Evaluating the Roman West in the $3^{\text {rd }}$ c. A.D.," JRA 17 no. 1 (2004): 251-281, especially 257. See also Barbara E. Borg, "Bilder für die Ewigkeit oder glanzvoller Auftritt?," in Statuen in der Spätantike, ed. Franz Alto Bauer and Christian Witschel (Wiesbaden: Reichert Verlag, 2007), 43-69. 
downturn, but this does not take into account other reasons for the reuse of building materials, such as the visual appropriation of power. ${ }^{17}$

Theories focusing on shifting cultural patterns rely on an understanding of the performative nature of buildings and their inscriptions, and also on the knowledge that the social significance of public spaces changes over time. A. Simon Esmonde Cleary uses this approach to explain why public munificence became less important in Roman cities towards the third century. He notes that buildings and inscriptions were social instruments in Imperial Rome, and were used to secure both an individual's status within the community and the city's status within the empire. Cleary argues that as the social order became more established, there was less need for individuals to demonstrate their status through public works, buildings, and inscriptions. ${ }^{18}$ This model of cultural transition is reflected at Jerash, where both a Greco-Roman urban structure and its social traditions were adopted, but there is no indication of the same type of transition in the other sites examined in the current study, which had greater concentrations on indigenous inhabitants in the Roman period.

During the second century, Jerash truly transformed itself into a Roman city with the erection of a number of cultural institutions - a hippodrome, an odeion, public baths, and a triumphal arch - that highlighted its wealth and status within the Empire. Likewise, Jerash's leading citizens adopted the Roman cultural tradition of euergetism and contributed to these projects as part of their civic obligations and as an expression of their

\footnotetext{
${ }^{17}$ Ludovico V. Geymonat, "The Syntax of Spolia in Byzantine Thessalonike," in Approaches to Byzantine Architecture and its Decoration: Studies in Honor of Slobodan Ćurčić, ed. Mark J. Johnson, Robert Ousterhout, and Amy Papalexandrou (Burlington, VT: Ashgate, 2012), 47-66. While not specific to Jerash, Geymonat provides a thorough analysis of the use of spolia in the Byzantine world.

${ }^{18}$ A. Simon Esmonde Cleary, The Roman West, 200-500: An Archaeological Study (Cambridge: Cambridge University Press), 459-460.
} 
status within the community. These contributions were memorialized in the Roman manner through inscriptions and honorific statues. As euergetism became the social norm, non-elite citizens also contributed, with smaller public donations made individually or through professional associations. By the end of the third century, both Jerash and its citizens had established their status and there was little need for additional public buildings. Although some traditions continued, Late Antique inscriptions and buildings from Jerash support the suggestion that social practices were adjusted as cultural attitudes shifted and the city's administration changed hands from the $\beta$ ov $\lambda \dot{\eta}$ to the Church. ${ }^{19}$

It is indisputable that there are fewer inscriptions dated to fourth-century Jerash than from previous centuries. Welles attributes only eight of the 361 inscriptions in his catalogue to this period, and four of these record acclamations of Julian on milestones outside the city. ${ }^{20}$ The other four record the erection of imperial honorific statues by local or regional magistrates. ${ }^{21}$ This situation is mirrored at other Late Antique sites and the concurrent rise in imperial portraits and their accompanying verse-epigrams has been interpreted by some as a move away from commemorative sculptures in favor of decorative ones. ${ }^{22}$ However, in light of Cleary's theory, one can also interpret this as a shift away from promoting individuals within the local urban context and toward promoting the city itself within the larger context of the empire.

In 284, Diocletian shifted the empire's political center eastward, a move that culminated in the establishment of Constantinople as the capital in 324. This provided

\footnotetext{
${ }^{19}$ For the role of the bishop in Late Antique politics, see Peter Norton, Episcopal Elections 250-600: Hierarchy and Popular Will in Late Antiquity (Oxford: Oxford University Press, 2007), 69.

${ }^{20}$ Welles, "Inscriptions," nos. 345-348 (pp. 489-490).

${ }^{21}$ Welles, "Inscriptions," nos. 103, 104 (p. 414), 160 and 161 (p. 431), all of which date between the late third century and the beginning of the fourth.

${ }^{22}$ Liebeschuetz, "End of the Ancient City," 5.
} 
opportunities for eastern officials to promote themselves and their cities in hopes of currying favor, while eastern emperors made administrative changes that provided strong incentive for such self-promotion. But Jerash's focus was not completely outward; public donations in return for personal recognition continued well into the sixth century, though the buildings, activities, and sponsors changed as the Church's influence extended into civic life. From the fourth century onward, the city council's role in organizing public building and communal events in the Greek East diminished. This power vacuum was filled by high-ranking members of the clergy, and bishops became active benefactors in their communities. Despite their religious affiliation, most bishops came from the same elite class as other influential donors, and it was part of their cultural practice to perform such acts of euergetism both to fulfill the social obligations of their class and to reaffirm their emerging status within the community. ${ }^{23}$ At Jerash, for example, Bishop Placcos paid for the construction of a public bathhouse in 454/457, while Bishop Paul donated a prison for those awaiting trial in $539 / 540 .^{24}$

The rise of Christianity also influenced the conception of public space in Late Antique societies. In Roman times, euergetism focused on areas where people congregated, especially in theaters and sports arenas. Church officials increasingly opposed such activities, and eventually the responsibility for producing these events was transferred from the $\beta$ ov $\lambda \eta$ to other groups and individuals, before being phased out in

\footnotetext{
${ }^{23}$ For a discussions of the social class of bishops in both the East and West, see Claudia Rapp, "The Elite Status of Bishops in Late Antiquity in Ecclesiastical, Spiritual, and Social Contexts," Arethusa 33 (2000): 379-399; Claudia Rapp, "Bishops in Late Antiquity: A New Social and Urban Elite?," in Elites Old and New in the Byzantine and Early Islamic Near East, Studies in Late Antique and Early Islam v. 6, ed. John Haldon (Princeton, NJ: Darwin Press, 2003), 144-173.

${ }^{24}$ Pierre-Louis Gatier, "Nouvelles inscriptions de Gérasa," Syria 62 no. $3 / 4$ (1985): 297-305.
} 
the sixth century. ${ }^{25}$ As these venues were abandoned, wealthy citizens internalized messages of their elite status within their homes, through wall paintings, decorative objects, and inscriptions on mosaics. ${ }^{26}$ However, there was also a new type of public building that notable members of society could patronize and use to publicize their elevated social position: churches. Jerash had at least fourteen churches and numerous chapels; all but one have been dated to the second half of the fifth century or later. ${ }^{27}$ Despite the fact that in many Late Antique communities the bishop assumed the role of local magistrate, including civic benefaction, few churches in Jerash were actually financed by bishops or other members of the clergy. ${ }^{28}$ Instead, local citizens contributed to ecclesiastical buildings as demonstrations of their faith and their status within the community, linking themselves to the bishop through inscriptions. Jerash's Greco-Roman cultural milieu structured a practice of public patronage that continued into the Late Antique period, when the custom was adapted into an increasingly Christian society.

\footnotetext{
${ }^{25}$ Weiss, Public Spectacles, 227-254, especially p. 249; Antoni A. Ostrasz, "The Hippodrome of Gerasa: A Report on Excavations and Research," Syria 66, no. 1 (1989): 73-75. An inscription dated to 578 attests to the continuation of the Blue faction into the sixth century. For a discussion of the significance of this inscription, see Fawzi Zayadine, "The Jerash Project for Excavation \& Restoration: A Synopsis with Special Reference to the Work of the Department of Antiquities," in Jerash Archaeological Project, 1981 1983, ed. Fawzi Zayadine (Amman: Department of Antiquities of Jordan, 1986), 17-18.

${ }^{26}$ Scheibelreiter-Gail, "Inscriptions in the Late Antique," 137-138.

${ }^{27}$ David Kennedy, Gerasa and the Decapolis (London: Bloomsbury, 2013), 101, Table 4.6.The so-called "Cathedral" bears no inscription but has been dated by excavators to the mid-fourth century. Two churches are dated by inscription to the second half of the fifth century, while ten are dated by inscription to the sixth century. The latest building, the Church of Bishop Genesios, is dated by inscription to 611 .

${ }^{28}$ Carl Hermann Kraeling, "History of Gerasa," in Gerasa: City of the Decapolis, ed. Carl Hermann Kraeling (New Haven, CT: Yale University Press, 1936), 66, note 224. Kraeling suggests that Bishop Paul contributed his own funds to the construction of the Procopios Church, as did Deacon Saolas (inscription no. 304, pp. 478-479), and Deacon Theodore funded the building of the Churches of St. John the Baptist and Saints Cosmas and Damian (inscriptions nos. 306, 314, pp. 479-480, 482). While the latter is clearly attested in the mosaic inscriptions, the wording in the former is less clear, and it is likely that the financial contribution was Soalas' alone and that Paul, like bishops mentioned in other inscriptions, oversaw the process or was in office at the time of the church's erection. Kraeling rightly does not include the donations of Anastasios at the Church of Sts. Peter and Paul, as he is not identified as a bishop in any of the building's three inscriptions (inscriptions nos. 327-328, 330, pp. 484-485).
} 
Jerash is unique amongst the cities examined in this study of topographic mosaics because it had a long history of Roman involvement. Many of the other sites surveyed in this project were smaller Aramaean towns that lacked large Roman public venues, and no evidence of pre-Christian euergetism exists at these sites. Even at Madaba, the only other town in this study with a significant population during the Roman period, there is no archaeological or textual record of monumental donations toward non-Christian civic structures. The lack of evidence does not preclude the possibility that such donations were made, especially since little has been recovered in Madaba from the Roman period. However, it is also probable that the new elite class, local bishops and clergy, adopted the now-Christian practice of euergetism and introduced it to indigenous communities that previously had been uninfluenced by Greco-Roman cultural practices. Dedicatory inscriptions from the other churches in Madaba, Khirbat al-Samra, and Umm al-Rasas, rarely mention laypeople (other than deacons) as donors, though such individuals are sometimes noted in supplementary votive inscriptions (Table 6). The only exceptions are the topographic mosaics at Khirbat al-Samra and St. Stephen, both of which have dedicatory inscriptions mentioning laypeople. ${ }^{29}$

At many sites there were far more churches than were necessary for the population, and several of these buildings are linked to the same bishop. It is not unlikely that Jerash, with an estimated population of about 10,000, had fourteen or more churches. ${ }^{30}$ Even Khirbat al-Samra, the smallest settlement examined in this study, had eight churches dated between the late fifth and sixth centuries, with no evidence to

\footnotetext{
${ }^{29}$ See below, p. 65 .

${ }^{30}$ Kraeling, "History of Gerasa," 12; Kennedy, Gerasa and the Decapolis, 124. Kraeling suggests that, at its height in the Roman period, Jerash was home to 20,000 or more people and it is this figure that is most often repeated by scholars in discussions of the Roman city; however, Kennedy, basing his estimations on more recent population density studies, proposes a more conservative number of 10,000.
} 
suggest that they did not operate concurrently. ${ }^{31}$ This attests not only to the economic viability of the region during the sixth century, but also to the local population's interest in constructing these buildings. Individual churches were purpose-built to serve specific functions, including the burial of prestigious figures, housing saints' relics, and accommodating pilgrims, thus requiring several buildings in each community. Moreover, it is possible that various churches were used for different ceremonies throughout the liturgical year. ${ }^{32}$ This cultural phenomenon provided individuals with numerous opportunities to demonstrate their wealth and status through the donation of mosaics with accompanying inscriptions and portraits. The patrons of the topographic pavements took full advantage of this and combined these memorials of their donations with topographic compositions to proclaim their status while signifying the purpose and significance of the church to which they had contributed.

\section{Patrons of the Topographic Mosaics and Their Churches}

Little is known about the patrons of the topographic mosaics as individuals. As with other pavements in Jordanian churches, the dedicatory inscriptions record only the laity's first names, and sometimes their familial relationships. Secular titles are rarely included. ${ }^{33}$ Whether this is because these individuals held no official administrative

\footnotetext{
${ }^{31}$ Jean-Baptiste Humbert and Alain Desreumaux, Fouilles de Khirbet es-Samra en Jordanie v. 1. (Turnhout: Brepols, 1998), 56.

${ }^{32}$ I am grateful to Dr. Sheila Campbell for this important observation.

${ }^{33}$ Michel, Les églises, no. 112, p. 293, no. 136, p. 370, no. 144c, p.392. Michel records three exceptions in the church inscriptions. The first, in the Upper Church of Quwaysmah, is a dedicated to the "health, peace, and longevity" of the tribune ( $\tau \rho ı \beta o v ́ v o \varsigma)$ Stephen. A second is found at the al-Dayr Church in Ma'in,

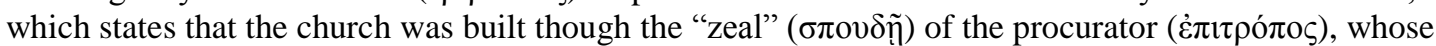
name has been lost. The third names one of the patrons of St. Stephen, examined in this study, as deacon

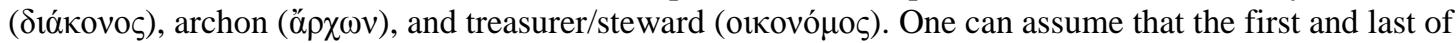
these titles are religious; however, the term "archon" refers to a secular magistrate. A fourth example is recorded by Welles ("Inscriptions," no. 311, p.481) that was found in the Church of Sts. Cosmas and Damian at Jerash and also mentions a tribune.
} 
positions, because such titles were considered inappropriate for inclusion in church mosaics, or for some other reason cannot be determined. In any case, this lack of identitymarkers makes it impossible to link these individuals to textual sources with any certainty. In contrast, ecclesiastic titles are common additions to dedicatory inscriptions, recording a range of positions in both churches and monasteries. Moreover, donor lists regularly included the name of the local bishop. In some cases this indicates the clergy's involvement in the construction of the church and/or its decoration, but it is probable that donors also referenced these figures to highlight their personal status through their connection to the Church and the ecclesiastic elite.

Just as little is known about the patrons, no texts survive documenting the purchase of the mosaics or the patrons' role in the selection of iconography. Compositions were limited, to some extent, by the motifs an individual workshop had mastered. However, as the topographic pavements from Jordan illustrate, even a small selection of images could be manipulated to create a wide variety of scenes. Dunbabin plausibly argues that patrons in domestic settings in North Africa had great influence on the design of their mosaic compositions. Owners designed pavements not only to suit their personal tastes but also to apprise guests of their economic and political status. Scenes including depictions of elite hunting parties, country estates, and the patrons' provision of public games first appeared in private homes at the end of the second century, before becoming part of the repertoire for public buildings in the fourth century. ${ }^{34}$ These motifs were popular throughout the empire and Jordanian church donors used similar iconography. While bishops or priests had oversight of the churches' decorative programs, such iconography was ambiguous enough to be acceptable, as it

\footnotetext{
${ }^{34}$ Dunbabin, Mosaics of Roman North Africa, 24.
} 
could also be interpreted with Christian connotations. Thus these motifs were deemed appropriate for ecclesiastic settings but still carried familiar connotations of wealth and status. This idea is bolstered by the unusually large number of inscriptions and donor portraits appearing in conjunction with such imagery in Late Antique Jordanian churches. This further suggests there was a strong connection between public donations and the elevation of personal or community status in the Late Antique East.

\section{Mosaic Elements and Their Architectural Contexts in Light of Church Patronage}

Mosaics allowed patrons to advertise their wealth through the size and quality of donated pavements, an important socio-economic consideration that is often ignored in mosaic studies. Also key was the placement of the mosaics in their architectural settings. Six of the nine pavements examined in this study are part of the nave pavements, while the rest are in the adjacent intercolumnar panels. This made the compositions visible to the congregation while also indicating importance through their visual alignment with the altar. The topographic mosaics are commonly accompanied by both dedicatory inscriptions and donor portraits. These are usually placed at the edge of the sanctuary, a location normally reserved for the clergy, providing the donors status by proxy.

\section{III.i. Size and Quality of the Topographic Mosaics}

Generally speaking, the topographic mosaics are uniformly high in quality and large in size, filling the nave or, in the case of St. John the Baptist in Jerash, the entire centrally-planned space. The only exception is the single intercolumnar panel from the Church of the Lions, which, along with the rest of the mosaics, was likely paid for by the

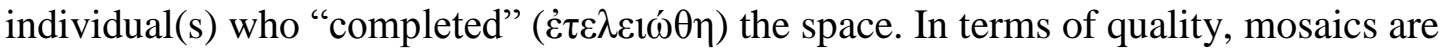


judged by the number of tesserae per $\mathrm{dm}^{2}$ : the higher the number, the more detailed the composition, and by extension, the higher the cost. In his survey of the mosaics of Palestine, Michael Avi-Yonah categorizes the pavements into three levels of quality, with forty-two to 100 tesserae per $\mathrm{dm}^{2}$ being considered "fine work" and those with ninety and above being the finest quality. ${ }^{35}$ With the exception of the Madaba pavement, the topographic mosaics range from seventy to ninety tesserae per $\mathrm{dm}^{2}$. The Madaba pavement is much finer, with certain sections containing as many as 150 tesserae per $\mathrm{dm}^{2}$ (Table 2).

It is impossible to determine how much donors paid for the topographic mosaics; there is no record preserved regarding their overall cost in Late Antique Jordan. The two expenses associated with mosaic production are materials and labor. The topographic pavements, like most in Jordan, are made primarily from local stone. Limestone is predominant and provides a wide range of colors, but basalt and jasper are also used. Glass tesserae are rare but are found in small quantities in the topographic mosaics at Sts. Peter and Paul, St. Stephen, and Madaba. This is not surprising, as the material is not only more expensive but also better suited to wall mosaics. ${ }^{36}$ Evidence of glass wall

\footnotetext{
${ }^{35}$ Michael Avi-Yonah, "Mosaic Pavements in Palestine," QDAP 3 (1933): 72; Claudine Dauphin, "A New Method of Studying Early Byzantine Mosaic Pavements (Coding and a Computed Cluster Analysis), with Special Reference to the Levant," Levant 8, no. 1 (January 1976): 123; Ruth and Asher Ovadiah, Hellenistic, Roman, and Early Byzantine Pavements in Israel (Rome: "l'Erma" di Bretschneider, 1987), 149. Claudine Dauphin and Ruth and Asher Ovadiah use slightly modified systems for assessing quality. For Israeli pavements, the Ovadiahs identify most monochromatic mosaics as having ten to forty tesserae per $\mathrm{dm}^{2}$, those with simple designs as having forty to eighty, and complex designs with more than eighty. Claudine Dauphin is more conservative with her categories, labeling mosaics with $60-110 \mathrm{dm}^{2}$ as "middle quality" and those with 110 or more as "high quality." She also points out that many mosaics are of mixed quality, with certain areas that require more detail, such as faces, having significantly higher tesserae counts than other areas of the same pavement. Using the Ovadiahs' system, the majority of the mosaics would be considered complex or high quality, but under Dauphin's they would be considered medium quality. These numbers are somewhat relative, as quality should be assessed in relation to local comparanda from the same period.

${ }^{36}$ Liz James, "Byzantine Glass Mosaic Tesserae: Some Material Considerations," Byzantine and Modern Greek Studies 30, no. 1 (2006): 31-33.
} 
mosaic is found in St. John the Baptist, and ancient glass sheets, perhaps used for tesserae production, were found in Jerash. ${ }^{37}$

Some evidence exists for the cost of mosaic labor, though it is not specific to either the chronological or regional scope of this study. Diocletian's Price Edict from 301 includes the maximum daily wages for two types of mosaicists: a musaearius, who made sixty denarii a day plus board, and a tessellarius, who made fifty. ${ }^{38}$ Scholars have traditionally assumed that the former created wall mosaics while the latter constructed floor pavements. However, Dunbabin has suggested the titles might indicate a different style of artistry, with the musaearius specializing in "fine decorative work," while the tessellarius assembled "plain tessellated pavements." 39 The topographic mosaics certainly fit into the first category and would have been more expensive. While the figures included in Diocletian's edict cannot be used to estimate labor costs in Late Antique Jordan, they do suggest that large representational pavements, such as the topographic compositions, were costly undertakings for church patrons.

Even though the exact cost of the topographic mosaics is unknown, one can estimate how long it took to complete them. In his examination of the Madaba mosaic, Avi-Yonah provides a formula for calculating the number of days necessary to lay the pavements, and this method can be applied to the other topographic mosaics as well. Based on his reconstruction of the mosaic, which he suggests filled a transept that was

\footnotetext{
${ }^{37}$ Franklin M. Biebel, "The Mosaics," in Gerasa, 517-518; C.M. Jackson and P.T. Nicholson, "The Provenance of Some Glass Ingots from the Uluburun Shipwreck," JAS 37, no. 2 (February 2010): 295-301. Biebel describes the find as a large quantity of circular "glass cakes" measuring up to $40 \mathrm{~cm}$ in diameter and between 5 and $30 \mathrm{~mm}$ in thickness. The range of colors and quality matches those of the glass tesserae found in Jerash. However, while Biebel identifies this as a glass-making site, no furnace has been found to corroborate this theory. It is known that glass was exported from Egypt in the Late Bronze Age, as evidenced by the blue and turquoise glass ingots found in the Uluburun Shipwreck, though there is no evidence that trade from this region continued in the Late Antique period.

${ }^{38}$ Diocletian, Edictum Diocletiani et collegarum de pretiis rerum venalium, 7.6-7.7.

${ }^{39}$ Dunbabin, Mosaics Greek and Roman, 275-276.
} 
wider than the walls of the modern church, Avi-Yonah suggests that its original measurements were $29.5 \mathrm{~m}$ long x $6.4 \mathrm{~m}$ wide, or roughly $190 \mathrm{~m}^{2}$. The number of tesserae per $\mathrm{dm}^{2}$ ranges from eighty to 150 , so he uses an average of 120 tesserae per $\mathrm{dm}^{2}$ and estimates $2,300,000$ for the entire mosaic. Based on the work of modern craftsmen, Avi-Yonah postulates that an individual mosaicist could lay about 200 tesserae per hour. At this rate, it would take 11,500 working hours to complete the mosaic. He suggests a crew of three men, working twelve-hour days under a master mosaicist who oversaw the production. In this scenario, it would have taken almost a year to finish the Madaba mosaic. ${ }^{40}$ This estimate does not take into account the complexity of this particular pavement, which would have added to the time and cost.

A crew of three is suggested because even though mosaicists' names are infrequently included in building inscriptions, three is generally the maximum number found when they are provided. ${ }^{41}$ It must be noted that these names could indicate the workshop's master craftsmen (perhaps responsible for different aspects of the mosaics' construction) or owners, rather than the individuals who laid the tesserae. In this case, the number of workmen would be larger and the time estimates would decrease significantly. However, even at a lower pay rate, a larger number of workmen would likely result in a similar final cost as is estimated in the scenarios outlined below. ${ }^{42}$

Herbert Donner modifies both the size of the Madaba pavement and the number of hours per day in his calculations. Based on the original plans published for the Late

\footnotetext{
${ }^{40}$ Avi-Yonah, Madaba Mosaic, 15, 18.

${ }^{41}$ Piccirillo, Mosaics, 47. In Jordan, there are six examples of such inscriptions, including one flanking the altar in the Church of St. Stephen, which lists Staurakios from Esbous, son of Zada, and his colleague Euremios as the mosaicists.

${ }^{42}$ For a further discussion of the records of mosaicists' names and their interpretation, see Dunbabin, Mosaics Greek and Roman, 276-277; Hachlili, Ancient Mosaic, 244-249.
} 
Antique church, Donner suggests the mosaic was a more modest ninety-three $\mathrm{m}^{2}$. He also reduces the number of working hours to ten per day, an estimate that has been adopted in the present study because it more closely conforms to the average number of daylight hours in Jordan. Donner estimates that it took 186 days, or roughly six months, to lay the tesserae. ${ }^{43}$ It is important to note that this calculation does not include developing the design, cutting the stone, or laying the foundation.

Applying Donner's formula to the other topographic mosaics shows that they were time-consuming and expensive projects in their era (Table 2). The smallest nave pavement, from the Church of the Priest Wa'il, measures $24.5 \mathrm{~m}^{2}$ and contains an average of eighty tesserae per $\mathrm{dm}^{2}$. As such, it would take a team of three workers about thirty-three days to lay the mosaic. For the largest pavement, at St. John the Baptist in Jerash, which has a density of eighty-five tesserae and measures approximately $234 \mathrm{~m}^{2}$, it would take almost a year to complete. This wide range suggests that patrons with varying degrees of wealth could donate mosaics to the church, though all projects of this sort were costly endeavors.

An additional aspect in determining the price patrons paid was the number of individuals involved in sharing the cost. The majority of dedicatory inscriptions include a single lay donor. The only exception in the churches from this study is St. Stephen, which names John in addition to the "people of Mefa'a," as well as a dedication to the memory of Aeias, son of Fidonos, indicating that Fidonos also likely contributed funds (Table 3). ${ }^{44}$ An inscription on a polycandela disc from another church in Umm al-Rasas

\footnotetext{
${ }^{43}$ Donner, Mosaic Map, 28.

${ }^{44}$ Leah Di Segni, "The Involvement of Local, Municipal, and Provincial Authorities in Urban Building in Late Antique Palestine and Arabia," in The Roman and Byzantine Near East: Some Recent Archaeological Research, ed. John Humphrey, JRA Supplementary Series 14 (Ann Arbor, MI: Journal of Roman
} 
demonstrates that patrons could donate a variety objects in a range of prices, few of which have survived in the archaeological record. ${ }^{45}$

Dedicatory inscriptions often include references to the specific work paid for by the patron(s) (Table 3). This may include the construction or more ambivalent

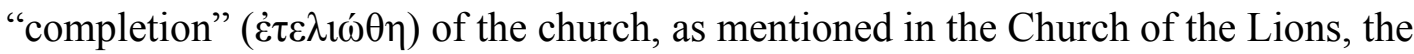
Church of the Priest Wa'il, and Sts. Peter and Paul. General references to contribution of

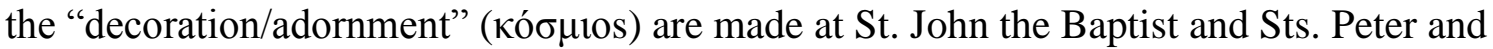
Paul. The former also specifically mentions mosaic, while the later mentions both mosaic and silver. Mosaic is the most frequently-mentioned decorative feature in the dedicatory inscriptions; the material is also highlighted in the dedicatory inscriptions from Khirbat al-Samra and St. Stephen. In the latter it is used twice: the bema pavement is described as

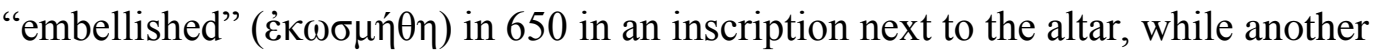
inscription in front of the chancel screen simply mentions that the mosaic was "finished" ( $\dot{\varepsilon \varepsilon \lambda \varepsilon 1 \omega ́ \theta \eta) ~ i n ~ 680 . ~ I t ~ i s ~ i m p o s s i b l e ~ t o ~ k n o w ~ w h e t h e r ~ t h i s ~ r e f e r s ~ t o ~ t h e ~ r e s t ~ o f ~ t h e ~ c h u r c h ~}$ or simply a portion.

In other parts of the empire, inscriptions record more information about the specific contributions of individuals, even if they do not mention monetary amounts. In some churches in Late Antique Italy, inscriptions record the number of square feet (fecit pedes) of mosaic that each donor paid for, while some inscriptions in Greece specify the

Archaeology, 1995), 312-313. The financial involvement of John must also be questioned, since the term "zeal" ( $\sigma \pi \mathrm{ov} \delta \tilde{\eta})$ is ambiguous; it indicates an active role in the project but not necessarily a financial one. See below, pp. 83-84.

${ }^{45}$ Michel, Les églises, no. 150a, pp. 415. The polycandela disc inscribed with "Saint Sergios, come to the aid of Thomas, Amen." was discovered in the North Twin Church at Umm al-Rasas. 
parts of the pavements each donor was responsible for. ${ }^{46}$ In both cases, the inscriptions indicate that the decoration of the church required the support of several individuals.

Unfortunately, the Jordanian inscriptions do not supply such specific information. With the exception of the bema mosaic in St. Stephen, there are no recorded distinctions about which mosaics were donated by whom, leading one to assume that the person(s) mentioned in the dedicatory inscription were responsible for the cost of the entire mosaic. However, three of the churches in this study have additional inscriptions that include supplementary names. In St. Stephen, these are accompanied by donor portraits (Table 7), suggesting that these individuals contributed something in order to be honored with an inscription. ${ }^{47}$ It is possible there was some sort of sliding scale for contributions, with the donor who made the largest donation receiving mention in the prominent dedicatory inscription (with or without a portrait), while others received a portrait and a supplementary inscription, or just an inscription. However, it is also possible that different people were responsible for different parts of the mosaic and chose different ways of memorializing their donations.

It is not difficult to imagine why so many people would be required to help pay for St. Stephen's pavement, as it contains the third largest mosaic in this study. It is also possible that the inscriptions refer to a number of decorating campaigns over time, as with the bema and nave mosaic, since some of the inscriptions are undated. However, supplementary inscriptions tend to be found in the youngest churches; the Church of the

\footnotetext{
${ }^{46}$ Jean-Pierre Caillet, "Les dédicaces privées de pavements de mosaïque à la fin de l'Antiquité: Occident européan et monde grec; données socio-économiques," in Artistes, artisans et production artistique au Moyen Age: Centre National de la Recherche Scientifique, Université de Rennes II- Haute-Bretagne, 2-6 mai 1983, v. 2, ed. Xavier Barral i Altet (Paris: Picard, 1987), 22-27.

${ }^{47}$ Six additional individuals are mentioned in the Church of the Lions, two in Khirbat al-Samra (one of whom might be the son of the donor mentioned in the dedicatory inscription), and twenty-two in St. Stephen.
} 
Lions is dated to the last quarter of the sixth century, St. John at Khirbat al-Samra to 634/639, and St. Stephen to 719/720. According to the inscriptions in the previously mentioned examples from Late Antique Italy, dating between the late fifth and early sixth centuries, the amount of mosaic each individual contributed decreased dramatically. ${ }^{48}$ However, the increased number of individuals mentioned in mosaic inscriptions in both Jordan and Italy does not necessarily indicate an economic decline in the region. In Italy, the later inscriptions record the occupations of the donors, the class of which broadened to include non-elites such as tailors and hairdressers. ${ }^{49}$ This valuable information is not included in the Jordanian mosaics. However, the large number of churches built or decorated in the late sixth century or later at Khirbat al-Samra (six) and Umm al-Rasas (eight) suggests that economic decline was not a factor. It is possible that in Jordan, as in Italy, the Late Antique practice of euergetism was adopted by the community's non-elite citizens, but is also possible that the economic boom in the early Umayyad period increased the individual wealth of local citizens. ${ }^{50}$

\section{III.ii. Location of the Topographical Motifs within the Churches}

Like the majority of the figural compositions used in Late Antique Jordanian churches, the topographic mosaics are all found within the nave or its intercolumnar panels (Table 4). Given the hierarchical structure of ecclesial space, one might assume that figural decoration, which generally requires more skill, time, and funding, would be used in the sanctuary. Instead it is predominantly found in the nave, where it was

\footnotetext{
${ }^{48}$ Caillet, "Les dédicaces," 26 . In the fourth and early fifth century, the contributions averaged about 100 $\mathrm{m}^{2}$ per person; however, by the late fifth and early sixth century, this was reduced to an average of $27 \mathrm{~m}^{2}$ per person.

${ }^{49}$ Ibid.

${ }^{50}$ Alan George Walmsley, "Byzantine Palestine and Arabia: Urban Prosperity in Late Antiquity," in Towns in Transition: Urban Evolution in Late Antiquity and the Early Middle Ages, ed. N. Christie and S.T. Loseby (Aldershot: Ashgate,1996), 121-158.
} 
accessible for (and more visible to) the congregation. An analysis of the fifty-two church plans published by Piccirillo in The Mosaics of Jordan, which includes detailed drawings of the geometric and representational mosaics in situ, shows that only twenty-two $(42.3 \%)$ have figural decoration in the sanctuary. ${ }^{51}$ This number includes motifs in one or more locations - the presbyterium, the altar area, or the apse - but does not include side rooms that flank the altar or apse. ${ }^{52}$

It is difficult to ascertain the floor decoration of the sanctuaries examined in this study since evidence does not survive from the churches at Madaba, Ma'in, and Umm alManabi ${ }^{`}$, and the sanctuaries at Khirbat al-Samra and Jerash are paved with flagstones. The only evidence for decorated pavements comes from Umm al-Rasas, where all three churches' sanctuaries are covered in mosaic. St. Stephen contains a geometric design, while the other two have geometric designs in the apse and figural compositions in the presbyterium. In the Church of the Priest Wa'il, there is a pair of facing bulls separated by grape vines and acanthus leaves, symbolizing biblical sacrifice (Figure 35 ). ${ }^{53}$ In the Church of the Lions, the bulls are replaced by lions turning their backs to deer in a variation of a "peaceful kingdom" scene (Figure 33). ${ }^{54}$ Two lambs flank the altar at the entrance to the apse, but the rest of the space contains a geometric design. The choice of figural motifs in the Umm al-Rasas sanctuaries is indicative of what is found in the other Jordanian churches: animals referencing biblical texts or serving an allegorical purpose,

\footnotetext{
${ }^{51}$ Despite the fact that Michel's catalogue is more recent and complete, she does not always include information about the churches' mosaic decoration or provide plans with the mosaics depicted, Piccirillo does both in Mosaics of Jordan. For this reason, I use his text in the preparation of these and many of the following statistics that reference the specific motifs and locations of church pavements.

${ }^{52} \operatorname{Six}(11.5 \%)$ have geometric mosaics, while nine $(17.3 \%)$ were left undecorated. The remaining nine sanctuaries $(17.3 \%)$ have not survived well enough to determine if or how they were decorated.

${ }^{53}$ There are numerous biblical references to the sacrifice of bulls on altars, including the passages from Psalms (51:21 and 87:2) included in the inscriptions at Ma'in.

${ }^{54}$ Isaiah 11:6-7.
} 
such as lambs symbolizing Christ's sacrifice. ${ }^{55}$ The use of human figures within the sanctuary was apparently avoided, as no examples exist in any Jordanian churches. Similarly, the representation of mankind's domain, in the form of walled city motifs, was reserved for the area outside the sanctuary.

All nine topographic motifs are found within the central spaces of their churches. Six of the nine Jordanian topographic motifs are part of the nave pavement, while three are located on the intercolumnar panels that separate the nave from the aisles. There was no restriction against figural motifs outside the sanctuary, but such compositions are mostly found in the nave. Forty-two of the churches $(80.8 \%)$ illustrated by Piccirillo contain representational imagery in this area. In this location, both clergy and laypeople could see the mosaics, but the mosaics' orientation toward the altar suggests they were meant to be viewed and interpreted mainly by the laypeople. With the exception of deacons, however, members of the laity were not able to move beyond the ambo and thus had limited access to the eastern end of the nave. ${ }^{56}$

In four of the mosaics (St. Peter and Paul, Umm al-Manabi', Madaba, and Khirbat al-Samra), the topographic motifs are found in the main field of the nave pavement. In each of these cases, one must stand within the nave and face the altar in order to view the topographic motifs. Their axial alignment with the altar imbues these mosaics with prestige and emphasizes the paired topographic motifs in Sts. Peter and Paul and Khirbat al-Samra. At Madaba, as Donceel-Voûte has indicated, the patron/artist used the altar's alignment to highlight both Jerusalem's centrality and the (lost) Madaba motif's

\footnotetext{
55 John 1:29.

${ }^{56}$ Joel Walker, "From Nisibis to Xian: The Church of the East in Late Antique Eurasia," in The Oxford Handbook of Late Antiquity, ed. Scott Fitzgerald Johnson (Oxford: Oxford University Press, 2012), 1012. The laity proceeded eastward through the nave with the clergy at the beginning of the liturgy and gathered within this space during the service.
} 
proximity to the holy city. ${ }^{57}$ Moreover, the mosaic's layout places Madaba closer to the sanctuary than Jerusalem, providing it an extremely prestigious location within the church. In contrast, the walled city depicted at Umm al- Manabi` is found in the southwest corner of the pavement, indicating that the motif labeled "Egypt" is used more to help establish the scene than to highlight the status of the Byzantine province.

In three of the topographic mosaics, St. John the Baptist, St. Stephen, and Ma'in, architectonic motifs are used to form borders around the nave pavements. Like the topographic motifs in the main fields, the imagery in these mosaics can be read as representations of the inhabited earth, but their use as framing devices also instructs the viewer to interpret the motifs in conjunction with the images and inscriptions found within the nave. The borders require the viewer to move throughout the space in order to see all the topographic features. In St. John the Baptist (Plan 3), viewers must stand with their backs to the wall, facing the altar as they move clockwise or counter-clockwise around the central space. This places the central mosaic, and the dedicatory inscription, continuously within the viewer's sight as the various topographic motifs are examined. It is the opposite for the Ma'in pavement (Plan 13), where one must stand in the main field and move around the mosaic looking outward in order to view the walled cities displayed in the border. This path allows one to read both the eastern inscription, which faces the altar, and the western one, which faces the entrance to the church.

The border from St. Stephen is the most complex (Plan 12), with two registers of walled city motifs. The inner border, containing depictions of Egyptian towns, is read facing outward, as with Ma'in's border. However, the outer register is formed by the four intercolumnar panels. To view these as they are meant to be seen, one must proceed twice

${ }^{57}$ Donceel-Voûte, "La carte," 539-540. 
toward the altar from west to east, once on the north side of the nave and once on the south. The layout emphasizes the eminence of both Jerusalem and Umm al-Rasas (Kastron Mefa'a) through their placement on the north and south sides, respectively, of the eastern end of the nave and in closest proximity to the sanctuary. ${ }^{58}$

In three churches, individual panels contain the architectonic motifs. In addition to its double border of walled motifs, St. Stephen contains two depictions of churches: one labeled Diblaton and the other Limbon (Figures 70-71), both of which are local towns. Each is found within a panel also containing donor portraits and votive inscriptions. They are located next to the chancel screen at the east end of the north and south aisles, respectively. Viewed as one faces east, they were to the clergy and the laity as they prayed towards the altar. These are meant to represent either the donors' hometowns, or collective donations from these villages, and should be interpreted within the context of the donor portraits. ${ }^{59}$

Individual depictions of walled cities are found in similar locations in the Church of the Lions (Plan 7) and the Church of the Priest Wa'il (Plan 8). In the former, a depiction of Kastron Mefa'a is found in the northeast intercolumnar panel. It cannot be determined whether this should be interpreted as a display of civic pride or as a record of the town's donation to the church. What is unquestionable is the status awarded to the city through the motif's proximity to the sanctuary, abutting the chancel screen and sitting parallel to the ambo, where the priest would give his sermon. The architectonic panel from the Church of the Priest Wa'il varies from the others in both iconography and orientation. It contains depictions of three unlabeled cities, is found in the southwest

\footnotetext{
58 Donceel-Voûte, "La carte," 524.

${ }^{59}$ See the discussion of donor portraits below, p. 84-89.
} 
corner of the church, and is oriented to the north instead of the altar. For these reasons, it should be "read" within the context of the other intercolumnar panels facing the same direction, thus having a distinctly different purpose than the depictions of individual cities. While most promote the donors' hometowns and their images are awarded a suitably privileged place within the nave, the topographic motif from the Church of the Priest Wa'il is connected to the biblical messages of salvation found in the north intercolumnar panels. ${ }^{60}$

Interest in representational decoration did not extend to the church aisles (Table 4). Of Piccirillo's fifty-two churches, forty-two (80.7\%) have paved aisles. ${ }^{61}$ Thirty-two of these $(61.5 \%)$ are geometric, while only ten $(19.2 \%)$ include figural motifs. ${ }^{62} \mathrm{~A}$ slightly different pattern is found in the aisle decoration of the churches containing topographic imagery. ${ }^{63}$ The Madaba mosaic is especially unusual in that it is laid out across the width of the church, covering the nave and aisles (Plan 5). In this respect, it is a unique example in Jordanian churches. The churches from Umm al-Rasas also contain figural images in their aisles, though mostly as part of a geometric design. The aisles at the Church of the Lion have traditional geometric designs, though the apses at the eastern end of the aisles each contain a krater flanked by two birds (Figure 32). In the Church of St. Stephen, the aisles contain geometric grid patterns, the centers of which contain a variety of motifs, including small animals and birds (Figure 43). In the Church of the

\footnotetext{
${ }^{60}$ For a new interpretation of the iconography of the Church of the Priest Wa'il, see Chapter 3, pp. 138143.

${ }^{61}$ One church has undecorated aisles, while not enough evidence survives in seven $(13.5 \%)$ to determine if or how they were decorated. Two of the churches have a central plan and therefore do not have aisles

${ }^{62}$ One of these consists of a bust within a tondo; otherwise, the rest of the aisle contains a geometric pattern.

${ }^{63}$ Not enough evidence exists at Khirbat al-Samra, Ma'in, or Umm al-Manabi' to determine how the aisles were decorated. No evidence for aisles remains at Umm al-Manabi' and their existence at Ma' in is disputed. The Church of St. John the Baptist has a central plan without aisles.
} 
Priest Wa'il, the aisles contain acanthus scrolls filled with hunters and animals. This evidence suggests there was no restriction against figural designs in the aisles but that most patrons saved the more expensive work for the nave, an area of greater religious importance and higher visibility.

While the upper stories of these churches have not survived, comparanda from other regions and the depictions of churches in the topographic mosaics show that the naves were often illuminated by windows above the western doorway and in the clerestory. In contrast, the outer walls of the aisles were punctuated with few windows so as to keep them structurally sound enough to support the roof; figural imagery was reserved for areas where it could be easily viewed and have the most impact.

The concentration of figural imagery in the nave can also be explained by the higher importance of the nave in liturgical activities and the interest of patrons in using this space to convey their personal status to the community. The laity moved through the western portion of the nave during liturgical processions and viewed the mosaics while doing so. At other parts of the service, when they were standing to the sides in the aisles, these compositions would still be visible, while the geometric patterns beneath their feet would be obscured by the masses. The topographic motifs, conveying important messages about the churches' purposes and/or the patrons'/communities' status, featured prominently within the nave.

\section{III.iii. Iconography Associated with the Topographic Motifs}

The topographic mosaics, like those from other Jordanian churches, draw from a limited repertoire of motifs and compositions (Table 5). The majority of the forty-two representational nave pavements Piccirillo illustrates contain either inhabited geometric 
patterns $(38.1 \%)$ or inhabited vine/acanthus scrolls $(45.2 \%)$. In some cases, the choice is likely dictated by the local mosaicist's repertoire. However, it is also probable that some of these choices reflect important regional socio-economic activities as well as religiously appropriate iconography. Six of the nine topographic mosaics contain inhabited acanthus or vine scrolls. Numerous authors have discussed the "Christianization" of the latter motif. Inhabited vine scrolls first appeared in third-century North Africa, where they were used in domestic contexts to show agricultural prosperity and wealth derived from latifundiae. But in Christian contexts, scholars have focused on a different interpretation, connecting the vine scrolls to Christians or Christ through a number of passages in the Old and New Testaments, such as Isaiah 5:1-7, which equates Jews (and Christians) to a vineyard tended by God, and a comparison of Christ to the vine in John 15:1-6. ${ }^{64}$

That these associations were made and that such connections allowed the motifs to be deemed appropriate for the decoration of churches is not disputed here. However, in making these associations, scholars have ignored the idea that the images would retain their original messages, especially as a means of illustrating the source of the patrons' or communities' economic livelihood, despite the fact that these motifs continued to be used in domestic contexts for exactly this purpose. ${ }^{65}$ Why should the community read them

\footnotetext{
${ }^{64}$ For an extended discussion of the religious interpretations of vine motifs in early Christian mosaics, see Sylvester Saller and Bellarmino Bagatti, The Town of Nebo: Khirbat el-Mekhayyat; with a Brief Survey of other Ancient Christian Monuments in Transjordan (Jerusalem: Franciscan Printing Press, 1949), 94-98; Henry Maguire, Earth and Ocean: The Terrestrial World in Early Byzantine Art (University Park, PA: Pennsylvania State University Press, 1987), 9-10; Mark Merrony, "The Reconciliation on Paganism and Christianity in the Early Byzantine Mosaic Pavements of Arabia and Palestine," Liber Annuus 48 (1998): 470-474.

${ }^{65}$ Doro Levi, Antioch Mosaic Pavements (Princeton, NJ: Princeton University Press, 1947), 323-345, $363-$ 365; Janine Balty, La grande mosaïque de chasse du triclinos (Brussels: Belgian Center of Archaeological Research in Apamea, Syria, 1969). Few domestic mosaics survive from Late Antique Palaestina and Arabia but in Syria, fifth- and sixth-century villas were decorated with hunting scenes, such as the Yakto complex (mid-fifth century), and the House of the Worcester Hunt (sixth century) in Daphne, outside of Antioch, both examined by Levi and the Triclinos Building (mid-fifth to early sixth century) in Apamea discussed by Balty.
} 
differently in a public setting, especially when patrons commonly included inscriptions and portraits highlighting their contributions to the construction and decoration of the church? Moreover, the topographic mosaics often combine the vine/acanthus scrolls with other symbols of prosperity traditionally linked to the elite, including hunting, as found in the mosaics from the Churches of the Lions, the Priest Wa'il, and St. Stephen (Figures $28,37,69$ ) and vintaging scenes, as in St. Stephen (Figures 69, 133).

It is possible that patrons chose specific motifs not only as generic symbols of status but also as representations of the source of their wealth, as was common in domestic pavements. In their examinations of the patron portrait of the Lady Silthous from the Church of Saint Elias in Kissufim, Israel, both Peter Baumann and Birte Poulsen identify the adjacent camel-driver as a servant, used as a visual reference to the source the donor's wealth (Figure 102). ${ }^{66}$ In contrast, Jean-Pierre Sodini believes the inclusion of the camel-driver's name identifies him as another patron. ${ }^{67}$ My interpretation of this figure, who I agree is a servant, is discussed in Chapter 3, but regardless of which interpretation is correct, both link the patrons' portraits with economic activities that provided their income. ${ }^{68}$ In this light, it is possible to examine the connection between the agricultural motifs on the topographic mosaics and the patrons who created them. In turn, this provides a new method of interpretation for the topographic motifs as symbols of status to which the patrons had a personal connection. The specific combinations of motifs, portraits, and inscriptions for each topographic mosaic are examined in greater detail in

\footnotetext{
${ }^{66}$ Peter Baumann, Spätantike Stifter im Heiligen Land (Wiesbaden: Reichert Verlag, 1999), 226-232, especially p. 228; Birte Poulsen, "Patrons and Viewers: Reading Mosaics in Late Antiquity," in Patrons and Viewers, 170.

${ }^{67}$ Jean-Pierre Sodini, "L'organisation liturgique des églises," in The Roman and Byzantine Near East: Some Recent Archaeological Research v. I, Journal of Roman Archaeology Supplementary Series 14, ed. John Humphrey (Ann Arbor, MI: 1995), 310.

${ }^{68}$ See Chapter 3 below, pp. 116-118.
} 
Chapter 3, which explores the possibility of more nuanced and personal messages regarding the donors' status. The possible socio-economic connections between the cities and Late Antique patrons are investigated in Chapter 4.

III.iv. Donor Inscriptions Associated with the Topographic Mosaics

The opportunity to be commemorated through inscriptions was a strong motivation for donors and part of a long tradition in the Roman world. Throughout the empire, the urge to be memorialized was the impetus for the construction of tombs, statues, and public buildings whose inscriptions recorded the name and status of the donor. ${ }^{69}$ This tradition continued in the Late Antique period, even if the variety of monuments constructed by patrons declined. Patrons of early Christian churches in Jordan took full advantage of inscriptions to memorialize their contributions to religious buildings, and the majority of the 150 Late Antique churches recorded in Anne Michel's Les églises d'époque Byzantine et Umayyade de la Jordanie contain some specific record of those responsible for the buildings' construction, restoration, and/or decoration. Of the 186 inscriptions in Michel's catalogue, sixty-nine dedicatory inscriptions and thirty-one supplementary inscriptions record such donations. ${ }^{70}$ This outnumbers salvific/votive inscriptions by almost three to one, indicating that patrons were equally concerned about

\footnotetext{
${ }^{69}$ For a discussion of the importance of being remembered in Roman society and the use of tombs, public buildings, and coins as commemorative and communication tools, refer to the various essays in Karl Galinsky, ed., Memoria Romana: Memory in Rome and Roman Memory (Ann Arbor, MI: University of Michigan Press, 2014).

${ }^{70}$ Sixty-nine of the 186 preserved inscriptions refer to the date of completion of the church and/or its decoration, usually in an inscription near the chancel screen at the eastern end of the nave. Of these, thirty mention the construction of the building, thirty refer to the installation of mosaics, and nine reference unspecific renovations. An additional thirty-one inscriptions mention the contributions of individuals or groups to these types of projects.
} 
being recognized by the community for their financial contributions as they were about receiving spiritual recompense for their actions. ${ }^{71}$ This is especially true of the churches in which topographic mosaics are found (Tables 3,6). In the nine churches in this study, there are seven dedicatory inscriptions that specifically mention the donors' contributions, and two more laudatory inscriptions that praise the donor for his gifts. There are seven inscriptions that simply record individual names, with five of these likely accompanying donor portraits. There are thirteen salvific/votive inscriptions, but all come from St. Stephen (a pilgrimage church) and all use the same formula asking God to remember the individual, a request that is also fulfilled by viewers when they read the inscriptions. Only two churches contain inscriptions that include biblical names or passages. At St. Stephen, Mary's name is recorded in the sanctuary and at Ma'in, there is one definite and one possible biblical passage at each end of the nave mosaic. For most of the donors, the focus was on public commemoration of their patronage.

This is also evident in the location of the inscriptions in the seven churches where inscriptions are extant (Table 7). Of the thirty-four examples, seventeen are located in the nave. This area is privileged space, important for its axial alignment with the altar, and also because it was accessed by the most important members of the community: the clergy. There is a practical element to this as well, since most of the clergy probably had enough education to read the inscriptions. Four churches in this study have extant

\footnotetext{
${ }^{71}$ There are thirty-two inscriptions containing votive inscriptions, which are generally formulaic in nature. Eleven ask for "aid for" an individual, five request "to give pity to" him or her, and another five to "remember" the individual. One asks for prayers, while another asks to pardon the person's sins, and a third asks, rather ambiguously, that "life be given" to them. Two priests ask for "recompense" in one inscription. Another three inscriptions ask for blessings, protection, and/or pity for the church or the village. Three ask for remembrance, two from the saints to whom the church is dedicated and one from Mary. Some of these formulas are also included in the 100 inscriptions that mention donations, including fourteen that mention that their contributions are "for the health of" certain individuals, nine for the memory of family members or other individuals, one for the pardoning of sins, and one for "pity for [the donor] and the whole world."
} 
inscriptions in the nave. In the Church of Sts. Peter and Paul, there is one dedicatory and one laudatory inscription in the nave. A second laudatory inscription is in the north aisle, right at the chancel screen. All three indicate that Anastasios was the donor; he took great care to commemorate his donations to the construction and decoration of this building. In the Church of the Lions, the names of two individuals are included in the apse of the south aisle. Perhaps these two were responsible for the decoration of this area, but since only their names are recorded, it is impossible to be sure. St. Stephen contains seventeen of the thirty-four inscriptions, and only one of these (the dedicatory inscription) is in the nave. Twelve salvific/votive or individual name inscriptions are located in the aisles, and donor portraits accompany five of these. At the doorway to the north chapel, an inscription asks God to remember three men. It is likely that the individuals named in both the aisles and the chapel were responsible for the decoration of those areas, an idea supported by the two inscriptions in the presbyterium recording both the dedication and the names of the mosaicists who paved the area in 756. Despite being in a less important area in terms of hierarchical space, the aisle inscriptions abut the chancel screen, a place of great importance that is still within the public eye, ensuring they would be seen by all and read by those who were able. The act of seeing was sometimes as important as reading in the Late Antique period, and the inscriptions' location superseded the donors' interest in legibility. ${ }^{72}$ That the congregation could view the inscription while facing the altar was enough. Moreover, as stand-ins for the donors, the inscriptions (and sometimes the accompanying portraits) perpetually inhabited privileged space within the church on behalf of their patrons.

\footnotetext{
${ }^{72}$ Antony Eastmond, "Textual Icons: Viewing Inscriptions in Medieval Georgia," in Viewing Inscriptions in the Late Antique and Medieval World, ed. Antony Eastmond (Cambridge: Cambridge University Press, 2015), 3-5.
} 
The language of the inscriptions also indicates they were used as status symbols. Ecclesiastic inscriptions in Jordan are almost exclusively Greek; only five of those catalogued by Michel are not. ${ }^{73}$ Even in a town like Khirbat al-Samra, where $70.8 \%$ of the funerary stele inscriptions are written in Christian Palestinian Aramaic, all ten of the inscriptions found in the eight extant churches are Greek. ${ }^{74}$ This corresponds to the account of the fourth-century pilgrim Egeria, who describes the mixed population in attendance for Easter services in Jerusalem. She explains that the bishop always spoke Greek, even if he was fluent in Aramaic. His presbyter translated the sermons into Aramaic, and Egeria mentions that this was done for the lessons read in church as well. ${ }^{75}$ Greek was the language of the Church, the Byzantine administration, and schools for the elite. As such, it served as a marker of status and high standing in the community, and this is reflected in the inscriptions. It is hard to determine Late Antique literacy rates, but one must remember that someone who could not read a book might still have been able to read simple words or names like those accompanying the patron portraits in the aisles. ${ }^{76}$ But more importantly, an inscription established the donor as someone possessing these skills even if, in reality, the donors did not write the inscriptions themselves.

\footnotetext{
${ }^{73}$ Robert Hoyland, "Aramaic and Old Arabic in Late Roman Palestine and Arabia," in The Development of Arabic as a Written Language (Supplement to the Proceedings of the Seminar of Arabian Studies 40), ed. M.C.A. Macdonald (Oxford: Archaeopress, 2010), 29-46; Michel, Les églises. The four inscriptions are in Christian Palestinian Aramaic in Michel's catalogue. Three are found at the Chapel at Khirbat al-Kursi (no. 109, pp. 288-289) and one is in the Lower Church at Quwaysmah (no. 111, p. 291). A fourth inscription, from the Church of St. George from Khirbat al-Mukhayyat, was identified as containing an Arabic word, though this identification has been questioned and some have suggested that it is Christian Palestinian Aramaic (no. 109, pp. 288-289).

${ }^{74}$ Alain Desreumaux and Dominique Couson, "Catalogue des stèles funéraires" in Fouilles de Khirbat, 287-301.

${ }^{75}$ Egeria, Travels, 47.3-5; John Wilkinson, trans. Egeria's Travels (Warminster, England: Aris \& Philips Ltd., 1999), 163. Egeria calls this language Syriac, though it Wilkinson explains that it is generally thought that she is referring to Christian Palestinian Aramaic.

${ }^{76}$ For the range of skills and competencies that ancient literacy encompassed, see Alan K. Bowman and Greg Woolf, "Literacy and Power in the Ancient World" in Literacy and Power in the Ancient World, ed. Alan K. Bowman and Greg Woolf (Cambridge: Cambridge University Press, 1994), 2-4.
} 
Toponyms are generally located in the western part of the nave or in the intercolumnar panels, parts of the nave that were most easily viewed by a layperson. In contrast, the dedicatory inscriptions were usually placed in front of the chancel screen at the east end of the nave. These inscriptions required the more developed reading skills obtained through an advanced education in Greek. Both the location and the longer texts suggest that the intended audience was the clergy, who often had the required education and unrestricted access to this part of the church. ${ }^{77}$ For elite members of society, like bishops and certain other members of the clergy, an advanced education in Greek rhetoric was still available in the Late Antique period; schools existed at Constantinople, as well as Alexandria and Antioch. Even closer was the school at Gaza in Palaestina Prima, about $150 \mathrm{~km}$ southwest of Amman on the Mediterranean coast. ${ }^{78}$

While it is likely that not all of the donors spoke Greek, some manipulated the language of the church inscriptions in order to highlight their erudition. In his dedication for St. John the Baptist, Theodore made the effort to compose the majority of the inscription in iambic trimeter. ${ }^{79}$ In the Late Antique period, this measure was used less frequently than the hexameter emphasized in classical paideia, despite the fact that it was easier to compose. Christian scholars of the time emphasized the sacredness of iambic trimeter due to its use in a variety of biblical passages. While rare, there are other examples of iambic trimeter used in Late Antique dedicatory inscriptions in both Greece

\footnotetext{
${ }^{77}$ Holger Gzella, A Cultural History of Aramaic: From the Beginnings to the Advent of Islam (Leiden: Brill, 2015), 281-329, especially p. 290. For a short but comprehensive overview of Byzantine education, see Athanasios Markopoulos, "Education," 785-795.

${ }^{78}$ For an in-depth discussion of this form of education, see George Alexander Kennedy, Greek Rhetoric under Christian Emperors: A History of Rhetoric (Eugene, OR: Wipf and Stock Press, 2008), especially pp. 169-176 for the School of Gaza; Rafaella Cribiore, The School of Libanius in Late Antique Antioch (Princeton, NJ: Princeton University Press, 2016).

${ }^{79}$ Wells, "Inscriptions," no. 306, p. 479.
} 
and the Near East. ${ }^{80}$ Given the mistakes in its composition, it is possible that Theodore did not receive an advanced classical education, though perhaps the errors reflect his infrequent use of these skills or, less likely, errors on the part of the mosaicist.

The other church in Jerash bearing a topographic mosaic, Sts. Peter and Paul, also contains poetic devices in two of its inscriptions. The donor, Anastasios, included no less than three inscriptions identifying his patronage. Two contain fanciful apostrophes addressing the mosaics, one asking who its donor was and providing the answer for the viewer, the other addressing the pebbles from which the mosaic is made. ${ }^{81}$ These dedicatory inscriptions from these two churches set themselves apart from the others through their creative use of language, which implies that their donors not only had the financial means to construct and decorate a church but had also received some form of advanced education, either through classical or Christian schools. ${ }^{82}$ The use of meter and poetic devices is only found in the inscriptions at Jerash, a city with a long Greco-Roman history. At the other eight sites in this study, the inscriptions are formulaic and use the same language as inscriptions throughout the region. These non-Greco-Roman towns adopted the tradition of euergetism and the corresponding displays of prestige like inscriptions and patron portraits, but their citizens lacked the education or cultural

\footnotetext{
${ }^{80}$ Gianfranco Agosti, "Late Antique Iambics and Iambikè Idéa," in Iambic Ideas: Essays on a Poetic Tradition from Archaic Greece to the Late Roman Empire, ed. Alberto Cavarzere, Antonio Aloni, and Alessandro Barchiesi (New York: Rowman \& Littlefield, 2001), 221-223. For other examples of sixthcentury Greek inscriptions written in iambic trimeter, see GVI 246, 538, 722, and 772. For an example from Syria, see Gianfranco Agosti, "The $\pi 0 \chi 1 \lambda 1 \alpha$ of Paul the Bishop," ZPE 116 (1997): 31-38.

${ }^{81}$ Wells, "Inscriptions," nos. 327-328, p. 484-485. Other poetic devices in the inscriptions at Jerash include an elegiac couplet from the nave mosaic of the Cathedral's chapel (no. 294, p. 475).

${ }^{82}$ Claudia Rapp, Holy Bishops in Late Antiquity: The Nature of Christian Leadership in an Age of Transition (Berkeley: University of California Press, 2005), 178-183. Rapp provides an overview of the location of and education at Christian schools in the Late Antique East, as well as information about the education of common clergy and bishops.
} 
background to make such specific and personal statements of membership in the true elite rank.

Lay donors are referenced in inscriptions by first name only, though the majority of the inscriptions include the donors' lineage in the form of their father's name (and sometimes their grandfather's) to serve as an identifier for the local community (Table 3). The names are Greek or Aramaic in origin, or they come from biblical characters, suggesting a mixed population at most settlements. Female donors are rare, though they are sometimes included with their husbands. At St. Stephen, Patrona is mentioned with her husband Rabbos and their unidentified children, while Talitha is cited on her own. At St. John the Baptist in Jerash, there is no mention of Georgina, wife of Theodore, in the inscription, although her labeled portrait is found along with her husband's in the adjacent church of St. George (Figures 98-99).

As previously discussed, civic titles in inscriptions are rare but a variety of ecclesiastic titles are included. All but two of the eight dedicatory inscriptions in this study include the bishop. The inscription at Khirbat al-Samra mentions the archbishop, and the extant part of the fragmentary inscription at Ma'in references a priest. Priests are also mentioned in the dedicatory inscriptions at the Church of the Priest Wa'il and in the sanctuary of the Church of St. Stephen, the latter of which also includes the church's treasurer/administrator (oikóvouos). Included in the individual inscriptions in St. Stephen

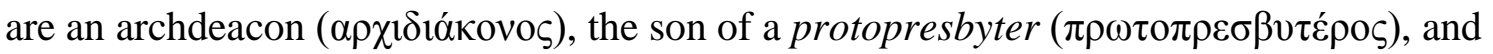

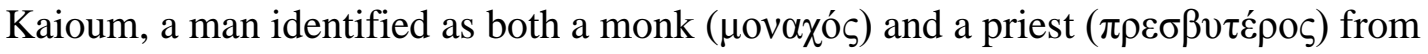
nearby Pisga (Mt. Nebo). The only possible use of a civic title in the churches from this study is also from St. Stephen, in the nave dedicatory inscription. The donor, John, is 


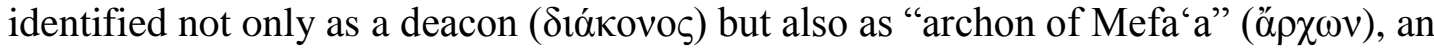
ambiguous title that may refer to an official or imperial position but may also indicate a member of the local landowning elite. ${ }^{83}$ Its use in this inscription is the unique extant example from the churches in Jordan, though it appears frequently in Roman and Late Antique synagogue dedicatory inscriptions. In these instances its use may be honorary and refer to the role of economic patron. ${ }^{84}$ In the St. Stephen pavement, John is also

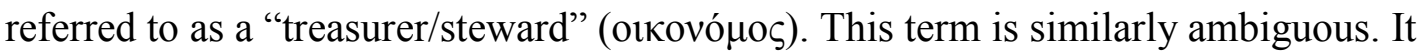
most commonly refers to either the manager of a monastery's financial and land assets or to the treasurer of a bishop's church. However, it is also used to describe a similar role on a private estate. ${ }^{85}$ Given John's membership in the clergy, it is most likely that his role as steward was in a religious capacity, which casts doubt on the possibility that his title of archon reflects a role in civic government.

The inclusion of the priest Kaioum's origin (Pisga) is another unusual feature in Jordanian inscriptions; the town is possibly included to emphasize Kaioum's status, as Mt. Nebo was an important Late Antique pilgrimage site. His inscription is placed within a mosaic panel at the east end of the south aisle, along with other inscriptions and a donor portrait. There are two more instances in St. Stephen in which individuals are associated

\footnotetext{
${ }^{83}$ John Haldon, "Social Élites, Wealth, and Power," in A Social History of Byzantium, ed. John Haldon (Maldan, MA: Wiley-Blackwell, 2009), 190-191.

${ }^{84}$ Andrew Chester, "The Relevance of Jewish Inscriptions for New Testament Ethics," in Early Christian Ethics in Interaction with Jewish and Greco-Roman Contexts, ed. Jan Willem (Leiden: Brill, 2013), 126.

${ }^{85}$ Haldon, "Social Élites," 152, 272; Christopher Haas, Alexandria in Late Antiquity: Topography and Social Conflict (Baltimore: Johns Hopkins University Press, 2006), 224-225. Haldon uses the term in an ecclesial context solely in reference to monasteries. However, Haas notes that the Council of Chalcedon decrees that all churches containing a bishop will have one of their clergy members chosen to serve as oıkovó $\mu$ os. Haas erroneously records this as Canon 25 from the Council, when it in fact is 26 . However, Canon 25 also carries important information about the oเкоvó $\mu$ os, who was tasked with making the financial decisions for the church if the bishop died without an immediate successor.
} 
with towns outside of Umm al-Rasas. ${ }^{86}$ Piccirillo believes their presence indicates donations from the entire town but I suggest that it indicates the origins of the individual patrons in the adjacent portraits and inscriptions because the figures are shown walking in a procession, as if they are making a pilgrimage from their communities to St. Stephen and Umm al-Rasas ${ }^{87}$ This impressively large and well-decorated church was important enough to draw donations from outsiders. Despite the fact that some of the church's inscriptions date to the Early Islamic period, there is no evidence to suggest the practice of Christianity was limited in nearby towns. Instead, the number of churches in Umm alRasas, and their impressive level of decoration, suggest that it had become a destination for Christians, if only on a local level. Might this be true of the other churches in this study? Unfortunately, their inscriptions offer no evidence to support this. Inscriptions offered patrons many ways of demonstrating their status in society. They marked the patrons' euergetism, often mentioning the specific contributions made by the donors. The inscriptions' placement in areas of privilege within the buildings and their use of Greek also helped to highlight the status such donations could confer on those who could afford it. However, with the exception of religious titles included for a few donors, there is no indication that the majority held any official position in their

\footnotetext{
${ }^{86}$ Michele Piccirillo, "Prima campagna di scavo a Um er-Rasas." Syria 64, nos. 3/4 (1987): 305; Bowersock, Mosaics as History, 72. Piccirillo suggests that "Diblaton" is a variation of the biblical Almon Diblathaim mentioned in Numbers 33:46-47 and Beth Diblathaim in Jeremiah 48:22. Bowersock agrees with this assessment and identifies Limbon as Livias, located about $10 \mathrm{~km}$ south of Mt. Nebo. The biblical references are not specific about Diblathaim's location; however, in Jeramiah, Beth Diblathaim is mentioned in direct relationship with Dibon (Dhiban) and Nebo. In Numbers, a journey is described from Dhiban to Diblaton to Mt. Nebo, with roughly a day's journey between each. Dhiban is about $40 \mathrm{~km}$ south of Mt. Nebo, suggesting that Diblaton would be about $20 \mathrm{~km}$ away from each.

${ }^{87}$ Michele Piccirillo, Mosaics, 275.
} 
communities. Instead, local bishops promoted the responsibility of church-building to both elite and non-elite individuals who had the funds to mark their place in society. ${ }^{88}$

Dedicatory inscriptions usually reference the local bishop, but the vagueness of the language makes it difficult to determine the bishop's level of involvement in, or financial commitment to, these projects. For example, Theodore is mentioned as the

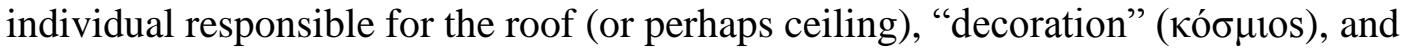
mosaic of St. John the Baptist in Jerash (Table 3). However, the inscription also mentions the "zeal" or "exertion" ( $\sigma \pi$ ov $\delta \tilde{\eta})$ of Bishop Paul. This term is also used to describe the involvement of both the priest Wa'il, and John, the deacon and treasurer at St. Stephen and archon of Mefa'a, respectively. A second term frequently used in connection with bishops in dedicatory inscriptions is "in the time of" ('̇ $\pi \dot{i})$, which appears in all three churches at Umm al-Rasas, as well as at Khirbat al-Samra. Both terms have often been interpreted to mean the bishops had financial involvement in the projects; however, they are used in different ways. In the Jordanian church mosaics, "Ė $\pi \mathrm{i}$ " is only used in dedicatory inscriptions to refer to bishops or archbishops, but " $\sigma \pi 0 v \delta \tilde{\eta}$ " is used for ecclesiastic figures and laypeople alike. I agree with Leah Di Segni, who suggests that “ $\sigma \pi \mathrm{ov} \delta \tilde{\eta} "$ infers active involvement, probably a financial contribution, while " $\dot{\varepsilon} \pi$ '” is used to acknowledge the bishop under whose authority the church was constructed. ${ }^{89}$ The

\footnotetext{
${ }^{88}$ Philip Wood, "Christianity and the Arabs in the Sixth-Century," in Inside-Out: Interactions between Rome and Peoples on the Arabian and Egyptian Frontiers in Late Antiquity, ed. G. Fisher and J. Djikstra (Leuven: Peeters, 2014), 353-368; Peter Brown, Through the Eye of the Needle: Wealth, the Fall of Rome, and the Making of Christianity in the West, 350-550 AD (Princeton, NJ: Princeton University Press, 2012), 280-281. Wood traces the origins of Arab Church patronage to Byzantine-client king relations in the fifth century, but notes that this euergetism takes new political significance in the sixth century amongst the Arab rulers. Brown examines the role of bishops as fundraisers, albeit from a western perspective, and discusses the challenges they faced due to parishioners' preference for donating to monasteries and other religious sites in the Holy Land. Bishops in the east would have faced similar challenges.

${ }^{89}$ Leah Di Segni, "Involvement of Local," 312-313. Di Segni notes some instances in which, in the absence of the bishop's name, غ̇ंí is used in conjunction with the priest's name.
} 
dedicatory mosaic inscriptions from churches in Madaba bolster this idea; no laypeople are mentioned by name but in each case "غ̇ $\pi$ " " is used in conjunction with the bishop, while " $\sigma \pi 0 v \delta \tilde{n}$ " is used to describe the involvement of a priest, a monk, and a deacon under the bishop. In only one case is the language explicit in regards to a clergy member's contribution: an inscription in the Madaba cathedral commands the viewer to look at the beautiful mosaics, the result of the priest John's "contribution and work"

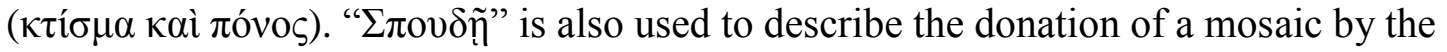
unnamed "Christ-loving people of Madaba" in the Church of the Virgin. ${ }^{90}$ The inclusion of the bishop's name was an important part of the dedicatory inscription. It acknowledged his authority as the person responsible for overseeing all church-building, while providing both clergy and laypeople an opportunity to link themselves in perpetuity to this important figure within the church.

III.v. Donor Portraits Connected to the Topographic Mosaics

Along with inscriptions, patrons sometimes included personal portraits to memorialize themselves in Late Antique mosaics in both ecclesiastical and secular contexts (Table 7). These are not portraits in the modern sense of the word; they are individualized to some extent but not made as an exact likeness of the individual. Instead, they emphasize the person's status through their clothing and accessories, the activities in which they engage, and their physical location within the building. For example, in St. Stephen, an image of a man named John is shown in one of the donor portraits (Figure 70). His features have been obscured by scrambled tesserae, but the scroll John carries on his back is still visible. His long tunic identifies him as patron, not a servant, so the scroll

\footnotetext{
${ }^{90}$ Michel, Les églises, no. 117, pp. 305-307 (the Cathedral), no. 120, pp. 318-319 (Church of the Virgin), no. 121, pp. 322-323 (Church of Elias), no. 124., pp. 327-328 (Church of the Apostles).
} 
serves as an indicator of his wealth and status (and possibly also his level of education), functioning in the same way donor inscriptions do. ${ }^{91}$

Patron portraits in Jordanian churches are generally limited to laypeople, which strengthens the idea that the bishops mentioned in the dedicatory inscriptions did not contribute financially to these projects. In her brief examination of Jordanian patron portraits, Basema Hamarneh suggests the only known example is that of the priest Wa'il at Umm al-Rasas. She concludes that the use of the term " $\sigma \pi \circ v \delta \eta^{\prime \prime}$ in the inscription combined with his portrait suggests he contributed financially to the church. ${ }^{92}$ However, the identification of this portrait as Wa'il must be questioned. Despite the placement of the tabula ansata inscription at the top of the nave pavement, the badly-damaged iconography might depict a layperson and not a member of the clergy- it is not labeled and there are four figures depicted in the scene. ${ }^{93}$ Anastasios' now lost image in Sts. Peter and Paul must also be questioned as a bishop's portrait, as there is nothing in the three inscriptions to indicate that he held this title or that he was a member of the clergy. ${ }^{94}$ Like inscriptions, donor portraits inhabited privileged space in Late Antique churches. There are sixty-one portraits in the churches examined in this study: fortyseven in the nave pavement or its border, eight in panels in front of the chancel screen, and five in the aisles in front of the chancel screen (Table 7). These are privileged areas

\footnotetext{
${ }^{91}$ For discussions of books and texts as status symbols, see Sigrid Mratschek, "Codices vestry nos sumus: Bücherkult und Bücherpreise in der christlichen Spätantike," in Hortus Litterarum Antiquarum: Festschrif für Hans Armin Gärtner zum 70 Geburtstag, ed. Andreas Haltenhoff and Fritz-Heiner Mutshler (Heidelberg: C. Winter, 2000), 369-380; Scheibelreiter-Gail, "Inscriptions in the Late Antique, 142. 92 Basana Hamarneh, "Ritratti immagini di donatori nei mosaici della Giordania," in Acta XIII Congressus internationalis archaeologiae christianiae, ed. N. Cambi and E. Marin (Split: Arheološki Muzej 1998): 411.

${ }^{93}$ For a discussion of the iconography, see Chapter 3, pp.138-144.

94 Gatier, Une lettre du pape Grégoire le Grand à Marianus éveque de Gerasa." Syria 64, no. 1/2 (1987): 135. There is no documentary evidence to support Gatier's claim. For a discussion of Anastasios, see Chapter 3, pp. 120-121.
} 
of the church, especially those closest to the chancel screen, an area generally restricted to the clergy. The portraits are not meant to be viewed closely. In these locations, they can still be seen by the congregation and thus serve as a record of the patrons' generosity. But, more importantly, these portraits act as visual "proxies" for donors, allowing them to inhabit spaces they would not be able to occupy in person. Donor portraits function as memorials in the same way commemorative statues did in previous centuries; however, churches offered the additional benefit of indirect access to sacred space and perpetuating the donor's presence there.

Like much of the iconography in Late Antique eastern churches, patron portraits have strong similarities to domestic mosaics originating in third-century North Africa. In that region, villa owners inserted themselves into popular scenes emphasizing their elite status, including scenes of hunting, public games, and agricultural landscapes. For example, a magistrate from El Djem, Tunisia, recorded his donations to the gladiatorial games in a pavement in his home. He highlighted his financial contributions through both inscriptions and his portrait (Figure 86). ${ }^{95}$ Similarly, the elite landowner, Julius, demonstrated his wealth to guests in his city home with a mosaic depicting him and his wife at their country estate surrounded by servants harvesting seasonal bounty (Figure 87). ${ }^{96}$ The popularity of these scenes spread from North Africa to all regions of the empire.

Patron portraits were more popular in the Late Antique churches of Palaestina and Arabia than they were in any other area. Nearly two dozen churches contain labeled images of donors and dozens more had portraits removed as part of the widespread

\footnotetext{
${ }^{95}$ Azzedine Beschaouch, “A propos de la mosaïque de Smirat,” Africa Romana 4 (1987): 677-680.

${ }^{96}$ W. Raeck, "Publica non despiciens. Ergänzungen zur Interpretation des Dominus-Julius-Mosaiks aus Karthago,” RömMitt 94 (1987): 295-308.
} 
iconoclasm that occurred in this region. These representations are often depicted in combination with the same iconography found in elite homes, strengthening the idea that this tradition was adopted from secular use and that the agricultural and hunting scenes carried similar messages of status in ecclesiastic use. While there is no evidence to support this, the popularity of these portraits in Jordan suggests a strong link to the artistic traditions popularized in North African mosaics.

Of the nine churches examined in this study, three definitely contained portraits, and three others possibly did (Table 7). Examples from other buildings in the region suggest that the number of figures previously recognized as patrons can be expanded, and that some earlier identifications must be questioned. The portraits in the Church of the Lions demonstrate the difficulties at hand. As many as forty figures were originally interspersed with trees on the mosaic border, but few remain and those that survive have suffered extensive iconoclastic damage (Plan 7). The only way to positively identify the images as portraits is the inclusion of one name in the northwest corner, above a figure carrying a basket of grapes on his head (Figure 30a). Another figure holds a censer (Figure 30b), suggesting that the composition originally contained a procession of people bringing offerings to the church. But if this second figure was labeled, it was not done in the same manner as the surviving one, as there is no space above the censor holder. Did this scene represent a large group of donors or were individual patrons inserted into a larger scene of everyday life? And did all patron portraits have to be labeled? ${ }^{97}$

\footnotetext{
${ }^{97}$ Birte Poulsen, "Patrons and Viewers: Reading Mosaics in Late Antiquity," in Patrons and Viewers in Late Antiquity, ed. Stine Birk and Birte Poulsen (Aarhus: Aarhus University Press, 2012), 177. Poulsen briefly examines four images from domestic contexts, which might represent the villa's owner. However, an owner would be able to make guests aware of who the mosaic represented, which would not be as feasible in an ecclesiastic setting.
} 
The question of patron portraits versus genre scenes must be asked for the images on the Church of the Lion's nave mosaic as well. The inhabited acanthus scroll in the main field was completely disfigured by iconoclasts but names next to human figures survive in two of the center scrolls (Figure 31). The labeled individuals are therefore visually linked to the harvest and hunting scenes that originally surrounded them. This could be interpreted as individual patron portraits, patron portraits situated amongst scenes of their economic prosperity, or a mixture of specific portraits and a genre scene. Given the specificity and personalization of the North African pavements, it seems more likely that the harvest and hunting scenes relate directly to the patrons and not generalized scenes of the earthly domain. If not all portraits were labeled, or if we are to associate the labeled individuals with the entire composition surrounding them, then we need to reconsider such "genre" scenes in the other topographic mosaics (Table 5) as possible patron portraits.

In light of these examples, one motif that needs to be reinvestigated is the man leading a pack animal on the Nilotic border in St. John the Baptist (Figure 7). This figure has been completely ignored by previous scholars, who have focused their attention on the topographic imagery. Since traditional Nilotic compositions usually contain scenes of daily life, it is understandable that this motif has gone unnoticed. However, in her study of Syrian patron portraits, Donceel-Voûte differentiates between "official" portraits, busts or standing figures like those found in the Church of the Lions border, and "natural" portraits of people shown participating in daily life like the individuals in the same church's scroll composition. ${ }^{98}$ My interpretations of this figure and others like it from

\footnotetext{
${ }^{98}$ Pauline Donceel-Voûte, Les pavements des églises Byzantine de Syrie et du Liban: décor, archéologie, et Catholique de Louvain, 1988), 479-480.
} 
Late Antique churches and synagogues are discussed with the analysis of the St. John the Baptist mosaic in Chapter 3; however, it is evident that the figure in this mosaic should be considered a possible portrait of the building's donor, Theodore, or a representation of the source of his income.

Since portraits are limited to laypeople and are usually combined with iconography connected with economic activities and/or elite activities, it is not unreasonable to assume that viewers would interpret the mosaic compositions, at least on some level, as they did in domestic settings. In the Late Antique period, portraits replaced the statues awarded to civic donors, just as churches replaced many of the public spaces patronized by the community's elite. However, the mosaic surfaces allowed donors to expand messages of their wealth and status by drawing on a rich visual history in conjunction with inscriptions and portraits in prestigious locations within the churches.

\section{Conclusions}

In large centers like Jerash, donations of Christian laypeople continued a long tradition in the Greco-Roman world, in which the elite contributed to community buildings in return for public recognition. At smaller sites in Jordan, unaffected by western practices, euergetism was introduced through local bishops and became an established method for individuals to assert their wealth and status in their communities. As part of the visual messaging system encoded in Late Antique culture, patrons manipulated both the iconography and placement of mosaics, inscriptions, and donor portraits to maximize viewer impact.

Figural mosaics were time-consuming and costly projects, and their expense was immediately apparent to viewers. The topographic motifs served a variety of purposes but 
were paired with traditional representations of elite status, such as hunting and agricultural scenes, that originated as symbols of status within the private homes of the wealthy. These compositions inhabited the church nave, where they were both highly visible to the congregation and in axial alignment with the altar. Patrons also made use of inscriptions and patron portraits to memorialize their donations toward the construction and decoration of churches. These features fulfilled a more personal role for the donor. While they could be seen by laypeople and worked to reinforce the patrons' status in the community, they could not necessarily be read or closely inspected by anyone other than the ecclesiastic elite. Placed in close proximity to the sanctuary, inscriptions and portraits not only kept the donors in the thoughts and prayers of the clergy, but also served as substitutes for the patrons in perpetual interaction with the divine. 


\section{CHAPTER 3:}

\section{THE TOPOGRAPHIC MOSAICS IN THEIR ARCHITECTURAL AND ICONOGRAPHIC CONTEXTS}

The last chapter has shown that Late Antique patrons uniformly used church pavements as a way of memorializing their euergetism and demonstrating their wealth

and social status. These characteristics were evidenced by the mosaics' size and density, their placement within the church, and the inclusion of donor inscriptions and portraits. This homogeneity does not apply to the selection of city motifs or other imagery in the topographic compositions. While the depictions of cities are similar, each is combined with an assortment of other motifs, and sometimes other decorations or furnishings, to create unique visual programs. Some examples, like those at Umm al-Manabi` and possibly Jerash, are variations of standard Nilotic motifs and carry more generalized messages of prosperity, while others, such as the funerary church at Khirbat al-Samra or the martyr church at Umm al-Rasas, were carefully constructed to reflect the building's purpose. Topographic mosaics sometimes served as more personalized illustrations of the patrons' source of wealth, as is perhaps illustrated in the Church of St. John the Baptist, or depicted the communities' role in the local pilgrimage trade, as demonstrated by the mosaic at Ma'in and all three pavements from Umm al-Rasas. The first part of this chapter examines Late Antique psychological and cultural attitudes toward images, and the second part presents iconological analyses of the mosaics within their architectural contexts. This study includes a discussion of the ways in which an ancient viewer might 
have interpreted the topographic mosaics, while recognizing that such readings differ from modern analyses. In addition, an examination is conducted into the ways in which patrons could use architectural contexts to enrich the mosaics' messages, while the pavements themselves enhanced their architectural space and helped clarify its purpose.

To understand these coexisting messages, the current study follows Pauline Donceel-Voûte's examination of spatial relationships between depictions of Jerusalem and other cities in two of the Jordanian topographic mosaics: Madaba and St. Stephen. Donceel-Voûte is one of the few scholars to have considered the pavements' architectural contexts in her analysis. In the Madaba mosaic, she notes that Jerusalem's centrality in early Christianity is emphasized by its placement in the middle of the pavement, in axial alignment with the nave. ${ }^{1}$ The physical proximity between the holy city and the (now lost) Madaba motif served to aggrandize the town's status for Late Antique viewers. In the St. Stephen mosaic, Donceel-Voûte compares the placement of Kastron Mefa'a to that of Jerusalem. Each is the easternmost topographic motif in the intercolumnar panels, placing them closest to the chancel screen. Kastron Mefa'a is twice privileged: once for its proximity to the sacred space of the sanctuary and a second time for creating a visual parity between it and the Holy City. ${ }^{2}$

In the current study, Donceel-Voûte's approach is expanded, both in terms of the number of topographic pavements and the breadth of iconographic material examined. Wherever possible, the topographic motifs are analyzed in relation to the churches'

\footnotetext{
${ }^{1}$ See above, note 14 .

2 Donceel-Voûte, “La carte,"519-542.
} 
archaeological remains, including floor plans, furnishings, and inscriptions, in order to interpret the meanings of the mosaic compositions. It has been shown that Roman and Late Antique mosaicists strategically utilized pavements' locations, and the resulting visual associations with other objects and between images, to convey specific messages while highlighting the patrons' erudition and reinforcing social hierarchies. These studies have generally focused on domestic floor pavements, though church wall and apse mosaics have also been investigated. ${ }^{3}(\mathrm{Re})$ placing the mosaics in their architectural contexts also provides ideas about how Late Antique viewers would have experienced the images within, and as part of, their original settings. Admittedly, there are some limitations to this approach given the churches' varying states of preservation; wall and ceiling decorations have not survived, nor have most of the furnishings. However, it is still possible to determine general sightlines and the relation of the mosaics' motifs to important liturgical structures, such as the sanctuary, altar, reliquaries, and auxiliary chapels.

In this type of spatial and iconographical analysis, one must be mindful of differences in the way the patron and a modern viewer would construe the mosaic compositions. The analyses of Late Antique descriptions of visual media in the first portion of this chapter provide vital information about how individuals from this period interpreted color and other formal properties of visual media. Additionally, ekphrases (literary descriptions of visual works of art) provide insight into how the mosaic

\footnotetext{
${ }^{3}$ See, for example, Bettina Bergman, "The Roman House as Mystery Theater: The House of the Tragic Poet in Pompeii," ArtB 76, no. 2 (June 1994): 225-256; Simon Ellis, "Power," 117-134; Dunbabin, Mosaics Greek and Roman, 304-316; Daniel Cochran, "Projecting Power in Sixth-Century Rome: The Church of Saint Cosma e Damiano in the Late Antique Forum Romanum," Journal of History and Cultures 3 (2013): 1-32; Rebecca J. Sweetman, The Mosaics of Roman Crete: Art Archaeology and Social Change (Cambridge: Cambridge University Press, 2013), 103-115, especially 112-115; Erik Thun $\varnothing$, The Apse Mosaic in Early Medieval Rome (Cambridge: Cambridge University Press, 2015), especially Chapters 2-3.
} 
compositions might have been interpreted in light of contemporary ideologies. More importantly, they demonstrate how patrons used church mosaics as status symbols and as a means of inciting public accolades.

In the second portion of this chapter, the Jordanian pavements are examined site by site. Since there are two examples at Jerash and three at Umm al-Rasas, this geographical arrangement provides an opportunity to determine if there are any local variations in the use of the topographic motifs. After a brief description of each site's religious, political, and/or economic significance, the mosaics are analyzed from a viewer's perspective in order to determine how they would have been "read" in conjunction with other decorations and liturgical furnishings as the viewer moved through the space. Comparisons to similar Late Antique motifs and compositions from both eastern and western sites in the empire, especially those from nearby Israel and Syria, assist in the identification of the depicted cities and the interpretation of the intended visual messages.

\section{Late Antique Visual Reception and Perception}

The mechanics of seeing are immutable; however, perception of what is seen is both individual and greatly influenced by the period and culture in which one is raised. Late Antique textual sources reveal that during this time people approached visual media in a very different manner than we do today, from their perception of color to their interpretation of iconography. ${ }^{4}$ Our modern preoccupation with naturalism and detail has

\footnotetext{
${ }^{4}$ Liz James, Light and Colour in Byzantine Art (Oxford: Clarendon Press, 1996), 139-140; Fabio Barry, "Walking on Water: Cosmic Floors in Antiquity and the Middle Ages," ArtB 89, no. 4 (December 2007): 627-656. James notes that Late Antique and Byzantine texts highlight color's importance in making what we consider hieratic figures more naturalistic and "life-like" to an ancient viewer. She also observes that these texts focus less on hue, as we do today, and more on the brightness or qualities of light in colors,
} 
obscured possible interpretations of the topographic mosaics. It has been repeatedly assumed that the often schematic topographic motifs are not realistic enough to be identified or to convey meaning. ${ }^{5}$ However, recent scholarship on Late Antique art has shown that viewers in that period were inured to the limited variations inherent in the hieratic style and were better equipped to identify and interpret slight modifications of standardized motifs. ${ }^{6}$ Hieratic art is characterized by a reduction of details and a rejection of naturalism in favor of more schematic poses. What is curious to the modern viewer, who sees no connection between the two, is that the ancient viewer saw them both as methods of "realistically" representing their prototypes. ${ }^{7}$

From the late third/early fourth century onward, the hieratic style was the common choice in artistic production. It has been suggested that one reason for its rising acceptance was the educational curriculum of the period, especially the instruction in laudatory rhetoric. Students of rhetoric were taught various styles of speech, from grand to plain. The latter incorporated complex ideas expressed through simple language; the hieratic visual style serves as a parallel to this rhetorical style. ${ }^{8}$ Moreover, rhetorical practice relied on creative descriptions that required both a keen imagination and the ability to see "more in [an image] than was there." Elite men of Late Antique society not only received this type of training, but also commissioned the majority of the public

\footnotetext{
which suggests a culturally different mode of visual perception in the Late Antique period. Barry provides another example of seeing "living" qualities in decoration, specifically the Late Antique perception of marble as the physical embodiment of water.

${ }^{5}$ Duval, "representations architecturales," 213; Talgalm, Mosaics of Faith, 390.

${ }^{6}$ Robert Nelson, "To Say and To See: Ekphrasis and Vision in Byzantium," in Visuality Before and Beyond the Renaissance, ed. Robert Nelson (Chicago: Chicago University Press, 2000), 144.

${ }^{7}$ Nelson, "To Say," 144; Liz James and Ruth Webb, "To Understand Ultimate Things and to Enter Secret Places: Ekphrasis in Byzantium," Art History 14, no. 1 (March 1991): 2.

${ }^{8}$ Antony Eastmond, "Consular Diptychs, Rhetoric, and the Languages of Art in Sixth-Century Constantinople," Art History 33 no. 5 (December 2010): 754-756. See also Sarah E. Bassett, "Style and Meaning in the Imperial Panels at San Vitale," Artibus et Historiae 29 no. 57 (2008): 49-57.

${ }^{9}$ Onians, "Abstraction and Imagination,"16.
} 
monuments where the influence of their education could be seen. Thus, as laudatory rhetoric became more popular, elite patrons required less naturalistic depictions because they were trained to "fill in the blanks" using reason and imagination. ${ }^{10}$

What does this mean in terms of the topographic mosaics? A Late Antique elite male viewer would see the city motifs and, inspired by his education, would use his personal experiences with these cities to provide an interpretation. For someone who had been to the places in question, this would invoke memories of important buildings, busy streets, and his own actions within the cities. Those who had not been to these places could draw from what was commonly known, the "common sense geography" of a place. ${ }^{11}$ Familiarity with the cities depicted in the topographic mosaics would vary from viewer to viewer, depending on where they were from and the period in which they lived. Unfortunately, information regarding general knowledge and perception of cities is recorded only sporadically in Late Antique texts. ${ }^{12}$ Nonetheless, one needs to accept that some ancient viewers would have been able to recognize the cities depicted on the mosaics based on visual or literary models that do not survive to the present. Moreover, they would have tried to "fill in the blanks," meaning they would have attempted to identify the topographic images in order to interpret the composition before them.

This is not to say that every Late Antique viewer would be able to recognize and interpret the mosaics' motifs and compositions. It is impossible to discuss the highly stratified Late Antique society as a homogenous whole. Depending on social class,

\footnotetext{
${ }^{10}$ Onians, “Abstraction and Imagination,” 12.

${ }^{11}$ For a description of "common sense geography" as it pertains to the ancient world, see Klaus Geus and Martin Thiering, "Common Sense Geography and Mental Modelling: Setting the Stage," in Features of Common Sense, 5-16.

${ }^{12}$ Helen G. Saradi, The Byzantine City in the Sixth Century: Literary Images and Historical Reality (Athens: Society of Messenian Archaeological Studies, 2006), 71-101.
} 
occupation, gender, and so forth. Late Antique individuals would have had varying access to education, travel, and knowledge of the world outside their hometown. Each of these factors would have an effect on interpretations of the topographic mosaic compositions. Based on the rhetorical language used in the earliest dedicatory inscriptions connected with topographic imagery, those from Jerash, it is apparent that those donors had an advanced education. Moreover, the bishops who oversaw the decoration of churches were also members of the elite class and would have been trained in rhetorical speech and interpretation. ${ }^{13}$

The Late Antique education system for young men was two-tiered. The average person who attended school learned to read and write, and developed his powers of recollection. ${ }^{14}$ Members of the social and economic elite received a much more thorough and rigorous instruction known as paideia, which combined the study of philosophy and classical literature with training in rhetoric and instruction in appropriate comportment in Late Antique society. ${ }^{15}$ Visual reception was enhanced through various rhetorical exercises, including ekphrasis and synkrisis, and was influenced by a number of philosophical ideals that would have varied depending on where and when a student received his education. In addition to institutes in Constantinople and Athens, elite young men from Jordan had access to rhetorical schools at Gaza, Antioch, and Alexandria, where they were introduced to rhetorical techniques that affected their visual perception.

\footnotetext{
${ }^{13}$ Claudia Rapp, Holy Bishops, 180-181.

${ }^{14}$ Henri Marrou, A History of Education in Antiquity, trans. George Lamb (Madison, WI: University of Wisconsin Press, 1956), 265, 272; Athanasios Markopoulos, "Education," 785-795. At the age of seven, boys and girls attended primary school, where they learned to read, write, and develop memory work. For the wealthy, this stage could also be accomplished at home with a tutor. At the age of eleven or twelve, boys would move on to the grammaticus, who taught grammar, poetry, and literature. For those who could afford it, youths as young as fifteen could study under a rhetor until they were twenty or older.

${ }^{15}$ Edward Jay Watts, City and School in Late Antique Athens and Alexandria (University of California Press, 2006), 2.
} 
Numerous ekphrases have survived from Late Antiquity. Many of the extant examples were part of the laudatory speeches made at church dedication ceremonies, and they served as another way of praising and commemorating the donation of an ecclesiastic building. The increased focus on architecture (mainly churches) in these sixth-century texts coincides with the development of architectural motifs in Late Antique mosaics. The image of the local bishop or pope presenting a model of the church whose construction or decoration he funded and supervised is found in numerous apse and tribune mosaics in western churches. ${ }^{16}$ It is unknown if the practice was also present in the Late Antique East, where few wall mosaics survive. However, a mosaic depicting Justinian holding a church model and Constantine holding a walled city was added to Hagia Sophia in the tenth century (Figure 89), so perhaps earlier models that have not survived did exist in the east as well. ${ }^{17}$ This is one possible origin for the Jordanian topographic motif.

Like the topographic mosaics, ekphrases of churches were once used as evidence to help reconstruct lost buildings and artworks, but modern scholarship has brought to light an even greater benefit of these texts. Ekphrases were not meant to act as a substitute for viewing the object, nor are they merely descriptions of what the authors saw. Instead, they record the author's responses to the work, which adds to our

\footnotetext{
${ }^{16}$ Examples from Rome include Pope Felix IV at Santi Cosmas e Damiano (527), Pope Pelagius II at San Lorenzo fuori le mura (580s), Pope Honorius I at Sant' Agnese fuori le mura (c. 625), Pope John IV in the Chapel of San Venanzio in the Lateran Basilica. Bishop Euphrasius is depicted in the Church of St. Mary in Poreč, Croatia (c. 553) and Bishop Ecclesius is included in the San Vitale mosaics (c. 546).

${ }^{17}$ Jeanny Vorys Canby, The "Ur-Nammu” Stele (Philadelphia: The University of Pennsylvania Museum of Archaeology, 2001); Claudia Suter, Gudea's Temple Building: the Representation of an Early Mesopotamian Ruler in Text and Image (Leiden: Brill, 2000), 270. Parallels from the ancient Near East survive, such as the Ur-Nammu stele that commemorates the Sumerian king's construction of ziggurat and temple dedicated to the moon-god Nanna at Ur, or the portrait of the Neo-Sumerian king Gudea holding a temple plan on his lap. However, these are too early to have provided inspiration for Late Antique patrons and no evidence survives to show that this tradition continued beyond the third millennium.
} 
understanding of Late Antique perception of visual media. ${ }^{18}$ Images evoked the senses and emotions of the ancient author and ekphrases were meant to do the same for those who were reading or listening to these texts. ${ }^{19}$ It is important to note that ekphrasis was used as more than a schoolwork exercise; laudatory ekphrases were delivered in front of an audience. As a result, women and lower class audience members, who were not formally trained in rhetorically-influenced perception, were exposed to and participated in these exercises during public dedications of churches.

Two Late Antique ekphrases of Hagia Sophia, one by Justinian's historian Prokopios, and another, written by Paul the Silentiary (Paulos Silentiarios) to commemorate the reconstruction of the church's dome in 563, praise the emperor for the expense he has incurred in building such a beautiful monument. They take great effort to detail the specific luxury materials he used. ${ }^{20}$ The panegyrical nature of ekphrases, and the fact that they were often read at the dedication services of the churches they describe, should not be ignored. Knowing that their euergetism would be publically praised served as an added incentive to potential donors and it is not unreasonable to suggest that some of the elite and educated donors, such as Theodore and Anastasios at Jerash, would have commissioned this type of tribute. Choricios' similar ekphrastic account of two churches in Gaza (Map 1) shows that this practice was not limited to the imperial capital or to imperial donations. ${ }^{21}$

\footnotetext{
${ }^{18}$ Ruth Webb, "The Aesthetics of Sacred Space: Narrative, Metaphor, and Motion in 'Ekphraseis'of Church Buildings," DOP 53 (1999): 64.

${ }^{19}$ James and Webb, "To Understand," 7-10.

${ }^{20}$ Procopios, De aedificiis, I.1; Paulus Silentiarios, Descriptio Sanctae Sophiae. 362-398.

${ }^{21}$ Choricios, Laudatio Marciani, I.17-40; II.28-51. Choricios describes two early sixth-century churches in Gaza, praising their patrons.
} 
Many ekphrases describe the interiors of Late Antique churches, providing complex interpretations of decorative elements that draw from early Christian beliefs and Neo-Platonist philosophy. In his foreword to The Mosaics of Jordan, Ernst Kitzinger suggests that the topographic mosaics might collectively reflect a Christian reassessment of the physical cosmos that was influenced by the writings of Pseudo-Dionysios. ${ }^{22} \mathrm{He}$ does not elaborate, but an examination of these Christian ekphrastic descriptions demonstrates that his argument has merit.

In Prokopios' De aedificiis, written in the mid-sixth century, the entire interior of Hagia Sophia is described as a vision of paradise, and the individual elements present a vertical hierarchy that mirrors contemporary Neo-Platonist ideas of the Christian cosmos. Procopios likens the range of colors used for the marble columns, flooring, and revetment to a "meadow in full bloom," while he compares the large supporting piers to "mountain peaks." ${ }^{23} \mathrm{He}$ describes the golden dome as floating, as if "suspended from Heaven by that golden chain. ${ }^{24}$ The floor represents the human world, while the ceiling signifies the celestial realm. Similarly, Pseudo-Dionysios divides the universe into two parallel groups: the hierarchy of the clerical orders on earth and the comparable hierarchy of angels in heaven. ${ }^{25}$

Paulos Silentiarios' interpretation of the ecclesial space is similar to Procopios', suggesting a shared text or underlying belief system that influenced their experiences. ${ }^{26}$

\footnotetext{
${ }^{22}$ Kitzinger, "Foreward," 10.

${ }^{23}$ Procopios, De aedificiiis, I.1:27, 19.

${ }^{24}$ Ibid., I.1:21.

${ }^{25}$ Pseudo-Dionysios, On the Ecclesiastical Hierarchy and On the Celestial Hierarchy.

${ }^{26}$ Paulos Silentiarios, Descriptio, 224; Nicoletta Isar, "Chorós of Light: Vision of the Sacred in Paulus the Silentiary's poem Descriptio S. Sophiae," Byzantinische Forschungen 28 (2004): 215-242; Nadine Schibille, Hagia Sophia and the Byzantine Aesthetic Experience (Burlington, VT: Ashgate, 2014), 224. In his description of the church's ambo, Silentiarios likens it to an isthmus rising from the sea, "adorned with cornfields, and vineyards, and blossoming meadows, and wooded heights." He compares the columns
} 
The most likely source is the work of Pseudo-Dionysios. Writing in the late fifth/early sixth centuries, the individual known as Pseudo-Dionysios produced a cosmological theory that reinterprets Neoplatonic ideals within a Christian framework. Through a series of texts, including The Divine Names, The Celestial Hierarchy and The Ecclesiastical Hierarchy, Pseudo-Dionysios presents two vertically structured universes. In the celestial realm, God interacts with three levels, each containing three celestial beings. Similarly, in the worldly realm, God interacts with the ecclesiastical level, which consists of bishops, priests, and deacons. Below this is another level with three more groups: monks, the laity, and catechumens. According to Pseudo-Dionysios, one's position on this vertical scale indicates the level of divine power one has within and the extent of one's ability to return to a state of divine contemplation. One of the duties of those in the ecclesiastical rank, especially priests and deacons, is to help members of the earthly order complete the rituals necessary to move up to the next rank within their level. Regardless of one's level, one can communicate through prayer, which travels upward to God, while the understanding of God travels downward to the various levels in the form of divine light. In Pseudo-Dionysios' cosmology, this light is not just a representation of an understanding of God but is an actual interaction with the divine.

Pseudo-Dionysios never discusses the role of art in his treatises but a few passages provide an understanding of his views on the subject of representation. According to Pseudo-Dionysios, God wishes to show himself to mankind but this is impossible because of God's dissimilar nature. God therefore reveals himself through a

found throughout the church to "a white cloud tinged by the ruddy rays of the sun" In his description of the new dome, he calls it the divine "head piece" of the church and notes the numerous sources of light provided by the windows, through which "brilliantly gleaming, enters rosy ankled Dawn." Isar provides an in-depth discussion of the influence of Pseudo-Dionysios on both Procopios and Paulos Silentiarios' interpretation of Hagia Sophia. 
series of symbols that make his divine light perceptible to humans, allowing them to have their minds and souls uplifted. The philosopher warns that the symbols used in religious iconography should be as dissimilar to the prototypes as possible, lest one inadvertently engage in idol worship. Mosaics are included in the media Pseudo-Dionysios believed could help humans achieve spiritual ascent. ${ }^{27}$

Pseudo-Dionysios' emphasis on divine light is echoed in the ekphrases of Procopios, Paulos Silentiarios, and Choricios. In each case, the writers place emphasis on the rays of light that enter the churches. Procopios' language clearly demonstrates the Pseudo-Dionysian influence on his interpretations of ecclesiastic space. His metaphor of the gold chain of heaven echoes Pseudo-Dionysios' description of how prayer connects one to God:

So let us stretch ourselves prayerfully upward to the more lofty elevation of the kindly Rays of God. Imagine a great shining chain hanging downward from the heights of heaven to the world below. We grab hold of it with one hand and then another, and we seem to be pulling it down to us. Actually, it is already there on the heights and down below instead of pulling it to us we are being lifted upward to that brilliance above, to the dazzling light of those beams. ${ }^{28}$

Procopios' and Paulos Silentiarios' descriptions of Hagia Sophia, and the decoration itself, illustrate the influence Pseudo-Dionysios had on the reception of Late Antique ecclesial space and its decoration. These concepts were immediately accepted and promoted by both Orthodox and Monophysite Church Fathers, and they spread rapidly through the east and west. ${ }^{29}$ It is therefore not surprising that Choricios'

\footnotetext{
${ }^{27}$ Pseudo-Dionysios, The Celestial Hierarchy, 336B; Moshe Barasch, Icon: Studies in the History of an Idea (New York: New York University Press, 1992), 174-178. Barasch points out that Pseudo-Dionysios highlights the heavenly qualities of bronze, electrum, and "multicolored stones."

${ }_{28}$ Pseudo-Dionysios, The Divine Names, 680C. The italics in the text are mine.

${ }^{29}$ Paul Rorem, Pseudo-Dionysios: A Commentary on the Texts and an Introduction to Their Influence (Oxford: Oxford University Press, 1993), 3.
} 
descriptions of St. Sergios in Gaza also reflect this delineation of vertical space into heavenly and earthly realms while suggesting that the entire church interior represents paradise. ${ }^{30}$

Considering the topographic mosaics within this philosophical context, it is easy to see why Kitzinger would relate them to Pseudo-Dionysios' cosmology. While none of the ceilings are preserved in these churches, one can imagine a decoration representing the celestial realm, perhaps through the use of gold mosaic, and clerestory windows in the galleries that provided light. The topographic mosaics helped to illustrate the earthly realm and their location on the floor where the congregation stood during prayers emphasized both the laity's universe and its connection to God. Moreover, the topographic images, being quite dissimilar to God's divine form but constructed in "multicolored stones," would provide both the patrons and the viewers "the starting point of the flight to heaven." ${ }^{31}$

Though not discussed specifically by the rhetoricians, Pseudo-Dionysios' hierarchy could also be expressed horizontally through the church building. Catechumens were associated with the level of the atrium, and this is where they waited while the laity received communion. The laity occupied the nave and aisles of the building during services, while the clergy performed the service from the sanctuary. ${ }^{32}$ The mosaics also reflect this hierarchy; the topographic motifs representing the laity and the earthly world are found in the nave, while more symbolic images, such as the Lamb of God depicted the heavenly realm, are found in the sanctuary. The chancel screen delineates the two

\footnotetext{
${ }^{30}$ Choricios, Laudatio I. 32-39. Choricios recalls that the golden dome in the church of St. Sergios resembles a "visible heaven," while the apses are decorated with trees and vines, alluding to the lushness of paradise.

${ }_{31}$ Barasch, Icon, 179.

${ }^{32}$ Rorem, Pseudo-Dionysios, 121-123.
} 
spaces. As mentioned in Chapter 2, the donors' portraits resided permanently at the threshold of the sacred. This visually places the patrons at the highest rank of PseudoDionysios' lay hierarchy, a philosophical and physical representation of their status within the community. This also presents a possibility for hierarchical readings of the mosaic compositions, especially those divided into three panels, such as Sts. Peter and Paul (Plan 3) and the Church of the Priest Wa'il (Figure 35). The second section of this chapter examines the physical and social contexts surrounding the placement of various motifs in their architectural spaces.

The connection between the topographic images and Late Antique Neo-Platonist philosophy does not preclude the idea that the motifs could be used to convey other messages and/or to illustrate patrons' socio-economic status. The churches described in the aforementioned ekphrases did not have figural floors, so we have nothing to compare. However, it is obvious that the mosaicists had the skills and repertoire to create scenes less laden with elite iconography than those found in the Jordanian churches. Images of hunting and vintaging were deeply ingrained in Late Antique visual culture, and the topographic images reinforce the concept of the inhabited earth while providing the patron an opportunity to make more specific statements.

Just as ekphrasis was part of the Late Antique education, so too was synkrisis, the rhetorical technique of juxtaposition used by both writers and artists. This device was used in the planning of Roman architectural decoration as early as the second century CE. Bettina Bergmann was the first to outline the Roman practice of actively looking for meaningful comparisons in Roman wall paintings. In her ground-breaking study of the complex rhetorical and mnemonic system incorporated in the decoration of the House of 
the Tragic Poet in Imperial Pompeii, she determines that three key elements were required for interpretation: "epic and dramatic exempla, the artful juxtaposition of likenesses and opposites, and the role of movement for comprehension." 33 The topographic mosaics from Late Antique Jordan certainly contain the last two: most of the topographic pavements provide an arrangement of different walled cities, for which the viewer might look to make comparisons and connections, and in order to view all of the motifs one would need to move along the church floor in a way that mimicked traveling between the depicted sites. In lieu of classical exempla, the Jordanian mosaicists utilized Christianized iconography, including adaptations of landscape and Nilotic compositions. But in order to adapt Bergmann's methodology to the Late Antique pavements, it is necessary to establish that this system was still valid nearly four centuries later, in the eastern portion of the former Empire.

Henry Maguire offers the necessary evidence in "The Art of Comparing in Byzantium," in which he outlines the continued importance of rhetoric in Byzantine education and provides numerous examples of the practice of synkrisis in the East well into the twelfth century. ${ }^{34}$ These comparisons create what Maguire terms "vertical axes" of significance, and he goes on to suggest that an educated Byzantine viewer would recognize the motifs as markers of higher level(s) of meaning. ${ }^{35}$ Through their commissions of the topographic mosaics, Late Antique patrons created images that could be interpreted on both philosophical and literal levels. For example, the walled city motifs were often set amongst images of grape vines and scenes of hunting and fishing. These images could illustrate the donors' status and wealth though the traditional

\footnotetext{
${ }^{33}$ Bergmann, "Roman House," 225-256.

${ }^{34}$ Henry Maguire, “The Art of Comparing in Byzantium," ArtB 70, no. 1 (1980): 88.

${ }^{35}$ Ibid.
} 
common visual language of the elite by depicting the sources of their income and representing leisure activities reserved for the upper classes. They could also carry religious connotations through Christian interpretations of this iconography, such as the suggestion that hunting scenes in Late Antique churches represented triumph over sin. ${ }^{36}$ Similarly, the arrangement of the composition within the church nave could depict a higher level of meaning, reflecting the popular Neo-Platonist ideas of the time. A large portion of the population would not have grasped such complex considerations influencing the mosaics' meanings, but this was not a concern for the elite; the very creation of the mosaics communicated their status to the lower classes, while those with higher social standing interpreted more specific messages.

Informed by a very different concept of visual imagery than we are today, Late Antique patrons used various motifs in combination with each other and with their architectural settings to convey messages about themselves, their churches, and their Christian community. For the modern viewer, trained to interpret images in a very different social context, these messages can be difficult to construe. When the mosaics are removed from their architectural contexts and presented on the walls of museums or as pictures in books, this endeavor becomes even more challenging. Given the poor state of preservation of the churches that housed the topographic mosaics, a complete reconstruction of the pavements' inhabited space is impossible. However, church plans provide some insight into how viewers would have moved through the churches, allowing one to determine the spatial alignment between the mosaics' motifs and significant liturgical objects like the altar. In the next section of this chapter, iconographic

\footnotetext{
${ }^{36}$ Hachlili, Ancient Mosaic, 175-178. Hachlili provides an excellent summary of the scholarly debate concerning the religious and secular interpretations of agrarian motifs in Late Antique religious contexts.
} 
and spatial analyses of the mosaics help expand our understanding of their individual purposes and functions.

\section{The Topographic Mosaics in Their Architectural Contexts}

The following analyses of the individual topographic mosaics are presented geographically by find-site from the north of Jordan to the south. This allows for an examination of the distribution patterns of specific city motifs. Individual images are often repeated in different buildings at the same site, such as the depiction of Alexandria at St. John the Baptist and Sts. Peter and Paul in Jerash, or Kastron Mefa'a at the Church

of the Lions and St. Stephen at Umm al-Rasas. While Jerash's affiliation with Alexandria remains the work of suppositions outlined below, the patrons at Kastron Mefa'a consciously included their city's motif to highlight its importance as a Late Antique pilgrimage site.

There is also a chronological development of the topographic motifs. During the sixth century, depictions of Holy Land cities replaced Nilotic or Nilotic-inspired pavements, and were sometimes used to convey apocalyptic/salvific messages in funerary churches or martyria. In the eighth century, compositions containing several city motifs were adapted for use in pilgrimage churches, utilizing route-like borders to reflect contemporary religious travel. These iconographic, geographical, and chronological trends are discussed at the end of the chapter, in sections investigating the role of topographic imagery in both Nilotic compositions and compositions reflecting realistic Holy Land and Egyptian geography.

In this section, the topographic mosaics are analyzed within their architectural contexts, as Late Antique viewers would have encountered them while moving through 
the building. Whenever possible, I include a discussion of the visual connections that observers would have made between motifs and in conjunction with known liturgical objects, such as the altar or reliquaries.

\section{II.i. Umm al-Manabi`, Unidentified Church (Figure 1)}

The Late Antique settlement at Umm al-Manabi‘, located about fifty-five kilometers north of Amman (Map 1), was not particularly large. The unidentified church discussed here was built at the top of the village's highest hill and is the only ecclesiastic building recorded in the immediate area. It has not been excavated; however, the nave mosaic was preserved through its reuse as flooring for a modern home. From the limited information available, it is difficult to determine if the church had a single aisle or three. Nelson Glueck's records suggest the former, but Augustino Augustinović and Bellarmino Bagatti mention nearby geometric mosaics, which could indicate the decoration of side aisles. ${ }^{37}$ Since they are unspecific about the location of these pavements, it is impossible to be certain. Single-aisled churches are not unheard of in Jordan but they make up less than $20 \%$ of the known examples, not including chapels. Most of these are from the Hauran, which is in close proximity to Umm al-Manabi ${ }^{6}{ }^{38}$ Given the relatively small size of the nave pavement and the existence of similar churches in the vicinity, it is assumed for the purposes of this study that the building was single-aisled.

As Late Antique viewers entered the church from the single central door in the western wall, they would have encountered the nave mosaic as they approached the altar

\footnotetext{
${ }^{37}$ Nelson Glueck, Explorations in Eastern Palestine (Philadelphia: American Schools of Oriental Research, 1934), 229-230; Agostino Augustinović and Bellarmino Bagatti, "Escursioni nei dintorni di 'Aglun." Liber Annuus 2 (1952): 286.

${ }^{38}$ Michel, Les églises, 23; Richard Krautheimer and Slobodan Ćurčić, Early Christian and Byzantine Architecture (New Haven, CT: Yale University Press, 1992), 141. Krautheimer and Ćurčić also mention the common occurrence of single-aisled buildings in the Hauran from the fourth to sixth centuries, but they note that these tend to be small chapel-like buildings.
} 
(Figure 90). At first glance, the composition contains a classical Nilotic scene. Such images were commonly found in mosaics, wall paintings, and other media throughout the empire from the first century BCE onward. Typically, these compositions include a waterscape/landscape filled with vignettes of bucolic life, such as fishing, hunting, and farming. Motifs specific to Egypt are also common, including Nilometers and Egyptian flora and fauna. These are not meant to be accurate representations of Egypt but instead highlight both the exoticism and the fecundity of the province. In Christian contexts, Egyptian imagery takes on additional meanings because the Nile was considered one of the four Rivers of Paradise and its flooding was seen as a representation of God's creation of the world. ${ }^{39}$

In contrast to the detailed depictions found in the Roman west, like the example from El Alia, Tunisia (Figure 91), the composition at Umm al-Manabi' is reduced to the essential elements; it sacrifices the natural landscape in favor of an emphasis on the Nilotic motifs. However, it is likely that Egyptian flora and fauna filled the blank spaces found on the existing sketch and that Glueck either could not see well enough to distinguish them or did not bother to record these details. Nonetheless, the measurements recorded on the sketch show that the field is dominated by five images. As one entered the building, one would see a river, within which are a boat and a fish (Figure 90). A

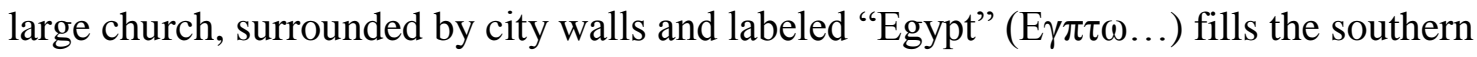
portion of the mosaic. One would see this before seeing the more traditional images, such as the central Nilometer and the large male river personification in the northwest corner. The presence of a hand holding a spear in the southwest corner suggests that a hunting

\footnotetext{
${ }^{39}$ Miguel John Versluys, Aegyptica Romana: Nilotic Scenes and the Roman View of Egypt (Leiden: Brill, 2002), 290, 294-295. Versluys provides a good but not exhaustive catalogue of Nilotic imagery from the Roman and Late Antique period.
} 
scene filled the southeast portion of the mosaic. As Maguire suggests, the inclusion of the church neutralizes the "pagan" connotations of this scene and presents an image of prosperity that Christ and the Church provided to the local parishioners. ${ }^{40}$ For this reason, the Umm al-Manabi' mosaic should be considered an adaptation and continuation of the Nilotic genre, separate from the eight other mosaics in this study.

\section{II.ii. Jerash (Gerasa)}

Modern Jerash, known as Gerasa in the Roman and Byzantine periods, is about forty kilometers north of Amman. The city was part of the province of Arabia and served as a bishopric under the Patriarch of Antioch from at least 359 until 553, at which time the Patriarch of Jerusalem oversaw all the bishoprics of Arabia. ${ }^{41}$ In his brief description of Arabia, the fourth-century writer Ammianus Marcellinus singles out Gerasa as a "mighty (walled) city," mentioning it along with Philadelphia (Amman), the provincial capital, and Bostra, the metropolitan city of the Church. ${ }^{42}$ Gerasa was a large and wealthy center, and an increase in building activity during the fifth and sixth centuries suggests continued financial prosperity in the Late Antique period. ${ }^{43}$ In the Roman period, Gerasa was one of the major cities on the King's Highway, the trade route between Memphis and Sergiopolis (modern Resafa) in Syria. ${ }^{44}$ Jerash's macellum, used in the Roman era as a marketplace, was expanded in the fifth century, and modified in the sixth century to serve as a center of industrial production that included a dye shop and pottery kilns, as well as

\footnotetext{
${ }^{40}$ Maguire, "Nile and Rivers," 181; Basema Hamarneh, "River Nile," 189.

${ }^{41}$ Epiphanios, Panarion, 73.26; Richard Price and Michael Gaddis, trans. The Acts of the Council of Chalcedon v. I (Liverpool: University of Liverpool Press, 2005), 281. Bishop Exeresios is recorded as the representative of Gerasa at the Council of Selucia in 359, and Placcos represented the city at the Council of Chalcedon in 451.

${ }^{42}$ Ammianus Marcellinus, Roman History, 14.13.

${ }^{43}$ Kraeling, "History of Gerasa," 66.

${ }^{44}$ Fergus Millar, The Roman Near East: 31 B.C.-A.D. 337 (Cambridge, MA: Harvard University Press, 1995), 512.
} 
stables. ${ }^{45}$ The area of the hippodrome was also converted for industry including ceramics, tanning, and lime production. ${ }^{46}$ Rather than reflecting a period of decline, this suggests continued prosperity and the elevated position of certain businesses or guilds within the city during the process of transformation away from a Greco-Roman model. ${ }^{47}$ The wealth of the Late Antique city is reflected in its lavishly decorated churches; fourteen have been found within the city walls (Plan 1). No Late Antique pilgrimage account mentions Gerasa as part of an itinerary, but Epiphanius of Salamis' heresiological text, written in 375 , includes a second-hand account of water miraculously turning into wine at the as-yet undiscovered martyrion at Gerasa; this was reportedly an annual event, recreating Jesus' miracle at Cana. ${ }^{48}$

There are two examples of topographic imagery in Jerash's churches, and both depict Egyptian cities. The motifs are very similar, which suggests that either they shared a prototype or that one was copied from the other. Only the example from St. John the Baptist can be dated by inscription. The original excavators believed the mosaic from Sts. Peter and Paul was created later because of its supposed "inferior" quality, but there is no concrete evidence to support this. ${ }^{49}$

\footnotetext{
${ }^{45}$ Alexandra Uscatescu and Manuel Martín-Bueno, "The Macellum of Gerasa (Jerash, Jordan): From a Market Place to an Industrial Area," BASOR 307 (August 1997): 77-81.

${ }^{46}$ Ina Kehrberg, "Roman Gerasa Seen from Below: An Alternative Study of Urban Landscape," ASCS Selected Proceedings 32 (2011): 8, accessed February 3, 2013, http://www.ascs.org.au/news/ascs32/Kehrberg.pdf

${ }^{47}$ Uscatescu and Martín-Bueno, "Macellum," 85.

${ }^{48}$ Epiphanios, Panarion, 30.3; John 2:1-11.

${ }^{49}$ John Winter Crowfoot, "The Christian Churches," in Gerasa, 251.
} 
II.ii.a. Jerash, Church of St. John the Baptist (Figures 2-11, Plans 1-2)

St. John the Baptist is a central-plan building flanked by adjoining basilicas; together, they make up a rare triple-church (Plan 2, Figure 2) ${ }^{50}$ Its plan mimics the metropolitan cathedral at Bosra, visually linking the church to this important contemporary building that was consecrated under the miaphysite Ghassanids, but was in orthodox hands by the time St. John the Baptist was built. ${ }^{51}$ Unlike the complexes at St. Stephen and the Church of the Lions in Umm al-Rasas (Plan 6), both of which contain multiple churches, St. John the Baptist does not include auxiliary structures; it was not part of a monastery or other building complex. All three churches of the complex (Sts. Cosmas and Damian, St. John the Baptist, and St. George) could serve as independent ecclesiastic spaces, but they were connected in such a way that the clergy could move between them in the eastern ends of the buildings. Before St. John's north chapel was turned into a baptistery, visitors to both St. John the Baptist and Sts. Cosmas and Damian could access this room, which might have been the location of the former church's reliquary. The reliquary might also have been placed in one of the niches in the north or south walls of the central space. ${ }^{52}$

\footnotetext{
${ }^{50}$ Cyprian, Life of Caesarius, 38; Robert Ousterhout, "Architecture, Art, and Kommnenian Ideology at the Pantokrator Monastery," in Byzantine Constantinople: Monuments, Topography, and Everyday Life, ed. Nevra Necipoğlu (Leiden: Brill, 2001), 133-152. To my knowledge, the only other Late Antique triplechurch is the Church of St. Mary in Arles, which was possibly dedicated during the Council of Arles in 524; however, Cyprian's language is vague and this might be a triple-aisled basilica and not three churches built together. Later examples of true triple-churches exist, such as the twelfth-century Monastery of Christ Pantokrator in Constantinople.

${ }^{51}$ Irfan Shahid, Byzantium and the Arabs in the Sixth Century v.2, no. 2 (Washington: Dumbarton Oaks, 2009), 281; Dennis O'Neill, Passionate Holiness: Marginalized Christian Devotions for Distinctive Peoples (Bloomington, IL: Trafford Publishing, 2010), 27. In 511, Emperor Anastasios I had orthodox bishops in Constantinople, Antioch, and Jerusalem replaced by miaphysites. Bosra came under the control of the Ghassanids in this period. This was reversed with Anastasios' death in 518, at which time Justin reinstated orthodoxy in the region.

${ }^{52}$ John Winter Crowfoot, The Churches at Jerash: A Preliminary Report of the Joint Yale British School Expeditions to Jerash 1928-1930 (London: The (Archaeology) Council, 1931), 26. Three reliquaries were
} 
The inscriptions and decorations of the triple complex at Jerash suggest that Theodore was a major donor for all three churches. His involvement in St. John the Baptist is secure - he is named in the dedicatory inscription as the individual responsible for its roof and mosaic. While the inscription in Sts. Cosmas and Damian does not mention Theodore by name, the tabula ansata is flanked by his labeled patron portrait and a portrait of a woman named Georgina, presumably his wife. Theodore is identified

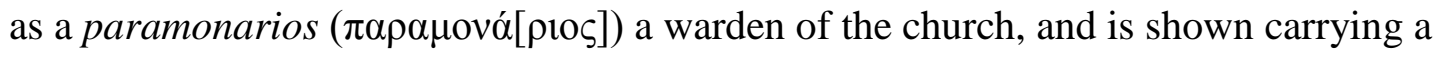
censer (Figures 98a-b). Theodore's involvement in St. George is uncertain; the inscription only mentions that its construction and decoration were financed by "the one whose name the Lord knows." ${ }^{53}$ It is possible that the choice of its titular saint, George, was in tribute to Georgina. ${ }^{54}$ It is obvious that Theodore was a wealthy and prominent member of the community, and he likely received some advanced education - the St. John the Baptist's inscription is written in iambic trimeter, though the structure is imperfect.

People could enter St. John the Baptist through three doors (Figure 100). Four columns supported the roof of the central space and frame the dedicatory inscription, highlighting its importance. The ambo would have been in this central space and it is likely that it obscured the view of both the inscription and the inhabited vine scroll pattern that precedes it. From this area one would have had an excellent view of the central motif of the Nilotic border (Plan 2), whose curvature invites movement inside and

found in St. George, though none were in situ. Crowfoot suggests that one would have been placed in each church originally, and that they were moved as the individual structures went out of use.

${ }^{53}$ Wells, "Inscriptions," nos. 309 (p. 481), 314 (p. 482). Wells suggests that the patron of St. George might be Georgina; however, this is unlikely as the pronoun used to identify the anonymous donor is male.

${ }^{54}$ Crowfoot, Churches at Jerash, 24. 
along the sides of the church. The central motif does not survive but it would have held a privileged place in axial alignment with the altar.

Entering through the side doors in St. John the Baptist's western wall led the viewer to the northwest and southwest portion of the topographic border that forms an almost complete circle around the central space. As people moved through the church, they would have walked along the curved mosaic border, whose inner portion contains topographic motifs situated amongst representations of trees on both the north and south sides. The trees suggest some geographic variation, as those behind each city are cypress, while a grove of red date palms, for which the area was well known, is found next to Alexandria. ${ }^{55}$ The shrine motif includes pomegranate trees flanking its entrance, perhaps recalling the orchards kept at religious outposts or the gardens along the canal outside Alexandria. The pomegranate trees might not be a geographical reference, however, as this fruit is also common in Christian art.

Below the landscape is a small fragment of a river that has fish in the water and aquatic birds and plants on the shore. Unlike the landscape, the river is depicted in a generic fashion (Figure 8). An outer border features an acanthus scroll inhabited by people, animals, and birds (Figure 9). The lost sections make a complete visual analysis of the topographic border difficult, but there is enough space in both the northwest and southwest portions of the mosaic to have contained an extra city motif. As it is preserved, the first city one would see on the north side is Alexandria (Figure 5). As capital of the Byzantine province of Aegyptos and also a patriarchal seat, Alexandria was likely the most well-known Late Antique Egyptian city, and this is evidenced by its inclusion in

\footnotetext{
${ }^{55}$ Crowfoot, Churches at Jerash, 24.
} 
contemporary Nilotic compositions. ${ }^{56}$ The Alexandria motif is also the only motif that was definitely labeled. It is possible that the others were not named, and that one was meant to read this simply as a Nilotic scene like that from Umm al-Manabi`. However, the city found directly opposite Alexandria on the south side (Figure 6) is nearly identical to the labeled depiction of Memphis found in Sts. Peter and Paul in the same city (Figure 15). Since the mosaic at Sts. Peter and Paul is undated, it is difficult to ascertain if one image was used as an archetype for the other or if the artists used a common prototype. Nevertheless, the original excavator, John Winter Crowfoot, rightly suggests that the St. John the Baptist image was intended to be Memphis, and he proposes that the remaining images would have correlated to other Egyptian sites. Based on the layout of the Madaba mosaic, he posits that the border followed a proper geographic layout. ${ }^{57}$ For this reason, Crowfoot suggests that the complex of buildings depicted to the east of the Alexandria motif represents Canopus and the healing shrine of Sts. John and Cyrus at Menouthis (Figure 3, Map 2). The proposal of a pilgrim shrine is plausible; however, Crowfoot's identification of the topographic motif as Menouthis is less certain. Little is known about the shrine of Sts. John and Cyrus. This site is now underwater, so archaeological excavations have been limited. Eyewitness accounts, such as that of Sophronios from the seventh century, focus on the miraculous healings and not on the physical aspects of the site. ${ }^{58}$ Moreover, there is no attribute depicted that would specifically link this image to

\footnotetext{
${ }^{56}$ See below, pp. 150-157.

${ }^{57}$ Crowfoot, Churches of Jerash, 24.

${ }^{58}$ Sophronios, The Passion and Miracles of Sts. John and Cyrus.
} 
Sts. John and Cyrus and there are no known depictions to which the mosaic can be compared. $^{59}$

While there is nothing to positively identify this image as Sts. John and Cyrus, the inclusion of a hexagonal building supports the idea that the motif represents a pilgrimage site. In the Roman and Late Antique periods, central-plan structures were commonly used for memorial churches and martyrs' shrines, though few have been found in Egypt. ${ }^{60}$ Two known examples come from the pilgrimage site of Abu Mena (Map 2), both dating to the sixth century. ${ }^{61}$ Iconographically, the lamp hanging from the gate in St. John the Baptists' topographic mosaic can also be connected to Abu Mena; it recalls the one placed above the saint's grave from which pilgrims could take oil to heal their ailments or to fill ampullae they carried home with them. A Coptic text describes the practice at Abu Mena, and images of the lamp above the shrine are found on an ampulla from the site (Figure 101) and also in Late Antique and Byzantine murals of St. Menas from Egypt. ${ }^{62}$ However, while such lamps are sometimes incorporated in St. Menas' iconography, later miracle accounts reveal they were also used at saints' graves throughout the

\footnotetext{
${ }^{59}$ Dominic Montserrat, "Pilgrimage to the Shrines of SS John and Cyrus at Menouthis in Late Antiquity" in Pilgrimage and Holy Space in Late Antique Egypt, ed. David Frankfurter (Leiden: Brill, 1998), 257-280, especially 257-260. Admitting that archaeological remains of the pilgrimage site have not been uncovered, nor do textual sources record much information about the structures, Montserrat provides some details about Menouthis' structure and orientation, based on descriptions of the types of cures provided and speculation based on other Egyptian pilgrimage sites.

${ }^{60}$ Hans Hondelink, Coptic Art and Culture (Cairo: Shouhdy Publishing House, 1990), 10.

${ }^{61}$ Judith McKenzie, The Architecture of Alexandria and Egypt c. 300 BC to AD 700 (New Haven, CT: Yale University Press, 2007), 291-293, 295. The Tomb (Martyr) Church was adapted to a tetraconch plan in the second quarter of the sixth century, while the mid-sixth century East Church also had a tetraconch plan.

${ }^{62}$ Gary Vikan, Byzantine Pilgrimage Art (Washington, DC: Dumbarton Oaks, 1982), 12; Elizabeth Bolman, Monastic Visions: Wall Paintings in the Monastery of St. Antony at the Red Sea (New Haven, CT: Yale University Press, 2002), 36, 42. Vikan presents a translation of the text: "The pilgrim suspended a lamp before the grave of [St. Menas]....It burned day and night, and was filled with fragrant oil. And when anyone took oil of this lamp... and rubbed a sick person with it, the sick person was healed of the evil of which he suffered." Bolman provides several examples of painted images of St. Menas.
} 
Mediterranean. ${ }^{63}$ Without a toponym or attribute linked to an individual saint, it is not possible to positively identify the site.

The motif's location within the composition might provide a clue to support Crowfoot's suggestion that the site should be identified as Menouthis. The discoveries of the topographic borders from Ma'in and St. Stephen at Umm al-Rasas post-date the excavation of St. John the Baptist, so Crowfoot does not include them as comparanda; however, both their city motifs are laid out to mimic circular routes on a map. These examples are significantly later in date than St. John the Baptist but since all the other examples from Jordan containing a large number of topographic motifs display geographically correct layouts, it is possible the Jerash border does as well.

The other element indicating directionality, and possibly providing a clue to the identities of the cities originally included, is the man leading a camel on the southeast side of the border (Figure 7). Like much of the mosaic, this area is badly damaged and only the lower portion of the man and one foot of the camel remain. As such, it is impossible to discern if the man was labeled or what, if anything, the animal carried on its back. While she does not discuss this figure directly, Basema Hamarneh proposes that the shrine, cities, and figure on the mosaic reference pilgrimage or trade. ${ }^{64}$ I believe the latter is the most likely interpretation for this pavement. The inclusion of people leading animals is extremely rare in Late Antique Nilotic mosaics but it is commonly found in

\footnotetext{
${ }^{63}$ Alice-Mary Talbot, "Pilgrimage to Healing Shrines: The Evidence of Miracle Accounts," DOP 56 (2002): 159. In Talbot's examination of Middle Byzantine pilgrimage accounts, she determines that $40 \%$ involve healings through contact with materials from the shrines, the most common of which was oil from lamps above the saints' graves. For historical accounts, see A.J. Festugière, trans. Saint Thècle, saints Côme et Damine, saints Cyr et Jean (extraits), saint Georges (Paris: A. and J. Picard, 1971), 225-227.

${ }^{64}$ Hamarna, "River Nile," 186. Hamarna references "other anonymous buildings, shrines, and people moving along with animals." However, the preserved mosaic only contains three walled cities, the architectonic structures that Crowfoot identifies as Canopus and Menouthis, and the lone figure.
} 
patron portraits from Jordan and Syria. ${ }^{65}$ Such figures are shown in relation to trade items rather than pilgrimage. In portraits possibly linked to pilgrimage, such as those from the three churches at Umm al-Rasas, the people are depicted on foot (Figures 28, 70-71), and the two known mosaic images of the translation of relics include horses rather than camels (Figures 117-118). ${ }^{66}$

The Jerash figure's stance and clothing most closely resemble the portrait of Orbikon found in an intercolumnar panel in the Church of St. Elias at Kissufim, Israel (Figure 102). In this image, Orbikon is shown holding a bunch of dates and leading a camel laden with amphorae. This image has been identified as either a patron portrait or an image showing the source of wealth for the patron depicted in the adjacent panel. ${ }^{67}$

The latter opinion is influenced, to some extent, by the modern perception that a cameldriver was relatively low in the Late Antique social order. ${ }^{68}$ This assessment is challenged by the mosaic panel at the eastern end of the nave in the Church of St. George at Deir el-Ádas, Syria (Figure 103). ${ }^{69}$ Situated in a prominent location, this mosaic depicts a man named Moukasos, who is labeled as a camel-driver ("Mov $\chi \alpha \sigma o \varsigma$

\footnotetext{
${ }^{65}$ Piccirillo, Mosaics of Jordan, 129, 164, 176, 187, 189, 191; Donceel-Voûte, Les pavements, 479-480. Mosaics with figures leading pack animals that cannot be positively identified as patron portraits do exist in Jordan. A man leading a donkey carrying grapes in an inhabited vine scroll is featured in the Church of alKhadir in Madaba, the Lower Church of Priest John and the Church of the Holy Martyrs Lot and Procopius at Khirbat al-Mukhayyat, the Church of the Deacon Thomas in the 'Uyun Musa Valley, the Lower and Upper Churches at Kaianos, and the Lower Church of Suwayfiah. The last example also contains an image of a bearded man in a long tunic leading a camel. However, these depictions are similar in form to "active portraits" of the camel drivers, as labeled by Donceel-Voûte, and it is likely that they illustrate the professions or source of income for the donors.

${ }^{66}$ Peter Grossman, "The Pilgrimage Center of Abû Mînâ," in Pilgrimage and Holy Space in Late Antique Egypt, ed. David Frankenfurter (Leiden: Brill, 1998), 281. The relics of St. Menas were reportedly translated via camel to Abu Mena, though there is no visual comparanda for this process in Late Antique mosaic art.

${ }^{67}$ Donceel-Voûte, Les pavements, 479-480; Baumann, Spätantike Stifter, 226-232; Poulsen, "Patrons and Viewers,"169-170. Donceel-Voûte proposes that the image of Orbikon is a portrait, while Baumann and Poulsen believe that it represents the source of the wealth of the female patron.

${ }^{68}$ Eivind Heldass Seland, "Kameler og kamelkaravaner i romersk kunst," Klassisk Forum 2 (2011): 50-51.

${ }^{69}$ Donceel-Voûte, Les pavements, 45-54.
} 


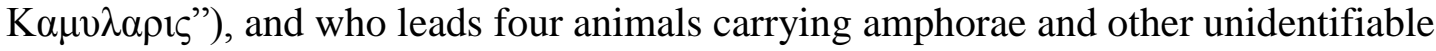
goods. ${ }^{70}$ In the Late Antique period such individuals were responsible for the conveyance of local trade goods and also for the safe transport of pilgrims and other travelers. In some cases, these images might not refer specifically to a camel driver but to a merchant or trader for whom such camel drivers worked. ${ }^{71}$ This is likely the case for both Orbikon and the figure on the St. John the Baptist mosaic, who are distinguished from Moukasos in terms of both their placement in less prestigious locations within the church and the fact that they wear tunics with two orbiculi at the hem. ${ }^{72}$ The tunics distinguish the men as servants; similar markings are found on the clothing of a servant taking the reins from Abraham in the synagogue mosaics from Sepphoris and Beth Alpha. ${ }^{73}$ In the synagogues these figures are found in illustrations of biblical narratives, but in Christian churches they are linked to local inhabitants. The tradition seems to originate in the west, where in the third and fourth centuries, servants were increasingly common additions to paintings, mosaics, and other artworks, and served to emphasize the patrons' status. These figures wear short tunics like those in the mosaics under discussion here. Dunbabin notes that clothing adornments help illustrate the patron's wealth. ${ }^{74}$ It appears that this attribute, like so many in Jordan, also originated in North Africa. ${ }^{75}$

\footnotetext{
${ }^{70}$ Piccirillo, Mosaics of Jordan, 191. Another portrait of a man leading a camel is found at the Upper Church of Kaianos, along with a vintner; however, his long tunic, sword, and camel without trade goods identify him as a Ghassanid soldier.

${ }^{71}$ Seland, "Kameler," 52 . Seland suggests that the reason such portraits were allowed in churches is the fact that incense and oils imported from the East were used in liturgical contexts, and that some Late Antique churches were engaged in the trade of such goods. However, there is no reason why this profession could not be illustrated in stand-alone portraits.

${ }^{72}$ I am grateful to Dr. Sheila Campbell for pointing out this feature to me. Katherine M.D. Dunbabin, "The Waiting Servant in Later Roman Art,” AJPh 124, no. 3 (2003): 446.

${ }^{73}$ Talgam, Mosaics of Faith, 283-285, 296-298.

${ }^{74}$ Dunbabin, "Waiting," 446-453.

${ }^{75}$ Dunbabin, Mosaics of Roman North Africa: 116. Leslie Dossey, Peasant and Empire in Christian North Africa (Berkley: University of California Press, 2010), 83-84. Dunbabin suggests that this is regional dress;
} 
The inclusion of a religious shrine on St. John the Baptist's mosaic border should not dissuade one from identifying the man leading a camel as someone connected to trade. A papyrus from late sixth- or early seventh-century Nessana in Palaestina Tertia records a trading company on a buying trip delivering donations to a monastery. ${ }^{76}$ Moreover, the shrine motif is located in the northeast portion of the mosaic, closest to the entrance of the small chapel that might once have held the church's reliquary. While an "itinerary" of the motifs is purely speculative given the state of the pavement, it is possible the shrine motif represents Menouthis, followed by Alexandria. As the viewer moved along the mosaic, the next sites encountered might have been Abu Mena, as suggested by John Crowfoot, and Naukratis on the western end. Next one would find the extant Memphis motif, and then the man leading the camel. The final city might be Peluseion, an important port town that also lay on the Via Maris trade route. Peluseion is depicted as a major city on the Madaba mosaic but as a simple church with a tower on the St. Stephen pavement. Unlike the Memphis motif, this unlabeled depiction has no match on any of the other mosaics.

Like many of the other topographic mosaics, the border of St. John the Baptist invites movement, leading viewers to the private chapel on the north and providing them with the virtual experience of a route laid out by the patron. The image of the man and camel, which likely demonstrates the patron's wealth through a depiction of his servant and livelihood, is not in the most prominent location but, like other images of donors, is

Dossey rightly points out the class distinction between those who wear long and short tunics but incorrectly differentiates these between townspeople and peasants, not masters and servants.

${ }^{76}$ Philip Mayerson, "The Ancient Agricultural Regime of Nessana and the Cultural Negeb," in Excavations at Nessana v. 1, ed. H. Dunscombe Colt (London: British School of Archaeology in Jerusalem, 1962), no. 89 (p. 211). The trip took the traders to the "Holy Mountain," which Mayerson identifies as Mt. Sinai, though he admits that Jebel Serbal might also be an option. In addition to the donations, the traders purchased beasts of burden, textiles, oil, barley, wine, and curtains for the church. Unfortunately, they do not mention the route that they took of the location(s) where they made their purchases. 
found in close proximity to the chancel screen. Not enough remains of the inhabited scroll design to determine its composition, but its calendar border reinforces the message of agricultural prosperity suggested by the Nilotic scene.

\section{II.ii.b. Jerash, Church of Sts. Peter and Paul (Figures 12-16, Plan 4)}

The Church of Sts. Peter and Paul, located just inside the southwest city wall, is distanced from the other ecclesiastic buildings in the center of town. Although it is adjacent to a small mortuary church flanked by caves used for burial, there is no physical evidence that it was used as a funerary church. Nonetheless, the language of one of the building's inscriptions suggests that it was constructed to hold the remains of the church's patron, Anastasios. In poetic language the inscription addresses the mosaic directly in language suggesting that it covers a grave. Moreover, the topographic imagery recalls apocalyptic/salvific imagery despite toponyms that contradict this identification.

Anastasios, the church's patron, made sure he was recognized and remembered no less than three mosaic inscriptions record his donations, and one of these mentions that his portrait was included in the church's decorative program. The portrait has not survived but the inscription is located at the east end of the north aisle. It indicates that

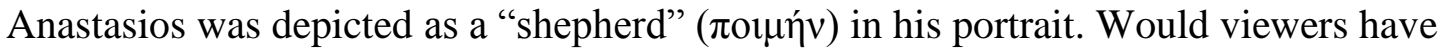
seen his image as they read the inscription? It seems unlikely that his portrait would grace the north apse or the triumphal arch, though bishops and popes are represented in these locations in western churches (Figure 104). It seems more likely that it would occupy the north intercolumnar panel, adjacent to the inscription. While the ambo would block the view of the southern intercolumnar panel, which has a non-figural design, the northern one would be visible to those standing in the nave and the north aisle. This location 
would also provide the proximity to the chancel screen normally afforded to patron portraits.

Anastasios' role in the construction and decoration of the church is clear, but his position in the community is not. Pierre-Louis Gatier suggests that Anastasios was a bishop, though no textual source confirms this. ${ }^{77}$ Anastasios was obviously wealthy enough to have been able to decorate the church with silver and mosaics, and the poetic language of the church's inscriptions suggests an upper level education, though the verse is imperfect. His word choices are sometimes peculiar. For example, he describes himself

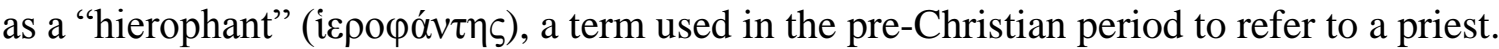
In the Late Antique period, however, this term was not used in reference to clergy, but to biblical figures including Christ, Moses, and various other prophets and saints. ${ }^{78}$ Between the overly boastful nature of his inscriptions and his use of archaic language, one must wonder if Anastasios was attempting to make himself more important than he was. If he was buried in the church, it is almost if the patron is setting himself up in the position of a saint, which would be highly unusual.

The decoration in Sts. Peter and Paul is badly preserved, so it is difficult to understand how the mosaics relate to the inscriptional evidence presented above. The church (Plan 4), a rectangular building with three interior eastern apses and a small chapel attached to the north aisle, is similar to Jerash's Church of Procopios. A reliquary was found in situ in front of the synthranon. A second reliquary was found in the debris but not in its original location. It is possible that it was kept in the niche in the apse wall, though it is also possible that it was located in the north side chapel, where visitors would

\footnotetext{
77 Gatier, "Une lettre," 135.

${ }^{78}$ G.W.H. Lampe, ed., Patristic Greek Lexicon (Oxford: Clarendon Press, 1961), 671b.
} 
have had more direct access to it. The decoration of these spaces does not survive, however, nor does any archaeological confirmation of these suppositions.

Before the southern entrance was blocked, a person could enter the church through one of three entrances on the western end of the building (Figure 105). The first panel encountered would have been an inhabited vine scroll, though very little of it remains. The central panel contains a large Nilotic scene (Figure 13), the upper portions of which are dominated by two walled cities labeled Alexandria and Memphis. Unlike the St. John the Baptist composition, a larger portion of this scene was devoted to the riverscape. Again, only a small portion of it survives. There are no other known Nilotic scenes with two cities, but a common double city motif in the Late Antique period is the representation of Bethlehem and Jerusalem, interpreted as an apocalyptic/salvific symbol. Normally, the combination of the inscription and a double city motif would be indicative of either a funerary church or one built to hold a saint's relics. However, the toponyms clearly identify the depicted cities as Alexandria and Memphis and problematize this interpretation. Was the patron/artist unaware that Jerusalem and Bethlehem were the appropriate images to depict to convey messages of salvation? Or did Alexandria and Memphis have some importance for the patron?

There is nothing in the inscriptions or surviving images to suggest that Anastasios had any personal connection to Egypt. One explanation, as Henry Maguire suggests, is that this panel was meant to be read as a symbol of the prosperity provided by Christ and the Church. ${ }^{79}$ The eastern panel contained a second inhabited vine scroll but, again, very little survives. The overwhelming message of this decoration is one of prosperity, while the location of the building, the inscriptions, and the topographic motifs suggest a

\footnotetext{
${ }^{79}$ Maguire, "Nile and the Rivers," 179-184.
} 
funerary context; without further excavations or information regarding the missing mosaic decorations, little more can be said about this enigmatic building and its patron.

II.iii. Khirbat al-Samra, Church of St. John (Figures 39-42, Plans 9-10)

Khirbat al-Samra is located about $50 \mathrm{~km}$ northeast of Amman. It was established as a station on the Nabatean caravan route between Aila, on the Red Sea, and the Hauran, a fertile region of southern Syria. Located along the Roman Via Nova Traiana, the site became part of the Limes Arabicus and a fort was constructed there, probably during the reign of Diocletian. The walled village is small, measuring approximately 200 by $300 \mathrm{~m}$ (Plan 9). Despite its diminutive size, there are eight Late Antique churches within the city walls and excavators date all of them between the sixth and seventh centuries, an estimate largely based on stylistic evidence. ${ }^{80}$ The floor plans of these churches are distinctly different from most found in Jordan; they possess rectangular choirs that lack the typical apsidal eastern wall. This style is more common in Egyptian churches, though a few examples are found in both Jordan and Syria. ${ }^{81}$ While it has been proposed that the style originally developed from Syrian temples, there is no evidence to suggest that this building type indicates a different liturgical practice or Christological belief. ${ }^{82}$ While some epitaphs on the gravestones in the local cemetery are written in Greek, the majority are written in Christian Palestinian Aramaic, a language used by Melkite (Orthodox) Christians. ${ }^{83}$

\footnotetext{
${ }^{80}$ Humbert and Desreumaux, Fouilles de Khirbat, 51-54.

${ }^{81}$ McKenzie, Architecture of Alexandria, 270.

${ }^{82}$ Richard Krautheimer, Early Christian and Byzantine Architecture (London: Harmondsworth, 1986), 151, 323; McKenzie, Architecture of Alexandria, 270. McKenzie records new discoveries from Kellis that disprove Krautheimer's suggestion that this style develops in Syria and is later adopted in Egypt.

${ }^{83}$ Alain Desreumaux, "Les inscriptions funéraires araméenes de Samra," in Fouilles de Khirbat es-Samra en Jordanie, v. 1, ed. Jean-Baptiste Humbert and Alain Dsreumaux, (Turnhout: Brepols, 1998), 435; Stefan Weninger, ed., The Semitic Languages: An International Handbook (Berlin: Walter de Gruter, 2012), 628-
} 
At the time of the mosaic's construction, individuals would have entered through at least two of three doors in the western wall; the north doorway was blocked at some point, as was the aisle, in order to create a side chapel (Figure 106). It is impossible to be sure whether this coincided with or post-dated the mosaic work. Excavators mention no material finds within the side chapel that would suggest it was used for burial, but the structure added to the northwest side of the building contained six bodies along with ceramics dating to the Umayyad period.

The church could certainly be entered from the nave or the south aisle. The latter was undecorated but provided views of the mosaic through the intercolumnar spaces. Entering from the central doorway allowed a better view and cements the axial alignment of the composition. The first image one encountered when moving eastward into the nave was an empty krater on a pedestal. Kraters are usually shown filled with vines, though this one is empty, which was a common motif in Dionysiac compositions and Orphic literature; in the latter they are considered the holder of souls. Empty kraters appear in a number of Jordanian and Syrian church mosaics. In Syria, kraters are replaced with baptismal fonts, further situating this symbol in a Christological context. ${ }^{84}$

Peacocks were also common choices and, combined with the krater, symbolize heaven and the immortal soul. Images of other animals are also found in the pavements. Iconoclastic damage has destroyed the figures on either side of the vessel. ${ }^{85}$

Moving eastward, the next motifs one encounters are the pair of unlabeled cities with a now-lost figure between them. Without explaining their choices, the excavators

629. Desreumaux calls Christian Palestinian Aramaic "Melkite Aramaic," one of the many terms used for the dialect used by Melkite Christians between the fifth and thirteenth centuries.

${ }^{84}$ Martin P. Nilsson, “Krater,” HTR 51, no. 2 (April 1958): 55-56; Donceel-Voûte, Les pavements, 165.

${ }^{85}$ Erwin R. Goodenough, Jewish Symbols from the Greco-Roman World v. 8 (New York: Pantheon Books, 1958), 52-58. 
suggest that the cities might be Jerusalem, Bethlehem, or Rome; however, they do not discount the idea that they were purely decorative and not meant to depict any specific city. ${ }^{86}$ In contrast, Piccirillo suggests that the flowers are Nilotic in nature, which encouraged others to infer the cities are Alexandria and Memphis, like the examples from Jerash. ${ }^{87}$ However, the other motifs in the composition provide clues to the cities' identities, as discussed below.

Continuing eastward, the next part of the mosaic contains an empty birdcage and an inscription stating the mosaic was commissioned to memorialize the deceased Pholeos. Like the empty krater, the unoccupied cage has been interpreted as a symbol of the soul, in this case the soul being released from the body. ${ }^{88}$ The decoration on either side of this motif has been lost but the areas are unusually shaped and not large enough for standing portraits, so they likely contained depictions of animals. To the east of this is the circular dedicatory inscription (Plan 10). It is difficult to read, as it requires standing in the center of the mosaic and turning in circles to read both the inner and outer border. The inscription explains that the church was dedicated to the martyr John, and the reliquary and glass container embedded in the altar table presumably hold remains of this local figure (Figure 40). ${ }^{89}$

Burials within martyr churches were desirable because they provided a permanent proximity to the holy figure, functioning in a similar fashion to the donor portraits placed next to chancel screens. We have no information about Pholeos but he must have been an

\footnotetext{
86 Jean-Baptiste Humbert. “Khirbat es-Samra, 1981-1982," Syria 60, no. 3/4 (1983): 311.

${ }^{87}$ Piccirillo, Mosaics of Jordan, 34; Hachlili, Ancient Mosaic, 104; Dey, "Urban Armatures," 190.

${ }^{88}$ Maguire, Earth and Ocean, 65; Hunt, "Byzantine Mosaics," 121.

${ }^{89}$ Humbert and Desreumaux, Fouilles de Khirbat, 51-54.
} 
important figure to have received such a privilege. ${ }^{90}$ His son took full advantage of this situation and recorded his own name, Kaomos (son of Pholeos) in the easternmost part of the nave mosaic. Kaomos' name is joined by another but there is no indication that these two individuals were related. Perhaps this second figure is related to the anonymous

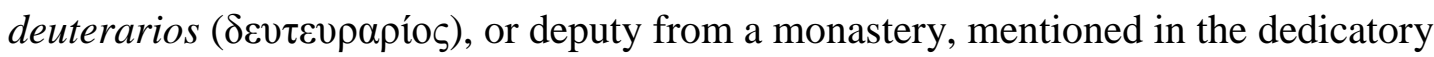
inscription. Unlike the priest from Mt. Nebo who contributed to the church's construction, the deuterarios does not include his place of origin; perhaps he was a member of the monastery at Khirbat al-Samra.

All of the surviving imagery relates to the burial of Pholeos and it makes sense that the cities would also contribute to the mosaic's purpose. Therefore, the excavators' original suggestion of Bethlehem and Jerusalem provides the most likely identification. Depictions of these cities were included in some of the earliest known decorated churches. The apse mosaic from Santa Pudenziana (Figure 107) displays Christ, flanked by the Apostles, handing down the law. The city behind Christ is Jerusalem; however, its jeweled appearance and the Four Beasts of Revelation in the sky indicate that this is the Heavenly Jerusalem. ${ }^{91}$ The image of the Jerusalem and its gates appears in the late fourth century on both western and eastern sarcophagi, along with images of Christ and the Apostles, the Four Rivers of Paradise, and other motifs (Figure 108).$^{92}$ In later mosaics, the triumphal arch bears the images of two cities, Jerusalem and Bethlehem (Figure

\footnotetext{
${ }^{90}$ Ann Marie Yasin, "From Roman Family to Christian Community," ArtB 87, no. 3 (September 2005): 433-457.

${ }^{91}$ Fredric W. Schlatter, "Interpreting the Mosaic of Santa Pudenziana," VigChr 46, no. 3 (September 1992): 276-295.

${ }^{92}$ See, for example Fr. Baratte and C. Metzger, Musée du Louvre: Catalogue de sarcophages en pierre d'époques romaine et paléochrétienne (Paris: Louvre, 1985), 312-316.
} 
104). ${ }^{93}$ Together the jeweled cities represent the New Jerusalem during the Age of Grace. $^{94}$

Bethlehem and Jerusalem are incorporated in at least one other church mosaic. At the Church of the Holy Martyrs in Tayyibat al-Imam in Syria, a pavement dated by inscription to 447 features the two cities in an elaborate composition (Figure 109). At the base, an eagle perches on an overturned krater, from which four rivers spill forth. The eagle is flanked by two pairs of facing deer in front of pomegranate trees. In the middle ground are three pavilions interspersed with peacocks. Inside the central pavilion is a lamb standing under a lamp, and the other two structures contain baptismal fonts. At the top of the mosaic, underneath the dedicatory inscription, are the labeled images of Jerusalem and Bethlehem (Figures 110a-b). Each is depicted as a single church surrounded by high walls.

The Khirbat al-Samra mosaic is an extremely abbreviated version of this scene; however, the depiction of one motif is similar (Figure 41). The city on the north side of the composition contains one long basilica that fills the horizontal space of the city. It is accompanied by three domes, which possibly reference the dome of the Holy Sepulcher. Given the funerary iconography found on the rest of the pavement from Khirbat alSamra, and the similarities to the Tayyibat motifs, its cities should be identified as Jerusalem and Bethlehem (Figures 41-42).

II.iv. Madaba, Church of the Map (Figures 17-27, Plan 5)

\footnotetext{
${ }^{93}$ Examples include Santa Maria Maggiore (fifth century), Santa Cecilia (fifth century) and San Lorenzo fuori le mura (580s) in Rome and Sant' Apollinare in Classe, Italy.

${ }^{94}$ Campanati, "Jerusalem and Bethlehem," 173.
} 
Madaba is located thirty kilometers southwest of Amman (Map 1). It is an ancient site, known in biblical times as the Moabite city Medeba. ${ }^{95}$ In the Hellenistic period, it came under Nabatean control but was taken by Trajan in 106 and absorbed into the Roman province of Arabia. Madaba was a significant Christian center in the Late Antique period and the city had obtained episcopal status by 451. At the Council of Chalcedon, the metropolitan bishop Constantine signed on behalf of Madaba's bishop Gaianos. Mosaic inscriptions from the city's ten known churches record successive bishops until the second half of the eighth century. While not a pilgrimage site itself, Madaba is in close proximity to many popular Late Antique loci sancti, including Mt. Nebo and the hot springs at Ma'in. The western pilgrim Egeria visited Madaba at the end of the fourth century and John Rufus records Peter the Iberian's visit at the end of the fifth. Neither source references Madaba's topographic mosaic, which suggests it was not yet constructed. Caspar René Gregory proposes that such an elaborate mosaic would have made the church famous and recalls an account of a Late Antique manuscript housed at Mt. Sinai that mentions the topographic mosaic; the existence of this text has not been confirmed. $^{96}$

Little is known about the Late Antique church discovered during the construction of St. George in the late 1890s. No inscriptions survive and the site was not excavated because building had already begun. Many authors have suggested plans for the original church; the most commonly accepted one depicts a single-apse basilica with a nave and two aisles (Plan 5). ${ }^{97}$ The new church is modeled on this plan and the Late Antique mosaic makes up part of the modern floor. It is unlikely that the modern plans follow the

\footnotetext{
${ }^{95}$ Numbers 21:30, Joshua 13:9.

${ }^{96}$ Gregory, "Mâdaba Map," 246-247.

${ }^{97}$ Michelle, Les églises, 310.
} 
ancient foundation exactly; the images at the edge of the south wall appear to have originally continued to the south, and the image of Jerusalem is slightly out of alignment with the apse. The mosaic is unusual in that it covers the nave and both aisles. It is unknown how much of the church was originally paved with the topographic scene. At present, 151 sites from the Holy Land and Egypt are depicted, but early accounts suggest that parts of Asia Minor were also included. ${ }^{98}$

Entering from one of the three western doors, viewers would have been presented with only a small portion of the mosaic (Figure 111). It is impossible to take in the whole composition from any one location and the piers would have blocked both sightlines and movement. Moreover, liturgical processions allowed for movement eastward into the church but not from north to south. Therefore, a virtual pilgrimage, either the physical type suggested by Herbert Donner or the mental one proposed by Victor Roland Gold, would be difficult. ${ }^{99}$ Another challenge is the large number of texts that fill the landscape. The Twelve Tribes of Israel are listed and each labeled site includes one or more names and sometimes a brief description. It is challenging to read even for someone with advanced literary skills. The viewer would be immediately impressed with the obvious education of the patron(s) and their awareness of the world outside their own community.

Madaba was most likely portrayed to the east of Jerusalem in axial alignment with the Holy City. The spatial arrangement confers status on Madaba, as Pauline DonceelVoûte has noted. ${ }^{100}$ It also places Madaba in axial alignment with, and closer to, the altar. In this way, the city is privileged above the Patriarchal center. Another technique used to convey importance is hierarchy of scale. The cities are generally presented using a

\footnotetext{
${ }^{98}$ Gregory, "Mâdaba Map,” 245.

${ }^{99}$ Donner, Mosaic Map, 30.

${ }^{100}$ Donceel-Voûte, "La carte," 222-225.
} 
semiotic system to indicate size. ${ }^{101}$ However, the ten cities depicted with walls do not necessarily represent the largest cities in the region. For example, Azotos Paralos is described as a townlet in the seventh century Life of Peter (Figure 24). ${ }^{102}$ This could simply be a mistake, but it also might be intentional since the ten cities fall along the major highways of the region.

The Dead Sea is also depicted in larger scale, as are the workers with two boats at its center. This places the focus on their work, the mining of salt and bitumen, and puts them in axial alignment with the altar and Madaba. This is the easiest motif to interpret, as it is the largest image in the composition and is not covered in text. Filling devices are rare but include crops of economic importance. The crops are not placed randomly, however, but are found in areas known for those particular products. Within the larger depiction of a Christian world holding Jerusalem at its center, the patron has emphasized local prosperity instead of offering generic images like those found in the lush Nilotic landscapes. In this way, the Madaba mosaic echoes the message found in the St. John the Baptist pavement, but hides it more carefully in the detailed composition. For those trained to notice and interpret such details, as the patron(s) undoubtedly was/were, these messages would be more apparent than they are for the modern viewer.

The Madaba mosaic has long been considered unique, but its layout bears some resemblance to a late third- or early fourth-century mosaic from Haïdra, Tunisia (Figure 112). That pavement measures roughly $6 \mathrm{~m}^{2}$ and contains images of twelve landmasses containing idyllic buildings and vineyards that recall traditional landscape scenes. Each landmass is depicted as an island in a body of water filled with fish. The motifs are

${ }^{101}$ Avi-Yonah, Madaba Mosaic, 21-23; Noël Duval, "représentations architecturales," 211-285.

102 John Rufus, Life of Peter, 114. 
labeled, and represent towns and islands from the Aegean and Mediterranean Seas. The layout does not completely coordinate with geographic reality, though many of the sites do form a "route" when considered in succession. The excavator suggests the mosaic might document a journey taken by the patron, but also proposes that the islands were chosen for their connection to the worship of Aphrodite because ten of the twelve locations were known cult sites. ${ }^{103}$ It is also possible that this mosaic represents some form of network, since Haïdra was part of the major inland trade route in Africa.

Several of the Jordanian mosaics incorporate some sort of route in their compositions and it is possible that this formula was borrowed from Tunisia, as were other popular church motifs. Vandal invasions caused a great reduction in mosaic production during the fifth century in North Africa, and this coincided with the contemporary increase in production of mosaics in Jordan. The movement of craftsmen to a more settled and prosperous area due to civil unrest in their homeland could explain the transfer of popular motifs from domestic settings in North African to ecclesiastic structures in Jordan.

\section{II.v. Ma'in, Church of the Acropolis (Figures 74-85, Plan 13)}

The site has not been well-excavated, so little is known about Late Antique Ma'in. Eusebius identifies the site as Beelmeon, the biblical $\mathrm{Ba}^{\prime} \mathrm{al} \mathrm{Me}$ 'on, and he mentions that it was the birthplace of the prophet Elisha. ${ }^{104}$ Fourth-century Ma'in is described as a "very large village" near the baths of Baaru, which Peter the Iberian visited

\footnotetext{
${ }^{103}$ Fathi Bejaoui, "Cyprus and cities of the Mediterranean on a mosaic from Haidra in Tunisia," Mosaic. Recent Discoveries, New Research. University of Cyprus Department of History and Archaeology. Accessed February 25, 2016. https://www.ucy.ac.cy/hisarch/en/news-events/conferences/26-en-articles/enbottomm/news-events/88-mosaics-recent-discoveries-new-research.

${ }^{104}$ Eusebius, Onamasticon, 44-46. Eusebius links it to Numbers 32:38 but it is also mentioned in 1 Chronicles 5:8 and Ezekiel 25:9. Ba' al Ma'on is also identified as Beon (Numbers 32:3) and Beth Ba'al Ma'on (Joshua 13:17). In 1 Kings 19:7, Elisha is said to have come from Abel Meholah.
} 
in hopes of curing his ailments. ${ }^{105}$ Three churches from the Late Antique period have been dated to the sixth and seventh centuries based on stylistic evidence and inscriptions. At that time, the settlement was known as Belemounta, as depicted in the topographic mosaic from the Church of the Acropolis and the contemporary pavement from St. Stephen at Umm al-Rasas.

The fragmentary inscriptions in the Church of the Acropolis mention no individual donors and the mosaics, which are disfigured and include large areas of loss, provide no other information. Working on the assumption that the building was a singleaisled church with a chapel annex on the north side, one would enter through the only door (Figure 113). The threshold inscription and first set of labeled cities (Maiumas, Gaza, and Odroa, Figures 78-80) face west and thus would be viewed upon exiting. The center portion of the nave is also badly damaged but figural images once filled the scutae. Only a few, such as a basket of grapes, have survived. The borders are viewed by facing outward, like the Nilotic border at St. Stephen, and would be more difficult to read as one advanced toward the altar. Nonetheless, they provide the viewer with a sense of moving along a route, especially because the cities are presented in a geographically correct order. In this way the mosaic is similar to those at both St. Stephen and St. John the Baptist. It also shares some characteristics with the Madaba mosaic, even though the Madaba pavement lacks the rigid directionality of the other examples.

In his interpretation of the mosaic, Roland de Vaux suggests that the community elevated its status by depicting its city amongst bishoprics that were under the authority of the Jerusalem patriarch. This cannot be the case, as not all of the depicted sites were

${ }^{105}$ Eusebius, Onamasticon, 46; John Rufus, Life of Peter, 89. 
bishoprics, nor were they all under the authority of Jerusalem. ${ }^{106}$ Based on the preserved plan, however, it is possible that the Ma'in motif occupied a privileged space within the nave (Plan 13). In his preliminary examination of the mosaic, Roland de Vaux suggested that it originally contained twenty-four city motifs. Based on the spacing of the remaining images, however, I believe it held no more than twenty-two: three each on the west end, perhaps three on the east, and eight each on the north and south ends. ${ }^{107}$ The lacunae make reconstruction difficult, but the surviving city motifs suggest that the border also outlined a geographic route, though perhaps not as neatly as the Holy Land routes depicted on the St. Stephen mosaic.

Working from the south as was done with St. Stephen; the first labeled city encountered in the southwest corner is Maiumas (Figure 78), which served as the port of Gaza (Map 5). This is a sensible place to start, both in terms of its location within the church and from a geographical standpoint, because Maiumas was an important port stop on the Mediterranean trade routes and was also a debarkation point for pilgrims. ${ }^{108}$ The next city is Gaza (Figure 79), followed by a site with a partially preserved label $(\mathrm{O} \Delta \ldots)$, which de Vaux identifies as "Adraa, east of Petra (Figure 80)." 109 Adraa is located to the west of Bosra, so this toponym should instead be connected with Udhruh, which is located east of Petra along the main Gaza-Petra road. ${ }^{110}$ From here, the viewer would proceed north to the first two cities depicted on the north side of the border: Charach

\footnotetext{
106 de Vaux, "Une mosaïque," 252; Piccirillo, Mosaics of Jordan, 36

107 de Vaux, "Une mosaïque," 241.

${ }^{108}$ Lionel Casson, "Speed under Sail of Ancient Ships," TAPA 82 (1951): 136-141; Stephen H. Werlin, Ancient Synagogues of Southern Palestine, 300-800 CE: Living on the Edge (Leiden: Brill, 2015), 239. 109 de Vaux, "Une mosaïque," 247.

${ }^{110}$ Pierre-Louis Gatier, "L'idéologie de la cite et la carte de Madaba," in Madaba Map Centenary, 237; Fawzi Abudanah, "Agriculture in Sixth-century Petra and its Hinterland: Evidence from the Petra Papyri," Arabian Archaeology and Epigraphy 23 (2012): 109-110. The city was also known as Augustopolis, as mentioned in the Petra papyri, and was an important agricultural center in the sixth century.
} 
Moba (Figure 81) and Aereopolis. After this, there seems to be a strange divergence. The next city listed is Gadaron (Figure 82), which de Vaux equates with either Gadara, north of Pella, or Gadora, near as-Salt northwest of Amman. He notes that both of these are geographically past the next sites depicted on the border, which are Belemounta (Ma'in, Figure 84) and Esbounta (Figure 83). ${ }^{111}$ Of all the sites that should be geographically correct, the one in which the mosaic is physically located would seem most important. The only explanation is that the depicted route would take a traveler near the site of Jesus' baptism in the Jordan River before turning back to Esbounta and ending at Belemounta (Ma'in), at the entrance to a chapel that might have contained relics or other material of interest to pilgrims.

Also unusual is the fact that the patron or mosaicist placed the Belemounta motif in the center of the north panel and not in a more prominent central and/or eastern location, as was done with the host cities in the St. Stephen and Madaba mosaics. The mosaic to the east of the Belemounta motif does not survive, and the pavement resumes on the south side with Nikopolis (Figure 74). How would the route continue from Belemounta- to the north or south? Or perhaps one was expected to cross the Dead Sea by boat. No contemporary accounts discuss this option, though it is mentioned in both Roman and later Arab sources; however, the direction of this type of travel was generally north to south, not east to west. ${ }^{112}$

Almost half of the mosaic border is missing. If the east side contained topographic images, then there would still be eleven cities to account for. If another scene filled that space, perhaps one depicting the donors making a journey, as with the St. John the

\footnotetext{
111 de Vaux, "Une mosaïque," 249.

112 Irfan Shahid, Byzantium and the Arabs, 32.
} 
Baptist or Church of the Lions borders, then there would be six. The latter choice makes the most sense when looking at the distance between the depicted cities. Based on Late Antique travel accounts and the other topographic mosaics, it is probable that cities like Scythopolis, Neapolis, Caesarea, and Jerusalem were included. The area of loss ends on the south side with Nikopolis, and the city most likely to be depicted east of it is Jerusalem. This would place Belemounta and Jerusalem on equal axes. If the Ma'in church was single-aisled, the Belemounta motif would align with the entrance to a sidechapel, which might explain the less prominent location for the image and its possible parallel with Jerusalem in the middle of the nave. On the south side, a route following known roads back to the coast proceeds (from Jerusalem) to the extant cities of Nikopolis and either Eleutheropolis (as de Vaux suggests) or Diospolis (which would also fit the fragmentary toponym), before ending at Askalon. ${ }^{113}$

The church's inscriptions are extremely fragmentary, but are variations of Psalms. ${ }^{114}$ Biblical references are rare but not unknown in the churches of Jordan. The first part of the text is especially apropos for the threshold upon which it is found: "It is the door of the Lord; the righteous shall enter." The second, at the western end of the nave ("the Lord prefers the gates of Zion to all the tents of Jacob") is also fitting, but as de Vaux notes, it sets up a negative comparison to an "other." Because he does not believe that such a fine mosaic could date to the eighth century, de Vaux suggests that "the tents of Jacob" refers to the local Jewish population. ${ }^{115}$ While earlier texts, such as John Chrysostom's late fourth-century Antiochene sermons, document competition between Christians and Jews, there is no evidence of any such problems in the early

\footnotetext{
${ }^{113}$ de Vaux, "Une mosaïque," 245.

${ }^{114}$ The first inscription references Psalm 98:20, while the second quotes Psalm 87:2.

${ }^{115}$ de Vaux, "Une mosaïque," 239-240.
} 
Islamic period, ${ }^{116}$ nor is there any indication the inscriptions could have been directed at Muslims. Accepting that an eighth-century date for this mosaic is correct, one can assume that the cities depicted on the border reflect existing Christian communities. The fact that Ma'in was connected to therapeutic springs popular with both Christians and Muslims during the Late Antique and Umayyad periods lends credence to an interpretation of this topographic mosaic as a representation of contemporaneous pilgrimage routes.

\section{II.vi. Umm al-Rasas (Kastron Mefa'a)}

Umm al-Rasas is located about $75 \mathrm{~km}$ southeast of Amman. The site was identified as Kastron Mefa' $a$ in 1986, when labeled images of the city were discovered in the Church of the Lions and St. Stephen (Figures 29, 52). Eusebius links the site to the biblical Mephaath, part of the lands given to the Levites, and mentions that in his time, Kastron Mefa'a served as a Roman garrison. ${ }^{117}$ Similarly, the late fourth-century Notitia Dignitatum records that auxiliary troops were stationed there under the command of the Dux Arabiae. ${ }^{118}$

Kastron Mefa'a grew from a Roman outpost into a significant center during the Late Antique period, and at least fourteen churches were constructed within and outside the fort walls. Several churches are part of larger complexes. The Church of the Priest Wa'il is connected to other buildings that have not yet been excavated, while the Church of St. Stephen is the largest structure in an impressive complex that contains three other churches of varying sizes. Outside the city walls, a vertical structure with a chapel at its

\footnotetext{
${ }^{116}$ Christopher Haas, Alexandria in Late Antiquity, 109-127. While Haas focuses on Alexandria, he provides a solid overview of documented disputes between the Christian and Jewish communities in the East.

${ }^{117}$ Eusebius, Onomasticon, 128.21.

${ }^{118}$ Michele Piccirillo, "L'identificazione storica delle rovine di Umm er-Rasas - Kastron Mefaa in Giordania," Biblica 71, no. 4 (1990): 527-541.
} 
base is commonly identified as a stylite tower, and an image of this structure is depicted on the mosaics from the Church of the Lions (Figure 29) and St. Stephen (Figure 52). ${ }^{119}$ If this was the tower's purpose, then during the Late Antique period Kastron Mefa'a likely served as a pilgrimage site similar to those found in Syria where pilgrims came to commune with hermit saints. ${ }^{120}$

\section{II.vi.a Umm al-Rasas, Church of the Lions (Figures 28-34, Plans 6-7)}

The dedicatory inscription mentions no specific donor, though it records the name of the bishop under whom the church was built. The names of individual donors are found in several locations throughout the church, however, including the north and south apses, on the nave mosaic and its border, and in front of the chancel screen. Access to the church was somewhat limited, as no north door existed in the western wall. This modification from the standard plan was made to accommodate a funerary chapel, the entrance to which is found in the northwest wall of the north aisle. Viewers entered either from the central door into the nave or the south door into the aisle (Figure 114). The latter was decorated with a geometric pattern that helped focus the viewer's attention on the nave.

If entering through the central door, one would see the inhabited vine scroll mosaic. It has suffered extensive iconoclastic damage, but enough remains to know the scrolls were filled with a mixture of animal and human figures, and may also have contained hunting scenes. One scroll contains an empty cage, which in this instance

\footnotetext{
${ }^{119}$ Piccirillo, Chiese e mosaici di Madaba (Jerusalem, Studium Biblicum Franciscanum, 1989), 301-302; Basema Hamarneh, "Dynamics and Transformations," 94.

${ }^{120}$ For more information of this very specific form of pilgrimage, only known in Syria, see David Frankfurter, "Stylites and Phallobates: Pillar Region in Late Antique Syria," VigChr 44, no. 2 (June 1990): 168-198; Lukas Amadeus Schachner, "The Archaeology of the Stylite," in Religious Diversity in Late Antiquity, ed. David Gwynn and Susanne Bangert (Leiden: Brill, 2010), 329-398.
} 
should be read as part of the hunt and not a reference to the soul. ${ }^{121}$ The central figures in the third and fourth rows were labeled, indicating donor portraits, and it is likely that more figures were labeled as well.

The border was also filled with human figures, now almost completely destroyed, alternating with fruit trees (Figures 30a-b). At the western end, the figures process northward along the western border, then along the northern border toward the altar, just as participants in the liturgy would have done. They then move southward across the nave before returning to the doors in the west. The setting amongst trees might indicate a depiction of Paradise, but it also suggests a procession to the church, either as part of a liturgical event or as a pilgrimage to the city. Only one image is found in proximity to the chancel screen: an image of the city featuring the possible stylite tower with a cross on the top (Figure 29). Its placement recalls that of the donor portraits, and this has been one of the purposes ascribed to it. It is possible it commemorates community donations, in the form of alms, too small to warrant individual portraits. However, I am more inclined to consider it a statement of the city's status, similar to motifs found in St. Stephen. While the Church of the Lions example is not paired with Jerusalem as it is in the larger church, its proximity to the sanctuary conveys status. ${ }^{122}$ Like the depiction in St. Stephen, it suggests that Kastron Mefa'a itself was a holy site. In St. Stephen, donors are shown leaving their nearby hometowns, perhaps as part of a pilgrimage, and the border of the Church of the Lions might depict a similar activity.

II.vi.b. Umm al-Rasas, Church of Priest Wa'il (Figures 35-38, Plans 6, 8)

\footnotetext{
${ }^{121}$ Hachlili, Ancient Mosaic, 140.

${ }^{122}$ Michele Piccirillo, "La Chiese dei Lioni a Umm al-Rasas- Kastron Meffa," Liber Annuus 42 (1992): 225 .
} 
The Church of the Priest Wa'il (Plan 8) is one of the smallest churches containing topographical motifs. Instead of the traditional entrances in the west wall, this building is accessed through two doorways in the south wall. This is due to the building's inclusion in a larger complex, the extent and purpose of which has not been determined. The size and location of the church suggest a side chapel, perhaps used for funerary purposes.

The church gets its name from the priest Wa'il, mentioned in the tabula ansata inscription at the east end of the nave pavement. It is assumed that the central figure found below the dedicatory information is his portrait. The iconoclastic damage has made it difficult to interpret the nave composition, though a few scholars have attempted to do so (Figure 35). The intercolumnar panels, including the one containing topographic imagery, have been generalized or ignored by scholars and thus require further examination.

As visitors entered the building, they would first encounter the acanthus scroll border that filled the south nave and was intended to be viewed as one moved north (Figure 115). Although the border is badly damaged, original excavators identified a sheep, a goat, a deer, and a horseman. ${ }^{123}$ From this, it can be assumed that the scrolls in both the south and north aisles contained scenes of hunting and pastoral life. If one entered through the southwest door, the next image would be the southwest intercolumnar panel, also oriented so as to direct the gaze northward (Figure 36). The panel originally contained four nude busts interspersed with three cities. Piccirillo identifies these figures as female, and thus links them to the Seasons. ${ }^{124}$ However, the Seasons are usually shown clothed and carrying bounty associated with seasonal harvests.

\footnotetext{
${ }^{123}$ Piccirillo, Mosaics of Jordan, 243.

${ }^{124}$ Piccirillo, Mosaics of Jordan, 242-243.
} 
Agreeing that they are female, Glen Bowersock instead suggests that the busts are personifications of the cities. ${ }^{125}$ Though he does not specify, one assumes that he reads them as double portraits of the three unlabeled cities, with a Tyche and a topographic motif for each. Bowersock's identification is equally problematic for despite the iconoclastic damage, it is clear the busts do not wear architectonic crowns, as would be expected for Tychai. Additionally, Bowersock ignores the fragmentary fourth bust, a small portion of which survives in the southwest corner.

The figures are nude, save for blue cloaks over their left shoulders. Moreover, they all carry identical vessels, from which water spills over their right shoulders, mimicking the folds of their cloaks. This attribute, along with the nudity, suggests these figures are rivers. Rina Talgam and Birte Poulsen also come to this conclusion, and Poulsen suggests that the figures should be seen as male, similar to the river personification found in the mosaic in the Chapel of the Martyr Theodore in Madaba. ${ }^{126}$ Neither scholar explicitly identifies the rivers but they most likely represent the Four Rivers of Paradise. While presented differently, the Rivers are also found in the church pavement from Tayyibat al-Imam in Syria that also contains apocalyptic/salvific imagery (Figure 109).

No one has connected the topographic motifs to specific cities, though most have mentioned them in relation to the mosaic from the so-called Hippolytus Hall in Madaba. ${ }^{127}$ This pavement, adjacent to the central-planned Church of the Virgin, contains

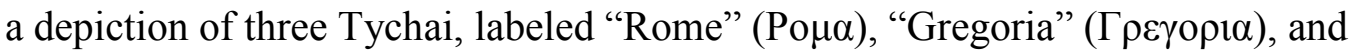
"Madaba" $(\mathrm{M} \alpha \delta \alpha \beta \alpha)$, respectively. It is challenging to compare the two mosaics, as the

\footnotetext{
${ }^{125}$ Bowersock, Mosaics as History, 83.

${ }^{126}$ Talgam, Mosaics of Faith, 209-210.

${ }^{127}$ Piccirillo, Mosaics of Jordan, 66.
} 
Madaba example contains labeled Tyche rather than unlabeled cities. Moreover, the inclusion of "Gregoria" has challenged scholars because no Late Antique city by this name has been identified. Several believe that it represents Constantinople, using the name from one of the city's districts to identify it. Bowersock outlines the difficulties with this interpretation, suggesting that the Tyche labeled Rome in fact represents Constantinople (the New Rome), and that Gregoria represents Antioch, city of the patriarch Gregoirus. Katherine Dunbabin has cast doubt on this proposal, pointing out that Gregorius' patriarchate pre-dates the mosaic. ${ }^{128}$ In any case, one can draw no parallels between the two mosaics that would help identify the cities depicted in the Church of the Priest Wa'il.

One would expect that if the architectonic motifs referred to cities connected with the Rivers of Paradise, there would be four of them instead of the three depicted in the panel. In the Bible, only one group of three cities is mentioned; several books of the Old Testament refer to the Cities of Refuge east of the Jordan River. ${ }^{129}$ There is no precedent for this subject in Late Antique art and, despite my suggestion that the north intercolumnar panels depict biblical scenes, there is nothing to link the two texts from which they originate. The passage in Genesis referencing the Four Rivers of Paradise mentions only three lands, but again, there is no precedence for these regions being represented by cities. ${ }^{130}$ Since textual sources provide no clues, it is important to examine the other topographic motifs for parallels.

\footnotetext{
${ }^{128}$ Katherine M.D. Dunbabin, "Mythology and Theatre in the Mosaics of the Graeco-Roman East," in Using Images, 236, especially note 17.

${ }^{129}$ Deuteronomy 4:41, Numbers 35:13, Joshua 20:7.

${ }^{130}$ Genesis 2:10-14.
} 
All three cities are highly stylized but also individualized. Each presents a variety of buildings within city walls and each contains a mile marker at the entrance of the main gate, suggesting that they represent major centers. The leftmost city contains one basilica church that extends the entire width of the city. In front of this building is a colonnade. This motif recalls both the Cardo Maximus of Jerusalem in the Madaba mosaic (Figure 20) and the depiction of the Holy City containing an elongated basilica with the Cardo behind it in the Church of the Holy Martyrs at Tayyibat al-Imam (Figure 110a).

The central motif bears some resemblance to the depictions of Kastron Mefa'a (Figures 29 and 52) found in the other two churches from Umm al-Rasas. It has an open courtyard displayed in the center of the walled city. However, the characteristic tower is missing, unless the brown rectangle is a clumsy attempt to represent it. The neatly executed mile marker depicted outside the city gate suggests that this is not the case. The city to the right of the central motif contains a few small churches and one large one, recalling the image of Bethlehem at Tayyibat al-Imam (Figure 110b). Despite the problematic identification of the central motif, I propose that this is an apocalyptic/salvific scene with Kastron Mefa'a flanked by the two holy cities in the Age of Grace.

This would be consistent with the message of salvation found in the two intercolumnar panels on the north side of the nave. Like the topographic panel, they are oriented north, indicating that they should be read as a group. Piccirillo identifies these motifs as Nilotic scenes, ${ }^{131}$ but aside from the fact that they include water, there is nothing to support this proposal, since the scenes contain no characteristic Nilotic flowers. Furthermore, in the first panel we find the strange inclusion of a fisherman,

\footnotetext{
${ }^{131}$ Piccirillo, Mosaics of Jordan, 243.
} 
unclothed except for his cap, who looks as if he is dipping his foot into the water (Figure 38). This unusual design indicates that this is more than a simple fishing scene. In some respects, this fisherman panel contains stylistic similarities to an intercolumnar panel found in the Church of the Holy Martyrs Lot and Procopios at Khirbat al-Mukhayyat (Figure 96), which Piccirillo also identifies as a Nilotic scene despite the absence of any Egyptian flora or fauna. The Lot and Procopios panel contains a basilica with three towers (city walls?), flanked by a man rowing a boat full of amphorae on the left and another man fishing from a riverbank on the right. The fisherman in Lot and Procopios wears a cap similar to the one in Umm al-Rasas, but he is clothed and carries a fishing net on his back. ${ }^{132}$

I propose that the Church of the Priest Wa'il's two intercolumnar panels should be read together and that the first depicts Jonah being swallowed by the whale, a scene that would have been depicted in the area of loss below the fisherman's feet. This panel is divided in two with unusually straight, vertical plants in the middle and another boat on the right side. These should not be read as two boats, but as the same boat presented in a narrative scene: Jonah swallowed by the whale, then Jonah after being saved (with the plants replacing the trellis). The next panel shows the whale in the peculiar way they are often depicted as sea monsters in the ancient world. ${ }^{133}$ The story of Jonah and the Whale was a popular theme in early Christian art and often appears on sarcophagi. It is also depicted in a church mosaic from Beth Guvrin, Israel, which shows Jonah being thrown to the whale by two men (Figure 116) and includes a small vine in lieu of the arbor. ${ }^{134}$ This is a more typical pose than Jonah's tentative toe dip shown in the Church of the

\footnotetext{
${ }^{132}$ Piccirillo, Mosaics of Jordan, 164-165.

${ }^{133}$ Marion Lawrence, "Ships, Monsters, and Jonah,” AJA 66, no. 3 (July 1962): 289-296.

${ }^{134}$ Ruth Ovadiah, "Jonah in a Mosaic Pavement at Beth Gurvin," IEJ 24, no. 3/4 (1974): 214-215.
} 
Priest Wa'il. Jonah is also sometimes depicted diving into the water alone. One trait helping to cement Jonah's identification in the Church of the Priest Wa'il panel is his nudity, which is near-constant in depictions of him regardless of the medium incorporated. $^{135}$

These images of salvation and the apocalypse would be fitting for a funeral chapel, framing the nave pavement that probably contained an image of the deceased. The only challenge to this interpretation is the church's dedicatory inscription. The language used suggests that Wa'il was responsible for its construction; however, there is no mention that it was made to honor Wa'il in death, or to commemorate one of his family members. The nave pavement is badly damaged, which makes interpretation difficult, but the scenes perhaps present an alternative to a funeral chapel designation. Upon reaching the nave, viewers would turn eastward to face the altar. The first part of the panel displays a traditional hunt, with men on horseback and dogs chasing wild animals, but the upper half contains a more unusual scene. In the bottom portion is a horse pulling a red cart, while the upper half depicts four people praying with outstretched hands. The cart is used for the translation of relics, and a similar image is featured on both church mosaics from Huarte, Syria and the Tayyibat al-Iman pavement (Figures 117-118). ${ }^{136}$ This suggests that the figures, who may or may not include Wa'il and whose names might have been included with their images, are shown in a procession of the translation of relics.

\footnotetext{
${ }^{135}$ See, for example, the fourth-century floor mosaic from the Cathedral of Bishop Theodore in Aquilea, the Jonah sarcophagus in the British Museum (1957.1011.1), and the early fourth-century sarcophagus in the Vatican Museums.

${ }^{136}$ P. and M.T. Cavinet, Sanctuaire chrétien d'Apemène (Paris: Librairie Orientaliste Paul Geuthner, 1987), 187; Abdul Zaqzuq and Michele Piccirillo, "The Mosaic Floor of the Church of the Holy Martyrs at Tayyibat al-Imam- Hamah, in Central Syria," Liber Anпииs 49 (1999): 448.
} 
The imagery indicates that the chapel might have been used as a martyrion to hold the relics of an unnamed saint. Two reliquaries were found in the church but neither was in situ. One has holes in the lid for pouring oil, which, after making contact with the sacred contents, could be bottled and taken by the faithful as a eulogia, a blessing and souvenir of their journey.

II.vi.c. Umm al-Rasas, Church of St. Stephen (Figures 43-73, Plans 6, 11-12)

St. Stephen is part of a large ecclesiastic complex that includes three additional churches and several other attached buildings (Plan 11). St. Stephen's importance is marked not only by its size but also by the individuals who are connected with its decoration. The dedicatory inscription lists several names and includes a man who served as deacon, treasurer, and archon. Additionally, this is the only church in which we have patrons who are identified as being from other towns. Individuals from Limbon, Diblaton, and Mt. Nebo, including a priest from Nebo, wanted to be connected with this building. This is significant because Mt. Nebo was and is one of the holiest sites in the region and is still an important pilgrimage center. By the eighth century, Umm al-Rasas had achieved a similar status in the Christian community.

The building complex evolved over time; for example, the church occupying the former western courtyard was a later addition, ${ }^{137}$ which complicates our understanding of access to this building (Figure 119). A doorway from the south aisle of the adjacent Church of Bishop Sergios leads to the north aisle of St. Stephen, which provides direct access to the small apsidal chapel at the eastern end. The reliquary found within the

\footnotetext{
${ }^{137}$ Piccirillo, Mosaics of Jordan, 234.
} 
church was likely installed in the small niche in the apse wall. ${ }^{138}$ The mosaic leading to this room is decorated with vignettes of offerings, such as bowls of food, while the south aisle mosaic has a geometric design. One could also enter from the east courtyard, which would lead to the south aisle, similar to the way in which one enters the Church of the Priest Wa'il, or through the slightly off-axis western doorway connected to the Courtyard Church. The directionality of the motifs in the nave and intercolumnar panels suggest that the east courtyard entrance was the original intent and that the western doorway was created with the addition of the Courtyard Church.

Entering from the west, one faced the Nilotic inner border (Figure 43). This is challenging to read, as one must walk while facing the border in order to read the toponyms of the depicted Egyptian cities. The water between the cities contains fish that are quite detailed and most closely resemble Nile perch and blue tilapia. ${ }^{139}$ The center of the nave panel has a similarly detailed depiction of vintaging and wine-making within the inhabited vine scrolls. This illustrates the economic reality of Umm al-Rasas, rather than having a religious interpretation. A wine press was found during the 1988 excavations of the Church of St. Paul, another church at Umm al-Rasas. ${ }^{140}$

As viewers progressed toward the altar from either the aisles or the nave, they would be able to see the cities and read the toponyms in the intercolumnar panels. While the easternmost cities are Jerusalem and Kastron Mefa'a, respectively, the others are not ordered in a hierarchical fashion. Instead, they illustrate two routes. The cities depicted

\footnotetext{
${ }^{138}$ Ibid.

${ }^{139}$ See Chapter 4 below, pp. 185-186. I am grateful to Dr. William D. Pearson, Professor of Biology at the University of Louisville, for providing these identifications.

${ }^{140}$ Michele Piccirillo, “Archaeological Excavations 1998 at Nitl and Umm al-Rasas,” Franciscan Archaeological Institute, accessed February 1, 2016, http://www.christusrex.org/www1/ofm/fai/FAIrasas98.html
} 
on the south intercolumnar panels are those located east of the Jordan River, while those on the north side are found west of the waterway. Here the Nilotic border stands in for the Jordan. ${ }^{141}$ The toponyms of the south side of the church, including Kastron Mefa'a, are marked with a palm or olive branch, indicating holiness. No such markers are included on the north side, even for Jerusalem.

Michele Piccirillo was the first to identify these routes, though he did not discuss the branches next to the motifs on the southern intercolumnar panels, nor does he explain the significance of the images' layout (Map 3). ${ }^{142}$ Both routes begin in the south (depicted in the western end of the church) and work roughly north (east in the church). The western route starts in Gaza on the Via Maris (Figure 51) but moves inland to Eleutheropolis along a Roman road by way of Askalon (Figures 49-50), before turning north to Caesarea (Figure 47). From here, the route turns south to Jerusalem, passing the cities of Sebastis and Neapolis (Figures 45-46). It is not the most direct route but it avoids most of the major ascents while reaching the maximum number of large cities.

On the south intercolumnar panels, the "eastern" route starts at Charach Moba (Figure 58) and moves north along the Via Nova Traiana past several cities to Philadelphia-Amman (Figures 54-57). It deviates from this route only once, following the road to the Dead Sea as far as Belemounta (Ma'in, Figure 56) before looping back to the highway and up to Philadelphia (Figure 53). The only variation of this northward path is to Umm al-Rasas, which requires heading south on a lesser road. Like the western route, this pathway includes the larger and more important cities in the region, while also allowing the patron to privilege Kastron Mefa'a both in terms of the motif's size (it is the

\footnotetext{
${ }^{141}$ Michele Piccirillo, "Mosaics of 785 AD at Um al-Rasas (K Mefa'a)," Holy Land 7, no. 2 (1987): 59-72.

${ }^{142}$ Piccirillo, "Mosaics at Umm er-Rasas," 227.
} 
only city occupying a double panel) and in its placement at the eastern end of the nave, equal to Jerusalem.

It is more difficult to determine if the placement of the Egyptian cities of the inner border represents a route, especially since the locations of cities like Pseudostomon are unknown. One challenge is deciding which motif should be the starting point; the west end is the most obvious choice since these are the cities one would see first upon entering the church. Alexandria is in the southwest corner, Kasion (Mt. Kasios) is in the center, and Thenesos is in the northwest corner. From a practical standpoint, it would make sense to read them beginning at either the westernmost image on the south side - Heraklion, the port of Alexandria where one might have arrived by sea - or Kasion, which is geographically closest to the Holy Land cities depicted in the intercolumnar panels (Figure 65). Because Kasion features in both scenarios, no matter which way one goes, I begin there.

Plotted on a map (Map 4), one moves westward from Kasion along the coast to Thenesos (Tell-Tennis), then down the Nile to Antinoë (Sheikh Ibada) (Figures 64-66). From there one travels north to Pseudostomon (Figure 68), the location of which is unknown, though the name suggests somewhere on the coast. ${ }^{143}$ Depending on its location, one would travel east or west to Tamiathis (Damietta), then south to Panau (Busiris), east to Peluseion, and back south to Kynopolis (Figures 59-61, 67). From there, one heads north to Heraklion and finally to Alexandria (Figure 64). This creates almost two complete sweeping circles of Egypt and, unless it is meant to be read as a series of shorter routes, or a repeated itinerary, such as Egeria's two separate journeys to Egypt,

${ }^{143}$ Because the location is not certain, this part of the route is outlined in green on Map 4. 
one cannot imagine such a trek having any practical purpose. ${ }^{144}$ The sites were more likely chosen for their ecclesiastical connection; all but Heraklion and Pseudostomon were bishoprics in the Late Antique period. ${ }^{145}$ The black ground, filled with men in rowboats surrounded by fish, depicts all but one of the traditional Nilotic plants that reinforce the message of prosperity associated with such scenes. The inclusion of the ten Egyptian cities clarifies this meaning, situating the scene within a Christian context, but also providing a contemporary and secular interpretation of prosperity though the city motifs and the inclusion of specific species of Nilotic fish that were pickled or brined and shipped throughout Egypt and Jordan. ${ }^{146}$

All the donor portraits in St. Stephen - four figures in the north aisle, seven in the nave, and one in the south aisle, all abutting the chancel screen - depict the patrons walking amongst fruit trees (Figures 70-72). The figures have been purposely damaged, but they carry censers, books, and other items of religious significance. As with the praying figures in the Church of the Priest Wa'il, these portraits suggest a procession, as part of either a pilgrimage or a religious ceremony. The decoration of St. Stephen emphasizes the community's economic and religious importance in the region. The former is obvious from the number of impressive churches constructed in the Late Antique period, many of which are decorated with mosaics that illustrate pilgrims and the translation of relics. The latter is more difficult to understand, as no contemporary textual

\footnotetext{
${ }^{144}$ Wilkinson, Egerias' Travels, 38, 42. According to Wilkinson's calculations, Egeria's first trip to Egypt lasted over two years. She arrived in Alexandria, then traveled south to the monastic sites at Nitria and Scetis. She continued south into the Thebaid before heading north to the Land of Goshen. On her second trip, she started at Mt. Sinai and made a detour on her way back to Jerusalem to revisit Goshen.

${ }^{145}$ Peluseion and Antinoë were metropolitans and Alexandria was a patriarchate.

${ }^{146}$ For a discussion of fish included in the mosaics and their reflection of economic prosperity, see Chapter 4, pp. 185-186.
} 
evidence exists to support the town's visual claims of religious significance as a Holy Land site. ${ }^{147}$

\section{Examinations of Iconographic Groups Related to the Topographic Mosaics}

While none of the topographic compositions are exactly alike, they can be grouped into four general categories: Nilotic or Nilotic-influenced images, compositions that mimic actual geography or geographic routes, apocalyptic/salvific imagery in the form of representation of Bethlehem and Jerusalem, and individual depictions of cities denoting the donor's place of origin or, alternatively, a site's communal donation. The last two categories and their limited comparanda have been sufficiently discussed above but the first two, Nilotic compositions and those that encourage mimetic movement, require further examination in light of the more substantial number of examples that have been discovered at Late Antique Mediterranean sites. These comparisons provide an understanding of the larger corpus of topographic imagery while offering suggestions about why patrons selected the specific combination of motifs that decorate the individual churches included in this study.

III.i. An Examination of Topographic Imagery in Nilotic Representations from Palestinian and Arabian Buildings

The Nilotic features that dominate the Umm al-Manabi‘ mosaic suggest that it should be categorized separately from the other topographic mosaics and interpreted as a version of the traditional Nilotic landscape genre. Nonetheless, the inclusion of a labeled walled city motif in the composition is likely the earliest known example from Jordan,

\footnotetext{
${ }^{147}$ Susanna Ognibene, Umm al-Rasas: la chiesa di Santo Stefano ed il "problema iconofobico" (Rome: "L'Erma" di Bretschneider, 2002), 27. Ognibene examines the Arab sources, dating to the ninth and tenth centuries that document visitations to monks while on the route to the Hajj.
} 
and an examination of comparanda from Israel demonstrates that this was a regional variation that gained popularity in the fifth century. Moreover, the variety of toponyms used in the examples discussed below suggests that patrons were concerned about the socio-political associations that viewers might make in reference to particular cities. The donor's careful selection aims to avoid political and religious connotations in the Nilotic mosaics, and foreshadows the decisions made by patrons of later topographic mosaics. Examples from the sixth to the eighth-centuries include representations of specific sites for the express purpose of encouraging the viewer to make socio-cultural associations between the city motifs in order to elevate the status of their own communities.

The inclusion of a walled city motif is generally uncommon in Nilotic compositions, though they often contain a variety of architectonic features ranging from straw huts and outdoor shrines to lavish villas (Figure 91). These unlabeled structures are used to enhance the landscape, and not to represent specific locations. In contrast, the Late Antique Nilotic landscapes in Palaestina and Arabia often include a building or city labeled with an Egyptian toponym. Of the eleven known examples from these provinces, seven contain labeled architectonic elements. ${ }^{148}$ Two more contain walled city motifs, both of which might have been labeled originally but are not well-preserved enough for

\footnotetext{
${ }^{148}$ Hachlili, Ancient Mosaic, 97-100, 104. In her examination of the inclusion of Nilotic iconography in Near Eastern mosaics, Hachlili identifies fifteen pavements from the provinces of Palaestina and Arabia. I have excluded four of these in my analysis. The pavement from Emmaus, ancient Eleutheropolis in Palaestina Prima, contains Nilotic birds and plants but these inhabit a geometric pattern and are not presented as a traditional landscape. The intercolumnar panel in the Church of Sts. Lot and Procopios in Arabia contains nothing distinctly Nilotic in its depiction, though it has an abbreviated river scene with a man in a boat, an unlabeled building, and a man fishing. As for the mosaics examined in this study, I have argued against the identification of the cities in the Khirbat al-Samra mosaic as Egyptian and while the Madaba mosaic (also part of this study) includes Egyptian cities, it cannot be characterized as a "Nilotic" pavement since the intent was to show the landscape of a much larger geographical area. Two more of Hachlili's examples contain no architectural features and are also excluded my analysis: the triclinium panel in the House of Dionysios from Sepphoris, Israel (Palaestina Secunda) and the border mosaic from Beth Jibrin, Israel (Palestina Prima).
} 
us to be certain. ${ }^{149}$ Three of the labeled mosaics are from Arabia: the pavements from St. John the Baptist (Plan 3), Sts. Peter and Paul (Plan 4, Figure 13), and the Nilotic border from St. Stephen (Figure 43). In these pavements, the landscape is dominated by the cities, which subsume the natural elements. In this way, these three topographic mosaics have, to various degrees, more in common with the Madaba and Ma'in mosaics than their Nilotic prototypes. With the exception of Sts. Peter and Paul, which might be a stylized Christian interpretation of a Nilotic scene, these four Jordanian topographic mosaics should be considered as a separate genre, one that aims to replicate a realistic landscape. These mosaics are discussed, individually and as a group, in the next section of this chapter.

The four remaining Nilotic landscapes from Palaestina and Arabia feature traditional motifs. In addition to the pavement from Umm al-Manabi` (Figure 1), these include two more from Palaestina Secunda: the mid-fifth century mosaic from the House of Leontis in Beth She'an, Israel (Figure 92) and the early fifth-century pavement from the Nile Festival Building in Sepphoris, Israel (Figures 93a-b). The third, a border mosaic from the Haditha Chapel in Israel, is from Palaestina Prima and is dated to the second half of the sixth century (Figures 94a-b). With the exception of the Haditha Chapel mosaic, for which only a fragment remains, the pavements are similar in composition if not style. All three include a Nilometer and a river personification. The Nile Festival

\footnotetext{
${ }^{149}$ Bargil Pixner, "The Miracle Church at Tabgha on the Sea of Galilee," Biblical Archaeologist 48, no. 4 (December 1985): 196-206; Piccirillo, Mosaics of Jordan, 324-325. The fifth-century Church of the Bishop Martyrios in Tabgha, Israel, which replaced the earlier Church of the Multiplication of the Loaves and Fishes, contains two Nilotic compositions its north and south transepts. The north pavement contains a tower, crenelated walls, and possibly an open gate. There is an area of loss above this motif, which could have contained a toponym. Only about half of the south pavement survives and the only architectural feature preserved on this mosaic is a Nilometer. Piccirillo includes a photo of the badly damaged nave mosaic from Zay al-Gharby contains a boat with two men on the Nile, represented by the crocodile in the water and papyrus plants on the bank. A church flanked with two towers is also preserved, though the pavement above this small section is lost.
} 
mosaic contains a hunting scene, while the Leontis mosaic depicts a crocodile attacking a bull. A similar scene is likely shown on the Haditha border, although only a figure wielding a stick and a portion of a bull survives. The Haditha mosaic also depicts a boat on the river, like the one found at Umm al-Manabi'. All four pavements have labeled architectural motifs, though the depictions vary greatly.

In the Leontis and Nile Festival mosaics, the architectonic features are labeled "Alexandria." In the former, the walled city is replaced with a highly stylized building consisting solely of a basilica-style pitched roof supported by three columns (Figure 92). ${ }^{150}$ Behind this structure is a brick tower, perhaps representing the Pharos or the city walls. The city is more fully articulated in the Nile Festival pavement (Figure 93b), though it is still highly stylized. A large, open rectangular gate is flanked by two round, crenelated towers. In contrast, the architectonic features from Umm al-Manabi ${ }^{`}$ and Haditha are labeled "Egypt." (ЕГҮПТ $\omega$ in the former and ЕГҮПТО $\Sigma$ in the latter). At Umm al-Manabi', the province is represented by a church of undeterminable plan flanked by towers, while the motif at Haditha includes a circular domed building flanked by two basilicas, all within a wall containing six towers and a partially open gate.

In his examination of the Haditha pavement, Michael Avi-Yonah provides an unusual interpretation for its toponym. He suggests that ЕГҮПТО $\Sigma$ is used to represent the city of Memphis, not the province of Aegyptos. His explanation is complicated and

\footnotetext{
${ }^{150}$ N. Zori, "The House of Kyrios Leontis at Beth Shean," IEJ 16, no. 2 (1966): 132; Avi-Yonah, Art in Ancient Palestine, 275. Zeev Safrai, "The House of Leontis 'Kaloubas'- A Judeo-Christian?" in The Image of the Judaeo-Christians in Ancient Jewish and Christian Literature: Papers Delivered at the Colloquium of the Insitutum Iudaicum, Bussels 18-19 November, 2001, ed. Peter J. Tomson and Doris Lambers-Petry (Tübingen: Mohr Siebeck, 2004), 245. Though Zori identifies the building as a private house, Avi-Yonah suggests that it was a synagogue. Safrai proposes that it served as a Jewish Christian worship space. Zori dates the mosaic to the mid-fifth century based on the archaeological material. Avi-Yonah believes it belongs to the sixth century, while Safrai dates it between the fourth and fifth centuries, though both of these suggestions are based on stylistic evidence.
} 
unconvincing. He suggests that the Late Antique patron drew from the Nilotic motif's Hellenistic origin and explains that, in this earlier period, Alexandria was considered "near to but not part of Egypt." ${ }^{, 151}$ For Avi-Yonah, a walled city motif must represent a city and a province and since it cannot be Alexandria, it must be Memphis. However, there is no known visual prototype, either contemporary or Hellenistic, labeling the city of Memphis as Egypt. This substitution would be strange in Umm al-Manabi` but especially so in Haditha, which was part of Palaestina Prima and in close proximity to the Byzantine province Aegyptos. Trade between Egypt and the Palestinian provinces was prolific in the Late Antique period and Memphis was also a bishopric, so at least some members of these Christian communities would have been aware of the city. There would be no reason not to label it Memphis if they had so wished.

As an alternative to Avi-Yonah's identification, I propose that the distinction between Egypt and Alexandria, also used on the Umm al-Manabi‘ pavement, was purposeful. While the sample is small enough that one should exercise caution when making conclusions, it appears that the function of the buildings housing the mosaics played a part in the selection of both the toponym and the architectonic motif. In the Nile Festival mosaic, found in a building that likely served as a communal public space, the depiction includes only the city walls with an undefined architectonic feature. In the House of Leonotis, a private house used as a synagogue, the feature is similarly vague. In contrast, the two examples from churches portray only ecclesiastical buildings within the city walls. It is only in the Christian buildings that the name of the province is used instead of Alexandria; this choice perhaps reflects the religious politics of the times. These mosaics were most likely constructed in the fifth century and probably post-date

${ }^{151}$ Michael Avi-Yonah, “The Haditha Mosaic Pavement.” IEJ 22, no. 2/3 (1972): 121. 
the Council of Chalcedon of 451, at which time Jerusalem patriarchate became autocephalous and gained control of the Palestinian provinces. The Alexandrian patriarchate not only rivaled Jerusalem for power, but was also the only patriarchate that did not accept the dual nature of Christ as outlined in the Chalcedonian Creed. It is not surprising that individuals overseeing the decoration of the Umm al-Manabi' and Haditha churches, bishops under the control of orthodox Jerusalem, would be reluctant to display an image of Alexandria. Instead, they identified the image with the less controversial provincial name to emphasize the Nilotic region's prosperity while avoiding the political and religious connotations held by Alexandria.

How were Nilotic mosaics meant to be read within an ecclesiastic space? In terms of the Haditha Chapel, Avi-Yonah is at a loss to provide a detailed interpretation. To strengthen his identification of Memphis, he explains that Late Antique Nilotic compositions demonstrate the continued fascination with Egypt's exoticism. ${ }^{152}$ However, the inclusion of Late Antique cities and architecture contemporizes the Nilotic compositions and lessens the exotic nature of the scenes. Moreover, the inclusion of specifically Christian cities places the concept of prosperity expressed by motifs under the authority of the Church; this idea is echoed in a sixth-century papyrus from Antinoë that contains a hymn to the Nile but ends with an invocation of Christ. In this sense, the Christian god becomes responsible for the agricultural abundance of the Nile Delta. ${ }^{153}$ The location of the walled church in the Umm al-Manabi' composition supports this interpretation. It dominates the southwest corner of the mosaic and would have been one of the first images a Late Antique viewer would have seen upon entering the church. In

\footnotetext{
152 Ibid., 122.

${ }^{153}$ Henry Maguire, "The Good Life," in Late Antique and Medieval Art of the Mediterranean World, ed. Eva Hoffman (Malden, MA: Blackwell Publishing, 2009), 76.
} 
this position, the church motif neutralizes the classical personification of the Nile and places the message of prosperity within a Christian context.

In his examination of the wide-spread popularity of natural motifs, including Nilotic compositions, Henry Maguire proposes that the idea of prosperity invoked in the elite villa mosaics continued in church pavements but that personal connotations were lost in ecclesiastic contexts. He suggests that this is one reason why Nilotic imagery was acceptable as church decoration despite its "pagan" connotations. ${ }^{154}$ However, the church patrons were likely the same people who used these motifs within their homes and it is difficult to believe that they and others would not continue to interpret these images as signs of personal prosperity as well, especially when combined with donor portraits and inscriptions. This polyvalent messaging could serve two purposes within ecclesiastic buildings.

This idea is bolstered by the depictions of trade and agricultural products found in the Late Antique east. Trade amphorae, like those depicted in the boats on the Haditha border, are frequently included in pavements from Palaestina and Arabia. The inclusion of these non-traditional Nilotic motifs emphasizes the economic prosperity afforded by both Egypt and the Holy Land in the Late Antique period. Glueck does not record the presence of anything in the boat on the Umm al-Manabi“ pavement but amphorae also appear in the boat in the Odysseus panel that makes up part of the mosaic in the House of Leontis (Figure 95).

Mosaicists in Palaestina and Arabia adopted the idea of Nilotic prosperity but transformed it into a reflection of local fortune through the inclusion of indigenous products. This trend begins in the fifth century, contemporary with the Nilotic

${ }^{154}$ Ibid., 79. 
compositions, and increases in popularity during the sixth, when it almost completely replaces the traditional Egyptian landscapes. Examples include mid-sixth century depictions of an amphorae-filled boat from the Church of Sts. Lot and Procopios at Khirbat al-Mukhayyat (Figure 96), salt and bitumen harvesting in the Madaba mosaic (Figure 97), and a variety of local fruit trees in vineyards in the topographic pavement from Ma'in (Figures 74-77). That such agricultural motifs regularly appear in mosaics with labeled cities suggests that patrons used topographic motifs to localize the source of their prosperity. Chapter 4 discusses the inclusion of these motifs in the topographic mosaics, and considers the socio-economic contexts of regional Late Antique agricultural production and trade.

\section{III.ii. Route-like Topographic Mosaics and Regional Comparanda}

An examination of Late Antique mosaics from Israel, Syria, and other parts of the Mediterranean determines that Jordan's topographic mosaics are not as unique as previous scholars have suggested. Like the Jordanian examples, many of the mosaics incorporate building and city motifs into their compositions representing routes, inviting the viewer on a mimetic journey through the depicted landscape. The comparanda provide suggestions for the identification of select unlabeled motifs in the Jordanian mosaics, and indicate that topographic imagery was often used to identify the specific purpose of a particular building. The combination of topographic imagery with representations of elite activities and religiously important objects helped to illustrate the status of the patron and/or community. Jordan's topographic pavements were part of a wide-spread visual language that communicated authority and status to the region's Late Antique Christian population. 
There is a distinct subset of the topographic pavements-those portraying large geographic areas, namely Madaba (Plan 5, Figure 17), or those portraying specific routes, as depicted at St. John the Baptist, Ma'in, and St. Stephen. The latter three had the specific function of encouraging movement through the church. At. St. John the Baptist (Plan 3), the border leads the congregation to the side chapel, which likely contained the reliquary found during the excavations. At Ma'in and St. Stephen (Plans 12-13), people followed the row of cities as they entered the church in the liturgical procession toward the altar. While archaeological remains are lacking at Ma'in, the placement of its city motif along the north wall suggests that it too may have held a reliquary chapel. At St. Stephen, the north intercolumnar panels ending with the depiction of Jerusalem, led pilgrims along the north aisle to a chapel with a niche for the church's reliquary. Pilgrims used this type of reliquary to sanctify oil or water as eulogia, small "souvenirs" that could be taken from the holy sites and which were thought to have healing powers. ${ }^{155}$

Similar topographic compositions have been discovered in Israel, Syria, and Italy. Located in both domestic and ecclesiastic settings, these mosaics often include hunting scenes or other markers of elite status within their compositions. Unlike the Jordanian examples, the comparanda either depict individuals moving between unspecified locations in generic landscapes or a series of buildings within one city. Images of unlabeled walled cities fill the corners of the fifth-century villa mosaic from Beth Guvrin, Israel (ancient Eleutheropolis). The buildings frame pastoral and hunting vignettes in a schematized version of traditional landscape scenes (Figure 120).

\footnotetext{
${ }^{155}$ For the many forms of Late Antique eulogia, see Cynthia Hahn, "Loca Sancta Souvenirs: Sealing the Pilgrim Experience," in The Blessings of Pilgrimage, ed. Robert Ousterhout (Chicago: University of Illinois Press, 1999), 7-40; William Anderson, "An Archaeology of Late Antique Pilgrim Flasks," AnatSt 54 (December 2004): 79-93; Daniel Caner, "Towards a Miraculous Economy: Christian Gifts and 'Material Blessings' in Late Antiquity,” Journal of Early Christian Studies 14, no. 3 (Fall 2006): 329-377;
} 
This arrangement is also adopted in the more complicated topographic mosaic from the Winter Baths at Caesarea Maritima (Figure 121). One of the building's small rooms is decorated with a geometric pavement. At its center is a personification of the "Beautiful Season" (KA $\Lambda$ OKEPIA) holding a scarf filled with fruit. The badly damaged border contains men riding on horseback or pairs of facing animals on each side, flanked by palm trees. Walled cities are placed diagonally in each corner. Both the cities and the figures were originally labeled but only two are still legible: a galloping horse named

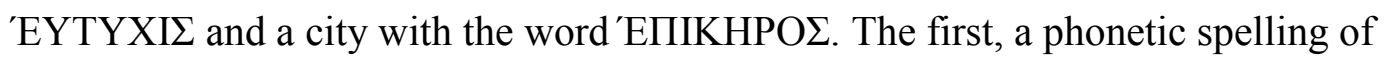
"lucky," suggests that this is the horse's name. Racehorses and circus events were often depicted in mosaics, especially in North Africa where both riders and horses are named. ${ }^{156}$ However, "غ̇ं "subject to death," or "mortal." How does one read this with the images? In her examination of the mosaic, Rina Talgam proposes that it is a visual illustration of a curse tablet. In the Roman and Late Antique periods, individuals wrote curses on lead tablets, sometimes to ensure the failure of opposing teams. ${ }^{157}$ Talgam's interpretation suggests that the mosaic's donor might have been connected to one of the local racing factions, or that the room was reserved for one of the teams' associations. Such a connection has also been made for the room containing a racehorse mosaic in the late fourth/early fifthcentury Maison des Chevaux in Carthage. (Figure 122). ${ }^{158}$ In terms of the architectonic motifs used in the Winter Baths, there is no reason to assume they are meant to represent

\footnotetext{
${ }^{156}$ Mongi Ennaïfer, "La theme des chevaux vainqueurs à travers la série des mosaïques africaines," Mélanges de l'Ecole française de Rome Antiquité 95, no. 2 (1983): 817-858.

${ }^{157}$ Talgam, Mosaics of Faith, 489, note 33. For the use of curse tablets in the Late Antique East, see N. Belayche, "Pagan Festivals in Fourth-Century Gaza," in Christianity in Gaza in Late Antiquity, ed. Brouria Bitton-Ashkelony and Aryeh Kofsky (Leiden: Brill, 2004), 11-12.

${ }^{158}$ For a concise overview of the function of the Maison des chevaux, see Anna Leone, Changing Townscapes in North Africa from Late Antiquity to the Arab Conquest (Bari: Edipuglia, 2007), 68-69, note 90.
} 
specific locations. They serve only to provide a generic setting for the important figures expressing the patron's message.

In contrast, several of the comparanda provide details of specific cities. One such example was found in fifth-century villas in Daphne, a wealthy suburb of Antioch. ${ }^{159}$ It frames the Megalopsychia Hunt mosaic in the Yakto Complex (Figure 123). Similar to the Winter Baths composition, its center contains a personification. In this case it is a bejeweled female; in one hand she distributes coins from a container she holds in her other hand. The figure is labeled "Megalopsychia" (МЕГА ОЧYХIIA), translated either as "Great-souled" or "Generosity." She is surrounded by a schematic landscape of fruit trees and conifers that contains a hunting scene with men spearing exotic animals. The men are labeled with the names of mythological heroes.

Some scholars have proposed a symbolic interpretation for this combination of figures, suggesting that the owner depicts himself as "great-souled" for overcoming his passions, which are represented by the wild animals. ${ }^{160}$ However, Katherine Dunbabin rightly notes that the men's contemporary clothing and novel names recall amphitheater venatores. ${ }^{161}$ Considering the socio-economic position of the villa's owner, the mosaic might be seen as an illustration of his financial contributions to Antioch's public games, a theme that also occurs in North Africa (Figure 86). ${ }^{162}$ The border, which depicts scenes of

\footnotetext{
${ }^{159}$ Sheila Campbell, The Mosaics of Antioch (Toronto: Pontifical Institute of Mediaeval Studies, 1988), 39. Another example of a topographic border was found in Daphne but is too fragmentary to identify the city depicted.

${ }^{160}$ Levi, Antioch Mosaic, 326, 336; Glanville Downey, "The Pagan Virtue of Megalopsychia in Byzantine Syria," TAPS 76 (1945): 279-286. Blake Leyerle, Theatrical Shows and Ascetic Lives: John Chrysostom's Attack on Spiritual Marriage (Berkeley, University of California Press, 2001) 2-4. Levi suggests that the topographic border represents a "tour" of Antioch and its suburb.

${ }^{161}$ Dunbabin, Mosaics Greek and Roman, 180-181.

162 John Matthews, The Journey of Theophanes: Travel, Business, and Daily Life in the Roman Near East (New Haven, CT: Yale University Press, 2006), 79-81.
} 
daily life in the city amongst labeled public and private buildings, localizes the owner's munificence within Daphne and Antioch.

A recent discovery in Israel might depict a similar cityscape, albeit featuring a foreign locale. The Israeli Antiquities Authority has excavated a church in Kiryat Gat, which lies on the Roman road between Askalon and Eleutheropolis (Map 3). The mosaic matrix contained a coin from the reign of Anastasios I (491-518), which remained in circulation under Justinian, and this provides a terminus post quem of the early sixth century. The fragmentary border mosaic contains a Nilotic scene with a boat and aquatic plants. Along the shore, a depiction of two buildings set along a colonnaded street has survived. One of the buildings contains a fragmentary toponym, which the excavators identify as "Chortaso," or modern Qartassa, Egypt (Figure 124). Based on this identification, the excavators suggest that the church's congregation originally came from that site in Lower Egypt. ${ }^{163}$ However, it is also possible that this city was singled out because of its importance as a grain supplier.

Little is known about Chortaso. The site is included as part of the Madaba mosaic's condensed depiction of Egypt, along the man-made Bolbitine channel that flowed into the Mediterranean (Figure 125). ${ }^{164}$ In his identification of the site as part of his study of the Madaba mosaic, Herbert Donner mentions that Greek and Coptic sources list Chortaso as both the burial site of the Hebrew prophet Habbakuk and the location of

\footnotetext{
${ }^{163}$ Personal correspondence with Dr. Rina Avner, Israeli Antiquities Authority. Information about this mosaic is not yet published.

${ }^{164}$ Eugenio Alliata, "The Legends of the Madaba Map," in Madaba Map Centenary, 100; Donner, Mosaic Map, 85. Unlike Donner, Alliata does not identify Chortaso's location and some of his other identifications of the Madaba mosaic's Egyptian cities should be questioned, such as Kainupolis. He connects this city with either modern Abu Sir Banu, which has since been identified as Busiris in the eastern portion of the Nile Delta.
} 
St. Shenufe's martyrdom, but he does not provide a bibliography. ${ }^{165}$ Late Antique sources focus on Chortaso as an agricultural center. Writing in the early sixth century, Stephen of Byzantium provides a rather questionable explanation for the city's name, linking it to the verb "to feed." He recounts that Cleopatra required grain for her troops and it was Chortaso that supplied it, thus earning its name from her in appreciation for its generosity. ${ }^{166}$ While the veracity of this story should be questioned, it reflects perceptions of the city that would be contemporary to the mosaic's construction.

Chortaso's agro-economic importance is echoed in a sixth-century papyrus mentioning the flooding of grain storerooms in Alexandria and similar damage in Chortaso. The language of the report suggests that the damage was deliberate. The Egyptian grain supply from Chortaso and other sites was vital to sustaining the population of Constantinople, and this crop became an important tool in the struggle of the Byzantine Emperor and his Orthodox Church against monophysite factions. ${ }^{167}$ In the fourth to seventh centuries, Alexandrian bishops played an active role in the transport of grain to the capital, an activity that eventually became quite profitable for the Church as well as for independent tradesmen and landowners. ${ }^{168}$ Could the visual reference to Chortaso in the Kiryat Gat mosaic reflect trade between the two sites or a donor's connection to the grain trade? Or might the images be connected to a religious figure associated with the church, perhaps through the ownership of relics? No evidence of a reliquary has been found and without more information about the mosaic, its imagery,

\footnotetext{
${ }^{165}$ Donner, Mosaic Map, 85. Note to committee. Documents relating to Shenufe's martyrdom can be found in H. Munier, "Fragments des actes du martyre de l'apa Chounbi," ASAE 17 (1917): 145-159.

${ }^{166}$ Stephen of Byzantium, Ethnica, 696:3.

${ }^{167}$ Margaret Maehler, "Trouble in Alexandria in a Letter of the Sixth Century," GRBS 17 (1976): 197-203.

${ }^{168}$ Michael J. Hollerich, "The Alexandrian Bishops and the Grain Trade: Ecclesiastical Commerce in Late Roman Egypt,” JESHO 25, no. 2 (1982): 187-207.
} 
and its archaeological context, no absolute conclusions can be made. The mosaic is extremely fragmentary, so it is possible that other buildings were also labeled with city names, in a variation of the walled city motifs found in Jordan. If that is the case, the Kiryat Gat border is more closely related to the Nilotic scenes from St. Stephen and St. John the Baptist, the latter of which might also reflect the economic activities of its patron.

In both the Megalopsychia and Kiryat Gat mosaics, the viewer makes a virtual journey through the individual cities as he or she moves along the pavement. This sense of procession is echoed in church mosaics found in both Italy and Syria. Theodoric's sixth-century palatine church, Sant'Apollinare Nuovo in Ravenna, Italy, depicts two such processions along the walls of the nave. On the north side, the Three Magi lead twentytwo female martyrs in single file from the labeled city of Classe toward the Virgin and Child at the east end of the nave (Figures 126a-b). On the south side is a similar scene, with twenty-six male saints walking from the labeled city of Ravenna toward an enthroned Christ (Figures 127). The depiction of Ravenna is dominated by the palace, from which images of Theodoric and his entourage were removed in 561. Various scholars have attempted to identify the buildings portrayed within the walls in order to determine Theodoric's exact claims of authority. ${ }^{169}$ Despite varying opinions, the overall message is the same. As Late Antique visitors entered the church, they encountered the ruler of the earthly realm and the cities under his control: Classe and Ravenna. The patron was memorialized in a permanent adventus, and viewers would see this while moving

\footnotetext{
${ }^{169}$ Maria Grazie Breschi. La cattedrale ed il battistero degli ariani a Ravenna (Ravenna: Edizione "Dante" di A. Longo, 1965), 10; Mark Johnson, "Toward a History of Theodoric's Building Program," DOP 42 (1988): 88. Breschi suggests that both the Orthodox and the Arian baptisteries are depicted, reflecting Thedoric's religious tolerance. On the other hand, Johnson proposes that all the buildings represented were Theodoric's constructions to emphasize his contributions to the city.
} 
eastward toward the altar, entering the "heavenly realm" in which representations of Jerusalem and Bethlehem likely decorated the church's triumphal arch. ${ }^{170}$ Classe and Ravenna therefore become earthly equivalents for these holy cities. No wall mosaics survive from Late Antique Jordan; however, the Ravenna example makes one wonder if topographic motifs decorated other areas of the churches examined in this study and enhanced the patrons' intended message.

Like the Sant'Apollinare wall mosaics, the floor mosaic from the Church of the Holy Martyrs in Tayyibat al-Imam, Syria contains a religious procession (Figures 128). It is possible this represents the translation of relics, an actual event in the church's history. Two horses with finely woven blankets carry a litter bearing a large reliquary box, similar to those found on both the North Church mosaic in Huarte, Syria (Figure 117), and an unprovenanced mosaic from Syria sold at auction in $2006 .{ }^{171}$ The horses have left a city or site represented by a gate with two fruit trees growing through the entrance. The motifs recall the gate with the lamp flanked by fruit trees in the St. John the Baptist mosaic (Figure 3) and might represent the holy sanctuary from which the relics originated. As with the St. John the Baptist mosaic, there are no identifiers to link the iconography to any particular saint.

The horses move toward a city consisting of a low wall surrounding a series of basilica churches and a central-planned structure flanked by two towers (Figure 128). The

\footnotetext{
${ }^{170}$ Deborah Mauskopf Deliyannis, Ravenna in Late Antiquity (Cambridge: Cambridge University Press, 2010), 163.

${ }^{171}$ Sotheby's, “A Byzantine Mosaic Panel, late $5^{\text {th }}$ Century A.D.," accessed March 22, 2016, http://www.sothebys.com/en/auctions/ecatalogue/2006/antiquities-n08253/lot.99.html. Unlike the other examples, this panel has a man leading the horses. He is dressed in a short tunic and high sandals, carrying a whip. This figure has many similarities to the one found in the Intercolumnar panel in the Church of the Priest Wa'il. It suggests that the figure in the Jordanian church, situated like a patron portrait, should be read as the person physically responsible for the translation of the relics. In the Sotheby panel the contents of the cart can be seen: a goblet filled with red fruit. This is remarkably similar to a motif found on the Kiryat Gat mosaic, though on the latter the goblet filled with fruit stands alone.
} 
city is not labeled, but it is easy to imagine that it is a depiction of Tayyibat al-Imam. Outside the city walls is a small building on a hill accessed by a set of stairs. Perhaps it represents a shrine or hermitage outside the city. The image has no equal in other mosaics, and without a toponym it is impossible to identify. Nonetheless, this interpretation of the translation of relics to Tayyibat al-Imam is reasonable when one considers the church's dedication to martyrs and the apocalyptic/salvific imagery found in the main field of the mosaic.

Other panels also depict images of holy sites or religious travel. An intercolumnar panel on the south side of the nave depicts a column (Figure 129), perhaps for a stylite, as has been suggested for the column images from the Umm al-Rasas mosaics (Figures 29 and 52). A rectangular panel in the Tayyibat al-Imam's nave contains two camels laden with bundles of unspecified materials in preparation for a long journey (Figure 130).

Eight individualized architectonic motifs set within the geometric pavement in the western portion of the nave also recall the Jordanian mosaics (Figure 131). However, in the Church of the Holy Martyrs, these consist of buildings rather than cities. Two of these are set amongst vegetation but no other geographic location is indicated. ${ }^{172}$ Unlike the eastern panel's labeled depictions of Jerusalem and Bethlehem, the buildings are not labeled so it is impossible to tell if they represent different sites like those found on the Jordanian borders, buildings within the same city like the Megalopsychia mosaic, or generic depictions of churches.

Topographic imagery promoting movement within a building was widely used in mosaics from the fifth century and earlier, especially in Syria. It is not surprising that such imagery was also adopted in Arabia and Palaestina, which had ties to Syria through

\footnotetext{
${ }^{172}$ Zaqzuq and Piccirillo, "Mosaic Floor," 447.
} 
the metropolitan in Bosra. While the relatively early border from St. John the Baptist, dated by inscription to 531, pulls from both Nilotic and topographic traditions, the eighthcentury examples from Ma'in and St. Stephen reflect a regional variation, usually depicting cities in the order they are found along actual roadways. In some respects this is similar to the sixth-century Madaba mosaic, which presents an expanded landscape that Late Antique viewers would traverse as they moved through the church's interior. This movement not only provides a spiritual journey, moving the participant from the earthly realm of the nave toward the heavenly realm represented by the altar, but it also allows the viewer to recreate a pilgrimage journey to churches like St. Stephen or Ma'in.

Topographic imagery could be used to help denote a building's purpose, but it was also combined with other motifs to make statements about the community's status within the region, and to illustrate the worldly knowledge of the patron. Topographic compositions recalled maps, which were as much objects of status in the Late Antique period as they were functional. In the next section, the route-like topographic mosaics from Jordan are examined within the context of these Late Antique documents.

\section{Route-like Topographic Mosaics in Light of Late Antique Maps}

In the modern world, maps are largely utilitarian in nature and are used to orient oneself in unfamiliar locations or to plan routes from one place to another. However, as observed by J.B. Harley and David Woodward, maps played a much greater and more abstract role during the Late Antique period. ${ }^{173}$ They could be used to illustrate philosophical beliefs, such as the cosmology presented by the sixth-century merchant

\footnotetext{
${ }^{173}$ See Chapter 1, above, pp. 22-23.
} 
traveler turned geographer Cosmas Indicopluestes. ${ }^{174}$ They could also be used as statements of authority, claiming power over the depicted sites. The topographic mosaics draw from both of these traditions, using images of local landmarks to propagandize their community's status in the region, while also encouraging ritualized and contemplative movement within the sacred space of the church. That patrons used these mosaics as part of a visual communication of their own importance is bolstered by examples of Late Antique maps, which themselves were used as status objects by their patrons.

Topographic motifs were used to encourage movement within Late Antique spaces and to mimic actual journeys within and between cities. The routes displayed on the borders at St. John the Baptist, St. Stephen, and Ma'in depict inter-city travel between sites along known roads and waterways. This would require the patron and/or mosaicist to have knowledge of the area, and perhaps access to a map or topographic descriptions. This is certainly true of the Madaba mosaic, a detailed composition containing over 151 labeled sites. We have very little information about the nature of Late Antique maps, however, as few examples exist and almost all of these are medieval copies. Moreover, one must examine these documents within their cultural contexts, keeping in mind they were not always produced to chart regional geographic features with mathematical precision. Like the topographic mosaics, maps were a form of "value-laden" imagery. The selection of the area represented and the way it was presented through the use of various signs and symbols helps to convey ideas about the space and the individual(s) for whom the map was made. ${ }^{175}$

\footnotetext{
${ }^{174}$ Cosmas Indicopluestes, The Christian Topography, 3.50-3.52.

175 J. Brian Harley, "Maps, Knowledge, and Power," in The Iconography of Landscape, ed. D. Cosgrove and S. Daniels (Cambridge: Cambridge University Press, 1988), 277.
} 
In the vast Roman Empire, land surveys were necessary for the construction of roads, the development of military camps and colonies, and the marking of frontier boundaries. ${ }^{176}$ These documents are not presented entirely in cartographic format but are preserved as manuscripts, some of which contain miniature illustrations. ${ }^{177}$ More in keeping with the modern idea of a map is the Forma Urbis Romae, a rendering of Rome and its monuments constructed under Septimius Severus (Figure 132). Made of marble, it originally measured about thirteen meters high by eighteen meters wide, however only a portion survives. Streets and public buildings are labeled but neither the scale nor the orientation of the plan is consistent. It was originally installed in a building near Trajan's Forum, possibly the Templum Sacrae Urbis or the Prefecture, which later became the Church of Sts. Cosmas and Damian. ${ }^{178}$ The Severan plan was apparently borrowed from a long-standing tradition; Jennifer Trimble identifies five earlier marble maps in Rome. ${ }^{179}$ More specifically, Lisa Taub links the tradition to Augustus and Vespasian, suggesting that in each case the ruler came to power after a period of instability and used monumental maps of Rome to promote their urban improvements while symbolically referring to other reforms. ${ }^{180}$

This connection between imperial authority and cartographic imagery was also expressed in other ways. In the late third century, the orator Eumenius delivered a panegyric dedicated to a map of the Roman Empire. He provided a vivid description of

\footnotetext{
${ }^{176}$ O.A.W. Dilke, Greek and Roman Maps (Ithaca: Cornell University Press, 1985), 87-101, 112-129.

${ }^{177}$ O.A.W. Dilke, "Maps in the Treatises of Roman Land Surveys," The Geographical Journal 127, no. 4 (December 1961): 417-426.

${ }^{178}$ Liba Taub, "The Historical Function of the Forma Urbis Romae," Imago Mundi 45 (1993): 9-11.

${ }^{179}$ Jennifer Trimble, "Process and Transformation on the Severan Plan of Rome," in Cartography in Antiquity and the Middle Ages: Fresh Perspectives, New Methods, ed. Richard Talbert and Richard Walson Unger (Leiden: Brill, 2008), 70-74.

${ }^{180}$ Taub, "Historical Function," 15-17.
} 
the map, including the sites held and recently reconquered by the Empire. ${ }^{181}$ Like the ekphrases of church buildings discussed earlier in this chapter, the purpose of this rhetorical composition has as much to do with highlighting the status of the patron as with providing a description of the object in question.

Geographical depictions were used to emphasize political power and they also became an important tool in the definition of early Christianity topography. The Onomastica of Eusebius (fourth century) and Jerome (fifth century), which are considered by most to be two of the main sources for the Madaba mosaic, provide contemporary identifications of biblical sites. Whenever possible, this information is supplemented with historical details and distances between the sites. Both manuscripts were likely illustrated. ${ }^{182}$ Wealthy travelers from the west made pilgrimages and documented their experiences in itineraria. These accounts served as a type of ekphrasis for those who read them, providing access to the Holy Land sites while emphasizing the authors' proximity to the sacred. The nature of these accounts varies widely and illustrates the pilgrim-authors' different interests. One of the earliest, that of the fourthcentury Bordeaux Pilgrim, reflects the practical and ideological aspects of Late Antique maps. His account contains two types of information: the first describes the mechanics of getting from place to place, such as distances and the locations of rest stops, while the second provides information about the importance of the sites he visits. ${ }^{183}$

\footnotetext{
${ }^{181}$ Natalia Lozovsky, "Maps and Panegyrics: Roman Geo-Ethnographical Rhetoric in Late Antiquity and the Middle Ages," in Cartography in Antiquity, 169-171.

${ }^{182}$ Alliata, "Legends," 84-101; Leah Di Segni, "The 'Onomasticon' of Eusebius and the Madaba Map," in Madaba Mosaic Centenary, 115-120. Alliata provides a compendium of sources for the sites depicted on the Madaba mosaic, drawing from Eusebius, Jerome, biblical passages, and other texts.

${ }^{183}$ Oded Irshai, "The Christian Appropriation of Jerusalem in the Fourth Century: The Case of the Bordeaux Pilgrim,” JQR 99, no. 4 (2009): 471-472.
} 
The Bordeaux Pilgrim's account reads like a literary version of the Peutinger Table, a medieval copy of a possible fourth century document. Documenting the Roman world from Britain to India, the original document was likely on one scroll, which accounts for the unusual rectangular shape of its copy. Because of its complex depiction of roads, rivers, and over 2500 toponyms, many believe that it served as an itinerary map (Figure 133). ${ }^{184}$ It has even been suggested that the systematic depiction of official rest stops (mansiones), similar to the semiotic illustrations of cities on the Madaba mosaic, reflect a rating system; this idea has been repeated in numerous subsequent publications despite that the fact that there is no evidence to corroborate it. ${ }^{185}$

In recent years, scholars have questioned the Peutinger Table's function. Its variance in scale between the north-south and east-west orientations, obvious errors in some areas (like the Egyptian Delta), and overwhelming number of depicted sites suggest it could easily have served as a decorative object rather than a functional map. ${ }^{186}$ Robert Talbert presents a novel argument that the Late Antique original was not a scroll but a tapestry or other material put on display in a manner similar to the Forma Urbis Romae. In the case of the Peutinger Table, Talbert believes that it decorated a wall behind the emperor's throne as a depiction of the inhabited world with Rome at its center. ${ }^{187}$ Talbert's theory of the Peutinger Table's ornamental function gains further acceptance in light of the discovery of medieval texts that describe maps displayed in a similar

\footnotetext{
${ }^{184}$ Alan M. MacEachren, “A Linear View of the World: Strip Maps as a Unique Form of Cartographic Representation," The American Cartographer 13, no. 1 (1986): 9, 14.

${ }_{185}$ Annalina Levi and Mario Levi, Itineraria Picta: Contribulto allo studio della Tabula Peuttingeriana (Rome: "L'Erma de Bretschneider, 1967), 79; Ekkehard Weber, "The Tabula Peutingeriana and the Madaba Map," in Madaba Map Centenary, 41.

${ }^{186}$ Emily Albu, "Imperial Geography and the Peutinger Map," Imago Mundi 57, no. 2 (2005): 137-138; Benet Salway, "The Nature and Genesis of the Peutinger Map," Imago Mundi 57, no. 2 (2005): 122-123. Both Albu and Salway argue that the Peutinger Map is not a copy of a Late Antique original but a medieval original.

${ }^{187}$ Talbert, “Urbs Roma,” 184.
} 
fashion. ${ }^{188}$ Late Antique maps were used to display their patrons' status, which reframes how one expects viewers to read the Peutinger Table and bolsters the idea that the stylistically similar Madaba mosaic might have been used in the same way.

Late Antique maps often had a dual function; they indicated the physical location of sites in a reasonably realistic fashion but also served as markers of status emphasizing the patrons' connection to, and "ownership" of, the depicted locales. To own a map implied many things: literacy, an understanding of or familiarity with the illustrated region, and the high status of someone who required such an object. The Jordanian topographic mosaics borrow from these messages of status and authority, just as they borrow other symbols of prosperity from the Roman and Late Antique visual repertoire.

\section{Conclusions}

The spatial and iconographical analyses of the topographic mosaics demonstrate that they served a number of purposes. In the case of Umm al-Manabi ‘ and St. Peter and Paul, depictions of contemporary walled Egyptian sites help strengthen the message of prosperity while neutralizing the Nilotic motifs' "pagan" connotations. At Khirbat alSamra and the Church of the Priest Wa'il, representations of Jerusalem and Bethlehem are paired as a means of highlighting the mosaics' messages of death and salvation in a funerary church and martyrion, respectively. On the Sts. Peter and Paul mosaic, the combination of Nilotic imagery with a pair of cities, problematizes the traditional interpretations of either prosperity or salvation; in cases like these, more information is required to provide a definitive interpretation.

\footnotetext{
${ }^{188}$ Salway, "Nature and Genesis," 122.
} 
Portrayals of individual cities, found in the Church of the Lions, as well as in the donor panels in the aisles of St. Stephen, identify the sites from which the patrons originate. In all three examples from Umm al-Rasas, the host city is featured and, on at least two, is identified through its distinctive stylite tower. The mosaics of St. Stephen and the Church of the Lions emphasize pilgrimage processions, visually indicating one purpose of these two churches.

Other topographic mosaics were designed to encourage movement within their buildings. The borders of St. John the Baptist, St. Stephen, and Ma'in all contain a series of walled cities that visitors "traveled" between as they moved through the church. In each case, the cities are not randomly placed but often reflect actual roadways or routes in the Late Antique East that can be plotted on a map. Similarly, the Madaba mosaic depicts a large portion of the Holy Land and Egypt with a semblance of geographic accuracy. Interpreting these compositions is challenging, since no true parallels to this imagery have been discovered outside of Jordan.

Comparanda do exist in the Late Antique Mediterranean, and especially in nearby Israel and Syria, that echo the expressions of prosperity found in the Jordanian examples. However, the pavements examined in this study place special emphasis on local agricultural products and allude to the prosperous enterprises of trade and pilgrimage, a specificity that is lacking in the comparanda. In the next chapter, the specific details of these agricultural and geographic motifs are examined and compared to the available historical sources regarding the economic importance farming, trade, and pilgrimage. 


\section{CHAPTER 4:}

\section{THE TOPOGRAPHIC MOSAICS IN THEIR SOCIO-ECONOMIC CONTEXTS}

In Chapter 2, it has been shown that the funding of church buildings and their decoration was a considerable expense, and that donors expected to be compensated by way of public recognition. Patrons ensured that they would be memorialized perpetually through their personalized portraits and inscriptions; these occupied some of the most privileged spaces within the church, in close proximity to the altar and often in axial alignment with it. Similarly, the images donors chose for the nave pavements, one of the most highly visible locations within the church, drew from the traditional visual language that elites had used for centuries to promote their status in domestic and public settings. Compositions were carefully crafted and utilized images of local agro-economic products combined with topographic motifs in order to localize the messages of personal or community prosperity.

Agricultural prosperity is featured in the mosaics from St. John the Baptist, St. Stephen, Ma'in, and Madaba, but the topographical motifs in these pavements are also arranged to represent geographically accurate routes. St. Stephen and Ma'in are located at pilgrimage sites, and their mosaic compositions allowed religious travelers to recreate their journeys as they participated in the liturgy inside the church. In both churches, the topographic motifs highlight the host city by awarding it a prestigious location within the nave. At St. John the Baptist and Madaba, the purposes of the depicted routes are 
more ambivalent and could reflect pilgrimage, trade, or both. Regardless, several of the topographic compositions reflect the socio-economic realities of the "inhabited earth" they represent, stressing the prosperity that Palaestina and Arabia enjoyed in the sixth to the eighth centuries.

\section{Agricultural Production and Trade}

When developing the topographic mosaic compositions, patrons and mosaicists drew heavily from iconography employed by the elite in secular contexts to indicate wealth and status. Generic hunting scenes do not necessarily allude to an actual practice but instead reference otium, leisure time available only to the wealthy. ${ }^{1}$ Similarly, nonspecific illustrations of flora and fauna may serve as generic indications of prosperity, or may simply reflect the world in which the patrons lived. However, the Jordanian mosaicists took special care to indicate specific crops that were the basis of the local economy, as well as the agricultural processes involved in their cultivation. These polyvalent messages were suitably malleable for an ecclesiastic setting, where they could be read as both a symbol of the earthly realm and as representations of the patron's or community's wealth.

\section{I.i. Grapevines and Trees}

While previous scholars have discussed vines as Christian symbols, their interpretations of the architectonic motifs have largely failed to address the symbolic

\footnotetext{
${ }^{1}$ Hunting scenes are included in the borders mosaics of St. John the Baptist and the Church of the Lions, and in the main fields of St. Stephen and the Church of the Priest Wa'il. It is possible that hunting scenes populated one of the panels at Sts. Peter and Paul as well.
} 
importance of trees. ${ }^{2}$ In the wider realm of Late Antique mosaics, scholars have noted the skill of Jordanian artisans in depicting trees and the popularity of trees as framing devices. ${ }^{3}$ Mosaicists took great care to include specific horticultural details in their depictions, and it is unlikely that this is simply a workshop style since the date range for the mosaics spans nearly two hundred years

Both acanthus and vine scrolls were commonly used in the Roman and Late Antique periods to fill naves and borders and to frame people, animals, and objects. Examples appear in St. John the Baptist (Plan 3), Sts. Peter and Paul (Plan 4), Madaba (Plan 5), and St. Stephen (Plan 12, Figure 69). In the first three, the pavements are extremely damaged so it is impossible to be certain what the scrolls contained. Despite the iconoclastic damage, St. Stephen's nave mosaic is well preserved enough to determine that many of the scrolls held figures participating in vintaging scenes, including one man crushing grapes inside a vat (Figure 134). A similar scene is found in the adjacent church of St. Sergios and the pavements of Khirbat al-Mukhayyat. ${ }^{4}$ Vintaging motifs are not unique to Jordan but occur sporadically throughout the Empire. They were especially popular in North Africa, where scenes of vintaging and latifundiae, large rural estates, decorated reception rooms in city homes of the wealthy. In one villa at Tabarka, Tunisia, the patron included images of three separate rural winemaking estates, suggesting his vast holdings in the country. At Cherchel, Algeria, an area where Roman wine production facilities have been discovered, one patron commissioned an extremely

\footnotetext{
${ }^{2}$ Hachlili, Ancient Mosaic, 144. Hachlili provides a brief but thorough overview of the religious connections to vine imagery for both Christians and Jews.

${ }^{3}$ Janine Balty, Mosaïques antiques du Proche-Orient: chronologie, iconographie, interpretation (Paris: Les Belles Lettres, 1995), 121-122. Balty sees no other role for trees other than as formal elements to help set the scene, and ascribes their popularity in Jordan to the Madaba workshop tradition.

${ }^{4}$ Piccirillo, Mosaics of Jordan, 165, 176, 234.
} 
detailed pavement of the seasonal activities required to maintain a vineyard. Such pavements reflect an economic reality and were strategically placed in dining rooms and reception halls to remind guests of the source of their host's wealth. ${ }^{5}$ The message of economic prosperity did not necessarily change in an ecclesiastic setting.

In Jordanian mosaics, the subject of winemaking only occurs in towns where there was a monastic complex with a wine press. At Umm al-Rasas, where wine making facilities were connected to the Church of St. Paul, vintaging scenes decorate St.

Stephen's nave pavement, as well as the connecting St. Sergios. Similarly, at Khirbat alMukhayyat, the churches around the monastic complex of al-Kanisah, which had a wine press, all contain vintaging imagery. ${ }^{6}$ Umm al-Rasas, like several other sites in the region, witnessed an economic upswing in the seventh and eighth centuries due to a rise in the number of large land-holding estates owned by both individuals and the Church. ${ }^{7}$ Vines and vintaging were suitably polyvalent symbols for ecclesiastic patrons, reflecting messages about the nature of Christ while also indicating the patron's prosperity.

As with vines, donors could make statements about their economic status by incorporating images of trees into their mosaics. Several of the pavements contain fruit trees and date palms, while the less recognizable balsam tree is depicted in St. John the Baptist, its adjacent churches, and the Madaba mosaic. In some Jordanian mosaics, trees were used for symbolic purposes like the representation of Paradise; however,

\footnotetext{
${ }^{5}$ Tracey Eckersley, "Iconography of the Vintage in the Mosaics of Roman Spain and North Africa" (MA thesis, McMaster University, 1996), 23, 109-111.

${ }^{6}$ J. Abela and A. Acconci, "Umm al-Rasas Kastron Mefa'a: Excavation Campaign 1997; Church of St. Paul: Northern and Southern Flanks," Liber Annuus 47 (1997), 486-487; Michele Piccirillo, "The Mosaics," in Mount Nebo: New Archaeological Investigations, ed. Michele Piccirillo and Eugenio Alliata (Jerusalem: Franciscan Printing Press, 1998), 205-209.

${ }^{7}$ Hamarneh, "Dynamics," 96; L.S. Schachner, "'I Greet You and Thy Brethren. Here Are Fifteen Shentasse of Wine.' Wine as a Product of the Early Monasteries of Egypt and the Levant," ARAM 17 (2005): 157184.
} 
topographic images are not included in these compositions. In the topographic mosaics, flora is generally used to reflect socio-economic reality rather than Christian ideology.

Fruit trees are an especially conventional motif in the Late Antique pavements of Jordan, but are generally reserved for two specific types of composition. The first depicts one or more animals flanking tree(s), as seen in the sanctuary mosaic of the Church of the Lions (Figure 33). This type is found in twelve other churches in Jordan, and in all but four cases, these pavements decorate the sanctuary or the apse. ${ }^{8}$ While there is some variation in the type of tree depicted, at least five contain pomegranate trees. As a whole, these compositions can be read as depictions of Eden or Paradise. The second type of composition is merely a variant of the first, with four trees and four pairs of animals, as found in the Church of the Apostles in Madaba (Figure 135). This motif appears in six Jordanian churches, four of which contain representations of the seasons noted with four distinct types of fruit trees. ${ }^{9}$ Three of these appear in the sanctuary or apse and should also be interpreted as depictions of Paradise. ${ }^{10}$ Laypeople could not easily see these mosaics, as their view to the sanctuary and apse floor was blocked by the chancel screen. These images are meant to reflect both the sacredness and hierarchical structure of the space.

In contrast, compositions containing fruit trees combined with topographic imagery are generally found in the nave or aisles, where they are highly visible.

\footnotetext{
${ }^{8}$ This composition is found in the Church of the Apostles and the Crypt of St. Elianus in Madaba, the New Baptistery at Mt. Nebo, the Church of Sts. Lot and Procopios, the Upper Chapel of Priest John, and the Church of St. George at Khirbet al-Mukhayat, the Church of the Deacon Thomas in the Uyn Musa Valley, the Chapel of Suwafiyah in Philadelphia-Amman, the Church of Bishop Sergios, the Double Church (twice), and the Church of the Lions at Umm al-Rasas, and in the North Church at Esbus.

${ }^{9}$ The four-tree motif is found in the Church of the Apostles, the Chapel of the Martyr Theodore, and the Chapel of Tawal in Madaba, the Church of Sts. Lot and Procopios in Khirbet al-Mukhayyat, the Church of the Deacon Thomas in the Uyn Musa Valley, and the Church of Bishop Isaiah in Jerash.

${ }^{10}$ Dunbabin, Mosaics Greek and Roman, 198; Hachlili, Ancient Mosaic, 206-207.
} 
Pomegranate trees surround the Christian cities of Alexandria and Memphis in the Sts. Peter and Paul mosaic, and generally symbolize holiness (Figure 13). Pomegranates are also found in St. John the Baptist, but here they were used to differentiate between the religious shrine (Figure 3) and the other architectonic motifs, all of which have non-fruit bearing trees (Figures 4-6). In the Church of the Priest Wa'il, a panel featuring a date palm decorates the north apse, while a pomegranate tree adorns the south apse (Figure 35). The location of these two trees flanking the central apse, along with the apocalyptic and salvation imagery found in the rest of the church, suggests that these are depictions of the Tree of Knowledge and the Tree of Good and Evil, respectively, which would help to reinforce the apocalyptic theme. ${ }^{11}$

In addition to these specific uses of trees to highlight the religious aspect of the topographic motifs, two of the mosaics in this study have borders that feature rows of fruit trees. In the Church of the Lions (Figures 30a-b), images of faithful donors process through the church carrying censers and baskets of fruit as offerings. They walk through an orchard filled with trees abundant with fruit. The trees serve as traditional flanking devices, simultaneously highlighting the donors and also the depiction of a landscape that reaffirms the concept of the inhabited earth. The mosaicist has taken great care to depict a wide variety of local trees: pomegranate, citrus, and small stone fruit, and the trees are pollarded, or pruned in a way that removes the upper branches. ${ }^{12}$ This reflects some of the agricultural technology utilized in the region and skills that helped the provinces prosper while other parts of the Mediterranean experienced economic recession.

\footnotetext{
${ }^{11}$ Genesis 2:9. The text does not specify the species of trees, though the pomegranate is commonly connected to the Tree of Knowledge and several pavements in Jordan include a date palm as the Tree of Life. See, for example, the depiction in the Church of St. George in Khirbet al-Mukhayyat, Jordan, c. 535. ${ }^{12}$ Pliny, Natural History, Book 17: 35. Pliny describes this type of pruning for the trees that support grapevines.
} 
Developments included the increased use of irrigation systems and the rise of large estates employing tenant labor. ${ }^{13}$ The cache of sixth- and seventh-century papyri found at Nessana in Palaestina Prima (Map 3), which had a much less hospitable climate than the region east of the Dead Sea, focuses on agricultural affairs. Twenty-five percent of the documents, or nearly 100 separate texts, record contracts for land, rights to water, and details about the wide variety of agricultural products grown in the region, including the fruit trees and date palms depicted in the topographic mosaics. ${ }^{14}$ The Petra Papyri, dated to the sixth century, portray a similar economic prosperity enabled through fruit production and its regional trade. ${ }^{15}$ Archaeological evidence of more unusual crops, including walnuts, peaches, and apricots, also serve as indicators of social prosperity. ${ }^{16}$

Similar depictions of fruit trees are found with the donor portraits from St. Stephen (Figures 70-72). The figures are shown in three processions and are carrying offerings. At the end of the aisles, the figures are shown making the day's journey to Umm al-Rasas from their hometowns of Diblaton and Limbon, both of which are depicted as churches on the panels. The local donors are portrayed on the eastern part of the nave, in front of the chancel screen. They also travel through a treed landscape, but no city is depicted since they are already at their destination. It is perhaps not surprising that the cultivated trees in these mosaics are similar to those from the Church of the Lions, since both buildings are in the same city; however, there is also a strong resemblance to the trees featured in the Ma'in mosaic (Figures 74-75). The latter depicts the agricultural

\footnotetext{
${ }^{13}$ Michael G. Morony, "Economic Boundaries? Late Antiquity and Early Islam,” JESHO 47, no. 2 (2004): 168-170, 174-175.

${ }^{14}$ Mayerson, “Ancient Agricultural Regime," 211-263.

${ }^{15}$ A. Arjava, M. Buchholz, and T. Gagos, eds., The Petra Papyri v. 3 (Amman: American Center for Oriental Research, 2007), 84; Fawzi Abudanah, “Agriculture in Sixth-century,” 109.

${ }^{16}$ Charlène Bouchard, Christiane Jacquat, and Danièle Martinoli, "Landscape Use and Fruit Cultivation in Petra (Jordan) from Early Nabatean to Byzantine Times ( ${ }^{\text {nd }}$ Century BC- $5^{\text {th }}$ Century AD)," Vegetation History and Archaeobotany (2016): 18, accessed August 2, 2016, doi: 10.1007/s00334-016-0582-y.
} 
practice of training vines to grow on fruit trees. The Nessana papyri also allude to this custom, mentioning "fig-vineyards, allowing two crops to be grown in one field to maximize the yield."17

A direct reference to the economic importance of date palms is made in the Madaba mosaic, which depicts several palm trees scattered along the Dead Sea, mostly near the northern and southern shores. Despite their schematic depiction, the mosaicists have taken care to include the fruit, an especially important local crop. The area had long been known for its quality dates. ${ }^{18}$ Herodotus mentions that dates grown in the salty soil around the Dead Sea were good for storing. ${ }^{19}$ Jericho, referred to as the "City of the Palm Trees" in the Bible, is depicted flanked by date palms. ${ }^{20}$ as is Zoara (Map 1, Figure 136), known as the "City of Dates" during the Roman period and located about $8 \mathrm{~km}$ southeast of the Dead Sea. ${ }^{21}$ Eusebius notes that both dates and balsam grew in the vicinity, and the fruit from this area is equally praised by the Piacenza pilgrim in the sixth century and the Persian geographer Ibn Khordadbeh in the late ninth/early tenth century. ${ }^{22}$ No other types of trees or plants are depicted, nor are these motifs found on the majority of the pavement. The included species refer to agricultural crops in specific locations that were responsible for the region's economic success.

Another important product depicted on the Madaba mosaic is a shrub known as Gilead balm or Gilead balsam (Commiphora gileadensis) (Figure 137). The shrub's resin,

\footnotetext{
${ }^{17}$ Mayerson, “Ancient Agricultural Regime,” p. 257, inscription no. 32.

${ }^{18}$ Asaph Goor, "The History of the Date through the Ages," Economic Botany 21, no. 4 (OctoberDecember 1967): 333-335.

${ }^{19}$ Herodotus, Histories, 2:6.

${ }^{20}$ Deuteronomy 34:3.

${ }^{21}$ Yael Wilfrand, “Aramaic Tombstones from Zoar and Jewish Conceptions of the Afterlife," Journal for the Study of Judaism 40 (2009): 512.

${ }^{22}$ Eusebius, Onomasticon, 42: 4-5; Piacenza Pilgrim, Travels 16; Ibn Khordadbeh, The Book of Roads and Kingdoms, 168.
} 
opobalsam, was renowned for its fine scent and was considered the most prized and expensive perfume in the Roman world. In the Late Antique period, balsam was used as incense within the church and as part of the baptism ritual. ${ }^{23}$ The Piacenza Pilgrim, traveling to the Holy Land in the late sixth century, participated in the Epiphany ceremony at the site of Christ's baptism in the Jordan River. He recounts that after the priest blessed the river, agents of Alexandrian ship owners poured spices and balsam into the water, then collected this aromatized holy water to bless their boats before sailing. ${ }^{24}$ Like the palm trees, the Gilead balm shrubs are not used indiscriminately or as a filling device on the Madaba mosaic, but only appear in a few select locations around the northern shoreline of the Dead Sea. While it is unlikely that these represent the exact location of balsam plantations, the mosaicists have included one of the most profitable resources in the region, a resource that could have been donated to the church housing the pavement. ${ }^{25}$

The final variety of tree, which is depicted with the Egyptian motifs at Jerash, is rather generic in nature but was identified by John Crowfoot as a type of cypress. ${ }^{26}$ It appears in the background of all three extant walled city motifs in the St. John the Baptist mosaic (Figures 4-6), and a similar example appears next to the donor portraits of Theodore and Georgina in the adjacent Church of Sts. Cosmas and Damian (Figures 98-

\footnotetext{
${ }^{23}$ Einar Thomassen, "The Performance of Baptism," in Ablution, Initiation, Baptism: Late Antiquity, Early Judaism, and Early Christianity, ed. David Hellhom, et al. (Berlin: Walter de Gruyter, 2011), 897; Susan Ashbrook Harvey, Scenting Salvation: Ancient Christianity and the Olfactory Imagination (Berkeley, University of California Press, 2006), 73.

${ }^{24}$ Piacenza Pilgrim, Travels, 11.

${ }^{25}$ Hepper and Taylor, "Date Palms," 37, 41. At first Hepper and Taylor suggest that the balsam plants cannot be located in realistic locations due to the proximity of some plants to the Dead Sea. However, they revise their statement in their conclusion, when they state that the Madaba mosaic "is reliable as a historical source for the locations of plantations of balsam in the sixth century CE." Their first statement is more feasible, since there have been no archaeological excavations to support the second.

${ }^{26}$ John Winter Crowfoot, Churches at Jerash, 26.
} 
99). The trees are depicted with distinct brown branches and dark green leaves, and have no visible fruit. The bark, only visible at Sts. Cosmas and Damian, has horizontal striping. In both mosaics, the trees have been pollarded. These types of trees are exclusive to these two pavements, appearing nowhere else in the corpus of Jordanian mosaics. It is possible that the mosaicist simply wanted to differentiate between Egyptian trees and local varieties; however, this is a very specific detail to include in a generally schematized composition. Moreover, such trees are not included in Nilotic compositions and their depiction would require familiarity with the tree's physiology. The artist most likely relied on a description from the patron, unless he had access to some unknown visual material that he could copy.

The trees bear great resemblance to the Balanite aegyptiaca, commonly known as the Egyptian balsam, Egyptian plum, or desert date tree. Not to be confused with Gilead balm, this tree is native to Egypt but also grows in the Dead Sea region. Pliny mentions a woodland near Memphis known for its large specimens and remarks that its most distinctive feature is its thorny branches, which could explain the emphasis on the branches in the mosaics. ${ }^{27}$ In the Late Antique period, oil from the Egyptian balsam (balanos), was used in medicines and as a base for perfumes. ${ }^{28}$ It is tempting to attribute the inclusion of these Egyptian trees to the manufacture of this oil and even more speculative to suggest that it represents the source of Theodore's wealth, which he used to build and decorate these three churches. This would provide an explanation for why these buildings, and these buildings alone, depict this type of tree. Unfortunately, there is

\footnotetext{
${ }^{27}$ Pliny, Natural History, Book XIII, 19.

${ }^{28}$ Hepper and Taylor, "Date Palms," 43; David Illuz, et al, "Medicinal Properties of Commiphora gileadensis," African Journal of Pharmacy and Pharmacology 4, no. 8 (August 2010): 517; Zohar Amar and Orit Shamir, "Egyptian Balsam and its Use in the Jordan Rift Region," Judea and Samaria Research Studies 22 (2013): 369-376.
} 
no textual or archaeological evidence to support this claim, and the fragmentary nature of St. John the Baptist's border makes it difficult to truly understand Theodore's intentions.

The depiction of specific fruit trees, date palms, and balsam in the Jordanian topographic mosaics is not the result of random choices. Flora was selected to reflect regional species that had economic value. The modern viewer might easily dismiss the variations in depicted flora as simple decorative choices, but Late Antique individuals would have recognized the species, especially since the depictions contain visual references to cultivation. The inclusion of these agricultural products, placed in conjunction with sites known for their production, was made deliberately to reflect the wealth and status of the patrons and the communities.

\section{I.ii. Other Economic Products Featured on the Madaba Mosaic}

Given the large number of sites depicted on the Madaba mosaic and the overwhelming amount of text that accompanies them, it is not surprising that scholars have focused their attention on identifying the written sources consulted by the mosaicists as they arranged the composition. However, as seen above, this mosaic also highlights agricultural resources that might have been used to pay for the pavement's construction. In addition to date palms and opobalsam, the Madaba mosaic features two other products: salt and bitumen. These products take center-stage in the mosaic, and can be seen in the over-sized boats depicted in the middle of the Dead Sea (Figure 97).

A mound of white salt rests in the center of the north boat, while bitumen is represented by the darker material in the south boat. Salt is the product the Dead Sea is best known for, and during the Late Antique period it was not only an important seasoning but also a vital preservative. Despite this, very little is known about its 
collection and distribution, especially east of the Jordan. On the western side of the Dead Sea, now modern Israel, the Late Antique Salt Road was used to transport the product by camel to Jerusalem and beyond. This route was also used for other products, such as datesugar and balsam. ${ }^{29}$ On the east side, transportation of salt to the north would have gone through Madaba, or south along the Via Traiana Nova. Having such a valuable resource available so close to Madaba would have provided a number of economic opportunities in the region, so it is not surprising that salt is featured on the Madaba mosaic.

Bitumen was another important natural by-product of the Dead Sea. Josephus recounts how the material was collected from the surface of the sea and dried. ${ }^{30}$ It was used for medicines, and as asphalt for the waterproofing of boats. ${ }^{31}$ Sulfur was also collected from the sea and was used in medicines and as a bleaching agent. ${ }^{32}$ Little is known about the transport and trade of these materials in the Late Antique period; however, bitumen was important enough for the patrons of the Madaba mosaic to feature it in a disproportionately large motif at the very center of their composition. In this mosaic, the Dead Sea competes for attention with the Holy City found just below it.

At the edges of the Dead Sea depiction, fish feature prominently (Figure 138). They turn away from the salt waters, and some scholars have suggested that they were included in the composition to demonstrate the unusually inhospitable environment

\footnotetext{
${ }^{29}$ Menashe Har-el, "The Route of Salt, Sugar, and Balsam Caravans in the Judean Desert," GeoJournal 2, no. 6 (1978): 550.

${ }^{30}$ Josephus, Dissertation III: 6.

${ }^{31}$ Jacques Connan and Thomas Van de Velde, "An Overview of the Bitumen Trade in the Near East from the Neolithic (c. 8000) to the Early Islamic Period." Arabian Archaeology and Epigraphy 21 (2010): 2-4; Asaf Oran, et al., "Early Maritime Activity on the Dead Sea: Bitumen Harvesting and the Possible Use of Reed Watercraft," Journal of Maritime Archaeology 10, no. 1 (April 2015): 66-74.

${ }^{32}$ Burton MacDonald, The Southern Transjordan Edomite Plateau and the Dead Sea Rift Valley (Oxford: Oxbow Books, 2015), 72.
} 
created by the salinated waters. ${ }^{33}$ Instead, I posit that they are included for the same reason that other natural resources are depicted in the composition - to highlight the agroeconomic products available in the area around Madaba. The mosaicist took great care to include minute details of the fish, which are much larger than the settlements on the banks. This precision allows biologists to identify the species as Sarotherodon galilaeus, or Galilee St. Peter's fish, which is still found in the Jordan River today. Similarly, the fish included in the Nilotic border mosaic are local to that body of water - Nile perch and blue tilapia. ${ }^{34}$ These fish were not only a vital part of the local diet but also were an important trade item; fish were salted and transported to other regions. ${ }^{35}$

\section{Routes, Roadways, and Pilgrimage}

In addition to the specific allusions to local agricultural products, four of the nine mosaics have topographic motifs that are organized to reflect a geographical reality. As mentioned above, these motifs sometimes helped identify the building's purpose and functioned as visual markers to guide viewers moving through the ecclesiastic space. Viewers experienced a mimetic pilgrimage recreating the one that brought them to these sites, but the patrons' choice of depicted cities provided other messages as well. At St. Stephen, the route east of the Jordan is placed in competition with the more visited western sites and elevates the status of Kastron Mefa'a (Umm al-Rasas) by visually

\footnotetext{
${ }^{33}$ Arie Nissenbaum, "The Microbiology and Biogeochemistry of the Dead Sea," Microbial Ecology 2 (June 1975): 140; Hepper and Taylor, "Date Palms," 35.

${ }^{34}$ Personal correspondence with Dr. William D. Pearson, Professor of Biology, University of Louisville. I am grateful to Dr. Pearson for taking the time to providing these identifications for me.

${ }^{35}$ Wim Van Neer and David Depraetere, "Pickled Fish from the Egyptian Nile: Osteological Evidence from a Byzantine (Coptic) Context at Shanhûr," Revue de Paléobiologie 10 (December 2005): 159-170;

Mayerson, Ancient Agricultural, 139, 251, 306. The importance of the fish trade is recorded in both the archaeological record and the Nessana papyri, one of which documents the correspondence between a deacon and an abbot concerning the shipment of fish, while another records a gift of fish from the Nile. Fish also figure prominently in accounts of purchases made on trading excursions.
} 
equating it with Jerusalem, the most important pilgrimage site in the Holy Land. Ma'in also inserts itself into the pilgrimage network by including the eponymous (Belemounta) architectonic motif with the other cities along the border, and possibly situating it at the entrance to a side chapel. The fragmentary nature of the remains prohibits certainty, but it is possible that Jerusalem would have been located directly opposite this motif, providing a comparison similar to the one found in St. Stephen. A reading of the Madaba mosaic is more challenging, but the depictions of the ten largest cities appear to have semiotic significance as markers of major regional roadways.

While pilgrimage allowed travelers to experience important religious sites firsthand, it was also an activity of great economic importance to those who lived at or near the various stops. Pilgrims required food and lodging, as well as guides and escorts to protect them along the routes, and they also purchased eulogiai and other local goods during their journeys. In addition, these travelers made donations that funded building projects, which in turn employed local builders and artisans. Pilgrims also acquired relics to transport back to churches in the West. ${ }^{36}$ In an early and often quoted article, AviYonah suggests that this economic boom was short-lived, but more recent sources and the itineraria, suggest otherwise. ${ }^{37}$ Of the nineteen pilgrim texts published in John Wilkinson's Jerusalem Pilgrims, one third date to the sixth century but three more date to

\footnotetext{
${ }^{36}$ Doron Bar, "Population, Settlement, and Economy of Late Ancient Palestine (70-641)," BASOR 67, no. 3 (2004): 315; Haas, Alexandria in Late Antiquity, 37-40; Basema Hamarneh, "Monasteries in Rural Context in Byzantine Arabia and Palaestina Tertia: A Reassessment," in Christ is Here! Studies in Biblical and Christian Archaeology in Memory of Michele Piccirillo, ed. L. D. Chrupcala (Jerusalem: Studium Biblicum Franciscarum, 2012), 275.

${ }^{37}$ Michael Avi-Yonah, "The Economics of Byzantine Palestine," IEJ 8 (1958): 41. Avi-Yonah divides this into three periods- a period of public funding by Constantine and his followers, a time of private patronage until the death of Eudocia in 460, then a brief resurgence of public funding under Justinian after a short stagnation.
} 
the eighth. Christian pilgrimage continued into the medieval period but Muslims also visited the sites on local pilgrimages or when en route to Mecca for the Hajj. ${ }^{38}$

The mosaics replicate a large number of cities from both the Holy Land and Egypt. In St. John the Baptist's border, the Nilotic imagery below the topographic motifs suggests that all of the depicted cities are Egyptian. The mosaic subverts the Nilotic genre to localize prosperity within the socio-economic context of either pilgrimage or trade. The presence of Menouthis or another shrine suggests pilgrimage, while the inclusion of balsam trees and a camel-driver suggests trade. With a fragmentary figural scene and only one of the four remaining cities labeled, it is impossible to say more.

As indicated in the surviving pilgrim itineraria and guides, there was no singular circuit used for travel and trade between the Holy Land and Egypt. Pilgrims' routes depended on what they wished to see, as well as the knowledge of their guides. Journeys were not always planned on the most direct route, and often involved doubling back along roads. Individuals had diverse interests in the various sites and each recorded different information. Some, like Egeria, focused on religious sites and the rituals that occurred at holy places while others, like the Piacenza Pilgrim, include more information about the conveniences that each city afforded travelers. Many pilgrims commented on the natural resources at different sites, echoing the importance of the crops and trade goods highlighted on the topographic mosaics.

Travel plans were also dependent on the pilgrim's budget - travel by boat was more expensive but provided faster travel times between sites. ${ }^{39}$ The threat of bandits or

\footnotetext{
${ }^{38}$ Andrew Peterson, The Medieval and Ottoman Hajj Routes in Jordan: An Archaeological and Historical Study (Oxford: Oxbow Books, 2012), 9-16; John Wilkinson, Jerusalem Pilgrims (Havertown, PA: Aris \& Phillips, 2015).
} 
hostile nomads sometimes required armed protection and/or the use of alternative routes. ${ }^{40}$ Nevertheless, the overall number of roadways was limited and the pilgrim itineraria indicate that pilgrims followed similar routes and visited many of the same sites from the fourth to the ninth centuries.

Some of the variations in travel are demonstrated by the fourth-century pilgrim Egeria, who made two trips to Egypt (Map 2). In the first she traveled from Jerusalem south along the Via Maris, through Askalon and Peluseion, then along the Egyptian coast to Alexandria. She then traveled by boat to Memphis, continuing south to the Thebaïd, then back up through Goshen to Jerusalem. She notes the connections to Moses at Taphnis and Memphis, and comments on the ancient Egyptian ruins at places like Babylon before returning to Jerusalem through Peluseion and Gaza on the Via Maris. ${ }^{41}$ After some time in the Holy City, Egeria returned to Egypt and visited Mt. Sinai. Once again she traveled along the Via Maris to Peluseion, then along the Red Sea to Mt. Sinai. She notes that Clysma was the port used by ships from India. Returning northward, she comments specifically on the fertility of Goshen in the Northeast Delta region, and mentions the vineyards, balsam, and orchards she saw there. ${ }^{42}$ With minor variations, these are the same routes taken by other pilgrims from the fourth to the ninth centuries. The Piacenza Pilgrim, traveling in 570, takes a slightly different path, moving from Gaza

\footnotetext{
${ }^{39}$ Blake Leyerle, "Mobility and the Traces of Empire," in A Companion to Late Antiquity, ed. Philip Rousseau (Maldan, MA: Wiley Blackwell, 2009), 110-124, especially 111-113.

${ }^{40}$ Benjamin Isaac, "Bandits in Judea and Arabia," HSCP 88 (1984): 196-203; Stephen Davis, "Pilgrimage and the Cult of St. Thecla in Late Antique Egypt," in Pilgrimage and Holy Space, 323. Isaaac provides an excellent summary of the primary sources regarding bandits in Late Antique Judea and Arabia. Davis discusses the provisions that the Emperor Zeno made in the fifth century to protect the pilgrim road in Egypt.

${ }^{41}$ Egeria, Travels, 2.

${ }^{42}$ Ibid., 4.
} 
(Figure 51) to Elusa and then through the desert to Mt. Sinai before taking a route similar to Egeria's up to Alexandria. ${ }^{43}$

The Egyptian cities on the St. Stephen mosaic (Figures 59-68) do not follow Egeria's path, but instead create two wide circular routes. Part of one sequence is similar to routes often taken by pilgrims and includes Peluseion, Kynopolis, Heraklion, and Alexandria (Map 4). No Late Antique travel account records Kynopolis, so it is possible that these cities were chosen for their ecclesiastic connections. Eight of the ten sites depicted on the mosaic were bishoprics in the Late Antique period, but Heraklion and Pseudostomen were not, which complicates this suggestion. Five sites had Late Antique monasteries, but again, there is no information for Heraklion and Pseudostomen, and no evidence of monastic activity at either Panou or Thenesos. Thus, the reasons behind the selection of the ten Egyptian cities depicted in the St. Stephen mosaic remain a mystery.

In contrast, the Holy Land cities in St. Stephen's intercolumnar panels (Figures 44-58) are depicted along known Late Antique roadways and the cities on the north intercolumnar panel follow portions of common pilgrimage routes (Map 3). The first motif is Gaza, a major port city where many pilgrims disembarked, sometimes booking passage on trade ships. Philip Mayerson suggests that it was religious travelers who made Gaza wine so popular in the West, and brought it home with them on their return journey. ${ }^{44}$ Gaza had no real religious significance for pilgrims but was a large city with amenities along the well-traveled Via Maris. ${ }^{45}$ The next motif represents Askalon (Figure

\footnotetext{
${ }^{43}$ These include the itineraries of Paula (385), the Piacenza Pilgrim (c. 570), Epiphanius the Monk (before 692), Willibald (780), and Bernard (870), as well as the travel guide prepared by Theodosius (c. 518). The Piacenza Pilgrim (Travels, 37-45) provides a detailed description which, like Egeria's, notes locations of abundant natural resources.

${ }_{44}^{44}$ Philip Mayerson, "The Wine and Vineyards of Gaza in the Byzantine Period," BASOR 257 (1985): 79.

${ }^{45}$ Theodosius, The Topography of the Holy Land, Itinerary 3; Piacenza Pilgrim, Travels, 33; Hugeburc, Life of Willibald, 23; Bernard the Monk, A Journey to the Holy Places and Babylon, 314.8-9. Only
} 
50), another large city about $15 \mathrm{~km}$ north of Gaza on the Via Maris. According to pilgrim accounts, it possessed a few religious sites, including a well supposedly dug by Adam, the tomb of the Three Egyptian Martyrs, and the tomb of Sts. Cosmas and Damian. ${ }^{46}$

From here, the St. Stephen mosaic directs the viewer inland to Eleutheropolis (Figure 49), located about $40 \mathrm{~km}$ east of Askalon. While there was not much to see within this city, Jerome, Egeria, and Theodosius mention smaller religious shrines that required passing through the city in order to reach them. ${ }^{47}$ After Eleutheropolis, the mosaic shows Diospolis (Figure 48), which was popular with later pilgrims because of miracles that occurred at St. George's tomb. ${ }^{48}$ The next motif is Caesarea Maritima (Figure 47), the placement of which is unusual; on an actual journey, the trip from Diospolis to Caesarea requires doubling back on the inland route, returning to the Via Maris along the coast. ${ }^{49}$ The pilgrim Paula stopped in Caesarea and visited many sites but the city held little interest for other authors. Theodosius, and the Bordeaux and Piacenza pilgrims provide brief accounts, but Caesarea elicited few comments from Egeria and others, who traveled south along the coastal road on their way to Jerusalem. ${ }^{50}$

\footnotetext{
Hugeburc mentions a religious significance of Gaza but only provides a vague reference to a "holy place" there. The other three focus on the contemporary city, stating that it has many provisions.

${ }^{46}$ Theodosius, Topography, Itinerary 4; Piacenza Pilgrim, Travels, 33; Epiphanius, 16; Wilkinson, Jerusalem Pilgrims, 228. The Piacenza Pilgrim identifies the well and the tomb of the Egyptian martyrs associated with it. Epiphanius mentions that the tomb of Sts. Cosmas and Damian is located in Askalon. Wilkinson notes that the Madaba mosaic highlights no religious buildings, instead highlighting civic structures.

${ }^{47}$ Jerome, Letter 108 to Eustochium, 14.1; Egeria, Travels, 3.8; Theodosius, Topography, 3.

${ }^{48}$ Piacenza Pilgrim, Travels, 25; Epiphanius, Holy City, 15; Hugeburc, Life, 25.

${ }^{49}$ Jerome, Letter, 313.2. Paula made this journey in reverse, moving inland from Caesarea to Diospolis.

${ }^{50}$ Jerome, Letter, 108.2; Bordeaux Pilgrim, Travels, 585; Theodosius, Topography, Itinerary 4; Piacenza Pilgrim, Travels, 46. Rina Avner, "The Account of Caesarea by the Piacenza Pilgrim and the Recent Archaeological Discovery of the Octagonal Church in Caesarea Maritima," PEQ 140, no. 3 (2008): 203212. It was long-assumed that the Piacenza Pilgrim was confused about his account of Caesarea Maritima and instead described Caesarea Philippi (Banias, Israel). Avner examines the pilgrim's narrative in light of recent archaeological discoveries and concludes that he did indeed visit Maritima.
} 
From Caesarea, the mosaic leads the viewer along a more typical route, moving inland and eastward to Sebastis (Figure 46). This city has a long history as a Christian cult site because it reportedly contains the tombs of St. John the Baptist, Obadiah, and Elisha, which are still visited today. Jerome, Egeria, the Piacenza, and Willibald each visited one or more of the tombs. ${ }^{51}$ Neapolis is the next topographic motif, which is another unusual feature of the mosaic (Figure 45). Traveling inland on the road from Caesarea, one would next encounter Neapolis, not Sebastis, so the two motifs have been switched in the pavement. This might be due to some confusion in the name associated with the site, as some Late Antique sources identify Neapolis as Samaria, and others link it to Sebastis. ${ }^{52}$ This suggests that St. Stephen's patrons might not have been personally familiar with the sites, and instead worked from a travel guide or some other document when choosing the motifs to represent cities to the west of the Jordan River. It is also possible that their source was a guide book or pilgrim account that included an indirect route describing the sites in an incorrect geographical "order."

The easternmost topographic motif on St. Stephen's north intercolumnar panel is Jerusalem. Situated closest to the chancel screen, a prestigious location within the church, the image's placement reflects Jerusalem's importance as the most holy site in Christianity and the ultimate goal for all pilgrims.

The group of cities depicted on the north side of St. Stephen does not represent a singular pilgrimage route but instead combines a number of typical itineraries including the Via Maris, the north-south inland road that leads from Eleutheropolis to Neapolis, and

\footnotetext{
${ }^{51}$ Jerome, Letter, 13.41; Egeria, Travels, 3.V6; Piacenza Pilgrim, Travels, 8; Hugeburc, Life, 27.

${ }^{52}$ Theodosius, Topography, 2; Piacenza Pilgrim, Travels, 6; Jerome, Letter, 13.3; Hugeburc, Life, 27. Theodosius and the Piacenza Pilgrim identify Neapolis as the biblical Samaria, while Jerome and Hugeburc correctly link it with Sebastis. This causes some confusion about the true site of the Samaritan Well, which is situated by some others in Neapolis and in Sebastis by others.
} 
the road between Neapolis and Jerusalem. The represented cities were some of the largest in the region and all but one, Sebastis, was a Late Antique bishopric. The inclusion of Sebastis rules out interpreting the depicted sites as an illustration of ecclesiastic politics, especially since it is difficult to determine if the other sites retained a bishop's seat into the eighth century. The selected cities were some of the most popular stops for international pilgrims, but were not necessarily locations of great religious significance. Presented in this way, the motifs would be recognizable to viewers but would not compete with the depiction of Jerusalem, whose placement within the hierarchical ecclesiastic space signifies its religious importance.

The south intercolumnar panels depict a more simplistic route, generally moving south to north along the Via Nova Traiana. Even though the eastern pilgrimage sites included on this side of St. Stephen are not as well documented in itineraria, they were probably more familiar to the mosaic's patrons, as all of the represented cities are situated relatively close to Umm al-Rasas. For international pilgrims, however, this was literally the road less traveled; few pilgrimage accounts mention extensive travel on the eastern side of the Dead Sea. Most pilgrims traveled from Jerusalem to Mt. Nebo, the site of the Memorial of Moses, and had little else to say about other cities along the way. Egeria describes her experience at Nebo in great detail but only mentions a few other sites besides her stop at the springs at Livias- she traveled more or less directly from Jerusalem and quickly returned the way she came. ${ }^{53}$ In his proposed itineraries, Theodosius includes a route from Jerusalem to Livias, pointing out the spring's curative powers for leprosy and the site's connection to Moses. ${ }^{54}$ An additional itinerary points out the holy sites near

\footnotetext{
${ }^{53}$ Egeria, Travels, 10.1-12.11.

${ }^{54}$ Theodosius, Topography, Itinerary 19.
} 
the Dead Sea, including the location of Jesus' baptism, while a third only records a list of cities in Provincia Arabia, without providing any other details. ${ }^{55}$ Only two of the thirteen cities included in Theodosius' list appear on the topographic mosaics: Madaba and Philadelphia. ${ }^{56}$ The Piacenza Pilgrim also crossed the Jordan, visiting Livias and celebrating Epiphany at the baptism site on the Jordan. He mentions hermitages and a number of monastic sites, some set up with guest houses for pilgrims, but makes no mention of Mt. Nebo or other sites before heading north to Jericho. ${ }^{57}$ John Rufus details Peter the Iberian's visit to Mt. Nebo, but focuses on Peter's miraculous summoning of rain in Madaba, using the region's connection to Moses as a device equating Peter to the Old Testament prophet. ${ }^{58}$

The accounts of foreign pilgrims, guidebooks, and saint's vitae do not necessarily reflect the habits of local pilgrims, for whom no travel narratives survive. ${ }^{59}$ Eugenio Alliata notes that many archaeological sites east of the Jordan contain architectural features indicative of shrines or other types of pilgrimage constructions. ${ }^{60}$ The success that these locales had in luring visitors is largely undocumented outside of narratives in saint's vitae. ${ }^{61}$ Brouria Bitton-Ashkelony provides an example from the Life of Sabas in which citizens of Madaba visited the saint for spiritual guidance and in return provided his monastery with wheat and vegetables. ${ }^{62}$ Donations from local individuals or groups to

\footnotetext{
${ }^{55}$ Ibid., Topography, Itinerary 20.

${ }^{56}$ Ibid., Topography, 24.

${ }^{57}$ Piacenza Pilgrim, Travels, 10-12.

${ }^{58}$ John Rufus, Life of St. Peter 116-118; Brouria Bitton-Ashkelony, “Imitatio Mosis and Pilgrimage in the Life of Peter the Iberian," in Christian Gaza, 111.

${ }^{59}$ For archaeological evidence, namely lamps, that indicates local pilgrimage to Jerusalem, see Jodi Magness, "Blessings from Jerusalem: Evidence for Early Christian Pilgrimage," Eretz-Israel 25 (1996): 37 45.

${ }^{60}$ Alliata, "Pilgrimage Routes," 123.

${ }^{61}$ Alliata, "Pilgrimage Routes," 123.

${ }^{62}$ Bitton-Ashkelony, "Encountering the Sacred," 189.
} 
Holy Land sites are sometimes recorded in inscriptions, like the Diblaton and Limbon mosaic panels at St. Stephen or a column capital labeled with Esbounta's toponym that was incorporated into the seventh-century basilica at Mt. Nebo. ${ }^{63}$ For lesser known sites east of the Jordan, and especially late-established monastic or stylite centers like Umm alRasas, there would have been a strong desire to reap the economic benefits of pilgrimage that sites like Mt. Nebo had enjoyed for centuries. Ecclesiastic buildings and their decoration helped lesser known sites proclaim their religious authority in a visually impressive manner. ${ }^{64}$

St. Stephen's south intercolumnar panels address this religious and economic imbalance by depicting six sites east of the Jordan River and visually attributing them equal status to the more established cities represented on the north side of the church (Map 3). The first motif that visitors encounter is Charach Moba (Figure 58), representing the southernmost illustrated portion of the Via Nova Traiana. The city is not mentioned in any known pilgrimage account, though it was a bishopric until at least the sixth century if not the ninth. ${ }^{65}$ The next motif depicts Areopolis (Figure 57), which is located about $15 \mathrm{~km}$ north of Charach Moba on the Via Nova Traiana. The city served as the capital of Palaestina Tertia and was also a Late Antique bishopric, but does not appear to have had any other religious significance.

Following the mosaic panels, viewers would continue their virtual journey to Belemounta (Ma'in, Figure 56). In reality, this requires traveling north, then veering west

\footnotetext{
${ }^{63}$ Werner Vyhmeister, "The History of Hesbon from Literary Sources," Andrews University Seminaries Studies 6 (1968): 169.

${ }^{64}$ Bitton-Ashkelony, "Encountering the Sacred," 187-189.

${ }^{65}$ Michel Lequien, Oriens christianus in quatuor patriarchatus digestus, v. 3 (Paris: no publisher, 1740), 729-734.Alexander Trieger, "Unpublished Texts from the Arab Orthodox Tradition (2): Miracles of St. Eustratius of Mar Saba (Written ca. 860)," Chronos 33 (2016): 10. Bishop Demetrios of al-Karak participated in the Council of Three Palaestina in 536. The Fourth Miracle of St. Eustratius recounts the story of two brothers, one of whom (John) became Bishop of al-Karak in the ninth century.
} 
off the Via Nova Traiana to reach the town, which was the last settlement before the famed hot springs. Peter the Iberian visited here in the fifth century on a trip that included Madaba and Mt. Nebo. ${ }^{66}$ The next depiction after Belemounta is Esbounta (Figure 55). Its placement on the mosaic is unusual in that it bypasses Madaba, which was the next city travelers would have encountered on the Via Nova Traiana. Egeria relates that when she visited Mt. Nebo, the priest pointed out Esbounta in the distance, but no other pilgrim account records any information about this site. ${ }^{67}$

To follow the route outlined on the St. Stephen mosaic, one would have to backtrack along the Via Nova Traiana to Madaba (Figure 54), the fifth city depicted on the south panels. Despite Madaba's proximity to the Memorial of Moses, the city is mentioned in few pilgrimage accounts, none of which discuss specific religious attractions. ${ }^{68}$ St. Stephen's patrons likely chose to display Madaba in the mosaic because it did not detract from their declaration of Kastron Mefa'a as an important pilgrimage site; an image of the famed Mt. Nebo would have overshadowed Umm al-Rasas' claims of regional authority.

The next city depicted in St. Stephen's mosaic is Philadelphia (Figure 53). In reality, this would require turning back north on the Via Nova Traiana or taking lesser roads east and north from Madaba (Map 3). In the sixth century, Theodosius included this city in his list of Arabian cities and by the time of St. Stephen's decoration in the eighth century, Philadelphia contained an Umayyad palace. ${ }^{69}$ The tenth-century Arab

\footnotetext{
${ }^{66}$ John Rufus, Life of St. Peter, 116-117. Josephus, Antiquites, XVII. 169-176. Peter suffered from a gastrointestinal illness, for which he sought a cure. Josephus describes the waters at the Baaru hot springs as "sweet-tasting," and indicates that cures were achieve by drinking the water as well as bathing in it.

${ }^{67}$ Egeria, Travels, 12.8 .

${ }^{68}$ Theodosius, Topography, Itinerary 24; John Rufus, Life of St. Peter, 90, 116-118.

69 Theodosius, Topography, Itinerary 24; Antonio Almagro Gorbea, "The Restoration of the Umayyad Monumental Constructions on the Amman Citadel (1979-1981),” ADAJ 26 (1982): 277-282.
} 
geographer al-Muqaddasi notes that Muslim pilgrims visited the Tomb of Uriah there, but there seems to have been no Christian monuments important enough to warrant a description from Late Antique pilgrims. ${ }^{70}$

The final destination in St. Stephen's virtual pilgrimage is Kastron Mefa'a (Figure 52). Pilgrims would have to backtrack south from Philadelphia along the same lesser road that they came north on from Madaba in order to recreate the complicated path portrayed in linear fashion on the mosaic. This arrangement places Kastron Mefa'a in the easternmost portion of the nave, across from Jerusalem, which gives it visual parity with the Holy City, but Kastron Mefa'a occupies a double panel, making it twice the size of Jerusalem. This hierarchy of scale lends an additional air of authority to the monastic pilgrimage site, as do the palm or olive branches depicted next to the toponym of Kastron Mefa'a and the other southern motifs. As with the north panels, the south side depicts a de facto pilgrimage route, laid out in an indirect fashion, resembling pilgrim itineraries without replicating any known account directly. It is unlikely that the patrons were unaware of the order in which the depicted cities appeared along the Via Nova Traiana given their proximity to Umm al-Rasas; the placement of Esbounta and Madaba could be a mistake or perhaps it references a route along a lesser road, for which no record has survived.

The cities chosen for St. Stephen's south panels were large and well-known in the Late Antique period, comparable to those shown on the north side of the church. All but Belemounta and Kastron Mefa'a were Late Antique bishoprics; these two, however, were the only locations depicted on the south side that were known pilgrimage sites. The patrons deliberately avoided the more prestigious pilgrimage sites, like Mt. Nebo and

\footnotetext{
${ }^{70}$ Wilkinson, Jerusalem Pilgrims, 338; al-Muqaddasi, Ahsānu-t-tāqasìm fì Ma'rifati-l-āqalīm, 244.
} 
Livias so as to not detract from the mosaic's message of Umm al-Rasas' spiritual preeminence. Belemounta provided less of a challenge for the patrons; while the site benefitted from its proximity to the curative Baaru hotsprings, it was not a pilgrimage site and presented no threat to Umm al-Rasas' claims of religious authority.

The motifs included on the Ma'in mosaic those found at St. Stephen and also suggest a pilgrimage route (Plan 13, Figures $74-84) .{ }^{71}$ Of the eleven extant cities depicted on Ma'in's border, eight are also found on the St. Stephen pavement. There are many areas of loss on the Ma'in mosaic, but based on the size of both the extant motifs and the border, there is enough space on this part of the mosaic for the inclusion of an additional eleven cities. Twenty-two topographic motifs would provide an even more elaborate depiction of travel route(s) than St. Stephen did. In addition to the shared topographic illustrations, the strategic placement of the host city's motif at both Umm al-Rasas (Kastron Mefa'a) and $\mathrm{Ma}^{\prime}$ in (Belemounta) visually elevated their authority in relation to the other depicted sites.

Unlike St. Stephen, Ma'in's topographic motifs are presented around the border, creating one inclusive route that incorporates sites both east and west of the Jordan River (Map 5). The Ma'in mosaic elaborates on the depiction of sites along the Mediterranean coast with the inclusion of Maiumas, the port city of Gaza (Figure 78). Several pilgrims traveled through here, including Paula, who took a boat from Peluseion to Maiumas on her way to Bethlehem. ${ }^{72}$ The Piacenza Pilgrim describes several religious attractions for pilgrims close the city. ${ }^{73}$

\footnotetext{
${ }^{71}$ Ma'in and St. Stephen both have depictions of Aereopolis, Askalon, Belemounta, Charach Moba, Eleutheropolis, Esbounta, and Gaza.

${ }_{72}$ Jerome, Letter, 14.3.

${ }^{73}$ Theodosius, Topography, Itinerary 3; Piacenza Pilgrim, Travels, 33.
} 
More importantly, the Ma'in mosaic includes Odroa (Figure 80), geographically connecting the sites west of the Dead Sea to those in the east via the Petra-Gaza road, which was originally established by the Nabateans in order to facilitate maritime trade. ${ }^{74}$ To the north of the Dead Sea, the patrons added a motif of Nikopolis (Figure 74), a site visited by early pilgrims, suggesting that the areas of loss following this motif would have included cities on the route to Jerusalem, thus also linking the east and western routes to the North of the Dead Sea. ${ }^{75}$

Unlike the patrons of St. Stephen, who wished to express the supremacy of their (relatively) new pilgrimage center over even the most holy Jerusaelm, the patrons at the long-established pilgrimage stop at $\mathrm{Ma}^{\text {' }}$ in were content to display their city as an integral part of Late Antique pilgrimage networks. Belemounta (Ma'in) was the last major settlement close to Baaru, thermal mineral springs that are still well-known for their restorative properties. ${ }^{76}$ As with the St. Stephen mosaic, the majority of the sites depicted at Ma'in were Late Antique bishoprics. Belemounta and Umm al-Rasas were not, however, and instead drew their religious importance from their identifications as pilgrimage sites.

In the Ma'in church, the depiction of Belemounta appears about halfway along the north side of the mosaic border, and perhaps marked the entrance to a side chapel used to house a reliquary (Plan 13). It is possible that the Belemounta motif was placed across from a depiction of Jerusalem, visually suggesting equal status to the Holy City; however, this is pure conjecture given the fragmentary nature of the mosaic border.

\footnotetext{
${ }^{74}$ Rudolph Cohen, "New Light on the Date of the Petra-Gaza Road," The Biblical Archaeologist 45, no. 4 (Autumn 1982): 242.

${ }^{75}$ Theodosius, Letter, 8.2; Theodosius, Topography, Itinerary 4.

${ }^{76}$ See above, Chapter 3, p. 132.
} 
The Madaba mosaic also has a composition that reflects actual geography. At first glance, it appears to have little in common with the topographic pavements at St. Stephen and Ma'in, yet the patron(s) of this mosaic also selected specific cities to include in the composition. Amongst the 151 extant sites, ten are depicted as walled city motifs (Figure 17). Four of these cities are repeated at St. Stephen and Ma'in: Askalon, Gaza, and Eleutheropolis to the west of the Dead Sea (Figures 23, 25-26), and Charach Moba to the east (Figure 18). Like St. Stephen, the Madaba mosaic highlights Diospolis, Neapolis, and Jerusalem (Figures 19-21), as well as the Egyptian port Peluseion (Figure 27). In addition, the Madaba mosaic includes Azotos Paralos, a Late Antique bishopric and Iamnia, a smaller port town located north of Askelon, as walled cities (Figures 22, 24). ${ }^{77}$ Why was Iamnia depicted in this manner? It was not sizeable in either area or population, and did not hold any great political or religious significance in the Late Antique period. The answer might lie in Iamnia's geographic location along the Mediterranean coast.

One aspect of the Madaba mosaic's composition that has been confusing for scholars is the lack of depicted roads; this has both challenged its identification as a map in the modern sense and complicated comparisons to the Peutinger Table. ${ }^{78}$ There is simply no room for roads amongst the verbose text that adorns the pavement. Instead, the artist represents the region's major north-south roads though the depiction of certain cities (Map 6). Peluseion, Gaza, Askalon, Iamnia, and Azotos Paralos mark the Via Maris. Diospolis and Neapolis represent the secondary, inland north-south highway.

\footnotetext{
${ }^{77}$ Wilkinson, Jerusalem Pilgrims, 283, 311. Wilkinson discusses the relatively small size of Iamnia, suggesting that it should be considered a town and not a city.

${ }^{78}$ Weber, "Tabula Peutingeriana," 43; Israel Roll, "The Roads in Roman-Byzantine Palaestina and Arabia," in Madaba Map Centenary, 112. Roll identifies only one road on the Madaba mosaic- that leading from Jerusalem's Damascus Gate.
} 
Finally, Charach Moba denotes the Via Nova Traiana. ${ }^{79}$ The eastern portion of the mosaic is extremely fragmentary but it originally would have depicted many of the cities illustrated on the St. Stephen and Ma'in pavements, including Madaba. Thus walled cities are used in the Madaba mosaic as part of the pavement's semiotic system to denote the major trade and pilgrimage routes in the region, further emphasizing the importance of both the natural resources and religious sites represented on the pavement.

The mosaic's areas of loss are greatest closer to the church's sanctuary and Alliata notes that only $10 \%$ of the toponyms appear in the sparsely populated eastern half of the mosaic. He compares this to the sites included in Eusebius' Onomasticon and determines that, despite the low percentage on sites depicted the pavement, this number is considerably higher than Eusebius' references. The Late Antique author is generally accepted as a major source for the Madaba mosaic's composition; Alliata's statistics suggest that the patron(s) and/or artist used their local personal knowledge of local sites to generate this section of the map, attributing greater importance to these cities than the early Christian sources did. In addition to the number of sites, Madaba and the surrounding area were emphasized using techniques similar to those utilized at St. Stephen: the hierarchy of scale of the Dead Sea, the inclusion of selected motifs to distinguish certain sites (agricultural crops in the Madaba mosaic and the palm branches accompanying toponyms at St. Stephen), and the strategic placement of Madaba in relation to Jerusalem and its axial alignment with the altar.

\footnotetext{
79 Susan Weingarten, "Road Use in Late Antique Palestine," BAR International Series 1084, no. 1 (2002): 243-258.
} 


\section{Conclusions}

In Late Antique Jordan, topographic images were frequently combined with agricultural iconography that was traditionally used to denote wealth and status in domestic settings. Fully aware of these connotations, donors manipulated the ecclesiastic compositions so that they could be read simultaneously as validations of the bounty provided by God and as demonstrations of the patron's wealth and status. The inclusion of topographic imagery and indigenous resources localized this affluence within the purview of the mosaic's patrons and their communities.

Donors not only included depictions of generic Egyptian plant life, which carried generalized messages of prosperity, but also species specific to Late Antique Palaestina and Arabia. The inclusion of fruit trees, date palms, and balsam plants, as well as resources like salt, bitumen, and fish referenced the economic prosperity that this region enjoyed in the sixth to the eighth centuries. This agro-economic success is attested by both the archaeological and textual records; however, the continued assertion that ecclesiastic pavements conveyed only religious or philosophical messages has hampered investigations of Late Antique mosaic iconography, especially the topographic motifs, in these broader cultural contexts.

Comparisons to pavements found throughout the Mediterranean suggest that the Jordanian topographic pavements were not a local workshop tradition but part of a wellestablished visual communication system. Many of these agrarian-themed statements of status originated in North Africa, and it is possible that their meaning was transported east with migrant mosaicists who moved during periods of political unrest in the fifth 
century. It is also possible that patrons were influenced by artistic traditions in nearby Israel and Syria, where several mosaics bearing similar imagery have been found.

While Michele Piccirillo's Mosaics of Jordan has been an invaluable resource in the examination of topographic pavements, its singular focus has led some scholars to assume that Late Antique architectonic mosaics were exclusive to Palaestina and Arabia. In truth, these were equally popular in other parts of the Mediterranean, especially in Syria, where patrons used the topographic motifs in elaborate compositions to direct movement through domestic and ecclesiastic buildings. In Jordan, a key use of topographic motifs was to define the specific purpose of the church in which the mosaic was located and there is a distinct correlation between route-like compositions and buildings connected to pilgrimage.

In certain cases, a series of topographic motifs was incorporated into the building's decoration to encourage movement, mimicking the procession toward the altar during the liturgy, as well as the route that viewers had taken to arrive at the church's city. Donors used these larger combinations of architectonic motifs at sites either directly related to pilgrimage, like Ma'in and Umm al-Rasas, or indirectly related, like Madaba. Patrons selected specific architectonic motifs and placed them strategically within the hierarchical space of the church to proclaim their city's spiritual authority in the Christian world. At St. Stephen, Madaba, and possibly Ma'in, this placement exaggerates the socio-religious importance of the host city through positive comparisons with Jerusalem. 


\section{CONCLUSION}

The period between the sixth and the eighth centuries witnessed the construction of an impressive number of churches in Palaestina and Arabia. One of the reasons for the surge in ecclesiastic building was the variety of roles that churches played in their community. They were used as mortuaries for important members of society, as sites of pilgrimage, and as depositories of saints' relics; even the smallest towns required several ecclesiastic buildings. Donors often customized the mosaic compositions to illustrate a church's function, and topographic motifs served as important tools in doing so. These images also provided patrons with opportunities to demonstrate their status, and the status of their communities, in a public forum.

Contributing funds for the building and decoration of churches was a highly ritualized form of gift-exchange developed from the Greco-Roman practice of euergetism. In exchange for their donations, civic patrons earned the right to publically memorialize their contributions through portraits and inscriptions. Until the fifth century, these were presented in the form of honorific statues placed in public forums. The practice was internalized under Christianity, when church interiors became the community's main public space and tributes were absorbed into the building's decoration. These reified accolades inhabited privileged locations within the church's 
highly stratified space, where they announced the donor's importance to the community and perpetually communicated with the divine on behalf of the patron.

This concept of celestial interaction within ecclesiastic space is indicative of Late Antique Neo-Platonist philosophy, which informed both the creation and interpretation of art. An elite patron's rhetorically-based education was grounded in these ideologies, providing donors with a concept of visualizing art that is very different from what we presently experience. For this reason it is imperative, whenever possible, to examine the topographic pavements within their original architectural and social contexts when considering possible interpretations.

Michele Piccirillo presents the topographic imagery as a phenomenon unique to Jordan and inherently tied to Nilotic iconography. Previous scholarship has been greatly influenced by these assumptions and the belief that ecclesiastic pavements were created solely to convey religious messages. While certain mosaics, like that from Umm alManabi‘, belong to the Nilotic genre and express Christianized messages of prosperity, the majority of the pavements examined in this study are disassociated from this iconographic tradition and should be considered as a distinct category.

Numerous examples of Late Antique topographic mosaics have been discovered in Israel, Syria, and the west, and comparisons between these pavements and the Jordanian corpus provide new avenues for the latter's interpretation. Topographic motifs were widely used in ecclesiastic and domestic contexts. In the third century, combinations of architectonic motifs with scenes of hunting and vintaging were popularized in North Africa as illustrations of a patron's wealth and status. During the fifth century, this imagery moved eastward; this date corresponds with the Vandal 
invasions of Africa, and migrant artisans fleeing political unrest might have contributed to the transmission of architectonic motifs and their underlying symbolism.

In some cases, patrons of the topographic mosaics drew from well-established iconography in the Christian semiotic system; for example, the pairing of Jerusalem and Bethlehem was used in both the east and west as apocalyptic/salvific imagery. At Khirbat al-Samra, depictions of the two cities are incorporated with other typical funerary motifs in a mosaic that commemorates the individual buried at the Church of St. John. Similarly, the various mosaics in the Church of the Priest Wa'il at Umm al-Rasas contain depictions of the translation of relics, the apocalyptic cities, and the biblical story of Jonah and the Whale. Combined, these motifs create a message of personal salvation that is appropriate for the church, where the faithful believed the saint whose relics occupied the space could intercede on their behalf. A depiction of Kastron Mefa'a (Umm al-Rasas) inserted between Jerusalem and Bethlehem emphasized the city's role in the salvation of its visitors.

By the eighth century, Umm al-Rasas had become an important Christian center and boasted several monasteries, pilgrimage churches, and possibly a stylite complex. Topographic mosaics in two of the churches at this site reinforce the city's identity as a pilgrimage center. In both the Church of the Lions and St. Stephen, the images in the border mosaics mimic religious travel while encouraging the viewer's movement within the space. In the Church of the Lions, a series of active patron portraits ring the nave, mimicking the congregation's movement toward the altar during the liturgy, as well as the visitor's journey to Umm al-Rasas. 
St. Stephen's intercolumnar panels and their depiction of a series of cities serve a similar function. Arranged into two rows flanking the nave, the mosaics encourage movement toward the altar and recreate two routes, one to the east and one to the west of the Jordan River. The placement of the mosaic and the inclusion of certain imagery visually positioned the burgeoning pilgrimage site of Umm al-Rasas in equal standing with Jerusalem.

The Church of the Acropolis at Ma'in, a city connected to a known Late Antique pilgrimage site, contains a mosaic composition similar to St. Stephen's. The fragmentary nature of Ma'in's architectonic motifs presents a challenge in identifying the depicted route, but the original composition can be surmised using the St. Stephen pavement, known roadways, and pilgrim itineraria. Unlike the St. Stephen's mosaic, Ma'in's architectonic motifs form a continuous border around the nave. The inclusion of the city's depiction promoted $\mathrm{Ma}^{\text {'in }}$ as an integral part of the Holy Land pilgrimage trade; the arrangement of architectonic motifs may have also displayed Ma'in in visual alignment with Jerusalem, providing a message of parity similar to that utilized in St. Stephen.

While the topographic mosaic from St. John the Baptist also serve to guide people through the church, its message is less clear because the mosaic's fragmentary condition hampers an interpretation. The Nilotic landscape situates the depicted cities in Egypt, though only one is labeled. Nilotic motifs carried general messages of prosperity but this mosaic also depicts a servant leading a pack animal, and thus bears similarity to donor portraits in Syria that emphasize the patron's source of income. This image, combined with those of a pilgrim shrine and balsam trees, leads one to read this composition as a representation of the donor's involvement with Egypt, either through trade or pilgrimage, 
or both, but the mosaic is too fragmentary to be certain. The St. John the Baptist mosaic includes highly detailed depictions of local flora in otherwise highly stylized compositions, a trait that is specific to Late Antique Jordan. Patrons took great care to ensure that these motifs would be recognized, as they reflected the reasons for the economic success of their communities.

Representations of natural resources appear on many of the topographic pavements, including the Madaba mosaic. Fruit trees, date palms, balsam, salt, fish, and bitumen were integral to the economic success of Late Antique Palaestina and Arabia, and these images are ambiguous enough to invite polyvalent interpretations. Patrons incorporated depictions of these resources to reflect both the bounty that God provided for the faithful and the realistic economic situation that allowed donors to contribute to ecclesiastic building projects. On the surface, the combination of agricultural and topographic motifs represents the inhabited earth, mirroring Christian philosophies that conceptualized the division of ecclesiastic space between the terrestrial and heavenly realms. However, topographic pavements also provided patrons with a forum for promoting their status, or their communities,' through the visual program of the mosaic and its physical placement within the church.

The examples of topographic imagery presented in this dissertation suggest that topographic motifs were, to some extent, codified in the Late Antique visual messaging system so that they could be used to identify the specific purpose of various types of ecclesiastic buildings while retaining enough flexibility to be customized as personal and communal expressions of status and authority. This study also reintroduces the patron into the discussion of Late Antique iconography, determining the active role that lay 
people played in the commissioning of ecclesiastic pavements and their reasons for doing SO. 


\section{REFERENCES}

Primary Sources:

Billerbeck, Margarethe, ed. Stephen of Byzantium: Stephani Byzantii Ethnica. New York: Walter de Gruyter, 2006.

Cindle, J.W.M., trans. Cosmas Indicopleustes: The Christian Topography. London: Hakluyt Society, 1897.

de Stefani, C., ed. Paul the Silentiary: Paulus Silentiarius Descriptio Sanctae Sophiae. Berlin: De Gruyter, 2011.

Dewing, H.B., and Glanville Downey, trans. Procopius: De Aedificis. Cambridge: Loeb, Harvard University Press, 1940.

Festugière, A.J., trans. Saint Thècle, saints Côme et Damine, saints Cyr et Jean (extraits), saint Georges. Paris: A. and J. Picard, 1971.

Foerster, Richard, ed. Choricius: Choricii Gazaei Opera. Stutgartt: Teubner, 1972.

Freeman-Grenville, G.S.P., trans. Palestine in the Fourth Century A.D.: The Onomasticon by Eusebius of Caesarea. Jerusalem: Carta, 2003.

Gascou, Jean, trans. Sophronius: Miracles des saints Jean et Cyr. Paris: De Boccard, 2006.

Gelzer, Henrich, ed. Georgius of Cyprus: Descriptio Orbis Romani. Leipzig: B.G. Teubner, 1890.

Giacchero, Maria, ed. Diocletian: Edictum Diocletiani et collegarum de pretiis rerum venalium. Genoa: Insituto di Storia Antica e Scienze, 1976.

Gildemeister, J., ed. Theodosius: De Situ Terrae Sanctae. Bonn: Adolph Marcus, 1882.

Horn, Cornelia, and Robert Phenix, trans. The Lives of Peter the Iberian, Theodosius of Jerusalem, and the Monk Romanus. Atlanta: Society of Biblical Literature, 2008. 
Klingshirn, William C., trans. Cyprian: Caesarius of Arles; Life, Testament, Letters. Liverpool: Liverpool University Press, 1994.

Macauly, G.C., trans. Herodotus: The History v. 1. London: MacMillan and Co., 1890.

MacPherson, James Rose, trans. Adamnan: The Pilgrimage of Arculfus in the Holy Land: About the Year A.D. 670. London: Palestine Pilgrims' Text Society, 1889.

Marcus, Ralph and Allen Wilkgren. Josephus: Antiquities v. 7 (Books 16-17). Cambridge: Loeb, Harvard University Press, 1963.

Price, Richard, and Michael Gaddis, trans. The Acts of the Council of Chalcedon. Liverpool: University of Liverpool Press, 2005.

Rackman, H. Pliny: Natural History (Books 12-16) v. 4. Cambridge: Loeb, Harvard University Press, 1945.

—. Pliny: Natural History (Books 17-19) v. 5. Cambridge: Loeb, Harvard University Press, 1950.

Ranking, G.S.A., and R.Z. Azou, trans. Al-Muqaddasi: Ahsānu-t-tāqasīm fì Ma'rifati-lāqalìm. Calcutta: Asiatic Society: 1897.

Rorem, Paul, trans. Pseudo-Dionysios: The Complete Works. London: SPCK, 1987.

Schroeder, H.J., trans. Disciplinary Decrees of the General Councils. St. Louis: B. Herder, 1937.

Stewart, Aubrey, trans. Anonymous Pilgrim of Bordeaux: Itinerary from Bordeaux to Jerusalem. London: Palestine Pilgrims' Text Society, 1887.

-Anonymous Pilgrim of Piacenza: Of the Holy Places Visited. London: Palestine Pilgrims' Text Society, 1887.

Whiston, William, trans. The New Complete Works of Josephus. Grand Rapids, MI: Kregel Publications, 1999.

Wilkinson, John, trans. Egeria: Egeria's Travels. Warminster: Aris \& Phillips, 2002.

Williams, Frank, trans. Epiphanius of Salamis: The Panarion, Book I. Leiden: Brill, 2009 
Secondary Sources:

Abela, J., and A. Acconci. "Umm al-Rasas Kastron Mefa'a: Excavation Campaign 1997; Church of St. Paul: Northern and Southern Flanks." Liber Annuus 47 (1997): 484488.

Abudanah, Fawzi. "Agriculture in Sixth-century Petra and its Hinterland: Evidence from the Petra Papyri." Arabian Archaeology and Epigraphy 23 (2012): 105-115.

Agosti, Gianfranco. "Late Antique Iambics and Iambikè Idéa." In Iambic Ideas: Essays on a Poetic Tradition from Archaic Greece to the Late Roman Empire, edited by Alberto Cavarzere, Antonio Aloni, and Alessandro Barchiesi, 219-255. New York: Rowman \& Littlefield, 2001.

_. "The $\pi$ ¿ $\chi 1 \lambda 1 \alpha$ of Paul the Bishop." ZPE 116 (1997): 31-38.

Albu, Emily. "Imperial Geography and the Peutinger Map." Imago Mundi 57, no. 2 (2005): 134-148.

Alexander, Philip S. "Jerusalem as the Omphalos of the World: On the History of a Geographical Concept." In Jerusalem: Its Sanctity and Centrality to Judaism, Christianity, and Islam, edited by Lee Levine, 104-119. New York: Continuum, 1999.

Alliata, Eugenio. "The Legends of the Madaba Map." In The Madaba Map Centenary, 1897-1997: Travelling through the Byzantine Umayyad Period; Proceedings of the International Conference held in Amman, 7-9 April 1997, edited by Michele Piccirillo and Eugenio Alliata, 47-102. Jerusalem: Studium Biblicum Franciscanum, 1999.

. "The Pilgrimage Routes during the Byzantine Period in Transjordan." In The Madaba Map Centenary, 1897-1997: Travelling through the Byzantine Umayyad Period; Proceedings of the International Conference held in Amman, 7-9 April 1997, edited by Michele Piccirillo and Eugenio Alliata, 121-124. Jerusalem: Studium Biblicum Franciscanum, 1999.

Almagro Gorbea, Antonio. "The Restoration of the Umayyad Monumental Constructions on the Amman Citadel (1979-1981).” ADAJ 26 (1982): 277-282.

Amar, Zohar, and Omit Shamir. "Egyptian Balsam and its Use in the Jordan Rift Region." Judea and Samaria Research Studies 22 (2013): 369-376.

Amiran, David H. K. "The Madaba Map as a Climate Indicator for the Sixth Century." IEJ 47, no. 1/2 (1997): 97-99. 
Anderson, William. "An Archaeology of Late Antique Pilgrim Flasks." AnatSt 54 (December 2004): 79-93.

Ashbrook, Harvey Susan. Scenting Salvation: Ancient Christianity and the Olfactory Imagination. Berkeley, University of California Press, 2006.

Arjava, A., M. Buchholz, and T. Gagos, eds. The Petra Papyri v. 3. Amman: American Center for Oriental Research, 2007.

. The Petra Papyri v. 4. Amman: American Center for Oriental Research, 2011.

Augustinović, Agostino, and Bellarmino Bagatti. "Escursioni nei dintorni di "Aglun." Liber Annuus 2 (1952): 227-341.

Avi-Yonah, Michael. Art in Ancient Palestine: Selected Studies. Jerusalem: Magnes Press, 1981

—. "The Economics of Byzantine Palestine," IEJ 8 (1958): 39-51.

—_. "The Haditha Mosaic Pavement.” IEJ 22, no. 2/3 (1972): 118-121.

- The Madaba Mosaic Map with Introduction and Commentary. Jerusalem: Israel Exploration Society, 1954.

—. "Mosaic Pavements in Palestine." QDAP 3 (1933): 136-181.

Avner, Rina. "The Account of Caesarea by the Piacenza Pilgrim and the Recent Archaeological Discovery of the Octagonal Church in Caesarea Maritima." PEQ 140, no. 3 (2008): 203-212.

Bacher, W. "Zur Mosaikkarte von Madaba.” JQR, 13, no. 2 (January 1901): 322-323.

Balderstone, Susan. Early Church Architectural Forms: A Theologically Contextual Typology for the Eastern Churches of the $4^{\text {th }}-6^{\text {th }}$ Centuries. Melbourne: Australian Institute of Archaeology, 2007.

Balmelle, Catherine. Le décor géométrique de la mosaïque romaine: Repertoire graphique et descriptive des compositions linéaires et isotropes. Paris: Picard, 1985.

Balty, Janine. La grande mosä̈que de chasse du triclinos. Brussels: Belgian Center of Archaeological Research in Apamea, Syria, 1969.

- Mosaïques antiques du Proche-Orient: Chronologie, iconographie, interpretation. Paris: Les Belles Lettres, 1995. 
."Thèmes nilotiques dans la mosaïque tardive du Proche-Orient." In Alessandria e il mondo ellenistico: Studi in onore di Achille Adriani, edited by Nicola Bonacasa et al, 827-834. Rome: L'Erma di Bretschnider, 1984.

Bar, Doran. "Population, Settlement, and Economy of Late Ancient Palestine (70-641)." BASOR 67, no. 3 (2004): 307-320.

Barash, Moshe. Icon: Studies in the History of an Idea. New York: New York University Press, 1992.

Baratte, Fr. and C. Metzger. Musée du Louvre: Catalogue de sarcophages en pierre d'époques romaine et paléochrétienne. 312-316. Paris: Louvre, 1985.

Barnes, T.D. "Latin Epigraphy and the History of the Western Roman Empire after Constantine." In XI congresso internazionale di epigrafia Greca e Latina, 18-24 settembre 1997 v. 2, 565-576. Rome: Edizioni Quasar, 1999.

Barry, Fabio. "Walking on Water: Cosmic Floors in Antiquity and the Middle Ages." ArtB 89, no. 4 (December 2007): 627-656.

Baumann, Peter. Spätantike Stifter im Heiligen Land. Darstelungen und Inscriften auf Bodenmosiaiken in Kirchen, Syanagoen und Privathäusern. Wiesbaden: Reichert Verlag, 1999.

Bassett, Sarah E. "Style and Meaning in the Imperial Panels at San Vitale." Artibus et Historiae 29 no. 57 (2008): 49-57.

Beazley, Charles Raymond. The Dawn of Modern Geography: A History of Exploration and Modern and Geographical Science v. 2. London: John Murray, 1901.

__. "Madaba Map.” The Geographical Journal 17, no. 5 (1901): 516-520.

Bejaoui, Fathi. "Cyprus and Cities of the Mediterranean on a Mosaic from Haïdra in Tunisia." Mosaic. Recent Discoveries, New Research. University of Cyprus Department of History and Archaeology. Accessed February 25, 2016. https://www.ucy.ac.cy/hisarch/en/news-events/conferences/26-en-articles/enbottomm/news-events/88-mosaics-recent-discoveries-new-research.

Belayche, N. "Pagan Festivals in Fourth-Century Gaza." In Christianity in Gaza in Late Antiquity, edited by Brouria Bitton-Ashkelony and Aryeh Kofsky, 5-22. Leiden: Brill, 2004.

Ben Abed, Aïcha. Tunisian Mosaics: Treasures from Roman Africa. Los Angeles: Getty Conservation Institute, 2006. 
Bergmann, Bettina. "The Roman House as Memory Theater: The House of the Tragic Poet in Pompeii." ArtB 76, no. 2 (1994): 225-256.

Beschaouch, Azzedine. “À propos de la mosaïque de Smirat.” Africa Romana 4 (1987): 677-680.

Biebel, Franklin M. "The Mosaics." In Gerasa: City of the Decapolis, edited by Carl Hermann Kraeling, 297-354. New Haven, CT: Yale University Press, 1936.

Birk, Stine, and Birte Poulsen, eds. Patrons and Viewers in Late Antiquity Aarhus: Aarhus University Press, 2012.

Birk, Stine, Troels Myrup Kristensen, and Birte Poulsen, eds. Using Images in Late Antiquity. Oxford: Oxbow Books, 2014.

Bitton-Ashkelony, Brouria. Encountering the Sacred: The Debate on Christian Pilgrimage in Late Antiquity. Berkeley: University of California Press, 2005.

_. "Imitio Mosis and Pilgrimage in the Life of Peter the Iberian." In Christianity in Gaza in Late Antiquity, edited by Brouria Bitton-Ashkelony and Aryeh Kofsky, 107-130. Leiden: Brill, 2004.

."Territory, Anti-Intellectual Attitude, and Identity Formation in Late Antique Palestinian Monastic Communities," Religion and Theology 17, no. 3-4 (2010): 244-267.

Bitton-Ashkelony, Brouria, and Aryeh Kofsky. Christianity in Gaza in Late Antiquity, Leiden: Brill, 2004.

Bolman, Elizabeth. Monastic Visions: Wall Paintings in the Monastery of St. Antony at the Red Sea. New Haven, CT: Yale University Press, 2002.

Borg, Barbara E. "Bilder für die Ewigkeit oder glanzvoller Auftritt?.” In Statuen in der Spätantike, edited by Franz Alto Bauer and Christian Witschel, 43-69. Wiesbaden: Reichert Verlag, 2007.

Bouchard, Charlène, Christiane Jacquat, and Danièle Martinoli. "Landscape Use and Fruit Cultivation in Petra (Jordan) from Early Nabatean to Byzantine Times ( $2^{\text {nd }}$ Century BC- $5^{\text {th }}$ Century AD)," Vegetation History and Archaeobotany (2016): 122. Accessed August 2, 2016. doi: 10.1007/s00334-016-0582-y.

Bowersock, Glen. Mosaics as History: The Near East from Late Antiquity to Islam. Cambridge, MA: Belknap Press of Harvard University Press, 2006. 
Bowersock, Glen, Peter Brown, and Oleg Grabar. Introduction to Interpreting Late Antiquity: Essays on the Postclassical World, edited by Glen Bowersock, Peter Brown, and Oleg Grabar, vii-xiii. Cambridge, MA: Belknap Press of Harvard University Press, 2001.

Bowman, Alan K., and Greg Woolf. "Literacy and Power in the Ancient World." In Literacy and Power in the Ancient World, edited by Alan K. Bowman and Greg Woolf, 1-16. Cambridge: Cambridge University Press, 1994.

Bowsher, Julian. “Civic Organization of the Decapolis.” ARAM 4 (1992): 265-281.

Branham, Joan R. "Mapping Sacrifice on Bodies and Spaces in Late-Antique Judaism and Early Christianity." In Architecture of the Sacred: Space, Ritual, and Experience from Classical Greece to Byzantium, edited by Bonna D. Wescoat and Robert G. Ousterhout, 201-230. Cambridge: Cambridge University Press, 2012.

Breschi, Maria Grazie. La cattedrale ed il battistero degli ariani a Ravenna. Ravenna: Edizione "Dante" di A. Longo, 1965.

Brown, Peter. Through the Eye of the Needle: Wealth, the Fall of Rome, and the Making of Christianity in the West, 350-550 AD. Princeton, NJ: Princeton University Press, 2012.

Bryson, Norman, Michael Ann Holly, and Keith Moxey. Introduction to Visual Culture: Images \& Interpretations, edited by Norman Bryson, Michael Ann Holly, and Keith Moxey, xv-xxii. Hanover, NH: University Press of New England for Wesleyan, 1994.

Bugbee, Lucius H. "The Mosaic Map of Medeba: A Contribution to the Topography of Ancient Palestine." MA thesis, University of Chicago, 1901.

Burke, Peter. Eyewitnessing: The Use of Images as Historical Evidence. Ithaca, NY: Cornell University Press, 2001.

Caillet, Jean-Pierre. "Les dédicaces privées de pavements de mosaïque à la fin de l'Antiquité: Occident européan et monde grec; données socio-économiques." In Artistes, artisans et production artistique au Moyen Age: Centre National de la Recherche Scientifique, Université de Rennes II-Haute-Bretagne, 2-6 mai $1983 \mathrm{v}$. 2, edited by Xavier Barral i Altet, 15-38. Paris: Picard, 1987.

Campbell, Sheila. The Mosaics of Antioch. Toronto: Pontifical Institute of Mediaeval Studies, 1988. 
Campanati, Raffaella Farioli. "Jerusalem and Bethlehem in the Iconography of Church Sanctuary Mosaics." In The Madaba Map Centenary, 1897-1997: Travelling through the Byzantine Umayyad Period; Proceedings of the International Conference held in Amman, 7-9 April 1997, edited by Michele Piccirillo and Eugenio Alliata, 173-177. Jerusalem: Studium Biblicum Franciscanum, 1999.

Caner, Daniel. "Towards a Miraculous Economy: Christian Gifts and 'Material Blessings' in Late Antiquity." Journal of Early Christian Studies 14, no. 3 (Fall 2006): 329-377.

Cassis, Marica. "Mensa, Thysiasterion, and Madebha: The Evolution of the Permanent Altar in the Early Christian Church." PhD diss., University of Toronto, 2006.

Casson, Lionel. "Speed under Sail of Ancient Ships.” TAPA 82 (1951): 136-141.

Cavinet, P. and M.T. Sanctuaire chrétien d'Apemène. Paris: Librairie Orientaliste Paul Geuthner, 1987.

Chester, Andrew. "The Relevance of Jewish Inscriptions for New Testament Ethics." In Early Christian Ethics in Interaction with Jewish and Greco-Roman Contexts, edited by Jan Willem, 107-145. Leiden: Brill, 2013.

Chippendale, Christopher. “'Social Archaeology' in the Nineteenth Century: Is it Right to Look for Modern Ideas in Old Places?.” In Tracing Archaeology's Past: The Historiography of Archaeology, edited by Andrew Christenson, 21-33. Carbondale, IL: Southern Illinois University Press, 1989.

Clark, David Chatford. "Viewing the Liturgy: A Space Syntax Study of Changing Visibility and Accessibility in the Development of the Byzantine Church in Jordan.” World Archaeology 39, no. 1 (March 2007): 84-104.

Clark, Timothy J. Image of the People: Gustave Courbet and the Second French Republic 1848-1851. Greenwich, CT: New York Graphic Society, Ltd., 1973.

Cleary, A. Simon Esmonde. The Roman West, AD 200-500: An Archaeological Study. Cambridge: Cambridge University Press, 2013.

Clermont-Ganneau, Charles. "The Land of Promise, Mapped in Mosaic in Madaba." PEFQ (1901): 235-246.

Cochran, Daniel. "Projecting Power in Sixth-Century Rome: The Church of Saint Cosma e Damiano in the Late Antique Forum Romanum." Journal of History and Cultures 3 (2013): 1-32.

Cohen, Rudolph. "New Light on the Date of the Petra-Gaza Road." The Biblical Archaeologist 45, no. 4 (Autumn 1982): 240-247. 
Connan, Jacques, and Thomas Van de Velde. "An Overview of the Bitumen Trade in the Near East from the Neolithic (c. 8000) to the Early Islamic Period." Arabian Archaeology and Epigraphy 21 (2010): 1-19.

Cribiore, Rafaella. The School of Libanius in Late Antique Antioch. Princeton, NJ: Princeton University Press, 2016.

Crowfoot, John Winter. "The Christian Churches." In Gerasa: City of the Decapolis, edited by Carl Hermann Kraeling, 171-264. New Haven, CT: American School of Oriental Research, 1938.

- The Churches at Bosra and Samaria-Sebaste. London: British School of Archaeology in Jerusalem, 1937.

- The Churches at Jerash: A Preliminary Report of the Joint Yale British School Expeditions to Jerash 1928-1930. London: The (Archaeology) Council, 1931.

. Early Churches in Palestine. College Park, MD: McGrath Publishing Co., 1971.

Dan, Anca, Klaus Geus, and Kurt Guckelsberger. "What is Common Sense Geography?: Some Preliminary Thoughts from a Historical Perspective." In Features of Common Sense Geography: Implicit Knowledge Structures in Ancient Geographical Texts, edited by Klaus Geus and Kurt Guckelsberger, 17-38. Münster: LIT Verlag, 2014.

Dauphin, Claudine. "A New Method of Studying Early Byzantine Mosaic Pavements (Coding and a Computed Cluster Analysis), with Special Reference to the Levant." Levant 8, no. 1 (January 1976): 113-149.

Davis, Stephen J. The Early Coptic Papacy: The Egyptian Church and Its Leadership in Late Antiquity. Cairo: The American University in Cairo Press, 2004.

—. "Pilgrimage and the Cult of St. Thecla in Late Antique Egypt." In Pilgrimage and Holy Space in Late Antique Egypt, edited by David Frankfurter, 303-340. Leiden: Brill, 1998.

Decker, Michael. Tilling the Hateful Earth: Agricultural Production and Trade in the Late Antique East. Oxford: Oxford University Press, 2009.

Deręgowski, Jan, and Denis M. Parker. "The Perception of Spatial Structure with Oblique Viewing: An Explanation for Byzantine Perspective?.” Perception 23, no. 1 (January 1994): 5-13.

Deliyannis, Deborah Mauskopf. Ravenna in Late Antiquity. Cambridge: Cambridge University Press, 2010. 
Desreumaux, Alain. "Les inscriptions funéraires araméenes de Samra." In Fouilles de Khirbat es-Samra en Jordanie, v. 1, edited by Jean-Baptiste Humbert and Alain Dsreumaux, 435-521. Turnhout: Brepols, 1998.

Desreumaux, Alain, and Dominique Couson. "Catalogue des stèles funéraires." In Fouilles de Khirbat es-Samra en Jordanie, v. 1, edited by Jean-Baptiste Humbert and Alain Dsreumaux, 281-316. Turnhout: Brepols, 1998.

de Vaux, Roland. "Une mosaïque byzantine à Ma“in (Transjordanie).” RBibl 47 (1938): 227-258.

Dey, Hendrik. "Urban Armatures, Urban Vignettes: The Interpretation of the Reality and the Ideal of the Late Antique Metropolis." In Using Images in Late Antiquity, edited by Stine Birk, Troels Myrup Kristensen, and Birte Poulsen, 190-208. Oxford: Oxbow Books, 2014.

Dilke, O.A.W. Greek and Roman Maps. Ithaca: Cornell University Press, 1985.

_ "Maps in the Treatises of Roman Land Surveys." The Geographical Journal 127, no. 4 (December 1961): 417-426.

Di Segni, Leah. "The Involvement of Local, Municipal, and Provincial Authorities in Urban Building in Late Antique Palestine and Arabia." In The Roman and Byzantine Near East: Some Recent Archaeological Research, JRA Supplementary Series 14, edited by John Humphrey, 312-332. Ann Arbor, MI: Journal of Roman Archaeology, 1995.

. "The 'Onomasticon' of Eusebius and the Madaba Map." In The Madaba Map Centenary, 1897-1997: Travelling through the Byzantine Umayyad Period; Proceedings of the International Conference held in Amman, 7-9 April 1997, edited by Michele Piccirillo and Eugenio Alliata, 115-120. Jerusalem: Studium Biblicum Franciscanum, 1999.

Donceel-Voûte, Pauline. "La carte de Madaba: cosmographie, anachronisme, et propogande," RBibl 95, no. 4 (1988): 519-542.

— Les pavements des églises Byzantine de Syrie et du Liban: décor, archéologie, et liturgie. Louvain-la-Neuve, Belgium: Publications d'Archéologie et d'Histoire de l'Art de l'Université Catholique de Louvain, 1988.

Donnan, Graeme. The King's Highway. Amman: Al Kutbah, 1994.

Donner, Herbert. The Mosaic Map of Madaba: An Introductory Guide. Kampen: Kok Pharos, 1992. 
Dossey, Leslie. Peasant and Empire in Christian North Africa. Berkley: University of California Press, 2010.

Downey, Glanville. “The Pagan Virtue of Megalopsychia in Byzantine Syria.” TAPS 76 (1945): 279-286.

Draycott, Jane. "Who is Performing What, and for Whom? The Dedication, Construction, and Maintenance of a Healing Shrine in Roman Egypt." In Medicine, Healing, and Performance, edited by Effie Gemi-Iordanu, et al., 42-54. Oxford: Oxbow Books, 2014.

Dunbabin, Katherine M.D. Mosaics of the Greek and Roman World. Cambridge: Cambridge University Press, 1999.

-The Mosaics of Roman North Africa: Studies in Iconography and Patronage. Oxford: Clarendon Press, 1978.

_. "Mythology and Theatre in the Mosaics of the Graeco-Roman East." In Using Images in Late Antiquity, edited by Stine Birk, Myrup Kristensen, and Birte Poulsen, 227-252. Oxford: Oxbow Books, 2014.

—_. "The Waiting Servant in Later Roman Art." AJPh 124, no. 3 (2003): 443-467.

Duval, Noël. "Essai sur la signification des vignettes topographiques." In The Madaba Map Centenary, 1897-1997: Travelling through the Byzantine Umayyad Period; Proceedings of the International Conference held in Amman, 7-9 April 1997, edited by Michele Piccirillo and Eugenio Alliata, 134-146. Jerusalem: Studium Biblicum Franciscanum, 1999.

-."Rappresentazioni architettoniche." In Umm al-Rasas Mayfa 'ah I: Gli scavi del complesso di Santo Stefano, edited by Michele Piccirillo and Eugenio Alliata, 165-230. Jerusalem: Studium Biblicum Franciscanum, 1994.

- "Les representations architecturales sur les mosaïques chrétiennes de Jordanie." In Actes de la journée d'études sur les églises de Jordanie et leurs mosaïques: organisée à l'occasion de l'inauguration de l'exposition "Mosaïques Byzantines de Jordanie" au museée de la civilization gallo-romaine à Lyon en avril 1989, edited by Noël Duval, 211-281. Beirut: Institut français d'archéologie du ProcheOrient, 2003.

Eastmond, Antony. "Consular Diptychs, Rhetoric, and the Languages of Art in SixthCentury Constantinople.” Art History 33 no. 5 (December 2010): 743-765. - "Textual Icons: Viewing Inscriptions in Medieval Georgia." In Viewing Inscriptions in the Late Antique and Medieval World, edited by Antony Eastmond,76-98 .Cambridge: Cambridge University Press, 2015. 
Eckersley, Tracey. "Iconography of the Vintage in the Mosaics of Roman Spain and North Africa." MA thesis, McMaster University, 1996.

Ellis, Simon. "Power, Architecture, and Décor: How the Late Roman Aristocrat Appeared to His Guests." In Roman Art and the Private Sphere: New Perspectives on the Architecture and Décor of the Domus, Villa, and Insula, edited by Elaine K. Gazda, 117-134. Ann Arbor, MI: University of Michigan Press, 1994.

Ennaïfer, Mongi. "La theme des chevaux vainqueurs à travers la série des mosaïques africaines." Mélanges de l'Ecole française de Rome Antiquité 95, no. 2 (1983): 817-858.

Fantar, M'hammed Hassine, et al. La mosqüque en Tunisie. Tunis: Alif, 1994.

Favro, Diane. "The Iconicity of Ancient Rome." Urban History 33, no. 1 (2006): 20-38.

Fine, Steven. "Between Liturgy and Social History: Priestly Power in Late Antique Palestinian Synagogues?" In Art, History, and Historiography of Judaism in Roman Antiquity, edited by Steven Fine, 181-193. Leiden: Brill, 2013.

Fisher, C.S. "Description of the Site." In Gerasa: City of the Decapolis, edited by Carl Hermann Kraeling, 11-25. New Haven, CT: Yale University Press, 1936.

Fox, Robin Lane. "Literacy and Power in Early Christianity." In Literacy and Power in The Ancient World, edited by Alan K. Bowman and Greg Woolf, 126-148. Cambridge: Cambridge University Press, 1994.

Frankfurter, David, ed. Pilgrimage and Holy Space in Late Antique Egypt. Leiden: Brill, 1998.

—_. "Stylites and Phallobates: Pillar Region in Late Antique Syria," VigChr 44, no. 2 (June 1990): 168-198.

Friedland, Elise. "Marble Sculptures from the North Hall of the East Baths at Gerasa." AJA 107, no. 3 (July 2003): 413-448.

Frösén, Jakko, et al. The Petra Papyri v. 1. Amman: American Center for Oriental Research, 2007.

Galinsky, Karl, ed. Memoria Romana: Memory in Rome and Roman Memory. Ann Arbor, MI: University of Michigan Press, 2014. 
Gatier, Pierre-Louis. "L'idéologie de la cite et la carte de Madaba." In The Madaba Map Centenary, 1897-1997: Travelling through the Byzantine Umayyad Period; Proceedings of the International Conference held in Amman, 7-9 April 1997, edited by Michele Piccirillo and Eugenio Alliata, 235-237. Jerusalem: Studium Biblicum Franciscanum, 1999.

—_. "Une lettre du pape Grégoire le Grand à Marianus éveque de Gerasa." Syria 64, no. 1/2 (1987): 131-135.

—_. "Nouvelles inscriptions à Gerasa.” Syria 62, no. 3/4 (1985): 297-312.

Gazda, Elaine, ed. Roman Art and the Private Sphere: New Perspectives on the Architecture and Décor of the Domus, Villa, and Insula. Ann Arbor, MI: University of Michigan Press, 1994.

Germer-Durand, Eugène. La carte mosaïque de Madaba: Découverte importante. Paris: Maison de la bonne presse, 1897.

Geus, Klau, and Martin Thiering. "Common Sense Geography and Mental Modelling: Setting the Stage." In Features of Common Sense Geography: Implicit Knowledge Structures in Ancient Geographical Texts, edited by Klaus Geus and Martin Therin, 5-16. Münster: LIT Verlag, 2014.

Geus, Klaus, and Martin Thiering, eds. Features of Common Sense Geography: Implicit Knowledge Structures in Ancient Geographical Texts. Münster: LIT Verlag, 2014.

Geymonat, Ludovico V. "The Syntax of Spolia in Byzantine Thessalonike.” In Approaches to Byzantine Architecture and its Decoration: Studies in Honor of Slobodan Ćurčić, edited by Mark J. Johnson, Robert Ousterhout, and Amy Papalexandrou, 47-66. Burlington, VT: Ashgate, 2012.

Gisler, M. "Jerusalem auf der Mosaikkarte von Madaba.” Das Heilige Land 56 (1912): 214-227.

Glueck, Nelson. Explorations in Eastern Palestine. Philadelphia: American Schools of Oriental Research, 1934.

Goicoechea, Emilio Olvarri. Excavaciones en el agora de Gerasa en 1983. Madrid: Dirrección General della Bella Artes y Archivos, 1986.

Gold, Victor Roland. "The Mosaic Map of Madeba.” The Biblical Archaeologist 21, no. 3 (1958): 50-71.

Goodenough, Erwin R. Jewish Symbols from the Greco-Roman World v. 8. New York: Pantheon Books, 1958. 
Goor, Asaph. "The History of the Date through the Ages." Economic Botany 21, no. 4 (October-December 1967): 320-340.

Gregory, Caspar René. “The Mâdaba Map.” The Biblical World 12, no. 4 (October 1898): 244-250.

Grig, Lucy, and Gavin Kelly, eds. Two Romes: Rome and Constantinople in Late Antiquity. Oxford: Oxford University Press, 2014.

Grossman, Peter. “The Pilgrimage Center of Abû Mînâ.” In Pilgrimage and Holy Space in Late Antique Egypt, edited by David Frankenfurter, 281-302. Leiden: Brill, 1998.

Guthe, H. "Das Stadtbild Jerusalems auf der Mosaikkarte von Madaba." ZDPV 28 (1905): 120-130.

Gzella, Holger. A Cultural History of Aramaic: From the Beginnings to the Advent of Islam. Leiden: Brill, 2015.

Haas, Christopher. Alexandria in Late Antiquity: Topography and Social Conflict. Baltimore: Johns Hopkins University Press, 2006.

Habas, Lihi. "The Bema and Chancel Screen in Synagogues and their Origins." In From Dura to Sepphoris: Studies in Jewish Art Society in Late Antiquity, JRA Supplementary Series 40, edited by Lee I. Levine and Zeev Weis, 111-130. Portsmouth, RI: Journal of Roman Archaeology, 2000.

_. "Donations and Donors as Reflected in the Mosaic Pavements of Transjordan's Churches in the Byzantine and Umayyad Periods." In Between Judaism and Christianity: Art Historical Essays in Honor of Elisheva (Elizabeth) Revel-Neher, edited by Katrin Kogmann-Appel and Mati Meyer, 73-90. Leiden: Brill, 2009.

Hachlili, Rachel. Ancient Mosaic Pavements: Themes, Issues, and Trends. Leiden: Brill, 2009.

Hahn, Cynthia. "Loca Sancta Souvenirs: Sealing the Pilgrim Experience." In The Blessings of Pilgrimage, edited by Robert Ousterhout, 7-40. Chicago: University of Illinois Press, 1999.

Haldon, John. "Social Élites, Wealth, and Power." in A Social History of Byzantium, edited by John Haldon, 168-211. Maldan, MA: Wiley-Blackwell, 2009. 
Hamarneh, Basema. "Dynamics and Transformation of the Rural Settlements of Provincia Arabia and Palaestina Tertia in the Omayyad and Early Abbasid Periods; Archaeological Evidence." In Proceedings of the 6th International Congress of the Archaeology of the Ancient Near East, 5 May-10 May 2009, edited by Paolo Matthiae, et al., 91-109. Wiesbaden: Harrassowitz, 2010.

. "Monasteries in Rural Context in Byzantine Arabia and Palaestina Tertia: A Reassessment." In Christ is Here! Studies in Biblical and Christian Archaeology in Memory of Michele Piccirillo, edited by L. D. Chrupcala, 275-296. Jerusalem: Studium Biblicum Franciscarum, 2012.

— . "The River Nile and Egypt in the Mosaics of the Middle East." In The Madaba Map Centenary, 1897-1997: Travelling through the Byzantine Umayyad Period; Proceedings of the International Conference held in Amman, 7-9 April 1997, edited by Michele Piccirillo and Eugenio Alliata, 185-189. Jerusalem: Studium Biblicum Franciscanum, 1999.

. "Ritratti immagini di donatori nei mosaici della Giordania." In Acta XIII Congressus internationalis archaeologiae christianiae v. 2, edited by N. Cambi and E. Marin, 411-422. Split: Arheološki Muzej, 1998.

Har-el, Menashe. "The Route of Salt, Sugar, and Balsam Caravans in the Judean Desert." GeoJournal 2, no. 6 (1978): 549-556.

Harley, J. Brian. “Maps, Knowledge, and Power.” In The Iconography of Landscape, edited by D. Cosgrove and S. Daniels, 277-312. Cambridge: Cambridge University Press, 1988.

Harley, J. Brian, and David Woodward. Preface to The History of Cartography, edited by J. Brian Harley and David Woodward, xv-xxi. Chicago: University of Chicago Press, 1987.

Haskell, Francis. History and Its Images: Art and the Interpretation of the Past. New Haven, CT: Yale University Press, 1993.

Hepper, Frank Nigel, and Joan E. Taylor. "Date Palms and Opobalsam in the Madaba Mosaic Map." PEFQS 136, no. 1 (2004): 35-44.

Hillier, Bill, and Julienne Hanson. The Social Logic of Space. Cambridge: Cambridge University Press, 1984.

Hollerich, Michael J. "The Alexandrian Bishops and the Grain Trade: Ecclesiastical Commerce in Late Roman Egypt." JESHO 25, no. 2 (1982): 187-207.

Hondelink, Hans. Coptic Art and Culture. Cairo: Shouhdy Publishing House, 1990. 
Hoyland, Robert. "Aramaic and Old Arabic in Late Roman Palestine and Arabia." In The Development of Arabic as a Written Language (Supplement to the Proceedings of the Seminar of Arabian Studies 40), edited by M.C.A. Macdonald, 29-46. Oxford: Archaeopress, 2010.

Humbert, Jean-Baptiste, and Alain Desreumaux. Fouilles de Khirbat es-Samra en Jordanie v. 1. Turnhout: Brepols, 1998.

Humbert, Jean-Baptiste. “Khirbet es-Samra, 1981-1982.” Syria 60, no. 3/4 (1983): 310313.

—. "Khirbet es-Samra, du diocese de Bosra." In Christian Archaeology in the Holy Land: New Discoveries; Essays in Honour of Virgilio C. Corbo, OFM, edited by G.C. Bottini, L. Di Segni, and E. Alliata, 467-474. Jerusalem: Franciscan Printing Press, 1990.

Hunt, Lucy-Anne. "The Byzantine Mosaics in Jordan in Context: Remarks on Imagery, Donors, and Mosaicists." In Byzantium, Eastern Christendom and Islam: Art at the Crossroads of the Medieval Mediterranean v. 1, edited by Lucy-Anne Hunt, 106-126. London: Pindar Press, 1998.

Illuz, David, et al. "Medicinal Properties of Commiphora gileadensis." African Journal of Pharmacy and Pharmacology 4, no. 8 (August 2010): 516-520

Isaac, Benjamin. "Bandits in Judea and Arabia” HSCP 88 (1984): 171-203.

Isar, Nicoletta. "Chorós of Light: Vision of the Sacred in Paulus the Silentiary's Poem Descriptio S. Sophiae.” Byzantinische Forschungen 28 (2004): 215-242.

Irshai, Oded. "The Christian Appropriation of Jerusalem in the Fourth Century: The Case of the Bordeaux Pilgrim.” JQR 99, no. 4 (2009): 465-486.

Jackson, C.M., and P.T. Nicholson. "The Provenance of Some Glass Ingots from the Uluburun Shipwreck.” JAS 37, no. 2 (February 2010): 295-301.

Jacobs, Ine. "'Encroachment' in the Eastern Mediterranean between the Fourth and Seventh Century AD.” Ancient Society (2009): 203-244.

Jacoby, Adolf. Das geographische Mosaik von Madaba: Die älteste Karte des Heiligen Landes. Leipzig: Dieterich, 1905.

James, Liz. "Byzantine Glass Mosaic Tesserae: Some Material Considerations." Byzantine and Modern Greek Studies 30, no. 1 (2006): 29-47.

. Light and Colour in Byzantine Art. Oxford: Clarendon Press, 1996. 
—_. "Senses and Sensibility in Byzantium." Art History 27, no. 4 (September 2004): $522-537$.

James, Liz, and Ruth Webb. "To Understand Ultimate Things and to Enter Secret Places: Ekphrasis in Byzantium." Art History 14, no. 1 (March 1991): 1-17.

Johnson, Mark. “Toward a History of Theodoric's Building Program.” DOP 42 (1988): 73-96.

Kehrberg, Ina. "Roman Gerasa Seen from Below: An Alternative Study of Urban Landscape." ASCS Selected Proceedings 32 (2011): 8. Accessed February 3, 2013. http://www.ascs.org.au/news/ascs32/Kehrberg.pdf.

Kennedy, David. Gerasa and the Decapolis. London: Bloomsbury, 2013.

Kennedy, George Alexander. Greek Rhetoric under Christian Emperors: A History of Rhetoric. Eugene, OR: Wipf and Stock Press, 2008.

Kennedy, Hugh. "Gerasa and Scythopolis: Power and Patronage in the Byzantine Cities of Bilad al-Sham.” BÉO 52 (2000): 199-204.

Kingsley, Sean. "The Economic Impact of the Palestinian Wine Trade in Late Antiquity." In Economy and Exchange in in the East Mediterranean during Late Antiquity, Proceedings of a Conference at Somerville College, Oxford, May 29, 1999, edited by Sean Kingsley and Michael Decker, 44-66. Oxford: Oxbow Books Monograph, 2001.

Kitzinger, Ernst. Foreword to The Mosaics of Jordan, by Michele Piccirillo, 9-10. Amman: American Center of Oriental Research, 1993.

Koenen, Ludwig. et al. The Petra Papyri v. 2. Amman: American Center for Oriental Research, 2013.

Kofsky, A. "Peter the Iberian: Pilgrimage, Monasticism, and Ecclesiastical Politics in Byzantine Palestine.” Liber Annuиs 47 (1997): 209-22.

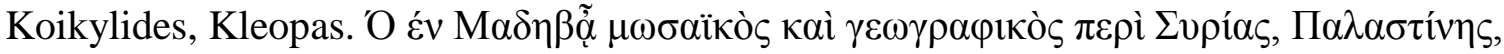

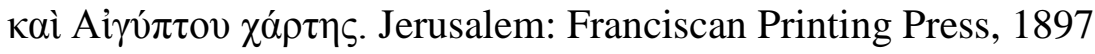

Kondoleon, Christine. "Signs of Privilege and Pleasure." In Roman Art and the Private Sphere: New Perspectives on the Architecture and Décor of the Domus, Villa, and Insula, edited by Elaine K. Gazda, 105-116. Ann Arbor: University of Michigan Press, 1994. 
Kouki, Paula. "Evidence of Land Tenure in the Petra Region, Jordan: Nabataean-Early Roman to Late Byzantine." Journal of Mediterranean Archaeology 22, no. 1 (June 2009): 29-56.

Kraeling, Carl Hermann, ed. Gerasa: City of the Decapolis. New Haven, CT: Yale University Press, 1936.

_ . "History of Gerasa." In Gerasa: City of the Decapolis, edited by Carl Hermann Kraeling, 29-69. New Haven, CT: Yale University Press, 1936.

Krautheimer, Richard. Early Christian and Byzantine Architecture. London: Harmondsworth, 1986.

_. "Introduction to an "Iconography of Medieval Architecture." JWarb 5 (1942): $1-33$.

Krautheimer, Richard, and Slobodan Ćurčić. Early Christian and Byzantine Architecture. New Haven, CT: Yale University Press, 1992.

Lagrange, Marie-Joseph. "Mosaïque géographique de Mâdabâ." RBibl 6 (1897): 165184.

Lawrernce, Marion. “Ships, Monsters, and Jonah.” AJA 66, no. 3 (July 1962): 289-296.

Leclercq, Henri. “Madaba." In Dictionnaire d'archéologie chrétienne et de liturgie v. 10, no. 1, edited by Fernand Cabrol and Henri Leclercq, 806-885. Paris: Letouzey et Ané, 1930.

Lefebvre, Henri. La production de l'éspace. Paris: Editions Anthropos, 1974.

Leone, Anna. Changing Townscapes in North Africa from Late Antiquity to the Arab Conquest. Bari: Edipuglia, 2007.

Lequien, Michel. Oriens christianus in quatuor patriarchatus digestus, v. 3. Paris: no publisher, 1740

Levi, Annalina, and Mario Levi. Itineraria Picta: Contribulto allo studio della Tabula Peuttingeriana. Rome: “L’Erma de Bretschneider, 1967.

Levi, Doro. Antioch Mosaic Pavements. Princeton, NJ: Princeton University Press, 1947.

Leyerle, Blake. "Mobility and the Traces of Empire." In A Companion to Late Antiquity, edited by Philip Rousseau, 110-124. Maldan, MA: Wiley Blackwell, 2009.

—.Theatrical Shows and Ascetic Lives: John Chrysostom's Attack on Spiritual Marriage. Berkeley: University of California Press, 2001. 
Lidov, Alexei. "Hierotopy: The Creation of Sacred Spaces as a form of Creativity and Subject of Cultural History." In Hierotopy: The Creation of Sacred Spaces in Byzantium and Medieval Russia, edited by Alexei Lidov, 32-58. Moscow: Progress-tradition, 2006.

Liebschuetz, Wolfgang. "The End of the Ancient City." In The City in Late Antiquity, edited by John Rich, 1-49. New York: Routledge, 1992.

Lozovsky, Natalia. "Maps and Panegyrics: Roman Geo-Ethnographical Rhetoric in Late Antiquity and the Middle Ages." In Cartography in Antiquity and the Middle Ages: Fresh Perspectives, New Methods, edited by Richard Talbert and Richard Walson Unger, 169-188. Leiden: Brill, 2008.

MacDonald, Burton. Pilgrimage in Early Christian Jordan: A Literary and Archaeological Guide. Oxford: Oxbow Books, 1989.

-The Southern Transjordan Edomite Plateau and the Dead Sea Rift Valley. Oxford: Oxbow Books, 2015.

MacEachren, Alan M. "A Linear View of the World: Strip Maps as a Unique Form of Cartographic Representation.” The American Cartographer 13, no. 1 (1986): 725.

Madden, Andrew. "A New Form of Evidence to Date the Madaba Map Mosaic.” Liber Annuus 62 (2012): 495-513.

Maehler, Margaret. "Trouble in Alexandria in a Letter of the Sixth Century." GRBS 17 (1976): 197-203.

Magness, Jodi. "Blessings from Jerusalem: Evidence for Early Christian Pilgrimage." Eretz-Israel 25 (1996): 37-45.

Maguire, Henry. "The Art of Comparing in Byzantium.” ArtB 70, no. 1 (1980): 88-103.

Earth and Ocean: The Terrestrial World in Early Byzantine Art. University Park, PA: Pennsylvania State University Press, 1987.

—. "The Good Life." In Late Antique and Medieval Art of the Mediterranean World, edited By Eva Hoffman, 63-85. Malden, MA: Blackwell Publishing, 2009.

- The Icons of their Bodies: Saints and their Images in Byzantium. Princeton, NJ: Princeton University Press, 1996.

—_. "The Good Life." In Late Antique and Medieval Art of the Mediterranean World, edited By Eva Hoffman, 63-85. Malden, MA: Blackwell Publishing, 2009. 
- "The Nile and the Rivers of Paradise," in The Madaba Map Centenary, 18971997: Travelling through the Byzantine Umayyad Period; Proceedings of the International Conference held in Amman, 7-9 April 1997, edited by Michele Piccirillo and Eugenio Alliata, 179-184. Jerusalem: Studium Biblicum Franciscanum, 1999.

Markopoulos, Athanasios. "Education." In The Oxford Handbook of Byzantine Studies, edited by Elizabeth Jeffreys, John Haldon, and Robin Cormack, 785-795. Oxford: Oxford University Press, 2008.

Marrou, Henri. A History of Education in Antiquity. Translated by George Lamb. Madison, WI: University of Wisconsin Press, 1956.

Matthews, John. The Journey of Theophanes: Travel, Business, and Daily Life in the Roman Near East. New Haven, CT: Yale University Press, 2006.

Mayerson, Philip. "The Ancient Agricultural Regime of Nessana and the Cultural Negeb.” In Excavations at Nessana v. 1, edited by H. Dunscombe Colt, 211-269. London: British School of Archaeology in Jerusalem, 1962.

— . "The Wine and Vineyards of Gaza in the Byzantine Period." BASOR 257 (Winter, 1985): 75-80.

Meimaris, Yiannis E. Sacred Names, Saints, Martyrs, and Church Officials in the Greek Inscriptions and Papyri Pertaining to the Christian Church of Palestine. Athens: National Hellenic Research Foundation, 1986.

McKenzie, Judith. The Architecture of Alexandria and Egypt, c. 300 B.C. to A.D. 700. New Haven, CT: Yale University Press, 2008.

Merrony, Mark. "The Reconciliation on Paganism and Christianity in the Early Byzantine Mosaic Pavements of Arabia and Palestine.” Liber Annuus 48 (1998): 441-482.

- Socio-Economic Aspects of Late Roman Mosaic Pavements in Phoenicia and Northern Palestine, BAR International Series 2530. Oxford: Archaeopress, 2013.

Michel, Anne. Les églies d'époque byzantine et umayyade de la Jordanie: Ve-VIIe siècle: Typologie architectuale et aménagements liturgiques. Turnhout: Brepols, 2001.

Millar, Fergus. The Roman Empire and its Neighbours. New York: Holmes \& Meier, 1981.

. The Roman Near East: 31 B.C.-A.D. 337. Cambridge, MA: Harvard University Press, 1995. 
Morony, Michael G. "Economic Boundaries? Late Antiquity and Early Islam." JESHO 47, no. 2 (2004): 166-194.

Mratschek, Sigrid. "Codices vestry nos sumus: Bücherkult und Bücherpreise in der christlichen Spätantike.” In Hortus Litterarum Antiquarum: Festschrif für Hans Armin Gärtner zum 70 Geburtstag, edited by Andreas Haltenhoff and FritzHeiner Mutshler, 369-380. Heidelberg: C. Winter, 2000.

Munier, H. "Fragments des actes du martyre de l'apa Chounbi." ASAE 17 (1917): 145159.

Nassaney, Michael S. "Social Archaeology.” In Archaeology: Encyclopedia of Life Support Systems v. 1, edited by Donald L. Hardesty, 258-272. Oxford: EOLSS Publishers, 2000.

Nassar, Mohammad. "The Art of Decorative Mosaics (Hunting Scenes) from the Madaba Area during the Byzantine Period ( $5^{\text {th }}-6^{\text {th }}$ c. AD)." Mediterranean Archaeology and Archaeometry 13, no. 1 (2013): 67-76.

Nelson, Robert. "To See and to Say: Ekphrasis and Vision in Byzantium.” In Visuality before and Beyond the Renaissance, edited by Robert Nelson, 143-168. Chicago: University of Chicago Press, 2000.

Nilsson, Martin P. “Krater.” HTR 51, no. 2 (April 1958): 53-58.

Nissenbaum, Arie. "The Microbiology and Biogeochemistry of the Dead Sea," Microbial Ecology 2 (1975): 139-161.

Norton, Peter. Episcopal Elections 250-600: Hierarchy and Popular Will in Late Antiquity. Oxford: Oxford University Press, 2007.

O’Callaghan, R. T. "Madaba.” In Dictionnaire de la Bible, Supplément 5, edited by L. Pirot and H. Cazelles, 627-704. Paris: Letouzey et Ané 1957.

Ognibene, Susanna. Umm al-Rasas: la chiesa di Santo Stefano ed il "problema iconofobico." Rome: "L’Erma" di Bretschneider, 2002.

O’Neill, Dennis. Passionate Holiness: Marginalized Christian Devotions for Distinctive Peoples. Bloomington, IN: Trafford Publishing, 2010.

Onians, John. "Abstraction and Imagination in Late Antiquity." Art History 3, no. 1 (March 1980): 1-24.

Oran, Asaf, et al. "Early Maritime Activity on the Dead Sea: Bitumen Harvesting and the Possible Use of Reed Watercraft." Journal of Maritime Archaeology 10, no. 1 (April 2015): 65-88. 
Ostrasz, Antoni A. "The Hippodrome of Gerasa: A Report on Excavations and Research 1982-1987." Syria 66, no. 1 (1989): 51-77.

Ousterhout, Robert. "Architecture, Art, and Kommnenian Ideology at the Pantokrator Monastery." In Byzantine Constantinople: Monuments, Topography, and Everyday Life, edited by Nevra Necipoğlu, 133-152. Leiden: Brill, 2001. ed. Blessings of Pilgrimage. Chicago: University of Illinois, 1990.

Ovadiah, Ruth. "Jonah in a Mosaic Pavement at Beth Gurvin." IEJ 24, no. $3 / 4$ (1974): 214-215.

Ovadiah, Ruth, and Asher Ovadiah. Hellenistic, Roman, and Early Byzantine Pavements in Israel. Rome: L'Erma di Bretschneider, 1987.

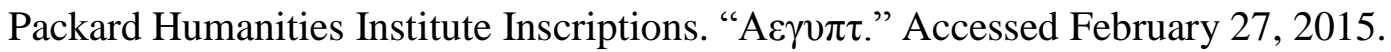
http://epigraphy.packhum.org/search?patt=\%CE\%B1\%CE\%B5\%CE\%B3\%CF\%8 $5 \% \mathrm{CF} \% 80 \% \mathrm{CF} \% 84$.

Paliou, Eleftheria. "Visibility Analysis in 3D Built Spaces: A New Dimension to the Understanding of Social Space." In Spatial Analysis and Social Spaces: Interdisciplinary Approaches to the Interpretation Prehistoric and Historic Built Environments, edited by Eleftheria Paliou, Undine Lieberwirth, and Silvia Polla, 91-114. Berlin: De Gruyter, 2014.

Papalexandrou, Amy. "Echoes of Orality in the Monumental Inscriptions of Byzantium." In Art and Text in Byzantine Culture, edited by Liz James, 161-186. Cambridge: Cambridge University Press, 2006.

Papodoupolos, Alex G. "Exploring Byzantine Cartographies: Ancient Science, Christian Cosmology, and Geopolitics in Byzantine Imperial-Era Mapping." Essays in Medieval Studies 27 (2011): 117-131.

Parker, Thomas S., “An Empire's New Holy Land: The Byzantine Period.” NEA 62, no. 3 (1999): 134-180.

Pentcheva, Bissera V. “The Performative Icon.” ArtB 88, no. 4 (December 2006): 631655 .

- The Sensual Icon: Space, Ritual, and the Senses in Byzantium. University Park, PA: Penn State University Press, 2010.

Perrone, Lorenzo. "Christian Holy Places and Pilgrimage in an Age of Dogmatic Conflicts." Proche- Orient crétien 48, no. 1/2 (1998): 5-37. 
Peterson, Andrew. The Medieval and Ottoman Haj Routes in Jordan: An Archaeological and Historical Study. Oxford: Oxbow Books, 2012.

Piccirillo, Michele. "Archaeological Excavations 1998 at Nitl and Umm al-Rasas." Franciscan Archaeological Institute. Accessed February 1, 2016. http://www.christusrex.org/www1/ofm/fai/FAIrasas98.html

—. "La cappella del Prête Giovanni di Khibat al-Mukhayyat (villagio di Nibo)." Liber Annuus 38 (1988): 521-538.

_ _ "La Chiesa dei Lioni a Umm al-Rasas- Kastron Meffa.” Liber Annuus 42 (1992) 199-225.

- Chiese e mosaici di Giordania settentrionale. Jerusalem: Franciscan Printing Press, 1981.

. Chiese e mosaici di Madaba. Jerusalem: Studium Biblicum Franciscanum, 1989.

—. "L'identificazione storica delle rovine di Umm er-Rasas - Kastron Mefaa in Giordania." Biblica 71, no. 4 (1990): 527-541.

__. "Le installazioni liturgiche." In Umm al-Rasas Mayfa ah I: Gli scavi di complesso di Santo Stefano, edited by Michele Piccirillo and Eugenio Alliata, 111-119. Jerusalem: Studium Biblicum Franciscanum, 1994.

—. Madaba: Le chiesi e i mosaici. Cuneo: Edizioni Paoline, 1989.

__. "I mosaici del complesso di Santo Stefano." In Umm al-Rasas Mayfa ah I: Gli scavi di complesso di Santo Stefano, edited by Michele Piccirillo and Eugenio Alliata, 121-164. Jerusalem: Studium Biblicum Franciscanum, 1994.

. “The Mosaics.” In Mount Nebo: New Archaeological Investigations, edited by Michele Piccirillo and Eugenio Alliata, 205-209. Jerusalem: Franciscan Printing Press, 1998.

—. "The Mosaics at Umm er-Rasas in Jordan." The Biblical Archaeologist, 51, no. 4 (December 2008): 208-213, 227-231.

—. The Mosaics of Jordan. Amman: American Center of Oriental Research, 1993. ."Mosaics of 785 AD at Um al-Rasas (K Mefa'a)." Holy Land 7, no. 2 (1987): 59-72.

—. "Prima Campagna Di Scavo a Um Er-Rasas." Syria 64, nos. 3/4 (1987): 302-05. 
__. "Gli scavi del complesso di Santo Stefano." In Umm al-Rasas Mayfa ah I: Gli scavi di complesso di Santo Stefano, edited by Michele Piccirillo and Eugenio Alliata, 51-54. Jerusalem: Studium Biblicum Franciscanum, 1994.

—_. "The Umayyad Churches of Jordan.” ADAJ 28 (1994): 333-341.

_ . "Umm al-Rasas, Church of St. Paul: Southeastern Flank." Liber Annuus 47 (1997): 542-546.

Piccirillo, Michele, and Eugenio Alliata, eds. The Madaba Map Centenary, 1897-1977: Travelling through the Byzantine Umayyad Period: Proceedings of the International Conference held in Amman, 7-9 April 1997. Jerusalem: Studium Biblicum Franciscanum, 1999.

- Mount Nebo: New Archaeological Investigations. Jerusalem: Franciscan Printing Press, 1998.

_. Umm al-Rasas Mayfa ah I: Gli scavi di complesso di Santo Stefano. Jerusalem: Studium Biblicum Franciscanum, 1994.

Pixner, Bargil. "The Miracle Church at Tabgha on the Sea of Galilee." Biblical Archaeologist 48, no. 4 (December 1985): 196-206.

Porter, Benjamin W. "Authority, Polity, and Tenuous Elites in Iron Age Edom (Jordan)." OJA 23, no. 4 (2004): 373-395.

Poulsen, Birte. "Patrons and Viewers: Reading Mosaics in Late Antiquity." In Patrons and Viewers in Late Antiquity, edited by Stine Birk and Birte Poulsen, 167-188. Aarhus: Aarhus University Press, 2012.

Raeck, W. "Publica non despiciens. Ergänzungen zur Interpretation des Dominus-JuliusMosaiks aus Karthago.” RömMitt 94 (1987): 295-308.

Rapp, Claudia. "Bishops in Late Antiquity: A New Social and Urban Elite?.” In Elites Old and New in the Byzantine and Early Islamic Near East, Studies in Late Antique and Early Islam v. 6, edited by John Haldon, 144-173. Princeton, NJ: Darwin Press, 2003.

- "The Elite Status of Bishops in Late Antiquity in Ecclesiastical, Spiritual, and Social Contexts." Arethusa 33 (2000): 379-399.

- Holy Bishops in Late Antiquity: The Nature of Christian Leadership in an Age of Transition. Berkeley: University of California Press, 2005.

Retzleff, Alexandra, and Abdel Majeed Mjely. "Seat Inscriptions in the Odeum at Gerasa (Jerash).” BASOR 336 (November 2004): 37-48. 
Rich, John. The City in Late Antiquity. London: Routledge, 1992.

Rocca, Samuel. Herod's Judea: A Mediterranean State in the Classic World. Eugene, OR: Wipf and Stock Publishers, 2015.

Roll, Israel. "The Roads in Roman-Byzantine Palaestina and Arabia." In The Madaba Map Centenary, 1897-1997: Travelling through the Byzantine Umayyad Period; Proceedings of the International Conference held in Amman, 7-9 April 1997, edited by Michele Piccirillo and Eugenio Alliata, 109-113. Jerusalem: Studium Biblicum Franciscanum, 1999.

Rorem, Paul. Pseudo-Dionysios: A Commentary on the Texts and an Introduction to Their Influence. Oxford: Oxford University Press, 1993.

Safrai, Zeev. "The House of Leontis 'Kaloubas'- A Judeo-Christian?.” In The Image of the Judaeo-Christians in Ancient Jewish and Christian Literature: Papers Delivered at the Colloquium of the Insitutum Iudaicum, Brussels 18-19 November, 2001, edited by Peter J. Tomson and Doris Lambers-Petry, 245-259. Tübingen: Mohr Siebeck, 2004.

Saller, Sylvester, and Bellarmino Bagatti. The Town of Nebo: Khirbet el-Mekhayyat; with a Brief Survey of other Ancient Christian Monuments in Transjordan. Jerusalem: Franciscan Printing Press, 1949.

Salway, Benet. "The Nature and Genesis of the Peutinger Map." Imago Mundi 57, no. 2 (2005): 119-135.

Saradi, Helen G. The Byzantine City in the Sixth Century: Literary Images and Historical Reality. Athens: Society of Messenian Archaeological Studies, 2006.

Satre, Maurice. The Middle East under Rome. Translated by Catherine Porter and Elizabeth Rawlings. Cambridge, MA: Belknap Press, 2005.

Schachner, Lukas Amadeus. "The Archaeology of the Stylite," in Religious Diversity in Late Antiquity, edited by David Gwynn and Susanne Bangert, 329-398. Leiden: Brill, 2010.

_. "I Greet You and Thy Brethren. Here Are Fifteen Shentasse of Wine.' Wine as a Product of the Early Monasteries of Egypt and the Levant." ARAM 17 (2005): $157-184$.

Scheibelreiter-Gail, Veronika. "Inscriptions in the Late Antique Private House: Some Thoughts about their Function and Distribution." In Patrons and Viewers in Late Antiquity, edited by Stine Birk and Birte Poulsen, 135-166. Aarhus: Aarhus University Press, 2012. 
Schibille, Nadine. Hagia Sophia and the Byzantine Aesthetic Experience. Burlington, VT: Ashgate, 2014.

Schick, Robert. The Christian Communities of Palestine from Byzantine to Islamic Rule: A Historical and Archaeological Study. London: Darwin Press, 1995.

Schlatter, Fredric W. "Interpreting the Mosaic of Santa Pudenziana." VigChr 46, no. 3 (September 1992): 276-295.

Schulten, Adolf. Die Mosaikkarte von Madaba und ihr Verhaltnis zu den altesten Karten und Beschi'eibungen des heiligen Landes. Berlin: Weidmann, 1900.

Schwartz, Seth. "Euergetism in Josephus and the Epigraphic Culture of First-Century Jerusalem." In From Hellenism to Islam: Cultural and Linguistic Change in the Roman Near East, edited by Hannah M. Cotton, et al., 75-92. Oxford: Oxford University Press, 2009.

Seland, Eivind Heldass. "Kameler og kamelkaravaner i romersk kunst." Klassisk Forum 2 (2011): 45-53.

Shahid, Irfan. Byzantium and the Arabs in the Sixth Century v. 2, no. 2. Washington: Dumbarton Oaks, 2009.

—_. "The Madaba Mosaic Map Revisited: Some New Observations on its Purpose and Meaning." In The Madaba Map Centenary, 1897-1997: Travelling through the Byzantine Umayyad Period; Proceedings of the International Conference held in Amman, 7-9 April 1997, edited by Michele Piccirillo and Eugenio Alliata, 147154. Jerusalem: Studium Biblicum Franciscanum, 1999.

Sodini, Jean-Pierre. "L'organisation liturgique des églises." In The Roman and Byzantine Near East: Some Recent Archaeological Research v. 1, Journal of Roman Archaeology Supplementary Series 14, edited by John Humphrey, 304-311. Ann Arbor, MI: 1995.

Sotheby's. “A Byzantine Mosaic Panel, late $5^{\text {th }}$ Century A.D.” Accessed March 22, 2016. http://www.sothebys.com/en/auctions/ecatalogue/2006/antiquitiesn08253/lot.99.html.

Sperber, Daniel. The City in Roman Palestine. Oxford: Oxford University Press, 1998.

Spieser, Jean-Michel. "The Representation of Christ in the Apses of Early Christian Churches." Gesta, 37, no. 1 (1998): 63-73.

Stanford University. "Icons of Sound." Accessed June 18, 2014. http://iconsofsound.stanford.edu/index.html. 
Suter, Claudia. Gudea's Temple Building: the Representation of an Early Mesopotamian Ruler in Text and Image. Leiden: Brill, 2000.

Sweetman, Rebecca J. The Mosaics of Roman Crete: Art Archaeology and Social Change. Cambridge: Cambridge University Press, 2013.

Talbert, Richard J.A. "Urbs Roma to Orbis Romanis: Roman Mapping on a Grand Scale." In Ancient Perspectives: Maps and Their Place in Mesopotamia, Egypt, Greece, and Rome, edited by Richard J.A. Talbert, 163-191. Chicago: University of Chicago Press, 2012.

Talbert, Richard, and Richard Walson Unger, eds. Cartography in Antiquity and the Middle Ages: Fresh Perspectives, New Methods. Leiden: Brill, 2008.

Talbot, Alice-Mary. "Pilgrimage to Healing Shrines: The Evidence of Miracle Accounts.” DOP 56 (2002): 153-173.

Talgam, Rina. "Constructing Identity through Art: Jewish Art as Minority Culture in Byzantium." In Jews in Byzantium, Dialectics of Minority and Majority Cultures, edited by Robert Bodfil, et al. 399-454. Leiden: Brill, 2011.

- Mosaics of Faith: Floors of Pagans, Jews, Samaritans, Christians, and Muslims in the Holy Land. University Park, PA: Penn State University Press, 2014.

Talgam, Rina, and Ze'ev Weiss. The Mosaics of the House of Dionysos at Sepphoris: Excavated by E. M. Meyers, E. Netzer, and C.L. Meyers. Jerusalem: The Institute of Archaeology at the University of Jerusalem, 2004.

Taub, Liba. "The Historical Function of the Forma Urbis Romae." Imago Mundi 45 (1993): 9-19.

Thébert, Yves. "Private Life and Domestic Architecture in Roman Africa," in A History of Private Life-from Pagan Rome to Byzantium, edited by Paul Veyne. 313-409. Cambridge, MA: Harvard University Press, 1987.

Thunø, Erik. The Apse Mosaic in Early Medieval Rome. Cambridge: Cambridge University Press, 2015.

Thomassen, Einar. "The Performance of Baptism." In Ablution, Initiation, Baptism: Late Antiquity, Early Judaism, and Early Christianity, edited by David Hellhom, et al, 897. Berlin: Walter de Gruyter, 2011.

Toynbee, Jocelyn Mary Catherine. "Ara Pacis Reconsidered and Historical Art in Roman Italy." ProcBritAc 39 (1959): 67-95. 
Trieger, Alexander. "Unpublished Texts from the Arab Orthodox Tradition (2): Miracles of St. Eustratius of Mar Saba (Written ca. 860)." Chronos 33 (2016): 7-20.

Trimble, Jennifer. "Process and Transformation on the Severan Plan of Rome." In Cartography in Antiquity and the Middle Ages: Fresh Perspectives, New Methods, edited by Richard Talbert and Richard Walson Unger, 67-98. Leiden: Brill, 2008.

Tronzo, William. "Mimesis in Byzantium: Notes towards the History of the Function of an Image." RES: Anthropology and Aesthetics 25 (Spring 1994): 61-76.

Uscatescu, Alexandra, and Manuel Martín-Bueno. "The Macellum of Gerasa (Jerash, Jordan): From a Market Place to an Industrial Area.” BASOR 307 (August 1997): 77-81.

Van Dam, Raymond. Saints and their Miracles in Late Antique Gaul. Princeton, NJ: Princeton University Press, 1993.

van Druzer, Chet, and Ilya Dines, Apocalyptic Cartography: Thematic Maps and the End of the World. Leiden: Brill, 2016.

van Minnen, Peter. "Hermopolis in the Crisis of the Roman Empire." In After the Past: Essays in Ancient History in Honor of H. W. Pleket, edited by W. Jongman and M. Kleijwegt, 285-304. Leiden: Brill, 2002.

van Neer, Wim, and David Depraetere. "Pickled Fish from the Egyptian Nile: Osteological Evidence from a Byzantine (Coptic) Context at Shanhûr." Revue de Paléobiologie 10 (December 2005): 159-170.

Versluys, M. J. Aegyptica Romana: Nilotic Scenes and the Roman Views of Egypt. Leiden: Bill, 2002.

Vikan, Gary. Byzantine Pilgrimage Art. Washington, DC: Dumbarton Oaks, 1982.

Vincent, L.H. "L'église des SS. Apôtres à Mâdabâ.” RBibl 11 (1902): 599

__. "Une villa gréco-romaine à Beit Djebrin," RBibl 31 (1922): 259-281

von Simson, Otto. Sacred Fortress: Byzantine Art and Statecraft in Ravenna. Princeton, NJ: Princeton University Press, 1948.

Vorys Canby, Jeanny. The "Ur-Nammu” Stele. Philadelphia: The University of Pennsylvania Museum of Archaeology, 2001.

Vyhmeister, Werner. "The History of Hesbon from Literary Sources." Andrews University Seminaries Studies 6 (1968): 158-177. 
Walker, Bethany. "Mamluk Investment in Transjordan: a "Boom and Bust" Economy." Mamluk Studies Review 8, no. 2 (2004): 119-147.

Walker, Joel. "From Nisibis to Xian: The Church of the East in Late Antique Eurasia." In The Oxford Handbook of Late Antiquity, edited by Scott Fitzgerald Johnson, 9941052. Oxford: Oxford University Press, 2012.

Walmsley, Alan George. "Byzantine Palestine and Arabia: Urban Prosperity in Late Antiquity." In Towns in Transition: Urban Evolution in Late Antiquity and the Early Middle Ages, edited by N. Christie and S.T. Loseby, 126-158. Aldershot, UK: Ashgate, 1996.

Watts, Edward Jay. City and School in Late Antique Athens and Alexandria. University of California Press, 2006.

Webb, Ruth. "The Aesthetics of Sacred Space: Narrative, Metaphor, and Motion in 'Ekphraseis'of Church Buildings.” DOP 53 (1999): 59-74.

. Ekphrasis, Imagination, and Persuasion in Ancient Rhetorical Theory and Practice. Farnham, UK: Ashgate, 2009.

Weber, Ekkehard. "The Tabula Peutingeriana and the Madaba Map." In The Madaba Map Centenary, 1897-1997: Travelling through the Byzantine Umayyad Period; Proceedings of the International Conference held in Amman, 7-9 April 1997, edited by Michele Piccirillo and Eugenio Alliata, 41-46. Jerusalem: Studium Biblicum Franciscanum, 1999.

Weingarten, Susan. "Road Use in Late Antique Palestine," BAR International Series 1084, no. 1 (2002): 243: 258.

Weiss, Zeev. Public Spectacles in Roman and Late Antique Palestine. Cambridge, MA: Harvard University Press, 2014.

. "Theaters, Hippodromes, Amphitheaters, and Performances." In The Oxford Handbook of Jewish Life in Roman Palestine, edited by Catherine Hezser, 623640. Oxford: Oxford University Press, 2010.

Weiss, Zeev, and Rina Talgam. "The Nile Festival Building and Its Mosaics: Mythological Representations in Early Byzantine Sepphoris." In The Roman and Byzantine Near East v. 3, JRA Supplementary Series 49, edited by J.H. Humphrey, 55-90. (Ann Arbor, MI: Journal of Roman Archaeology, 2002).

Weitzmann, Kurt. “The Mosaic in St. Catherine's Monastery on Mount Sinai.” PAPS 110, no. 6 (1966): 392-405. 
Welles, Charles Bradford. "The Inscriptions." In Gerasa: City of the Decapolis, edited by Carl Hermann Kraeling, 355-496. New Haven, CT: Yale University Press, 1936.

Weninger, Stefan, ed. The Semitic Languages: An International Handbook. Berlin: Walter de Gruter, 2012.

Werlin, Stephen H. Ancient Synagogues of Southern Palestine, 300-800 CE: Living on the Edge. Leiden: Brill, 2015.

Wilfrand, Yael. "Aramaic Tombstones from Zoar and Jewish Conceptions of the Afterlife." Journal for the Study of Judaism 40 (2009): 510-539.

Wilkinson, John. Jerusalem Pilgrims. Havertown, PA: Aris \& Phillips, 2015.

Wilson, Andrew. "Cyrenaica and the Late Antique Economy." In Ancient West and East v. 3, no. 1, edited by Gocha Tsetskhladze, 143-154. Leiden: Brill, 2004.

Witschel, Christian. "Re-Evaluating the Roman West in the $3^{\text {rd }}$ c. AD." JRA 17 no. 1 (2004): 251-281.

Wood, Philip. "Christianity and the Arabs in the Sixth-Century." In Inside-Out: Interactions between Rome and Peoples on the Arabian and Egyptian Frontiers in Late Antiquity, edited by G. Fisher and J. Djikstra, 353-368. Leuven: Peeters, 2014.

Yasin, Ann Marie. "From Roman Family to Christian Community." ArtB 87, no. 3 (September 2005): 433-457.

_. "Sacred Space and Visual Art." In The Oxford Handbook of Late Antiquity, edited by Scott Fitzgerald Johnson, 935-969. Oxford: Oxford University Press, 2012.

- Saints and Church Spaces in the Late Antique Mediterranean: Architecture, Cult, and Community. Cambridge: Cambridge University Press, 2009.

—_ "Sight Lines of Sanctity at Late Antique Martyria." In Architecture of the Sacred: Space, Ritual, and Experience from Classical Greece to Byzantium, edited by Bonna D. Wescoat and Robert G. Ousterhout, 248-280. Cambridge: Cambridge University Press, 2012.

Yon, Jérôme. "Euergetism and Urbanism in Palmyra." In Recent Research in Late Antique Urbanism, JRA Supplementary Series 42, edited by Luke Lavan, (Portsmouth, RI: Journal of Roman Archaeology, 2001): 173-18. 
Zaqzuq, Abdul, and Michele Piccirillo. "The Mosaic Floor of the Church of the Holy Martyrs at Tayyibat al-Imam- Hamah, in Central Syria.” Liber Annuus 49 (1999): 443-463.

Zayadine, Fawzi. "The Jerash Project for Excavation \& Restoration: A Synopsis with Special Reference to the Work of the Department of Antiquities." In Jerash Archaeological Project, 1981-1983, edited by Fawzi Zayadine, 7-27. Amman: Department of Antiquities of Jordan, 1986.

Zori, N. "The House of Kyrios Leontis at Beth Shean." IEJ 16, no. 2 (1966): 123-134.

Zuiderhoek, Arjan. "Oligarchs and Benefactors: Elite Demography and Euergetism in the Greek East of the Roman Empire." In Political Culture in the Greek City after the Classical Ages, edited by Onno M. van Nijf and Richard Alston, 185-196.

Leuven: Peeters, 2011. 


\section{APPENDIX I: ABBREVIATIONS}

\begin{tabular}{|c|c|}
\hline$A D A J$ & Annual of the Department of Antiquities of Jordan \\
\hline$A J A$ & American Journal of Archaeology \\
\hline$A J P h$ & American Journal of Philology \\
\hline AnatSt & Anatolian Studies \\
\hline$A S A E$ & Annales des Sevices des Antiquités de l'Égypt \\
\hline$A r t B$ & Art Bulletin \\
\hline BASOR & Bulletin of the American Schools of Oriental Research \\
\hline$B A R$ & British Archaeological Reports \\
\hline$B E ́ O$ & Bulletin d'études orientales (Damascus) \\
\hline$D O P$ & Dumbarton Oaks Papers \\
\hline$G R B S$ & Greek, Roman, and Byzantine Studies \\
\hline$H S C P$ & Harvard Studies in Classical Philology \\
\hline$H T R$ & Harvard Theological Review \\
\hline$I E J$ & Israel Exploration Journal \\
\hline$J A S$ & Journal of Archaeological Science \\
\hline$J E S H O$ & Journal of the Economic and Social History of the Orient \\
\hline$J Q R$ & Jewish Quarterly Review \\
\hline$J R A$ & Journal of Roman Archaeology \\
\hline JWarb & Journal of the Warburg and Courtauld Institutes \\
\hline
\end{tabular}




$\begin{array}{ll}\text { NEA } & \text { Near Eastern Archaeology } \\ \text { OJA } & \text { Oxford Journal of Archaeology } \\ \text { PAPS } & \text { Proceedings of the American Philosophical Society } \\ \text { PEFQ } & \text { Palestine Exploration Fund Quarterly Statement } \\ \text { PEQ } & \text { Palestine Exploration Quarterly } \\ \text { ProcBritAc } & \text { Proceedings of the British Academy } \\ \text { QDAP } & \text { Quarterly of the Department of Antiquities in Palestine } \\ \text { RBibl } & \text { Revue biblique } \\ \text { RömMitt } & \text { Mitteilungen des deutschen archäologischen Instituts, Römische Abteilung } \\ \text { TAPA } & \text { Transactions and Proceedings of the American Philological Association } \\ \text { TAPS } & \text { Transactions and Proceedings of the American Philological Society } \\ \text { VigChr } & \text { Vigiliae Christianae } \\ \text { WorldArch } & \text { World Archaeology } \\ \text { ZDPV } & \text { Zeitschrift des deutschen Palästina-Vereins } \\ \end{array}$




\section{APPENDIX II: CATALOGUE OF TOPOGRAPHIC MOSAICS IN JORDAN}

The following catalogue provides descriptions of the nine topographic mosaics and the buildings in which they were installed, as well as any surviving liturgical furnishings, other pavements, and decorations. The nine entries are presented in

chronological order. When based on stylistic evidence, prior scholars' proposed dates are reexamined and, in some cases new ones are proposed based on the evidence. The bibliography at the end of each entry is not exhaustive but references the most salient sources for the relevant archaeological information.

The buildings are described from west to east, from the entrance to the sanctuary. The mosaics are described "as seen," or from the viewer's perspective. In the case of square or rectangular pavements this means from left to right and from top to bottom. For nave pavements, this means starting in the northeast (top left) corner and moving to the southeast (top right), and continuing in this fashion down the pavement, ending in the southwest (bottom right) corner. If the mosaic is a different shape than those mentioned above, it is described from left to right (as seen) in the direction that one faces the mosaic. Borders are described from the exterior inward and in a clockwise order. The terms used to describe their geometric patterns follow the standards outlined in Le décor 
géométrique de la mosaïque romaine. ${ }^{1}$ Buildings are stylized but generally include two general ecclesiastic types: basilicas and central planned buildings. The former is represented by a rectilinear building with a pitched roof. In the catalogue, each is identified simply as a basilica and salient features are described. The latter type varies greatly and these buildings are described in greater detail.

\section{Unidentified Church, Umm al-Manabi‘ (Figure 1)}

Byzantine City: Unknown (Map 1).

Byzantine Province: Palaestina Secunda.

Mosaic Construction Date: Unknown, possibly fifth century. The inclusion of a classical personification might lead one to assume that the mosaic is early in date; however, several examples of similar motifs from the region exist that have been dated to the second half of the sixth century. ${ }^{2}$ Based on the Nile personification and walled city motif, Augustinović and Bagatti link the mosaic to sixth-century compositions with human figures engaged in hunting and fishing. They compare it to the topographic pavements from Jerash, Madaba, and Ma'in, as well as the Nilotic mosaic from al-Tabgha, Israel. ${ }^{3}$ However, more recent analyses suggest that the Ma in pavement dates to the eighth century. ${ }^{4}$ The al-Tabgha mosaic, the iconography of which more closely relates to Umm

\footnotetext{
${ }^{1}$ Catherine Balmelle, Le décor géométrique de la mosaïque romaine: repertoire graphique et descriptive des compositions linéaires et isotropes (Paris: Picard, 1985).

${ }^{2}$ L.H. Vincent, "L'église des SS. Apôtres à Mâdabâ," RBibl 11 (1902): 599; Michelle Piccirillo, "La cappella del Prête Giovanni di Khibat al-Mukhayyat (villagio di Nibo)," Liber Annuus 38 (1988): 297-315. See, for example, the personification of Thalassa (the Sea) in the mosaic from the Church of the Apostles in Madaba, securely dated to 578 by its inscription, or the personification of $\mathrm{Ge}$ (the Earth) from the Upper Chapel of the Priest John in Madaba, which has an incomplete inscription mentioning a local mid-sixth century bishop.

${ }^{3}$ Agostino Augustinović and Bellarmino Bagatti, "Escursioni nei dintorni di “Aglun," Liber Annuus 2 (1952): 288.

${ }^{4}$ Michele Piccirillo, "The Umayyad Churches of Jordan," ADAJ 28 (1994): 334; Robert Schick, The Christian Communities of Palestine from Byzantine to Islamic Rule: A Historical and Archaeological Study (London: Darwin Press, 1995), 398-399.
} 
al-Manabi' 's, is tentatively dated by inscription to the late fifth century. ${ }^{5}$ Similarly, the Nile Festival mosaic in Sepphoris, which also has a similar composition, is dated by archaeological evidence to the early fifth century. ${ }^{6}$ As such, I am more tempted to date the Umm al- Manabi' pavement to the fifth century. However, without archaeological evidence, or at least seeing the mosaic to investigate its stylistic traits, it is impossible to provide a secure date.

Religious Affiliation: The village was likely under the jurisdiction of the episcopal see at Pella. If the mosaic was constructed before 451, the metropolitan of Caesarea Maritima would have overseen this area under the authority of the Antiochene patriarch. However, if it was made after the Council of Chalcedon, it would have been under the control of the metropolitan see at Nysa-Scythopolis and the patriarch at Jerusalem.

Excavation History: The Late Antique structure has not been excavated. Nelson Glueck discovered it during his survey of the area in June, 1942. Due to the poor lighting conditions, Glueck made only cursory notes, expecting to be able to study the figural mosaic in detail after it was lifted by the Transjordan Department of Antiquities. However, it was damaged beyond repair during removal. Agostino Augustinović and Bellarmino Bagatti surveyed the site in May, 1949, and recorded details about additional mosaics in the area. They also published a sketch of the topographic mosaic (Figure 1),

\footnotetext{
${ }^{5}$ Bargil Pixner, "The Miracle Church at Tabgha on the Sea of Galilee," Biblical Archaeologist 48, no. 4 (December 1985): 201. An inscription within the sanctuary mentions the "repose" of Patriarch Martyios of Jerusalem, who died in 486. It is likely that this mosaic and the Nilotic compositions in the nave both date to same construction period.

${ }^{6}$ Zeev Weiss and Rina Talgam, "The Nile Festival Building and Its Mosaics: Mythological Representations in Early Byzantine Sepphoris," in The Roman and Byzantine Near East v. 3, JRA Supplementary Series 49, ed. J.H. Humphrey (Ann Arbor, MI: Journal of Roman Archaeology, 2002): 58-61; M. J. Versluys, Aegyptica Romana: Nilotic Scenes and the Roman Views of Egypt (Leiden: Bill, 2002), 245. Versluys outlines other mosaics with Nilotic composition from this region that are commonly dated to the fifth and sixth centuries, though largely based on stylistic evidence.
} 
which derives from a drawing provided to them from the Department of Antiquities and Glueck's original notes.

Building Plan and Furnishings: Unknown. The construction of a modern house, which incorporated the topographic mosaic as the floor of its single room and thus preserved the pavement, likely damaged the original structure. None of the surveyors make mention of visible foundations; however, several features suggest that the topographic mosaic decorated the nave of the church: it was large and rectangular in shape, and laid out in an east-west orientation, which would be consistent with a nave pavement. Furthermore, Augustinović and Bagatti's sketch indicates that the entrance to the Late Antique building was at the west end, which is also typical for a church.

Topographic Mosaic: Since the current location of the mosaic fragments is unknown, the following description is of the 1949 sketch. The mosaic is roughly $6.1 \mathrm{~m}$ long by $3.4 \mathrm{~m}$ wide. Augustinović and Bagatti mention the remnants of a triple border (about $0.44 \mathrm{~m}$ wide) which had been repaired in antiquity. The fine tesserae create a guilloche, a pattern of squares, and a floral design. ${ }^{7}$ The main field depicts a Nilotic scene, viewed as one faced the altar from the western end of the nave.

In the northeast corner is a personification of the Nile, represented by a kneeling man reaching his hand out between what might have been two flowers. It is labeled "Nile" (NI $\Lambda \omega C)$. In the southeast corner is a man's hand; this area was roughly repaired in antiquity. Below this hand is another hand holding a spear, but Glueck does not indicate if the two hands belonged to the same figure or not. ${ }^{8}$

\footnotetext{
${ }^{7}$ Augustinović and Bagatti, "Escursioni," 286.

${ }^{8}$ Glueck, "Explorations," 230.
} 
A representation of a Nilometer, $1.3 \mathrm{~m}$ high, stands in the center of the pavement. It is marked with four horizontal lines labeled with the measurements IA, IB, I $\Gamma$, and I $\Delta$, and topped with a lotus leaf. ${ }^{9}$

The northwest corner of the mosaic did not survive but an image of a church, 1.2 $\mathrm{m}$ high is set between two towers located in the southwest corner of the pavement. It is difficult to determine the style of the church plan, as the sketch indicates that the artist used the multiple perspective popular in the Late Antique period. The front of the building is depicted as a vertical rectangle, divided into three registers. In the center of each register is a square or a rectangle, representing a window or a door. The roof is triangular in shape with a square window on the pediment. Above this, the roof curves unusually and there is a depiction of a round window, probably representing the back of the church. The two lateral sides are projected slightly outward so that they can be seen. On the left side is an empty arched window and on the right are two smaller arched windows filled with lamps. At the top of each side is a triangular pediment with a square window. The part of the building in frontal perspective suggests a basilica-plan building; however, the pediments at the side might indicate a central-plan structure of some sort. The church is labeled as "Egypt" (ЕГҮПТ mosaic ground in his notes, the sketch indicates that there is a boat depicted in front of

\footnotetext{
${ }^{9}$ Glueck, "Explorations," 230. Agostino Augustinović and Bellarmino Bagatti, "Escursioni," 287. In his publication, Glueck lists four numbers on the Nilometer, while Augustinović and Bagatti mention that the column was divided into eight sections labelled with numbers from eleven to eighteen (their sketch depicts $1 \mathrm{~A}, 1 \mathrm{~B}, 1 \Gamma, 1 \Delta, 1 \mathrm{C}, 1 \zeta, \ldots, 1 \mathrm{H})$ The character " $\mathrm{C}$ " is likely a lunate $\mathrm{E}$, to which they did not add the small crossbar on the sketch. Glueck does not mention the lotus top in his publication.

${ }^{10}$ Packard Humanities Institute Inscriptions, accessed February 27, 2015, http://epigraphy.packhum.org/search?patt=\%CE\%B5\%CE\%B3\%CF\%85\%CF\%80\%CF\%84. The spelling "ЕГҮПТ $[\Sigma]$ ” instead of "АІГҮПТО $\Sigma$ " is uncommon but not unknown in Late Antique contexts. The Packard Humanities Institute's online database includes seven texts in which the the word is spelled with an epsilon instead of an alpha and two more using the spelling "A $\varepsilon \gamma v \pi \tau \tau o \varsigma$." In Late Antique contexts, the omega and omicron were used interchangeably.
} 
the church, as well as a fish amongst the waves. A cistern, presumably modern, disturbs the southwest corner of the mosaic.

Other Mosaic Decoration: Augustinović and Bagatti describe several fragments of geometric mosaic, some of which were repaired in antiquity, but only mention their locations in relation to modern structures, not the Late Antique topographic mosaic or the building that housed it. ${ }^{11}$ As such, it is impossible to determine which, if any, belongs to other areas within the church.

Current Location of Topographic Mosaic: The main field of the pavement was destroyed during removal in 1942; at the time of this writing, the location of the fragments is unknown.

\section{Bibliography:}

Augustinović, Agostino, and Bellarmino Bagatti. "Escursioni nei dintorni di 'Aglun." Liber Annuus 2 (1952): 285-289.

Glueck, Nelson. "Explorations in Eastern Palestine, IV Part I: Text.” AASOR 25/28 (1951): 229-230.

II. Church of St. John the Baptist, Jerash (Figures 2-11, Plans 1-3)

Byzantine City: Gerasa (Map 1, Plan 1).

Byzantine Province: Arabia.

Mosaic Construction Date: 531. A date of December, 531 has been established for both the completion of the building and its decoration, based on the dedicatory inscription located in front of the chancel area. The decorations of adjoining buildings are dated by inscription to $529 / 530$ for St. George and 533 for Sts. Cosmas and Damian.

\footnotetext{
${ }^{11}$ Augustinović and Bagatti, "Escursioni,” 286.
} 
Religious Affiliation: In 531, Gerasa was an episcopal see under the metropolitan at Bosra and fell under the authority of the Antiochene patriarch.

Excavation History: The church and the buildings that flanked it were excavated between March 20 and May 30, 1929, as part of the joint excavations of Yale University and the British School of Archaeology in Jerusalem. This triple church complex accounts for three of the fourteen churches that have been discovered to date, at least seven of which were constructed in the Justinianic period.

Building Plan and Furnishings: St. John the Baptist is the central building of a triple church complex (Figure 2, Plan 2), which includes Sts. Cosmas and Damian to its north and St. George to its south. ${ }^{12}$ The three buildings share a colonnaded porch on the west side, which is decorated with a different red and white geometric mosaic in front of the entrance to each church; three octagonal stoups were also found here. Three doors lead from the atrium to St. John the Baptist: a large central entryway flanked by two smaller ones.

Like other churches at Jerash, St. John the Baptist (Plan 3) incorporates stones from earlier structures. It measures $29.5 \mathrm{~m}$ long by $23.8 \mathrm{~m}$ wide and has a modified central plan that mimics that of the cathedral church at Bosra: both buildings have a circle inscribed with a square plan, with four exedrae in the corners, though St. John the Baptist is smaller in scale. ${ }^{13}$

\footnotetext{
${ }^{12}$ John Winter Crowfoot, The Churches at Jerash: A Preliminary Report of the Joint Yale British School Expeditions to Jerash 1928-1930 (London: The (Archaeology) Council, 1931), 20. Crowfoot identifies the churches that flank St. John the Baptist as "parakklesia." This term is both anachronistic and incorrect, as a parakklesion is a side chapel that became a popular feature of churches in the mid and late Byzantine periods.

${ }^{13}$ Crowfoot, Churches at Bosra, plate 2. The church at Bosra measures $50 \mathrm{~m}$ x $38 \mathrm{~m}$.
} 
St. John the Baptist's two smaller doors lead from the atrium to the northwest and southeast exedra, which were roofed with tufa, while the larger one opens into the main space. The north and south walls of the central area each contain two small niches. Rows of holes in the walls show that they were originally covered with stone or marble revetment, while archaeological evidence suggests that the exedrae walls were decorated with mosaic. The central square is formed by four spoliate Corinthian columns, the sole interior support for what was likely a timber-domed roof. To the east, fittings for a chancel screen sit in front of a horseshoe-shaped apse, though the screen does not survive. Similarly, no altar or ambo were discovered, though one support for the latter was found in an unspecified location in the nave. Like the exedrae, mosaic originally covered the apse walls, which was roofed with tufa. There is evidence of tiers of seats for a synthronon in the apse, though it has not survived.

To the north of the central apse is a small, apsidal room that opens to both the central apse of St. John the Baptist and the south aisle of Sts. Cosmas and Damian. Excavations revealed that it was originally used as a chapel flanked by two small side rooms decorated in mosaic. At some point the chancel screen was removed and replaced with a baptistery. Marble laid in a cross-shaped pattern decorates the floor under the font. After the baptistery was installed, a set of stairs was constructed in the south room over the mosaic, which created an entrance to the street on the east wall.

A doorway in the room to the south of the central apse provides access to both the apse and the southeast exedra; however, an entrance to St. George's was blocked at some point in antiquity. The room adjacent to the apse presumably served as a sacristy for both 
St. John the Baptist and Sts. Cosmas and Damian. The northeast quarter is raised one step above the rest of the floor, and is paved in large, plain white tesserae.

Topographic Mosaic: The topographic pavement serves as a wide inner border that surrounds the mosaic in the central square. The border measures $2.5 \mathrm{~m}$ at its widest points, in the middle of all three sides. A register of badly damaged walled city motifs survive to the north and south of the central mosaic panel; a lower register with a river scene remains only in the southeast corner. While no images survive from the western side, the excavators mention a single fragment of mosaic of the same type, which probably indicates that the register was a continuous scene that ringed the central space to the chancel screen. The band consists of a series of architectonic motifs on a hatched ground line, below which are fragments of a river populated with plants, birds, and fish. One must face towards the interior of the church to view the motifs.

On the north side, three distinct architectonic groupings survive of what was possibly originally four. In front of the northeast exedra is a brick double-shelled hexagon plan building with curtained windows on the two visible sides (Figure 3). The interior hexagon supports a peaked roof with clearstory windows. Attached to the building is a tall square column, similar to the towers depicted on walled city motifs. To the west of this structure is a monumental arch, flanked by two tall fruit trees, with a window at its center; a lamp hangs from the keystone.

To the west of this motif is a partially preserved walled city motif with two arched gates and four towers, flanked by a fruit tree and a date palm (Figure 4). Within the walls are a large domed structure supported by two arches and a basilica with a parted curtain 
at its entrance. Dividing this and the final walled city on the north side is a field of one fruit tree and three date palms.

The next city motif, in the center of the northern side, contains the only label: "Alexandria (A $\Lambda$ E $\Xi A N \triangle P I A)$ (Figure 5). ${ }^{14}$ It is difficult to determine if any of the other images originally had toponyms as the register is badly damaged. Alexandria is the largest and most ornate city of those that have survived, with nine towers and an arched gate adorned with two columns and a lamp. There are five structures depicted within the city walls. On the left is a domed building topped with a cross and a clerestory at its base. Behind the dome is a colonnade with three columns. To the right of this is a basilica with six small Greek crosses on the roof. At its front is an open door and a square window on the pediment, while on the side there are two square windows. To the right of this building is a large domed structure with a spire at the top and two large arches at its sides. Directly in front of the arches are two short square buildings. If they are part of the domed structure, they form a cruciform building but it is also possible that are depictions of individual structures. To the right of the dome is another basilica with a round window on its pediment and a large Greek cross on the roof. The front door is depicted as a square and a rectangle with a diamond pattern. There are two small, square windows on the side of the basilica. Two large deciduous trees are behind the city, flanking the toponym. A small palm tree to the west of the city stands next to a tall square tower, topped with a dome. There is room for another motif on the north side but the section does not survive.

On the south side of the church, the first motif to survive is in the center of the panel, directly across from the depiction of Alexandria. It is a walled city with six towers and two arched gates, each with a colonnade visible inside (Figure 6). Unlike the

\footnotetext{
${ }^{14}$ The letters " $\Lambda E \Xi$ " of this inscription are written in the miniscule " $\lambda \varepsilon \xi$."
} 
depictions of walls on the other motifs, which have rectangular bricks, a portion of the top of the back wall contains a meander with double returns.

A basilica stands at the center of the city, with two ornate doors, a small round window at the front, and one large window at the side. It the left of this building is a colonnade with three columns; to its right is a small basilica. This building has a small round window on its pediment, a large rectangular window on the side, and a cross on its roof. In the background is a large rectangular structure with a central cross at the top of its façade. In front of building is a tall rectangular entranceway with a cross on its flat roof. Behind this are three deciduous trees, beyond the city walls.

To the east of this city motif is a section of loss, followed by the lower portion of a male figure, walking to the right between two trees (Figure 7). He wears sandals and a short blue and white striped tunic with two orbiculi on the hem. The foot of an animal that he is leading (most likely a camel, based on the hoof) is shown in front of the tree. Immediately to the east of this figural group is a badly damaged walled city (Figure 8). Only the front portion remains, with three towers and an arched gate filled with a colonnade represented by one column. Below this scene is the only portion of the second register to survive. It contains a depiction of a river. On the banks are a row of plants and two sets of alternating herons and ducks. In the water are two more ducks and six fish. Other Mosaics: The entire building, up to the chancel screen and including the exedra, has a wide border. The outermost band of this consists of a row of semis of black poised crosslets on a white ground, followed by a thin band with a simple meander on a dark ground. Then there is a wide band with an inhabited acanthus scroll, bordered by a single row of white tesserae (Figure 9). Within the scrolls are humans, animals, and birds. Some 
scrolls were meant to be read as a pair, as with the fanciful depiction of a man leading an animal (destroyed and repaired) on a string, or a dog chasing a rabbit. The last, smaller band contains a polychrome, three-dimensional crinkled ribbon in frontal perspective interspersed with crosslets.

In the exedrae, only the southeast and part of the northeast mosaics survive. Each contains a fanciful depiction of a lamp, constructed from human figures, acanthus leaves, storks holding lamps, and grape vines. The northeast and southeast exedrae contained semi-circular niches filled with mosaics; only the southeast survives (Figure 10). It contains two birds facing a plant, bordered by a swastika-meander with recessed and reversed returns.

The final mosaic is located within the central square. On each side, between the Corinthian columns, is a border of figural panels alternating with a swastika-meander of alternate double-turned and recessed reverse-returned swastikas. Of the sixteen panels, only the toponyms for three partially survive: ПA[NHM]O $\Sigma$ (June) and A $\Omega \mathrm{O} \Sigma$ (July) on the two south-most sections of east side and $\Delta[\mathrm{IO}] \Sigma$ (October) in the center of the south side. It is assumed that the panels contained personifications of the twelve months and four seasons. The excavator's reconstruction shows all the toponyms facing outward, except on the west side; however, it is more likely that all four sides were oriented in the same direction, requiring a viewer to stand within the square and look out.

Inside this border, on the east side, is a rectangular tabula ansata measuring $0.5 \mathrm{~m}$ high by 4.9 m long with round decorations on each side (Figure 11). There is a dedicatory inscription in (mostly) iambic trimeter within, viewed from the center square facing east:

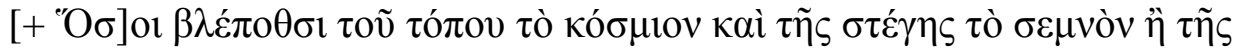

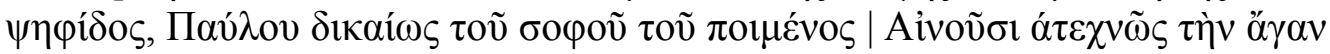




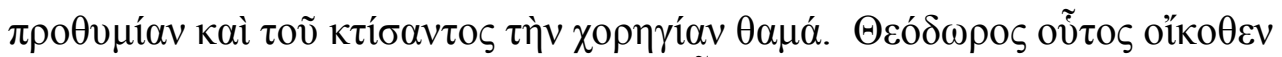

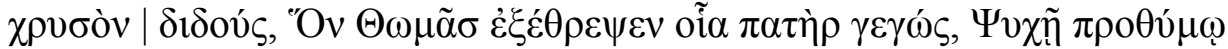

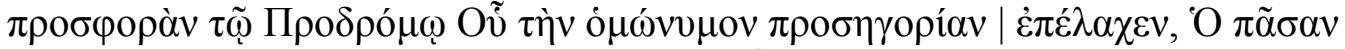

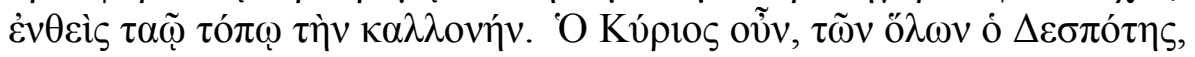

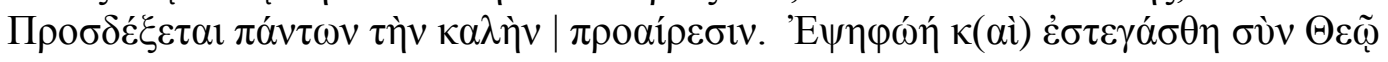

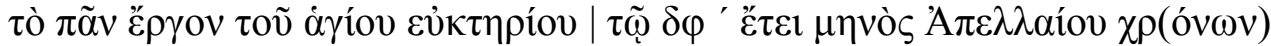
$\delta \varepsilon \kappa \alpha ́ \tau \eta \varsigma$ i $\delta \iota \kappa \tau(1 \tilde{\omega} \vee \mathrm{o})$.

Those who see the decoration of the place and the magnificence of the roof (ceiling?) and of the mosaic work, justly and frankly praise the extraordinary zeal of the wise Bishop Paul and together with the procurements of the founder. This [the founder] is Theodore, raised by Thomas, who acted as his father, the donor who with ready spirit and his own gold made an offering to the Precursor [St. John] who gave him the same name. It is he that has conferred all the beauty on the place. Therefore, the Lord, the Father of all things, will accept the good intentions of all. The entire edifice of the holy chapel was covered with mosaics with the help of God in year 594 in the month of December in the tenth indiction. ${ }^{15}$

Below the inscription, in the center square, is a thin wave border surrounding the

main field. In each corner was a krater from which sprouted grape vines that formed inhabited scrolls; only the northeast krater survives, along with the front feet and part of the body of an animal in the southeast corner. A few vines remain along the east side.

\section{Bibliography:}

Crowfoot, John Winter. Churches at Jerash: A Preliminary Yale-British Expeditions to Jerash 1928-1930. London: British School Archaeology of Jerusalem, 1931.

Kraeling, Carl Hermann, ed. Gerasa: City of the Decapolis. New Haven: American Schools of Oriental Research, 1938.

\footnotetext{
${ }^{15}$ Yiannis E. Meimaris, Chronological Systems in Roman-Byzantine Palestine and Arabia: The Evidence of the Dated Greek Inscriptions (Athens: FNRS Athenes, 1992). The dates in the inscriptions relate to the Gerasene calendar. December, in the tenth indiction equates to December, $531 \mathrm{CE}$. Meimaris provides an excellent resource for understanding the various cities' calendars and indiction dates.
} 
III. Church of Sts. Peter and Paul, Jerash (Figures 12-16, Plan 4)

Byzantine City: Gerasa (Map 1).

Byzantine Province: Arabia.

Mosaic Construction Date: Mid-sixth century. The church's inscriptions mention the donor Anastasios, for whom no information has survived. The excavators note the similarities in plan and stylobate size between Sts. Peter and Paul and the Church of Procopius (dated by inscription to 526/7) and the theme and style of the decorations of St. John the Baptist (dated by inscription to 531). However, they consider the mosaics of Sts. Peter and Paul to be inferior and, from this, determine that this church must post-date the others. As such, they suggest that Anastasios must have been the successor to Bishop Paul, who is mentioned in both other church inscriptions. This leads them to date Sts. Peter and Paul to c. $540 .^{16}$

Based on textual information not related directly to the site, Pierre Gatier makes an interesting argument for a later date for the church. In a letter sent from Pope Gregory I in Rome to a certain Marianos, "bishop in Arabia" in 601, he grants the translation of relics to the east. The only known Arabian bishop named Marianos is mentioned in a church inscription in Jerash that dates to 570. Gatier suggests that the unnamed relics that Marianos requested were those of Peter and Paul but that he the bishop died before building a church dedicated to the two saints. Therefore, his successor Anastasios was left to the task. ${ }^{17}$ Gatier's argument would be stronger if the saint(s) in question were named in the letter, as other options (such as Laurence) are possible. The fact that

\footnotetext{
${ }^{16}$ John Winter Crowfoot, "The Christian Churches," in Gerasa, City of the Decapolis, ed. John Winter Crowfoot (New Haven, CT: American School of Oriental Research, 1938), 251.

${ }^{17}$ Pierre-Louis Gatier, "Une letter du pape Grégoire le Grand à Marianus éveque de Gerasa," Syria 64, no. 1/2 (1987): 131-135.
} 
portions of two reliquaries within the building, which Gatier does not mention, perhaps strengthens his case. However, it is highly unusual for a bishop not to include his title in the church's dedicatory inscription.

A stylistic date of c. 540 seems too precise, since Bishop Paul was still active at this date, and this should possibly be adjusted to the mid-sixth century ${ }^{18}$

Religious Affiliation: Gerasa was an episcopal see under the metropolitan at Bosra, and fell under the authority of the Antiochene patriarch.

Excavation History: The church was excavated between March 20 and April 11, 1929, as part of the joint excavations of Yale University and the British School of Archaeology in Jerusalem.

Building Plan and Furnishings: The church is separated from the majority of the churches, which are clustered in the center of the city, and is located to the southwest, near the city walls in an area reserved for burials (Plan 1). The basilica has a triple-apse inscribed in a rectangle plan and is approximately $31.8 \mathrm{~m}$ long by $18.5 \mathrm{~m}$ wide (Figure 12, Plan 4). As was typical at Jerash, Sts. Peter and Paul was built stone reused from earlier monuments. The atrium and portico are badly preserved. The atrium (not shown on the plan) has two entrances on the north side: a small one near the Ionic colonnade and a larger one to the west, which is about $4.0 \mathrm{~m}$ wide and flanked by two niches. A passage in the southwest corner of the atrium leads to a cave under the city wall. The excavators' plan shows a tentative reconstruction of the portico that includes an Ionic colonnade paved with octagonal and square stones.

From the porch, a door to the north leads to the antechamber of a small chapel, $8.7 \mathrm{~m}$ long by $5.5 \mathrm{~m}$ wide. The main room of this chapel, which measures $6.2 \mathrm{~m}$ long by

${ }^{18}$ Ibid., 299. Paul is recorded as the patron of a new prison in Jerash in 539/540. 
$5.5 \mathrm{~m}$ wide, has an apse at the east end that is separated from the rest of the space by a chancel screen which was still in situ when excavated but has since been removed. A small niche is found in the center of the apse. The floor, which is badly preserved, was paved with stone and marble.

There are three entrances into the church from the porch, one that opens into each aisle and a slightly larger one that leads to the nave. The roof was supported by eight spoliated Corinthian columns of varying heights on each side of the nave. ${ }^{19}$ The walls of the aisles were plastered and painted with a floral design, only a small portion of which survived (it has since been removed). At the western end of each aisle is a doorway. On the north, this leads to the chapel described above; directly across from this, on the south side, it lead either to an exterior porch or small room. It is impossible to tell from the remains.

At the southeast end of the nave, in front of the chancel screen, remains of a large ambo with at least three stairs were found. Two limestone panels which decorated the platform were found in the nave, each with an interlace design. The chancel screen separates the apses from rest of the church. It crosses the seventh bay at the nave and the last bay in the aisles. It is made of limestone on the south side and a shale-like material on the north. The south side was particularly well-preserved, with two plain panels and three posts in situ; they have since been removed.

\footnotetext{
${ }^{19}$ Crowfoot, Early Churches in Palestine, 68. While the use of spolia from Roman buildings was common practice in Late Antique Jerash, Crowfoot notes the high quality of the decoration of this church but is surprised by the different heights of the spoliated columns. He suggests that the mismatched columns indicate that the reserve of second- and third-century materials had run dry and that Anastasios was forced to use a mixture from various buildings. This opinion reflects a modern preference for "matched sets" that was not necessarily shared by Late Antique patrons. However, if this was the case, it might be further evidence to assign Sts. Peter and Paul with a date later than c. 540.
} 
The stylobate is raised one step above the nave and accessed through a central opening in the chancel screen. The holes for two tables are located at the rail in the northwest and southwest corners of the stylobate. The floor of this area was paved in stone but only a small portion in the north apse survives, with a pattern of a circle surrounded by four octagons. The walls of the north and south apses have traces of plaster and contain shell niches. The ceilings in these areas were covered with coarse, white tesserae.

The wall of the central apse originally had revetment, though none survives, and the ceiling was decorated with glass tesserae. A synthranon with two rows of seats ringed the apse. Above the synthranon, in the center of the apsidal wall, was a relief carving of a cross within a circle; it has been removed since its discovery. A reliquary was found within the apse, which the excavators suggest marks the location of the altar, for which no evidence survives. The square stone box, which was originally covered in marble, was fixed to the floor. Inside there are three rectangular niches, though the relics were not found. It is assumed that the altar table would either have been placed above this reliquary or directly in front of it. The cover of a second reliquary, decorated with a cross in the center and pierced with a hole, was also found in the church.

Topographic Mosaic: The topographic mosaic decorates the nave of the church and viewers would have to face the chancel screen when viewing the pavement (Figure 13). An acanthus scroll border likely survived in the southwest corner and the middle of the southern border. It has since been removed. A small portion of the east border suggests that there were personifications of a meander pattern alternating with personifications of the seasons. In the north corner was summer, indicated by the toponym @EPINH and the 
tops of wheat sheaves. Next to this was a portion of a meander; both motifs have now disappeared.

The main panel was divided into three registers, each measuring $5.2 \mathrm{~m}$ high by $8.0 \mathrm{~m}$ wide. Each was bordered with a serrated single filet. Only the lower portion survives of the easternmost register survives. It consists of a grape vine scroll issuing from a krater decorated with a meander pattern. The vine scrolls were likely inhabited but not enough survives to be certain.

The lower two thirds of the central register is lost; however, the depictions of two labeled cities survive in the upper third. At the center of the top of the panel is a tabula ansata, measuring $0.7 \mathrm{~m}$ high by $3.7 \mathrm{~m}$ long, with stylized ivy leaves at the sides. The dedicatory inscription within reads:

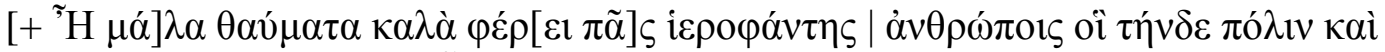

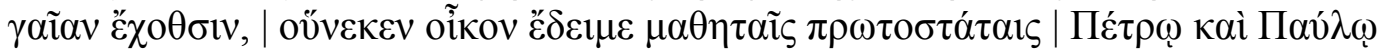

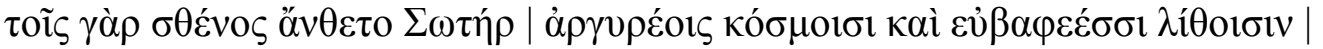

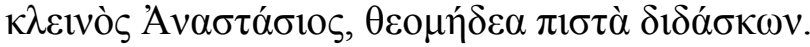

Certainly, my hierophant brings beautiful marvels to the people who inhabit this city and land, because he built a house (of worship) to Peter and Paul, the chiefs of the disciples (for the Savior imparted the authority to them), and adorned it with silver and beautifully colored stones; the renowned Anastasios who teaches the true precepts of God.

Below the inscription on a white ground, from the left, is a large fruit tree that bends towards the city next to it. There is an area of loss to the right but it must have contained a depiction of the lighthouse of Alexandria, the toponyms remains: "Pharos" (ФАРОС). To the right of this is a city labeled A $\Lambda$ EXAN $\triangle P I A$ (Figure 14). The motif is about $1.1 \mathrm{~m}$ high and $2.2 \mathrm{~m}$ wide. The rightmost section has not survived but seven towers of what must have been eight on octagonal walls are extant. The bricks are depicted in a distinct fashion, quite different from those in the Egyptian city motifs of St. 
John the Baptist in the same city; each square is particolored diagonally with brown and white or grey and white. At the top of the wall is a border with a vine scroll pattern. The towers have no windows and are shown from an angled perspective to show the tops with space for a guard. One semicircular gate to the city is shown on the left side with two angled colonnades visible from the opening.

While the exterior walls are different, the buildings inside are very similar to those from St. John the Baptist in number and design, if not style. At the left is the roof of a basilica with a pitched roof, shown on a diagonal to show both the façade and the side of the roof. The roof is hatched with white horizontal and vertical lines to indicate tiles. The façade has a circular window in the pediment and three square windows on the entablature. To the right of this is a circular building consisting of three columns that support a domed roof. The drum of the dome is pierced with windows and the tip of the dome has a cross or perhaps another ornament. In front of this building is a very small basilica with a pitched roof, shown from the side. Like the first, it has white horizontal and vertical lines to indicate tiles. It has two square windows along the side entablature and a square window in the pediment. To the right of the domed building is another basilica, shown front the front. There is a curtain tied back at the front door and a circular window on the pediment. Three small white crosses are on the roof. To the right of this is a large domed building with three columns supporting large arches. A gold ornament sits atop the tiled roof. The bottom of this building has been lost. To the right of this building is another basilica roof. No tiles are indicated but there is a round window on the pediment. The area below and to the right of this is lost but there was likely a second gate depicted here. Behind the city is another fruit tree. 
Between the cities are the tops of two fruit trees above the area of loss. To the right of this is another city, labeled "Memphis" (..МФН.) (Figure 15). It measures approximately $2.4 \mathrm{~m}$ high by $1.9 \mathrm{~m}$ wide. The exterior is similar to Alexandria's, with octagonal walls depicted with the same particolored diagonal design, eight towers, and two semicircular gates with angled colonnades within. Inside the city, on the left, is a pitched roof of a basilica, shown on an angle. There is a Greek cross on the pediment and black horizontal and vertical lines on the white roof to indicate tiles. To the right of this church is larger basilica, also shown on an angle. There is a large rectangular door on the façade and a circular window on the pediment above. The roof is divided into six tiles. To the right of this is a circular structure with a pitched roof supported by three columns; the drum is pierced with windows. To the right of this is a fourth basilica with a pitched roof. The red roof is divided into tiles and the pediment has a square window. To the right of the city is another fruit tree.

Both cities sit on an irregular ground line. Below this was a row of aquatic plants but only a small section survives. It is likely that below this was a depiction of the Nile but one cannot be certain. In the center of the very bottom of this panel a fragmentary inscription survives. It is possibly also in a tabula ansata that measures at least $0.4 \mathrm{~m}$ high by $1.4 \mathrm{~m}$ long (Figure 16):

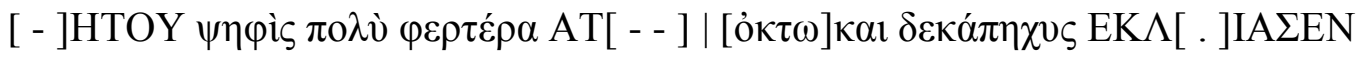

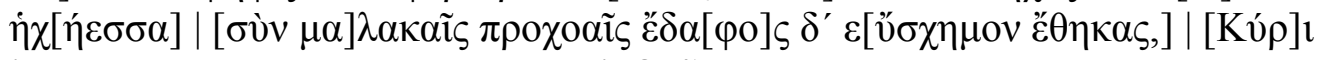

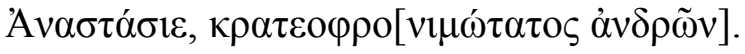

Mosaic, upon whom do you lie? You who completes these buildings. According to whose account do you recount these deeds? The name Anastasios is the four cities, the prayable Savior. 
The westernmost register is completely destroyed, save for a section of vine in the southeast corner and a portion of a krater in the southwest. The panel likely had four kraters in the corners with vine scrolls filling the space. It is impossible to know if they were inhabited or if any other motifs were used in the composition.

Other Mosaics: Both the north and south aisles were paved with geometric mosaics. Only a portion of each survived in the east end of the church and these have deteriorated greatly since they were exposed. Both sides are bordered by meanders alternating with squares filled with geometric designs. The north side contains a grid of scalloped edged squares, three across, quartered diagonally by single filets. The colors include orange, yellow, violet, dark red, brown, and black. On the south there is a grid of serrated filets of squares of four tesserae filled with circles, squares, and a large foliate motif. The colors used are the same as above.

At the east end of the north aisle, an inscription is written addressed to the mosaic:

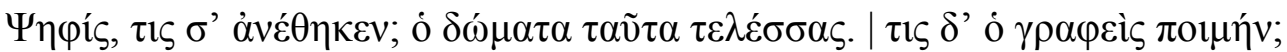

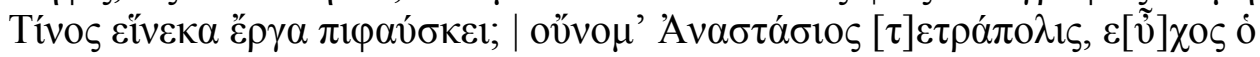
$\Sigma \omega \tau \eta ́ p$.

Mosaic, who has offered (you)? He who has funded the building. And who is the shepherd who is painted? For whom do these works shine? His name is Anastasios, praise the Savior.

The inscription suggests that Anastasios was depicted, either in a wall painting or on a mosaic within the building.

Current Location of the Topographic Mosaic: The pavement is currently on display at the Yale University Art Gallery in New Haven, Connecticut. 


\section{Bibliography:}

Crowfoot, John Winter. Churches at Jerash: A Preliminary Yale-British Expeditions to Jerash 1928-1930. London: British School Archaeology of Jerusalem, 1931.

Kraeling, Carl Hermann, ed. Gerasa: City of the Decapolis. New Haven: American Schools of Oriental Research, 1938.

IV. Church of the Map, Madaba (Figures 17-27, Plan 5)

Byzantine City: Madaba.

Byzantine Province: Arabia.

Construction Date: Unknown, Mid-sixth Century. No inscriptions containing dates were found. The mosaic has been dated, based on the inclusion of a depiction of what is believed to be the Nea Church, to no later than 543. This is a challenging connection because the mosaic is used to confirm the identity and location of the Nea Church. ${ }^{20}$ Nevertheless, stylistic comparisons with other mosaics in the region provide the most commonly accepted date at present time: the mid-sixth century. ${ }^{21}$ Religious Affiliation: Madaba was a bishopric under the control of the metropolitan at Bosra and the authority of the Jerusalem Patriarch.

Excavation History: The remains of the church were first recorded by Gottlieb Schumacher in 1891; however, the mosaic was not discovered until work began on the construction of a modern Greek Orthodox church over the remains of the Late Antique structure. No archaeological excavations were ever conducted at the site.

\footnotetext{
${ }^{20}$ See, for example, Michael Avi-Yonah, The Madaba Mosaic Map (Jerusalem, Israel Exploration Society), 57.

${ }^{21}$ Andrew Madden, “A New Form of Evidence to Date the Madaba Map Mosaic,” Liber Annuus 62 (2012): 495-513. Madden provides a summary of the more recent attempts to date the Madaba mosaic, as well as a new method for corroborating this date based on stylistic comparisons to the natural and architectonic motifs in the mosaic of Sts. Lots and Procopios at Khirbat al-Mukhayyat.
} 
Building Plan and Furnishings: The exact size and layout of the original church is greatly disputed and several plans have been suggested (Plan 5). The new church has obscured any indication of the original building's plan. However, both Schumacher and Father Paul Séjourné, who saw the remains in 1892, record that it had a three-aisle basilica plan with a single entrance on the west façade. The nave was divided by two rows of four Corinthian columns on each side. The early explorers agree that the building had a central apse but differ in their suggestions for the ends of the aisles.

Both Schumacher and Séjourné also note a small rectangular annex to the southwest of the church, accessed from a doorway in the church's south wall; Séjourné indicates that the east wall of this structure was apsed, while Schumacher does not. In turn, Schumacher is the only one to mention a cistern at the western end of the nave, as is found at the unidentified church at Umm al- Manabi‘.

Topographic Mosaic: A full description of the mosaic is outside the scope of this project; other sources provide detailed listings of the 150 sites labeled on the pavement (Figure 17). ${ }^{22}$ Instead, this overview focuses on the salient features of the composition, especially the ten extant city motifs. The description follows the mosaic's orientation within the building, which is from east (top) to west (bottom) and from north (left) to south (bottom). One would face the altar as one viewed the mosaic, which is laid out so that the depicted cities are oriented within the church as they are in the region.

\footnotetext{
${ }^{22}$ Adolf Schulten, Die Mosaikkarte von Madaba und ihr Verhältniss zu den ältesten Karten und Beschiebungen des heiligen Landes (Berlin: Weidmannshche Buchhandlung, 1900); Avi-Yonah, Madaba; Eugenio Alliata, "The Legends of the Madaba Map," in The Madaba Map Centenary 1897-1997: Travelling through the Byzantine Umayyad Period, Proceedings of the Conference Held in Amman, 7-9 April 1997, ed. Michele Piccirillo and Eugenio Alliata (Jerusalem: Studium Biblicum Franciscanum, 1999), 47-101.
} 
The extant mosaic is roughly $5.0 \mathrm{~m}$ high by $10.5 \mathrm{~m}$ wide, though there are large areas of loss. The fragment on the north wall is bisected by the modern wall, indicating that the original mosaic, and church, was wider than the present one. The pavement includes 151 sites from the Holy Land and Egypt, from Charach Moba (al-Kerak) in the east to the Mediterranean in the west and from Sarepta (in modern Lebanon) in the north to several towns along the Canopic branch of the Nile in the south. Reports from the 1890s suggest that the original area depicted was much larger and included depictions of Ephesus and Smyrna on the southwest coast of Turkey. ${ }^{23}$ If this was depicted at the same scale as the extant composition, it would almost double the size of the pavement, and extent it considerably to the north and west.

With the exception of the ten cities described below, the sites are generally represented in a schematic fashion: small cities have walls with four or five towers as well as the roofs of buildings; large villages have walls and three or four towers; and smaller villages with two towers flanking a city gate. Some sites are represented by a single building, often a basilica with a red-tiled pitched roof. ${ }^{24}$ The significance of the represented places varies from those with biblical significance to contemporary cities. All of the sites are labeled, sometimes along with descriptions or alternate names. Also included in the extant mosaic are toponyms for five of the regions of the Twelve Tribes of Israel. No roads are represented but geographical features are, including mountainous regions, waterways, animals, and plant life. Some like the Dead Sea and branches of the

\footnotetext{
${ }^{23}$ Caspar René Gregory, “The Mâdaba Map,” The Biblical World 12, no. 4 (1898): 245.

${ }^{24}$ Avi-Yonah, Madaba Mosaic, 21-23; Noël Duval, "Les représentations architecturales sur les mosaïques chrétiennes de Jordanie," in Les églises de Jordanie et leur mosaïques: actes de la journée d'étude organisée le fevrier 1989 au musée de la Civilisation gallo-romaine de Lyon, ed. Noël Duval (Beirut: Presses de l'Institute français du Proche Orient, 2003), 211-285. This semiotic system for displaying different sized communities is first discussed by Michael Avi-Yonah but it echoed in Noël Duval's research on architectonic motifs.
} 
Nile, are geographically accurate, while others seem to be used to fill empty spaces. Figural images have suffered iconoclastic damage. At some point, parts of the mosaic were also damaged by fire.

There are ten cities depicted on the mosaic that are more detailed than the rest. In the eastern extremity of the extant mosaic is Charach Moba [XAPA]XM $\Omega$ B[A] (Figure 18). It is depicted on a hill, surrounded by a low, circular city wall. The northernmost portion does not survive. The south gate and its towers are shown flattened on the right in order to display the arched entryway. Another rectangular tower is shown in the background. In the center of the city are two arched colonnades, one in front of the other. To the left of the second one is a basilica building, angled to the right to show both the façade and side. The building has an arched doorway at the front and two square windows at the side. Its pitched tiled roof is depicted with red, vertical stripes. Next to the gate is another basilica depicted in the same fashion. In front of this is a small, square building with square windows on two sides.

The next city is northwest of the Dead Sea: Neapolis (NEAПО $\Lambda$ IC) (Figure 19). This depiction has been damaged by fire but details of the partially extant. Two colonnades bisect the city, at the middle of which stands a small domed building supported by columns. Along the back wall, the colonnade leads to an arched city gate, flanked by two towers. A building to the right of this colonnade bears a red Greek cross on its roof. In front of this building is a square arch and to the right of the arch, a dome turned on its side.

To the south of Neapolis is Jerusalem (Н АГIA ПО $\Lambda$ IS IEPOUCA[ $\Lambda \mathrm{HM}]$ (Figure 20). It is the largest and most detailed depiction of the cities. It is oblong in shape 
and ringed with wall with sixteen extant towers. The north gate, represented by a flattened arched opening flanked by two towers, opens onto an oblong courtyard with a single column: the mile marker of the city. From here, a double filet of white and yellow represents the Cardo Maximus that almost completely bisects the city. It is flanked on either side with unarched colonnades topped with red roofs. Halfway along the lower one, the colonnade is interrupted by four lines, representing steps, and a rectangle with a rectangular door flanked by square windows. Below this is the pitched roof of a basilica, with a red grid representing roof tiles and an upside down gold dome. This is likely the Church of the Holy Sepulcher. To left of the church, below the colonnade, are seven small buildings, three of which are likely churches because of their red tiled roofs. To the right of the Holy Sepulcher is two more small buildings, one a church. From a small gate in the wall, another road leads into the city and then turns right, leading to a large basilica. The church is shown in such a way to show both sides of the pitched, tiled roof, the façade, and one side. The road leads to the side, on which are two rectangular doors or windows. The façade has two closed doors and a small, round window on the pediment. To the right of this church is a small square building with a red roof, perhaps another church or possibly an annex. Bounded by the road, the basilica and the wall are five more small buildings, one of which has a red roof and is likely a church.

At the end of the second colonnade is another basilica, which fronts onto the cardo. Its façade has a closed double door and a pitched tiled roof with a grid-shaped pattern. This is the building that has been identified as the Nea Church. ${ }^{25}$ Between this church and the south wall are three more small, indistinguishable buildings. A second roadway, also with yellow and white single filets, curves from the north courtyard to the

\footnotetext{
${ }^{25}$ Avi-Yonah, Madaba, 51.
} 
south, parallel to the city wall. In the space between the road and the second colonnade are six small buildings, two of which are basilica churches. Behind the road is another colonnade, which is bisected by the street that leads to the east gate. Three buildings stand behind each section of colonnade, including one basilica on each side. The east wall of the city is topped with t-merlons. A small portion of the southeast section of the city does not survive.

Directly to the west is Diospolis, labelled with three names: "Lod also Lydea, and Diospolis" $(\Lambda \Omega \Delta$ HTOI $\Lambda$ Y $\Delta \mathrm{EA} H \mathrm{~K}(\mathrm{AI}) \Delta \mathrm{IOC} \Pi \mathrm{O} \Lambda \mathrm{IC})$ (Figure 21). It is shown without walls. An unidentifiable structure is at the left of the image, where there is an area of loss. Behind this is likely a basilica, shown with a red Greek cross on the roof, which is supported by three columns. To the right of this is a roofed colonnade that angles back to the right. It is met by a curving colonnade that has been flattened to show both the red roof and the columns. Parallel to this is a curved street made from a white and yellow single filet. Behind the road is a large basilica, angled to the right to show both the front and the side. It has a square, open door and a small window in the pediment. Its pitched roof is marked with a red Greek cross and there are two square windows on the side of the building. To the right of the church are three irregularlyshaped buildings.

Just to the south of Diospolis is Iamnia, also recorded as Iabneel (IABNH $\Lambda \mathrm{H}$ KAI IAMNIA) (Figure 22). It is depicted with a large basilica in the center, ringed by a six of small, flat, rectangular structures, two of which have Greek crosses on their red roofs and therefore might be churches. In the back is a tall structure that might be a tower with a gate below, while on the right is perhaps another gate. The basilica in the center is 
preceded by two steps that lead to an arched doorway. There are square windows on both the front and side of the building. The pitched roof has tiles in a red grid pattern and there is a widow on the pediment.

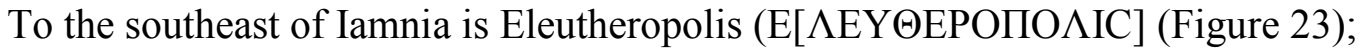
since only one letter of the toponym survives, it has been identified largely based on its size and location on the composition. Only a small portion of the city survives. It is bisected by a road of a white and yellow filet that curves at the south end of the city. In front of the road is a circular structure with a yellow dome supported by four columns. Behind the road is a colonnade that meets the road, with a red tiled roof. To the right of this is a large basilica with a single, open doorway in the façade, a round window on the pediment, and two square windows on the side. Its pitched, tiled roof is depicted with red vertical lines. Where the road curves, another red roofed colonnade runs parallel to it. Behind these structures are three rectangular towers, spread out along the city wall.

Along the coast is Azotos Paralos (AZ $\Omega$ TOC ПАРА $\Lambda(O)[C]$ (Figure 24). Both the north and south sections of the city have disappeared. A red roofed colonnade crosses the city from left to right. In the middle of the colonnade is a basilica, angled to the left to show the front and side. The low rectangular door opens to a set of steps that lead to the road, which is depicted with two white filets. To the right of the church are two towers, while between the colonnade and the road are indistinguishable structures.

After an area of loss, the next city along the coastline to the south is Askalon $(\mathrm{ACKA} \Lambda[\mathrm{ON}])$ (Figure 25). Only a small portion of the motif survives. Along the back is the city wall, with a tower on the left and a monumental gate flanked by two towers on the right. The gate has an arched entrance, above which is a second story with a square 
window. In front of the gate is an empty court. From two corners of this stretch roads to the west, each bordered by a colonnade (shown flat to display both the red roof and the columns) on its outside edge. In the space between the roads is a building. Another road and colonnade stretches from north to south, bisecting both streets. At the intersection with the leftmost street there is a small domed structure in the roadway. There a few buildings in behind the colonnades.

A large portion of the mosaic is missing to the south of Askalon but the southern portion of the city of Gaza ([ГA]ZA) survives (Figure 26). The city was originally oblong in shape. It is cut into quarters by the Cardo and Decumanus Maximus, both shown lined with red roofed colonnades. At the south end of the city, the road ends with two flattened towers and a black square representing the open gate. Only the two rightmost quarters of the city survive. In front and two the right of the streets are two basilicas, angled to the right. The first is enclosed in a temenos with a columned entranceway. Both have red tiled roofs depicted with vertical lines and a single entrance at the façade. A row of clerestory windows is at the roofline and each pediment has a small window. In the back section of the city, a wide road leads from the Decumanus to the theater, shown as two concentric half circles. The outer one is red, suggesting a tiled roof.

To the south of Gaza, in the Nile Delta, is Peluseion (TO ПН $\Lambda$ OUCIN) (Figure 27). It depicted between the Pelusiac bank and the Sebennytic arms of the river. Only the southern portion of the city survives. The city wall is almost nonexistent at the front but four towers are shown at the back. Along the front, just inside the wall is a colonnade with a red roof. Running parallel to this, in the center of the city, is another colonnade with a street in front (likely the Cardo Maximus). The colonnade stops before reaching 
the city wall. This can be explained by a small square building that adjoins it. On the other side, the colonnade continues, at a different angle, to the wall. A small portion of roof that is at right angles to the Cardo on the leftmost side of the city suggests that this is where the Decumanus Maximus was depicted. Behind the Cardo are three buildings, from left to right: a basilica, a square building, and another basilica. The last building has either a colonnade or a double door that fronts onto the Cardo. In front of the road are more buildings, at least one of which is a church.

Other Mosaic Decoration: No other mosaic survives but, according to Lagrange's plan, both rooms of the south annex were paved with figural mosaic. The west room had an inhabited vine scroll with a person, a donkey, and other animals. There are two notes for the east room. One says that it has a pattern of interlaced medallions, while the second mentions birds and various foliage surrounded by a meander border. ${ }^{26}$ This is likely an inhabited scroll design similar to the one found in the first room.

Current Location of Topographic Mosaic: The extant fragments of the topographic were incorporated into the floor of the modern Greek Orthodox church and are currently on display.

Bibliography:

Alliata, Eugenio. “The Legends of the Madaba Map.” In Umm al-Rasas Mayfa ah I: Gli scavi di complesso di Santo Stefano, edited by Michele Piccirillo and Eugenio Alliata, 47-101. Jerusalem: Studium Biblicum Franciscanum, 1994.

Avi-Yonah, Michael. The Madaba Mosaic Map with Introduction and Commentary. Jerusalem: Israel Exploration Society, 1954.

Lagrange, Marie-Joseph. "La mosaïque géographique de Mâdabâ.” RBibl 6 (1897): 165-184.

${ }^{26}$ Marie-Joseph Lagrange, "Mosaïque géographique de Mâdabâ" RBibl 6 (1897): 167. 


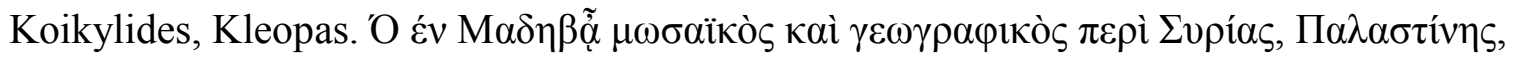

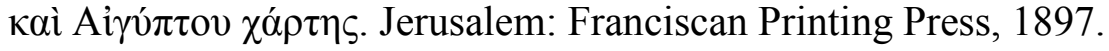

Schumacher, Gottlieb. "Madaba.” ZDPV 18 (1895): 115-116.

Séjourné, Paul. "Médeba: Coup d'oeil historique, topographique, et archéologique." RBibl 1 (1892): 617-644.

V. Church of the Lions, Umm al-Rasas (Figures 28-34, Plans 6-7)

Byzantine City: Kastron Mefa'a (Map 1, Plan 6).

Byzantine Province: Arabia.

Construction Date: 573 or 588 . The dedicatory inscription that records the completion of the church mentions a bishop Sergios, and the seventh indiction. Sergios held the seat from at least when he is referenced in an inscription in the crypt of Madaba's Church of the Prophet Elias. The seventh indiction refers to either the year 573 or 588 , so the latter is certainly probable, though either is possible.

Religious Affiliation: The bishop of Madaba oversaw this area, under the authority of the metropolitan and patriarch of Bosra.

Excavation History: The Franciscan Archaeological Institute excavated the church during its 1989 and 1990 campaigns, investigating the areas surrounding the church between 1991 and 1992. The western end of the west courtyard was excavated in 1998.

Building Plan and Furnishings: The church has a triple-apse basilica plan inscribed in a rectangular wall, measuring approximately $26.0 \mathrm{~m}$ long by $15 \mathrm{~m}$ wide (Figure 28, Plan 7). Several structures adjoin the building to the north, west, and south; in the west these take up much of the atrium space. There are two entrances in the western façade of the church: one at the nave and one at the south aisle. The lack of a door leading to the north aisle is explained by the appearance of a funerary chamber that abuts the western façade to the 
north of the nave door. Access to the south door is not from the atrium but through a series of rooms to the southwest of the church. The northern and southern structures narrow the main passage into the church, which is preceded by five steps that lead down into the structure. The lintel of the main door has a carving of a cross inscribed in a circle. The nave is separated from the aisles by four sets of pillars, each carved with geometric designs. The pillars originally supported arcades. The plan shows the fallen voussoirs as they were found but several sets have since been restored. The arcade originally supported a tiled roof.

Two doors on the north aisle, one at the first bay and one east of the fourth, opened onto a courtyard that extends the length of the building. These were closed off at some point in the church's history. Other adjustments to the aisles include the addition of a lime-coated basin in the northwest corner of the north aisle and a staircase in the southwest corner of the south aisle. These last two modifications likely post-date the building's use as a church. $^{27}$

In the nave, between the third and the fourth bay on the south side of the church, is the base of ambo. At the time of excavation it was found largely intact but has since been removed. Accessed from the presbyterium, it had six steps that led up to a hexagonal platform supported by $1 \mathrm{~m}$ tall columns. The sides of the stairway and the platform were covered with panels made from kerogen shale. The sides of the stairway were carved with an intertwined scrolls (filled with a stylized papyrus flower, a krater, and a floral cross) with papyrus flowers filling the upper spaces between the scrolls. The platform's panels were carved with a mixture of geometric and floral designs.

\footnotetext{
${ }^{27}$ Anne Michel, Les églises d'époque Byzantine et Umayyade de la Jordanie: Ve-VIIe siècle (Turnhout: Brepols, 2001), 405.
} 
At the fourth bay, two steps lead up from the nave to the sanctuary, which was contained by a chancel screen that extended the width of the apse, and from the fourth bay to the apse. Several kerogen change screen posts and panels were found in situ but have since been removed. Five of the panels included cross motifs, two (and perhaps three) of which include patterns of geometric or vegetal crosses inscribed in circles or scutae. The fifth portrays a krater. At some point after the mosaic was laid, a two-legged table was installed on the sanctuary side of the chancel screen,

At the entrance to the apse, a the masonry base of the altar was also found in situ, along with three column capitals, indicating that it originally had a ciborium above. When this was removed, the remains of an earlier altar was revealed, including the bases of three table legs set into the mosaic designed for this purpose (see "Other Mosaics" below). Excavators found the remnants of a reliquary in the earth covering the eastern floor of the church. Made of marble, it was originally rectangular in shape and contained three compartments. Also near the altar was a square stone support for an incense burner which had traces of burnt incense. At the north east corner of the nave was a glass lamp with bronze fittings.

Topographic Mosaic: A representation of Kastron Mefa'a fills the intercolumnar panel between the third and fourth bay at the northeast end of the church, parallel to the ambo on the southeast side of the nave (Figure 29). It is viewed as one faces the altar and measures by $2.4 \mathrm{~m}$ high $0.9 \mathrm{~m}$ wide. There is damage to the right side with an ancient repair in one portion (a figure damaged by iconoclasts would be unusual here).

At the top is the label "Kastron Mefa'a" (KASTPON MEФ...). Below, the city is divided into two vertical parts. The top is a walled city, probably octagonal. Four towers 
remain on the left side. Each has a pair of windows in the horizontal registers that make up the structures. The towers and the wall are topped with column-like crenellations. At the front of the wall is an open arched gateway. Within the walls are two adjoined basilica churches. They are approached by two steps. The building on the left has an arched doorway and a large window in the pediment above. It is covered with a pitched tiled room, indicated by dark red diagonal lines on the lighter red roof. To the right of this is a colonnade with two columns below and two square windows above. The church to the right is fragmentary but it is either missing a door or there are several steps, indicated by five rows of tesserae, to it. This could also depict a second-story window. This structure also has a pitched room and a window in its pediment.

From the city gateway, the scene opens up below to a ring of buildings interspersed with crenelated walls. Starting at the left and working counter-clockwise, there is a wall tower with a city gate in front, indicated by the vertical lines on the structure and the open semicircular doorway. It is preceded by a series of steps. In front of this is a basilica, with a pitched tiled roof like the others, a window in the pediment, and three semicircular openings, one on the front and two on the sides. The size suggests that all are doorways. In front of this another gate, flanked by towers. To the right of the tower are two more basilica churches, side by side. The first has a semicircular entrance and a window above the pediment, while the second has a pointed entryway; both pediments are shown on this structure, each with a window. To the right of these churches is another gate flanked by towers. Behind this is another basilica, shown from the front. Behind this is another tower. The rest of the right side has been lost. In the 
center of the ring of buildings is a column on a base with three steps. It is topped with a crosslet.

Other Mosaics: The nave and aisles were paved in mosaics, though only the eastern end survives and these have suffered intermittent iconoclastic damage. The nave mosaic is bordered with an alternating pattern of fruit trees and human figures (Figures 30a-b). By the direction of the foot of one figure and the shapes of the rest, which possibly numbered as many as forty figures, they were shown walking in a clockwise position. The toponym above one figure survives in the northwest corner, read as one faces outward toward the north wall:

\section{$\Pi \alpha \tilde{\lambda} \operatorname{os} \operatorname{K} \alpha \sigma \sigma 1 \alpha v o(v)$}

Paul, son of Kassianos.

A single guilloche divides the border from the main field, which is filled with an inhabited vine scroll assembled three wide (and probably originally with ten to twelve rows). Again, all the figures have been removed and the spaces filled with scrambled tiles but the outlines indicate a mixture of animal and human figures, perhaps with hunting scenes. In the center scroll of the easternmost row, there is an inscription, read facing the altar (Figure 31):

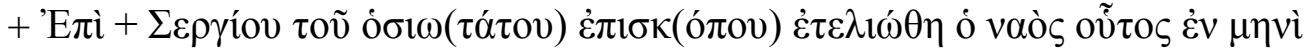
$\Delta \varepsilon \sigma$ íov iv $\delta(\imath \kappa \tau \imath \tilde{\omega} v o \zeta)+\zeta^{\prime}+$

In the time of Sergios, the very holy bishop, this temple was completed in the month of Desios, the seventh year of the indiction.

In the first scroll of the second row is an empty bird cage with perhaps two birds outside. The central figures of the third and fourth rows are labeled, both facing the altar: 
$\Sigma \alpha \lambda \alpha|\mu \alpha v \eta \varsigma| \Sigma o \beta \alpha / v o v$

Salamenais, son of Sobanos

'I $\omega \alpha|v \eta \varsigma| \Sigma \alpha \omega \lambda$ ov

John, son of Saul

Between the Kastron Mefa'a panel and the ambo, in front of the chancel screen is a rectangular pavement with a serrated single filet grid filled with parallel squares. Along the top is an extremely fragmentary inscription:

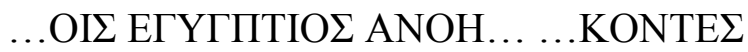

\section{? Egyptios ? ?}

The excavators note that this name also appears on an inscription in Syria but do not elaborate. ${ }^{28}$

The same serrated single filet grid pattern is used to decorate both the north and south aisles, which are bordered with a double guilloche. The intercolumnar panels dividing the nave and the aisles are all geometric patterns, with the exception of the city motif. The aisle apses are both decorated with kraters flanked with a pair of birds, which have been removed and replaced with scrambled tesserae. On the south side, curved along the eastern edge of the mosaic is an inscription recording more donors (Figure 32):

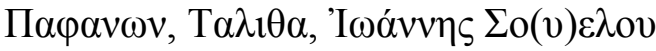

Paphanon, Talitha, John (son of) Souelos

The presbyterium is decorated with a rectangular mosaic (Figure 33). The border consists of white circles on a black ground. Each circle is filled with a bird or fruit; some

${ }^{28}$ Michele Piccirillo, "La Chiese dei Lioni a Umm al-Rasas- Kastron Meffa," Liber Annuus 42 (1992): 221. 
of the birds have been erased by iconoclasts while others remain. The two birds at the center of the eastern border have red ribbons tied around their necks (Figure 34). The center panel has three fruit trees with twisted trunks. Flanking the central one are two lions. The lower portions of their bodies have been reworked with random tiles but their heads remain. Behind each lion is another tree, from which a deer nibbles at the leaves. The deer on the left has been completely erased, while the one on the right remains completely untouched.

The apse has a semicircular border of is covered in a regularly spaced pattern of rosebuds on a white ground, with a semicircular border of a serrated saw tooth single guilloche. To the north and south of the altar are two lambs facing inward. They have been almost completely removed by iconoclasts, save their tails and hooves.

Current Location of Topographic Mosaic: The topographic panel, along with the rest of the mosaics are buried in situ in order to preserve them.

\section{Bibliography:}

Piccirillo, Michele. "La Chiese dei Lioni a Umm al-Rasas- Kastron Meffa." Liber Annuus 42 (1992): 199-226.

VI.. Church of the Priest Wa'il, Umm al-Rasas (Figures 35-38, Plans 6, 8)

Byzantine City: Kastron Mefa'a (Map 1, Plan 6).

Byzantine Province: Arabia.

Construction Date: 586. The completion of the building and its mosaics are dated by inscription to 586. It is physically connected to the undated Church of the Tabula Ansata to its south. 
Religious Affiliation: The bishop of Madaba oversaw this area, under the authority of the metropolitan and patriarch of Bosra.

Excavation History: The church was excavated by Franciscan Archaeological Institute and the Department of Antiquities of Jordan in 1990 and 1991.

Building Plan and Furnishings: The church is a three-aisled basilica with a central apse inscribed in a rectangle (Figure 35, Plan 8). It measures $12.0 \mathrm{~m}$ long by $9.0 \mathrm{~m}$ wide. Unlike most churches, it is oriented roughly north-south. The north wall of the nave is slightly angled in relation to the rest of the church. The building's entrance was in the west wall through two doorways opening to an aisle: one at the north end of the church and the other almost level with the chancel screen. The nave is separated from the aisles by two columns, which supported arcades that extended to engaged pillars in the north and south walls. The roof was tiled. At the end of the west aisle, an arched doorway leads to the nave of the Church of the Tabula Ansata. The south wall of the east aisle contains an arched niche.

A chancel screen encloses the sanctuary, which is two steps above the church. An opening in the central axis of the screen allows access to the sanctuary. Only fragments of the chancel screen and its posts were found. It was made from kerogen shale and the panels were originally decorated with figural designs, though these were purposefully damaged at some point. A table in the northwest corner of the sanctuary was added after the mosaic was laid in 586; one leg was found in situ and went through the existing pavement.

The altar stood at the entrance to the apse. The first version of this was replaced at some point after the initial construction; like the offering table, its legs disrupted the 
mosaic. A third altar, a solid masonry structure, was installed with the legs of the second table within. A mensa, made of kerogen shale and measuring $0.9 \mathrm{~m}$ wide, was also found during the excavations. Two reliquaries were found inside the building. Only a fragment of one remains but the other is largely intact. Made of local stone, the rectangular container has three rectangular compartments; attached to one of the long sides is a curved receptacle in which to pour liquid into the reliquary. Holes were drilled through the dividing walls of the reliquary to distribute this liquid. The cover, while broken, displays a bronze cross.

Topographic Mosaic: The topographic mosaic, measuring $0.6 \mathrm{~m}$ high by $3.7 \mathrm{~m}$ wide, is located in the intercolumnar panel between the north wall and the pillar on in the center of the nave (Figure 36). It is viewed as one stands in the west aisle, facing east. The composition is bordered by two black filets. Originally the composition consisted of four human figures alternating with three depictions of cities. However, at some point iconoclasts removed the faces and much of the bodies of the figures, and replaced them with random tesserae. Additionally, a portion of the north end is lost, obliterating all but a fragment the figure and part of the city on this end. The figures are depicted in the same manner: female (?) nudes shown from the waist up, facing the viewer directly. Each figure holds a cornucopia from which spills water that encircles the figure. The cities also have some formulaic elements but each has a different configuration of cities. The first has a colonnade of four columns in front of a basilica church. It is angled to the right to show both the façade and the side. On the front is an open doorway with a red curtain tied back within. The pitched roof is separated by a grid of red lines indicating tiles. There are four arched windows on the side. Behind the church is an open gateway with a single 
column inside, possibly representing a mile marker. To the right of the church is a tall tower with an arched window. The top is has not survived.

The next city has a similar depiction of a tower on the left but with a circular window. There are three crenellations at its top. To the right of this are two small rectangular buildings with pitched roofs. They are shown from the side and each have three square windows. The roofs are light brown. To the right of the second buildings is another tower with an arched window and three crenellations. Behind the second building is a larger basilica. It is shown angled to the left to show both the façade and the side. Its open door has a tied white curtain in it. The pediment has a semicircular window, while the roof has red tiles. The side of the building doesn't have windows but is depicted with a brown grid. Behind and to the left of the church, is a gate with two open doors and three crenellations above. Inside the gate is a single column. In front of the column is a brown rectangle, representing a road.

The final city has more buildings than the first two. In the front are two rectangular buildings with brown pitched roofs. The one on the left has three square windows and the one on the right has two. Behind these is another building shown from the side, with a brown roof and a large rectangular window. To the right of this is another depiction of a roadway that leads back to the open city gate, with two open doors and a column at the entrance. To the right of this is a large basilica, angled to the left to show both the façade and the side. There is a red curtain tied back in the open doorway. It has a red tiled pitched roof and an arched window in the pediment. There are three windows on the side, which also has a brown grid pattern on the wall. To the right of the basilica is another tower, with an arched window and three crenellations. 
Other Mosaics: The rest of the church is also decorated with mosaics which were intermittently defaced by iconoclasts. The nave panel is bordered by a series of inhabited white circles on a black background. The figural motifs, likely animals and birds, have been disfigured but other motifs, like a cage, flowers, and a bowl, remain. An image of a krater inhabited each corner. At the top of the main field is a rectangular inscription flanked by entwined lozenges. The inscription is read as one faces the altar:

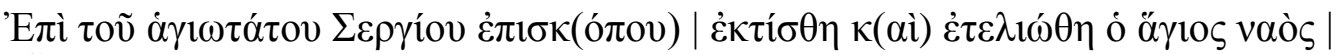

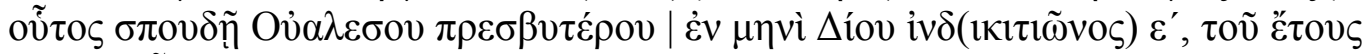

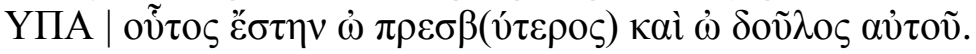

Under the very holy bishop Sergius, this holy temple was built and completed by the zeal of the priest Oualesos (Wa'il) in the month of Dios, the fifth (year of the) indiction, the year 481 . He is the priest and His servant.

Below this, the field is divided into three registers (Figure 37). At the south end, there were four figures, now erased. There were two figures on the left, each holding sticks. The next figure to the right had both arms outstretched in an orant position, one of which held a branch. To his right was a figure riding an animal with a basket of branches. Behind this figure, flowers grow from the ground line. The middle register has a red carriage pulled by an erased horse to the right among a field of flowers. The lowest register has two dogs chasing an erased animal to the left while below two men on horseback, one of which is spearing a boar.

In addition to the architectonic composition, there are three additional intercolumnar panels. The one on the northwest side is viewed as one faces east. It is badly damaged but originally contained two boats on a river filled with fish, separated by a bank (Figure 38). While there has been damage and repair, the figure on the left survives. He is nude, save for a yellow cap on his head, and holds both oars as he sticks 
one leg out of the boat. The second boat is visible but the figure has been completely obliterated. A smaller panel on the southeast side has a sea monster of some sort, though its head does not survive, which is viewed in the same direction as the boating scene. The last intercolumnar panel is a solitary figure in a red cloak, holding a whip in his left hand as he faces east. Unlike the other three panels, one must face north, with one's back to the altar, to see this scene.

There are two mosaics in the sanctuary, a rectangular panel with an acanthus panel flanked by two animals (lambs?). Behind this, in the apse, is a geometric pattern consisting of an oblong grid of alternating squares and oblong hexagons. The squares are black and filled with white Maltese cross, and the hexagons are white with an orange lozenge with a black center.

The aisles both contain inhabited acanthus scrolls. The figures have been destroyed, with the exception of the body of a horse or donkey in the northwest corner. At the central entrance to the church, the threshold panel contains two facing ducks. The south end of each aisle has a separate pavement panel. At the east aisle, in front of the niche, is a depiction of a date palm. In the west aisle, at the entrance to the Tabula Ansata Church, is a depiction of a pomegranate tree. Both are viewed facing the south wall. Current Location of Topographic Mosaic: All of the church's mosaics remain in situ but are currently covered to conserve them.

\section{Bibliography:}

Piccirillo, Michele. "La chiesa del prete Wa'il a Umm al-Rasas Kastron Mefaa." In Early Christianity in Context: Monuments and Documents, edited by E. Alliata and F. Manns, 313-334. Jerusalem: Studium Biblicum Franciscanum, 1993.

VII. Church of St. John, Khirbat al-Samra (Figures 39-42, Plans 9-10) 
Byzantine City: Khirbat al-Samra (Map 1, Plan 9) has been connected to Haditha/Aeditha as recorded on the Peutinger Table and in the Notitia Dignitatum, respectfully.

Byzantine Province: Arabia.

Construction Date: 634 or 639. The initial construction of the building is undated and there are several renovation phases. The original excavators suggest that it is the oldest church at the site and that it is Justinianic in date, based on the reuse of material from the fort. They connect Justinian's disbanding of the imperial army to the abandonment of the fort and the subsequent construction of the church, but this is a tenuous link. ${ }^{29}$ However, the topographic mosaic, which was installed during a renovation of the church, is dated by inscription to 634 or $639 .^{30}$

Religious Affiliation: The metropolitan bishop of Bosra, who was under the authority of the Antiochene patriarch, oversaw this area.

Excavation History: The church was excavated between 1981 and 1982 under the direction of Alain Desreumaux and Jean-Baptiste Humbert for the French Biblical and Archaeological School of Jerusalem, in conjunction with the Jordanian Department of Antiquities.

Building Plan and Furnishings: The Church of St. John is almost at the center of town, facing what excavators believe to be the main city gates (Plan 9). ${ }^{31}$ The church has a rectangular basilica plan with a nave flanked by two aisles (Figure 39, Plan 10). It is the

\footnotetext{
${ }^{29}$ Jean-Baptiste Humbert, "Khirbet es-Samra, du diocese de Bosra," in Christian Archaeology in the Holy Land: New Discoveries; Essays in Honour of Virgilio C. Corbo, OFM, ed. G.C. Bottini, L. Di Segni, and E. Alliata (Jerusalem: Franciscan Printing Press, 1990), 471. The excavators admit that the repaving of the church had disturbed the earlier stratigraphy to the point that any material below is unreliable for dating. ${ }^{30}$ Humbert and Desreumaux, Fouilles de Khirbet, 390-391. The inscription is damaged where the numbers indicate the indiction year and cycle. Other dated mosaics on the site provide a date for Archbishop Theodore in the first half of the seventh century. The cycle number is most likely eleven; however, seven is also possible. Therefore, the date is likely 639 but could also be 634 .

${ }^{31}$ Ibid., 53.
} 
largest church in the village, measuring $17.3 \mathrm{~m}$ long by $14.7 \mathrm{~m}$ wide. Unlike the others, which were constructed using local black basalt, it is made from white limestone.

There were originally three entrances of equal size leading into the building on the western end, each opening onto an aisle. After the installation of the mosaics in 639, the central door was shifted slightly to the north, probably when a small structure was added to the northwest exterior corner of the building. This rectangular room has an entrance on its south wall in front of the church's central doorway and another on its east wall which allows access to the church through the north aisle entrance. Inside the room, excavators found six skeletons and Umayyad period ceramics.

The main hall is almost square, with five piers on each side that divided the nave from the aisles. Early in the building's history, the ends of these aisles were blocked off to make separate rooms (see below). After the addition of the floor mosaic in 639, brick banquettes were added to north and west walls. It is possible that the northwest entrance to the church was closed at this time but it is also conceivable that this happened at a later date, when the bays between the first four north piers were walled in, as was the space between the forth pier and the north wall. This construction created a separate room, accessed through a doorway found between the first and second piers.

At the east end of the nave is a rectangular sanctuary, the space for which was increased twice. It first extended to the easternmost set of piers. Before 639, this space was divided through the addition of two rectangular rooms to the north and south, each measuring $3.5 \mathrm{~m}$ long by $2.5 \mathrm{~m}$ wide. Each room has a door on its western wall that opens to the aisle. In a later modification, the sanctuary was extended to the fourth set of piers and a chancel screen was added between them to separate this space from the nave. 
This does not survive but holes for the fittings do, as does a small opening in the center, which allowed for access to the sanctuary. During one of the renovations, a two-tiered synthranon was added to the eastern apse. In front of this was the altar table. It does not survive but four holes in the floor mark where its legs were. In the center of these, still in situ, was a cylindrical loculus containing a white limestone reliquary and a small blue glass bottle (Figure 40).

The church's flooring was laid in three stages. The original plastered floor was covered with large flagstones constructed with architectural spolia, including a late fourth-century Latin inscription taken from the fortress. In 639, the side aisles were paved with white tesserae and the nave with a figural mosaic while the sanctuary and eastern rooms remained unchanged.

Topographic Mosaic: The topographic mosaic decorated the church nave and is oriented so that the viewers sees the motifs as they look east toward the sanctuary. The figural pavement, measuring $9.4 \mathrm{~m}$ by $5.3 \mathrm{~m}$ wide, does not fill the nave. A plain white mosaic measuring between 0.3 and $1.0 \mathrm{~m}$ wide fills the remaining space.

The border consists of a solid black line, followed by a band containing a reverse swastika pattern on the east side and a reverse swastika pattern alternating with square filled with random geometric patterns, including a an " $\mathrm{X}$ " inscribed with circles, a diamond, crosslets, etc. The interior border is comprised of black crenelated triangles.

The main field has a white background. At the north east end, is a badly damaged one-line inscription:

\section{$\mathrm{PAB}[\mathrm{BO} \Sigma ?] \Lambda \mathrm{EON}[\mathrm{TIO \Psi}]$}

Rabebos, son of Leontus 
In the south east corner, is a two-line inscription, slightly better preserved: $\mathrm{KAOM}[\mathrm{O} \Sigma] \Phi \mathrm{O} \Lambda \mathrm{E} \Omega$

Kaomos, son of Pholeos

Below these inscriptions are large areas of loss; however, these are not as deep as on the rest of the pavement, which reveal the flagstones beneath. Between this, the spacing between this and the other motifs, it is unlikely that this area contained donor portraits though it is possible that the area displayed images of small birds other animals.

Below these inscriptions, in the center of the upper portion of the mosaic, is a circular motif. It is flanked on both sides by clusters of aquatic plants, two on the left and three on the right. The circle is framed by a single guilloche, then two rings of inscription. To read these with ease, one would have to stand in the center of the circle and turn, facing the walls of the church. Both the outer and inner inscription are badly damaged, but Paul Louis Gatier suggests the following reconstruction:

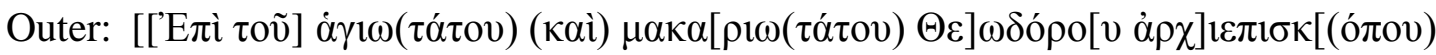

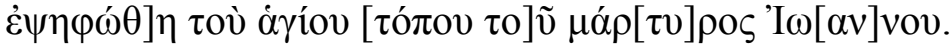

Under the very holy and very blessed Archbishop Theodore was made this mosaic in the holy place of the martyr John.

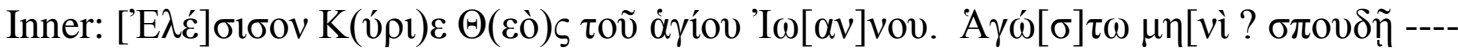

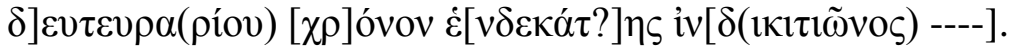

Lord, have mercy, God of St. Jean. In the month of August, for the care of a certain deuterarios at the time of the eleventh (?) year of the ? indiction. ${ }^{32}$

The inside of the circle has been similarly destroyed, perhaps because it contained a figural representation. Below the circle are three more areas of loss; the two directly

\footnotetext{
${ }^{32}$ Ibid., 54.
} 
under the circle are large enough to have contained the figures of larger animals or people. The smaller one, to the right of the circle, might have contained a bird or small animal. Between the large areas of loss, just left of the center of the pavement, is a small bird cage. It is empty and the door is open. Directly below this and slightly to the right, is another inscription:

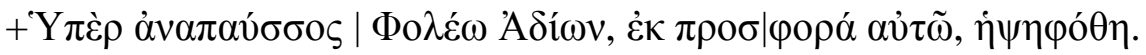

For the eternal rest of Pholeos, son of Adion, for his offering the mosaic was made.

Below the inscription was a central figure, now lost. It is flanked by two elaborate walled city motifs. The one on the left has a heptagonal wall and six towers (Figure 41). Originally there were probably seven, though there is an area of loss in the upper right portion of the motif. The tops of the walls and towers are crenellations that look like column capitals. An arched gate with an open door is in the middle of the front central wall. Two other gates are shown in the towers in the background of the city. Each tower has a small slit of a window in its upper section, all except the one to the left of the front gate. Behind the gate is a domed building, the bottom of which is formed by three columns creating two arches. The dome is topped with a cross. Behind this building, is a long, peaked roof that fills the entire city's width. The roof is divided into diagonal red tiles and there is a window at each end; however, the artist has not represented the lower half of this building. Behind this structure, in the center of the city, is a triangle, possibly representing another roof. It is flanked by two domes, each with four columns creating three arches. The one on the left might be capped with a cross. The top of the one on the right has not survived. Above and to the left of the walled city is an aquatic plant. 
The walls of the second city are similar but the buildings inside are different (Figure 42). It is either hexagonal or heptagonal (the buildings in the background obscure the number) but there are seven towers and the walls have the same capital crenellations. An arched gate is found in the front central wall and the central tower at the back. All seven towers have a small window it their upper sections. Directly behind the gate are four rectangular buildings with pitched roofs. They are displayed on an angle so that their length is apparent. Each has a diagonal tiled roof and a window in the pediment. Behind these buildings are two domed structures, each supported with four columns that create three arches.

Below the area of loss between the two walled cities is an empty krater. On either side is an area of loss, which likely held a pair of birds or animals originally. An aquatic plant is found above each area of loss.

Other Mosaic Decoration: The north and south aisles are paved with plain white tesserae. Current Location of Topographic Mosaic: The entire nave mosaic has been left in situ but is not visible, as it is currently covered in order to preserve it.

\section{Bibliography:}

Humbert, Jean-Baptiste. "Khirbet es-Samra, du diocese de Bosra." In Christian Archaeology in the Holy Land: New Discoveries; Essays in Honour of Virgilio C. Corbo, OFM, edited by G.C. Bottini, L. Di Segni, and E. Alliata, 467-474. Jerusalem: Franciscan Printing Press, 1990.

Humbert, Jean-Baptiste, and Alain Desreumaux, eds. Fouilles de Khirbet es-Samra en Jordanie v. 1. Turnhout: Brepols, 1998.

VIII. Church of St. Stephen, Umm al-Rasas (Figures 43-73, Plans 6, 11-12)

Byzantine City: Kastron Mefa'a (Map 1, Plan 6).

Byzantine Province: Arabia. 
Construction Date: 718/719. The church is part of a complex of several buildings (Plan

11). St. Stephen was built over the remains of an existing building, perhaps another church. St. Stephen's construction post-dates that of the Church of Bishop Sergios to which it is connected. The mosaic for the latter building was laid in 587 but it is uncertain if this was contemporary to the Bishop Sergios' construction. There are two dated mosaics within St. Stephen but they record the laying of pavements and not the construction of the building. The first is found in the nave; while damaged, it would appear to date to $718 / 719 .{ }^{33}$ The flattened style of the topographic border is similar to that of the Church of the Acropolis in Ma'in, which is similarly dated by inscription to $719 / 720$, though it does not mention what work is included in the dedication. Few mosaics can be securely dated to the eighth century in Jordan, making stylistic comparisons and identification impossible. Nonetheless, the geometric pavements in St. Stephen's sanctuary are equally fine and dated by inscription to 756 .

Religious Affiliation: The bishop of Madaba oversaw this area, under the authority of the metropolitan and patriarch of Bosra.

Excavation History: The church was excavated by members of the Franciscan Archaeological Institute and the Department of Antiquities of Jordan in 1986 and the adjoining buildings were investigated between 1987 and 1989.

\footnotetext{
${ }^{33}$ Piccirillo, I mosaici del complesso di Santo Stefano," in Umm al-Rasas Mayfa 'ah I: Gli scavi di complesso di Santo Stefano (Jerusalem: Studium Biblicum Franciscanum, 1994), 149; Schick, Christian Communities, 472-473. Piccirillo dates the mosaic to 756, based on the current reading of the mosaic. However, Schick notes two problems with this: damage and repair to the year and the incompatibility between the year 680 and the second indiction. 680 corresponds with the eighth or ninth indiction. The area of repair includes the upper right portion of the X, indicating ' 600 ,' and the area to the right. Schick suggests that the artist, who did not know Greek, saw the two parallel lines and connected them to make ' $\Pi$ ' (80) instead of the original ' $I \Gamma$ ' the letters for which would also fit in the space provided. Thus, according to Schick, the date should read XIГ (613 of the Arabian Era), which corresponds with the second indiction and the year 718/719.
} 
Building Plan and Furnishings: The church belongs to a larger complex, including the Church of the Niche, the Church of the Courtyard, and the Church of Bishop Sergios. St. Stephen is a triple-aisle basilica with an apse flanked by two lateral rooms. It measures approximately $24.0 \mathrm{~m}$ long by $13.5 \mathrm{~m}$ wide (Figure 43, Plan 12 ).

Three steps from the Church of the Courtyard lead up to the western façade of St. Stephen. This doorway, which is not in axial alignment with the apse, has crosses carved into the lintel's exterior. A doorway in the west end of the north aisle has five steps which lead up to the east end of the Church of Bishop Sergios' south aisle. One can also enter St. Stephen through two doors leading from an exterior courtyard into the eastern end of the church's southern aisle. Fragments of pebbles in an oblique grid pattern filled with geometric motifs were found on the interior west wall.

A pair of engaged pilasters and two sets of pillars divide the nave from the aisles. At the southeast end of the nave is the hexagonal base for an ambo, with five holes for the platform's supports. Excavators believe that this structure and the mosaic were planned together, since the borders of the surrounding pavements frame the space; however, there are some floral motifs east of the ambo that seem to be partially covered by the structure, which would suggest otherwise. ${ }^{34}$

Two steps lead from the nave to the sanctuary, which is marked off by a chancel screen in an unusual shape that blocks the north aisle from the presbyterium. One of the posts, found in the south room, is engraved with an inscription: "For the health of..." (YחER ГOTHPIAS). At the entrance to the apse is a rectangular slab of sandstone on

\footnotetext{
${ }^{34}$ Michele Piccirillo, "Le installazioni liturgiche," in Umm al-Rasas, ed. Michele Picirillo and Eugenio Alliata (Jerusalem: Studium Biblicum Franciscanum, 1994), 114-115.
} 
which stood a masonry altar. Excavators believe that a grey marble column found nearby was part of a ciborium that covered the altar. These columns disrupt the sanctuary mosaic, which is dated by inscription to 756. A small rectangular hole is carved out of the east side of the slab, likely to hold a reliquary. No reliquary was found inside the building but a fragment of a marble top for one was found just outside the building in the south courtyard. Another mosaic was found underneath the altar slab and it had four stone bases that marked the position of an earlier altar table.

To either side of the apse is a room. On the north side, the rectangular room was separated from the aisle by a low barrier. Inside the room stood a four-legged table, two of the bases for which were found in situ. At one point, the eastern end was expanded to include an apsidal wall with a polygonal niche. Excavators found black, red, green, and gold glass tesserae in the apse, which they suggest were used in repairs of an unspecified location; however, it seems more likely that these were part of the apsidal decoration. ${ }^{35}$ The table was moved back into this space and two stone supports were found in situ. An arch was added to its entranceway, which was later replaced with a door to restrict access to this space. A cylindrical piece of stone, with a concave top was found at this entrance. The mosaic decoration in this area shows that this piece was included in its design but excavators are unsure of its purpose. At only thirty $\mathrm{cm}$ high, it is too short to be a stoup. Not enough remains to be sure but the archaeologists suggest that it possibly served as a support for a reliquary or processional cross. ${ }^{36}$

\footnotetext{
${ }^{35}$ Michele Piccirillo, "I mosaici," 149.

${ }^{36}$ Piccirillo, "Le installazioni," 113.
} 
The room to the south was covered with a barrel vault. The north wall of this room contains a rectangular niche. Under the floor, excavators found two pit graves with painted crosses; they believe that these belong to an earlier building. ${ }^{37}$

Topographic Mosaic: Topographic motifs are found in both borders of the nave mosaic, as well as in the panels at the east end of the north and south aisles. The nave pavement, which measures roughly $11.5 \mathrm{~m}$ long by $5.3 \mathrm{~m}$ wide fills the space up to the ambo. The intercolumnar spaces are filled with depictions of walled cities, which serve as an outer border for the nave mosaic. The north side contains eight motifs, four on each panel, each divided into a rectangular frame and labeled with its toponym at the top of the panel. These sections are bordered by a single black filet and presented on a white ground. One views the cities as one faces the altar. The first city, at the east end, is Jerusalem. It is labeled "Holy City" (НАГIA П $\Omega \Lambda \mathrm{IC}$ ) (Figure 44). Below is a walled city protected by seven towers. Each tower is three stories high, with rectangular windows on the top two, and topped with a crenellated watch post. The towers are shown in unusual perspective: those in the front are the shortest, while they get progressively larger towards the background. The crenellations are shown in a flattened perspective, providing a sense of an overhead view while still showing the structures' facades. The city gate at the center, between the two smallest towers. Its arched door is open and surmounted by three rectangular windows of various size. Behind the gate is a round central plan structure. Its pitched roof is supported by three columns and its peak bears a small ornament. This building is flanked by two basilicas, which angle out diagonally from the large tower at the back of the city. Both are two storied buildings with rectangular windows on both

\footnotetext{
${ }^{37}$ Michele Piccirillo, "Gli scavi del complesso di Santo Stefano, in Umm al-Rasas, 83.
} 
levels. On the façades, their rectangular doors are open. Their pitched tiled roofs are portrayed with a gradient grid design and their pediments each have a rectangular window. The city's back wall curves around the roofs of these buildings.

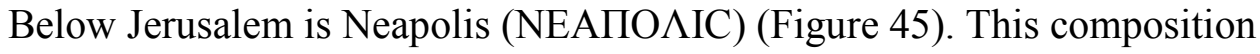
focuses on a single building, depicted at an angle to show both sides. It is classical in style, surrounded by a peristyle of five columns, which supports a frieze of triglyphs and undecorated metopes. The pediment at the front is interrupted with a floral motif, while the one on the side is undecorated. Behind the building is a portion of the city wall topped with crenellations. The wall has two unusual motifs that look like acanthus leaves rising up its side.

To the west of Neapolis is Sebastis (CEBACTIC) (Figure 46). Its panel is divided into two registers. The lower one has a double set of Roman arches. To the right of this is a cylindrical structure, topped with a peaked roof. Three vertical lines indicate either columns or fluting on its surface. Three bands wrap horizontally around the structure. In the upper register is a large three-story basilica. It angles to the left so that both the front and side can be seen. The lowest level has two large square windows on the side and an open rectangular door on the façade. The second level has rectangular windows on both sides, and the top has square windows. The pediment also has a square window, as well as a small ornament at its peak. The tiled roof is depicted with a gradient grid. The church is flanked by two four story towers, each with a doorway at the bottom and rectangular windows at each level. The watch posts at the top are ringed with crenellations.

Below Sebastis is Caesarea (KECAPIA) (Figure 47). Its depiction is similar to Jerusalem's, though smaller in scale and more linear in style. There are four towers, two 
on each side of the city and one at the back in the center. The ones in the font are three stories in height, with a square window on the upper two levels and a watch post at the top with flattened crenellations. The two behind are larger and have rectangular doors at their lower levels. The one in the back shows only its watch post. The arched city gate, in the center of the front wall, is open. Behind the gate is a double-shelled circular structure. There are two sets of columns, one that supports the peaked tile roof and one that supports the roof that flares out over the ambulatory. Behind this structure are two basilicas. The both angle back toward the center, meeting in the middle of the city. They are essentially identical, with an open rectangular doorway on the front, a row of square windows on the second story, a single square window on the pediment, and a gradient grid indicating a tiled roof. Behind each church are the crenellations of the city wall. In the second intercolumnar panel are four more cities. The first is Diospolis $(\triangle \mathrm{IOC} П \mathrm{O} \Lambda \mathrm{IC})($ Figure 48$)$. Its composition is split into two registers. The lower portion has a flattened depiction of the city wall. The city gate has a large, rectangular opening. It is flanked by two towers, each two-stories high with a rectangular window on each level. The top of the tower on the left is a gradient grid of four squares, the one on the right has gradient stripes. The walls next to the towers have two rectangular windows towards the top and flattened crenellations, which are also found above the gate. At the end of each wall is a larger two-story tower, with a rectangular window at each level and a grid of four squares at the top. The upper register contains a large two-story basilica flanked by towers. The church is angled to the left to show both the façade and one side. There is a large rectangular open at the front, topped by an arched window and two rectangular ones. The side of the building is made of a Roman arched colonnade surmounted by a 
row of five rectangular windows. The second story has a clerestory with arched windows. The pitched, tiled roof has white vertical filets and black horizontal filets that create a grid filled with gradient squares. The pediment has an arched window and a vertical ornament at its peak. The two towers are four-storied structures, with rectangular entrances and a rectangular window in each level above. They are topped with a grid of four gradient squares.

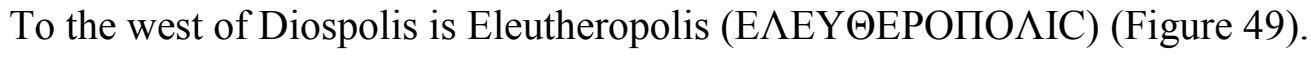
Along the front of the panel is a colonnade of Roman arches, with seven columns. It is flanked by two towers, each three stories high with a rectangular doorway and two rectangular windows. The top of the left one has a grid of four squares while the one on the right has a serrated white oblique filet. Behind the colonnade are two basilicas. The one in front is angled to the left and the one behind is angled to the right. The colonnade obscures the bottom of the first basilica but its second story has a row of rectangular clerestory windows. The pitched, tiled roof consists of a grid of gradient squares, and the pediment contains an arched window. The second basilica is larger but depicted in the same manner. Its first story has a row of rectangular windows on the side. Flanking the second basilica are two towers, in vertical alignment with the ones below. They are four stories high, with rectangular doorways and three rectangular windows above. The tops are marked with an X-shaped filet. Behind the church are two small towers with a Greek cross marked on their tops. Joining the four towers is sections of the curved city wall marked with a dentil pattern representing crenellations.

Below this is Askalon (ACKA $\Lambda \mathrm{ON})$ (Figure 50). In the center of the city is a circular central-plan building with five columns. The peaked roof is tiled in a gradient 
grid and topped with a vertical ornament. The city walls are depicted in two flat sections, one in front of the building and one behind. In the center of the foreground is the arched gate, topped with flattened crenellations. The two towers on either side of the gate almost blend into the walls on the other side- there are no vertical divisions. Each of the towers has a square window, while the walls have a rectangular one. The towers are topped with a white "x," and the walls have the same crenellation as the gate. The walls are flanked by two slightly larger towers. They have three stories, with a rectangular door surmounted by two rectangular windows. The one on the right has a horizontal black filet across the top, while the one on the left has nothing. Behind the building are four larger towers interspersed with sections of wall. The towers behind the building have a rectangular window in the upper level and are marked with a vertical filet. The high walls have vertical rows of three rectangular windows and are topped with flattened crenellations. The outer set of towers have four stories, with a rectangular door and three rectangular window. The top of the left one is marked with a vertical filet, while the one on the right has a horizontal one.

The final panel on the north side contains a depiction of Gaza (ГAZA) (Figure 51). The walls are depicted is an identical layout to those of Askalon's, with minor variations to the decorative elements at the top of the towers. The gate has a large, arched doorway topped with two square windows on top. The center of the city is filled with a large, three-storied basilica. It is angled to the left to show both the front and sides. The top and bottom levels have rows of square windows, while the middle one has a row of arched windows. The pitched tiled roof is marked with a large gradient grid and the pediment bears an arched window. 
On the south side, the two intercolumnar panels contain images of seven more cities. The toponym of each is prefaced with a stylized leaf motif. At the east end is Kastron Mefa'a (KACTPON MEФAA) (Figure 52), which takes up the space of two cities. It resembles the depiction from the Church of the Lions, separated into sections, but with the addition of a third register containing a basilica. The top register contains a large basilica with flattened cities walls in front and behind it. The basilica is two-storied, with a row of rectangular windows at the top. Its pitched tiled roof consists of a gradient grid and the pediment has an arched pediment. Behind it is an undulating wall with stepped isosceles triangle-shaped crenellations. It is broken up by five towers, each with rectangular window and two crenellated blocks. In front of the church is the city gate, with a large, open rectangular doorway topped with four rectangular windows. It is flanked by two towers, then a section of wall and another tower on each side. The towers have three stories, with a rectangular doorway topped with two rectangular windows. The walls are two-storied, with a pair of rectangular windows on each level. All of the structures are crenellated with the exception of the wall on the right.

The second register has a border of schematized buildings that surround a single column, topped with a vertical ornament, in a pentagonal court. The buildings are indistinguishable, consisting of squares with rectangular windows. At the top are gradient grids suggesting basilica roofs but there are no buildings attached. The bottom register shows a basilica in a perspective that includes the side and both facades. The front and the back of the building each have an open, rectangular doorway, with two windows in the clerestory and an arched window in the pediment. The tiles of the pitched roof are 
represented with a grid pattern. The side of the building has three large, arched windows. Hanging in each is a lantern.

The next city is Philadelphia ( $\Phi \mathrm{I} \Lambda \mathrm{A} \Delta \mathrm{E} \Lambda \Phi \mathrm{IA})$ (Figure 53). There are three buildings within the city walls. In the front are two basilicas, one angled to the left and one angled to the right; they share one façade. All three sides have rectangular windows in the clerestory. The pediment has an arched window and the tiled pitched roof is represented with a grid pattern. Behind these buildings are another basilica, angled to the left to show the façade and the side. There is a row of windows at the façade, a pitched, tiled roof and an arched window in the pediment. Behind this church is the curved and crenellated city wall and two towers. The church is flanked by two crenellated two-story towers, with rectangular windows at each level.

The last city in this section is Madaba (MI $\triangle \mathrm{ABA}$ ) (Figure 54). Within the city walls is a single large basilica, angled to the right to show the façade and the side. It is two stories high, with a row of rectangular windows on the upper level. A clerestory supports a pitched, tiled roof depicted with a grid pattern. The pediment contains a rectangular window. In front of the building is the city wall. At its center is the open, arched gate. It is flanked by two towers connected by a wall on each side. The brick walls are depicted with an uneven grid pattern. The towers have three stories with a rectangular window on each level. Both the walls and towers are crenellated. Behind the building is a curved wall punctuated with four towers. The three to the left have are rectangular window; the one on the right is a three-story structure that stands to the right of the basilica. The towers and walls are crenellated with the exception of the leftmost wall. 
The second south intercolumnar panel has four more cities. The first is Esbounta, modern Hesbon (ECBOYNTA) (Figure 55). The cities within the walls are highly schematized. A pediment with an arched at the front and center suggests a basilica. To the left is a polygonal grid shape suggesting one, or perhaps more, tiled roofs. Behind this is a large rectangular structure with three angled stories. Each level has two rectangular windows. This likely represents a gate or tower from the other side of the wall, though perhaps it is a secular building. To either side of this is an oblique rectangle with a grid of " $\Gamma$ " shapes. These tiled roofs usually are connected with churches but they cover a number of squares that with rectangular windows; perhaps these are meant to represent two churches, or maybe even more. The buildings are bounded in front and back by the city walls. In the foreground, they are angled back to suggest perspective. The rectangular city gate is open. It is flanked on both sides by a tower, a section of wall, and another tower. The two closest towers are dark and have three levels of rectangular windows. The outer towers have three stories on the left and two on the right. The brick walls are portrayed with an irregular grid pattern. The back wall has two tall towers flanking two short ones. All of the walls and the towers are crenellated.

To the west of Esbounta is Belemounta, modern Ma'in (BE 1 EMYNTA) (Figure 56). Inside the city are three or four basilicas. On the left is half of a pediment with a rectangular window. The façade below has two rectangular windows. The pitched roof is angled in such a way that it also lines up with the pediment of the second building. This church is shown with both facades and the side, as one can tell by the band of clerestory windows on all three sides. However, the second pediment also lines up with a roof that angles to the right. The effect is that one sees different churches every time one looks at 
the picture, giving the impression of a city filled with basilicas. Behind the churches is a rectangular structure with four pairs of rectangular windows. To the left of this, the triangular space has two more rectangular windows, suggesting another building. A flat brick wall in front of the buildings has a rectangular gate with an open arched entrance. It is flanked by a tower, a wall, and another tower on each side. Each tower has three levels with a rectangular window. The back wall is topped with stepped isosceles triangleshaped crenellations interspersed with four towers.

Below this is Areopolis (АРЕ $\Omega \Pi \mathrm{O} \Lambda \mathrm{IC}$ ) (Figure 57), which has three basilicas in a row within the city walls. On the left there is an area of loss. To the right of this is a church with barrel vault with an apse-shaped window. The pitched tiled roof has a pattern of squares and angles back to the right. To the right is a triangular pediment with an apsed window. The pitched tiled roof, with is depicted in a grid pattern, angles to the right. The third building has a barrel vault with an apsed window and its grid-patterned tiled roof also angles to the right. Clerestory windows for all three churches are represented by a continuous row of rectangular windows below the three facades. Behind the churches, two more buildings are represented by two pairs of square windows. The brick wall in front of the buildings is flattened. Its low, rectangular gate is open and flanked by a two towers joined by a segment of wall on each side. The towers have three stories with a rectangular window on each level. All sections are covered with crenellations. The back wall is curved and has five towers, each with a rectangular window. There are no crenellations.

The final image in the intercolumnar panel is Charach Moba, modern al-Karak (XARAX MOYBA) (Figure 58). In the center of the city is a central-plan building with a 
tiled dome supported by three columns. On either side of the edifice is a rectangular structure with three rectangular windows topped with a triangular structure with two windows. Whether these are meant to depict buildings of some type or temenos for the circular structure is uncertain.

The border of the nave mosaic proper contains images of ten labeled Egyptian cities interspersed with Nilotic scenes. One must stand inside the nave and face out to the walls to view the cities. The human and animal figures have suffered iconoclastic damage. This border is framed by two rows of a complex wave pattern. The cities are much simpler than those from the Holy Land and depicted on a black ground. In the north east corner is Tamiathis (TAMIA@IC) (Figure 59). There are two basilicas, one angled to the left and one to the right, which meet in the center. Each has two stories, with an open rectangular door on the façade and a row of rectangular windows on the upper level. The pediments each have a small square window. The pitched roof on the left has a gradated grid pattern, which the one on the right is marked with oblique lines. The lower level of the churches have a brick pattern, possibly representing the city walls. Between and behind the basilicas are a circular dome with an apsed window in the tower. To the right of the city, a nude putto catches a fish on his line as he sits on the bank facing south. Another figure faces him, straddling a fish. There is a krater behind him and they are surrounded by fish.

The next city, in the center of the east border, is Panou (ПANOY) (Figure 60). It is represented by a circular building with a tiled roof supported by four Corinthian columns, two of which are fluted and two that aren't. It is flanked by rectangular towers shown in perspective to show both the front and one side. Each tower has two levels with 
rectangular windows on each side and each level. The watch posts have square crenellations. To the right of the city is a winged putto, facing north, holding a shell. To the right is a wingless putto mans the oars of a sailboat towards him.

In the southeast corner is the city of Peluseion (TO ПI $\Lambda$ YCHN) (Figure 61). There are three structures. To the left is a rectangular tower, shown from both the front and one side. There are two windows on each face, one of which has a grid-like frame. The watch post is crenellated. To the right of this is an indeterminable structure- a rectangle with three sets of horizontal stripes. To the right of this is a basilica, angled to the right. It has two stories. The façade has an open, arched doorway with a barrier, perhaps the chancel screen inside. Above this is a small circle above an ellipse- perhaps a person? The second story has three rectangular windows. The side of the building has four windows with grid-like frames. The roof and pediment are supported by a row of clerestory windows. The apsed window is split in two, while the tiled roof is represented by a grid bichrome adjacent serrated squares. Below this, on the south wall, is a putto rowing a boat to the east, amongst a number of shells and sea creatures, including an octopus.

The next city is Antinoë (ANTI[N]AY) (Figure 62). It is the only depiction to include a natural setting: the church sits atop a hill. The building is an abbreviated version of a basilica, with a grid of bichrome adjacent squares on the roof and two rectangular windows on the side. To the left of the building is a stylized tower, with three vertical lines and a foliated top, reminiscent of a Corinthian column. It could represent either a church tower, a city wall tower, or perhaps a stylite perch. To the right of this is a wide selection of fish and shells, with a putto rowing a boat to the east. 
West of Antinoë is Herakleion (TO HRAK towers are two basilicas. The one in front is angled to the left and the one behind is angled to the right. Both have a row of square windows on the upper level, a round window in the pediment, a tiled pitched roof with a grid pattern, and an ornament at the peak. The front basilica has an open rectangular door. The tower to the left has a rectangular doorway with three windows on its two sides above. The tower to the right is one story taller and has a pair of rectangular windows on each level, above the rectangular door. Neither is depicted with a watch post. Instead, one has six gradated rectangles and the other a Greek cross pattern. To the right of this is a putto rowing a boat to the west amongst a number of sea creatures, including a jellyfish, and shells.

In the southwest corner is a depiction of Alexandria (A AEZAN $\triangle$ RIA) (Figure 64). It is the only motif with its toponym below the city. The city's layout is very similar to Herakleion's. There are two basilicas between two towers. The first church angles to the right, while the one behind angles to the left. Neither has any windows on the lower lever but has a row in the clerestory. The front church has a rectangular door, and a circular window in the pediment; the second has a square window in its pediment. Both have tiled roofs depicted with a gradient grid and a small ornament at their peaks. The towers are four-storied, with rectangular doors, one rectangular window on the second level, and two each on the third and fourth. They do not have watch posts and the tops are represented with a grid of six rectangles on the left and twelve on the right. To the right of the city is a putto riding a swan or a stork to the south, surrounded by fish and shells.

The city on the west border is Kasion (TO KACIN) (Figure 65), which is represented simply by two towers. The one on the left has three stories and the one on the 
right has four. Each has a rectangular door on the first level and pairs of rectangular windows on each level above. The tops of the towers have roofs that overhang the buildings and are decorated with gradient grids in the manner of basilica roofs. To the right of the city, a putto lunges to the north, perhaps catching a fish. To the right of this is an empty boat with oars and an unfurled sail. To the right of this is some fish and an aquatic plant.

In the northwest corner is the city of Thenesos (@ENECOC) (Figure 66). It is similar to the depiction of Panau. It has a circular-plan building with a tiled oblong dome supported by three columns. Three square windows above the columns suggests a clerestory in the drum. A small ornament tops the structure. On either side of the building are two tower. Each has a rectangular door, and two rows of three windows. The watch post is topped with square crenellations. To the right of this a putto rows a boat to the west in water filled with fish and shells.

The next city on the north side is Kynopolis (KYNOחO $\Lambda I \Sigma$ ) (Figure 67). It has a basilica between three towers. The church is angled to the right to show both the façade and the side. The front door is apsed. A row of clerestory windows rings the building. There is a small square window on the pediment, and tiled pitched roof with a white filet grid, and an ornament at the peak. The tower on the left has three stories, with a rectangular door, three windows on the upper levels, and a crenellated watch post. The tower on the right has four stories. It is similar to the one on the left but with three square windows on the extra level and it is depicted straight-on, so the watch post is not visible. Behind the church is a tower with an angled grid roof that overhangs the structure, so it could represent a structure connected to the church. To the right of the city, a putto sits in 
the water, facing east and reaching towards a putto with outstretched hands in a boat. They are surrounded by fish and shells.

The second city on the north side is Pseudostomon (IEY $\triangle O C T O M O N)$ (Figure 68). Like Kasion, it is depicted with towers. In this case, there are three: a skinny tall one in the center with an arched gate and two levels of windows, flanked by shorter ones with rectangular doors and windows. The roofs of the latter structures are flush with the building are but the taller one overhangs the tower, suggesting a roof. To the right of this is a putto rowing a boat amongst fish, aquatic birds, and a flower.

The main field of the mosaic is an inhabited vine scroll (Figure 69) that issues from acanthus leaves in the west end of the pavement, flanked by peacocks. The scrolls form a grid of eleven rows of four scrolls. Badly damaged by iconoclasts, each contained a figural representation. Still visible are togated individuals, a nude male stomping grapes into a vat of juice next to an amphora, a basket of grapes, a horse, a boar, and a hunter spearing and animal in the next scroll. Some of the scrolls were left empty, while others had geometric motifs added.

The mosaic panels at the east end of each aisle also contain architectonic motifs. Both are read facing east. The one on the north side (Figure 70) has an image of a basilica, showing the side and both facades. The entrance is on the side, with a rectangular door flanked by two columns. Each façade has two pairs of square windows and an apsed window on the pediment. The pitched roof is made with a grid of gradient squares. The church is depicted on a red square ground with a black frame. Its toponym, Diblaton $(\triangle \mathrm{IB} \Lambda \mathrm{ATON})$, is between the cylindrical post and the church motif. To the right of the motif, side by side at the top of the panel, are two inscriptions: 


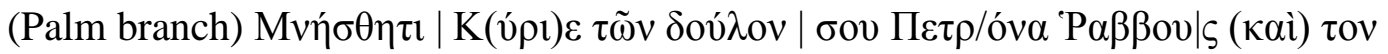
$\alpha u ̉ \tau \mid \tilde{u} \tau \varepsilon ́ \kappa v o v$.

Remember, Lord, your servants Petrona (and) Rabbos, (and) their children.

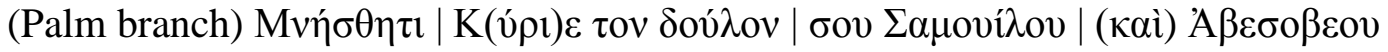
| $\pi \alpha \tau \rho o ̀ s ' O v \alpha i ́ \alpha s$.

Remember, Lord, your servant Samuel and Abesobos, father of Ouaias.

Below are three figures on a platform flanked by two pomegranate trees. The figures have been erased by scrambling the tiles but the individual on the left holds a palm branch. Between the first two figures is an inscription:

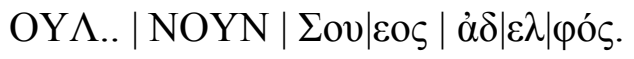

--and brother of Someos.

To the right of the inscription, the second figure faces toward the third, extending his or her hand. The third figure carries a scroll, and to the right is another inscription:

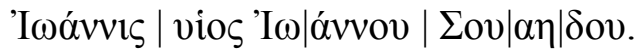

John, son of John (son of?) Souaidos.

To the right of the second tree is another figure whose scrambled body has been covered with geometric designs. He or she is carrying a balm branch and stands next to a large flowering plant.

The last architectonic motif is found at the east end of the south aisle in front of the chancel screen with three inscriptions that are read as one faces east (Figure 71). The panel, which has a white ground framed with a single black filet, contains two donor inscriptions on the left, one above the other: 


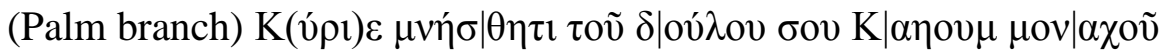

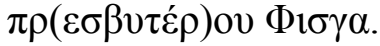

Lord, remember your servant Kaioum, monk and priest of Phisga.

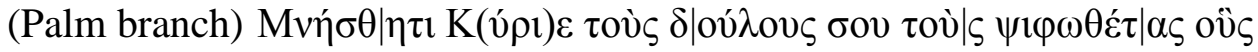

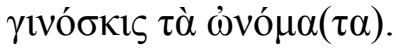

Remember, Lord, your servants the mosaicists whose names you know.

To the right of the inscriptions is a pear tree, with two lower branches cut off. To the right of the tree is a human figure with an inscription above his or her head:

A $\beta ı \beta \mid$ viòs $Z \omega|\gamma o| v \ldots \mid$.E.....N.

Abib, son of Zogon.... E....N.

To the right of this figure is the depiction of the labeled city Limbon (Palm branch $\Lambda \mathrm{IMBON})$. Highly stylized, it likely shows three basilicas and one or two other structures. At the bottom, on the right are two stacked rectangles, each with a vertical row of two rectangular windows. This might be a depiction of a tower, or perhaps two separate small buildings. To the right of this is a basilica shown from the side, with gird of gradient squares depicting the tiled roof and two pairs of square windows on the wall. To the right of this building is the façade of another building, likely a basilica. It has a pitched roof but without tiles. There are three square windows on the pediment, and three rectangular doors and two windows on the façade. Behind these buildings is a large basilica, with three sides shown. There are two pairs of windows on each side. The pitched roof has a grid of gradient squares, and there are two square windows and an apsed one on the pediment. 
Other Mosaics: The rest of the church is decorated with elaborate mosaics and numerous inscriptions. To the east of the nave mosaic, in front of the chancel screen is a dedicatory inscription above a panel depicting seven (now destroyed) donors in between seven fruit trees (Figure 72). At least one donor carries an animal. The inscription is read as one faces the altar. It seems to date the nave mosaic to 756 but this area has been damaged and repaired:

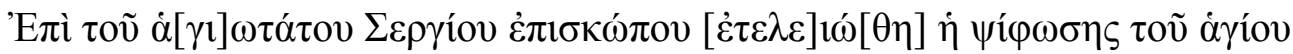

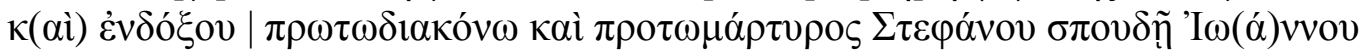

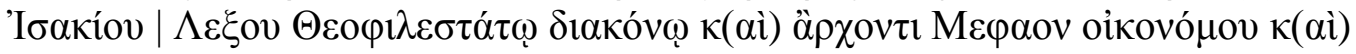

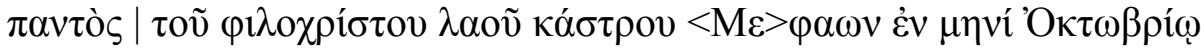

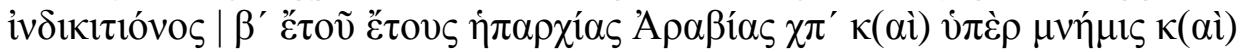

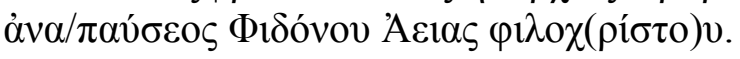

Under the very holy bishop Sergios the mosaic was finished by the holy and glorious protodeacon Stephen, by the zeal of John, (son of) Isacios, by Lexos, very beloved by God, the deacon, archon of Mefa' $a$, and treasurer, and all the people in the camp of Mefa'a who love Christ, in the month of October the second year of the indiction, the year 6[80] of the province of Arabia and for the memory and eternal rest of Fidonos (son of Aeias) who loves Christ.

To the right of this, around the ambo base, are a few flowering plants and, in front of the pillar as one faces east, a horizontal lozenge, a palm branch and the words Kastron Mefa'a (KACTPON MЕФAA).

The north aisle of the church is decorated with a grid pattern of tangent interloped circles inscribed with circles and recumbent spindles inscribed with horizontal lozenges, with interloped squares inscribed in the compartments. Each pair of squares is filled with like objects: birds, kraters, baskets of fruit or fish. The figural items have mostly been erased and a few have been replaced with flowers. The two squares at the east end of the pavement contain an inscription to be read as one:

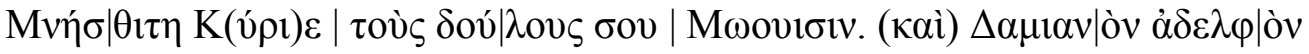

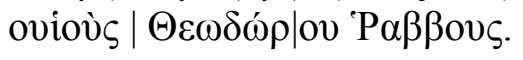


Remember, Lord, your servants Moses (and) Damien (his) brother, son of Theodore (son of?) Rabbos.

To the east of the aisle mosaic is the Diblaton panel, described above. To the east of this, in front of the chapel, is a square panel with fans in the corners. A single guilloche creates a Greek cross, within which is a circle of alternating and interlooped circles, filled with inscriptions, and oblique lozenges filled with smaller lozenges. The interlooped circle in the center once had a bust of a figure. The four inscriptions are, from east clockwise:

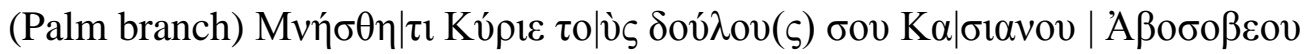

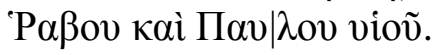

Remember, Lord, your servants Cassianos (son of) Abosobeos, Rabos and Paul (his) son.

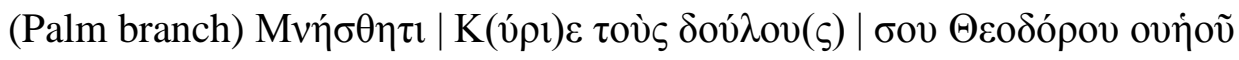

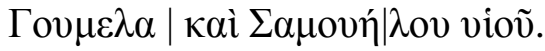

Remember, Lord, your servants Theodore, son of Goumela and Samuel, his son.

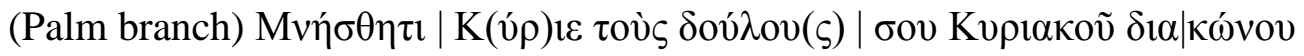

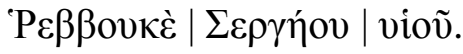

Remember, Lord, your servants Kuriakos the deacon, son of Rebbos, and Sergios, his son.

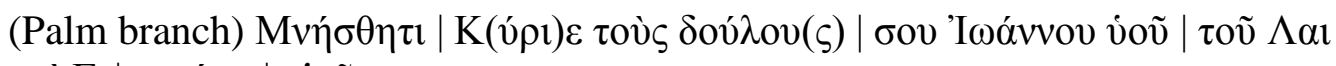

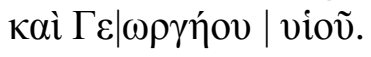

Remember, Lord, your servants John son of Lai, and George (his) son. 
To the east of this, at the doorway to the north chapel, is an inscription in a partial

tabula ansata:

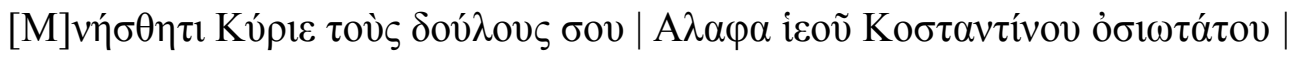

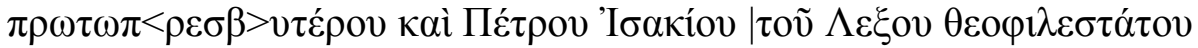

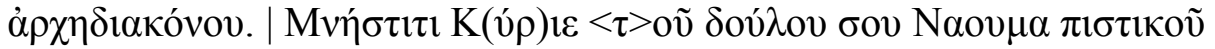
$\Gamma \varepsilon \rho \mu(\alpha v)$ oṽ.

Remember, Lord, your servants Alapha, son of Constantine the pious protopresbyter and Peter, son of Isacios, (son of?) Lexos, archdeacon greatly loved by God. Remember, Lord, your servant, the man of confidence Naouma, son of Germanos.

The chapel contained a grid pattern of oblique triffid leaves inscribed with rosettes, but this has since been lifted.

The south aisle contains a grid pattern of alternating interloped circles and squares inscribed with a denticulated border and birds (including two with ribbons around their necks), leaves, fruit, and baskets of fruit. The birds have been erased and, in some cases, replaced with flowers.

The sanctuary (Figure 73) contains two geometric mosaics and a dedicatory inscription. Behind the chancel screen, in the central portion of the sanctuary, is a mosaic bordered by strapwork of interlaced poised rounded squares. A rectangular panel in the presbyterium has an orthogonal pattern of squares interlooped at the angles interlaced with cushions inscribed with circles. Two panels on either side of the altar contain two inscriptions, read as one faces the apse. The first is on the left and the second on the right:

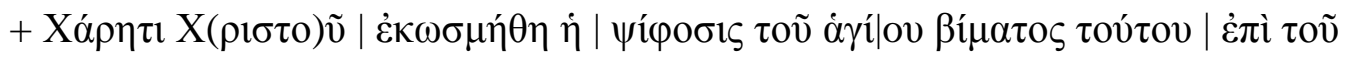

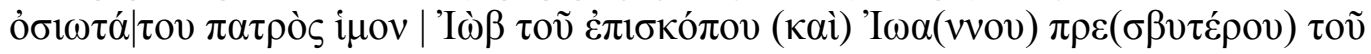

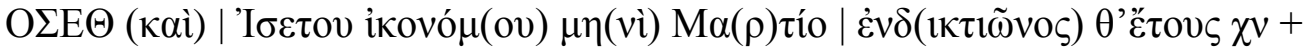


By the grace of Christ the mosaic of this holy bema was embellished in the time of our very pious father Job, the bishop, and John, the priest... and Isetos, the treasurer, in the month of March, the ninth year of the indiction, the year 650 .

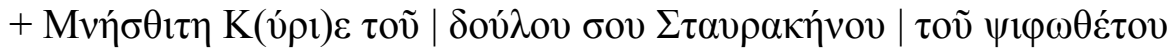

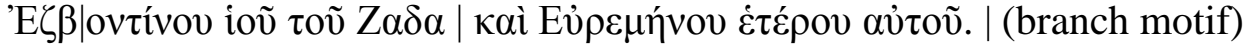

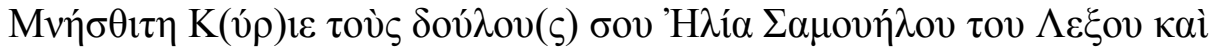

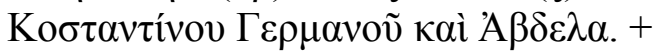

Remember, Lord, your servant Staurakios, the mosaicist from Esbous, son of Zada, and Euremios his associate. Remember, Lord, your servants Elie, (son of) Samuel (son of) Lexos, Constantine (son of) Germanos, and Abdela.

In the apse is a half-shield pattern of polychrome squares in a radiating pattern of overlapping obliques. At the center is a polychrome fan pattern with "Mother Mary" (A $\mu \alpha$ M Mía) below. To the south of the apse, at the end of the south aisle, is a square pavement bordered with guilloche strapwork. Inside is a wreath-like pattern wreath of eight circles interlaced with triangles within a circle. At two corners are stylized kraters and vines. The separate room at the east end of the south aisle was covered in mosaic. At some this was paved over with plaster and none of the original survives.

Current Location of Topographic Mosaic: The mosaic is currently on display in situ in Umm al-Rasas, which is a protected UNESCO heritage site.

\section{Bibliography:}

Michele Piccirillo and Eugenio Alliata, eds. Umm al-Rasas Mayfa'ah I: Gli scavi di complesso di Santo Stefano (Jerusalem: Studium Biblicum Franciscanum, 1994).

IX.. The Church of the Acropolis, Ma'in (Figures 74-85, Plan 13)

Byzantine City: Belemounta (Map 1).

Byzantine Province: Arabia. 
Construction Date: Unknown, possibly 719/720. A fragmentary inscription includes a date of 719/720; however, it does not specify what aspect of construction or decoration it commemorates. de Vaux believes that it is unlikely that a mosaic of this quality was produced it the eighth century, so the inscription must refer to repairs of the iconoclastic damage. Based on comparisons to other mosaics with similar architectonic and agricultural motifs, he dates the pavement to the end of the sixth century or the beginning of the seventh. ${ }^{38}$ Michele Piccirillo, who examined the mosaic in 1982, disagrees and believes that the date refers to the installation of the mosaic. He bases his conclusions on the similarity between the original and repair work, concluding that they must have been done by the same workshop. ${ }^{39}$ Another comparison that should be made is with the St. Stephen mosaic, which also has a topographic border and is dated by inscription to the eighth century. Both have a certain flatness in their architectural depictions that is not found in the other topographic mosaics in Jordan. For St. Stephen, this might be a result of the artist trying to put such detailed motifs into a relatively small frames and subsequently compromising a sense of depth. However, the same flattening effect is used at Ma'in in varying degrees, but especially with the depiction of Nikopolis. Stylistic comparisons based on so little data should be treated with caution but this combined with Piccirillo's observations suggest that an eighth-century construction date is not implausible for the Ma'in mosaic.

Religious Affiliation: This bishop of Madaba oversaw the area, under the authority of the metropolitan of Bosra and the patriarch of Antioch.

\footnotetext{
${ }^{38}$ Roland de Vaux, "Une mosaïque byzantine à Ma in (Transjordanie)," RBibl 47 (1938): 233.

${ }^{39}$ Piccirillo, Chiese e mosaici, 231.
} 
Excavation History: In 1902, Alois Musil discovered the remains of the church on a high hill, often referred to as the "acropolis." The topographic mosaic was discovered during the construction of a modern house in 1934. While the pavement was studied in situ by Father Roland de Vaux on behalf of the French Biblical and Archaeological School of Jerusalem, the church was never excavated. In 1982, the Franciscan Archaeological Institute lifted and conserved the mosaic, at which time another study was conducted. Building Plan and Furnishings: Because the church was not excavated, only a hypothetical plan can be suggested. Based on de Vaux's observations, it was a singleaisle basilica plan measuring $16.5 \mathrm{~m}$ long by $9.5 \mathrm{~m}$ wide (Plan 13). One entered through a single doorway in the west. From the nave, a large opening, $4.5 \mathrm{~m}$ wide, in the north wall led to a small rectangular room. It measured $6.8 \mathrm{~m}$ long and $3.5 \mathrm{~m}$ wide, and was built against the northwest corner of the main building. de Vaux does not mention the layout of the sanctuary. However, he does record finding the hexagonal base of an ambo in the floor. Six holes in a hexagonal pattern, measuring $1.2 \mathrm{~m}$ in diameter were discovered, with part of a limestone fitting still attached to one hole.

While single-aisle churches are not unheard of in Late Antique Jordan, they are rare. A number of column capitals were found within the structure, which could suggest aisles. Moreover, de Vaux mentions a mosaic fragment to the south of what he considered the southern wall of the church. Was this part of a separate building, an intercolumnar panel, or mosaic from a south aisle? The "threshold" mosaic on the north wall that de Vaux identifies could also be an intercolumnar panel. However, the figural panel of the "annex" is more common for an additional chapel than an aisle, but again, 
examples do exist in Late Antique Jordan. It is impossible to determine the plan with certainty without more information about the structure.

Topographic Mosaic: The topographic motifs are part of the outer border of the nave mosaic, which originally measured $16.5 \mathrm{~m}$ long by $9.5 \mathrm{~m}$ wide. The mosaic is badly damaged, with the majority of the western portion surviving but only a small fragment from the eastern side. The mosaic has a double border and two additional panels, one each on the east and west end. Of the eastern panel, almost nothing survives save some vine and with a partial inscription:

\section{NEПIT $\Theta$}

Paul Louis Gatier interprets this as part of Psalm 51:21:

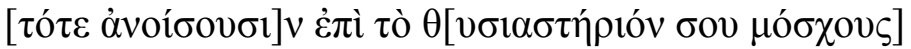

Then they will offer young bulls on Your altar, (Lord).

However, if the plan offered by Piccirillo is correct, there is not enough room for the beginning of this text on the mosaic, for the extant letters are in the northeast corner.

At the west end of the church, there is an inscription in a tabula ansata adorned with hearts, measuring $0.6 \mathrm{~m}$ high by $2.3 \mathrm{~m}$ wide. It is at the entrance to the church but read as one exits, facing west. It is badly damaged but based on the surviving words, which appear in other inscriptions, de Vaux proposes the following:

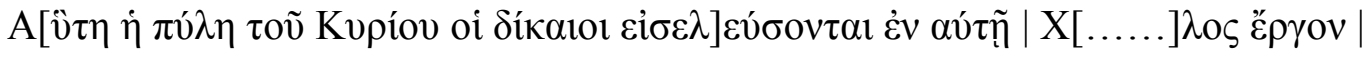
$\tau[\ldots . . \Theta] \varepsilon$.

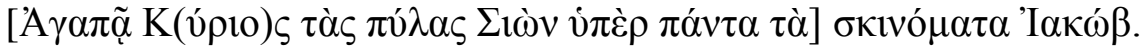

It is the door of the Lord; the righteous shall enter. X ... T ... work ... T... priest and the third year of the indiction, the year 614. The Lord prefers the gates of Zion to all the tents of Jacob. ${ }^{40}$

\footnotetext{
${ }^{40}$ de Vaux, "Une mosaïque," 239-240. The beginning of the passage is from Psalm 98:20, the end quotes Psalm 87:2.
} 
To the south of the inscription are three inhabited vine scrolls, though only a bird in the scroll closest to the inscription is intelligible. To the north of the inscription there remains a small portion of an orthogonal pattern of adjacent scales.

The outer border is an alternating pattern of labeled cities and fruit trees of various types. The toponyms are read facing outwards and one would have to walk around the border to see and read all of the motifs. Unlike the other mosaics examined in the current study, the cities here are not shown walled but with individual or combinations of buildings. However, the inclusion of toponyms shows that they represent these communities. de Vaux suggests that, based on the spacing and size of the motifs (about $0.8 \mathrm{~m}$ high by $1.3 \mathrm{~m}$ each), the original number of cities must have been twentyfour. ${ }^{41}$ Only a fragment remains from the north east corner but enough of a tree and the edge of building survives to suggest that these motifs continued on all four sides of the mosaic. The rest of the east border does not survive.

Moving clockwise, the next extant section is at the southwest side of the building. It begins with a fragment of a tree and, to the right of this, Nikopolis (NHK $\Omega \Pi O \Lambda E I C)$ (Figure 74). Beneath the letters is a depiction of a two-story apsed basilica church, with a conflated perspective to show both facades and one side of the building. The walls of each side are divided into four and each quadrant has a rectangular window. Both the triangular pediment of the west façade and the semicircular apse on the east have an arched-shaped window. The roof that joins them is made of a grid of bichrome adjacent serrated squares with, particolored diagonally and identically. Below the roof is a clerestory with three small rectangular windows in a horizontal line.

\footnotetext{
${ }^{41}$ de Vaux, “Une mosaïque,” 241.
} 
To the right of this is another tree. All of the arbor motifs are depicted in a similar fashion: a wide trunk that narrows towards the top and three straight branches. The center one is vertical and the other two are at forty-five degree angles from it. The leaves are also the same, though the fruit is varied. At the bottom of the trees, a sapling branch trails out from each side of the trunk. To the right of Nikopolis they are round and orange, indicating apricots or oranges (Figure 75).

To the right of this, the city has been identified as Eleutheropolis, though little of the inscription remains (.O $\Lambda \mathrm{I} \Sigma$ ) (Figure 76). The length of the toponym supports this suggestion. It is represented by a two-story rectangular building with a pitched roof. There is a monumental façade in the center, with a clerestory and pediment supported by six columns. The wings of the building look like a un-apsed basilica. Its roof is tiled with the same pattern as Nikopolis', only with the pattern reversed. A set of clerestory windows rings the top of the building. Both sides of the building have windows on each story; on the left this is four pairs of rectangular windows and on the right, four individual square ones.

To the right of the city is a tree with pear-shaped fruit; only the left side survives. The next city is Askalon (ACKA $\Lambda \mathrm{ON}$ ) (Figure 77). It is represented by three buildings. An area at the left makes it difficult to determine the first structure, which is shown from the side but with a flattened perspective. It is likely a basilica with a pediment façade in the area of loss. The building is only one story, and has two rectangular windows on the side. Above this are two rectangular windows in the clerestory and a tiled roof, shown in a grid of gradient squares. To the right of this is a larger, two-story basilica. It is shown from an angle to show both the side and the front façade. The front has two pairs of 
rectangular windows and a semicircular window in the pediment. The side of the building has a large rectangular window on the bottom, almost like a continuation of the previous church, and three small rectangular windows above. A row of clerestory windows goes around the building. The pitched roof also has a grid of gradient squares. The building to the right of this one is a slightly smaller two-story basilica, set at the same angle. The side has two rows of square windows, above which is the clerestory and pitched roof. The façade has not survived. There was a tree to the right only a few leaves of which survive. There was likely one more city on the south side.

The southeast corner also has a section of loss. The east border contains three extant cities, read from south to north as one faces the western exit of the building. The first is Maiumas (MAHOYMAC) (Figure 78), represented as three buildings: a domed central plan structure flanked by two basilicas. Both facades are shown and the church on the left angles to the left while the other angles to the right, presenting almost a mirror effect. Both have pitched rooves with grids of bichrome adjacent serrated squares with, particolored diagonally and identically, but in the reverse color scheme of each other. Both have a semicircular window in their pediments and small ornaments at the peak. Both have two square windows: the building on the left has one on the front and one on the side, while the one on the right has them both on the side. The central domed building is supported by two wide columns and has a small ornament on its roof. To the right of this scene is an area of loss that would have contained a tree. To the right of this is Gaza (...ZA) (Figure 79). The depiction has three buildings in a row, lined up so that the windows on the two-story buildings form two horizontal bands. The left building's roof is in an area of loss but both stories of the wall have three rectangular windows. The center 
building is shown from the font, with two pairs of rectangular windows and a peaked roof with a semicircular window in the pediment. The building on the right is a basilica, with three rectangular windows on each level and a tiled roof in a grid pattern.

To the right of Gaza is another fruit tree, then a depiction of Odroa $(\Omega(\Delta) \ldots)$ (Figure 80). The architectonic motif is similar to Eleutheropolis', with a building shown from the front, and consisting of a central section flanked by two wings. While there is an area of loss in the top portion, the curving angles suggest that the central portion had a domed roof. Below are three pairs of window, indicating a three-story building or two stories and a set of windows in the dome's drum. The two wings of the building both have a pitched tile room and two pairs of square windows that line up with those of the central structure. To the right of this building is another tree, on a few leaves of which survive. There is room on the east side for another building.

The northeast corner of the north side also has not survived. The first building, level with the opening onto the annex/north aisle, is very fragmentary. A partial toponym (YBA) identifies Charach Moba (Figure 81). Only the rightmost portion of the building survives. The angle and decoration of the motif (bichrome adjacent serrated squares with, particolored diagonally and identically) suggest a basilica but the space where the façade should be has been left blank. Some of the space is filled with a large tree with pearshaped fruit.

To the right of the tree is Areopolis (A. $\Omega \Pi \mathrm{O} \Lambda \mathrm{EI \Sigma})$ (Figure 81). It is one of the more elaborate, and confusing depictions. In the center is a barrel-vaulted structure flanked by two tall structures or four shorter one, stacked in pairs. At first glance, one might assume that they are tower walls but they also resemble the sides of two stacked 
basilicas, with angled rooves and the facades missing as in the depiction of Charach Moba. Only the "roof" of the bottom structure survives, while the top has two small square windows and a similar "roof." Both use the bichrome adjacent serrated square pattern. The barrel vaulted structure is shown on an angle and has two stories. The side has two pairs of square windows, while the façade has one. A clerestory with four windows is also depicted and there is an arched window in the façade's roof. The rest of the roof is tiled like the other two structures. The building on the right suggests that these should be read as two buildings. The lower portion is like the side of a basilica, with two pairs of square windows and clerestory above, topped with a tiled roof in a gradated grid pattern. The upper portion looks like the top story of a basilica, with two small square windows topped with a pitched roof with bichrome adjacent serrated squares. One wonders if the artist depicted the trees first and didn't leave room for the facades or if the schematic drawing of five buildings was enough for the viewer to understand. To the right is another tree, though this one does not bear fruit.

To the right of Areopolis is Gadoron (ГA $\triangle \mathrm{OPON}$ ) (Figure 82). It is represented with two, or only one building. A large basilica is shown from the side but with both facades. The facades each have three stories, each with a pair of windows. Their pitched roofs have a semicircular window in the pediment and a small ornament at the hip. The roof that joins them is a grid of gradient squares. Below this, one would expect a clerestory with windows, but there is simply a white wavy line. Below this are three windows on the second story and two on the first. To the left of this building is perhaps a smaller basilica missing its façade. The side is shown with only one window and an angled roof with the same gradient grid coloration as the larger building. For this reason 
it is perhaps meant to be seen as either an annex or even the side of an apsidal end of the church. If the latter is true, it could explain the unusual structures mentioned in the previous two cities, though this explanation seems less likely for the other motifs. The tree to the right of this group has oblong fruit.

To the right of Gadoron is Esbounta (ECBOYN[TA]) (Figure 83). Like Maiumas, it is represented by a central planned domed structure flanked by two basilicas. The dome is smaller and much less elaborate than Maiumas'. The two basilicas are shown from the side. They each have two stories, two pairs of windows, a clerestory, and pitched rooves in a gradient grid pattern. Small ornaments decorate the top of each of the three buildings. The rightmost basilica is missing, as is most of the next tree.

The last surviving city is Belemounta (BE $\Lambda$ EMOYN(TA) (Figure 84), modern Ma'in. It is shown with three buildings, though the only a portion of the rightmost one survives, perhaps with a rounded roof like the barrel vault in the Areopolis motif. The first building is a basilica, angled to the right to show the façade and side simultaneously. The bottom does not survive but its height suggests a two-story building, with two extant windows on each wall. The pitched roof is a solid color and the pediment bears a semicircular window. To the right of this is a basilica shown head-on. Again, only the top half survives but it has similar features to the one next to it.

The inner border consists of an inhabited acanthus scroll. Only two small portions survives, one from the north side and one from the south. One has suffered iconoclastic damage, while in the other shows an animal with a lance though its body, indicating that at least part of the border displayed a hunting scene. 
The main field of the mosaic is decorated with a pattern of interwoven scutae made from a simple wave pattern and a polychrome three-dimensional undulating and twisted ribbon with a leaf alternately inverted in each undulation. The scutae form hexagons, lozenges, and circles. At least some were once filled with figural elements but were redone with non-figural motifs. A basket of grapes survives and one scuta is filled with rosettes but the ears of a rabbit still show at the top.

Other Mosaic Decoration: To the south of the nave is a small portion of mosaic with a swastika with double returns. According to de Vaux, this is outside the area of a church, and would thus be part of a chapel or other structure but it is also possible that it was part of a south aisle border. Based on the geometric mosaic described below, it could not be an intercolumnar panel, this would make one aisle narrower than the other.

Similarly, on the north side, above the image of Areopolis, a small portion of interlaced ellipses and lozenges, filled alternatively with tassels and inscribed lozenges. This mosaic either decorates the threshold of the annex chapel or is an intercolumnar panel dividing the nave from a north aisle decorated with figural mosaic.

The figural mosaic found to the north of the nave is divided into two, and more likely three, registers though only the top register and a small portion of the one below survives. One would have to face east in order to view the scenes. The fact that this is a divided panel strengthens de Vaux's assertion that this is a separate space and not a nave, which tend to be paved in one continuous pattern. The mosaic, originally measuring 6.8 $\mathrm{m}$ long by $3.5 \mathrm{~m}$ wide, is bordered by a double guilloche. In the top register, at the eastern end, is an inscription quoting Isiah 65:25:

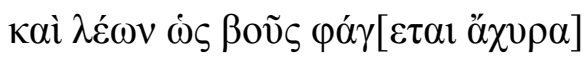


And the lion like the ox will eat (the straw) like the ox.

Below this, the scene has been reworked in an unusual manner (Figure 85). A small shrub is on the left, with the tail and two hooves of an animal coming out of it. To the right of this is a tree and to the right of that a krater with vines spilling forth. The original scene would have been an ox (on the left) facing a lion (covered with the krater), separated by the tree, which is original. In the second register, a globular krater is in the northeast corner with grape vines but the rest of the panel does not survive.

Current Location of Topographic Mosaic: The pavement has been divided into segments that are on display at the Madaba Archaeological Park in Madaba, Jordan.

\section{Bibliography:}

de Vaux, Roland. "Une mosaïque byzantine à Ma'in (Transjordanie)." RBibl 47 (1938): 227-258.

Piccirillo, Michele. "La Chiesa dell'Acropoli di Ma'in," in Chiese e mosaici di Madaba, 228-234. Jerusalem: Studium Biblicum Franciscanum, 1989. 


\section{APPENDIX II: TABLES}

Table 1a: Distribution of Holy Land Topographic Motifs in Jordanian Churches

\begin{tabular}{|c|c|c|c|c|c|c|c|c|c|}
\hline Depicted City & $\begin{array}{l}\text { Umm al- } \\
\text { Manabi' }\end{array}$ & $\begin{array}{c}\text { St. John } \\
\text { the } \\
\text { Baptist }\end{array}$ & $\begin{array}{l}\text { Sts. } \\
\text { Peter } \\
\text { and } \\
\text { Paul }\end{array}$ & Madaba & $\begin{array}{l}\text { Church } \\
\text { of the } \\
\text { Lions }\end{array}$ & $\begin{array}{c}\text { Church } \\
\text { of the } \\
\text { Priest } \\
\text { Wa'il }\end{array}$ & $\begin{array}{c}\text { Khirbat } \\
\text { al- } \\
\text { Samra }\end{array}$ & $\begin{array}{c}\text { St. } \\
\text { Stephen }\end{array}$ & Ma'in \\
\hline Areopolis & & & & & & & & $\mathrm{L}$ & $\mathrm{L}$ \\
\hline Askalon & & & & $\mathrm{L}$ & & & & $\mathrm{L}$ & $\mathrm{L}$ \\
\hline Azotes Paralos & & & & $\mathrm{L}$ & & & & & \\
\hline Belemounta & & & & & & & & $\mathrm{L}$ & $\mathrm{L}$ \\
\hline Bethlehem & & & $\mathrm{A}$ & & & $\mathrm{A}$ & $\mathrm{A}$ & & \\
\hline Charach Moba & & & & $\mathrm{L}$ & & & & $\mathrm{L}$ & $\mathrm{L}$ \\
\hline Diblaton & & & & & & & & $\mathrm{L}$ & \\
\hline Diospolis & & & & $\mathrm{L}$ & & & & $\mathrm{L}$ & \\
\hline Eleutheropolis & & & & $\mathrm{L}$ & & & & $\mathrm{L}$ & $\mathrm{L}$ \\
\hline Esbounta & & & & & & & & $\mathrm{L}$ & $\mathrm{L}$ \\
\hline Gadoron & & & & & & & & & $\mathrm{L}$ \\
\hline Gaza & & & & $\mathrm{L}$ & & & & $\mathrm{L}$ & $\mathrm{L}$ \\
\hline Iamnia & & & & $\mathrm{L}$ & & & & & \\
\hline Jerusalem & & & $\mathrm{A}$ & $\mathrm{L}$ & & $\mathrm{A}$ & $\mathrm{A}$ & $\mathrm{L}$ & $\mathrm{A}$ \\
\hline $\begin{array}{l}\text { Kastron } \\
\text { Mefa'a }^{6}\end{array}$ & & & & & $\mathrm{~L}$ & A & & $\mathrm{L}$ & \\
\hline Caesarea & & & & & & & & $\mathrm{L}$ & \\
\hline Limbon & & & & & & & & $\mathrm{L}$ & \\
\hline Madaba & & & & & & & & $\mathrm{L}$ & \\
\hline Maiumas & & & & & & & & & $\mathrm{L}$ \\
\hline Neapolis & & & & $\mathrm{L}$ & & & & $\mathrm{L}$ & \\
\hline Nikopolis & & & & & & & & & $\mathrm{L}$ \\
\hline Odroa & & & & & & & & & $\mathrm{L}$ \\
\hline Philadelphia & & & & & & & & $\mathrm{L}$ & \\
\hline Sebastis & & & & & & & & $\mathrm{L}$ & \\
\hline
\end{tabular}

$\mathrm{L}=$ Labeled $\quad \mathrm{U}=$ Unlabeled but city identification proposed by previous scholars 
Table 1b: Distribution of Egyptian Topographic Motifs in Jordanian Churches

\begin{tabular}{|c|c|c|c|c|c|c|c|c|c|}
\hline Depicted City & $\begin{array}{l}\text { Umm al- } \\
\text { Manabi }^{6}\end{array}$ & $\begin{array}{c}\text { St. } \\
\text { John } \\
\text { the } \\
\text { Baptist }\end{array}$ & $\begin{array}{l}\text { Sts. } \\
\text { Peter } \\
\text { and } \\
\text { Paul }\end{array}$ & Madaba & $\begin{array}{c}\text { Church } \\
\text { of the } \\
\text { Lions }\end{array}$ & $\begin{array}{c}\text { Church } \\
\text { of the } \\
\text { Priest } \\
\text { Wa'il }\end{array}$ & $\begin{array}{c}\text { Khirbat } \\
\text { al- } \\
\text { Samra }\end{array}$ & $\begin{array}{c}\text { St. } \\
\text { Stephen }\end{array}$ & Ma'in \\
\hline Egypt & $\mathrm{L}$ & & & & & & & & \\
\hline Alexandria & & $\mathrm{L}$ & $\mathrm{L}$ & & & & $\mathrm{U}$ & $\mathrm{L}$ & \\
\hline Antinoë & & & & & & & & $\mathrm{L}$ & \\
\hline Canopus & & $\mathrm{U}$ & & & & & & & \\
\hline Herakleion & & & & & & & & $\mathrm{L}$ & \\
\hline Kasion & & & & & & & & $\mathrm{L}$ & \\
\hline Kynopolis & & & & & & & & $\mathrm{L}$ & \\
\hline Menouthis & & $\mathrm{U}$ & & & & & & & \\
\hline Memphis & & $\mathrm{U}$ & $\mathrm{L}$ & & & & $\mathrm{U}$ & & \\
\hline Panou & & & & & & & & $\mathrm{L}$ & \\
\hline Peluseion & & $\mathrm{A}$ & & $\mathrm{L}$ & & & & $\mathrm{L}$ & \\
\hline Pseudostomon & & & & & & & & $\mathrm{L}$ & \\
\hline Thenesos & & & & & & & & $\mathrm{L}$ & \\
\hline
\end{tabular}


Table 2: Estimation of Time Required to Lay the Nave Mosaics in Churches Containing Topographic Images

\begin{tabular}{|l|c|c|c|c|c|}
\hline \multicolumn{1}{|c|}{ Church } & $\begin{array}{c}\text { Square Footage of } \\
\text { Nave Mosaic } \\
\text { in Meters } \\
\text { (Not Including } \\
\text { Intercolumnar } \\
\text { Panels) }\end{array}$ & $\begin{array}{c}\text { Approximate } \\
\text { Number of } \\
\text { Tesserae per } \\
\text { Square } \\
\text { Meter }\end{array}$ & $\begin{array}{c}\text { Approximate } \\
\text { Number of } \\
\text { Tesserae in } \\
\text { Nave Pavement }\end{array}$ & $\begin{array}{c}\text { Estimated } \\
\text { Number of } \\
\text { Days to Lay } \\
\text { Tiles } \\
\text { with 3 } \\
\text { Workmen }\end{array}$ & $\begin{array}{c}\text { Number of } \\
\text { Individually } \\
\text { Named Donors } \\
\text { Mentioned in } \\
\text { Dedicatory } \\
\text { Inscription }\end{array}$ \\
\hline $\begin{array}{l}\text { Umm al- } \\
\text { Manabi }\end{array}$ & 20.7 & N/A & N/A & N/A & N/A \\
\hline $\begin{array}{l}\text { St. John the } \\
\text { Baptist }\end{array}$ & $\begin{array}{c}233.8 \\
\text { (approximate) }\end{array}$ & 8,500 & $1,987,300$ & 331 & 1 \\
\hline $\begin{array}{l}\text { Sts. Peter and } \\
\text { Paul }\end{array}$ & 28.6 & 7,000 & 200,200 & 33 & 1 \\
\hline $\begin{array}{l}\text { Madaba } \\
\text { (estimated) }\end{array}$ & 67.3 & 12,000 & $1,123,200$ & 187 & N/A \\
\hline $\begin{array}{l}\text { Church of the } \\
\text { Lions }\end{array}$ & 24.5 & 8,000 & 196,000 & 33 & 1 \\
\hline $\begin{array}{l}\text { Church of the } \\
\text { Priest Wa'il }\end{array}$ & 37.4 & N/A & N/A & N/A & 1 \\
\hline $\begin{array}{l}\text { Khirbat al- } \\
\text { Samra }\end{array}$ & 65.0 & 8,500 & 552,500 & 92 & 3 \\
\hline St. Stephen & 58.3 & 8,500 & 495,550 & 83 & N/A \\
\hline Ma'in & & & 538,400 & 90 & 1 \\
\hline
\end{tabular}


Table 3: Donors of the Topographic Mosaics

\begin{tabular}{|c|c|c|c|c|}
\hline Church & $\begin{array}{l}\text { Clergy Mentioned } \\
\text { in Dedicatory } \\
\text { Inscription }\end{array}$ & $\begin{array}{l}\text { Manner in } \\
\text { Which the } \\
\text { Clergy is } \\
\text { Mentioned }\end{array}$ & $\begin{array}{l}\text { Lay Donor(s) Mentioned } \\
\text { in Dedicatory Inscription } \\
\text { and their Titles }\end{array}$ & $\begin{array}{l}\text { Work Mentioned in } \\
\text { Dedicatory Inscription }\end{array}$ \\
\hline Umm al-Manabi ${ }^{6}$ & N/A & N/A & N/A & N/A \\
\hline St. John the Baptist & Bishop Paul & $\sigma \pi 0 v \delta \tilde{n}$ & $\begin{array}{c}\text { Theodore } \\
\text { (adopted son of Thomas) }\end{array}$ & $\mathrm{D}, \mathrm{M}, \mathrm{R}$ \\
\hline Sts. Peter and Paul & N/A & N/A & N/A & $\mathrm{B}, \mathrm{D}, \mathrm{M}, \mathrm{S}$ \\
\hline Madaba & N/A & N/A & N/A & N/A \\
\hline Church of the Lions & Bishop Sergios & $\dot{\varepsilon} \pi \mathrm{i}$ & N/A & $\mathrm{C}$ \\
\hline Church of the Priest Wa'il & $\begin{array}{l}\text { Bishop Sergios } \\
\text { Priest Oualesos } \\
\text { (Wa'il) }\end{array}$ & $\begin{array}{c}\dot{\varepsilon} \pi \grave{r} \\
\sigma \pi 0 v \delta \tilde{n}\end{array}$ & N/A & $\mathrm{B}, \mathrm{C}$ \\
\hline Khirbat al-Samra & Archbishop Theodore & $\dot{\varepsilon} \pi \grave{i}$ & $\begin{array}{c}\text { Pholeos } \\
\text { (son of Adion) }\end{array}$ & M \\
\hline St. Stephen: Nave Mosaic & Bishop Sergios & $\dot{\varepsilon} \pi \mathrm{i}$ & $\begin{array}{l}\text { John (son of Isacios, son of } \\
\text { Lexos), deacon, archon, and } \\
\text { treasurer } \\
\text { People of Mefa'a }\end{array}$ & M \\
\hline $\begin{array}{l}\text { St. Stephen: Sanctuary } \\
\text { Mosaic }\end{array}$ & $\begin{array}{l}\text { Bishop Job } \\
\text { Priest John }\end{array}$ & $\dot{\varepsilon ̇ \pi i ̀ ~}$ & $\ldots$ and Treasurer Isetos & $\mathrm{M}$ \\
\hline Ma'in & $\begin{array}{l}\text { Priest (name does not } \\
\text { survive) }\end{array}$ & N/A & N/A & N/A \\
\hline
\end{tabular}

$\mathrm{B}=$ Construction $\mathrm{C}=$ Completion $\quad \mathrm{D}=$ Decoration $\quad \mathrm{M}=$ Mosaic $\quad \mathrm{R}=$ Roof $\quad \mathrm{S}=$ Silver 
Table 4: Distribution of Representational and Geometric Mosaics in Churches with Topographical Motifs

\begin{tabular}{|c|c|c|c|c|c|c|c|c|c|c|}
\hline Church & Nave & $\begin{array}{c}\text { Inter-columnar } \\
\text { Panels }\end{array}$ & $\begin{array}{c}\text { North } \\
\text { Aisle }\end{array}$ & $\begin{array}{l}\text { South } \\
\text { Aisle }\end{array}$ & Presbyterium & Altar & $\begin{array}{c}\text { Central } \\
\text { Apse }\end{array}$ & $\begin{array}{l}\text { North Side } \\
\text { Room/Apse }\end{array}$ & $\begin{array}{l}\text { South Side } \\
\text { Room/Apse }\end{array}$ & $\begin{array}{l}\text { External } \\
\text { Chapels }\end{array}$ \\
\hline $\begin{array}{l}\text { Umm al- } \\
\text { Manabi` }\end{array}$ & $\mathrm{R}$ & $\begin{array}{ll}- & \text { r }\end{array}$ & - & - & - & - & - & - & - & - \\
\hline $\begin{array}{l}\text { St. John } \\
\text { the Baptist }\end{array}$ & $\mathrm{R}$ & N/A & N/A & N/A & Flagstones & Flagstones & Flagstones & $\begin{array}{c}\text { Opus sectile } \\
\text { (originally } \\
\text { mosaic) }\end{array}$ & $\begin{array}{l}\text { White } \\
\text { mosaic }\end{array}$ & N/A \\
\hline $\begin{array}{l}\text { Sts. Peter } \\
\text { and Paul }\end{array}$ & $\mathrm{R}$ & $\begin{array}{c}1 \mathrm{G} \\
15 \mathrm{DNS}\end{array}$ & G & $\mathrm{G}$ & Flagstones & Flagstones & Flagstones & Flagstones & Flagstones & DNS \\
\hline Madaba & $\mathrm{R}$ & N/A & $\mathrm{R}$ & $\mathrm{R}$ & - & - & - & - & - & $\mathrm{R}$ \\
\hline $\begin{array}{l}\text { Church of } \\
\text { the Lions }\end{array}$ & $\mathrm{R}$ & $\begin{array}{l}1 \mathrm{R} \\
5 \mathrm{G} \\
2 \mathrm{DNS}\end{array}$ & G & G & $\mathrm{R}$ & $\mathrm{R}$ & G & $\mathrm{R}$ & $\mathrm{R}$ & N/A \\
\hline $\begin{array}{l}\text { Church of } \\
\text { the Priest } \\
\text { Wa'il }\end{array}$ & $\mathrm{R}$ & $4 \mathrm{R}$ & $\mathrm{R}$ & $\mathrm{R}$ & $\mathrm{R}$ & G & G & N/A & N/A & N/A \\
\hline $\begin{array}{l}\text { Khirbet } \\
\text { al-Samra }\end{array}$ & $\mathrm{R}$ & DNS & DNS & DNS & Flagstones & Flagstones & Flagstones & Flagstones & DNS & - \\
\hline $\begin{array}{l}\text { St. } \\
\text { Stephen }\end{array}$ & $\mathrm{R}$ & $4 \mathrm{R}$ & $\mathrm{R}$ & $\mathrm{R}$ & $\bar{G}$ & Flagstones & G & G & DNS & - \\
\hline Ma'in & $\mathrm{R}$ & - & - & - & - & - & - & - & - & $\mathrm{R}^{*}$ \\
\hline
\end{tabular}

- $\quad$ = No evidence of this architectural feature remains

N/A = This type of architectural feature was not part of this church

DNS $=$ The architectural feature survives but evidence of its flooring does not
$\mathrm{R}=$ Representational motifs
$\mathrm{G}=$ Geometric patterns
* $\quad=$ This external chapel has been alternatively identified as the north aisle 
Table 5: Representational Motifs in Churches with Topographical Motifs

\begin{tabular}{|c|c|c|c|c|c|c|c|c|c|c|c|}
\hline Church & Nave & $\begin{array}{c}\text { Nave } \\
\text { Border }\end{array}$ & $\begin{array}{l}\text { Intercolumnar } \\
\text { Panels }\end{array}$ & $\begin{array}{c}\text { North } \\
\text { Aisle }\end{array}$ & $\begin{array}{c}\text { South } \\
\text { Aisle }\end{array}$ & Presbyterium & Altar & Apse & $\begin{array}{c}\text { North } \\
\text { Side } \\
\text { Room } \\
\end{array}$ & $\begin{array}{c}\text { South } \\
\text { Side } \\
\text { Room } \\
\end{array}$ & $\begin{array}{l}\text { External } \\
\text { Chapels }\end{array}$ \\
\hline $\begin{array}{l}\text { Umm al- } \\
\text { Manabi` }^{\circ}\end{array}$ & $\mathrm{N}(\mathrm{WC})$ & N/A & - & - & - & - & - & - & - & - & - \\
\hline $\begin{array}{l}\text { St. John } \\
\text { the } \\
\text { Baptist }\end{array}$ & IV, K, PR & $\mathrm{L}$ & N/A & N/A & N/A & N/A & N/A & N/A & N/A & N/A & N/A \\
\hline $\begin{array}{l}\text { Sts. Peter } \\
\text { and Paul }\end{array}$ & IV (2?), N (?) & IV & - & N/A & N/A & N/A & N/A & N/A & N/A & N/A & N/A \\
\hline Madaba & $\mathrm{L}$ & N/A & N/A & $\mathrm{L}$ & $\mathrm{L}$ & - & - & - & - & - & IV \\
\hline $\begin{array}{l}\text { Church of } \\
\text { the Lions }\end{array}$ & $\mathrm{A}, \mathrm{F}, \mathrm{H}, \mathrm{IV}, \mathrm{K}, \mathrm{P}$ & $\mathrm{P}, \mathrm{T}$ & $\mathrm{WC}$ & N/A & N/A & $\mathrm{A}, \mathrm{FT}$ & $\mathrm{A}$ & N/A & KB & KB & N/A \\
\hline $\begin{array}{l}\text { Church of } \\
\text { the Priest } \\
\text { Wa'il }\end{array}$ & $\mathrm{A}, \mathrm{H}, \mathrm{P}$ & $\mathrm{B}, \mathrm{K}$ & $\mathrm{P}, \mathrm{PR}, \mathrm{WC}$ & A, IV & A, IV & $\mathrm{A}$ & N/A & N/A & N/A & N/A & N/A \\
\hline $\begin{array}{l}\text { Khirbet } \\
\text { al-Samra }\end{array}$ & $\mathrm{A}, \mathrm{B}, \mathrm{K}, \mathrm{WC}$ & N/A & N/A & N/A & N/A & N/A & N/A & N/A & N/A & N/A & N/A \\
\hline $\begin{array}{l}\text { St. } \\
\text { Stephen }\end{array}$ & $\mathrm{A}, \mathrm{IV}, \mathrm{H}, \mathrm{P}, \mathrm{V}$ & $\mathrm{L}$ & $\bar{L}$ & $\mathrm{~K}$ & $\mathrm{~K}$ & N/A & N/A & N/A & N/A & N/A & - \\
\hline Ma'in & $\mathrm{V}$ & $\mathrm{L}$ & N/A & N/A & N/A & - & - & - & - & - & $\mathrm{A}, \mathrm{IV}, \mathrm{K}$ \\
\hline
\end{tabular}

- $\quad$ = No evidence of this architectural feature remains

$\mathrm{N} / \mathrm{A}=$ Representational imagery does not exist in this area $\quad \mathrm{A}=$ Animals

$\mathrm{B}=$ Birdcage
$\mathrm{F}=$ Fruit Trees
$\mathrm{H}=$ Hunting
IV= Inhabited Vine Scroll
$\mathrm{KB}=$ Krater with Birds
$\mathrm{P}=$ Person
$\mathrm{PR}=$ Personification
$\mathrm{T}=$ Trees
$\mathrm{V}=$ Vintaging Scene
$\mathrm{WC}=\mathrm{Walled}$ City

$\mathrm{L}=$ Topographic Landscape

$\mathrm{N}=$ Nilotic 
Table 6: Types of Inscriptions and Locations in the Churches with Topographic Mosaics

\begin{tabular}{|c|c|c|c|c|c|c|}
\hline Church & Dedicatory & $\begin{array}{r}\text { Laudatory } \\
\text { (of Donor) }\end{array}$ & $\begin{array}{l}\text { Salvific } \\
\text { (Votive) }\end{array}$ & $\begin{array}{l}\text { Commemorative } \\
\text { (of the Deceased) }\end{array}$ & Biblical Quote & $\begin{array}{c}\text { Individual } \\
\text { Names }\end{array}$ \\
\hline Umm al-Manabi & - & - & - & - & - & - \\
\hline St. John the Baptist & TA-CS & - & - & - & - & - \\
\hline Sts. Peter and Paul & TA-N & TA-N & - & - & - & - \\
\hline & & R-A & & & & \\
\hline Madaba & - & - & - & - & - & - \\
\hline $\begin{array}{l}\text { Church of the } \\
\text { Lions }\end{array}$ & S-N & - & - & - & - & \\
\hline & & & & & & LDP-N (2) \\
\hline & & & & & & LDP-A (2) \\
\hline $\begin{array}{l}\text { Church of the } \\
\text { Priest Wa'il }\end{array}$ & TA-N & & & & & \\
\hline Khirbet al-Samra & $\mathrm{C}-\mathrm{N}$ & & & U-N & & LDP (?)- N (2) \\
\hline St. Stephen & R-CS & & R-A & & & LDP-A \\
\hline Ma'in & & & & & $\begin{array}{c}\text { ?-N } \\
\text { TA-N }\end{array}$ & \\
\hline
\end{tabular}
Types: $\quad \mathrm{C}=$ Circular
LDP= Labeled Donor Portrait
$\mathrm{R}=$ Rectangular $\mathrm{S}=$ Square
$\mathrm{TA}=$ Tabula Ansata
$\mathrm{U}=$ Unframed
?= Unknown
Location: $\quad \mathrm{A}=$ Aisle $\quad \mathrm{CS}=$ Chancel Screen $\quad \mathrm{N}=$ Nave 
Table 7: Donor Portraits in the Churches with Topographic Mosaics

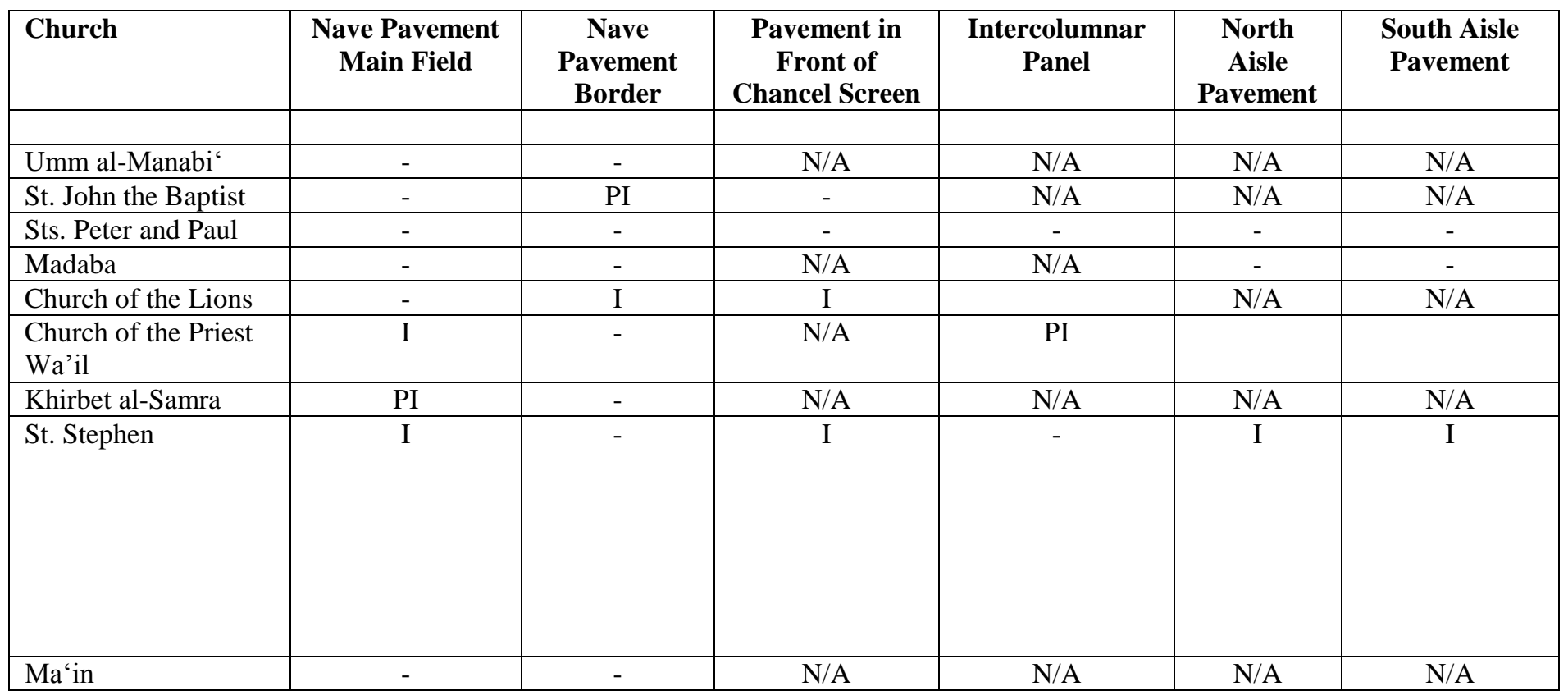

$\mathrm{F}=$ Formal Portrait

I= Informal Portrait

$\mathrm{P}=$ Possible Portrait 


\section{APPENDIX IV: MAPS}

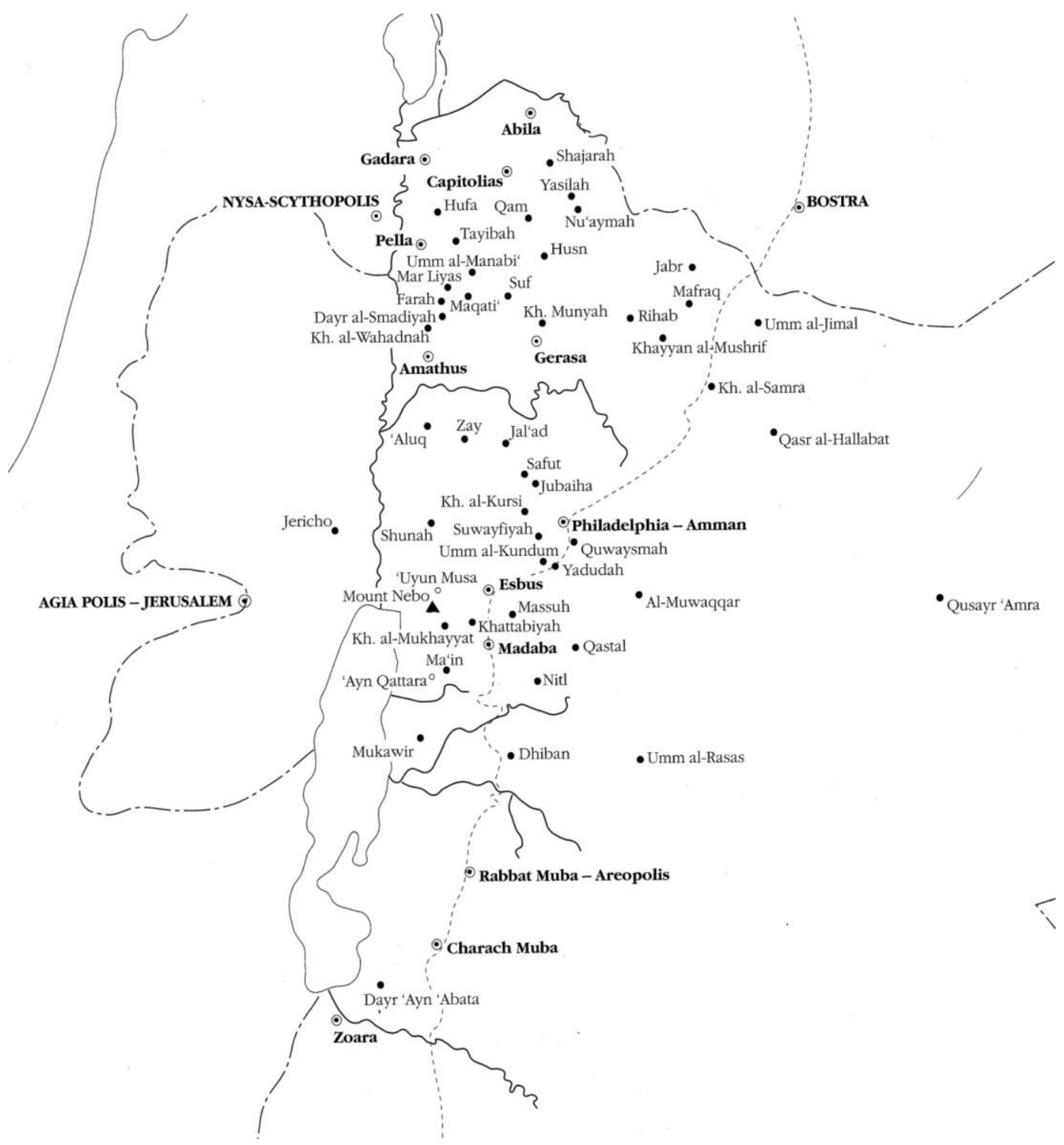

Map 1: Late Antique Sites in Jordan

Michele Piccirillo, The Mosaics of Jordan (Amman: American Center of Oriental Research, 1993), 14. 


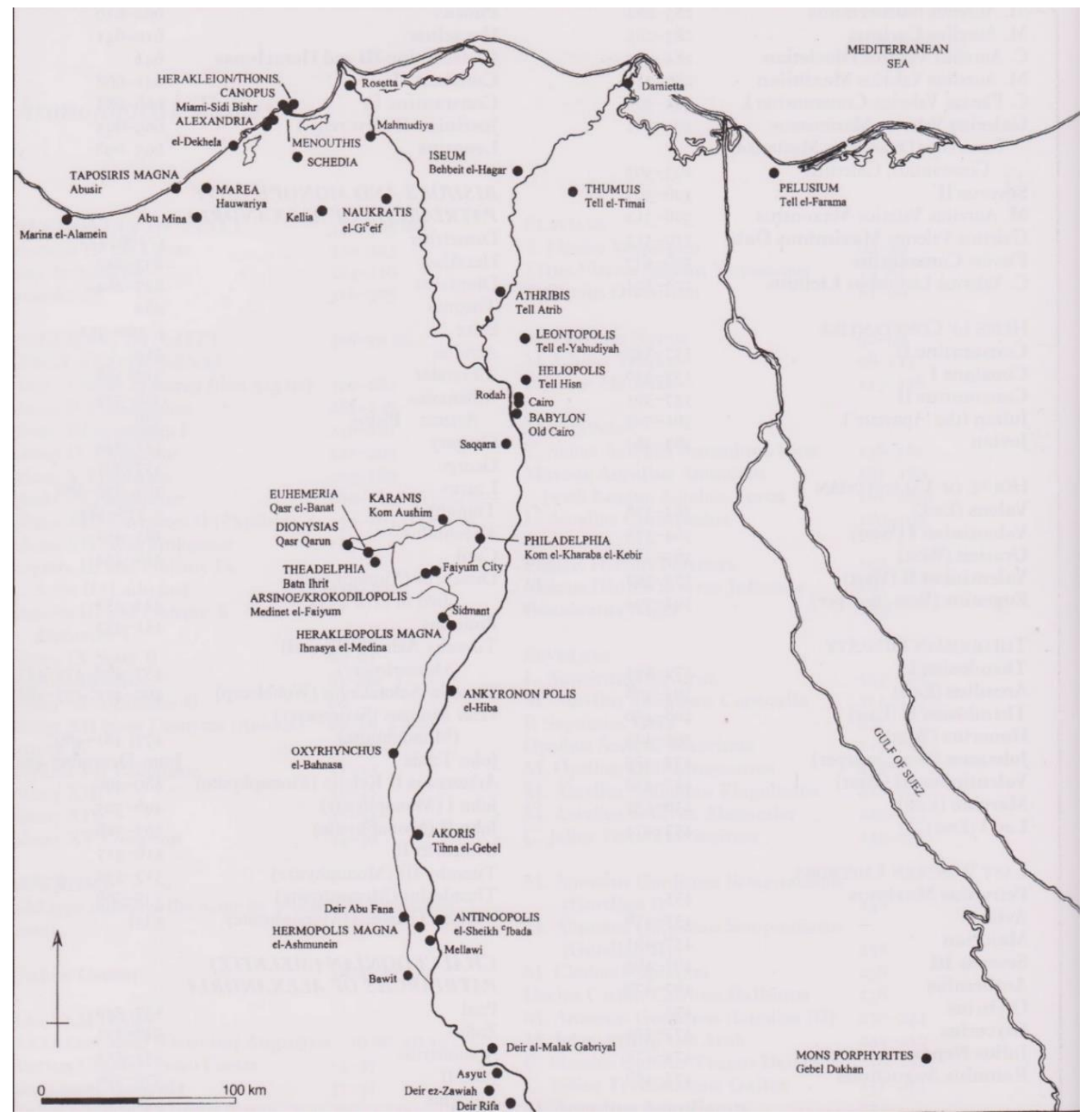

Map 2: Late Antique Sites in Egypt

Judith McKenzie, The Architecture of Alexandria and Egypt, c. 300 B.C. to A.D. 700 (New Haven, CT: Yale University Press, 2008), Map 1. 


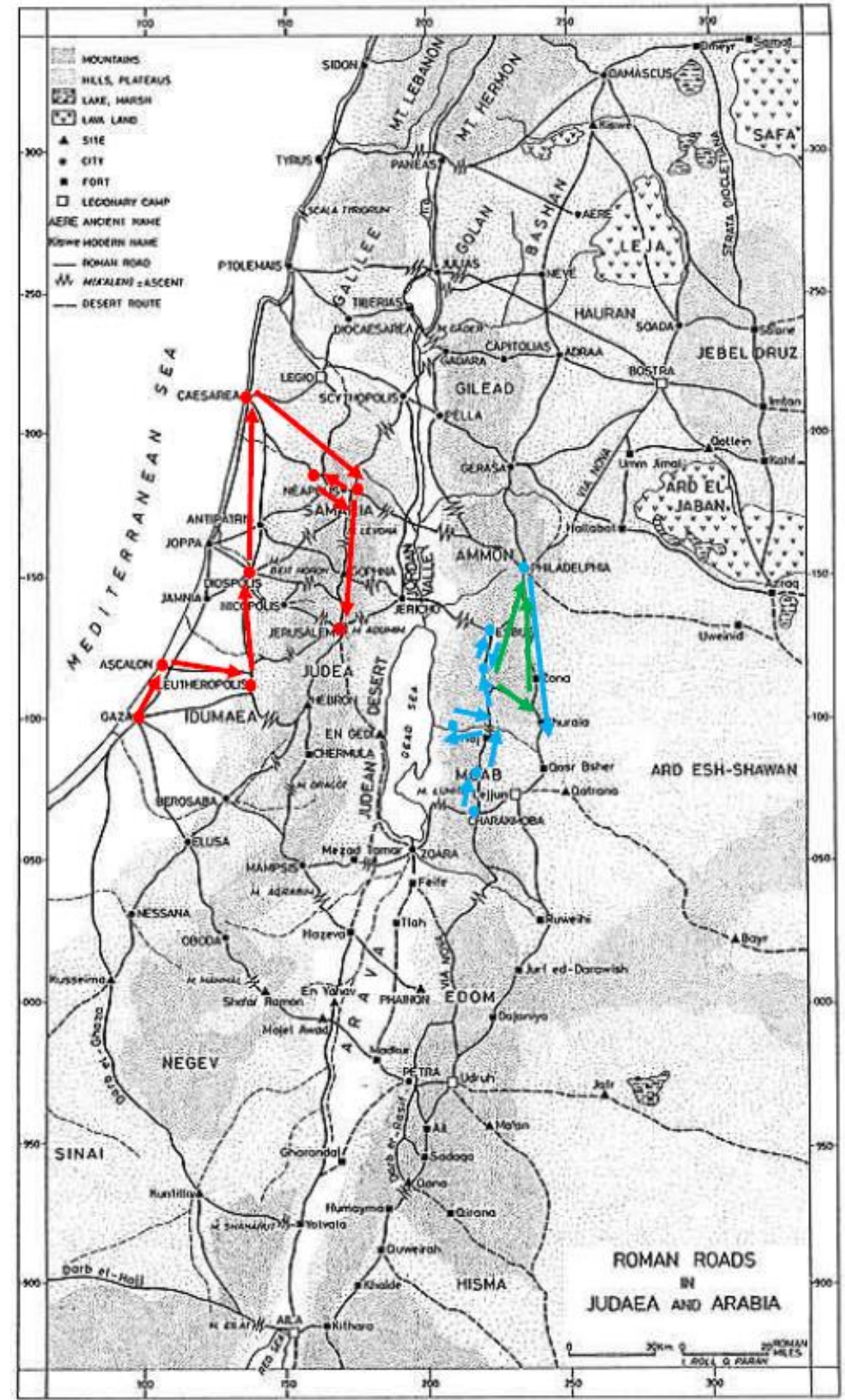

Map 3: The Order of Holy Land Sites Depicted on the St. Stephen Intercolumnar Mosaics

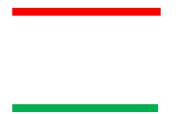

North Intercolumnar Motifs

South Intercolumnar Motifs

Possible Routes from Madaba

Israel Roll, "The Roads in Roman-Byzantine Palaestina and Arabia," in The Madaba Map Centenary, 1897-1997: Travelling through the Byzantine Umayyad Period; Proceedings of the International Conference held in Amman, 7-9 April 1997, ed. Michele Piccirillo and Eugenio Alliata

(Jerusalem: Studium Biblicum Franciscanum, 1999), 108. 


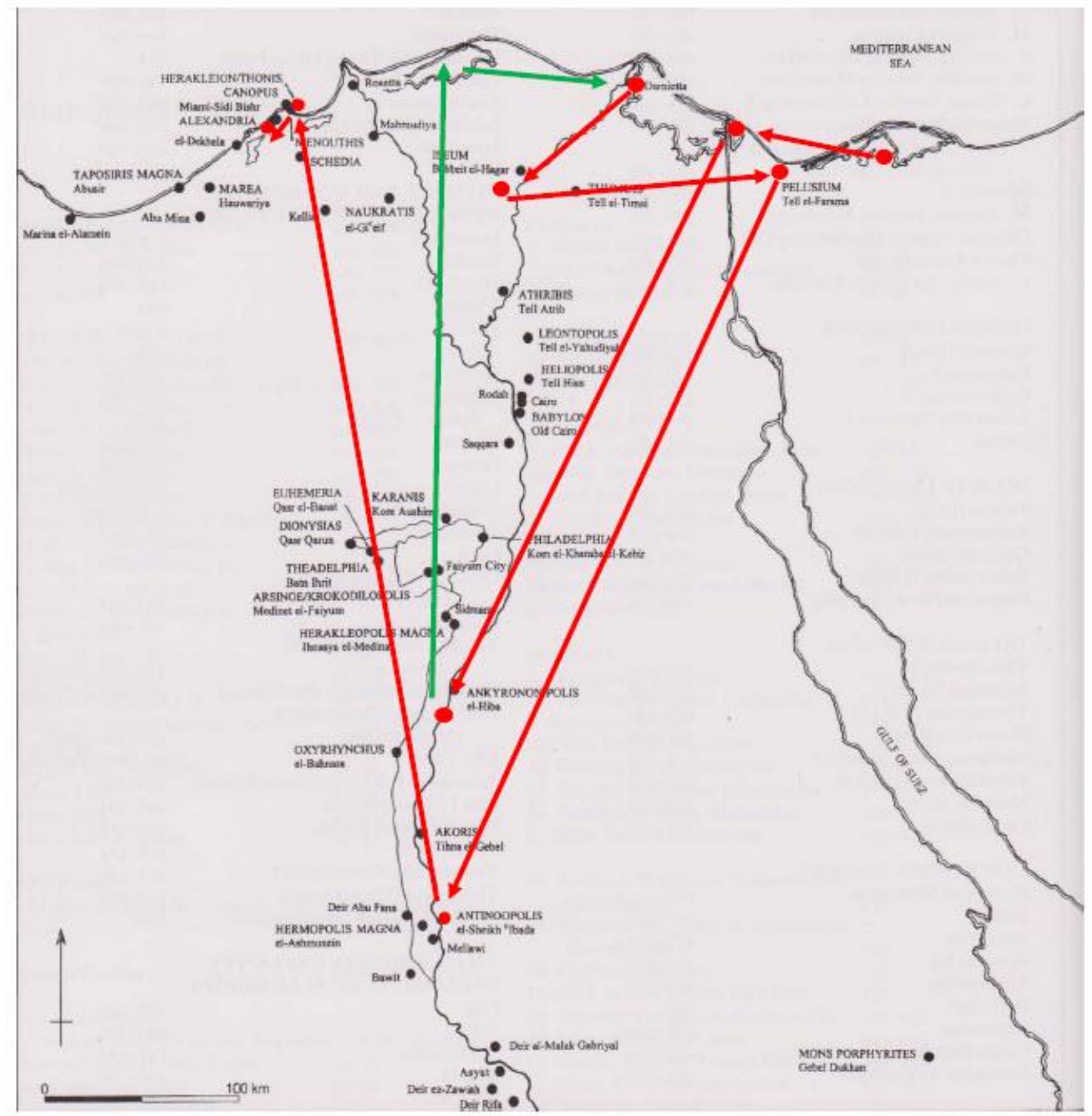

Map 4: The Order of Egyptian Sites Depicted on the St. Stephen Border Mosaic

Sites Depicted Along Known Routes

Possible Routes to/from Pseudostomon

McKenzie, Architecture of Alexandria, Map 1. Modified by the Author. 


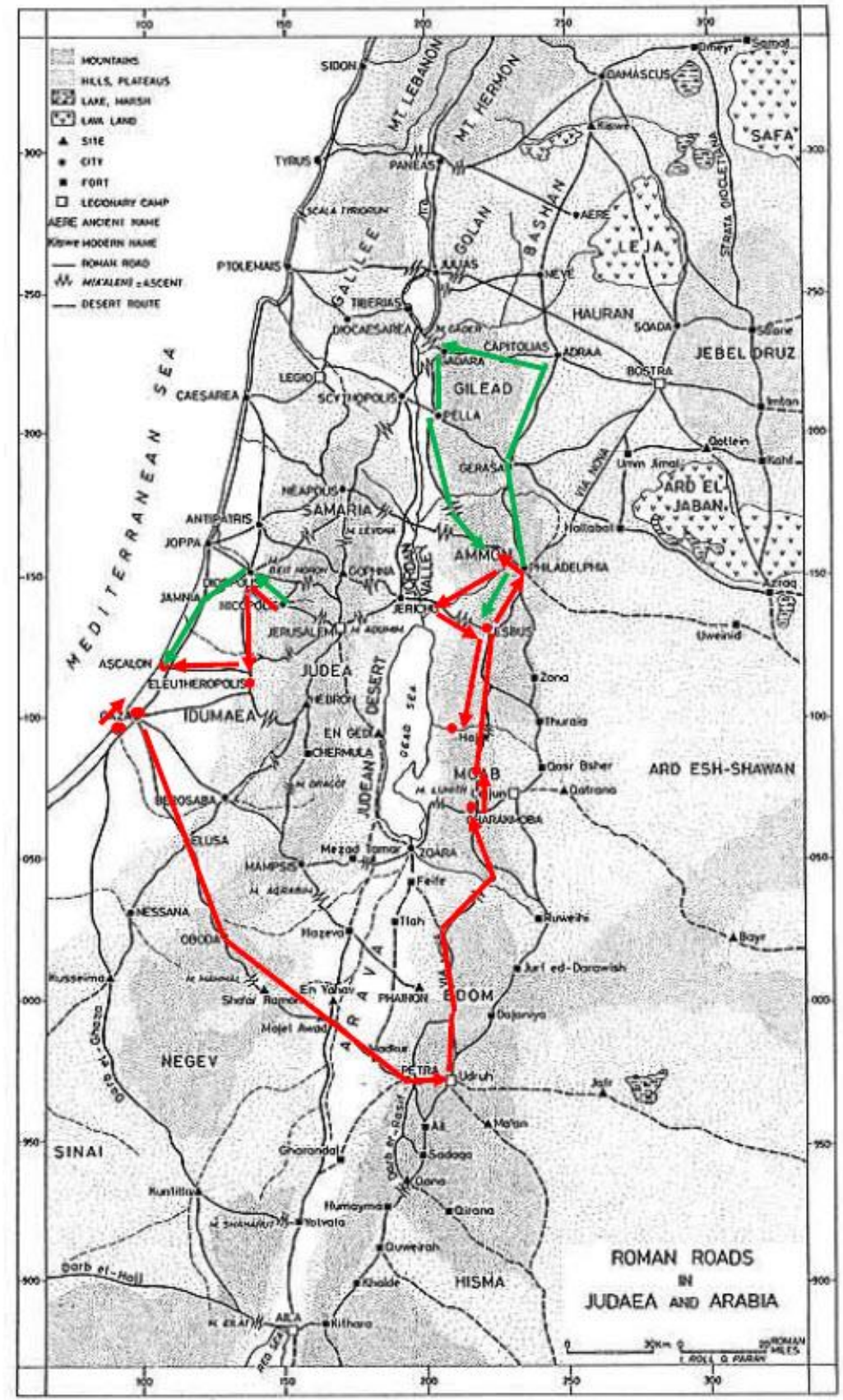

Map 5: The Order of Holy Land Sites Depicted on the Ma'in Border Mosaic

Sites Depicted Along Known Routes

Possible Routes between Sites

Roll, "Roads in Roman-Byzantine," 108. Modified by the Author. 


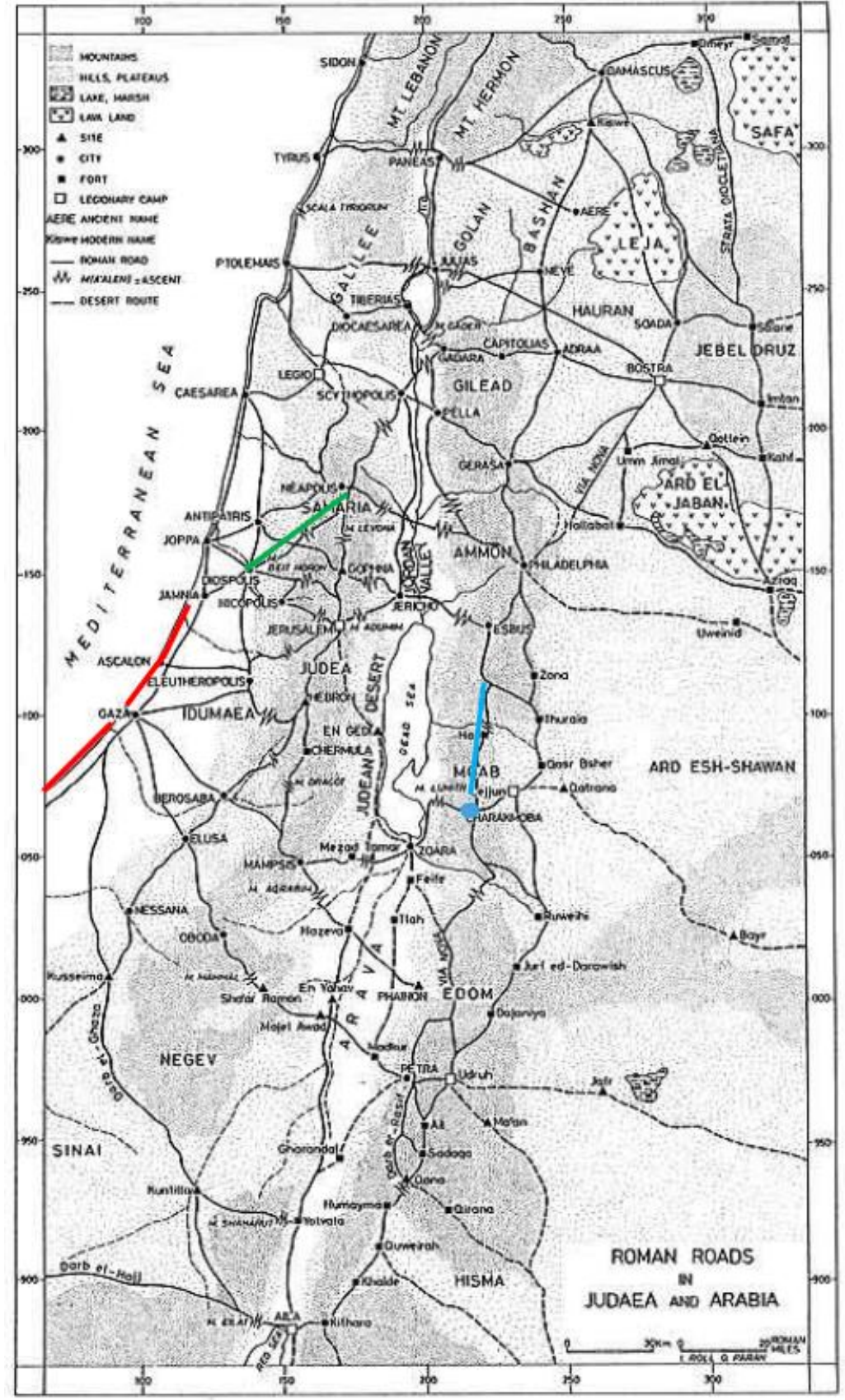

Map 6: Routes Depicted Using Walled City Motifs on the Madaba Mosaic

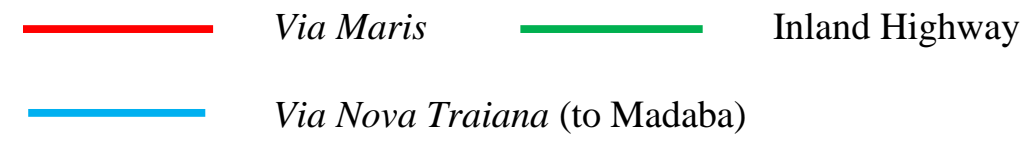

Roll, "Roads in Roman-Byzantine," 108. Modified by the Author. 
APPENDIX V: PLANS

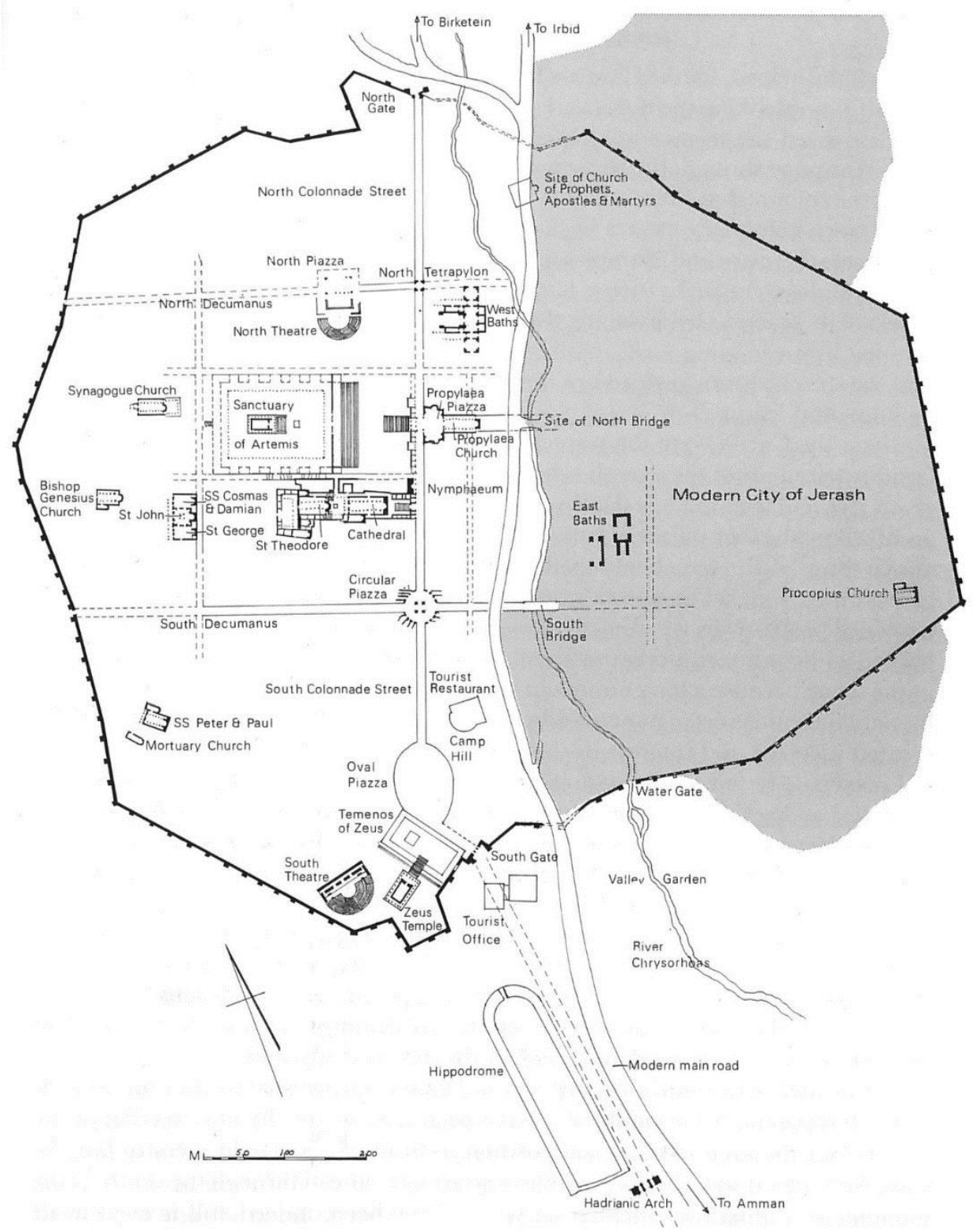

Plan 1: Site Plan of Jerash (Gerasa)

Iain Browning, Jerash and the Decapolis (London: Chatto \& Windus, 1982), 83. 


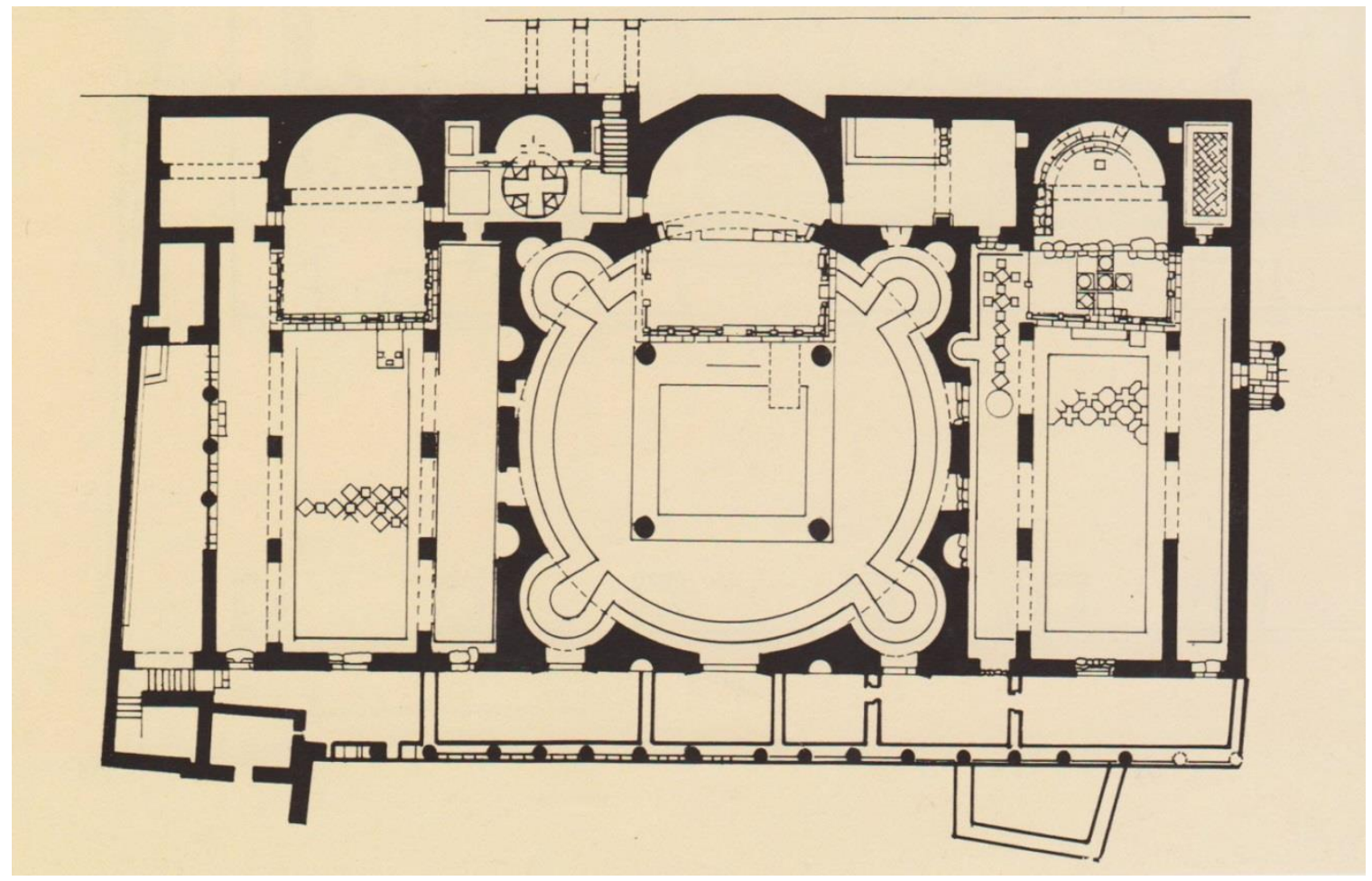

Plan 2: Churches of Sts. Cosmas and Damian, St. John the Baptist, and St. George, Jerash $(533 / 531 / 529$ or 530$)$

Michele Piccirillo, The Mosaics of Jordan (Amman: American Center of Oriental Research, 1993), 288. 


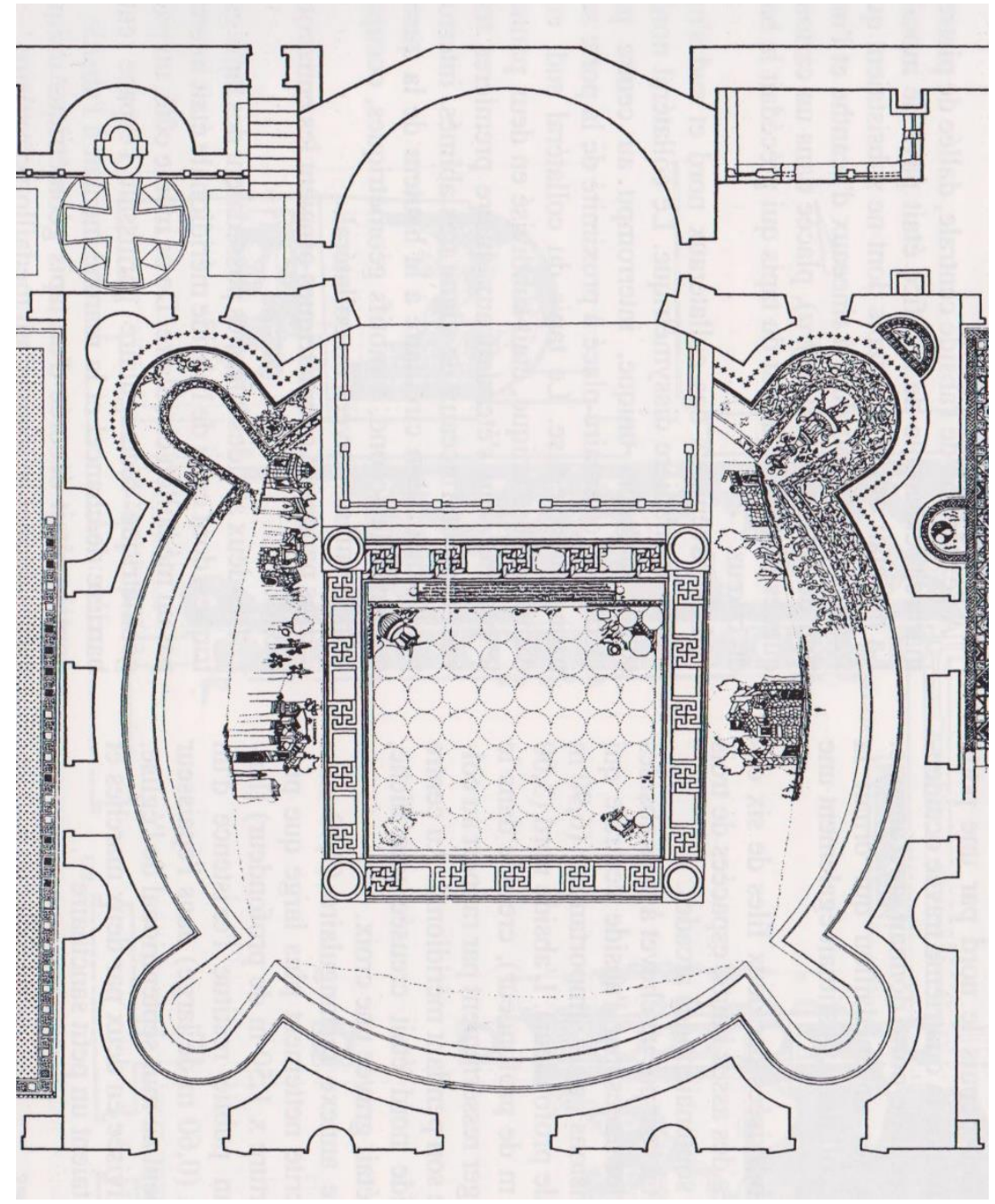

Plan 3: Church of St. John the Baptist, Jerash (531)

Anne Michel, Les églises d'époque byzantine et umayyade de la Jordanie: Ve-VIIe siècle: Typologie architecturale et aménagements liturgique (Turnhout: Brepols, 2001), 244. 


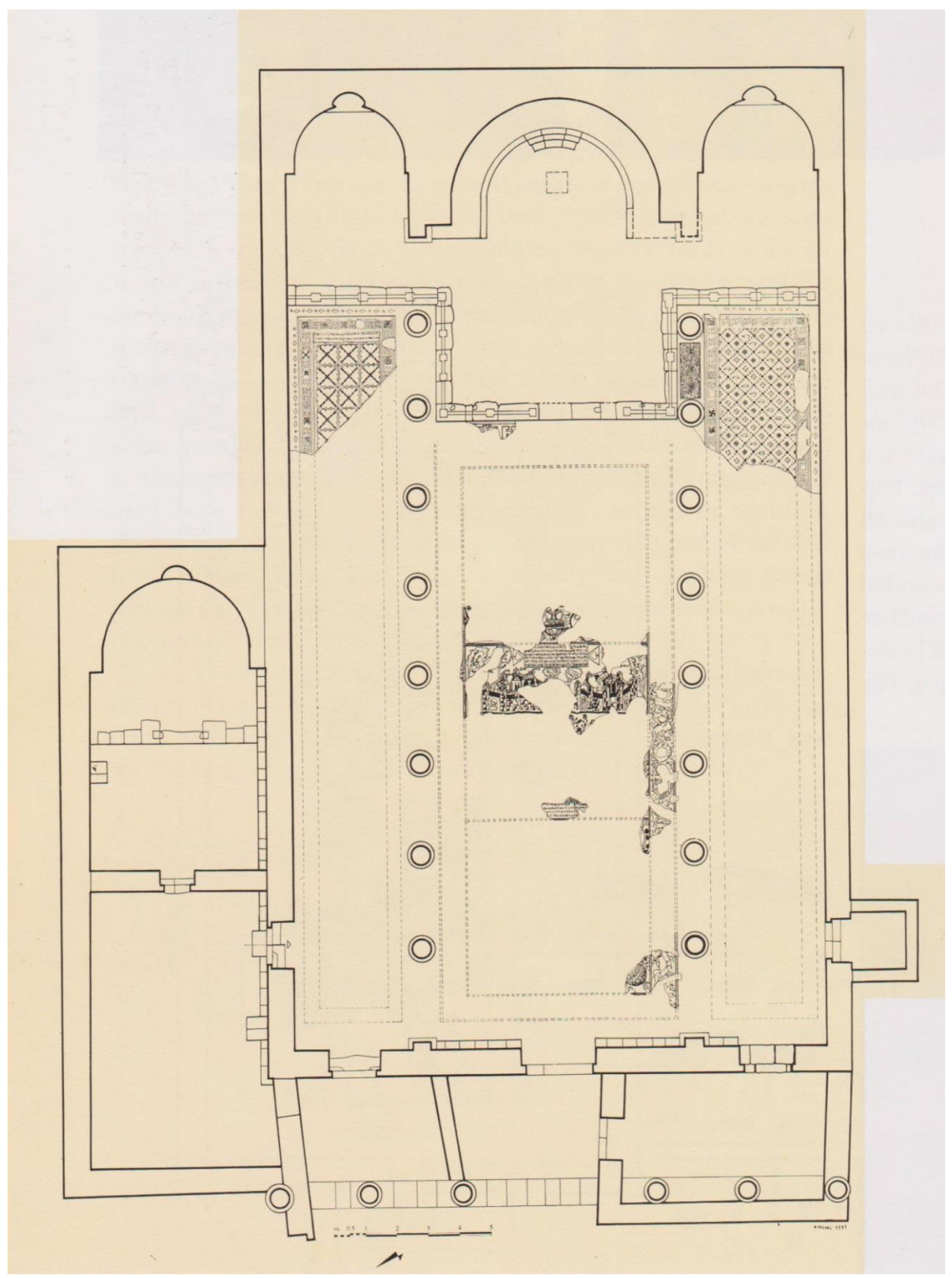

Plan 4: Church of Sts. Peter and Paul, Jerash (Mid-sixth Century)

Piccirillo, Mosaics of Jordan, 292. 


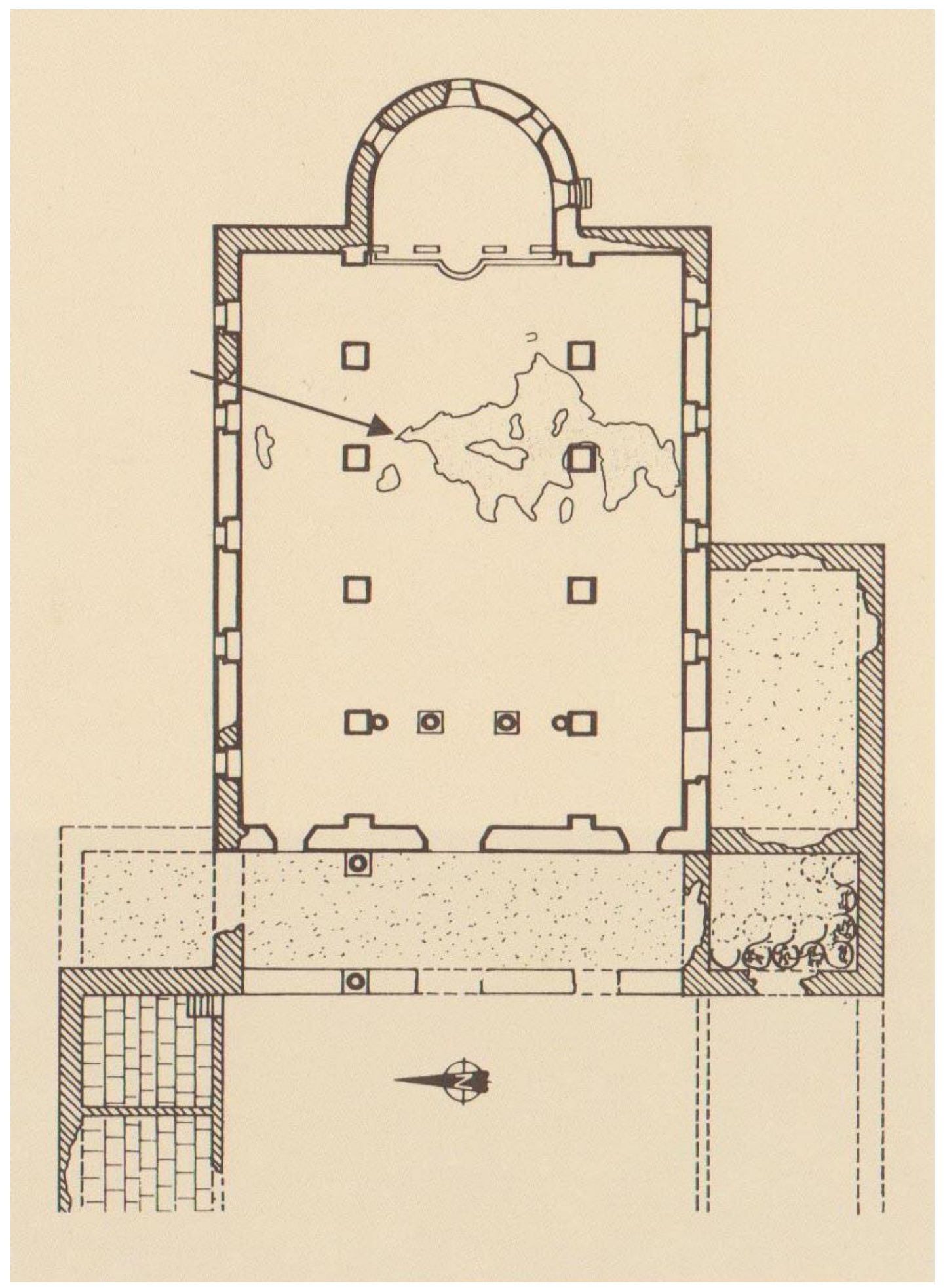

Plan 5: Proposed Plan of the Church of the Map, Madaba (Mid-sixth Century)

Piccirillo, Mosaics of Jordan. 94. 


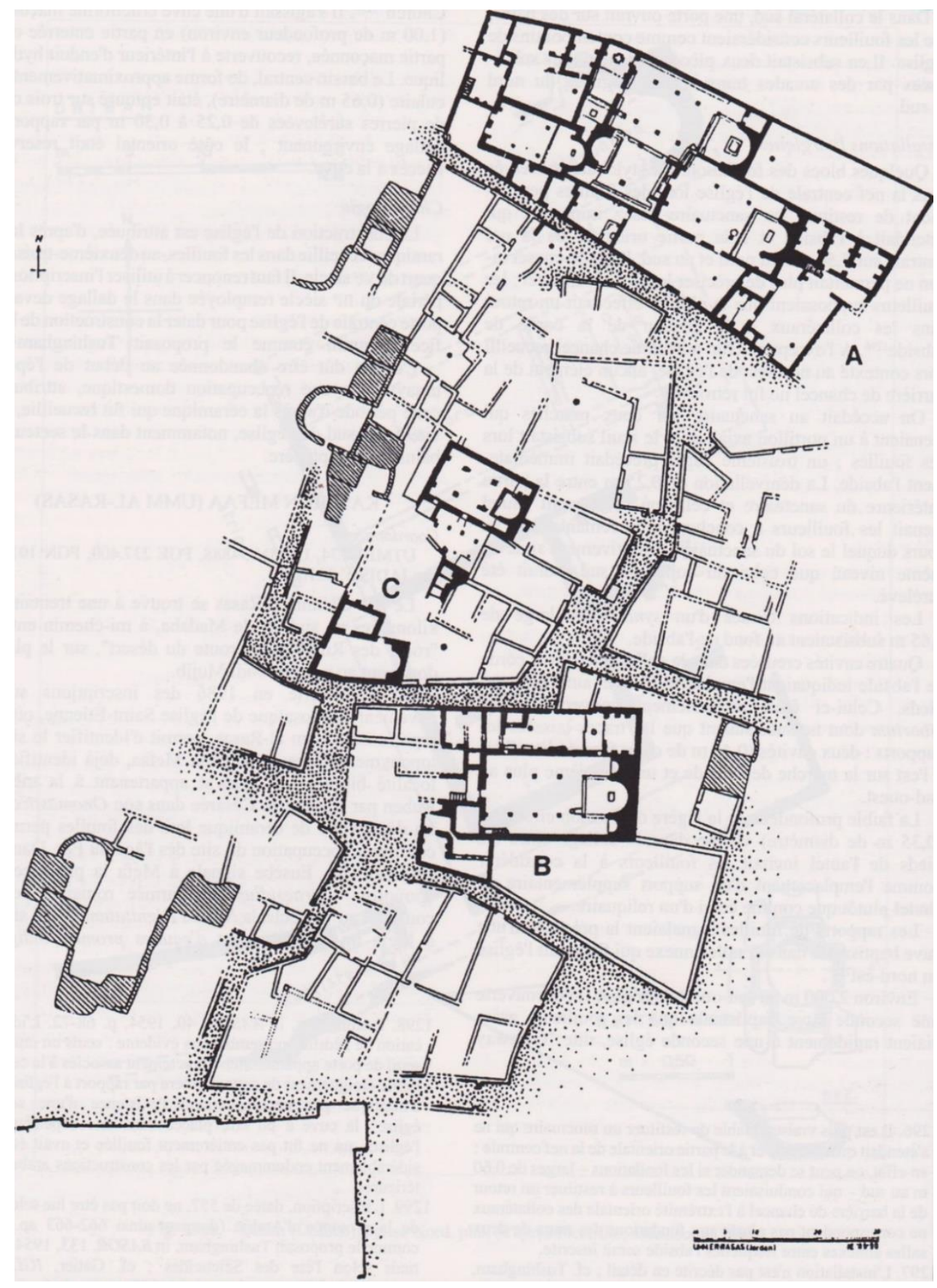

Plan 6: Partial Site Plan of Umm al-Rasas (Kastron Mefa'a)

A- St. Stephen Complex $\quad$ B- Church of the Lions $\quad$ C- Church of St. Paul Michel, Les églises, 380. 


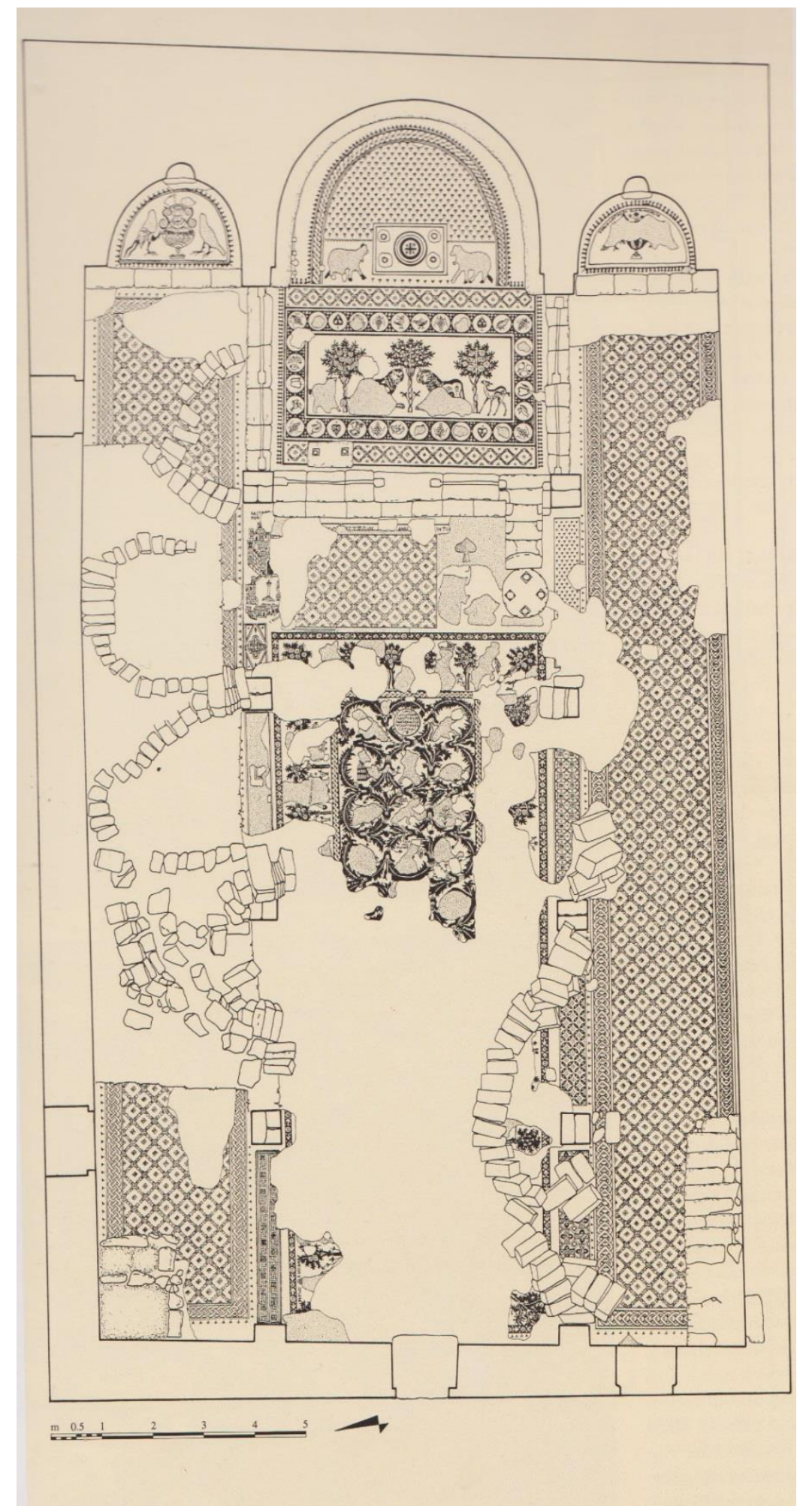

Plan 7: Church of the Lions, Umm al-Rasas (573 or 588)

Piccirillo, Mosaics of Jordan, 237. 


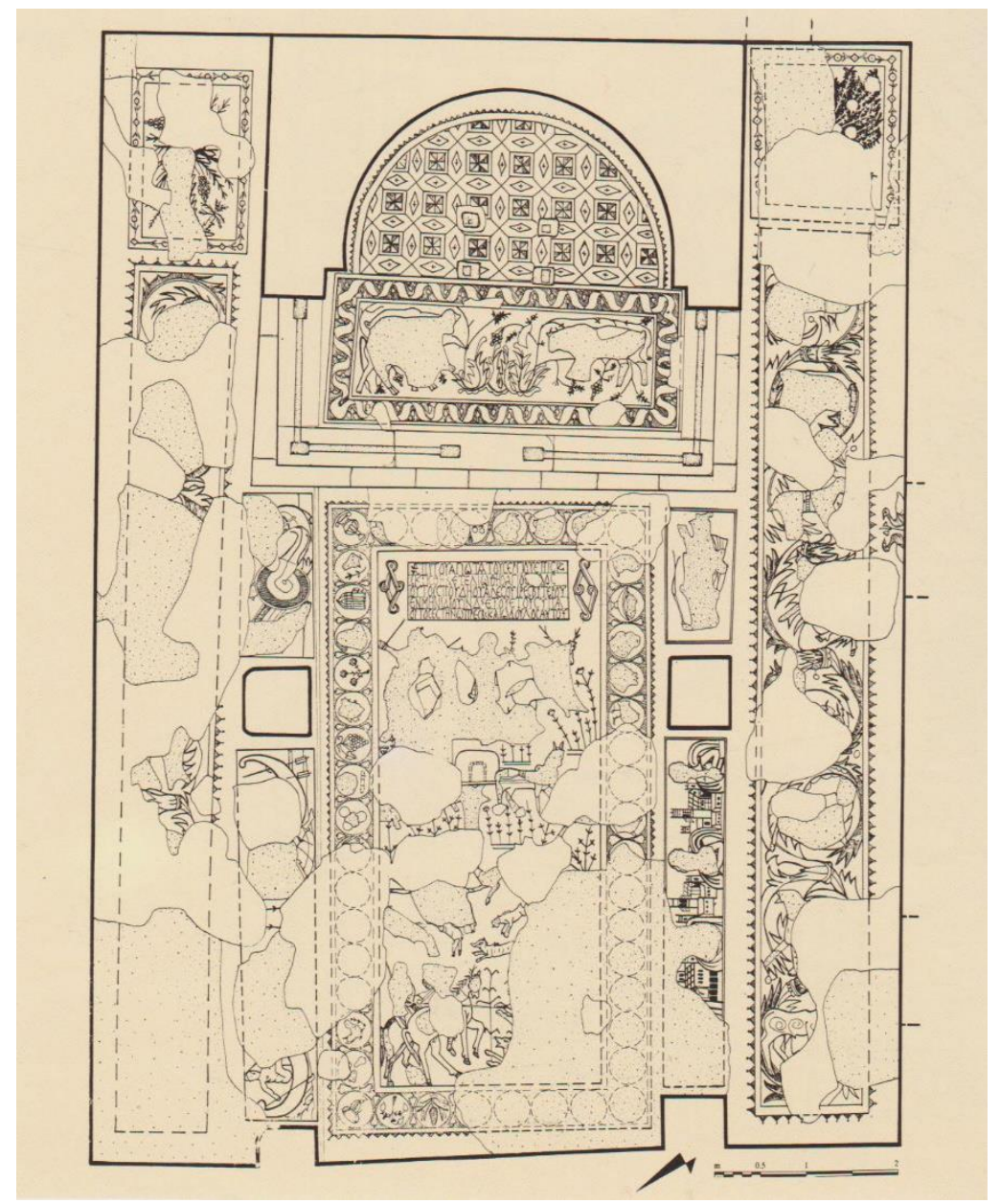

Plan 8: Church of the Priest Wa'il, Umm al-Rasas (586)

Piccirillo, Mosaics of Jordan, 242. 


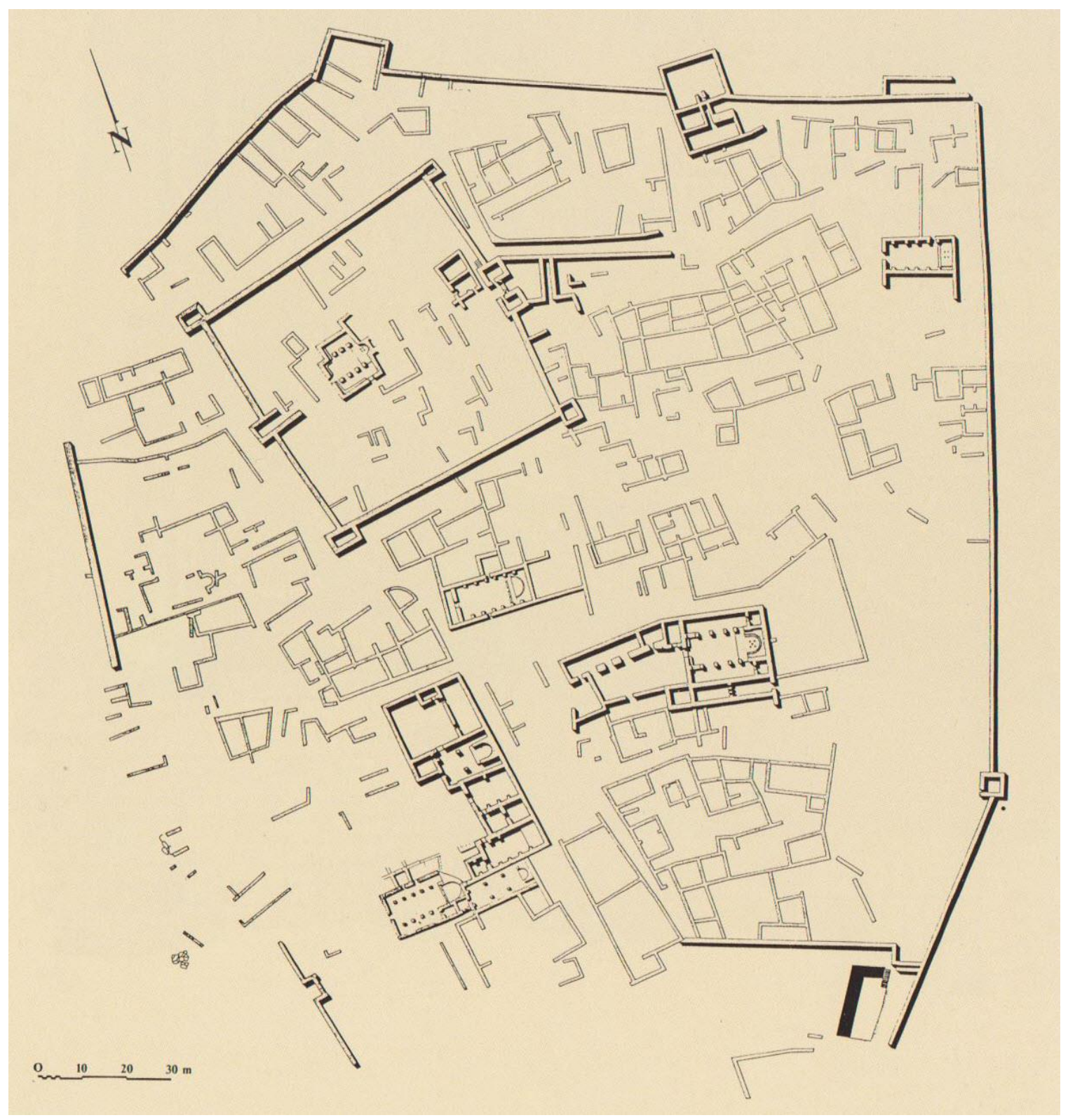

Plan 9: Site Plan of Khirbat al-Samra

Piccirillo, Mosaics of Jordan, 304. 


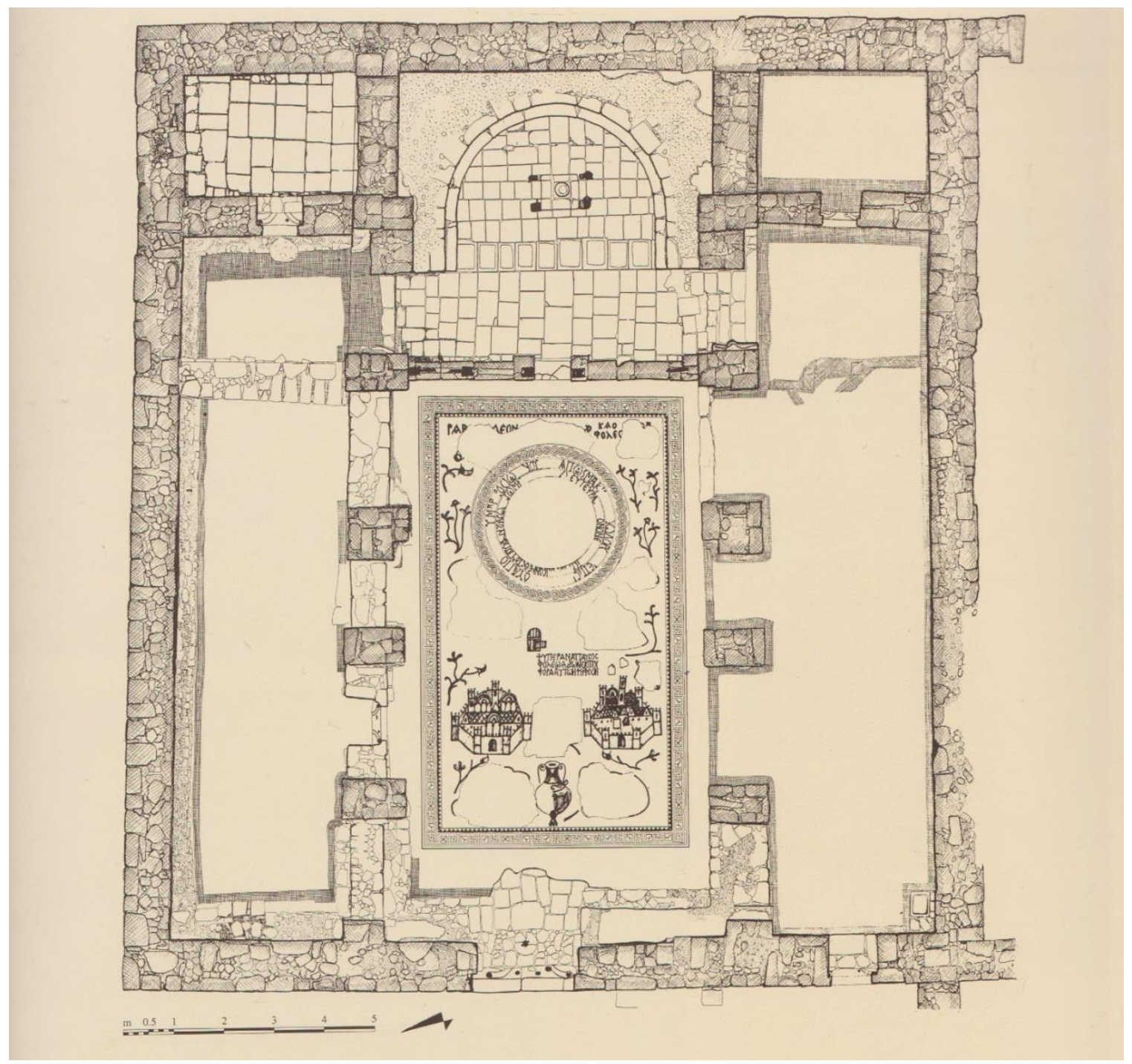

Plan 10: Church of St. John, Khirbat al-Samra (634 or 639)

Piccirillo, Mosaics of Jordan, 305. 


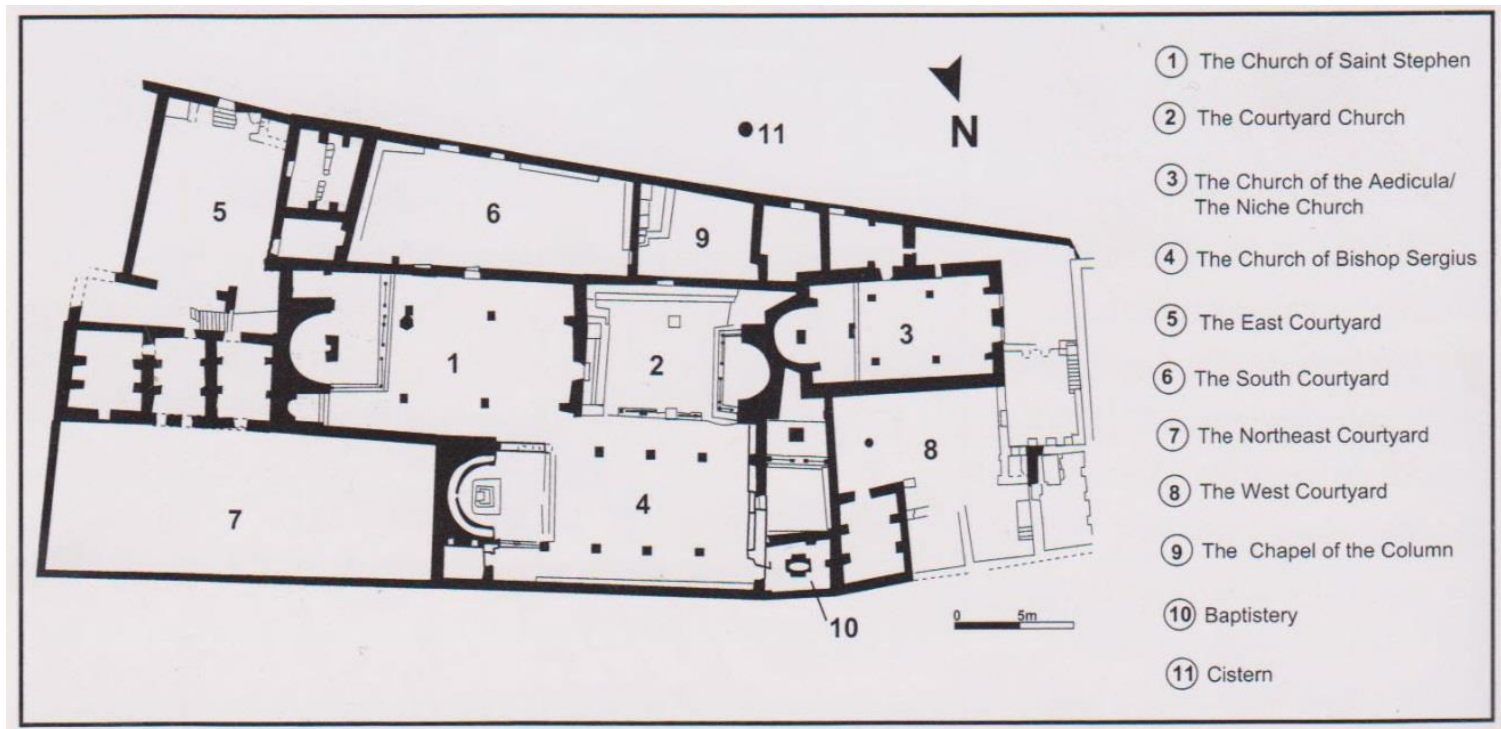

Plan 11: Church Complex Including St. Stephen, Umm al-Rasas

Burton MacDonald, Pilgrimage in Early Christian Jordan: A Literary and Archaeological Guide (Oxford: Oxbow Books, 2010), 154. 


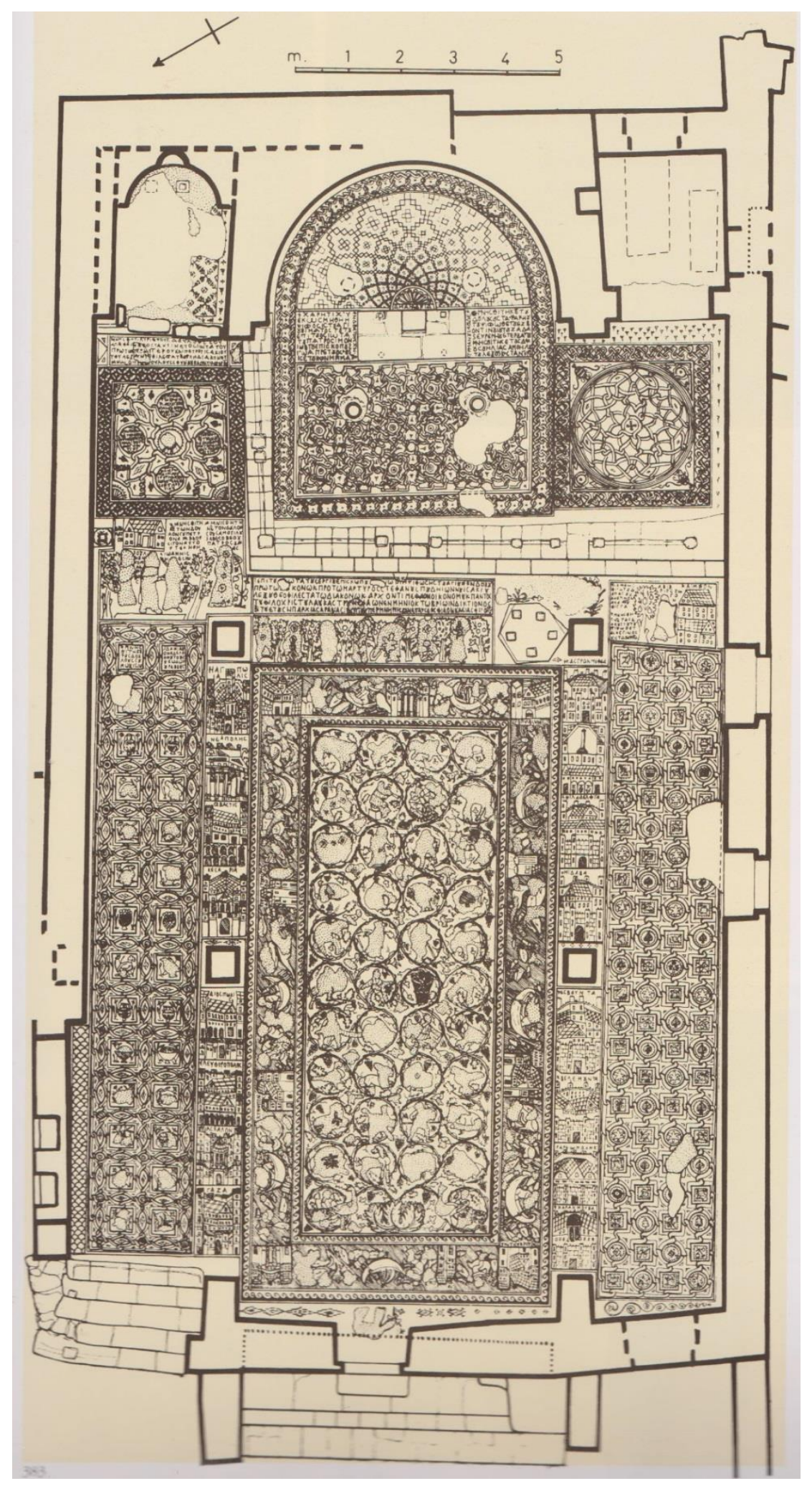

Plan 12: Church of St. Stephen, Umm al-Rasas (718/719)

Piccirillo, Mosaics of Jordan, 239. 


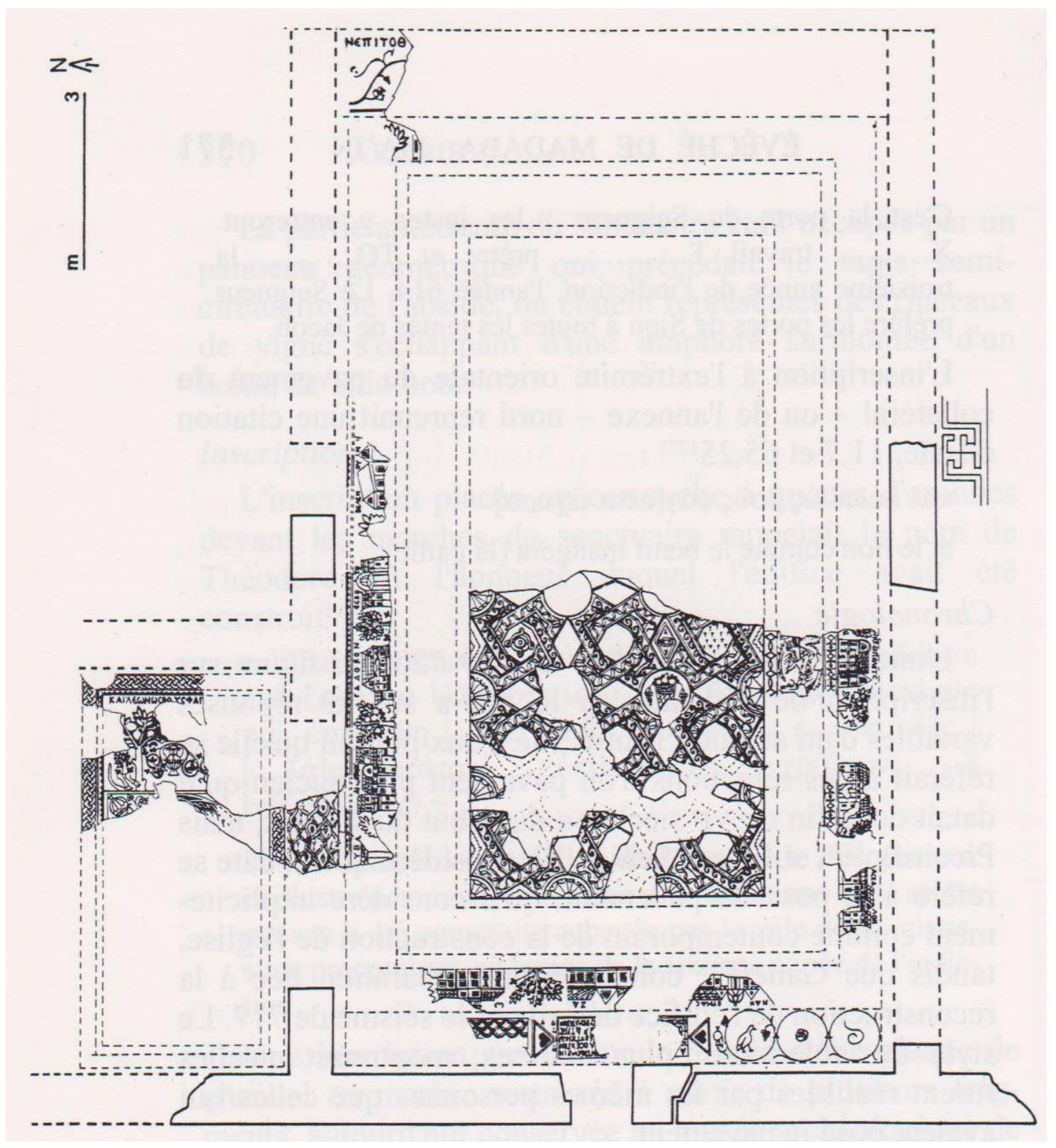

Plan 13: Church of the Acropolis, Ma'in (719/720)

Michel, Les églises, 372. 


\section{APPENDIX VI: FIGURES}

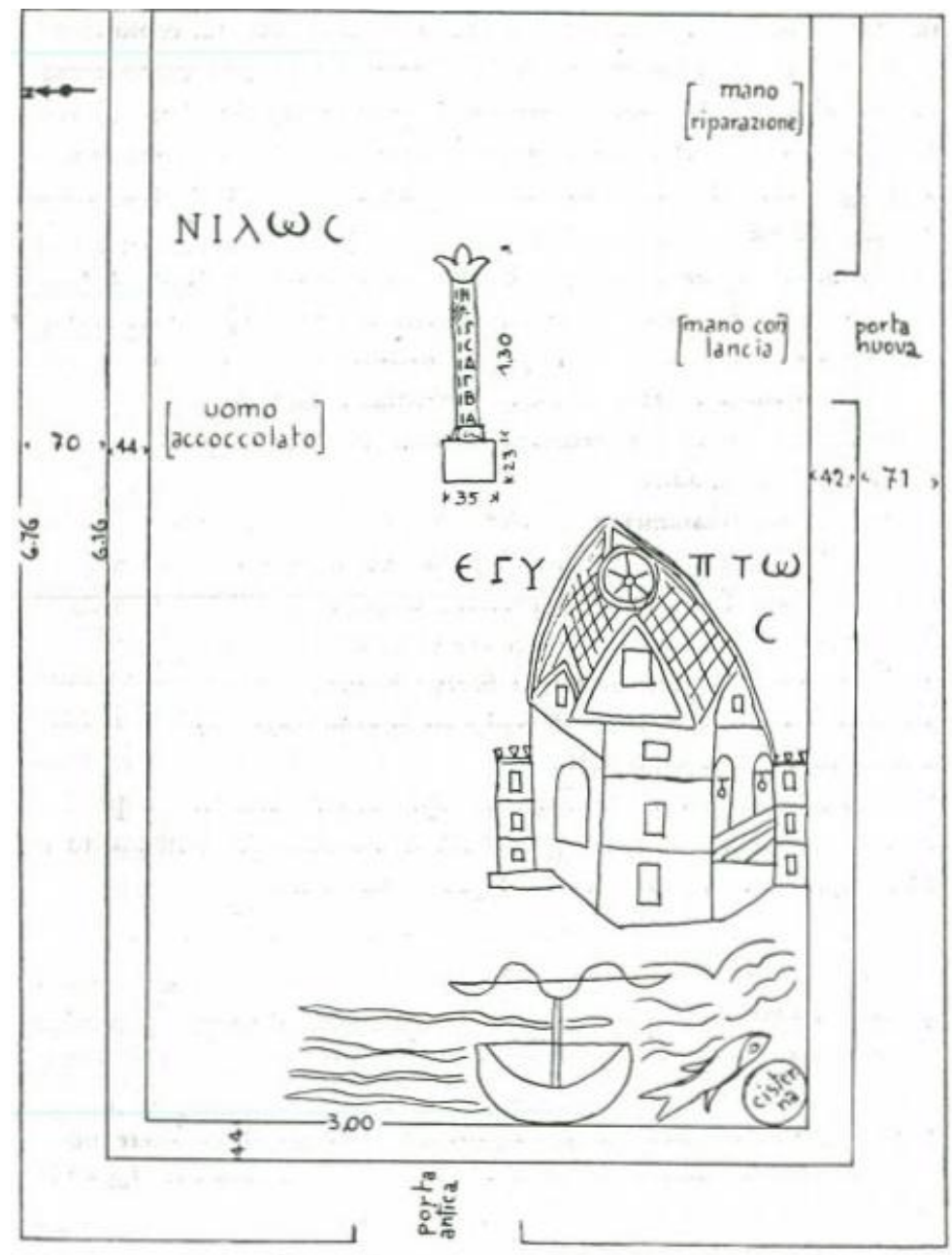

Figure 1: Drawing of the Topographic Mosaic from Umm al-Manabi

Agostino Augustinović and Bellarmino Bagatti, "Escursioni nei dintorni di "Aglun," Liber Anпuиs 2 (1952): 287. 


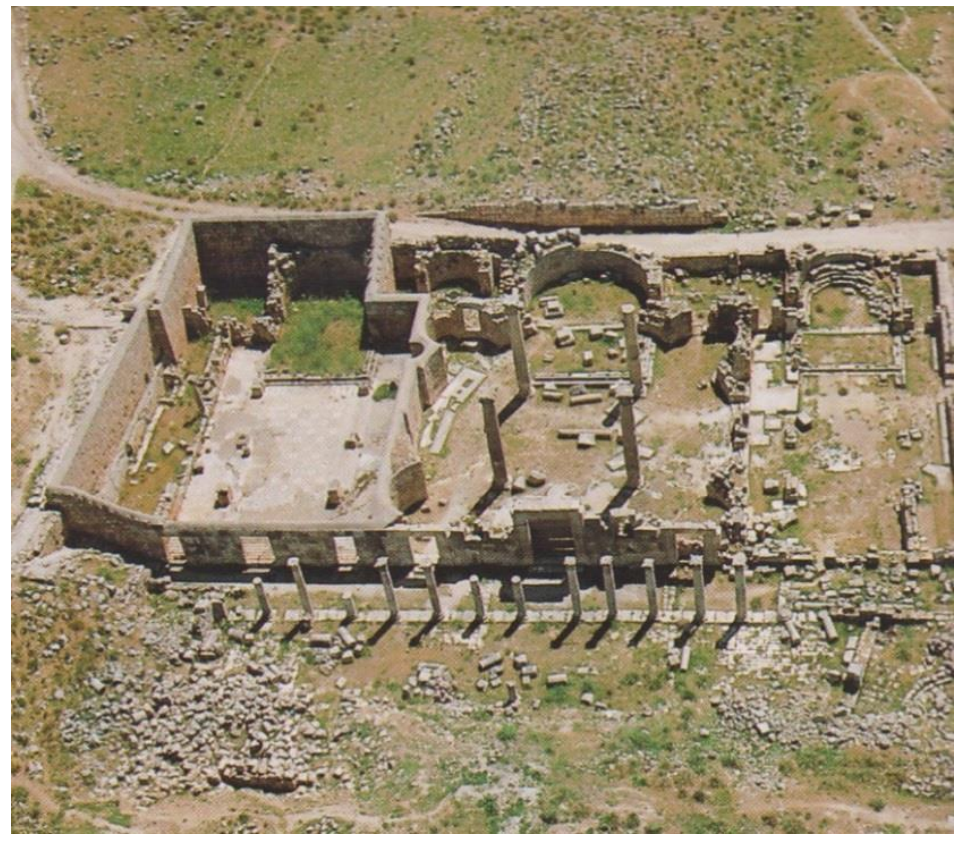

Figure 2: Aerial View of the Churches of Sts. Cosmas and Damian, St. John the Baptist, and St. George, Jerash (Gerasa)

Michele Piccirillo, The Mosaics of Jordan (Amman: American Center of Oriental Research, 1993), 288.

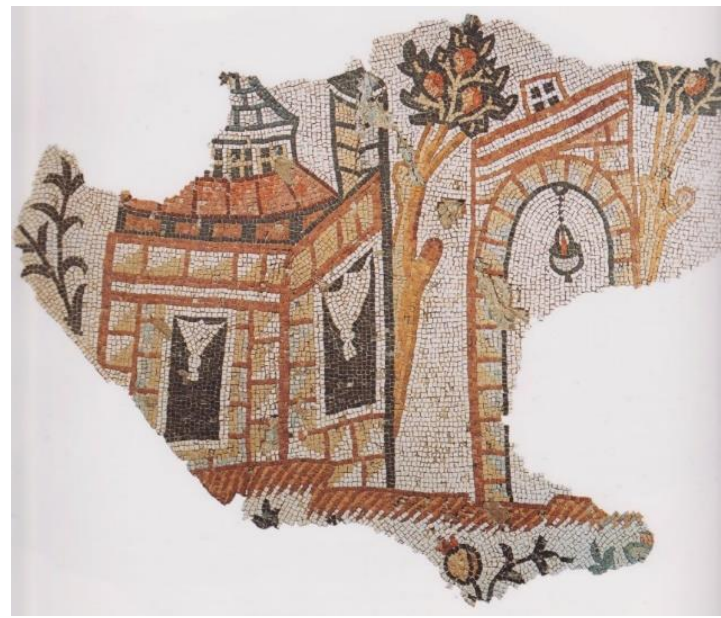

Figure 3: Depiction of a Religious Shrine (Sts. Cyrus and John at Menouthis?), St. John the Baptist, Jerash

Piccirillo, Mosaics of Jordan, 274. 


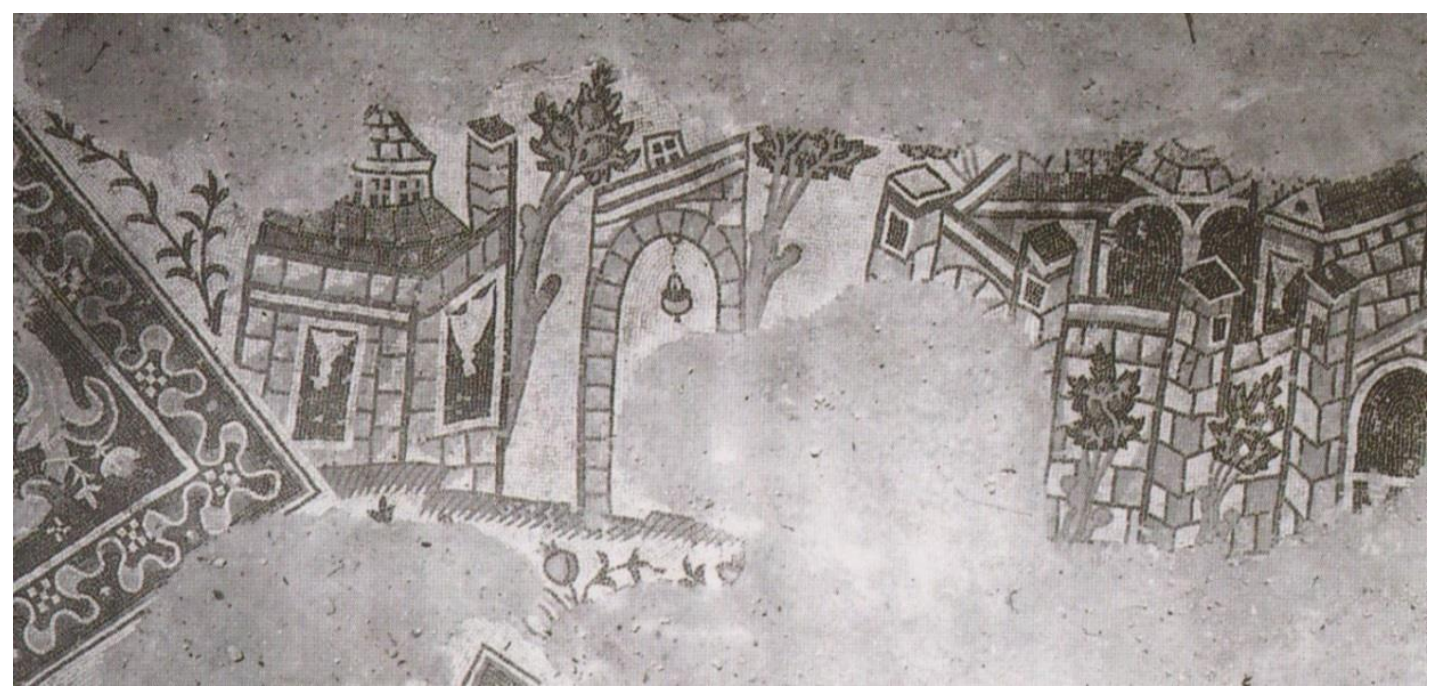

Figure 4: Depiction of a City (Canopus or Menouthis?), St. John the Baptist, Jerash

Piccirillo, Mosaics of Jordan, 289.

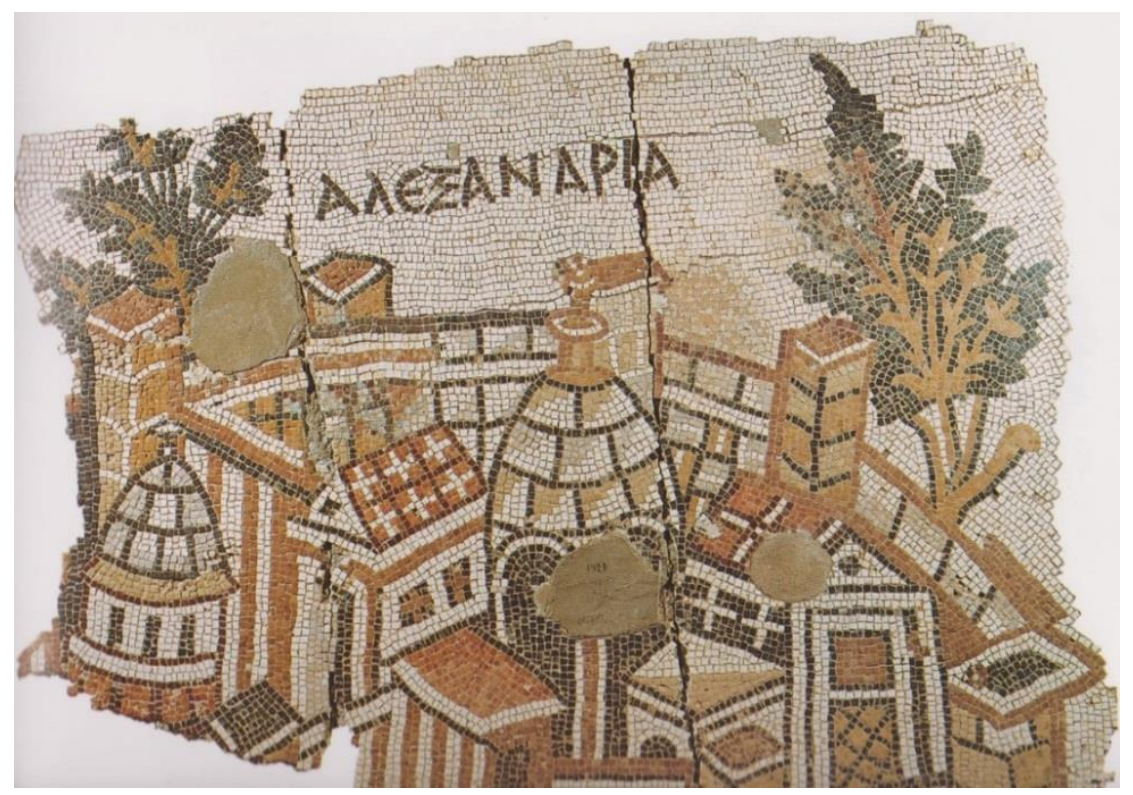

Figure 5: Depiction of Alexandria, St. John the Baptist, Jerash

Piccirillo, Mosaics of Jordan, 273. 


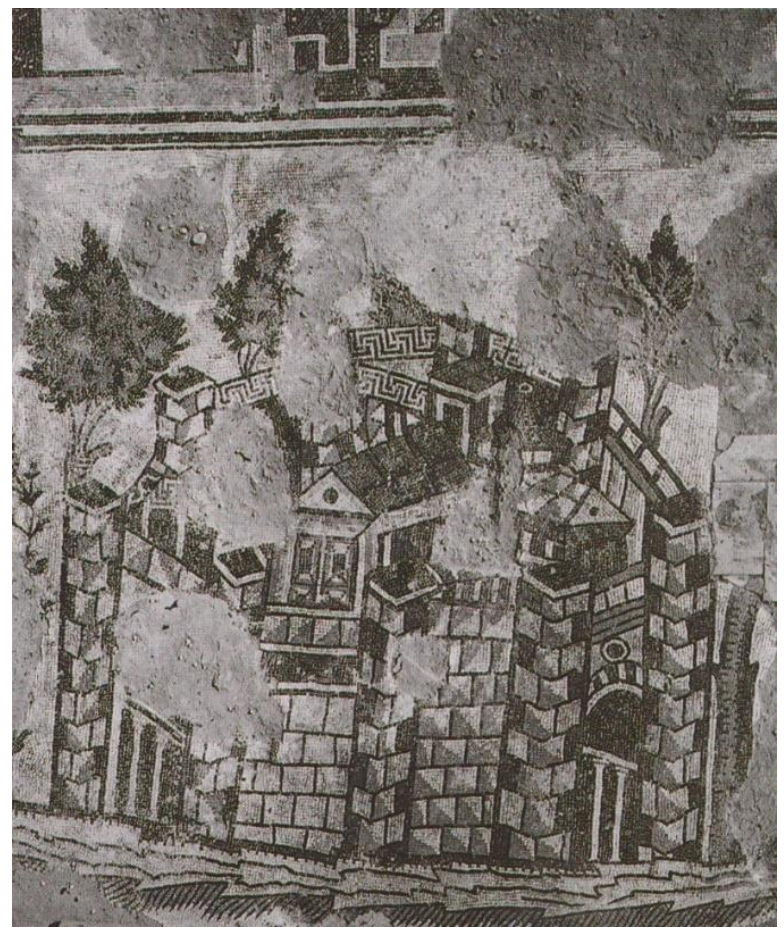

Figure 6: Depiction of Memphis, St. John the Baptist, Jerash

Piccirillo, Mosaics of Jordan, 289.

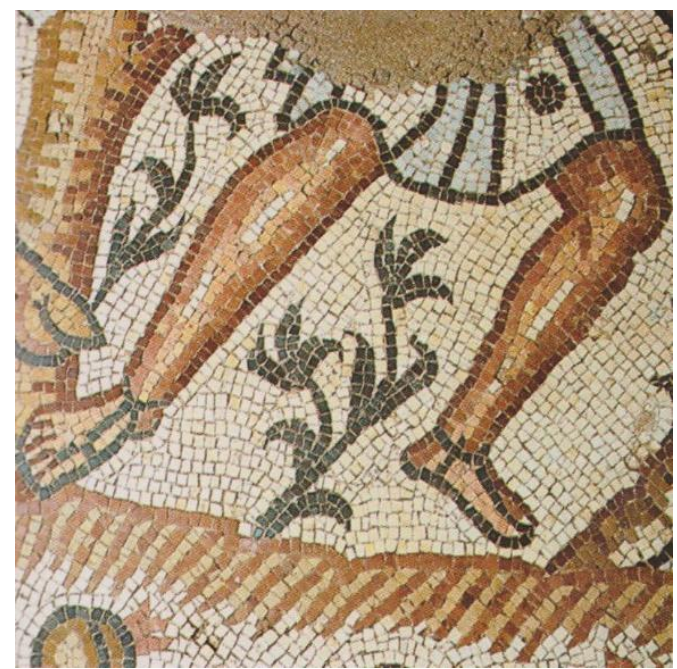

Figure 7: Depiction of a Servant Leading a Camel, St. John the Baptist, Jerash

Piccirillo, Mosaics of Jordan, 289. 


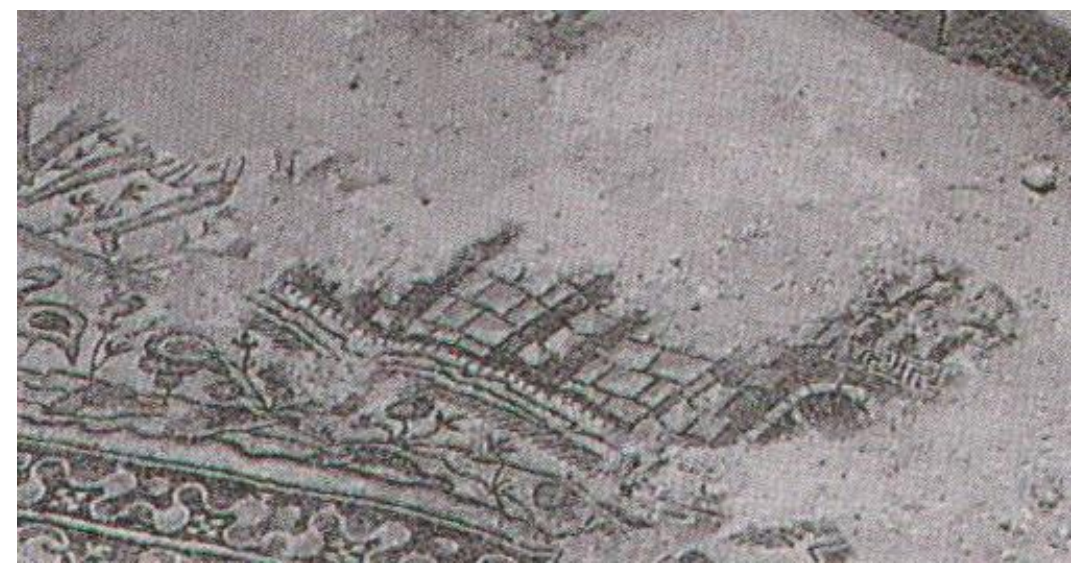

Figure 8: Depiction of an Unidentified City (Peluseion?), St. John the Baptist, Jerash

Carl Hermann Kraeling, ed., Gerasa: City of the Decapolis (New Haven, CT: Yale University Press, 1936), Plate LXVII.

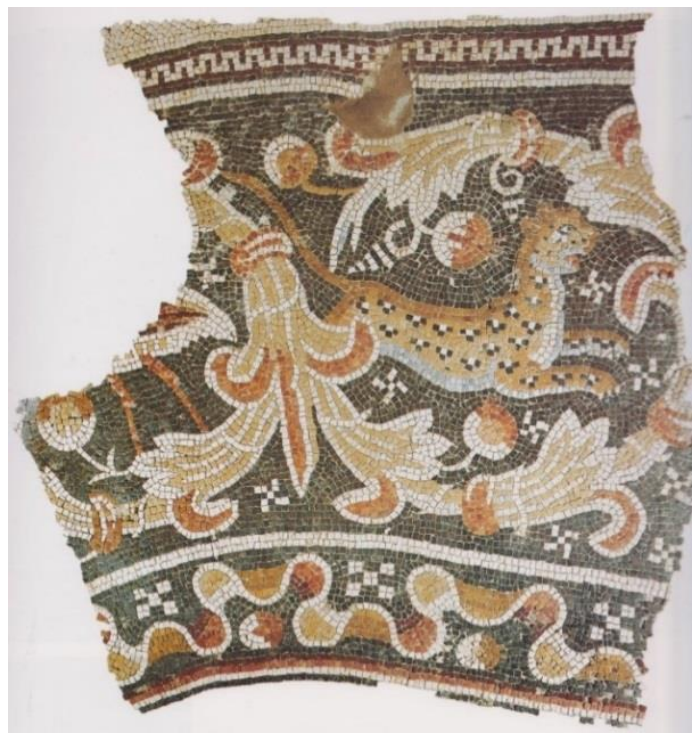

Figure 9: Inhabited Acanthus Scroll Border, St. John the Baptist, Jerash

Piccirillo, Mosaics of Jordan, 275. 


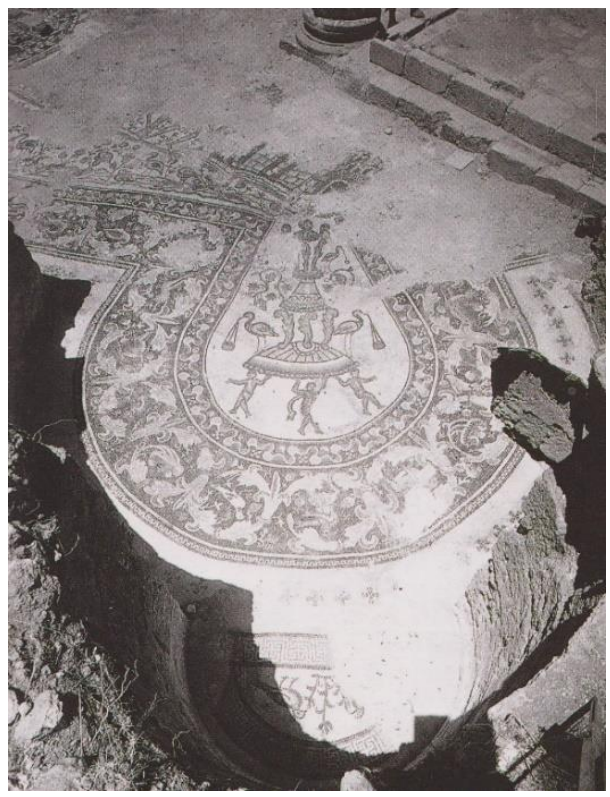

Figure 10: Exedra Mosaic, St. John the Baptist, Jerash

Piccirillo, Mosaics of Jordan, 289.

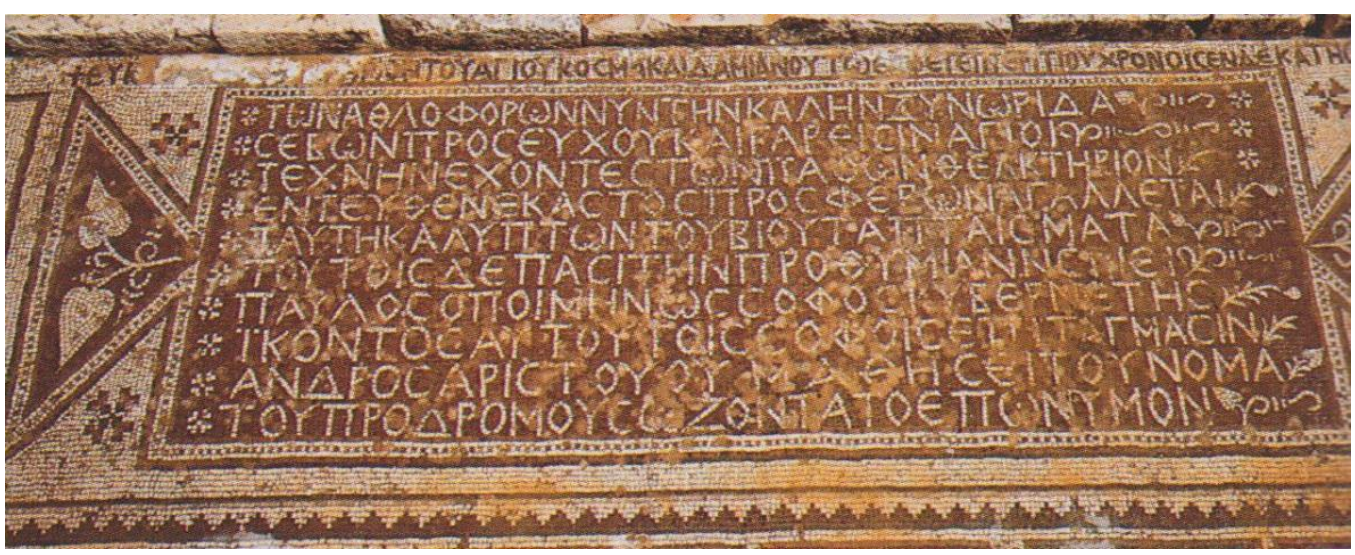

Figure 11: Tabula Ansata Inscription, St. John the Baptist, Jerash

Piccirillo, Mosaics of Jordan, 288. 


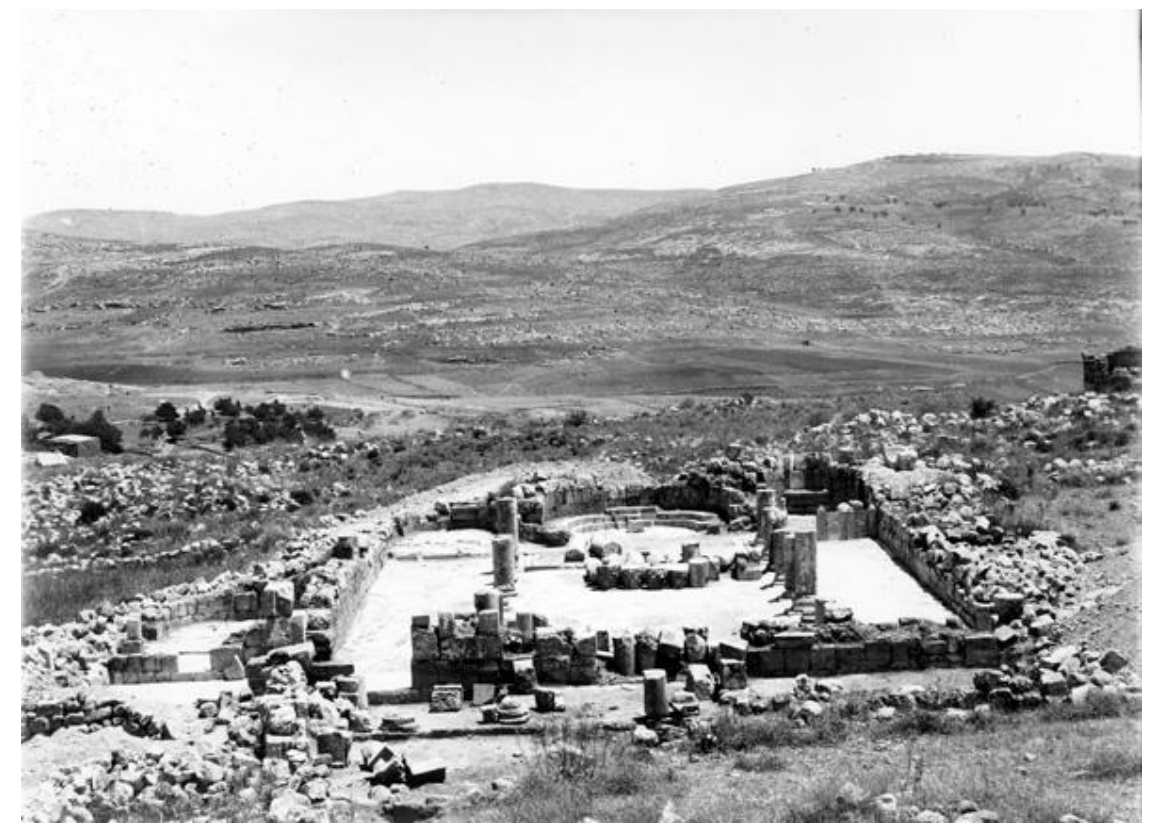

Figure 12: The Church of Sts. Peter and Paul, Jerash (Gerasa)

Metropolitan Museum of Art, "Gerasa," accessed March 10, 2016, http://www.metmuseum.org/exhibitions/listings/2012/byzantium-and-islam/blog/where-in-theworld/posts/gerasa.

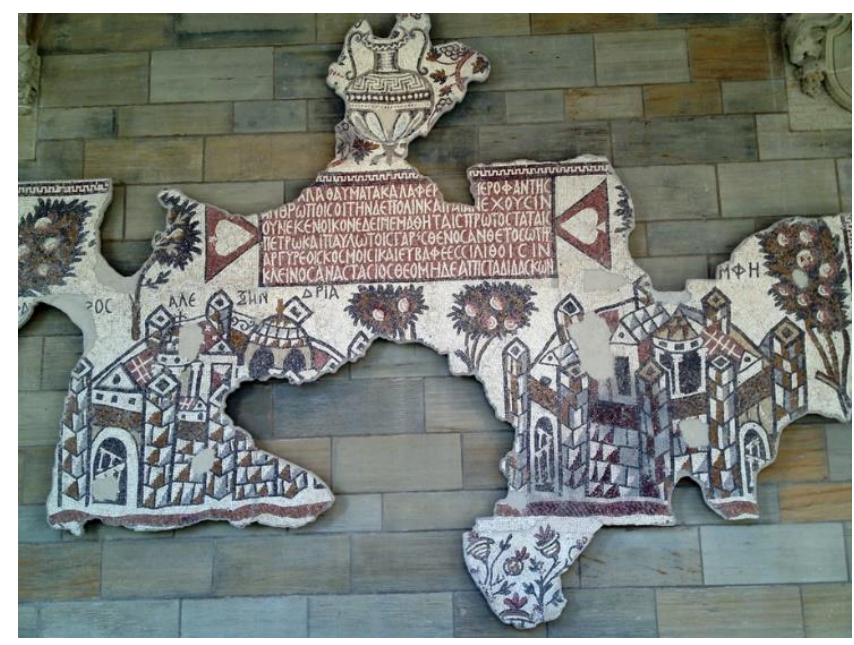

Figure 13: Topographic Panel with Depictions of Alexandria and Memphis, Sts. Peter and Paul, Jerash

Author's Photograph. 


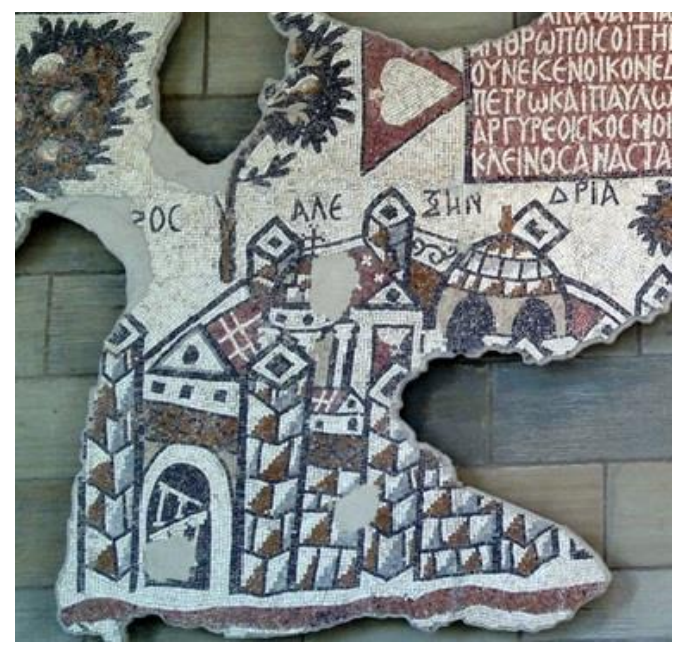

Figure 14: Depiction of Alexandria, Sts. Peter and Paul, Jerash

Author's Photograph.

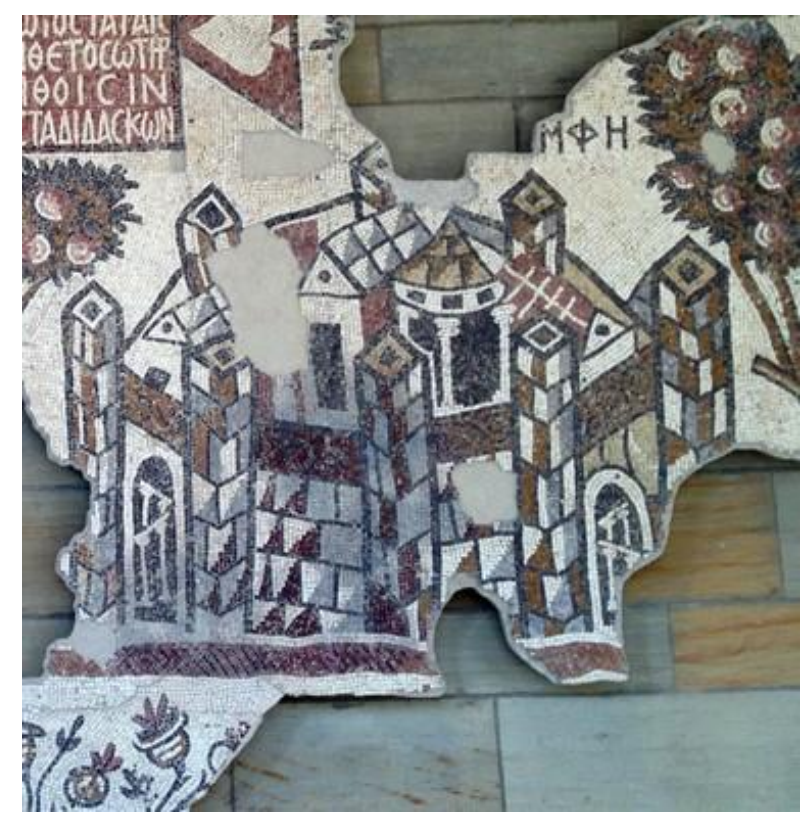

Figure 15: Depiction of Memphis, Sts. Peter and Paul, Jerash

Author's Photograph. 


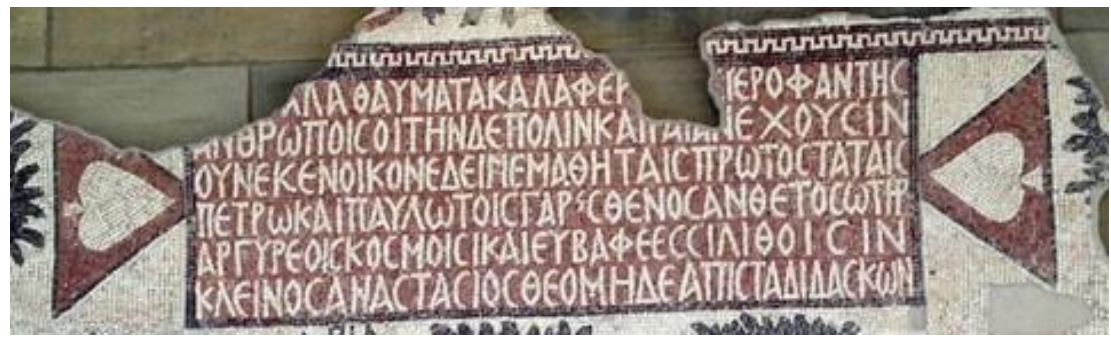

Figure 16: Tabula Ansata Inscription, Sts. Peter and Paul, Jerash

Author's Photograph.

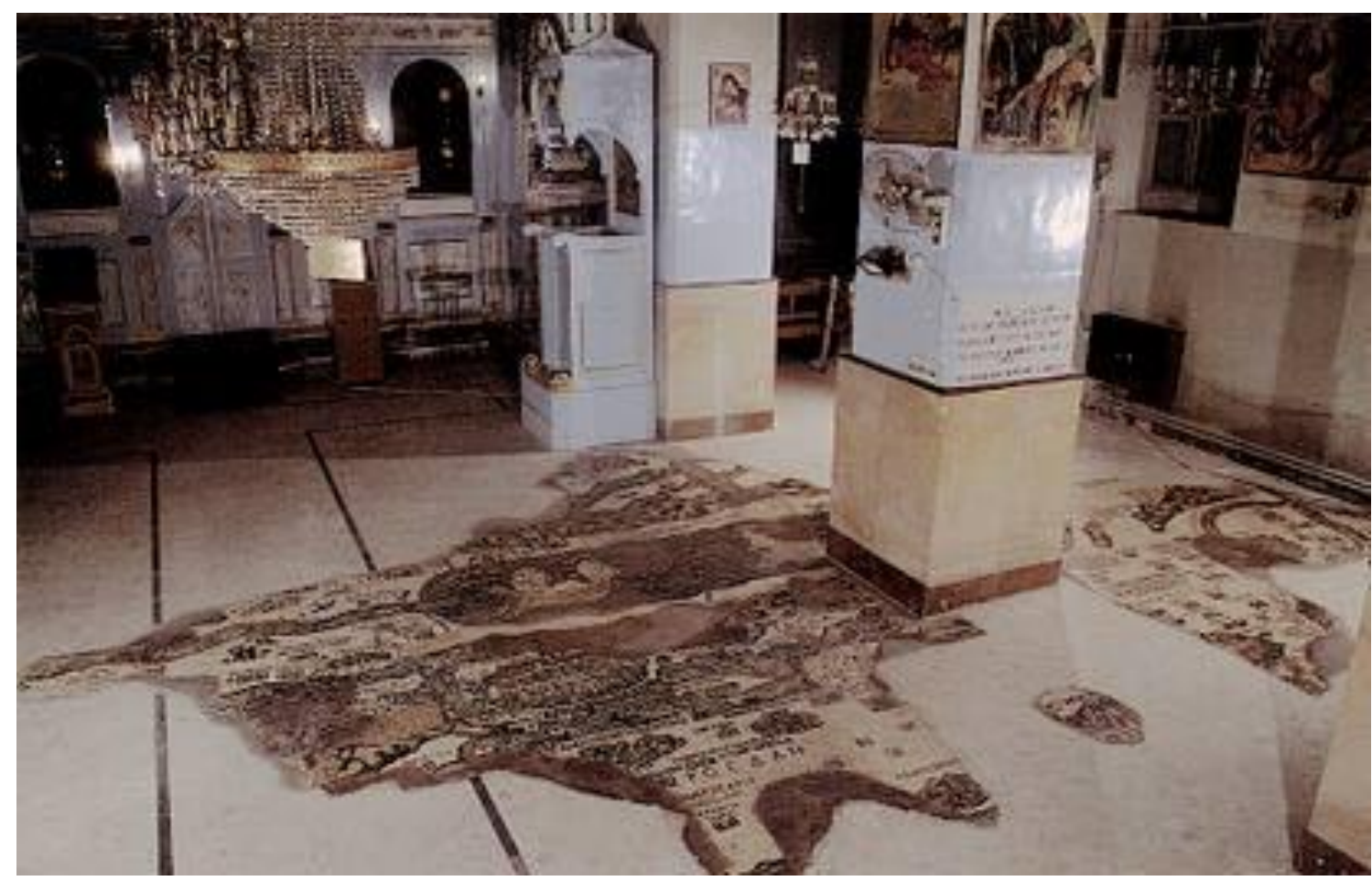

Figure 17: Mosaic, Church of the Map, Madaba

Franciscan Archaeological Institute, “The Madaba Mosaic Map,” accessed March 10, 2016, http://www.christusrex.org/www1/ofm/fai/FAImap.html. 


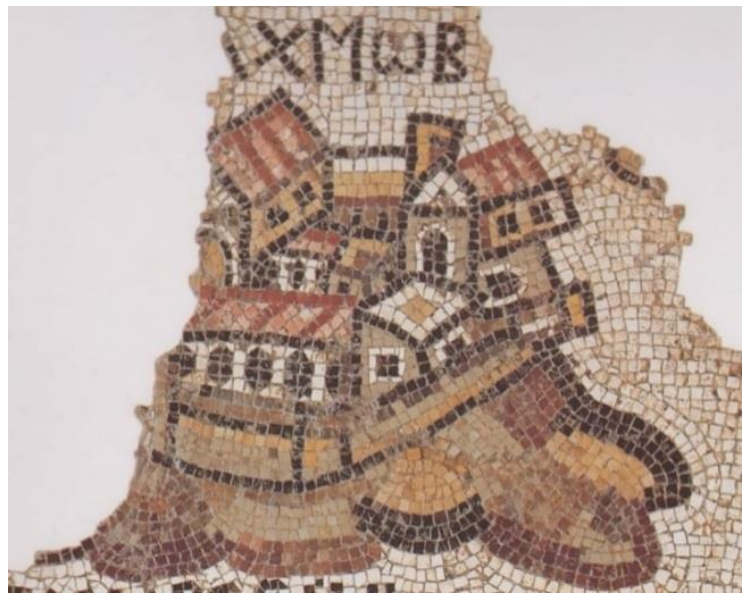

Figure 18: Depiction of Charach Moba (al-Karak), Madaba Mosaic

Piccirillo, Mosaics of Jordan, 86.

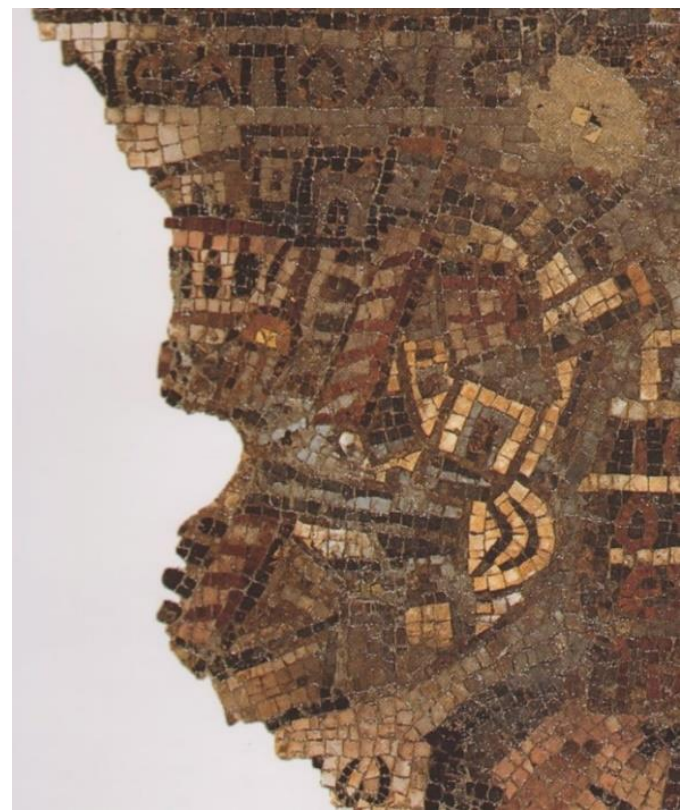

Figure 19: Depiction of Neapolis (Nablus), Madaba Mosaic

Piccirillo, Mosaics of Jordan, 88. 


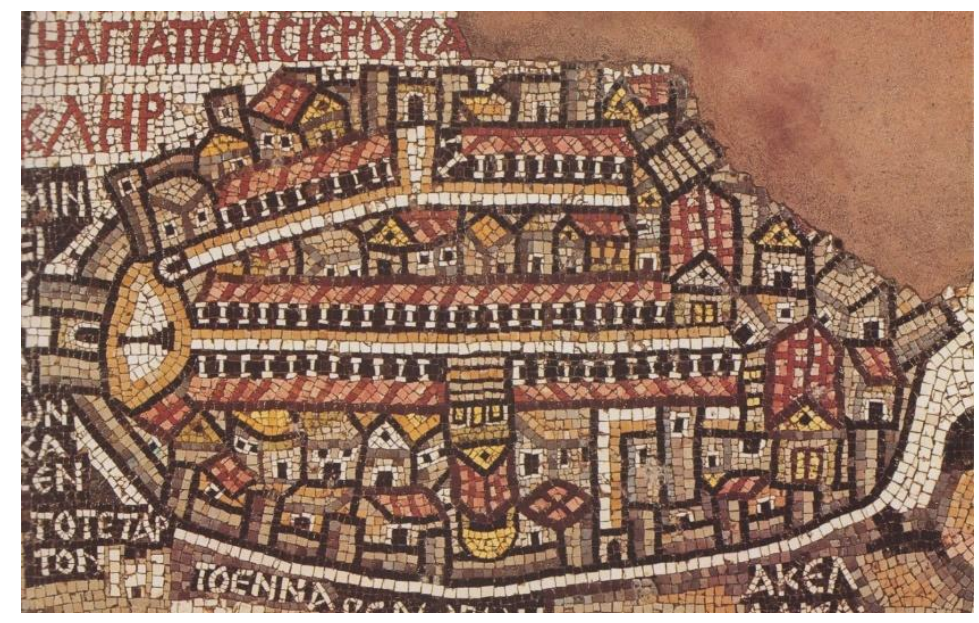

Figure 20: Depiction of Jerusalem, Madaba Mosaic

Piccirillo, Mosaics of Jordan, 83.

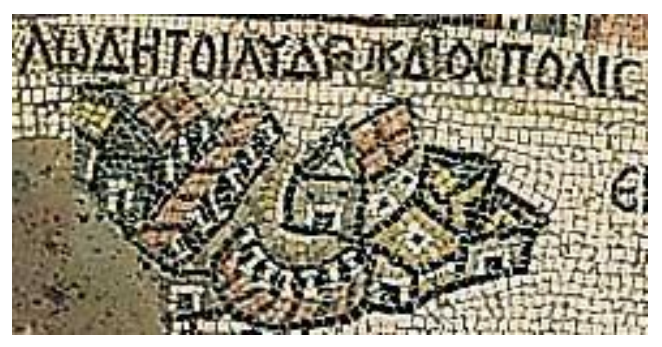

Figure 21: Depiction of Diospolis (Lod), Madaba Mosaic

Franciscan Archaeological Institute, The Madaba Mosaic Map, "The Sea Coast: Lod," accessed March 10, 2016, http://www.christusrex.org/www1/ofm/mad/discussion/086discuss.html. 


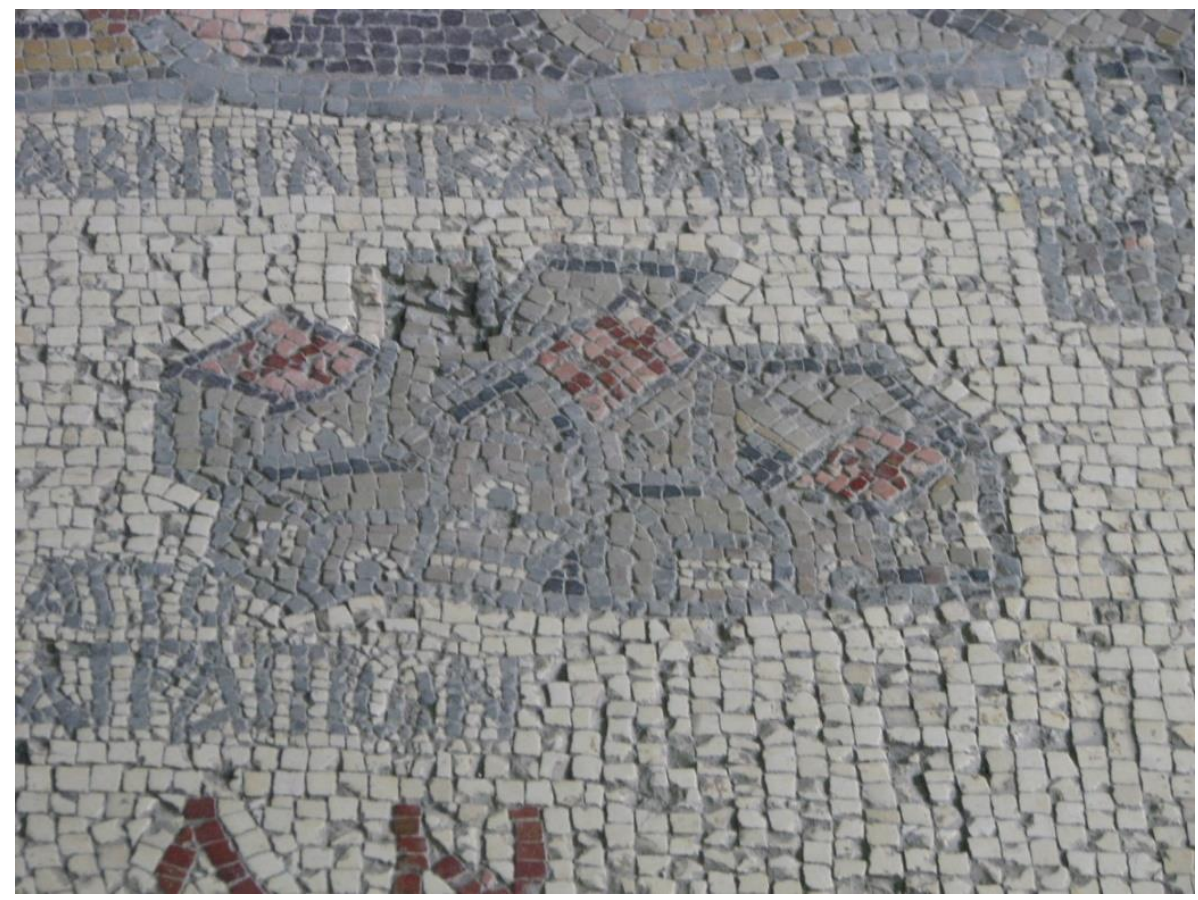

Figure 22: Depiction of Iamnia (Yavne), Madaba Mosaic

Author's Photograph.

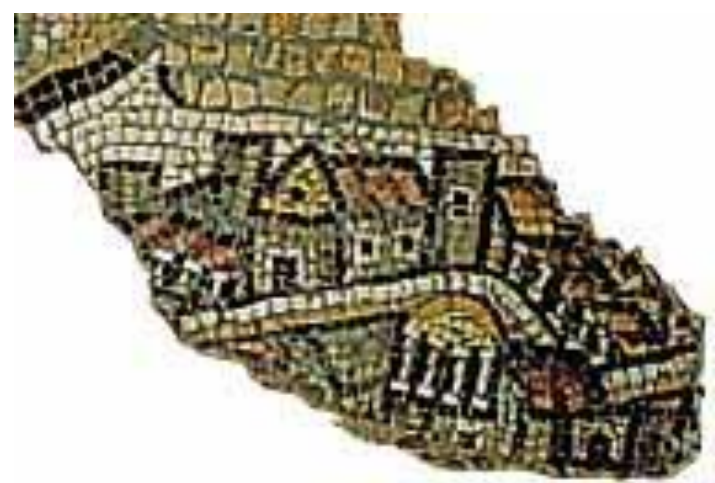

Figure 23: Depiction of Eleutheropolis (Beit Guvrin), Madaba Mosaic

Franciscan Archaeological Institute, Madaba Mosaic Map, "The Mountain of Judah and the Shephelah (South): Eleutheropolis," accessed March 10, 2016.

http://www.christusrex.org/www1/ofm/mad/discussion/084discuss.html. 


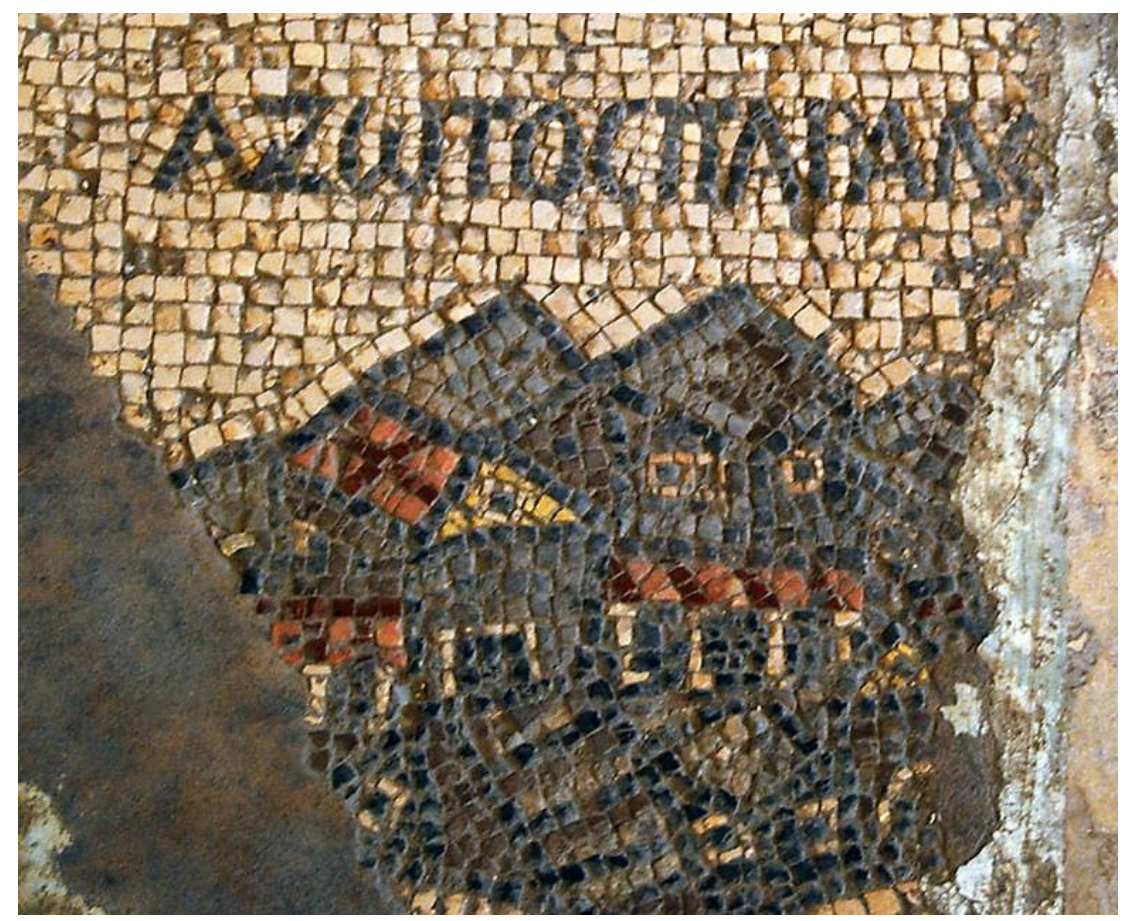

Figure 24: Depiction of Azotos Paralos (Ashdod), Madaba Mosaic Author's Photograph.

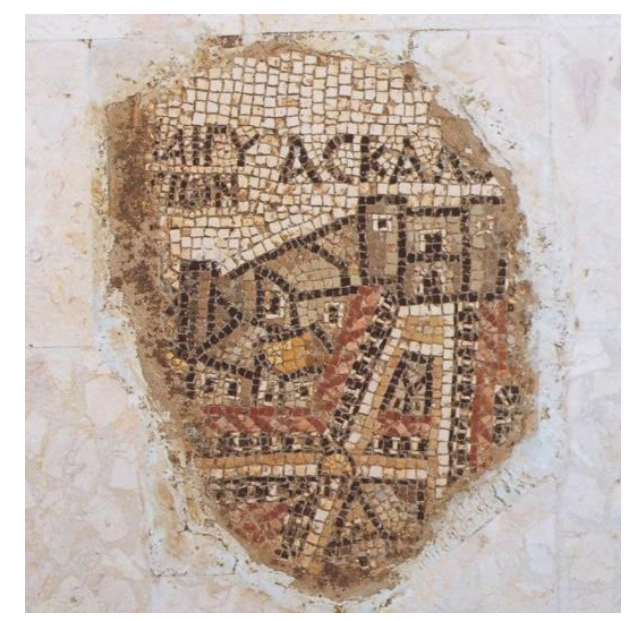

Figure 25: Depiction of Askalon (Ashkelon), Madaba Mosaic

Piccirillo, Mosaics of Jordan, 95. 


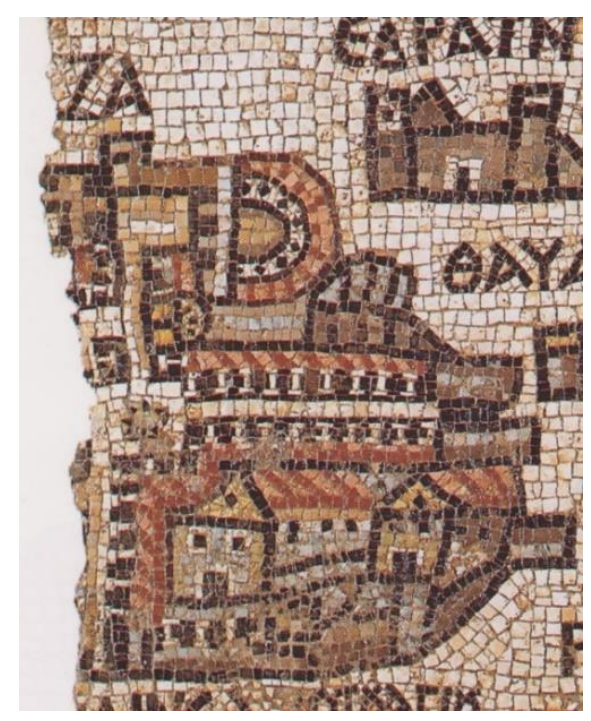

Figure 26: Depiction of Gaza, Madaba Mosaic

Piccirillo, Mosaics of Jordan. Amman, 90.

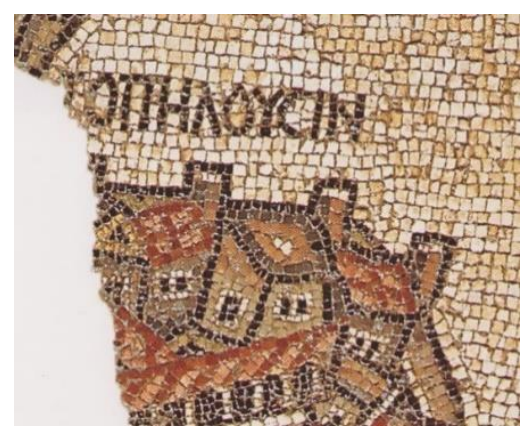

Figure 27: Depiction of Peluseion, Madaba Mosaic

Piccirillo, Mosaics of Jordan, 91. 


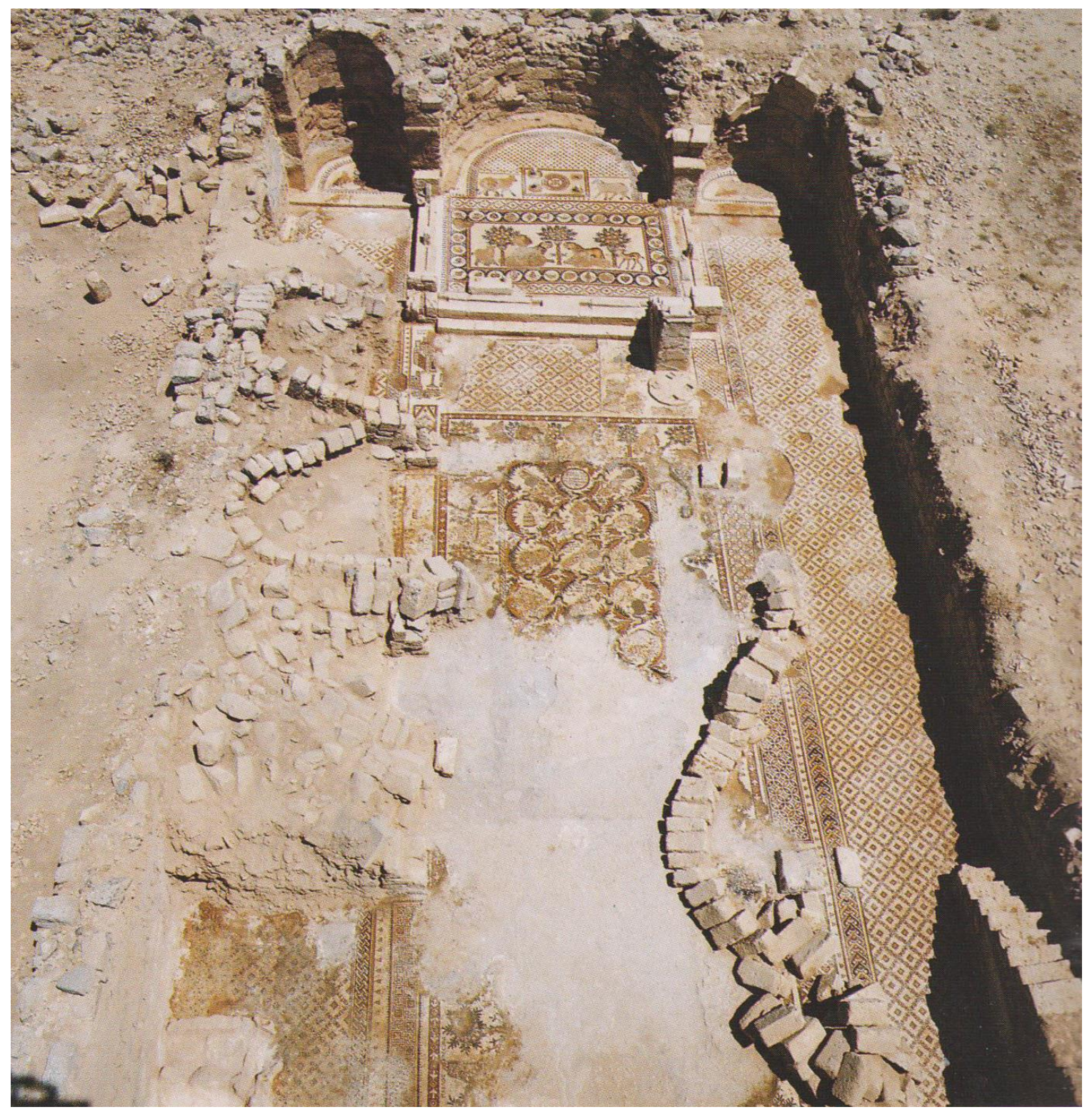

Figure 28: Aerial View of the Church of the Lions, Umm al-Rasas, Kastron Mefa'a

Piccirillo, Mosaics of Jordan, 236. 


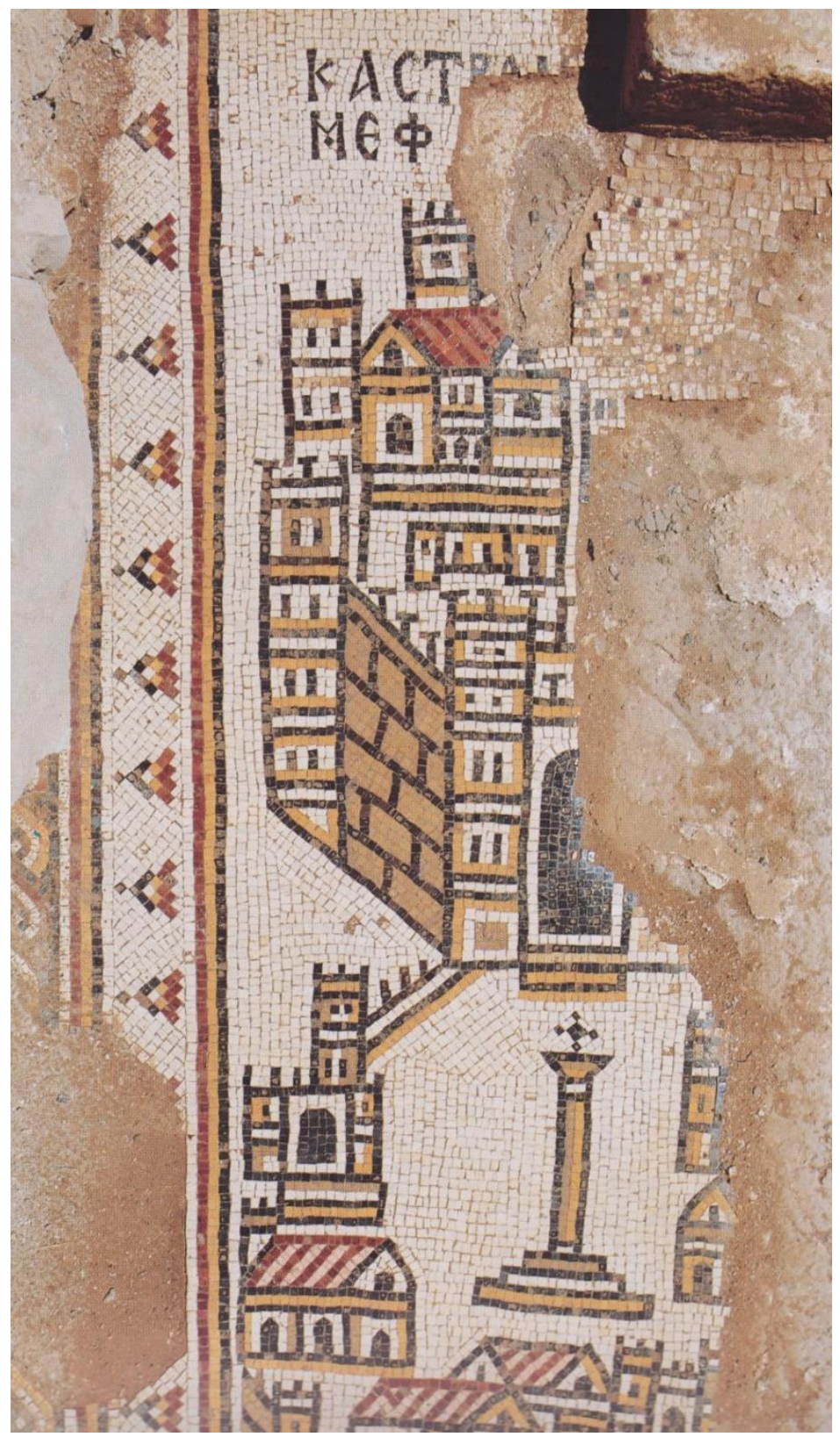

Figure 29: Depiction of Kastron Mefa'a (Umm al-Rasas), Church of the Lions

Piccirillo, Mosaics of Jordan, 210. 

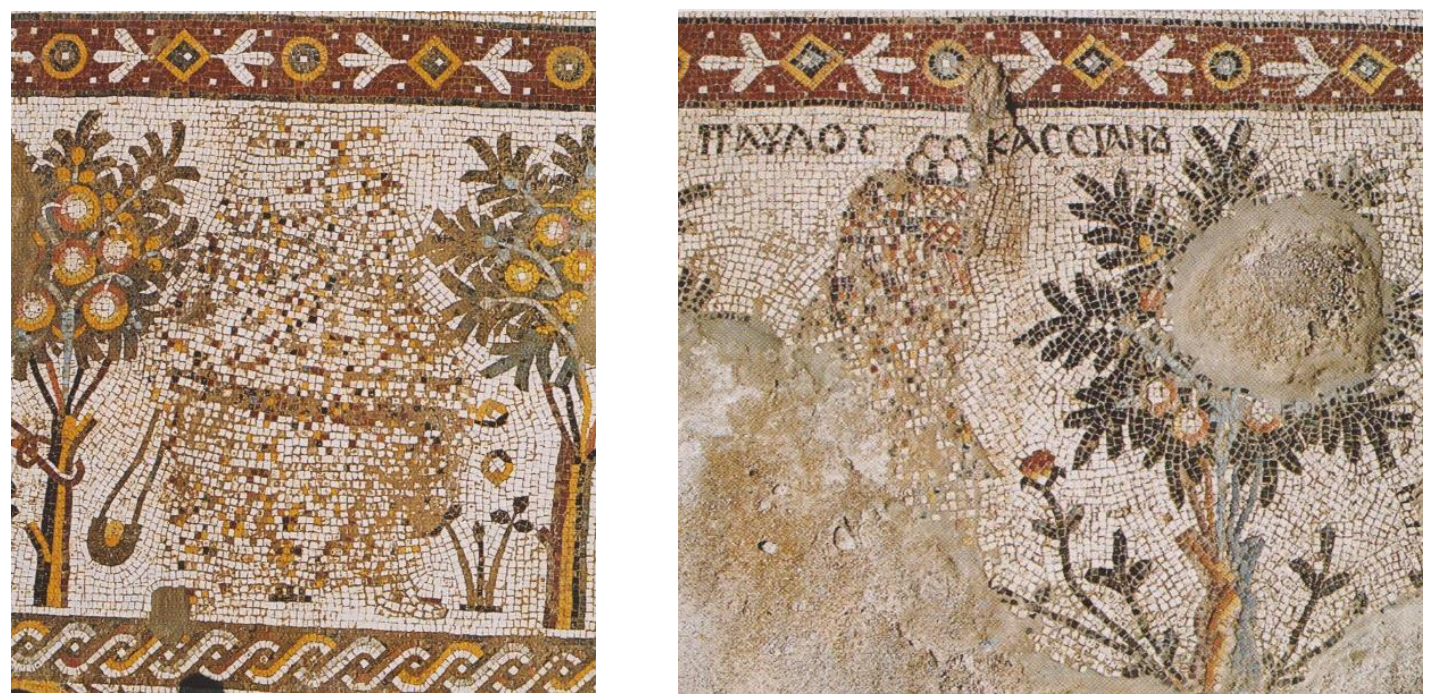

Figures 30a-b: Border Mosaic with Alternating Depictions of People and Fruit Trees, Church of the Lions, Umm al-Rasas

Piccirillo, Mosaics of Jordan, 237.

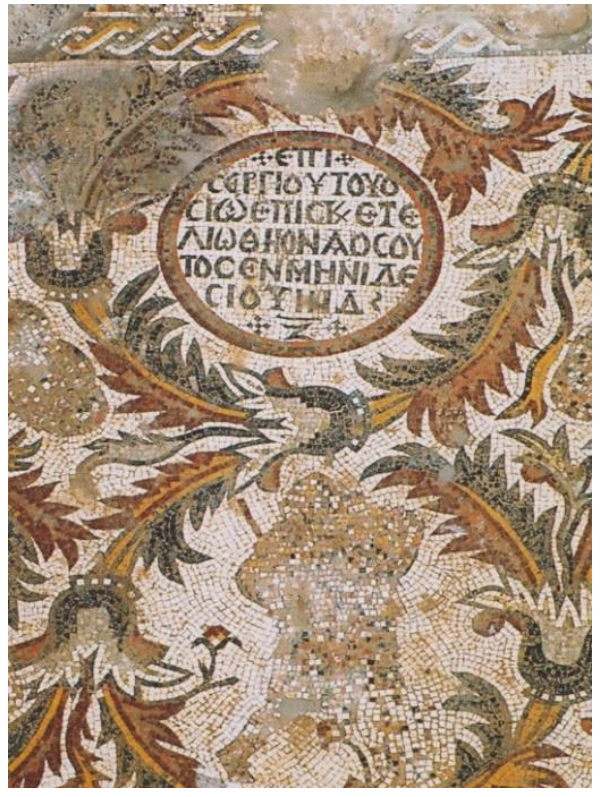

Figure 31: Inhabited Vine Scroll with Inscription, Church of the Lions, Umm al-Rasas Piccirillo, Mosaics of Jordan, 237. 


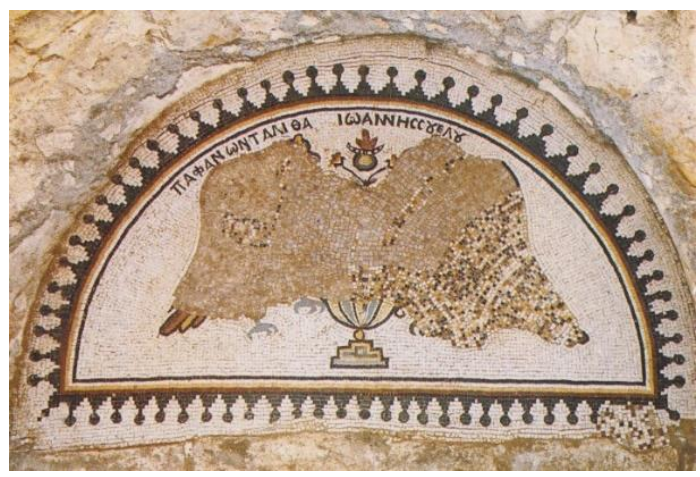

Figure 32: South Apse Mosaic, Church of the Lions, Umm al-Rasas

Piccirillo, Mosaics of Jordan, 236.

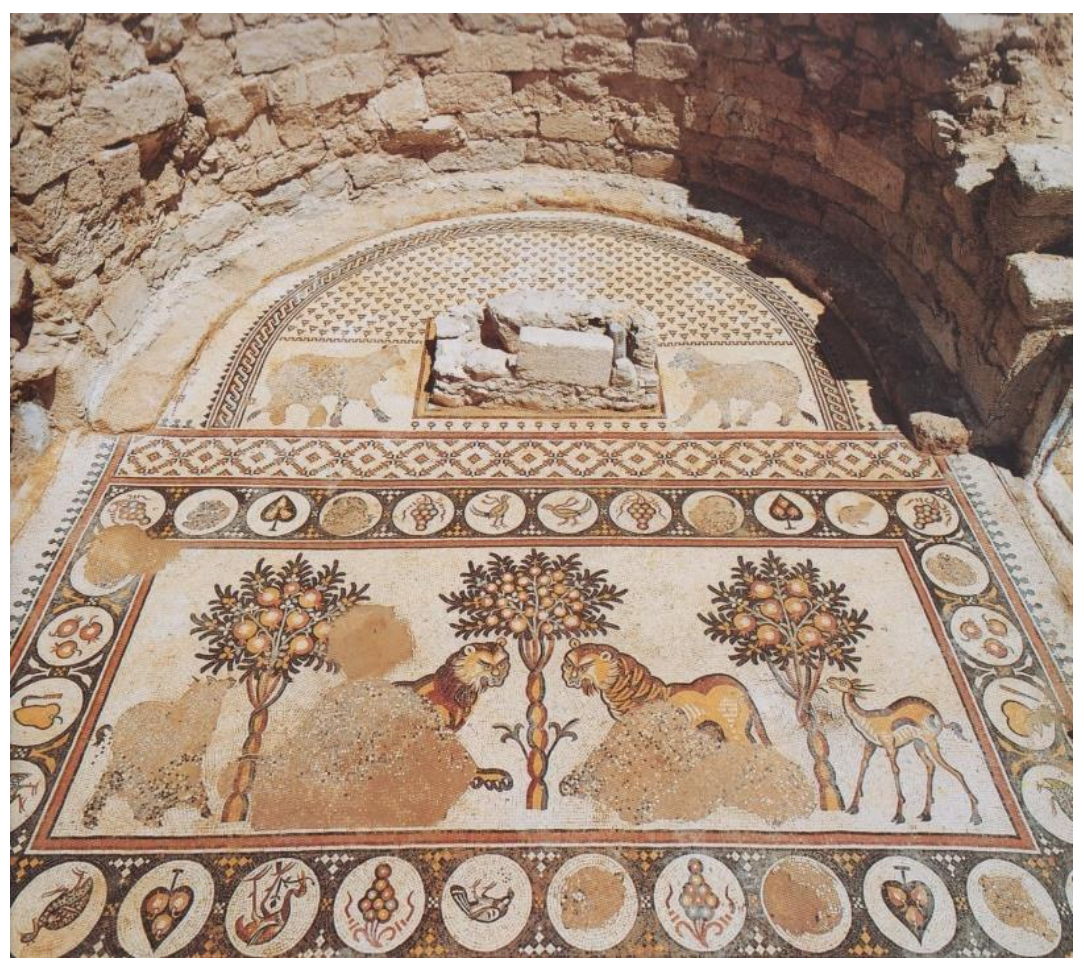

Figure 33: Sanctuary and Central Apse Mosaic, Church of the Lions, Umm al-Rasas

Piccirillo, Mosaics of Jordan, 211. 


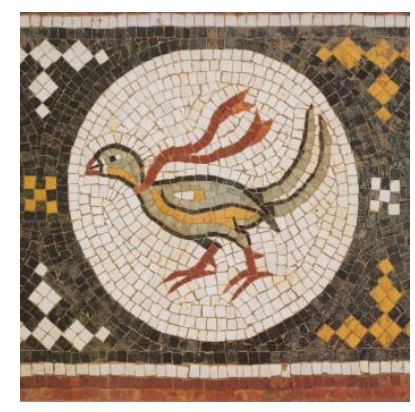

Figure 34: Depiction of a Beribboned Bird, Sanctuary Mosaic, Church of the Lions, Umm al-Rasas

Piccirillo, Mosaics of Jordan, 217.

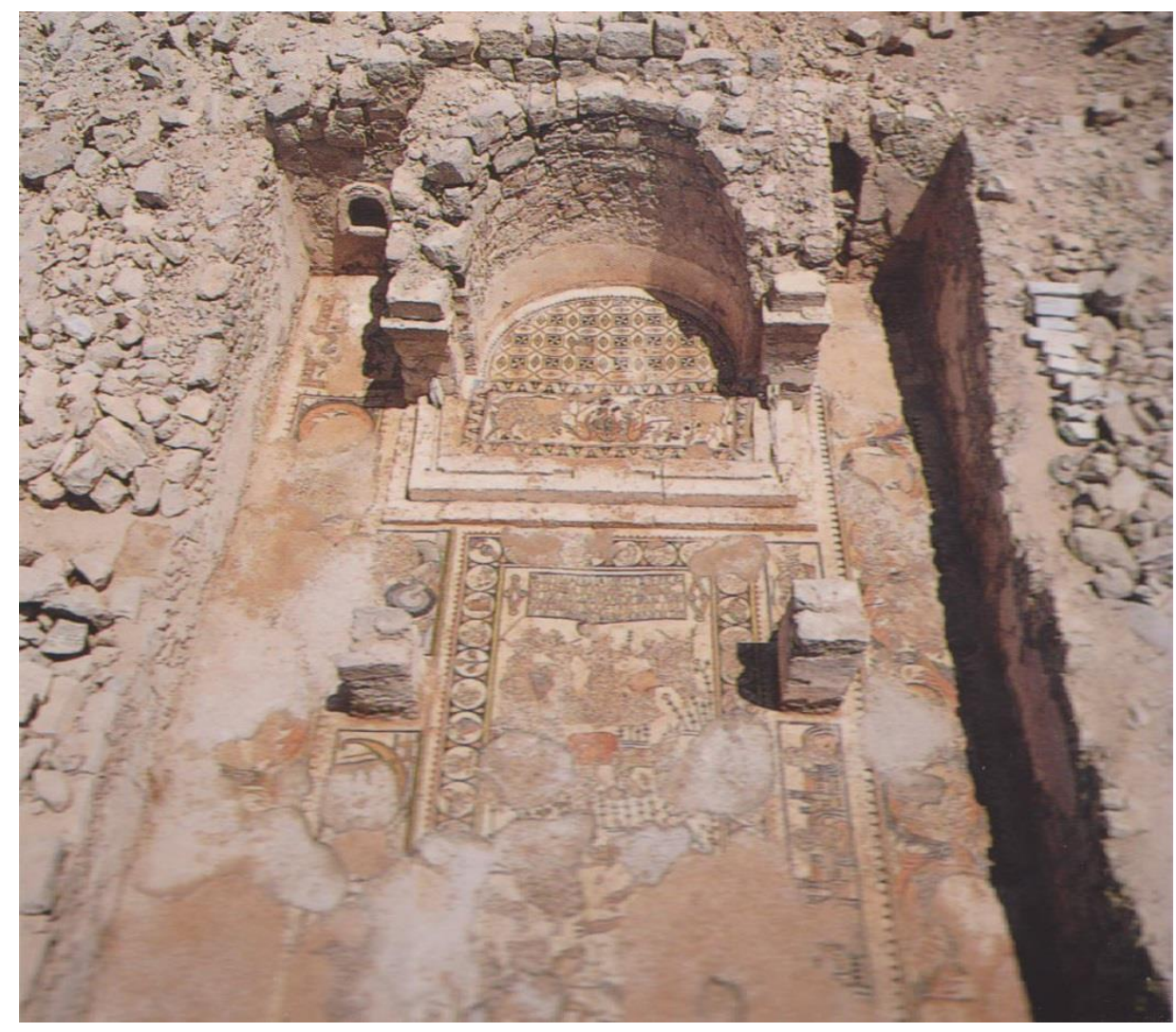

Figure 35: Aerial View of the Church of the Priest Wa'il, Umm al-Rasas (Kastron Mefa'a)

Piccirillo, Mosaics of Jordan, 24 


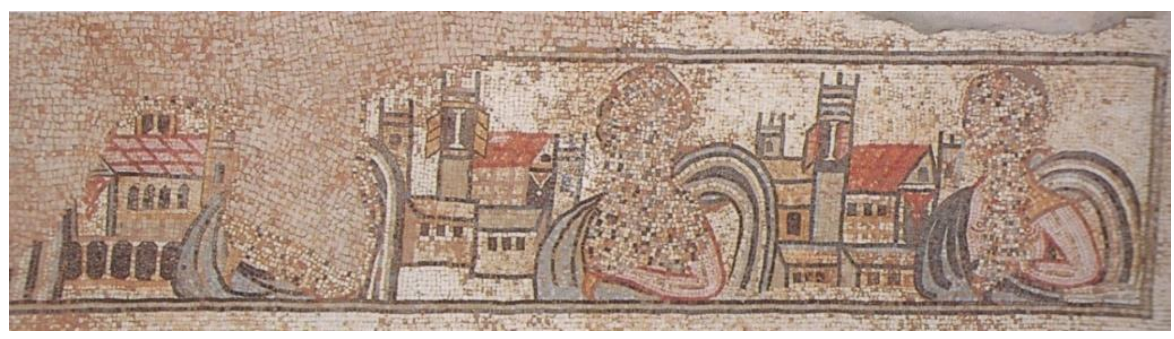

Figure 36: Depictions of Cities and Personifications of Rivers, Church of the Priest Wa'il, Umm al-Rasas

Piccirillo Mosaics of Jordan, 243.

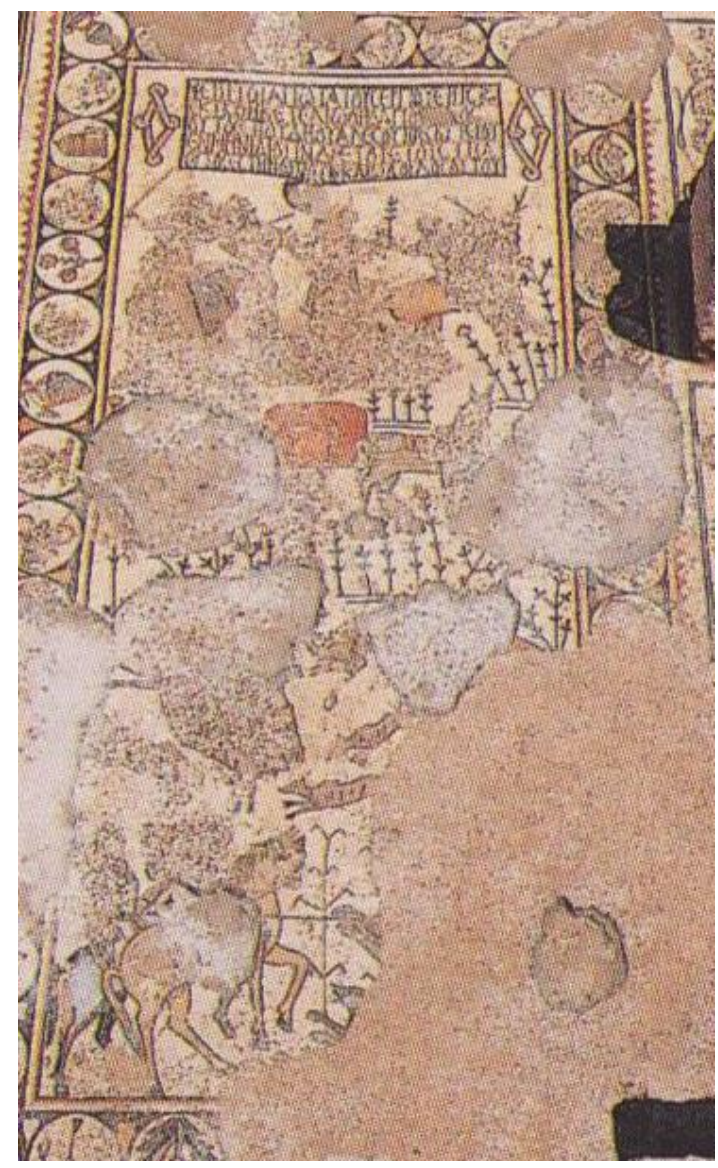

Figure 37: Nave Mosaic, Church of the Priest Wa'il, Umm al-Rasas

Piccirillo, Mosaics of Jordan, 243. 


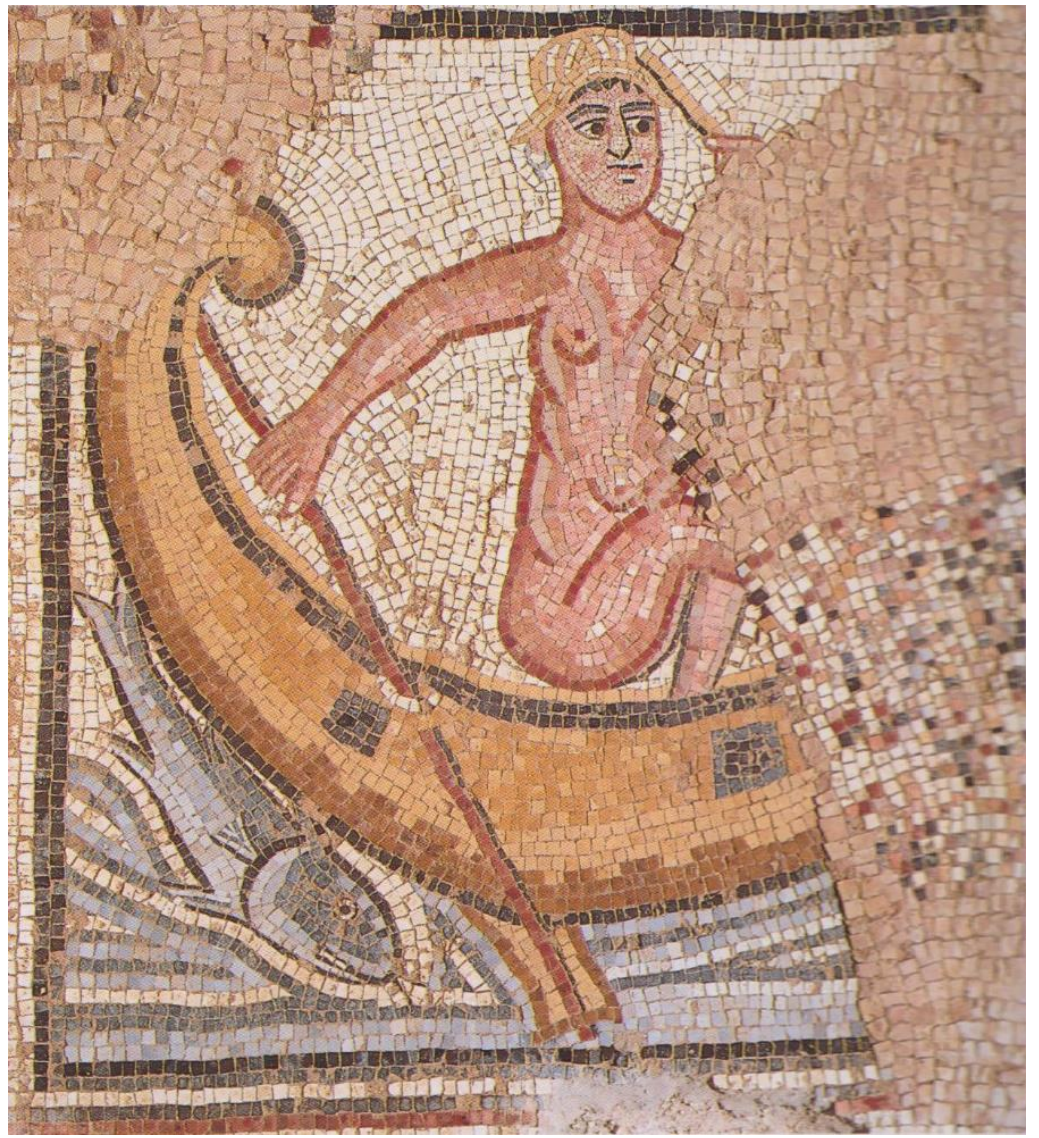

Figure 38: Depiction of Jonah, Church of the Priest Wa'il, Umm al-Rasas

Piccirillo, Mosaics of Jordan, 243. 


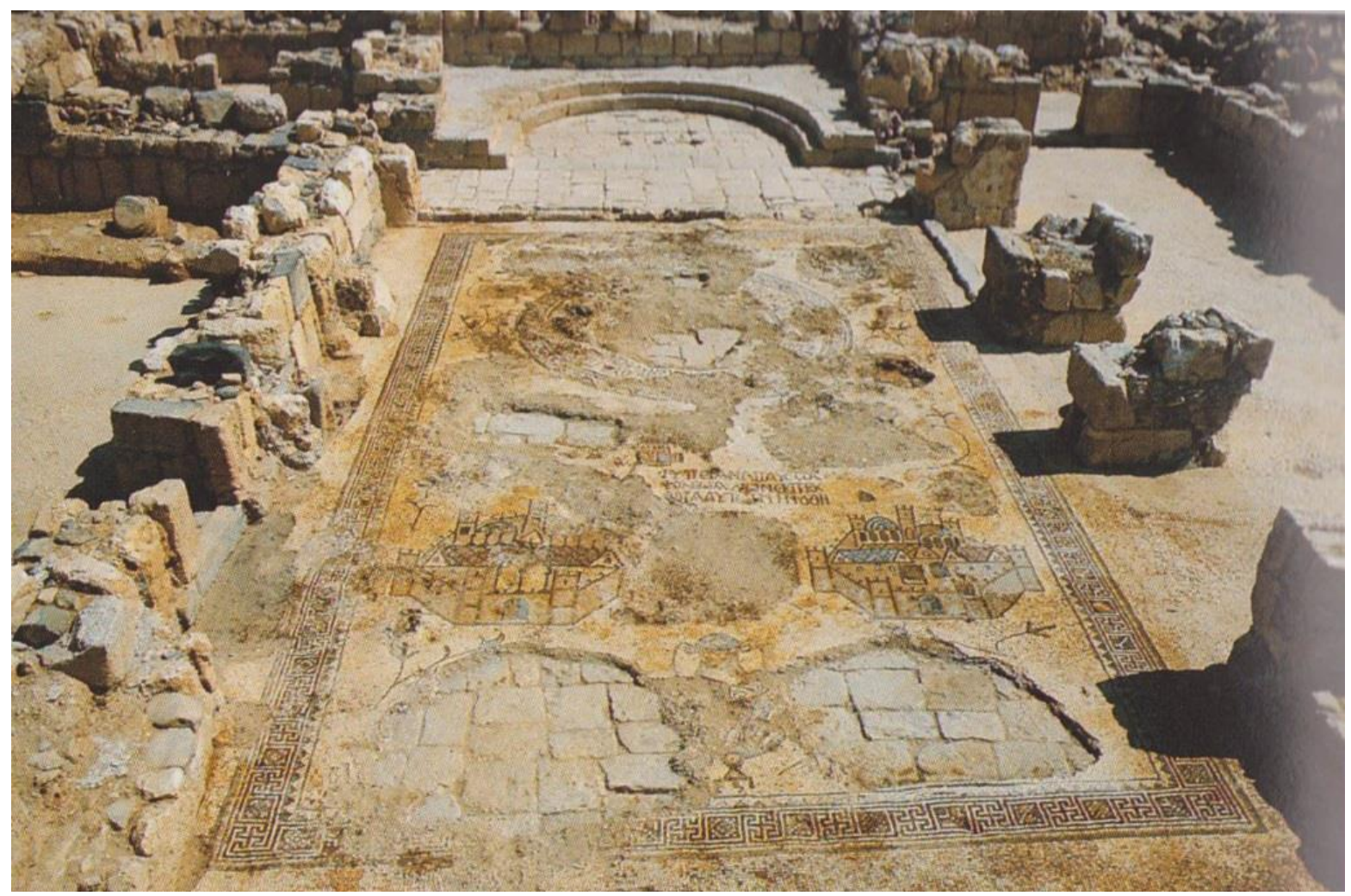

Figure 39: The Church of St. John, Khirbat al-Samra, Jordan

Piccirillo, Mosaics of Jordan, 304.

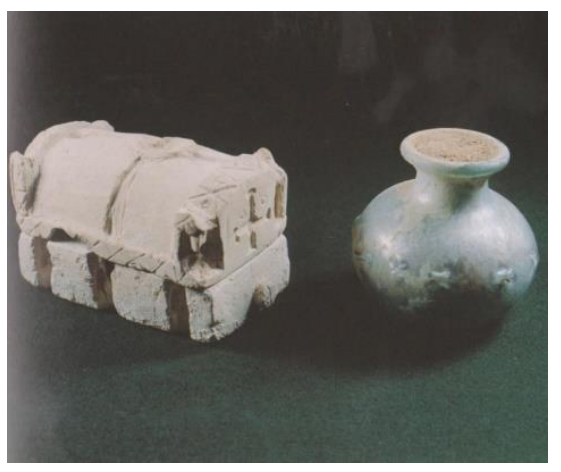

Figure 40: Reliquary and Glass Bottle, Church of St. John, Khirbat al-Samra

Piccirillo, Mosaics of Jordan, 305. 


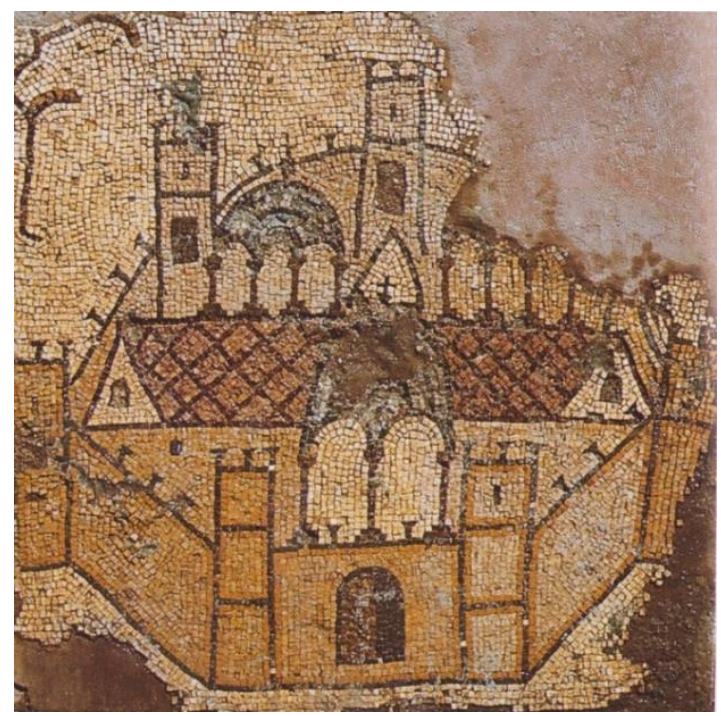

Figure 41: Depiction of Jerusalem, Church of St. John, Khirbat al-Samra

Piccirillo, Mosaics of Jordan, 304.

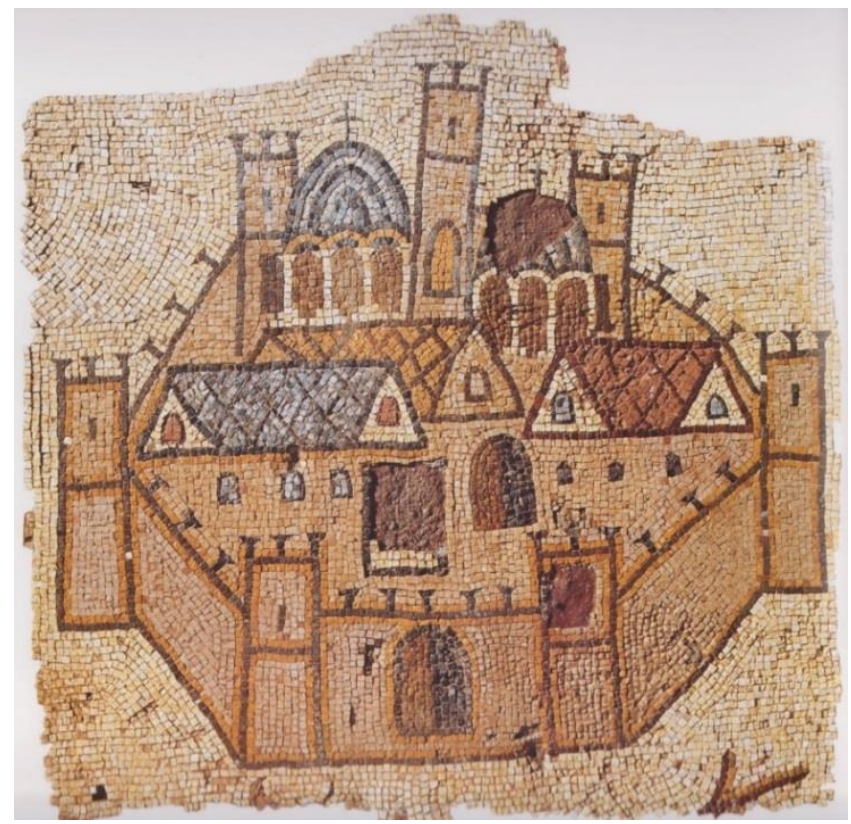

Figure 42: Depiction of Bethlehem, Church of St. John, Khirbat al-Samra

Piccirillo, Mosaics of Jordan, 302. 


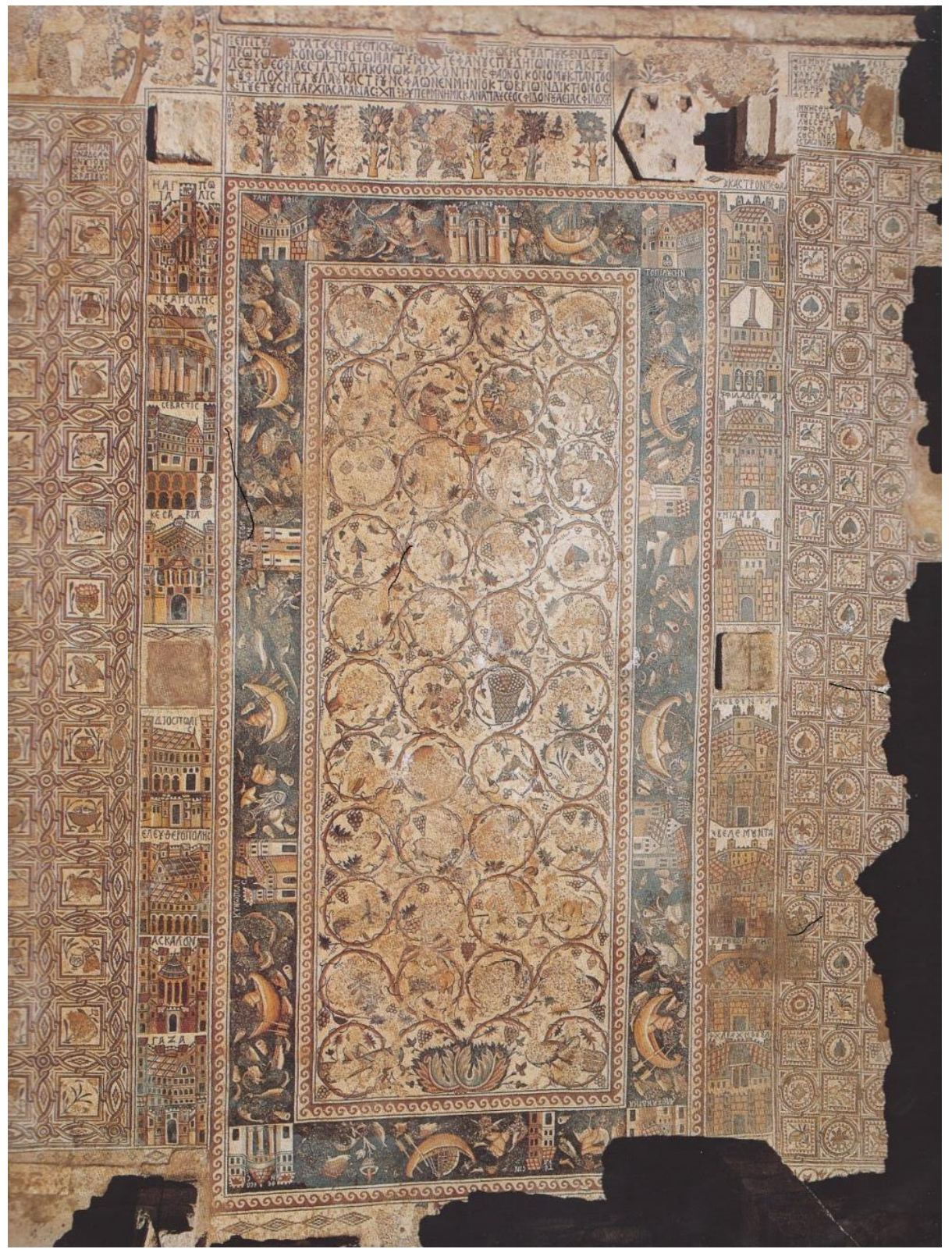

Figure 43: Aerial View of Church of St. Stephen, Umm al-Rasas (Kastron Mefa'a)

Piccirillo, Mosaics of Jordan, 219. 


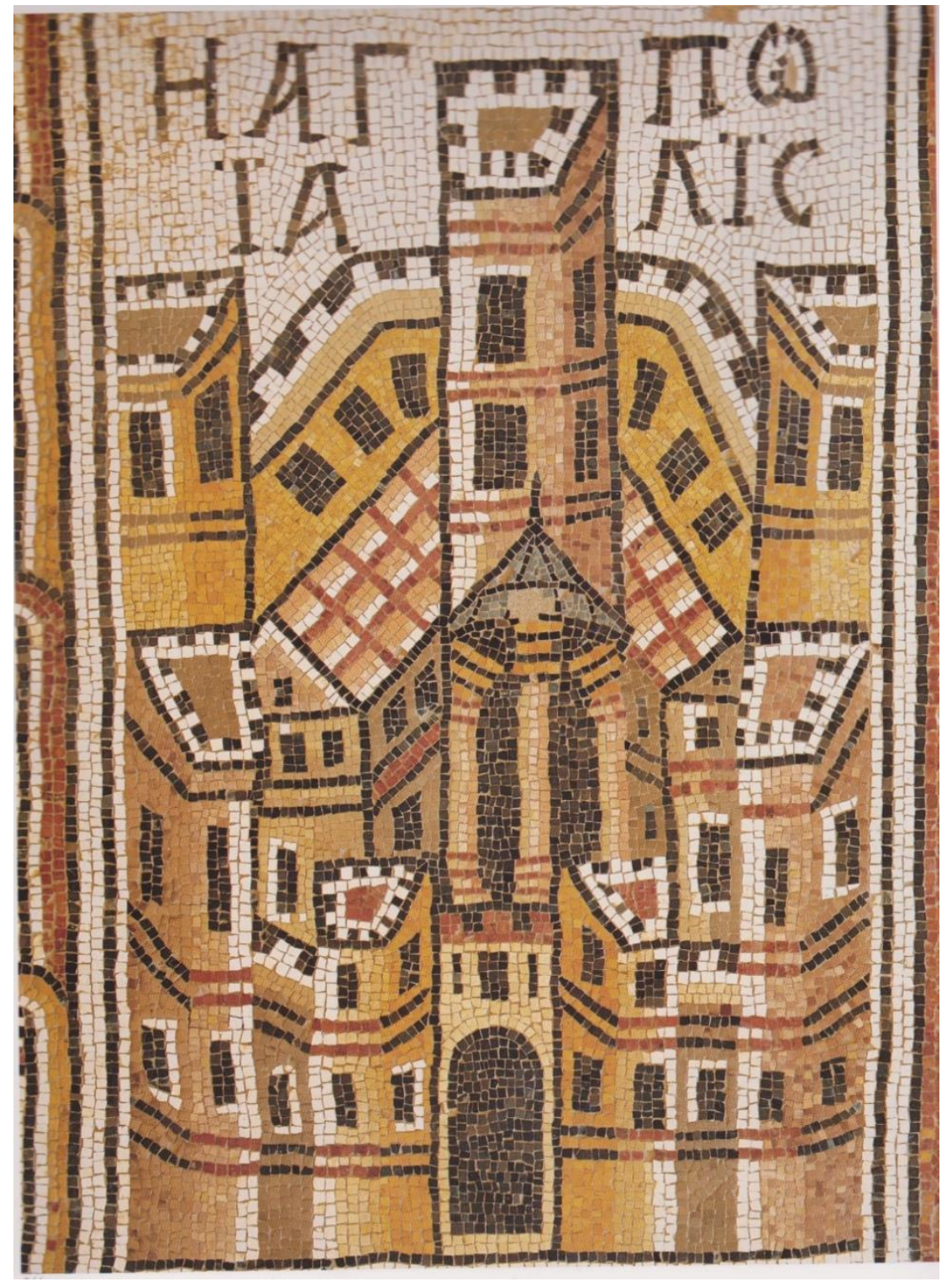

Figure 44: Depiction of Jerusalem, St. Stephen Mosaic, Umm al-Rasas

Piccirillo, Mosaics of Jordan, 218. 


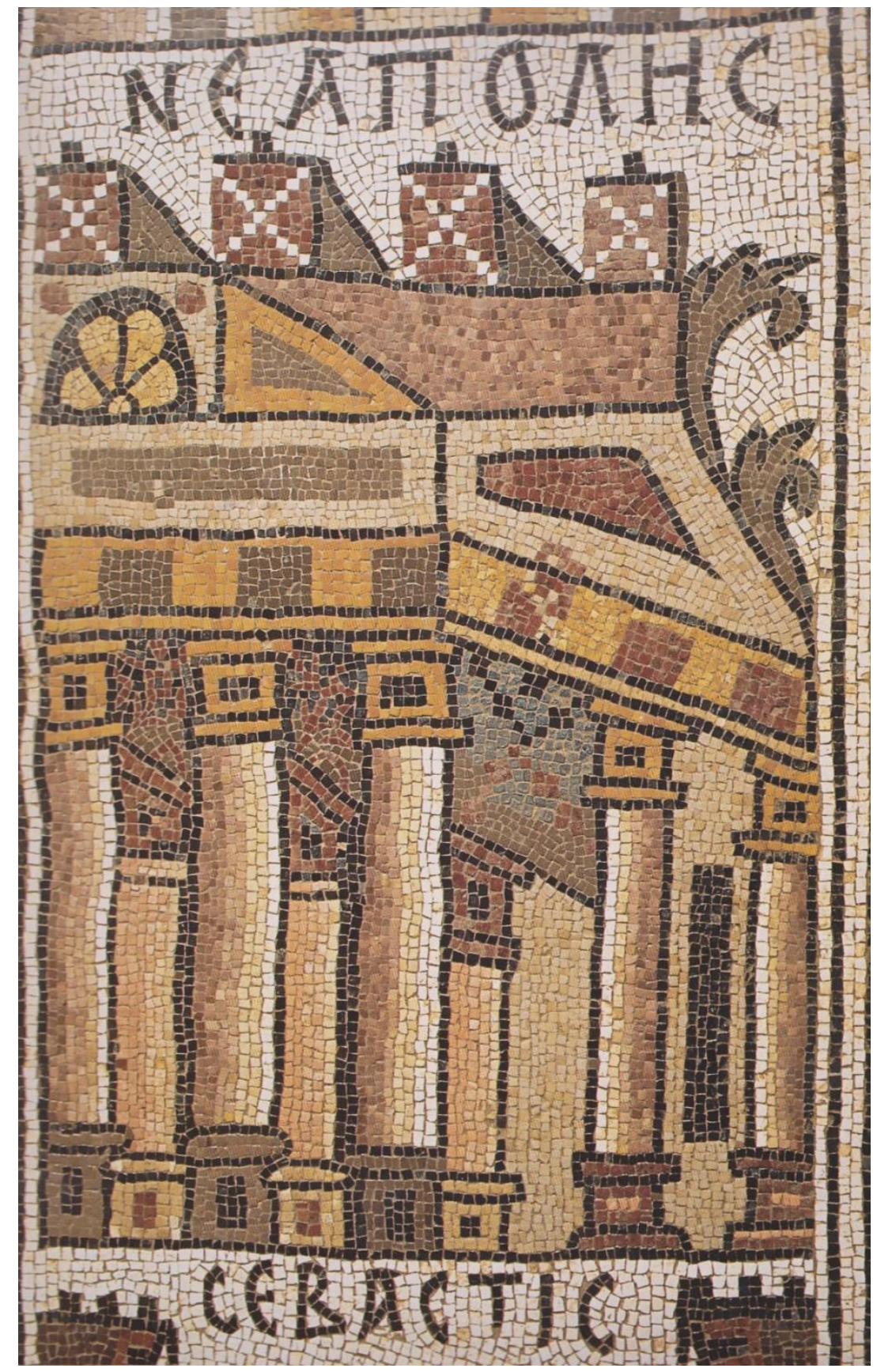

Figure 45: Depiction of Neapolis, (Nablus), St. Stephen Mosaic, Umm al-Rasas

Piccirillo, Mosaics of Jordan., 225. 


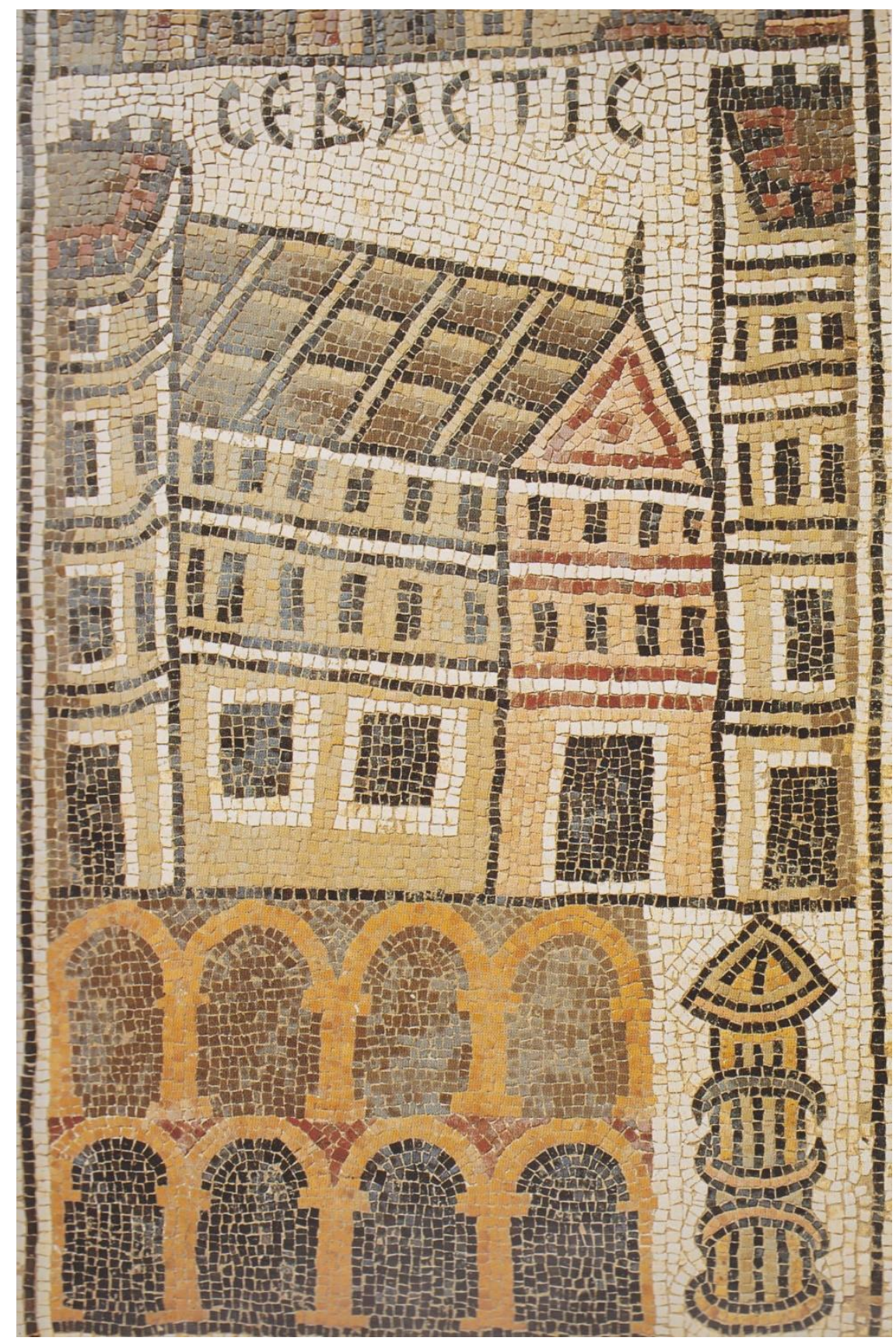

Figure 46: Depiction of Sebastis (Sebastia), St. Stephen Mosaic, Umm al-Rasas

Piccirillo, Mosaics of Jordan, 224. 


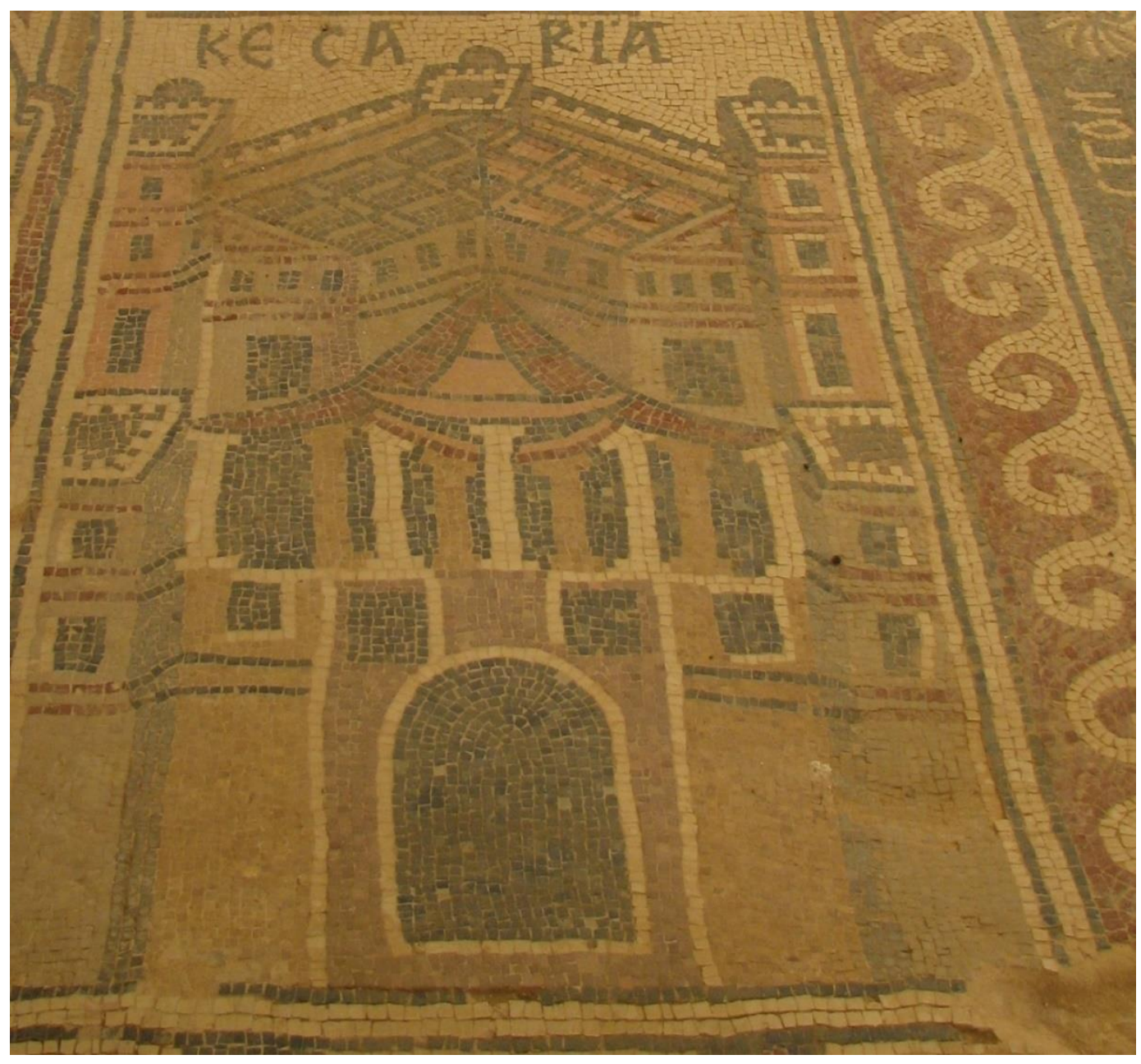

Figure 47: Depiction of Caesarea (Maritima), St. Stephen Mosaic, Umm al-Rasas Author's Photograph. 


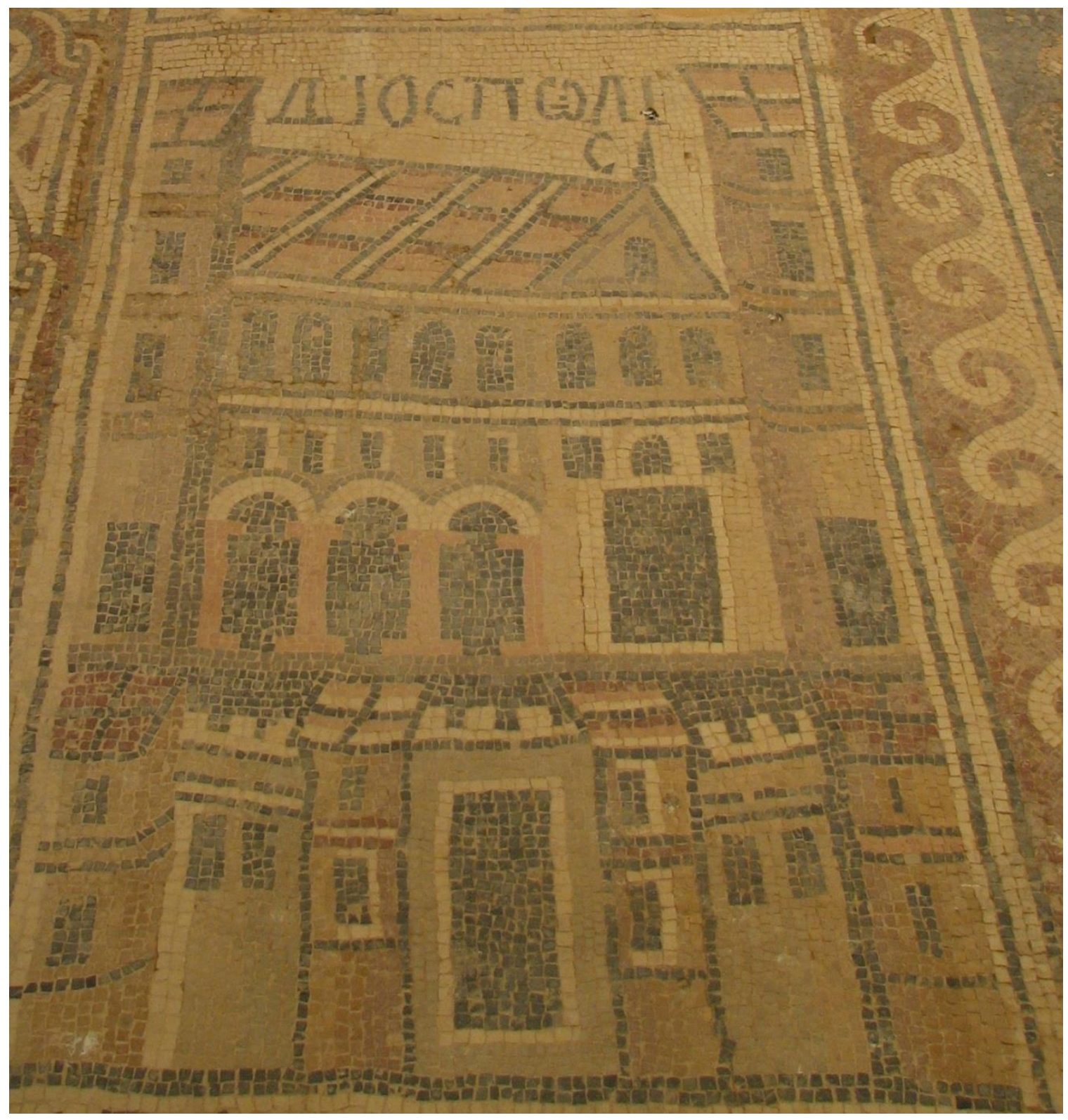

Figure 48: Depiction of Diospolis (Lod), St. Stephen Mosaic, Umm al-Rasas

Author's Photograph. 


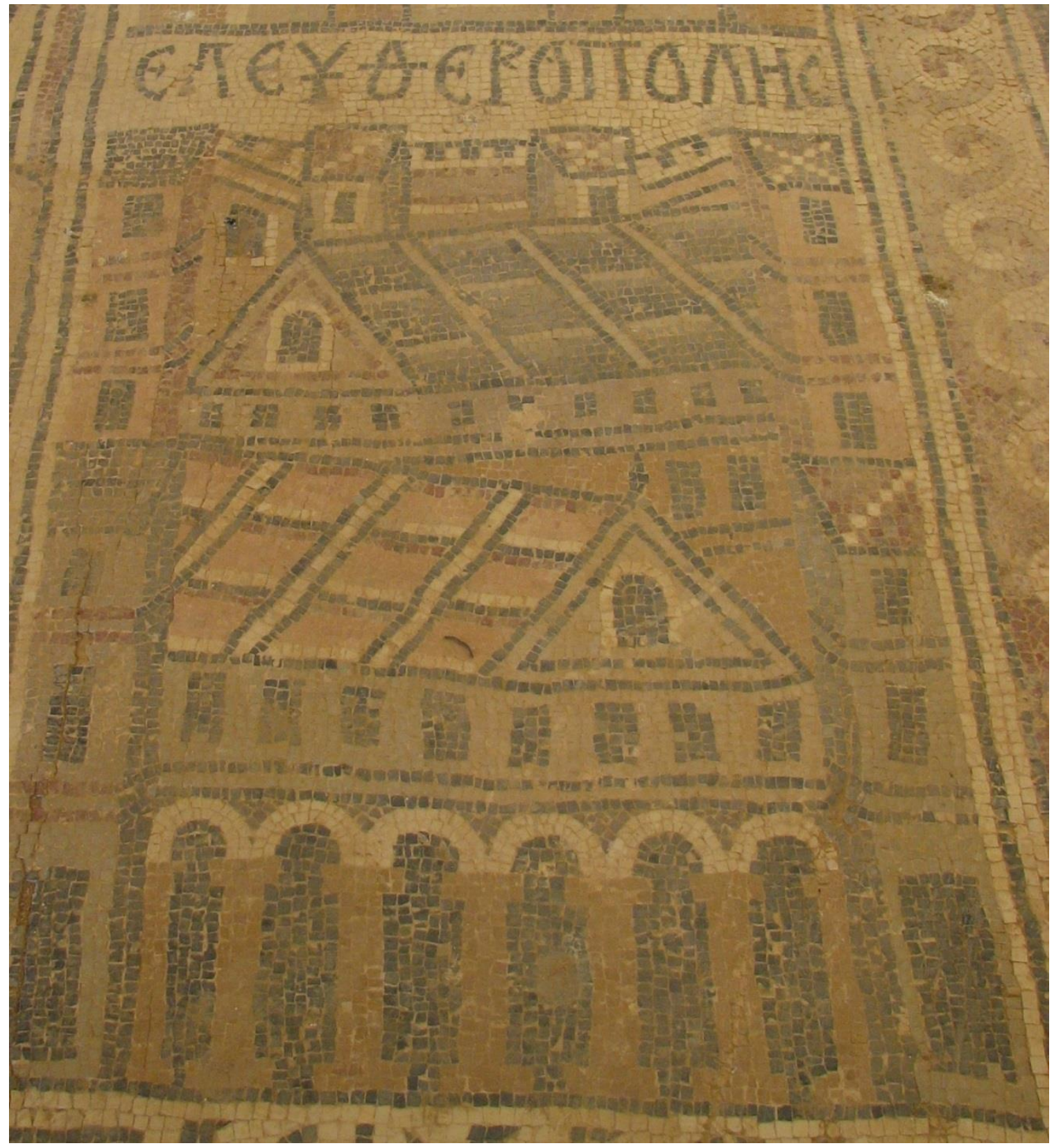

Figure 49: Eleutheropolis (Beit Guvrin), St. Stephen Mosaic, Umm al-Rasas

Author's Photograph. 


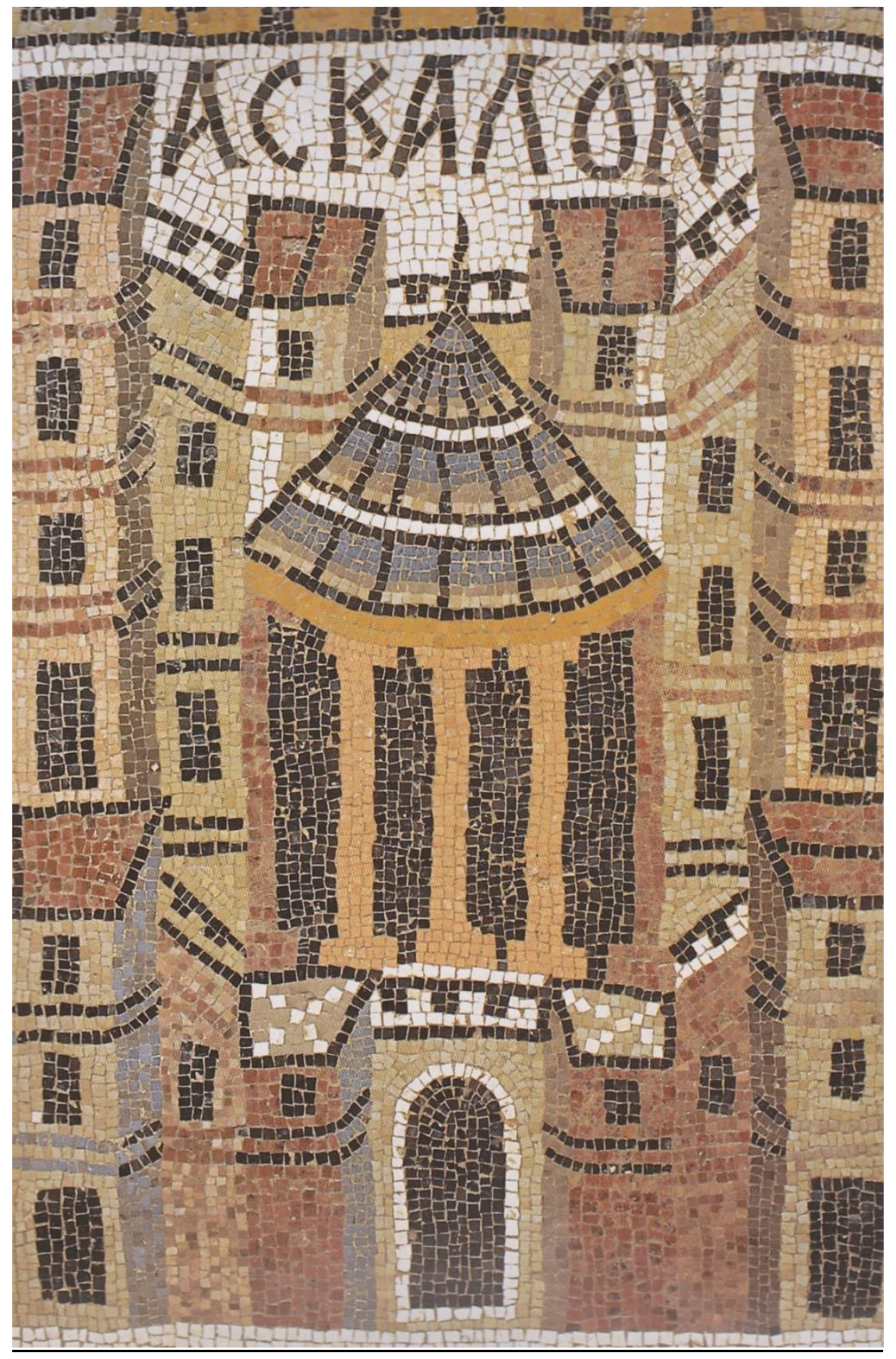

Figure 50: Depiction of Askalon (Ashkelon), St. Stephen Mosaic, Umm al-Rasas

Piccirillo, Mosaics of Jordan, 226. 


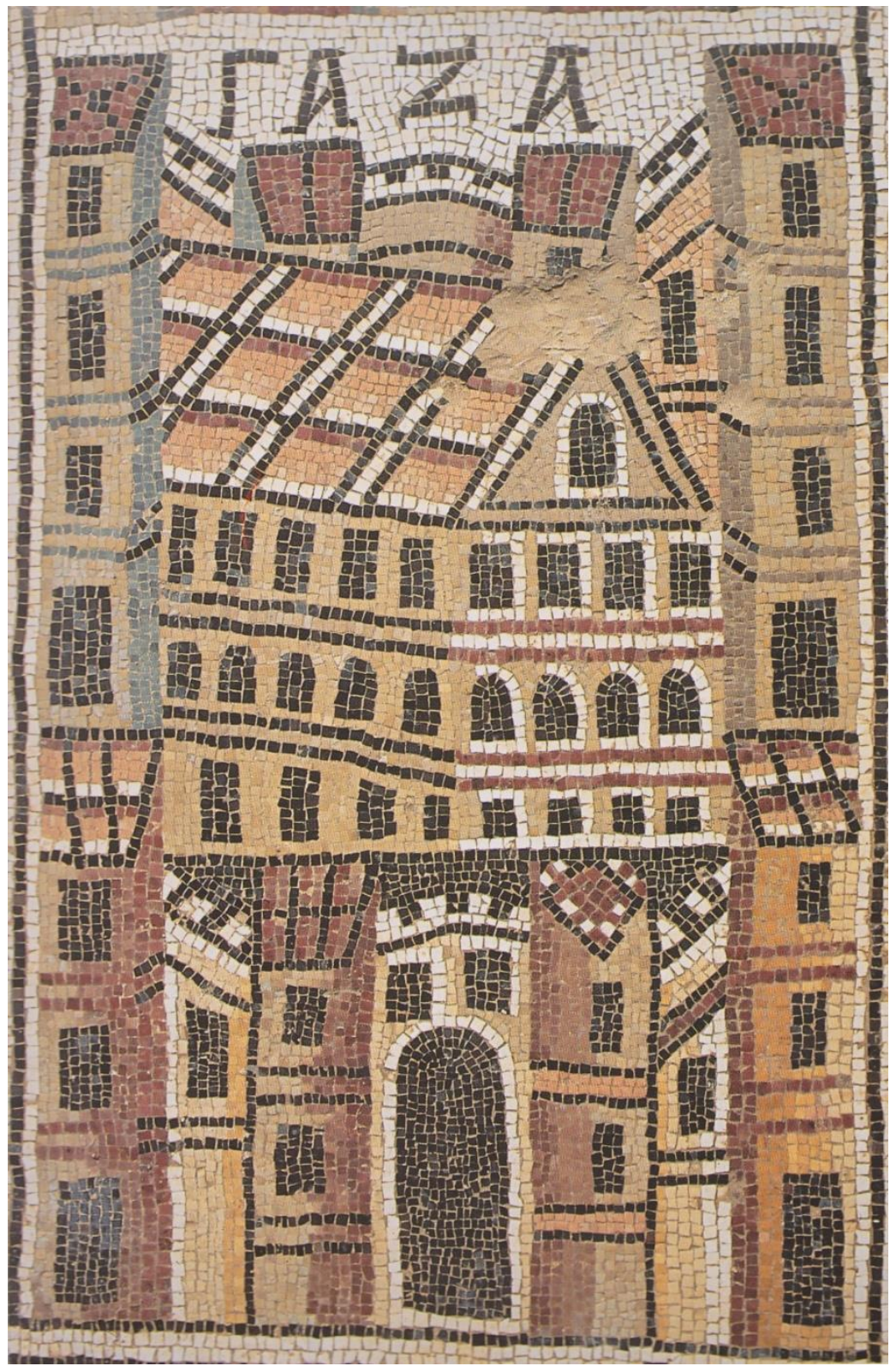

Figure 51: Depiction of Gaza, St. Stephen Mosaic, Umm al-Rasas

Piccirillo, Mosaics of Jordan, 227. 


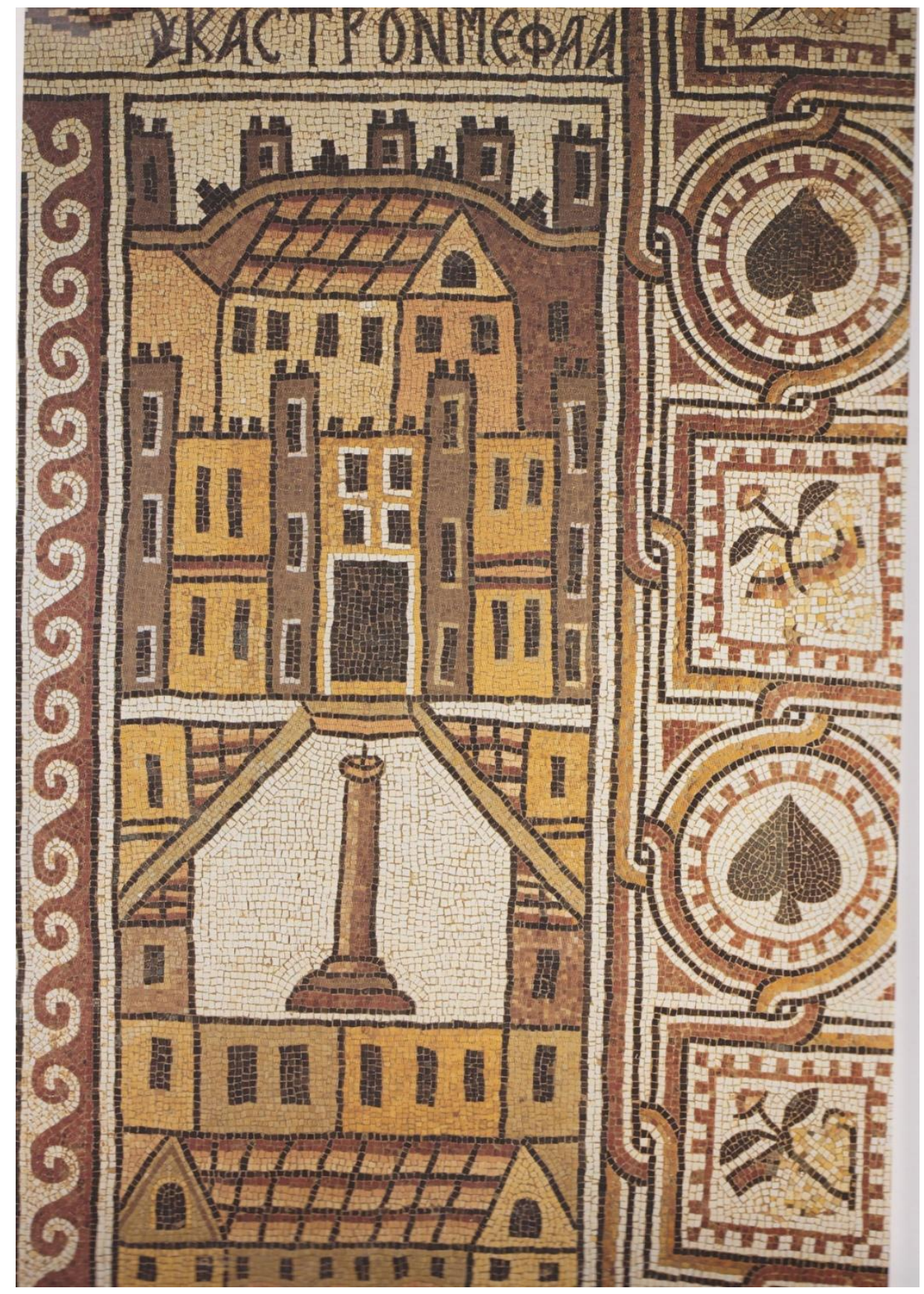

Figure 52: Depiction of Kastron Mefa'a (Umm al-Rasas), St. Stephen Mosaic, Umm al-Rasas

Piccirillo, Mosaics of Jordan, 221. 


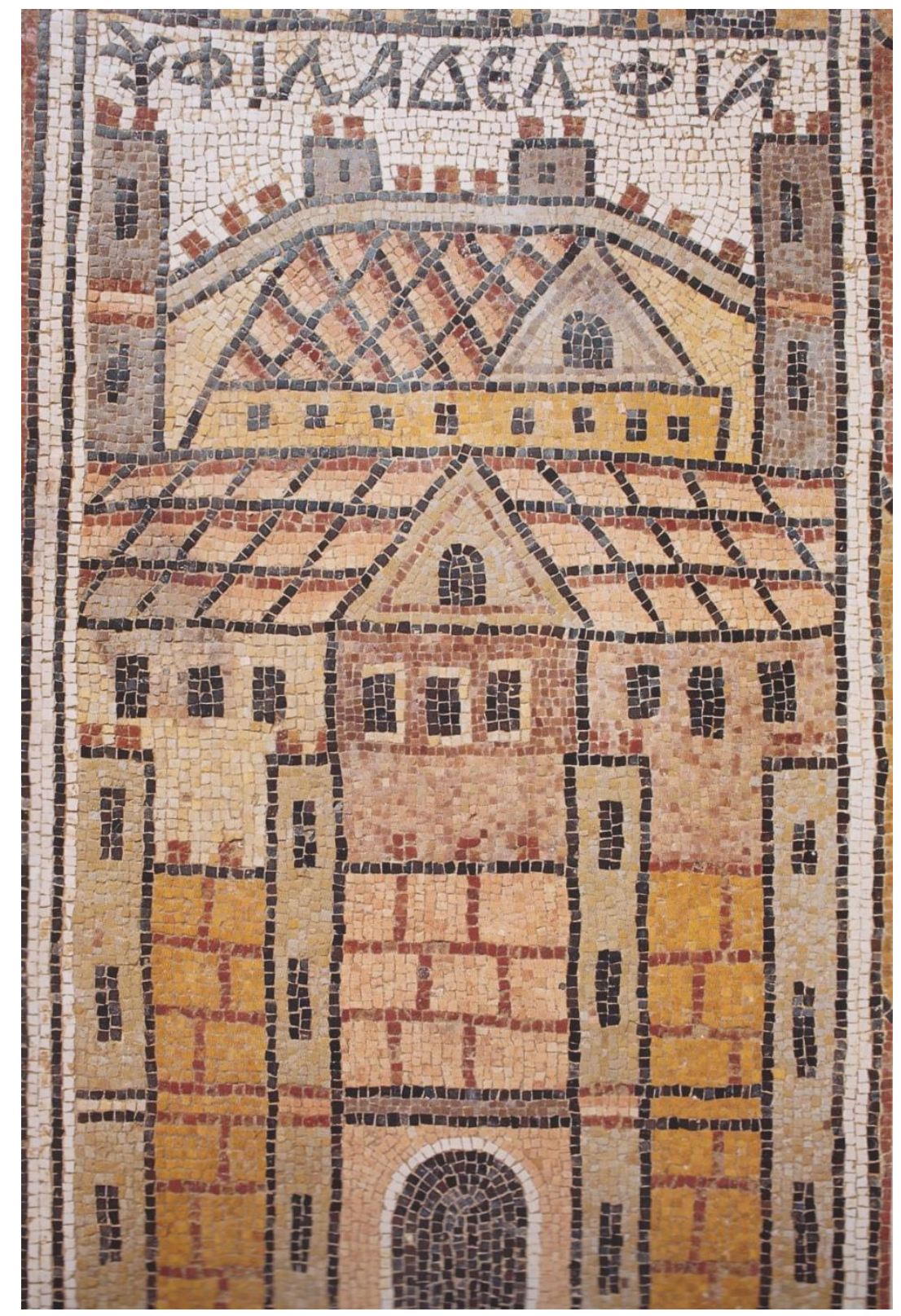

Figure 53: Depiction of Philadelphia (Amman), St. Stephen Mosaic, Umm al-Rasas

Piccirillo, Mosaics of Jordan, 223. 


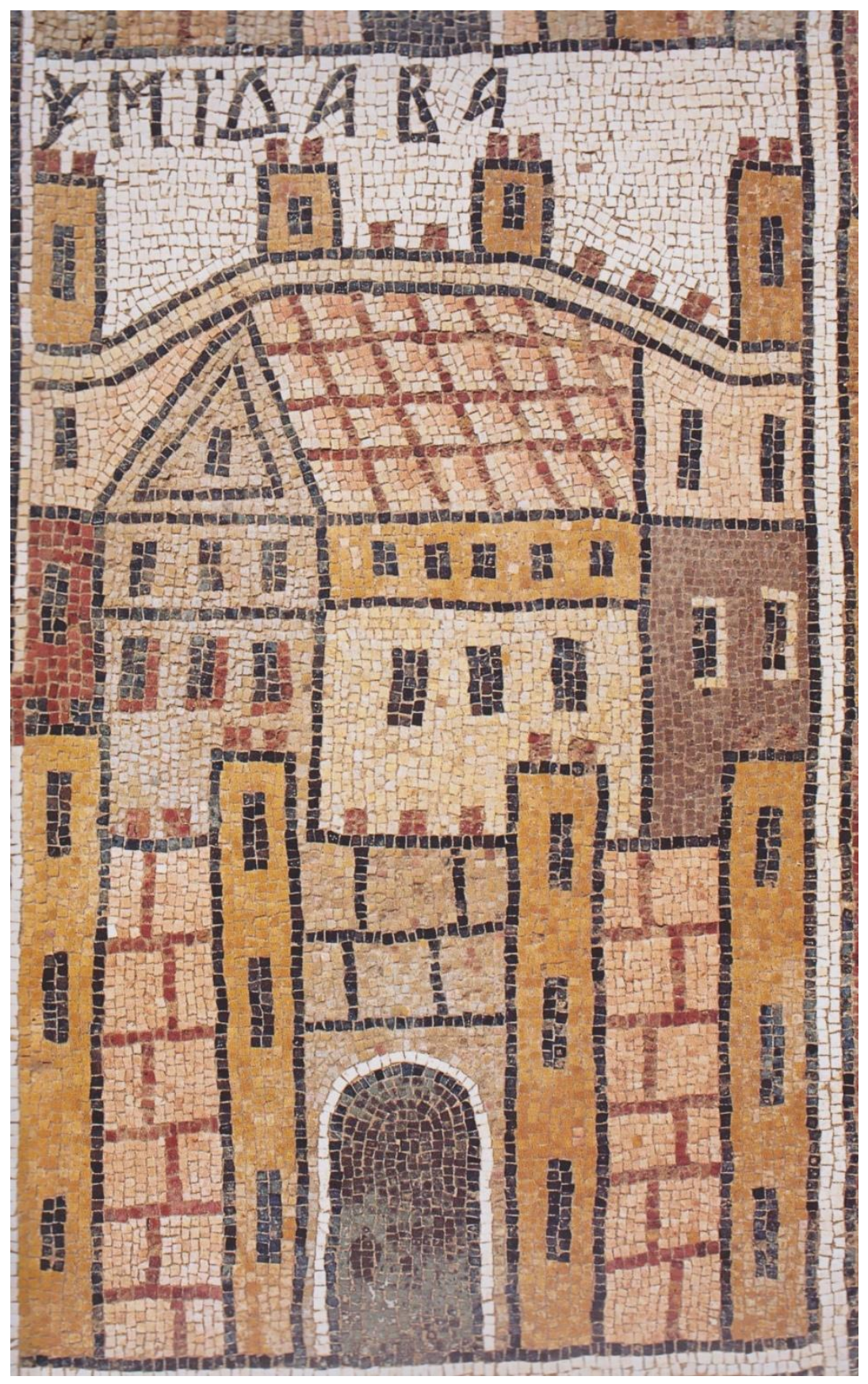

Figure 54: Depiction of Madaba, St. Stephen Mosaic, Umm al-Rasas

Piccirillo, Mosaics of Jordan, 222. 


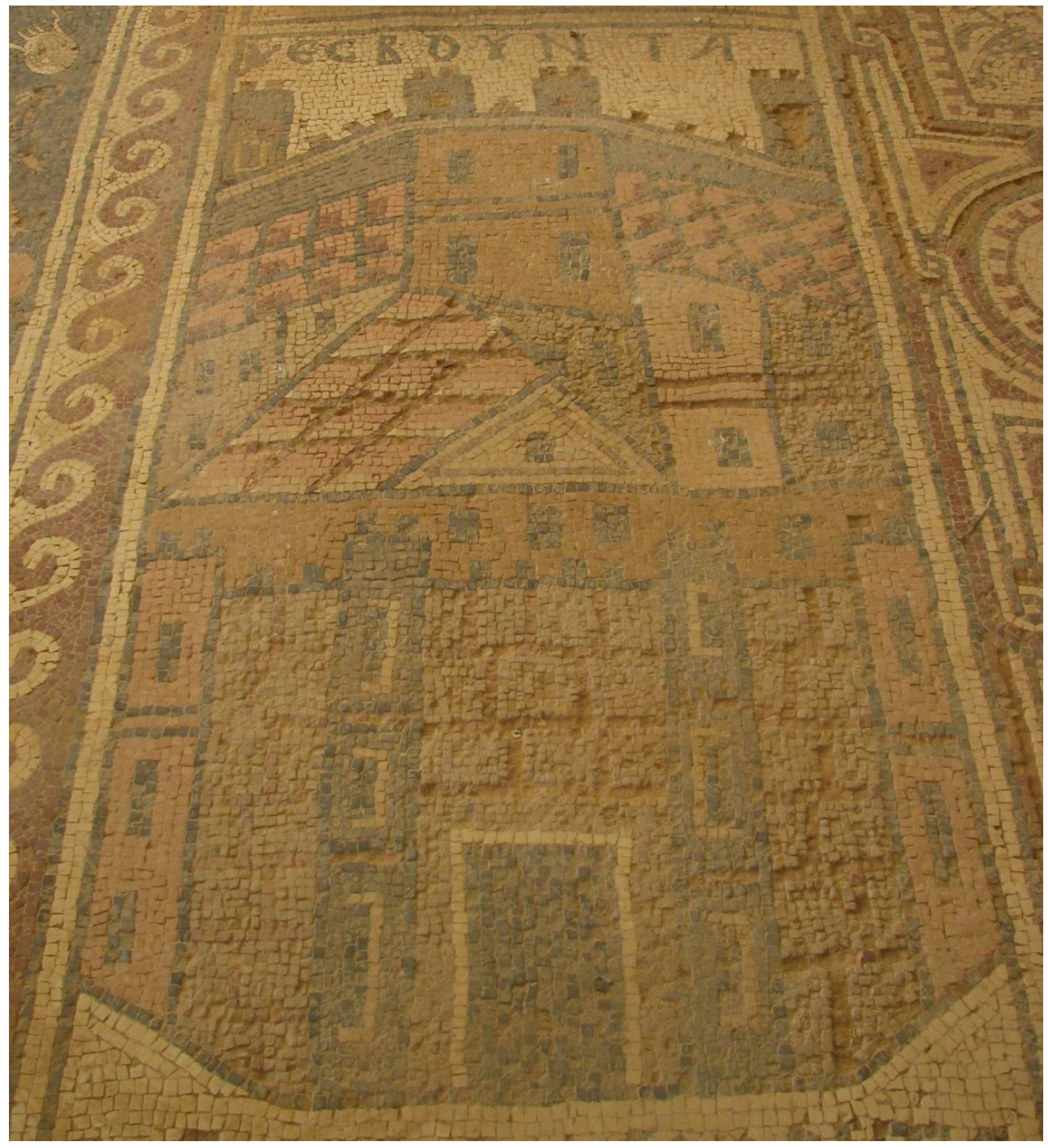

Figure 55: Depiction of Esbounta (Heshbon), St. Stephen Mosaic, Umm al-Rasas

Author's Photograph. 


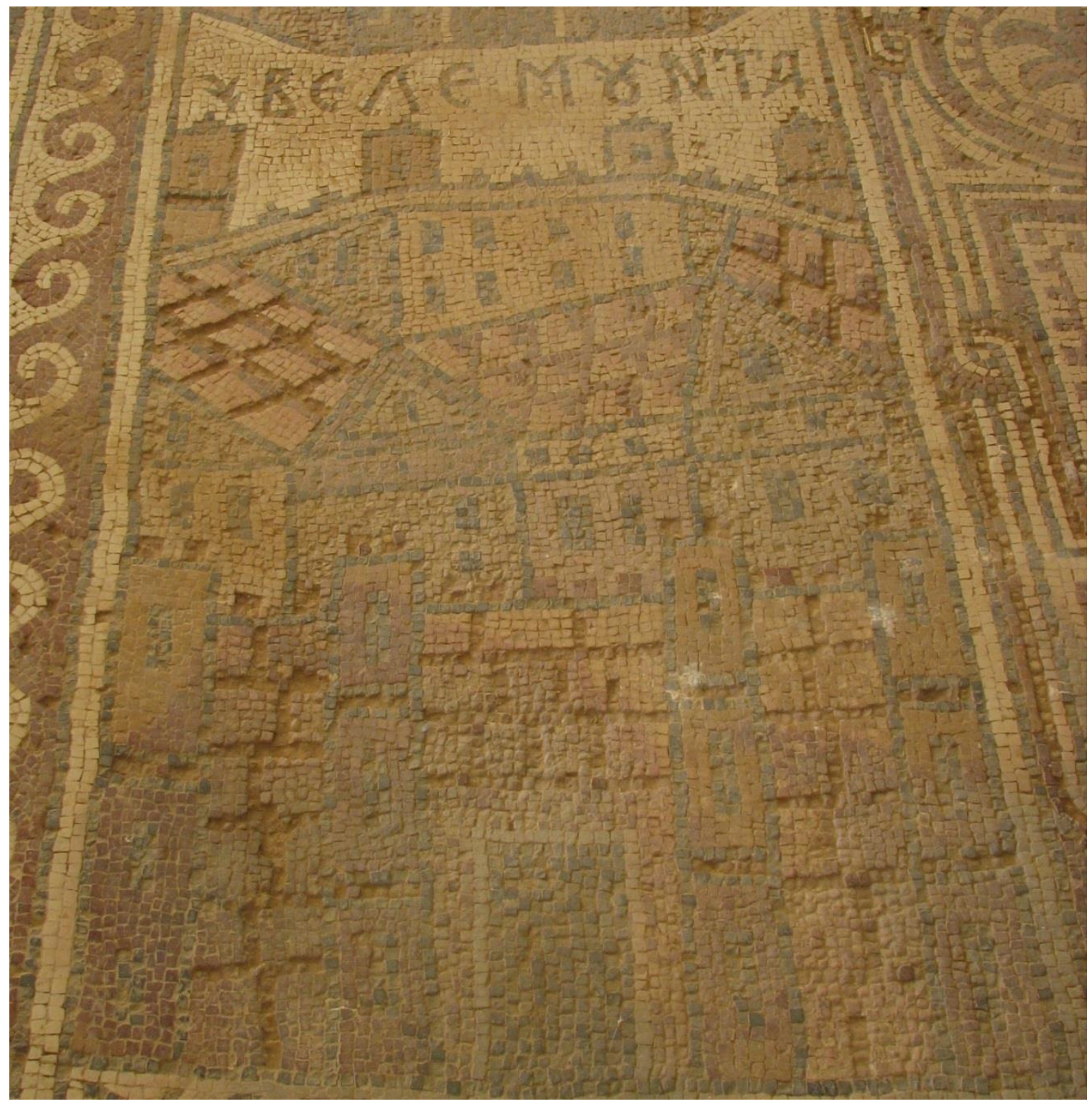

Figure 56: Belemounta (Ma'in), St. Stephen Mosaic, Umm al-Rasas

Author's Photograph. 


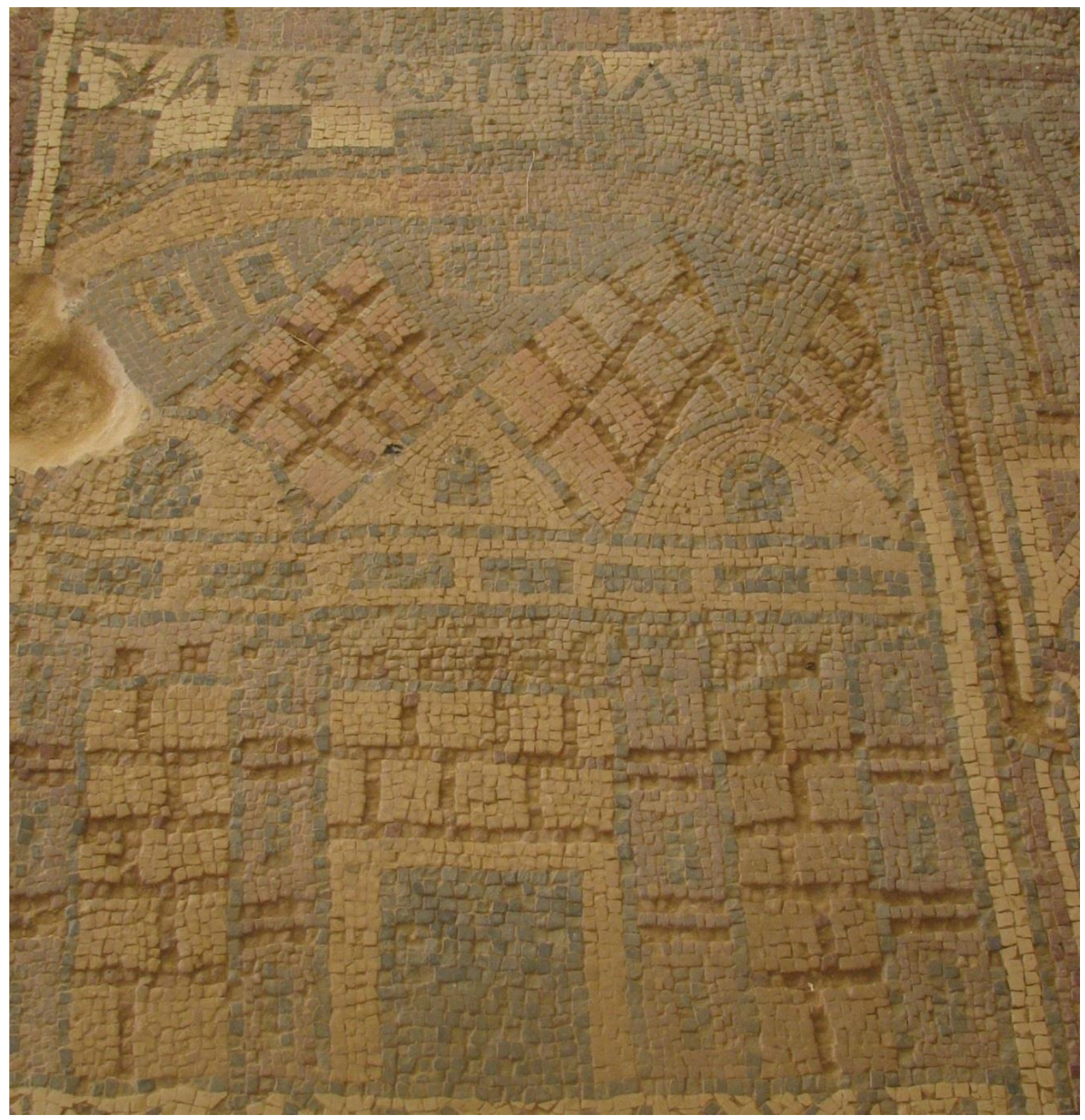

Figure 57: Depiction of Areopolis (Rabba), St. Stephen Mosaic, Umm al-Rasas

Author's Photograph. 


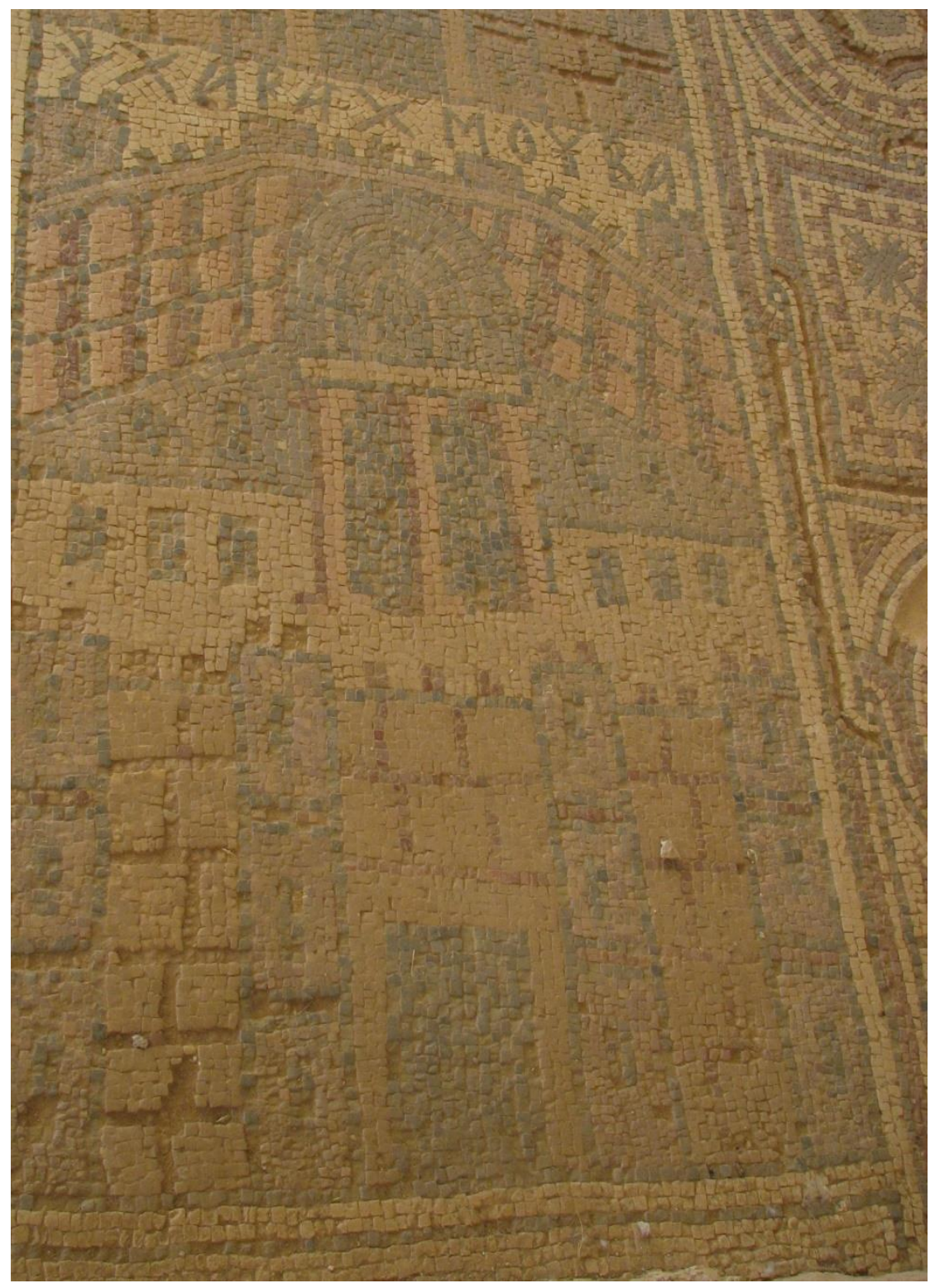

Figure 58: Charach Moba (al-Karak), St. Stephen Mosaic, Umm al-Rasas Author's Photograph. 


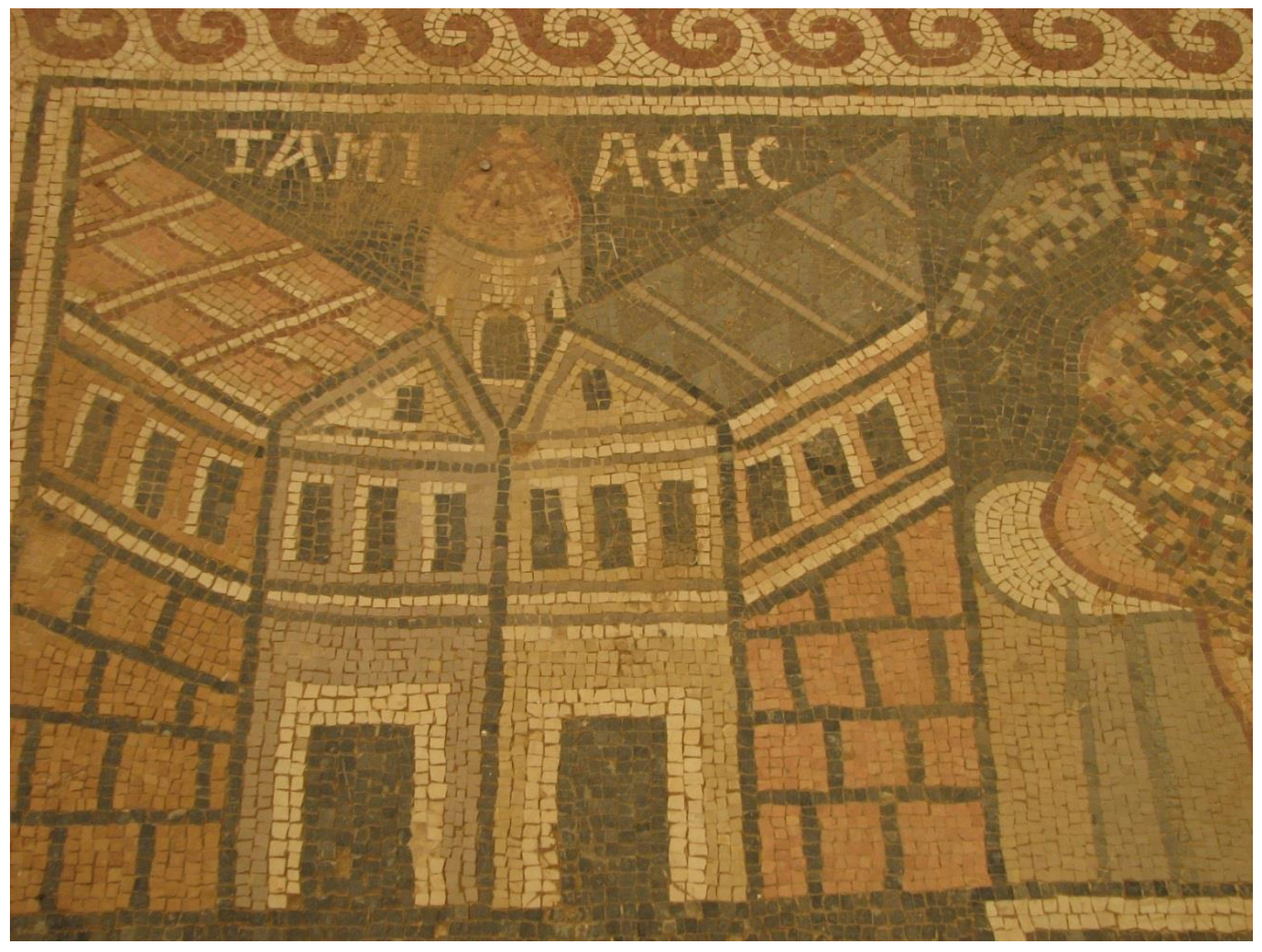

Figure 59: Depiction of Tamiathis (Damietta), St. Stephen Mosaic, Umm al-Rasas

Author's Photograph. 


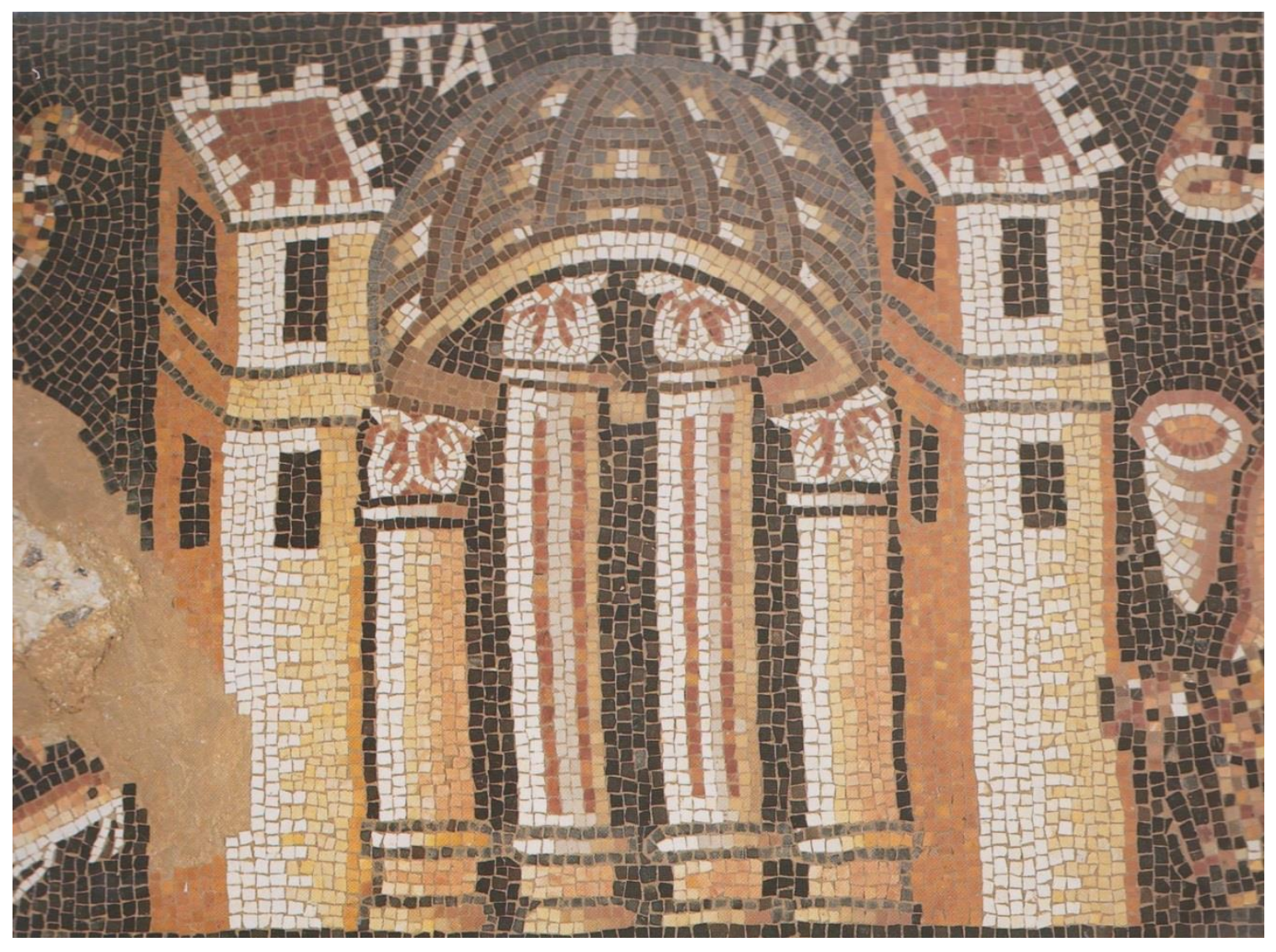

Figure 60: Depiction of Panau (Busiris), St. Stephen Mosaic, Umm al-Rasas

Piccirillo, Mosaics of Jordan, 229. 


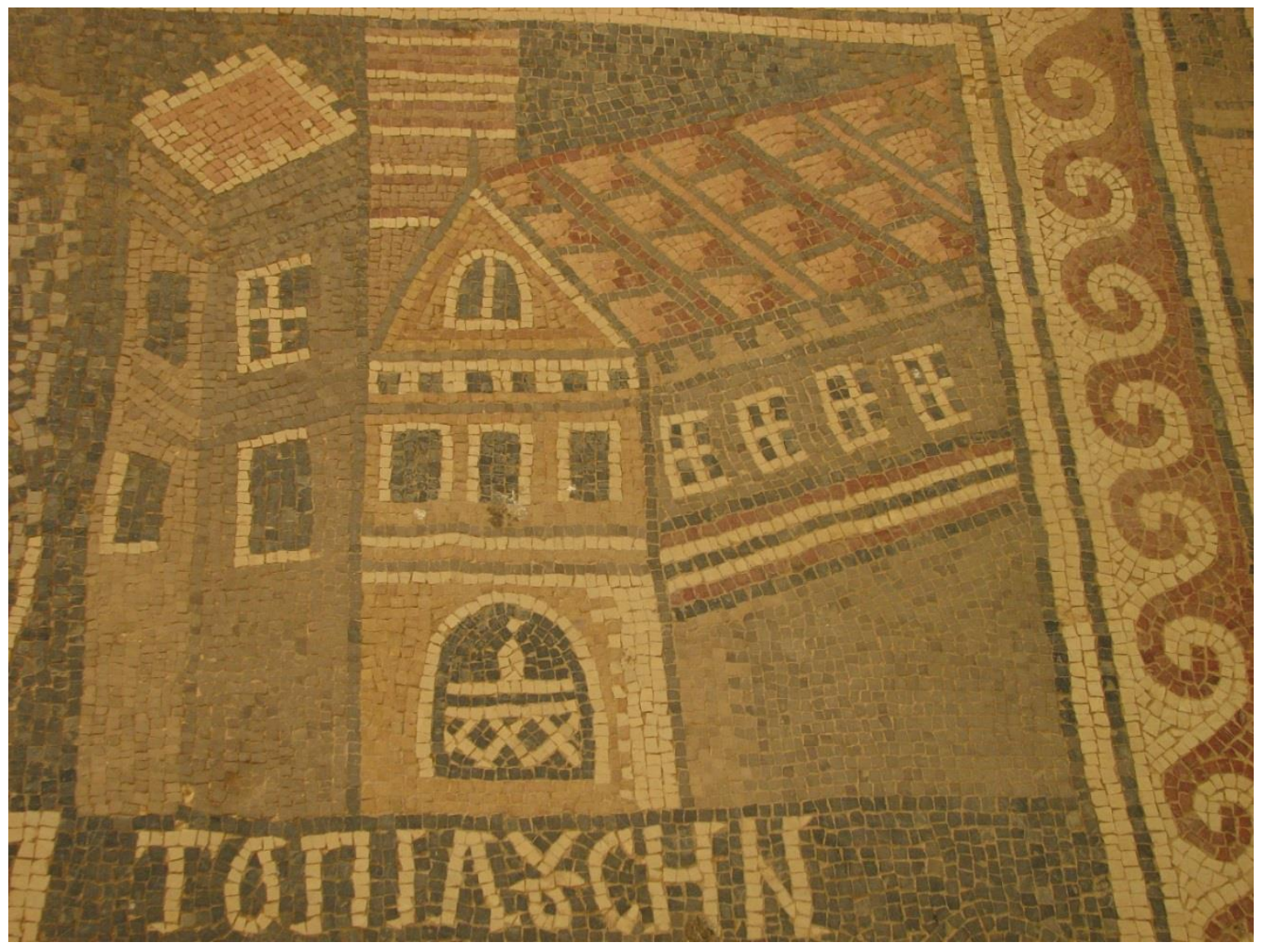

Figure 61: Depiction of Peluseion, St. Stephen Mosaic, Umm al-Rasas

Author's Photograph. 


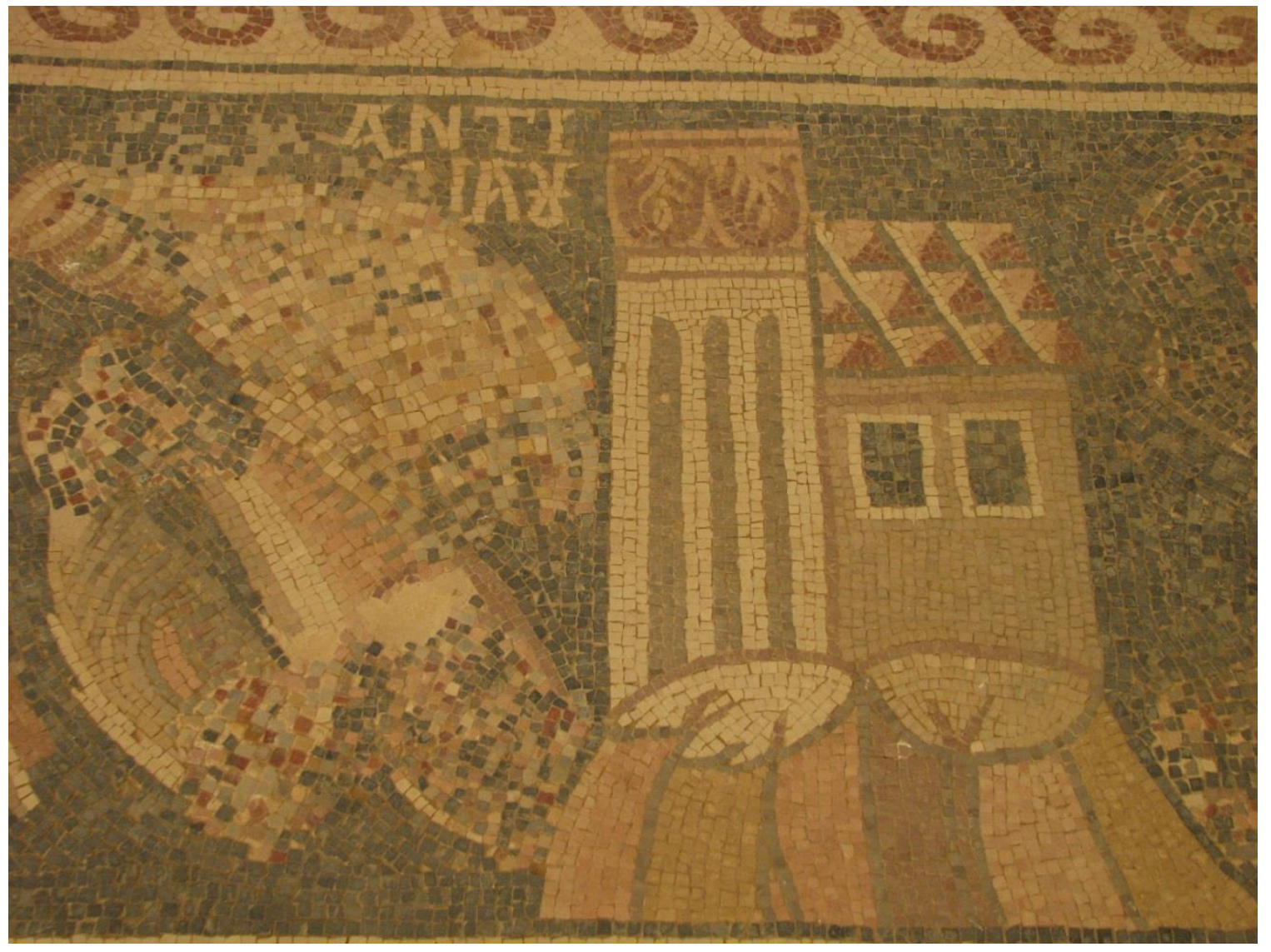

Figure 62: Antinoë (Sheikh Ibada), St. Stephen Mosaic, Umm al-Rasas

Author's Photograph. 


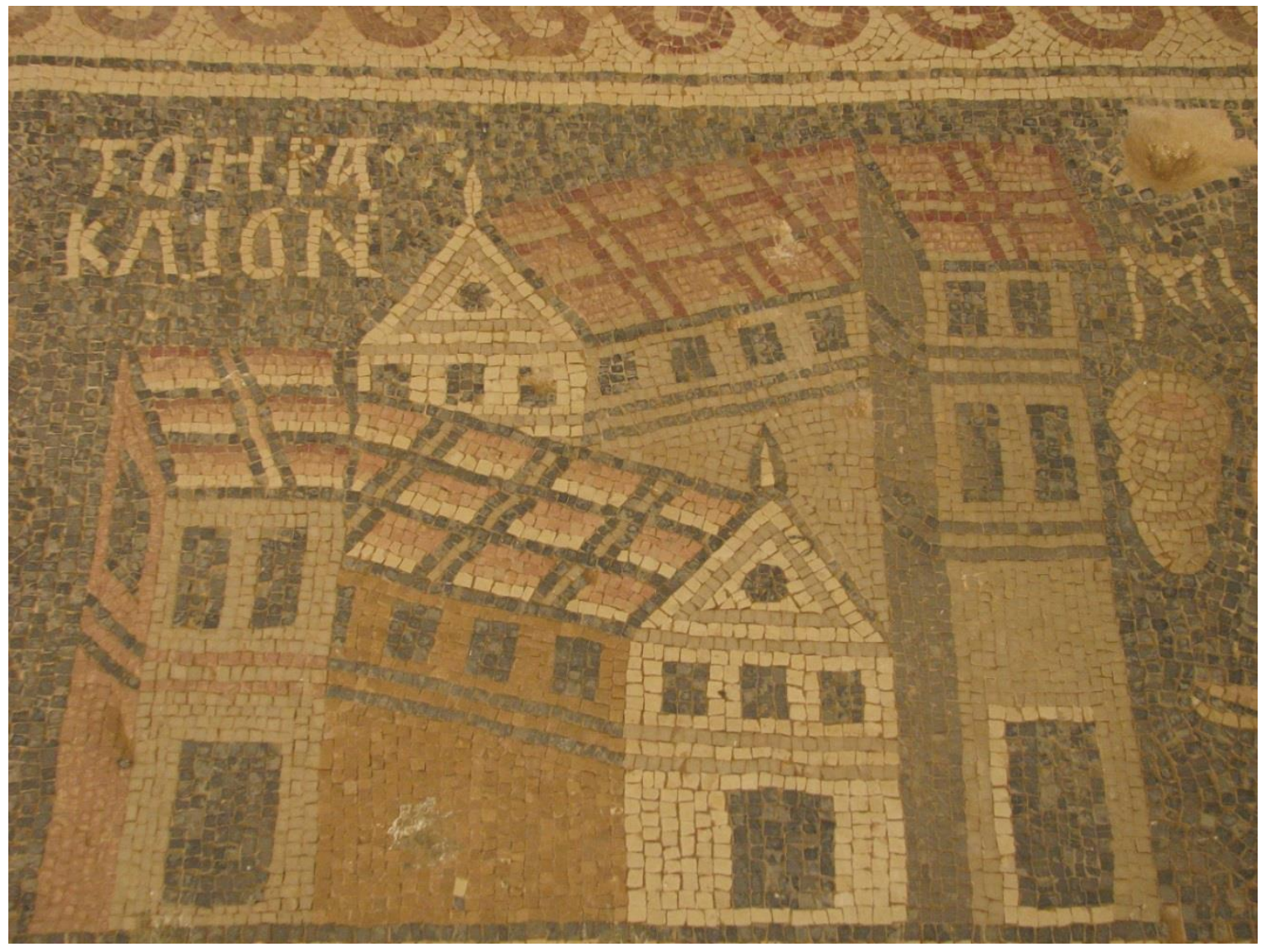

Figure 63: Depiction of Heraklion, St. Stephen Mosaic, Umm al-Rasas

Author's Photograph. 


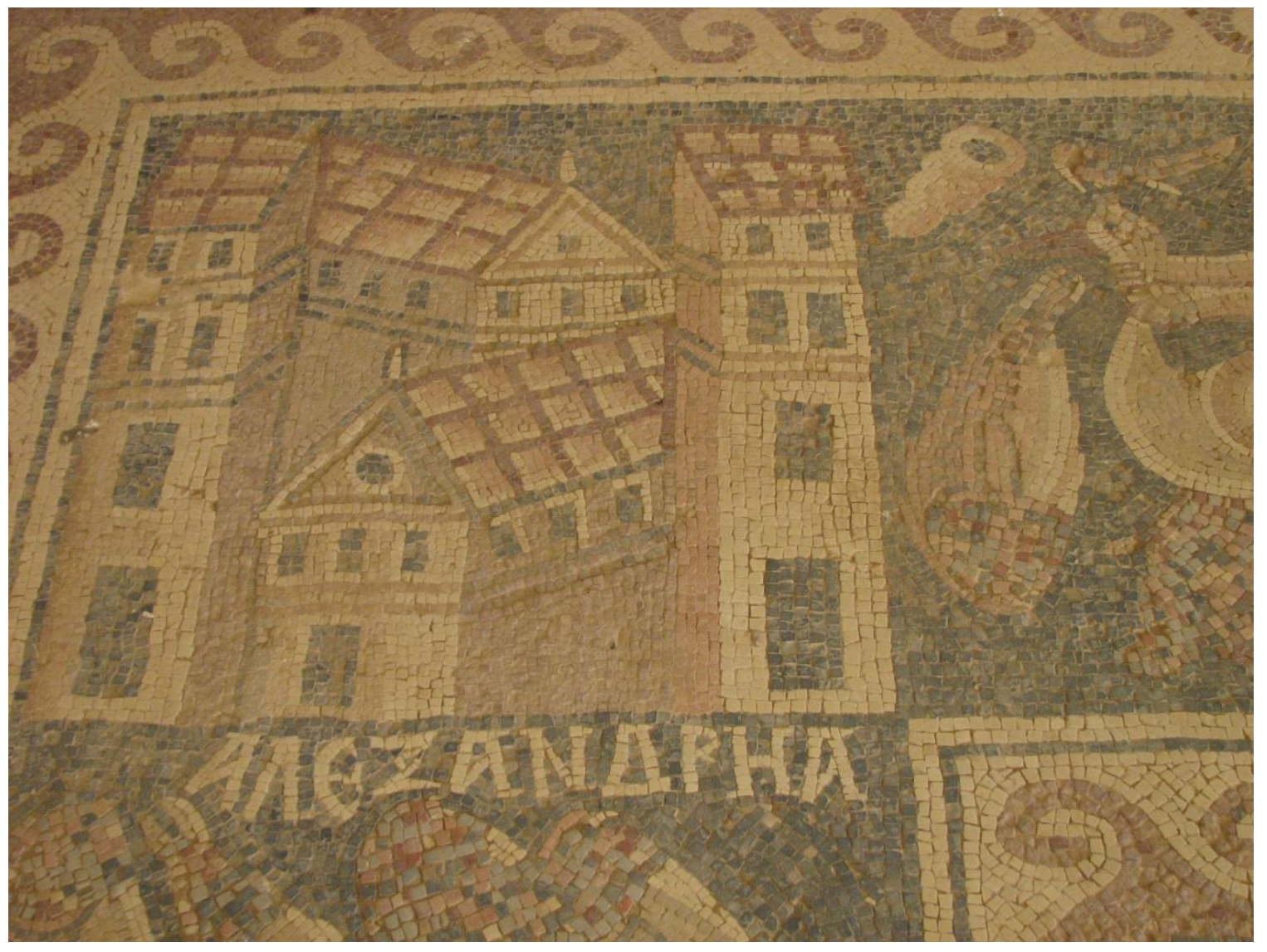

Figure 64: Depiction of Alexandria, St. Stephen Mosaic, Umm al-Rasas

Author's Photograph. 


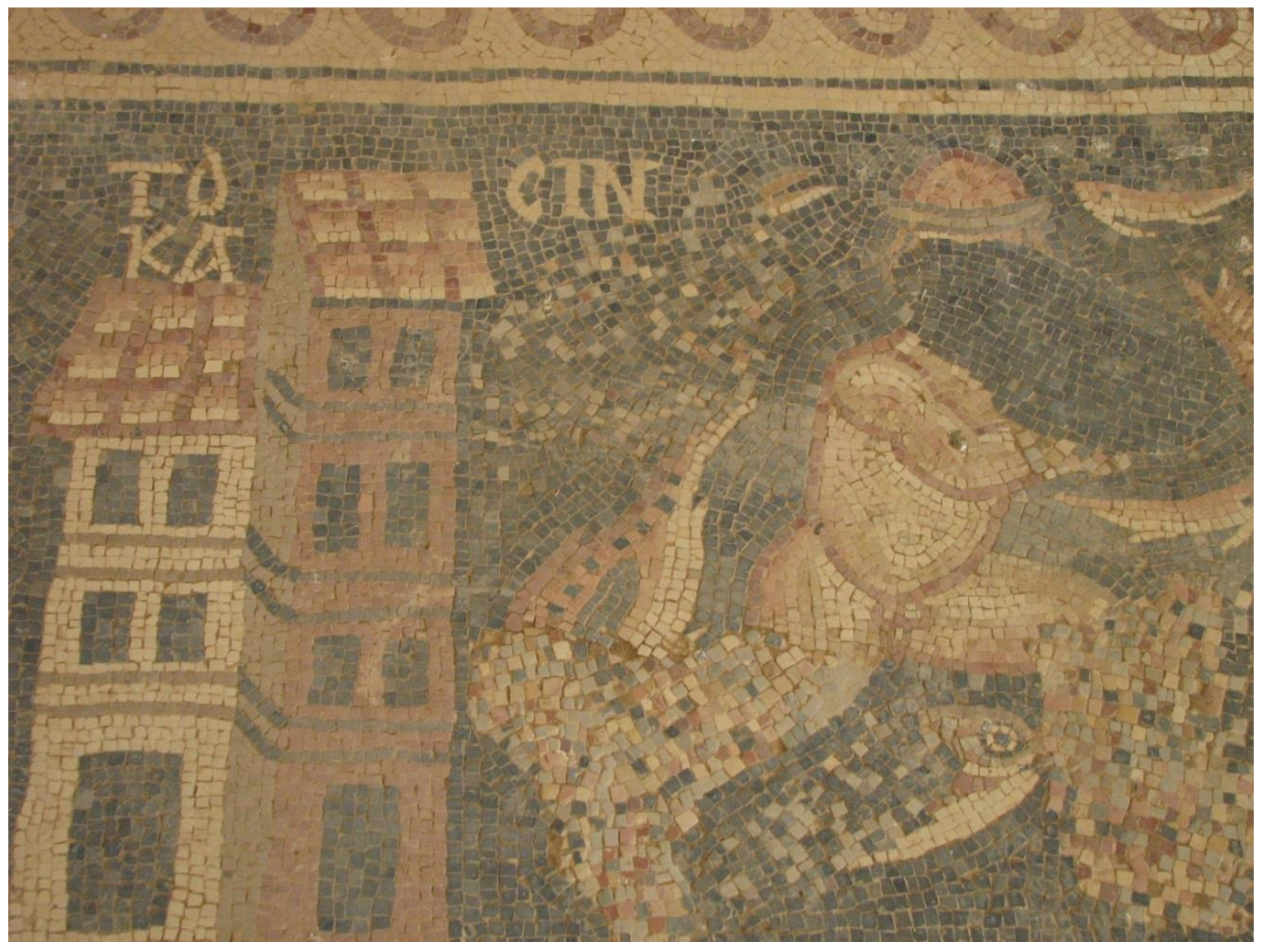

Figure 65: Depiction of Kasion (Mt. Kasios), St. Stephen Mosaic, Umm al-Rasas

Author's Photograph. 


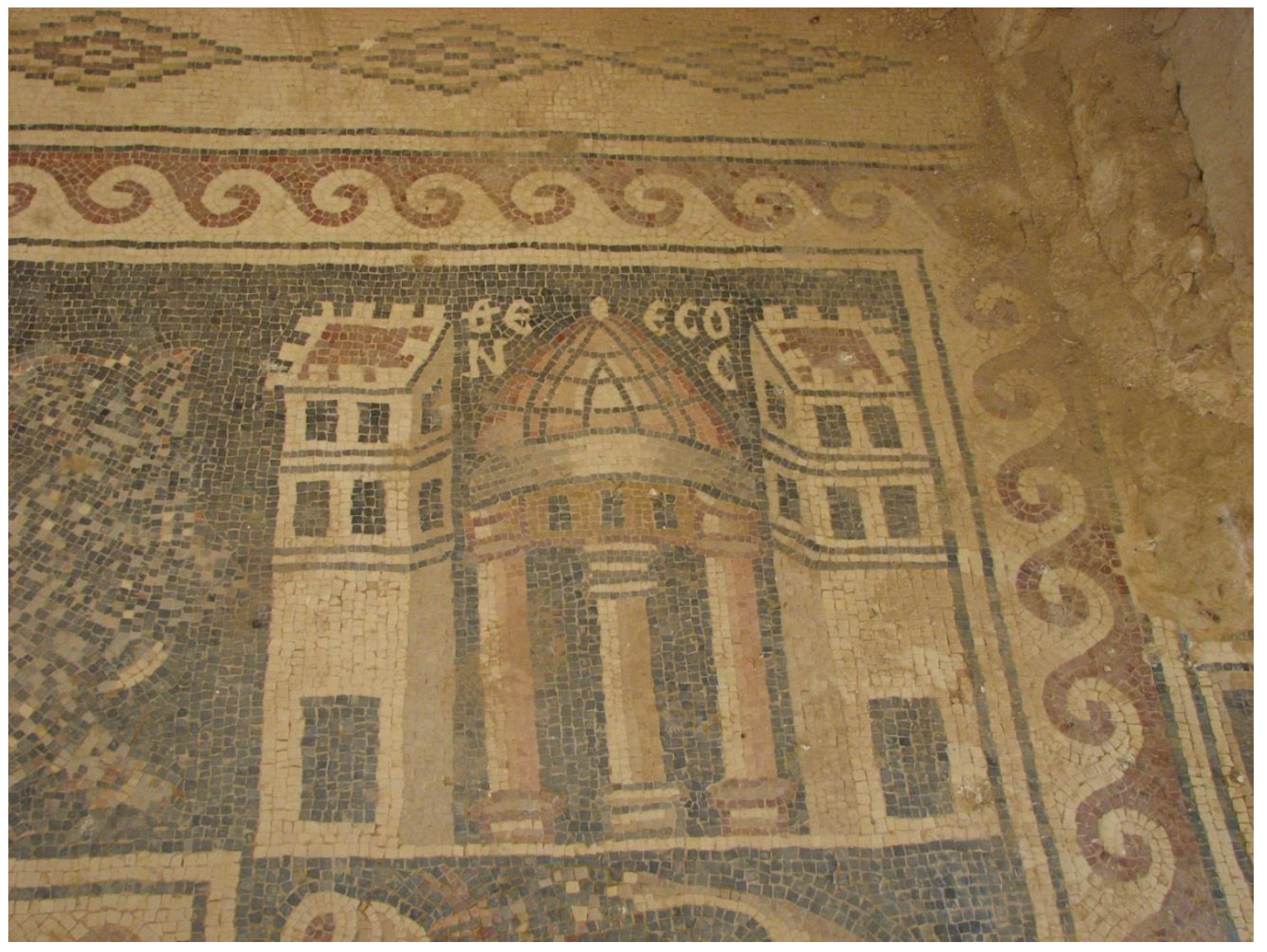

Figure 66: Depiction of Thenesos, St. Stephen, Umm al-Rasas

Author's Photograph. 


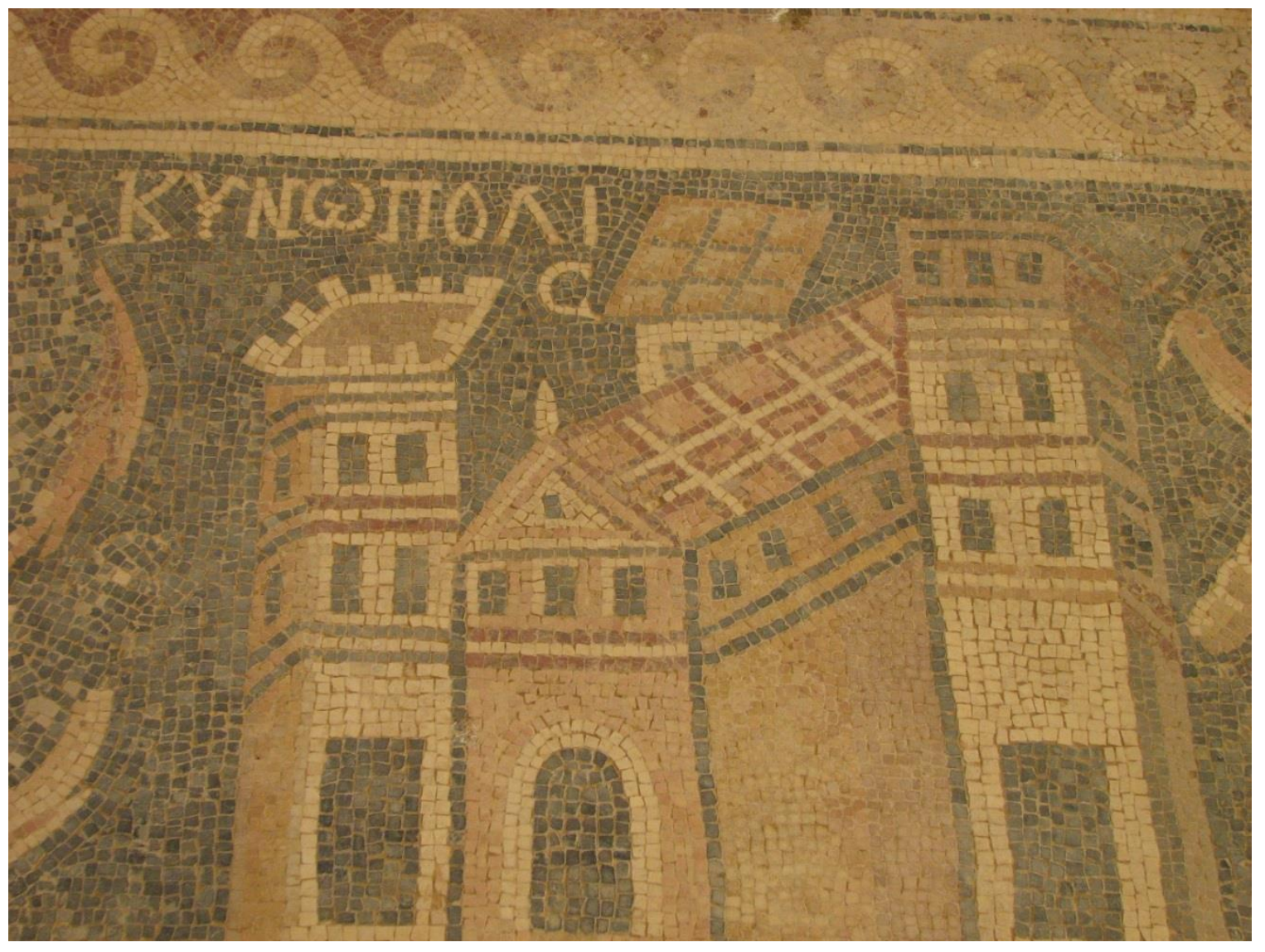

Figure 67: Depiction of Kynopolis, St. Stephen Mosaic, Umm al-Rasas

Author's Photograph. 


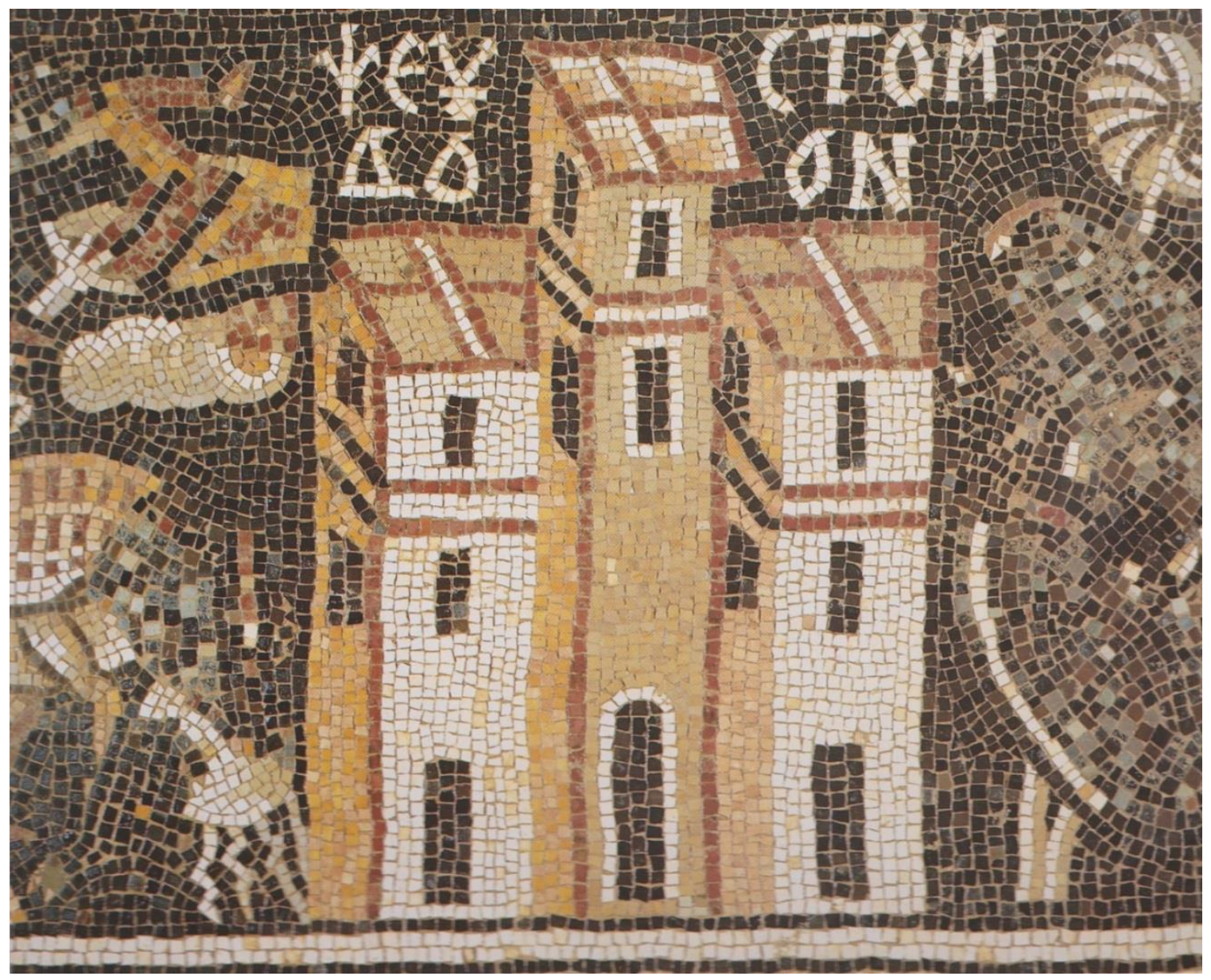

Figure 68: Depiction of Pseudostomon, St. Stephen Mosaic, Umm al-Rasas

Piccirillo, Mosaics of Jordan, 229. 


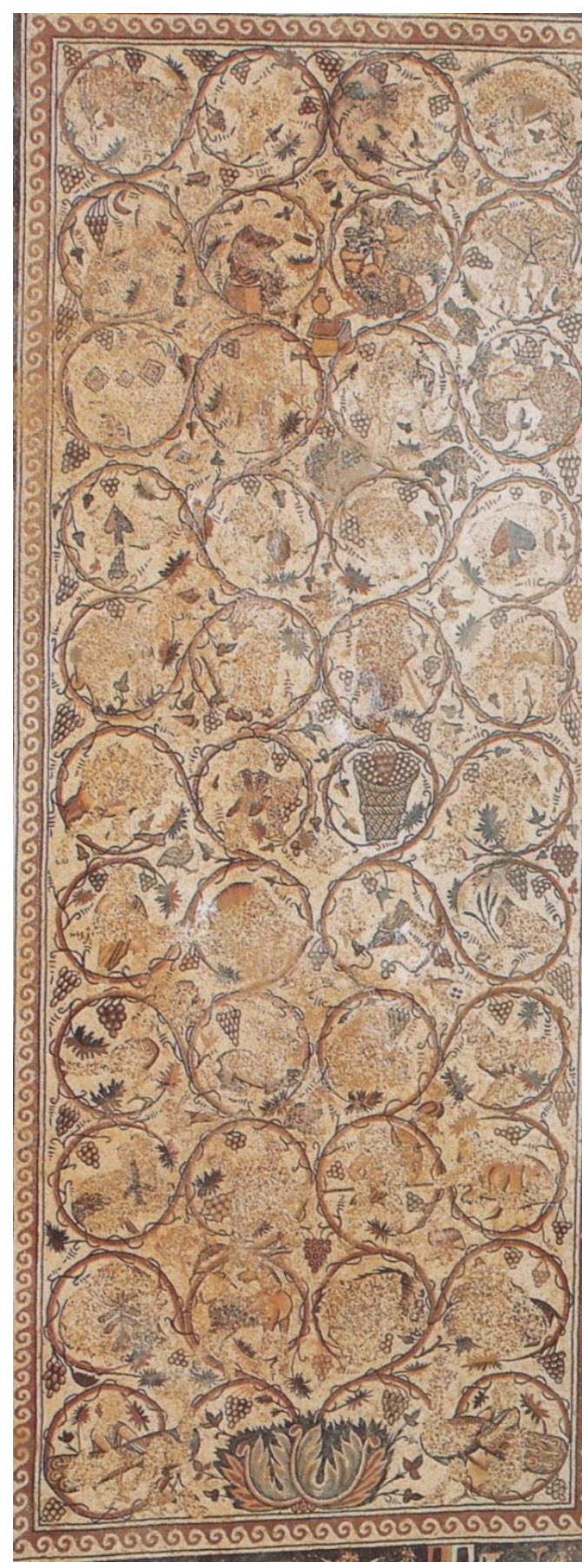

Figure 69: Inhabited Vine Scroll, Nave Pavement St. Stephen, Umm al-Rasas

Piccirillo, Mosaics of Jordan, 219. 


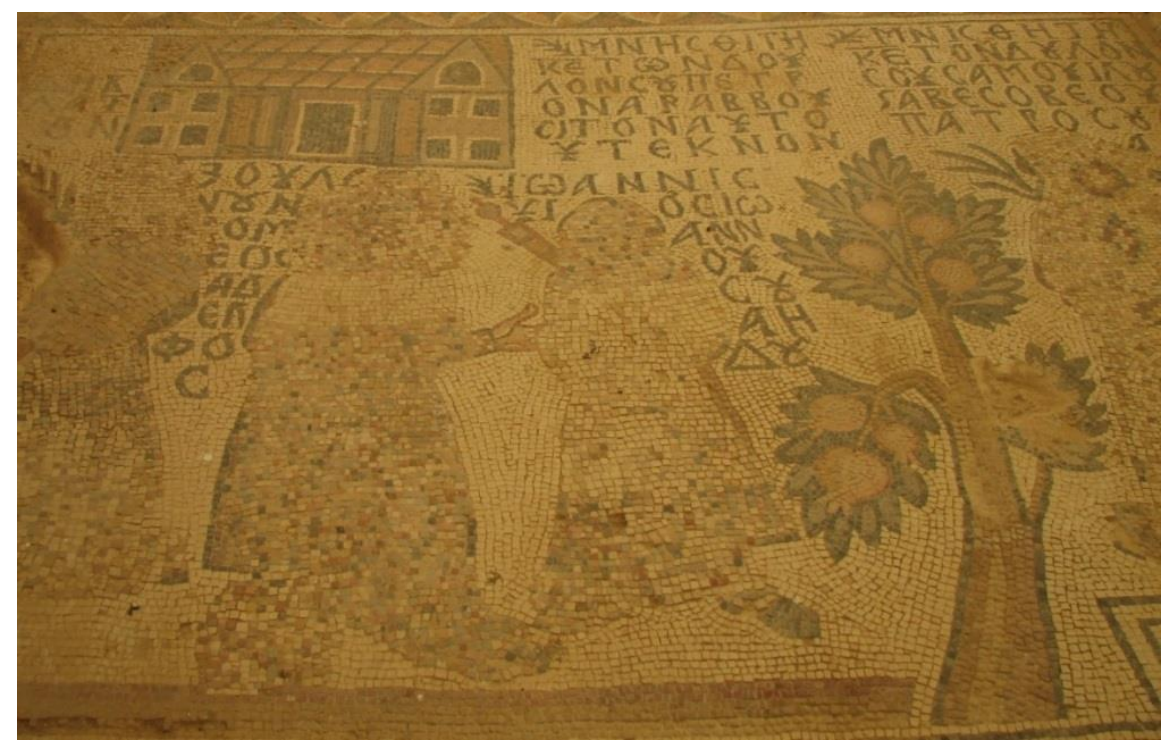

Figure 70: Depiction of Diblaton and Donor Portraits, North Aisle, St. Stephen, Umm alRasas

Author's Photograph.

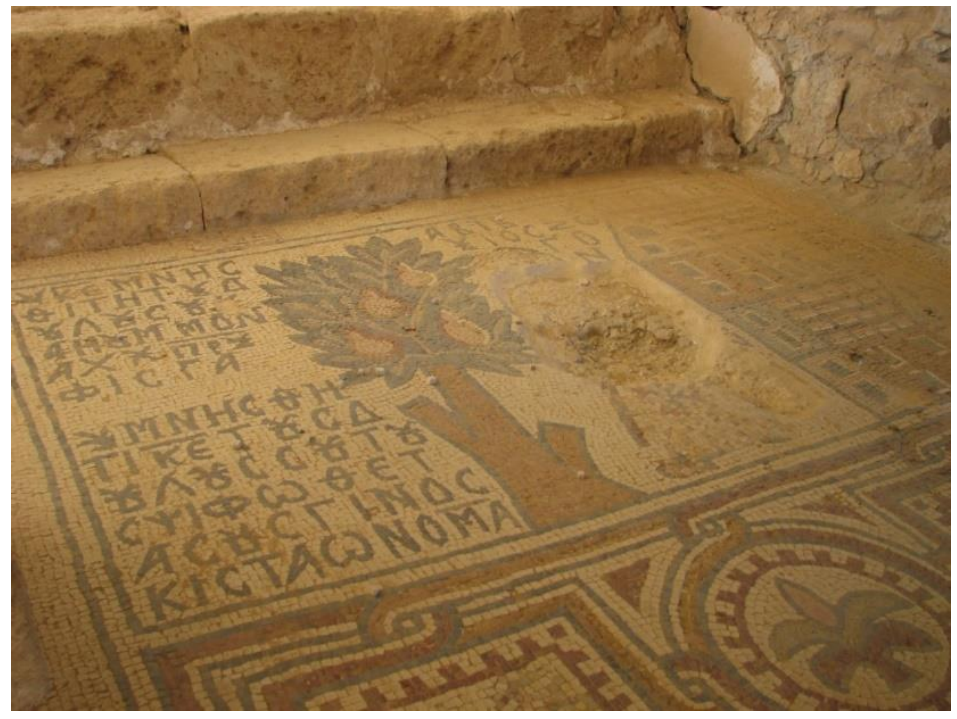

Figure 71: Depiction of Limbon and Donor Portrait, South Aisle, St. Stephen Mosaic, Umm al-Rasas

Author's Photograph. 


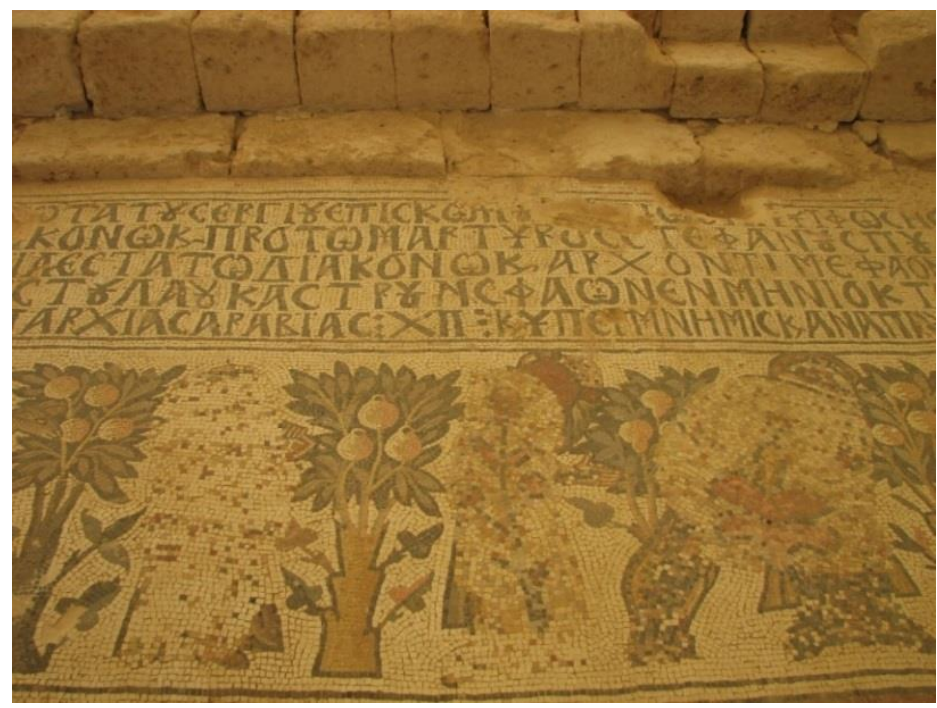

Figure 72: Donor Portraits Amongst Fruit Trees, Eastern Portion of the Nave, St. Stephen, Umm al-Rasas

Author's Photograph.

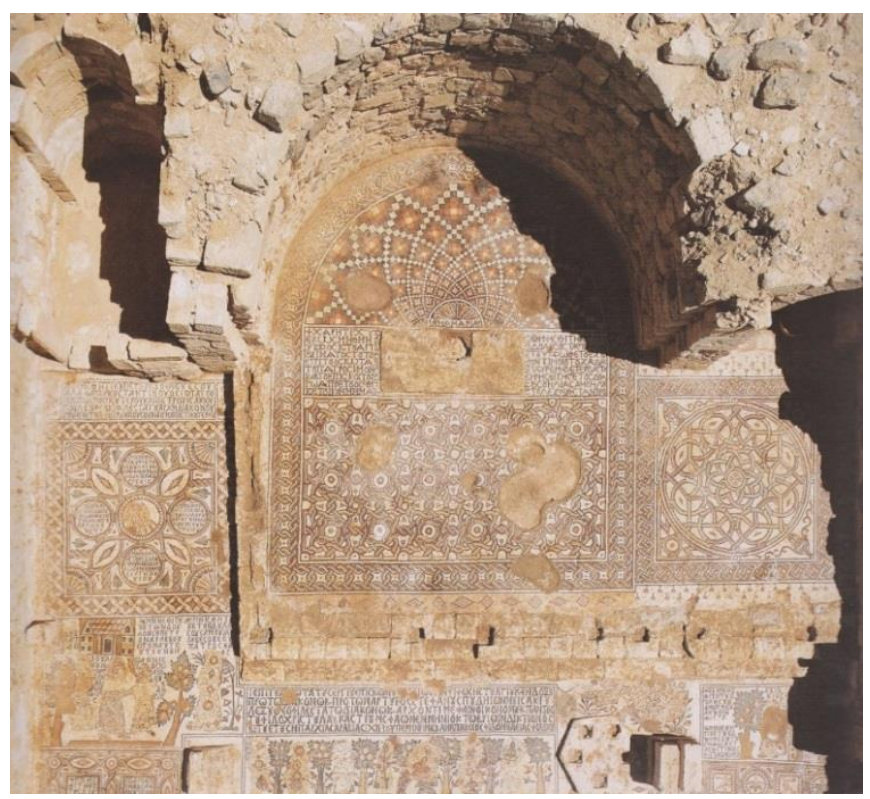

Figure 73: Aerial View of the Sanctuary, St. Stephen, Umm al-Rasas

Piccirillo, Mosaics of Jordan, 220. 


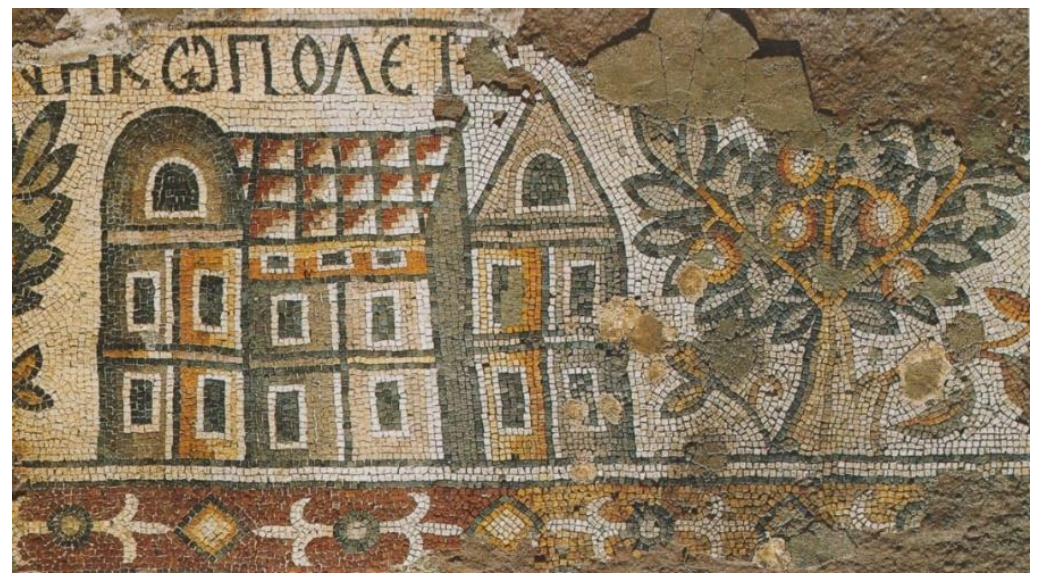

Figure 74: Depiction of Nikopolis, Church of the Acropolis, Ma'in Author's Photograph.

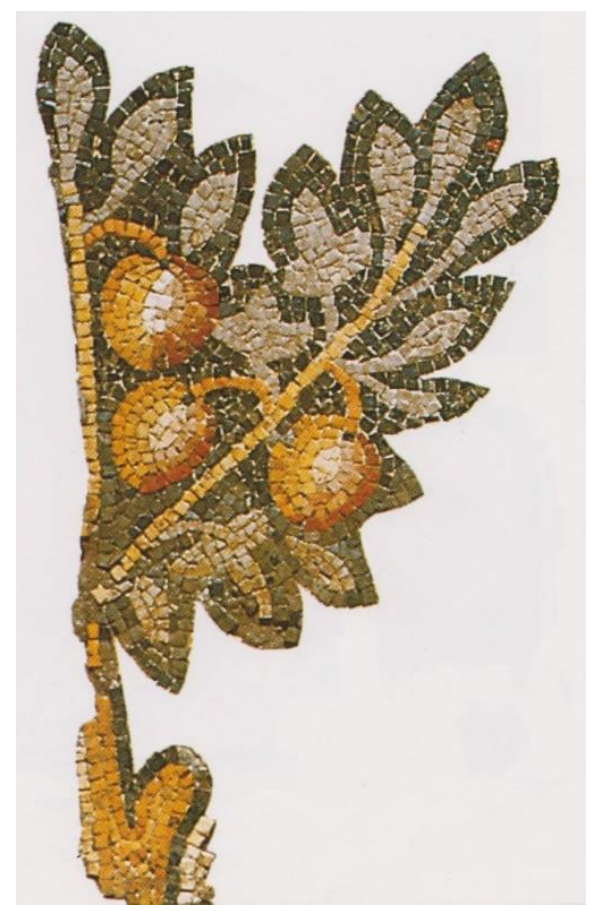

Figure 75: Depiction of a Fruit Tree, Church of the Acropolis, Ma'in

Piccirillo, Mosaics of Jordan, 197. 


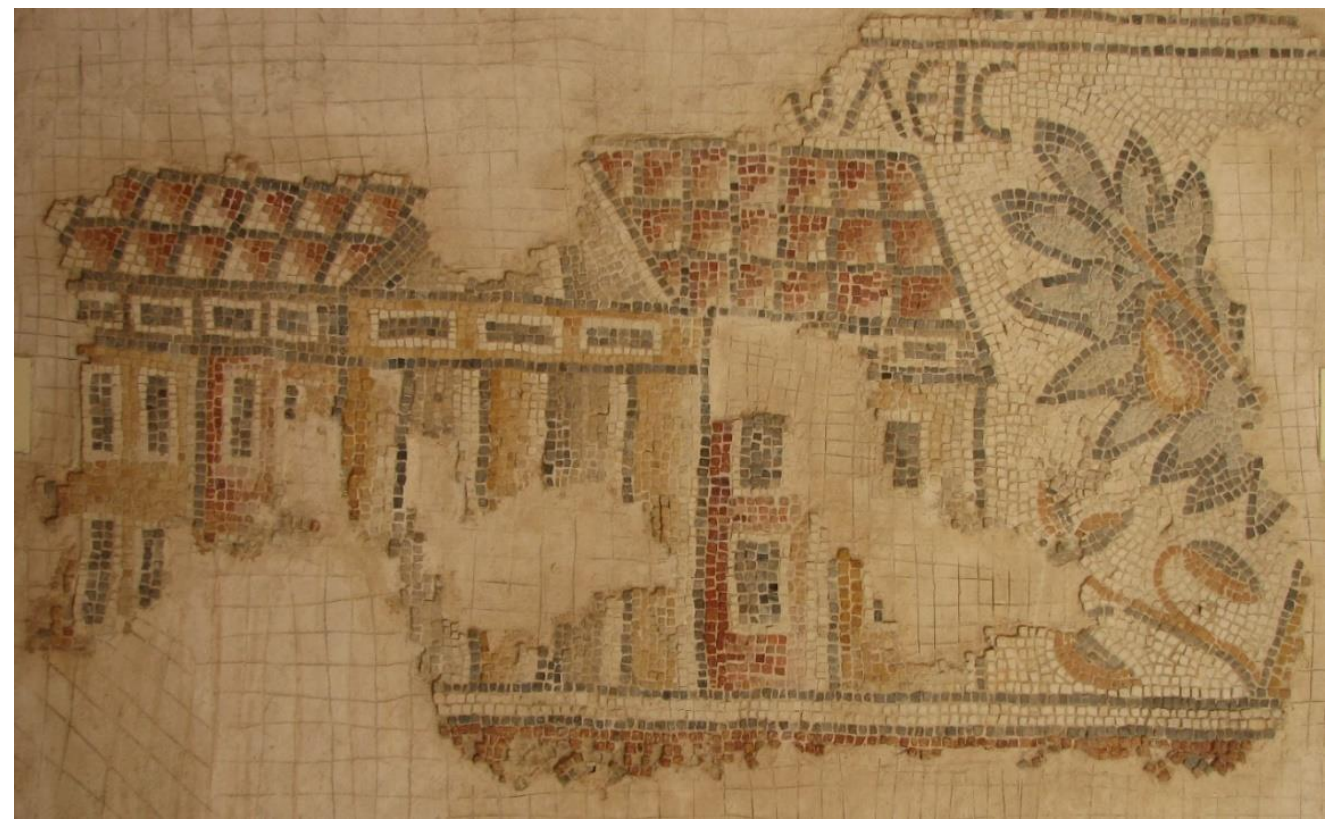

Figure 76: Depiction of Eleutheropolis (Beit Guvrin), Church of the Acropolis, Ma'in Author's Photograph.

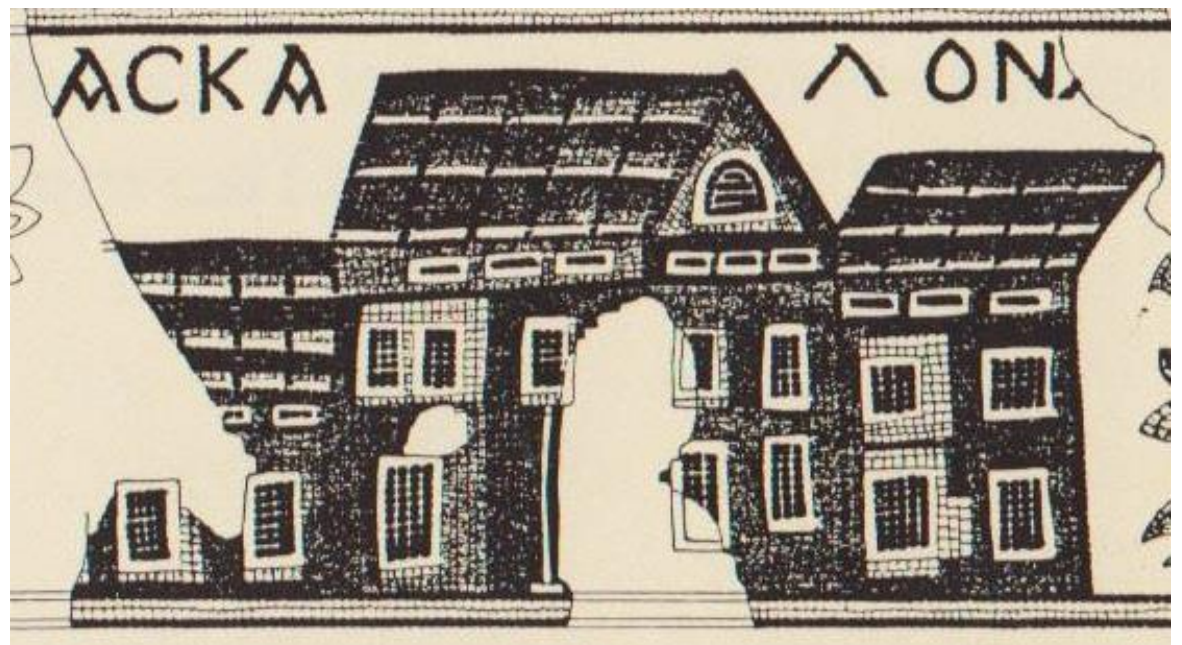

Figure 77: Drawing of the Depiction of Askalon (Ashkelon), Church of the Acropolis, Ma'in

Piccirillo, Mosaics of Jordan, 201. 


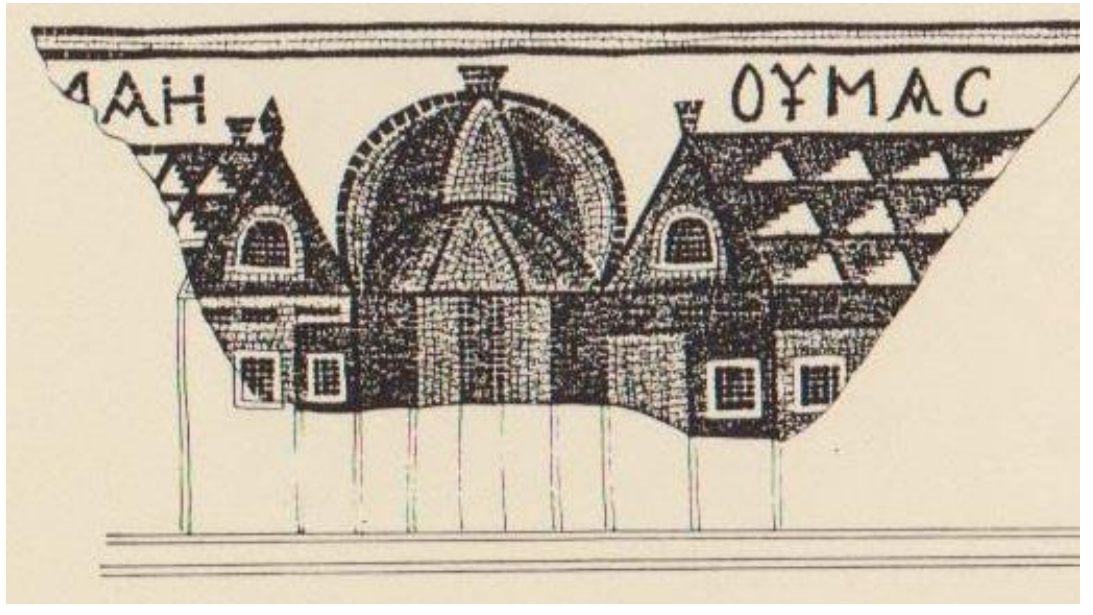

Figure 78: Drawing of the Depiction of Maiumas, Church of the Acropolis, Ma'in Piccirillo, Mosaics of Jordan, 201.

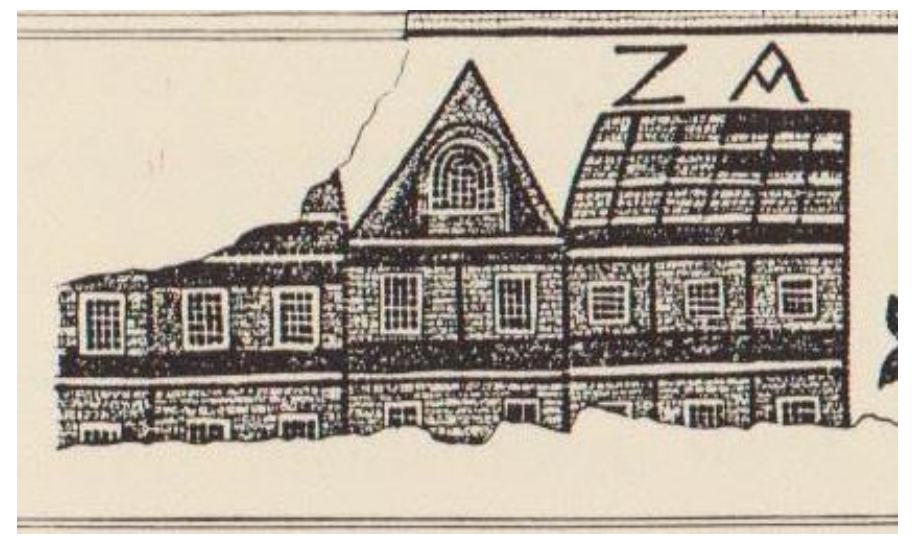

Figure 79: Drawing of the Depiction of Gaza, Church of the Acropolis, Ma'in Piccirillo, Mosaics of Jordan, 201. 


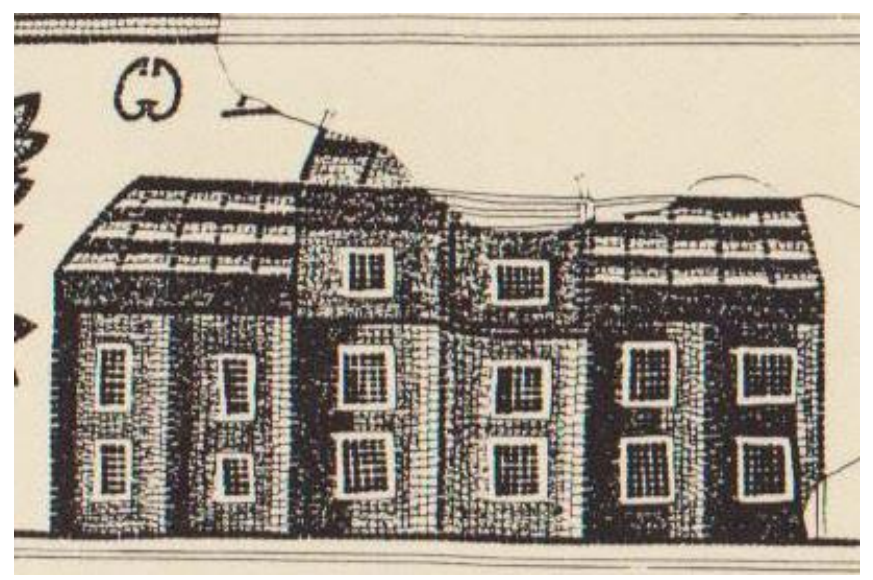

Figure 80: Drawing of the Depiction of Odra, Church of the Acropolis, Ma'in

Piccirillo, Mosaics of Jordan, 201.

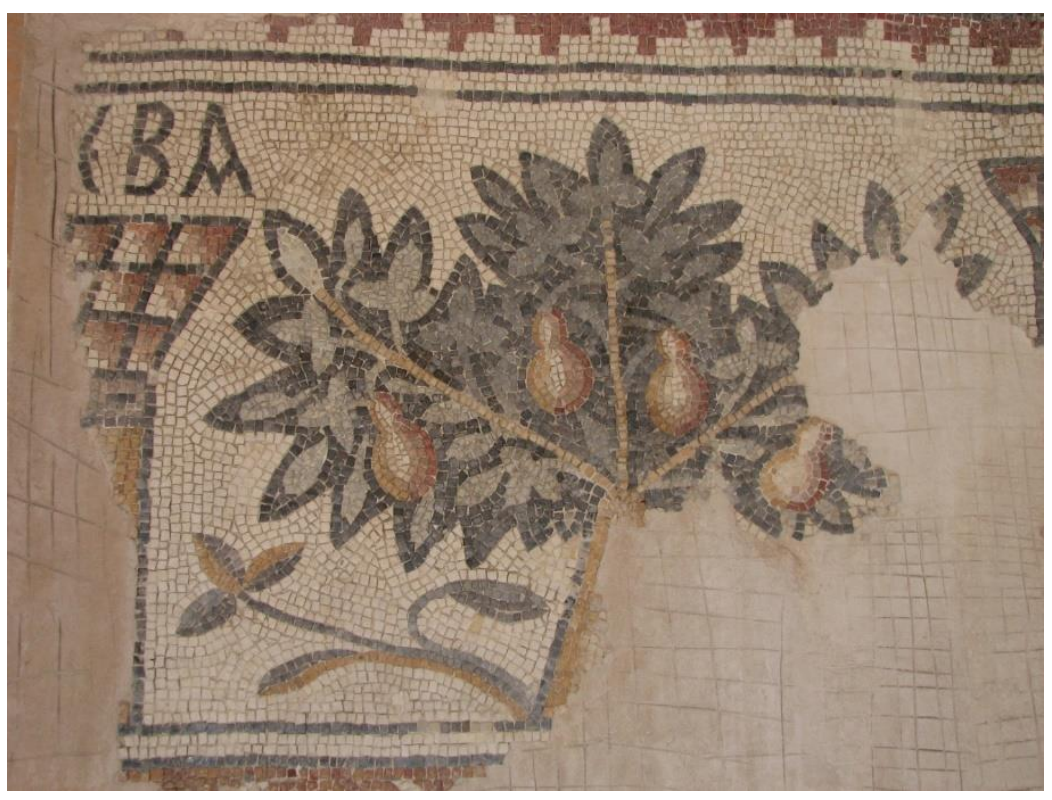

Figure 81: Depiction of Charach Moba (al-Karak), Church of the Acropolis, Ma'in Author's Photograph. 


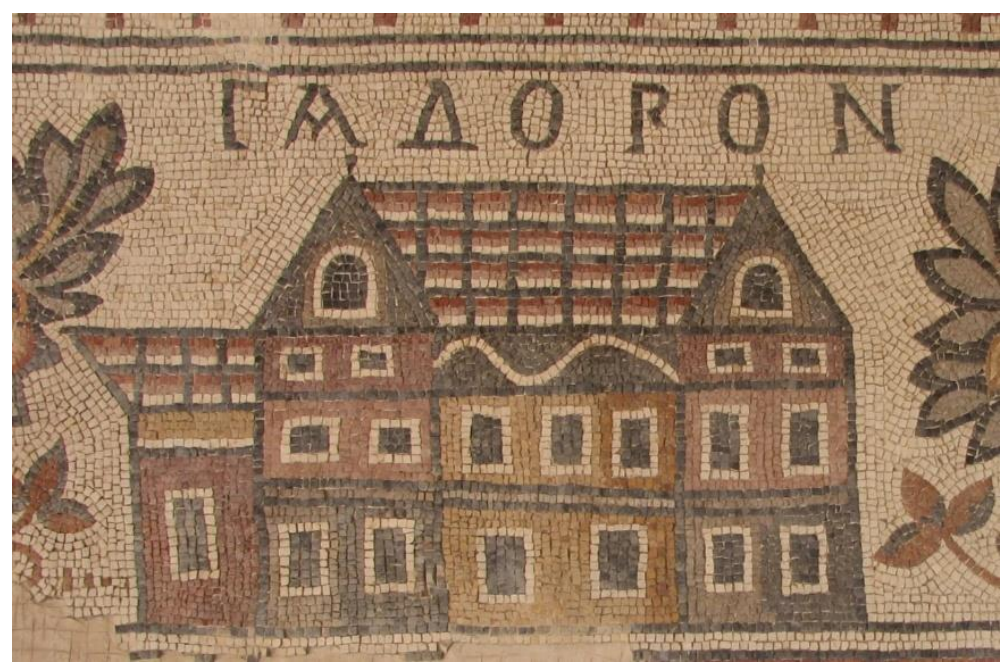

Figure 82: Depiction of Gadoron (Gadara or Gadora), Church of the Acropolis, Ma'in Author's Photograph.

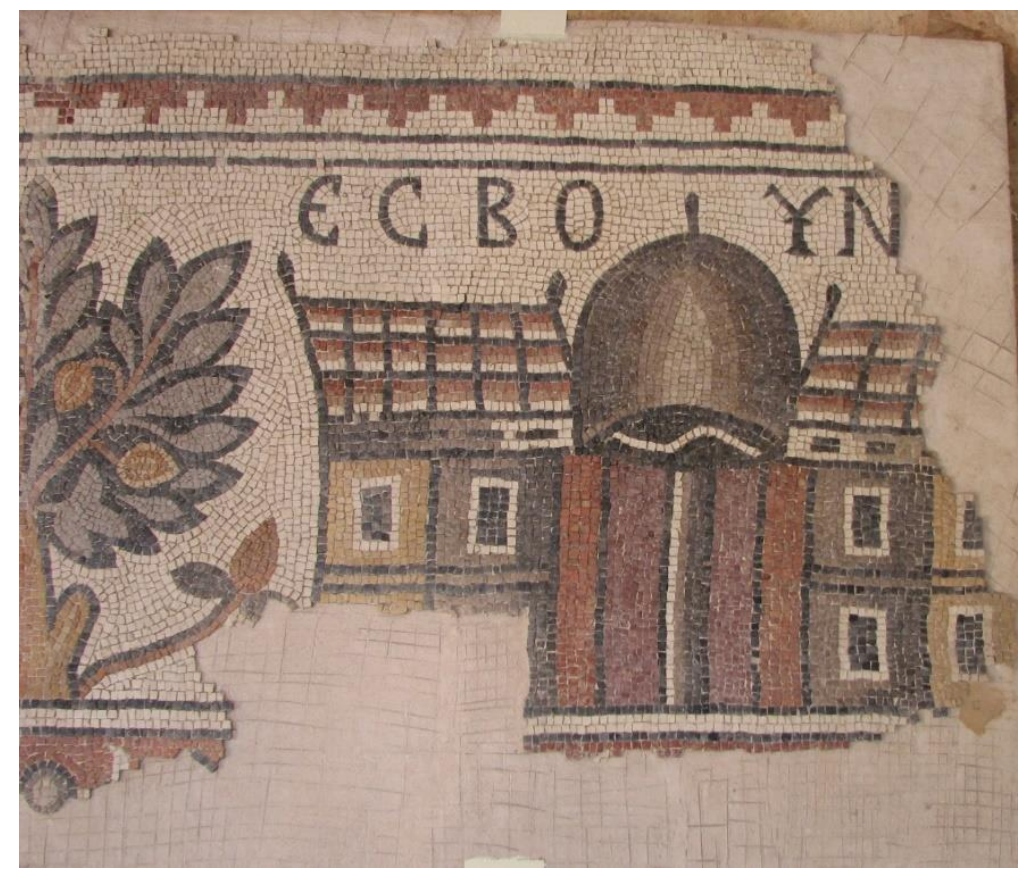

Figure 83: Depiction of Esbounta (Heshbon), Church of the Acropolis, Ma'in Author's Photograph. 


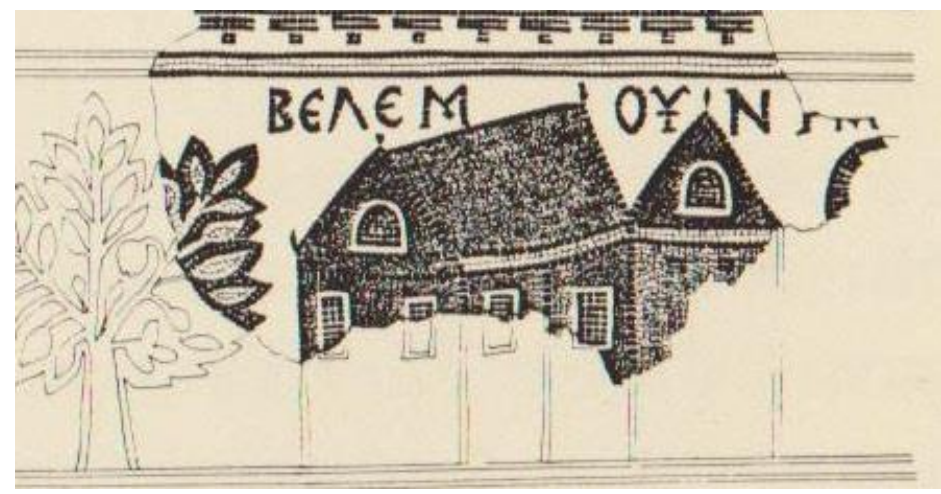

Figure 84: Drawing of the Depiction of Belemounta (Ma'in), Church of the Acropolis, Ma'in

Piccirillo, Mosaics of Jordan, 201.

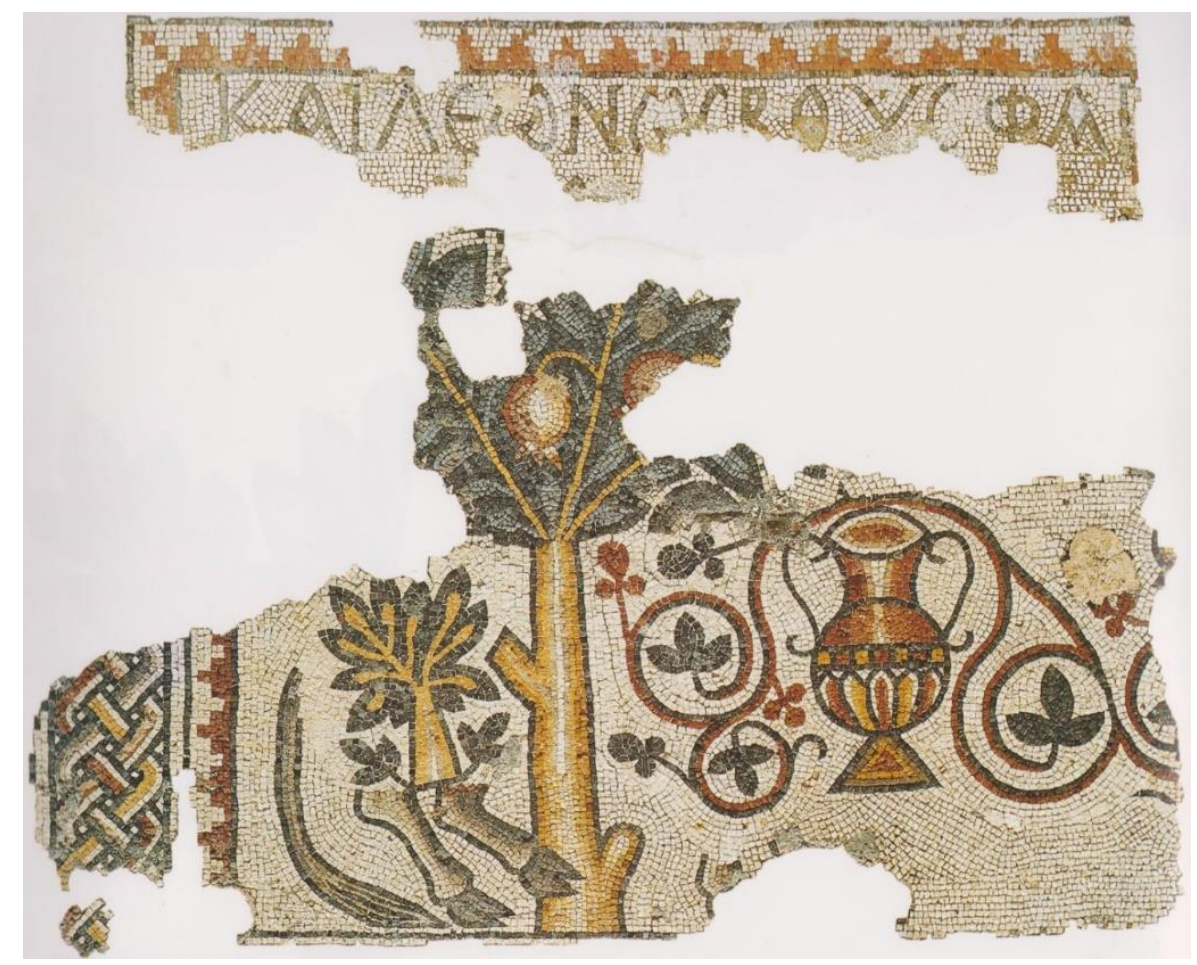

Figure 85: Side Chapel Mosaic with Iconoclastic Repair, Church of the Acropolis, Ma'in Piccirillo, Mosaics of Jordan, 198. 


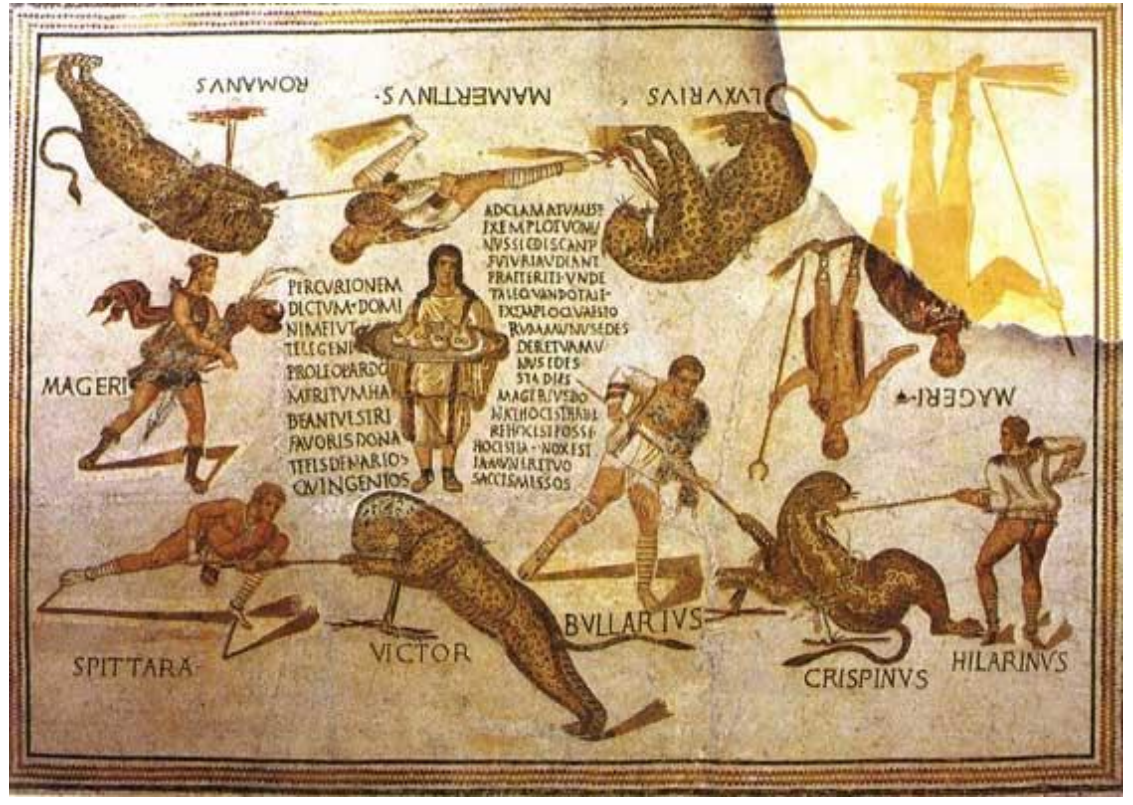

Figure 86: The Magerius Mosaic, El Djem (Smirat), Tunisia, Mid-third Century

M'hamed Hassine Fantar, et al, eds., La mosaïque en Tunisie (Paris: CNRS Editions, 1994), 159.

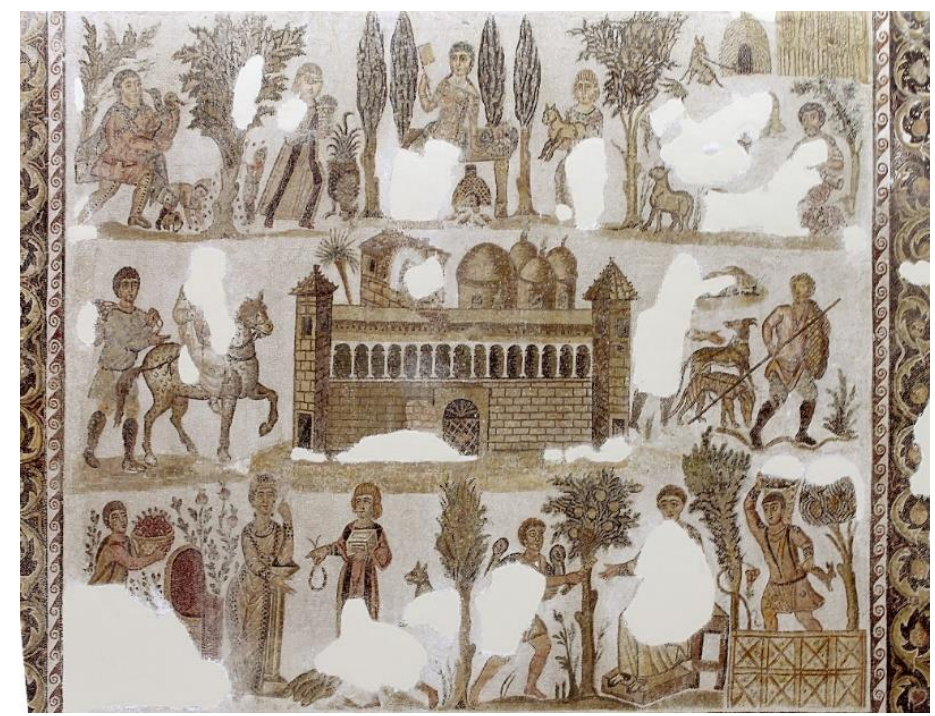

Figure 87: The Dominus Julius Mosaic, Carthage, Tunisia, Late-fourth Century

Aïcha Ben Abed, Tunisian Mosaics: Treasures from Roman Africa (Los Angeles: Getty Conservation Institute, 2006), 28. 


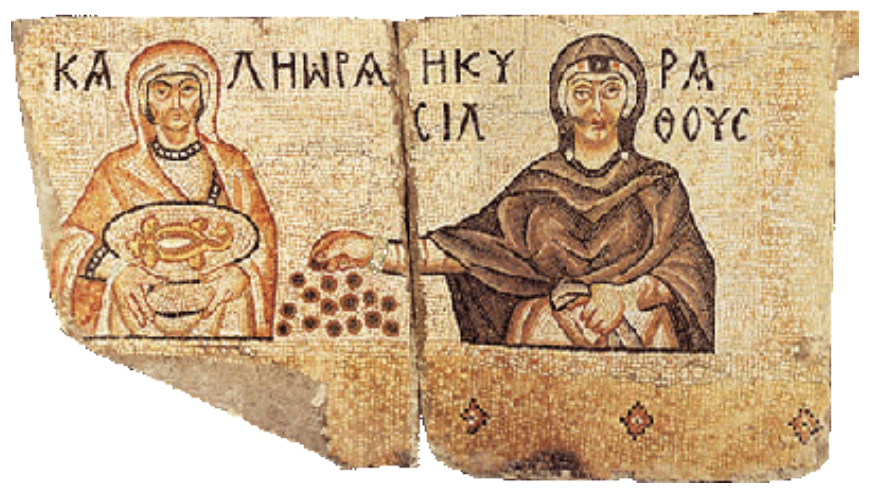

Figure 88: The Lady Silthous Mosaic, Church of St. Elias, Kissufim, Israel, Late-sixth Century

The Israel Museum, "The Cradle of Christianity: The Church Treasure," accessed February 10, 2016, http://www.imj.org.il/images/exhibitions/christinity/photplong.gif.

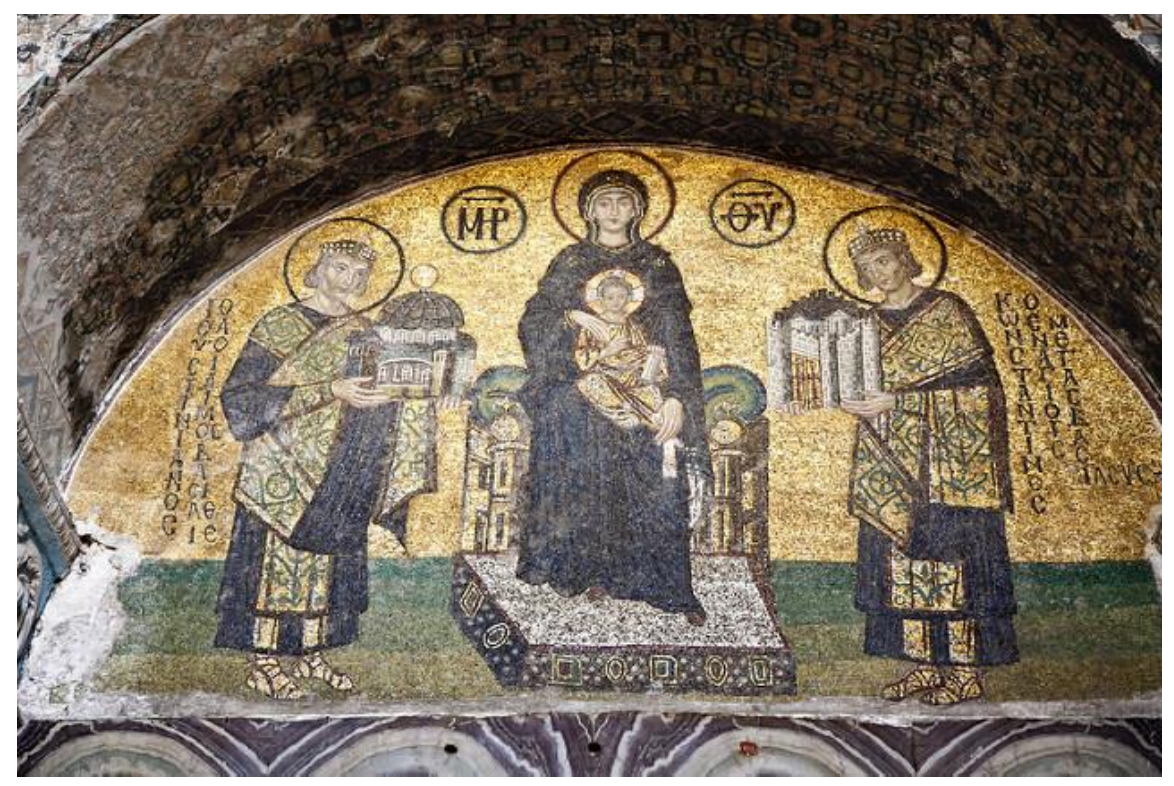

Figure 89: Justinian Presenting a Model of the Church and Constantine Presenting a Model of the City to the Theotokos and Child, Hagia Sophia, Istanbul, Turkey, Tenth Century

Author's Photograph. 


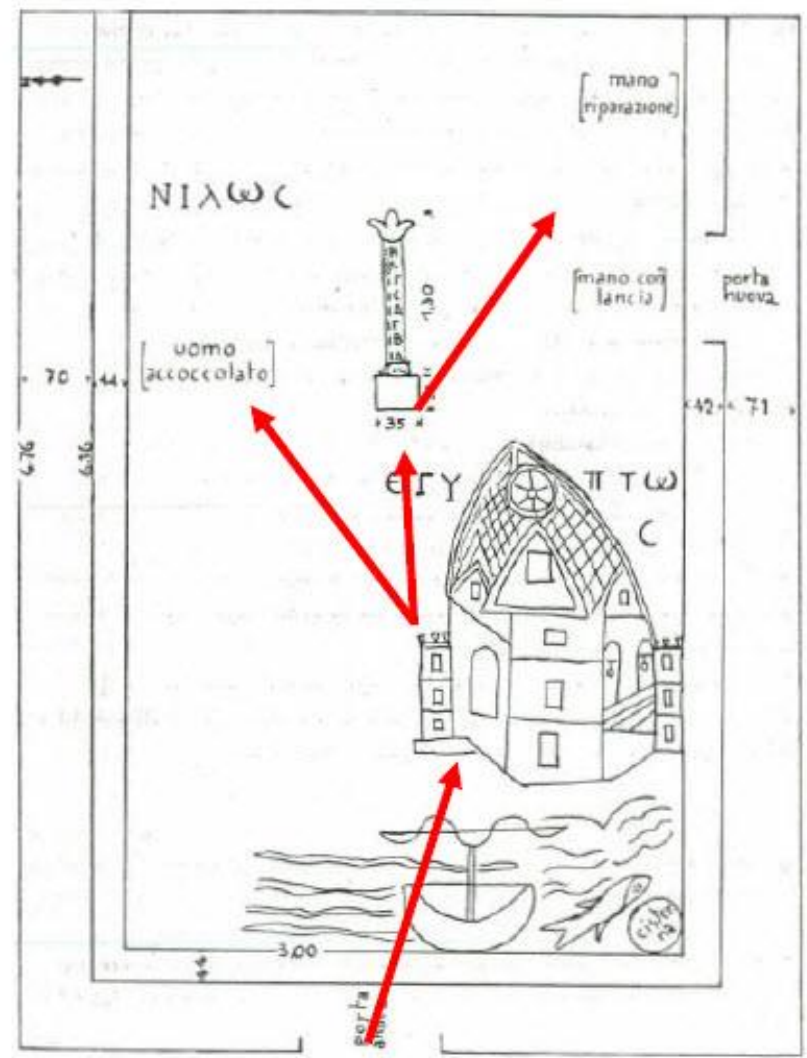

Figure 90: Viewing Patterns, Nave Mosaic, Umm al-Manabi“ Augustinović and Bagatti, "Escursioni," 287. Modified by the Author. 


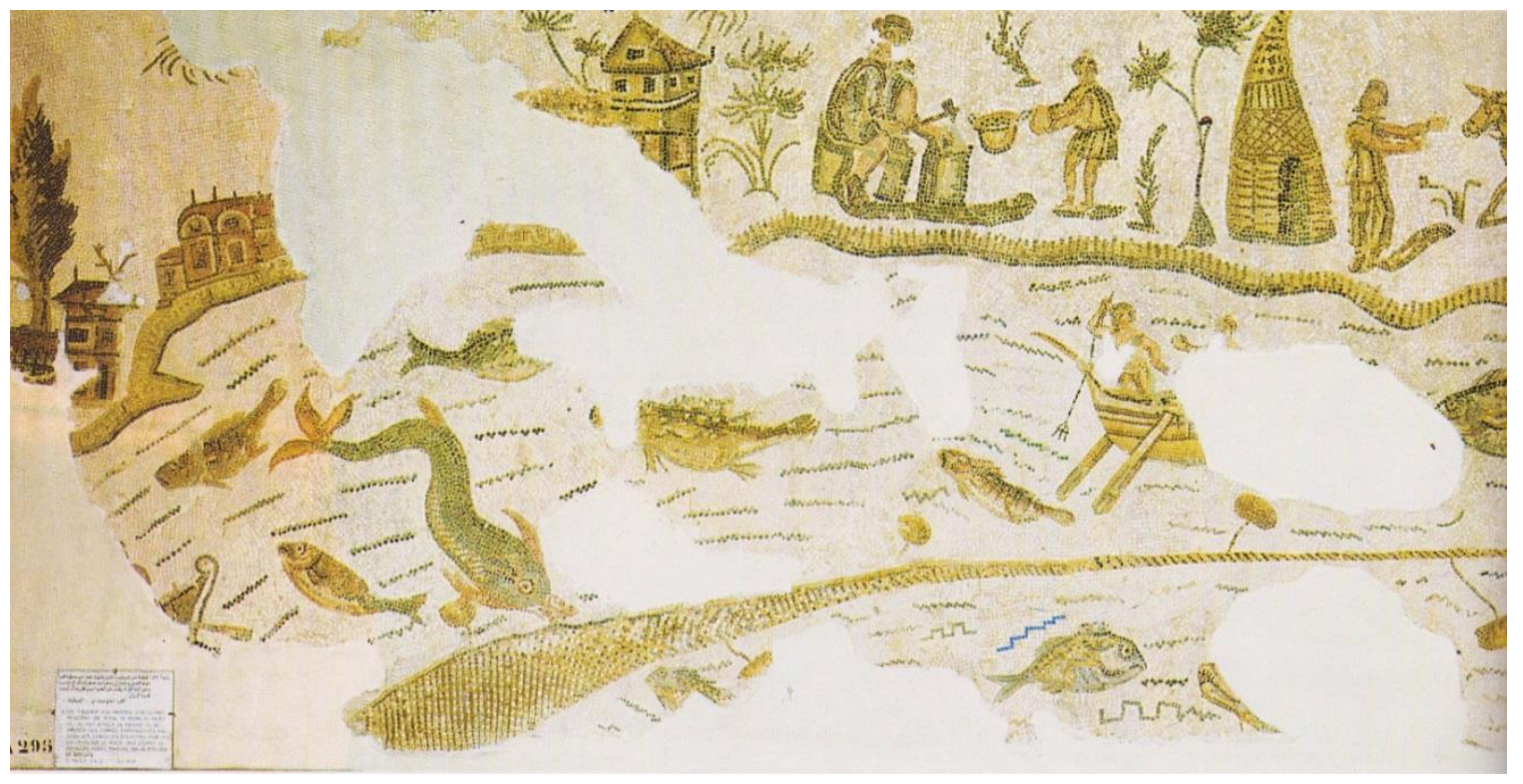

Figure 91: Nilotic Mosaic with Depictions of a Hut and a Country Villa, El Alia, Tunisia, Second Century

Fantar, La mosä̈que, 130.

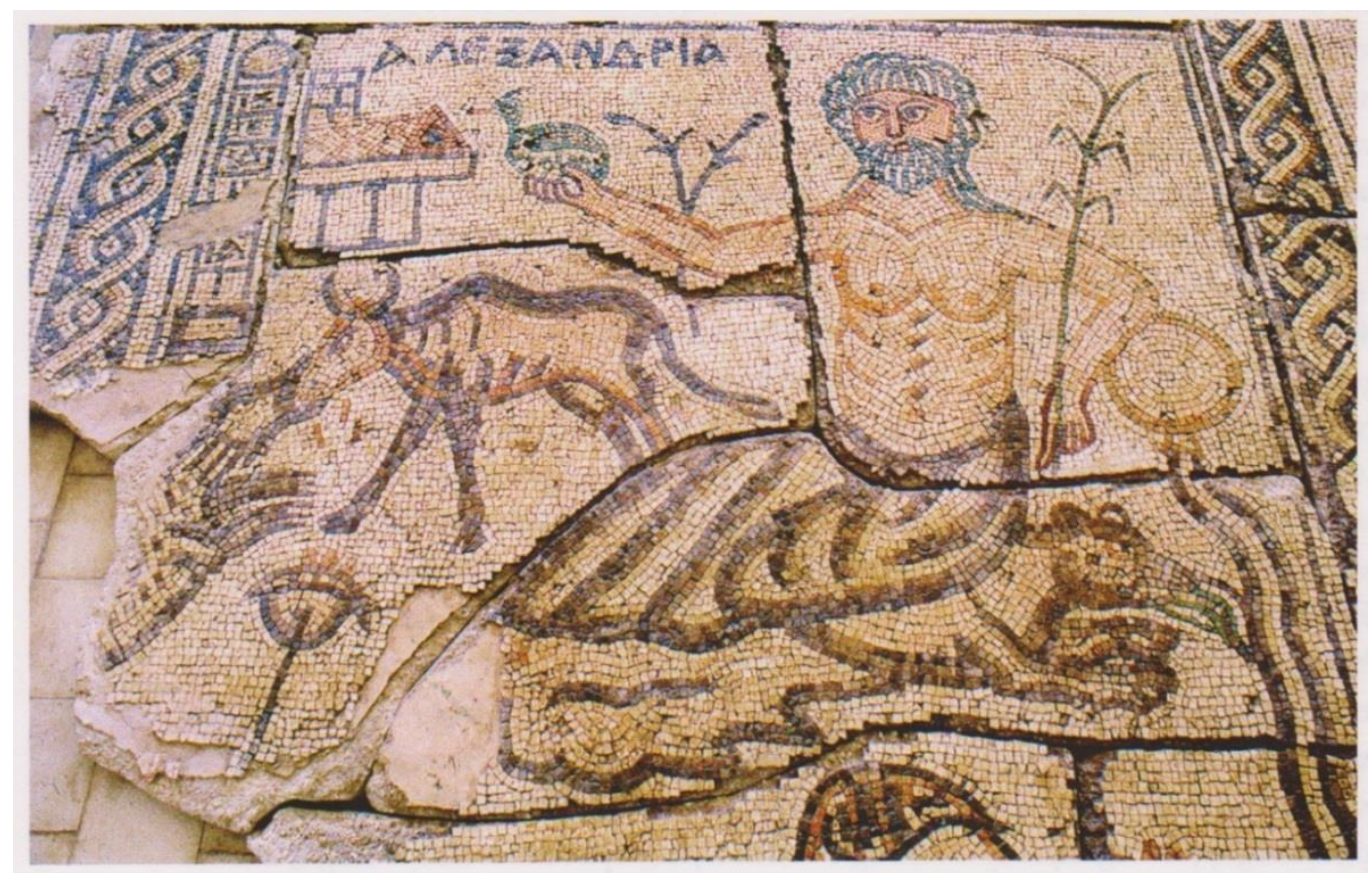

Figure 92: Nilotic Mosaic, House of Leontis, Beth She'an, Israel, Fifth Century

Rina Talgam, Mosaics of Faith: Floors of Pagans, Jews, Samaritans, Christians, and Muslims in the Holy Land (University Park, PA: Penn State University Press, 2014), 114. 


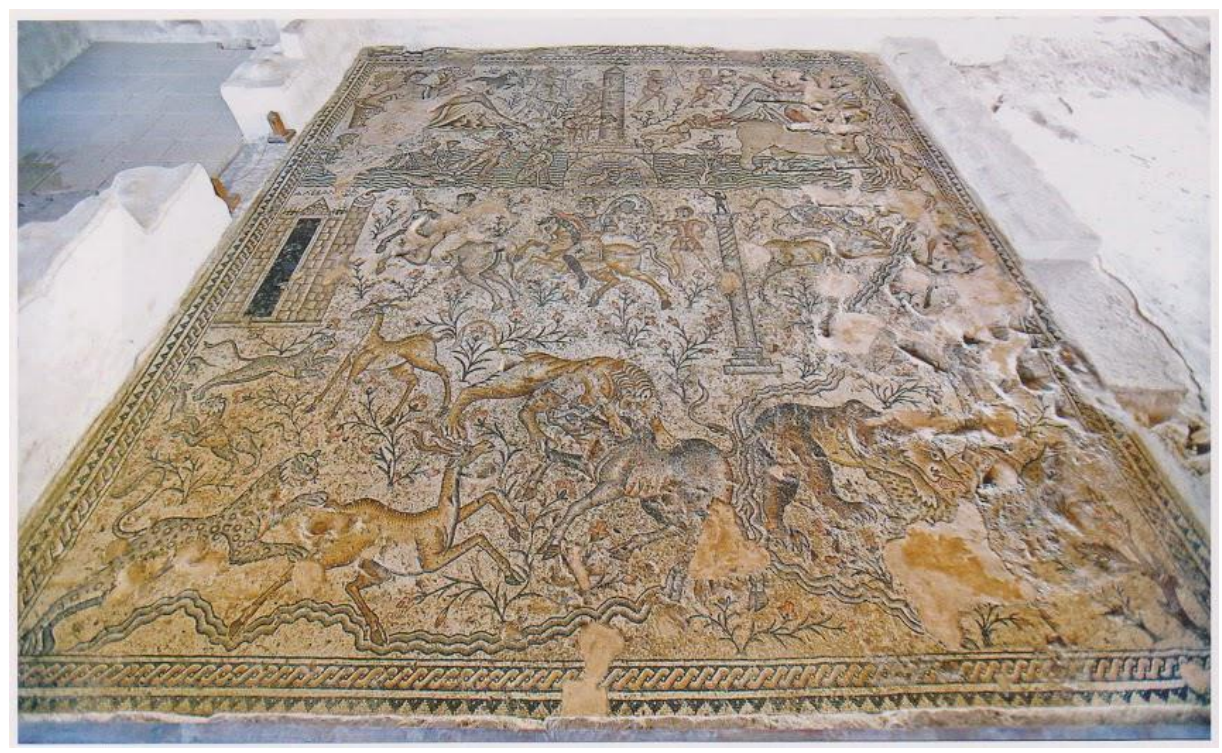

Figure 93a: Nilotic Mosaic, The Nile Festival Building, Sepphoris, Israel, Early Fifth Century

Talgam, Mosaics of Faith, 114.

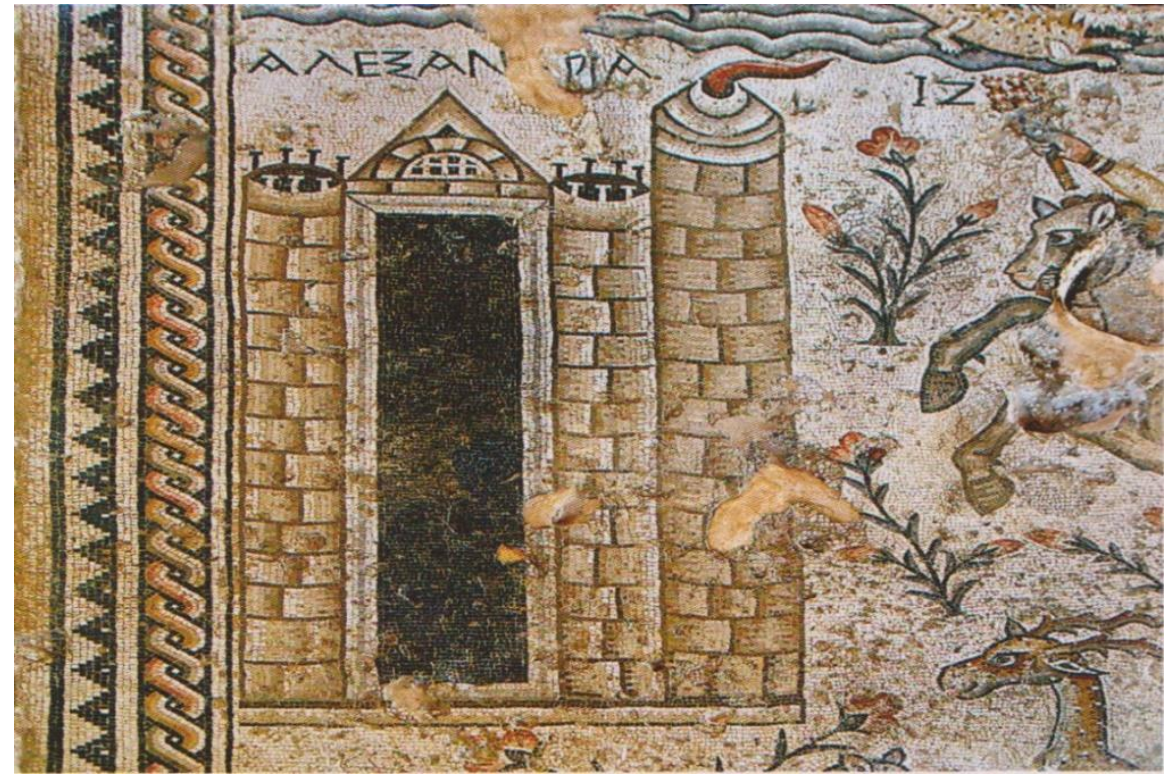

Figure 93b: Depiction of Alexandria, Nilotic Mosaic, The Nile Festival Building, Sepphoris

Talgam, Mosaics of Faith, 359. 


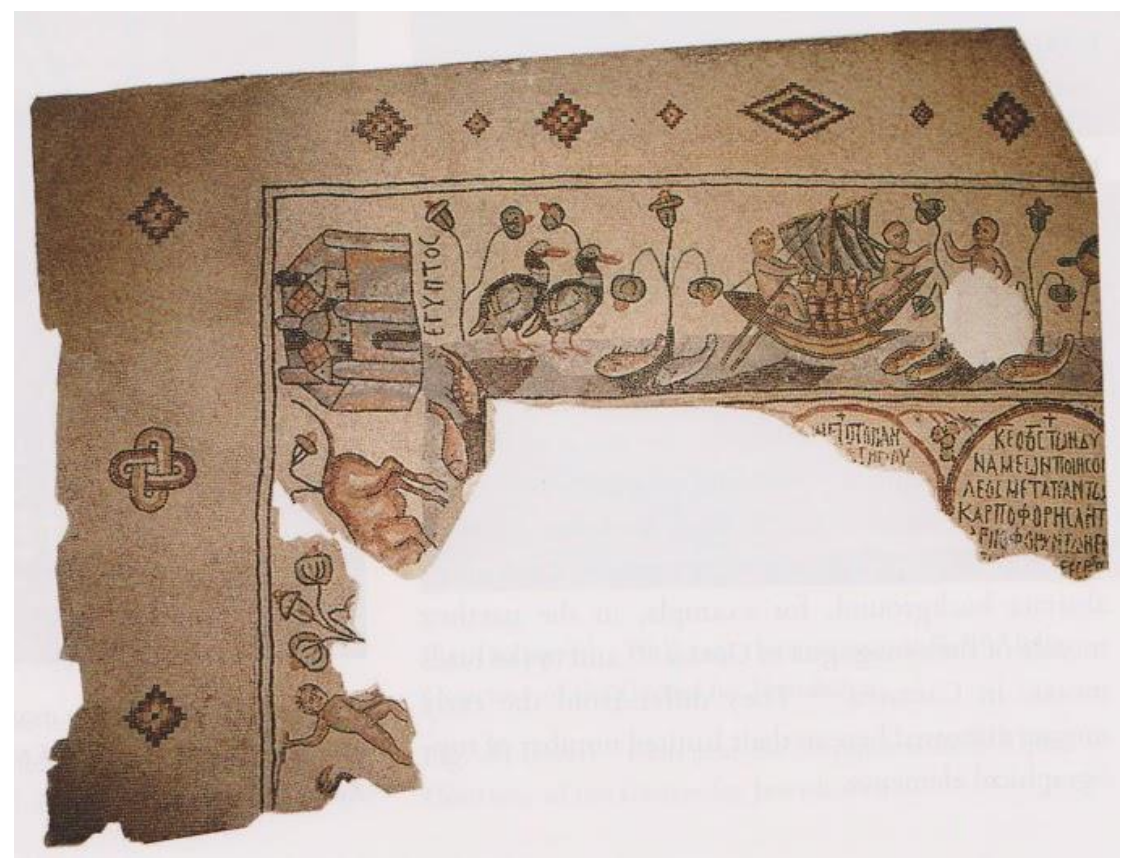

Figure 94a: Nilotic Border, Haditha Chapel, Haditha, Israel, Second Half of the Sixth Century

Talgam, Mosaics of Faith, 125.

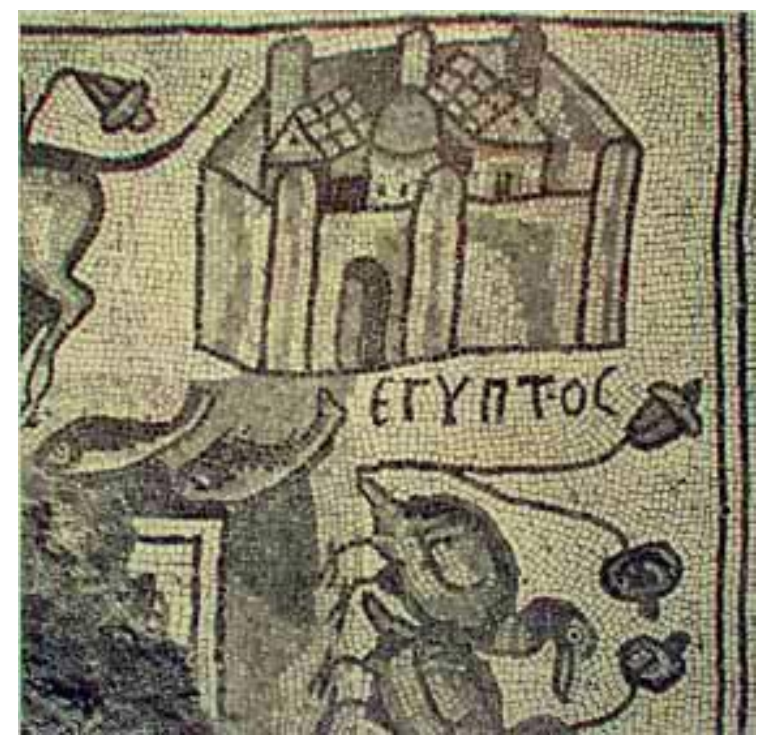

Figure 94b: Depiction of Egypt, Nilotic Border, Haditha Chapel

Franciscan Archaeological Institute, The Madaba Mosaic Map, "The Mountain of Judah and the Shephelah: Adiathim," accessed February 1, 2016, http://www.christusrex.org/www1/ofm/mad/discussion/065discuss.html. 


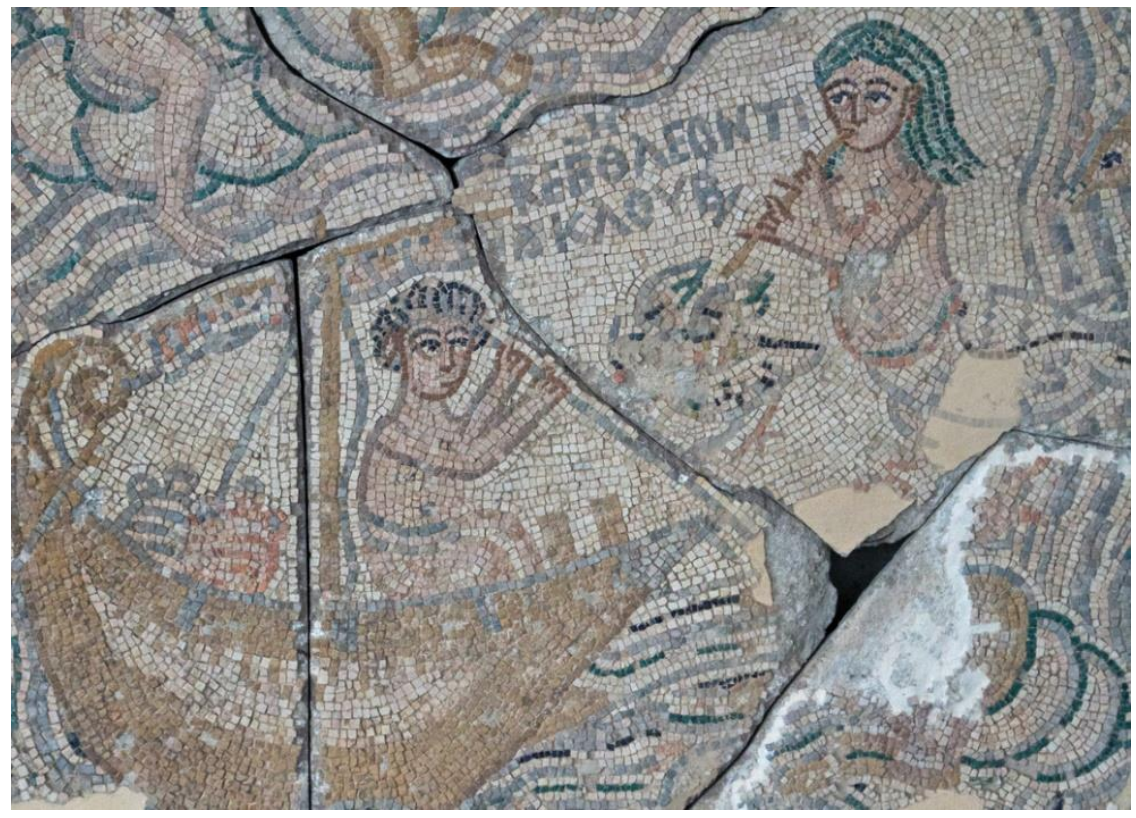

Figure 95: Odysseus Mosaic, House of Leontis, Beth She'an, Israel, Fifth Century Talgam, Mosaics of Faith, 377.

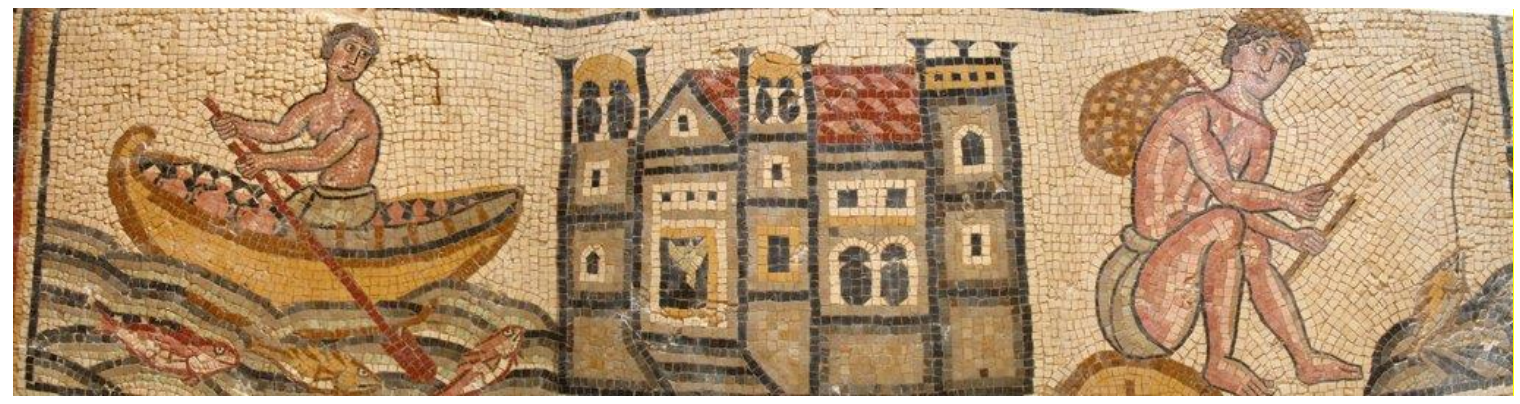

Figure 96: Intercolumnar Panel, Church of Sts. Lot and Procopios, Khirbat al-Mukhayyat, Jordan, Mid-sixth Century

Author's Photograph. 


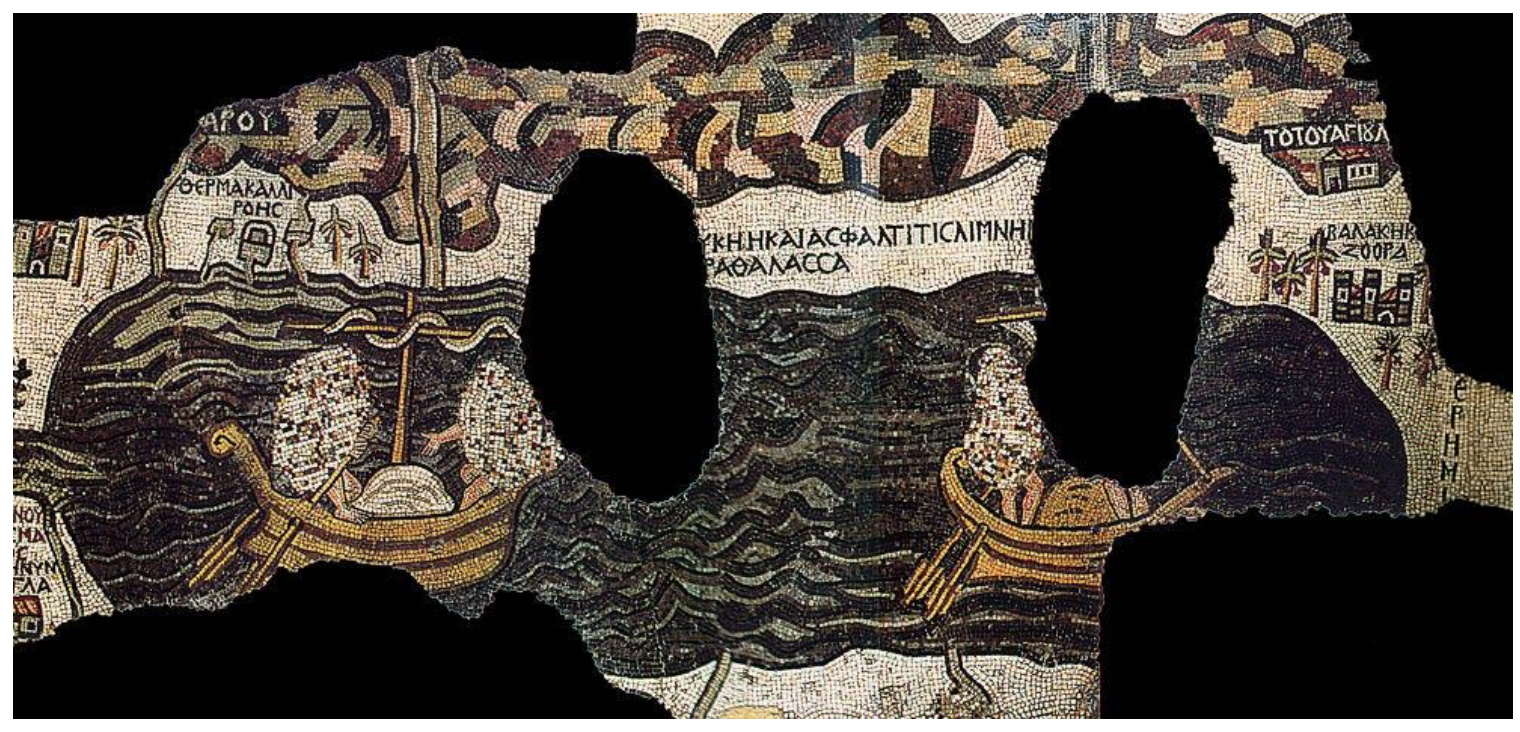

Figure 97: Depiction of Salt and Bitumen Harvesting on the Dead Sea, Madaba Mosaic, Mid-sixth Century

Franciscan Archaeological Institute, The Madaba Mosaic Map, "The Dead Sea," accessed February 1, 2016, http://www.christusrex.org/www1/ofm/mad/sections/section3.html. 


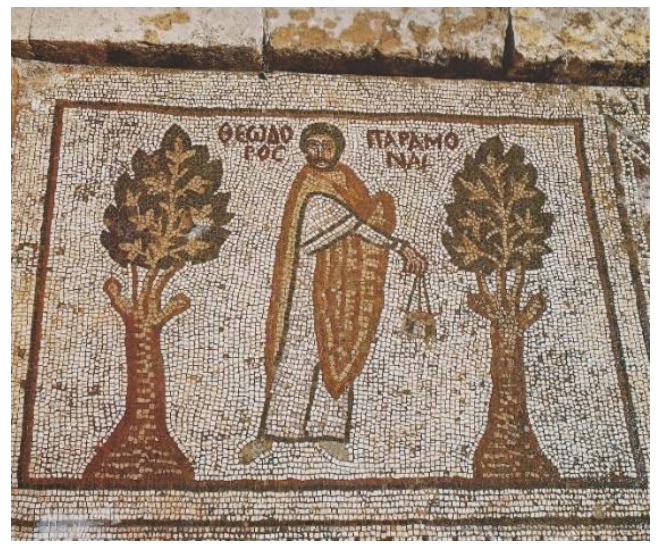

Figure 98: Patron Portrait of Theodore, Church of Sts. Cosmas and Damian, Jerash Author's Photograph.

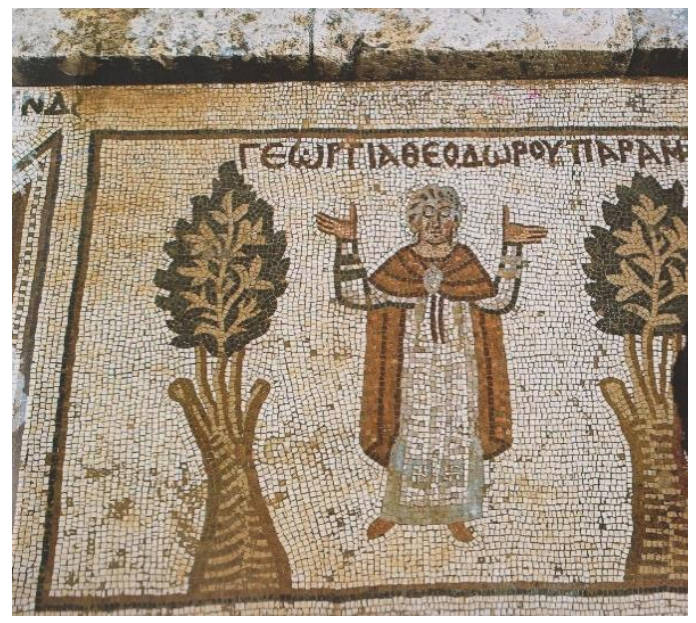

Figure 99: Patron Portrait of Georgina, Church of Sts. Cosmas and Damian, Jerash Author's Photograph. 


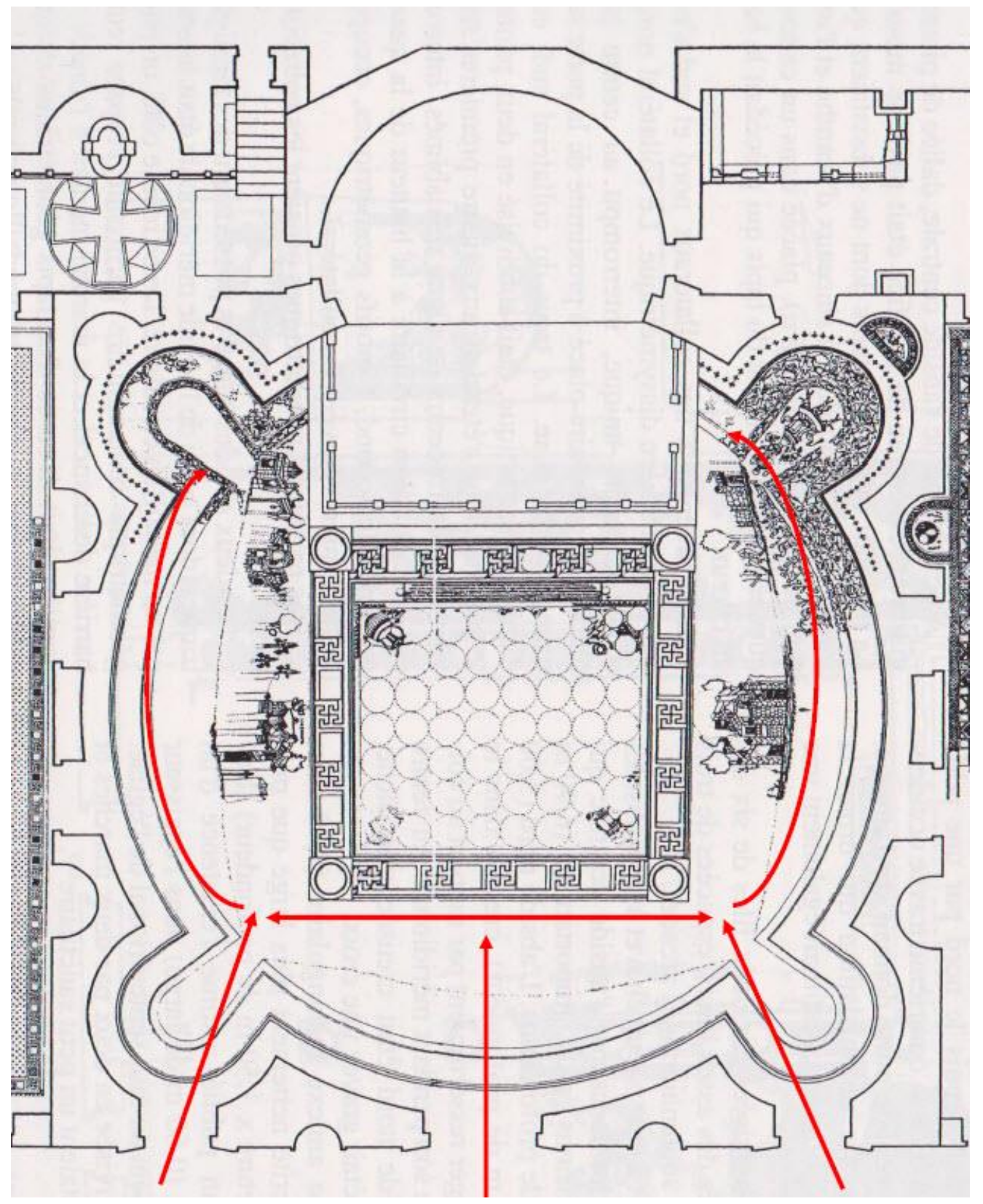

Figure 100: Patterns of Movement/Vision, Central Mosaic, St. John the Baptist, Jerash Michel, Les églises 244. Modified by the Author. 


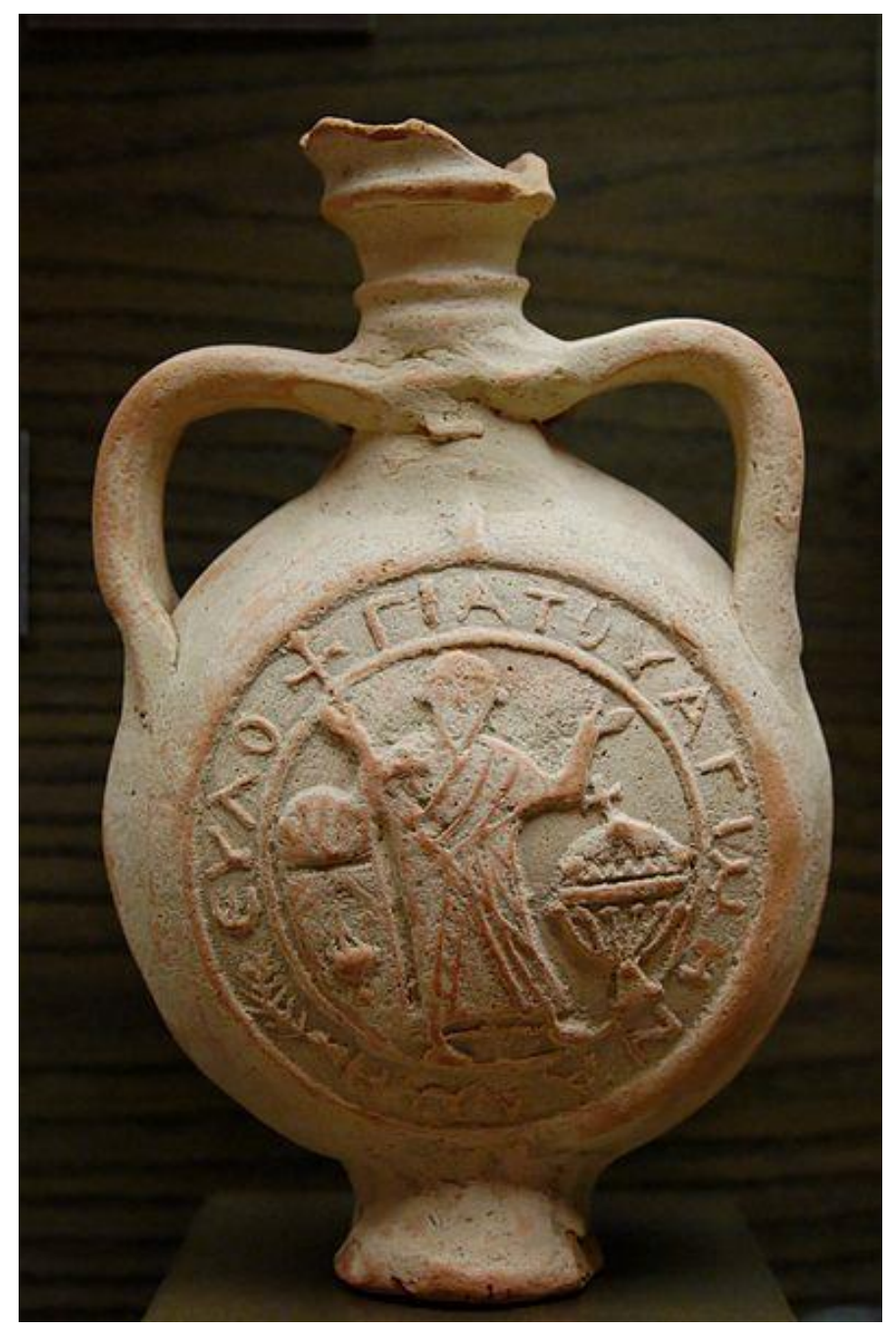

Figure 101: Pilgrim Ampulla with a Lamp over a Shrine, St. Menas, and a Censer, Abu Mena, Egypt (Louvre Museum, MNC 1926)

Louvre Museum, “Ampoule à eulogie: saint Ménas et sainte Thècle," accessed February 22, 2016, http://cartelen.louvre.fr/cartelen/visite?srv=car_not_frame\&idNotice=20735. 


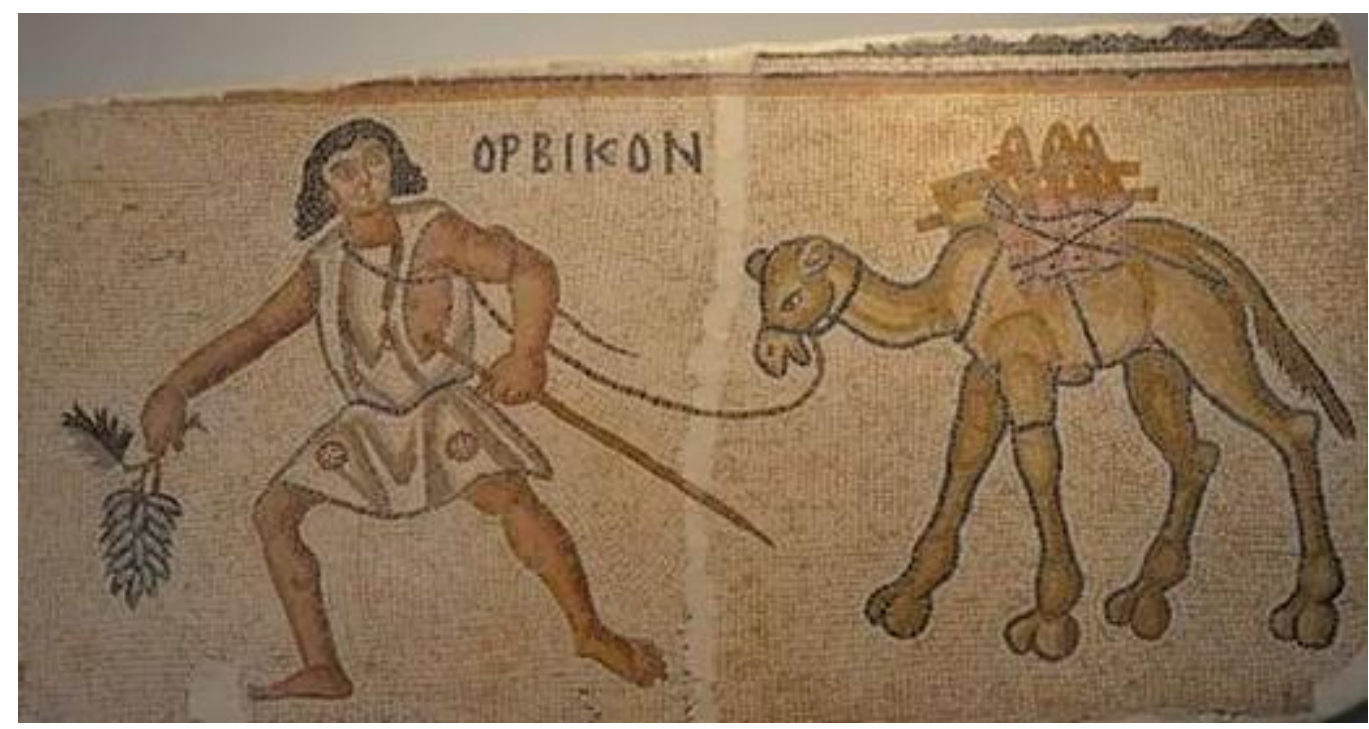

Figure 102: Intercolumnar Panel Featuring Orbikon, Church of St. Elias, Kissufim, Israel, 576

Talgam, Mosaics of Faith, 154.

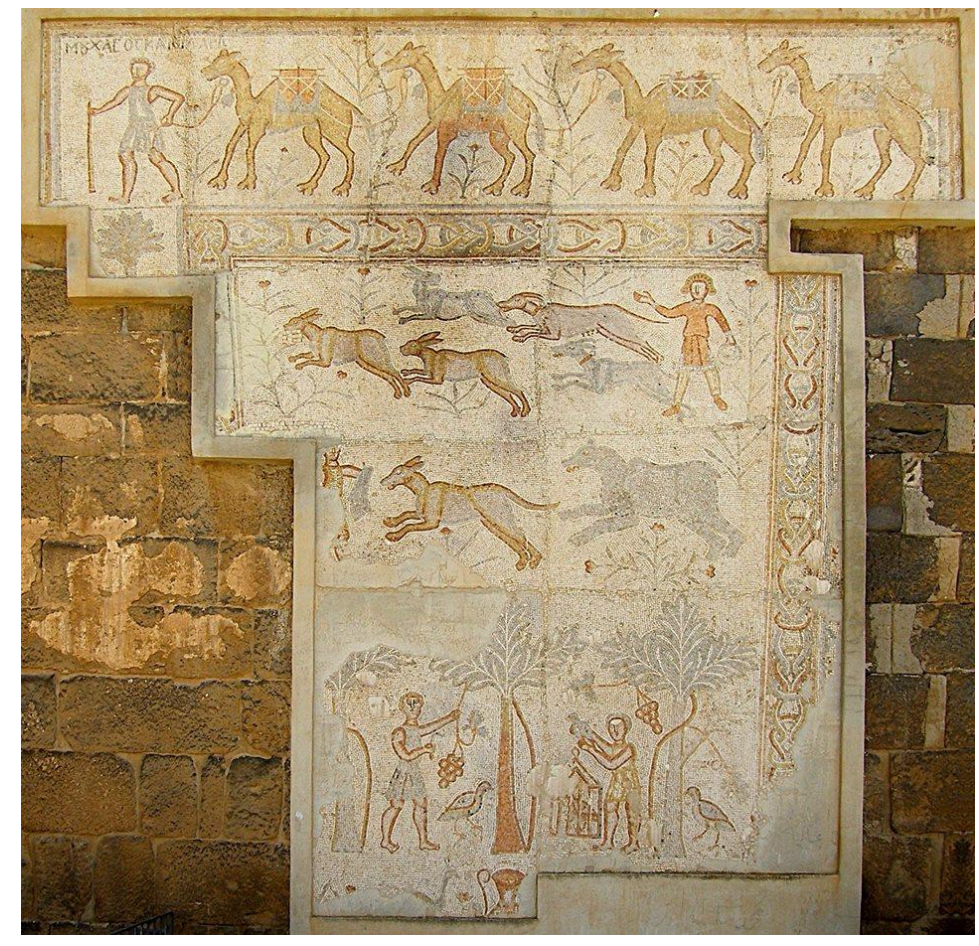

Figure 103: Nave Pavement with Image of a Camel-Driver, Church of St. George, Deir el-Ádas, Syria, 722

Donceel- Voûte, Les pavements, 52. 


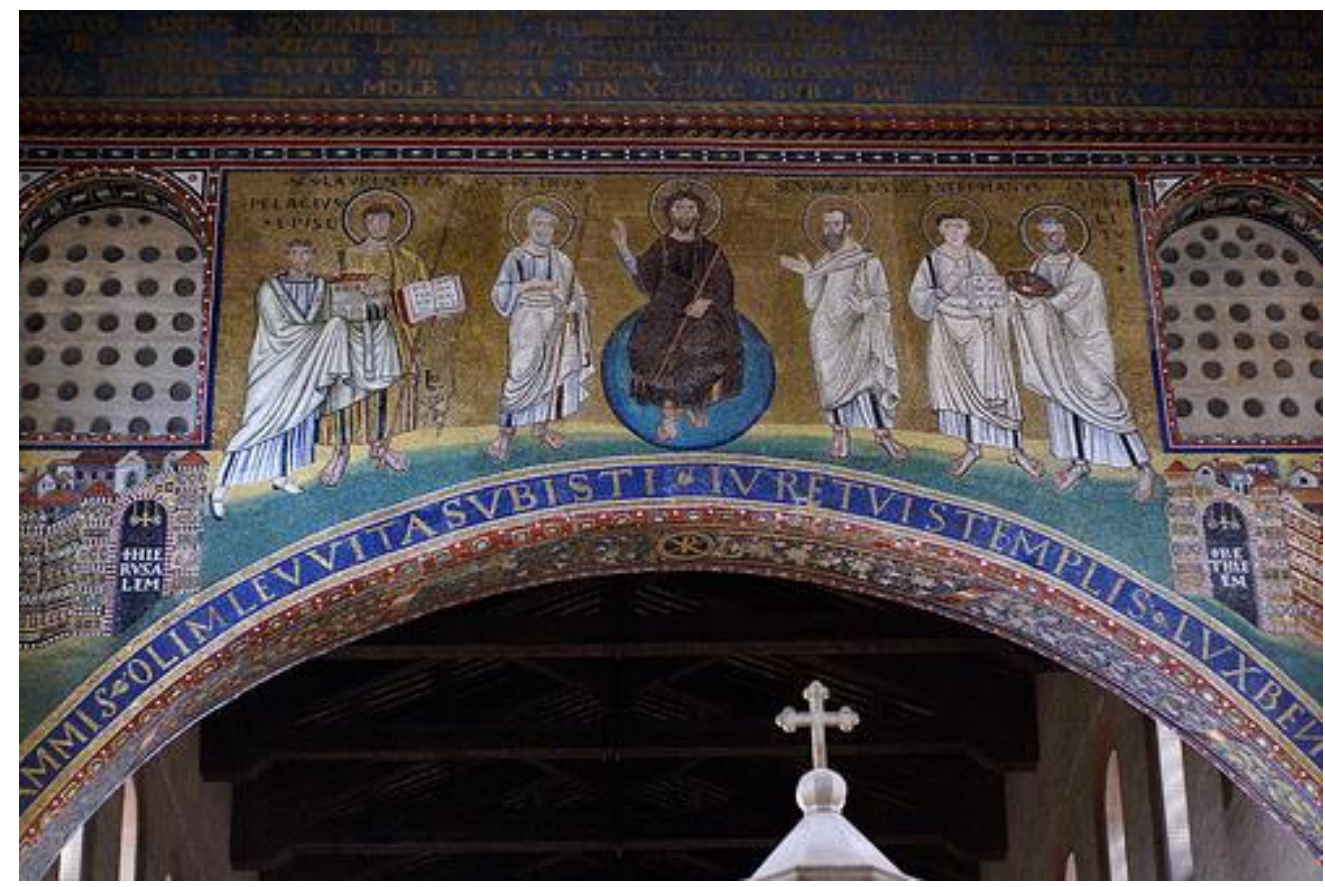

Figure 104: Image of Pope Pelagius II Presenting a Model of the Church to Christ, San Lorenzo fuori la mura, Rome, Sixth Century

Author's Photograph. 


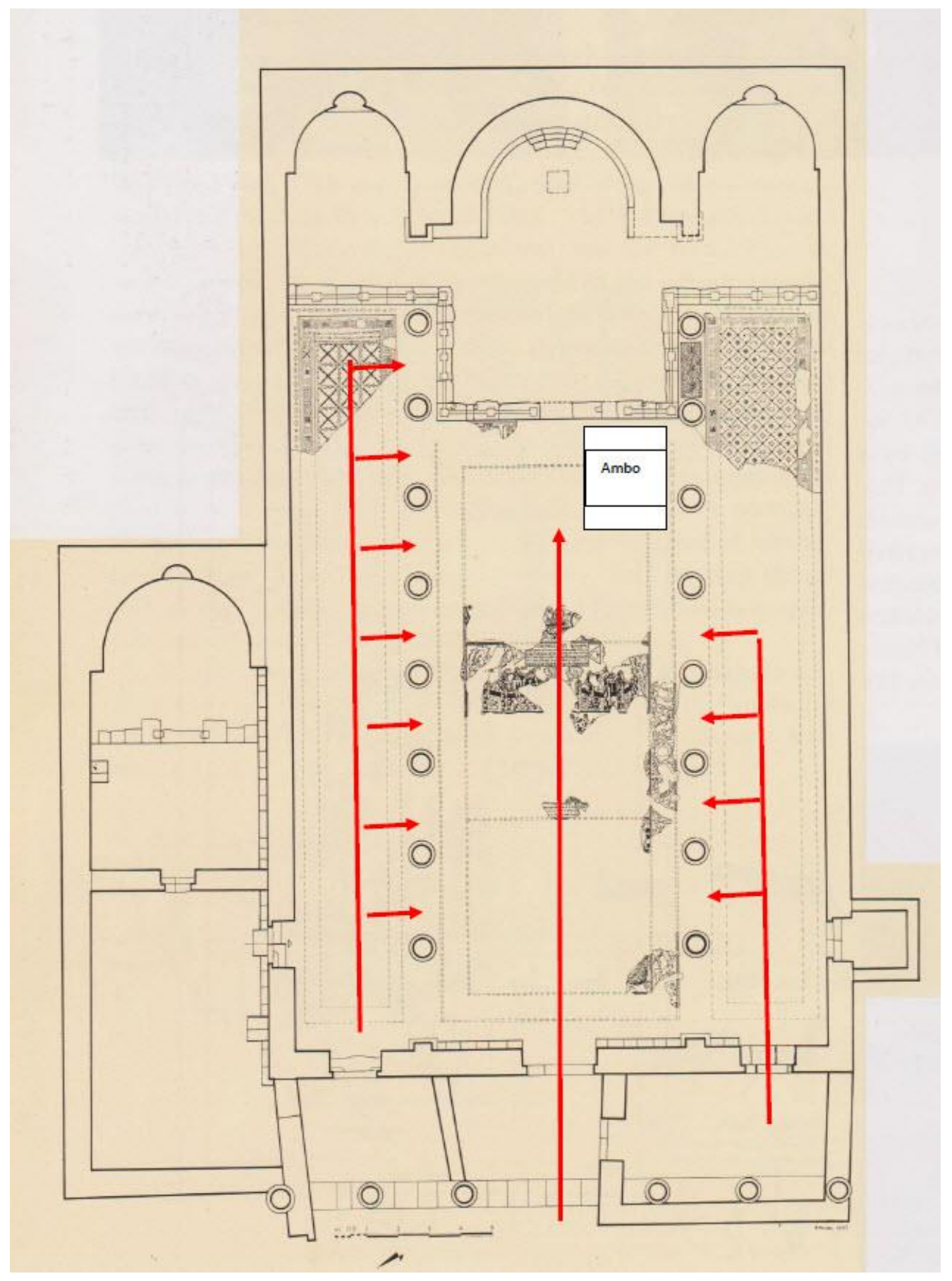

Figure 105: Patterns of Movement/Vision, Church of Sts. Peter and Paul, Jerash

Piccirillo, Mosaics of Jordan, 292. Modified by the Author. 


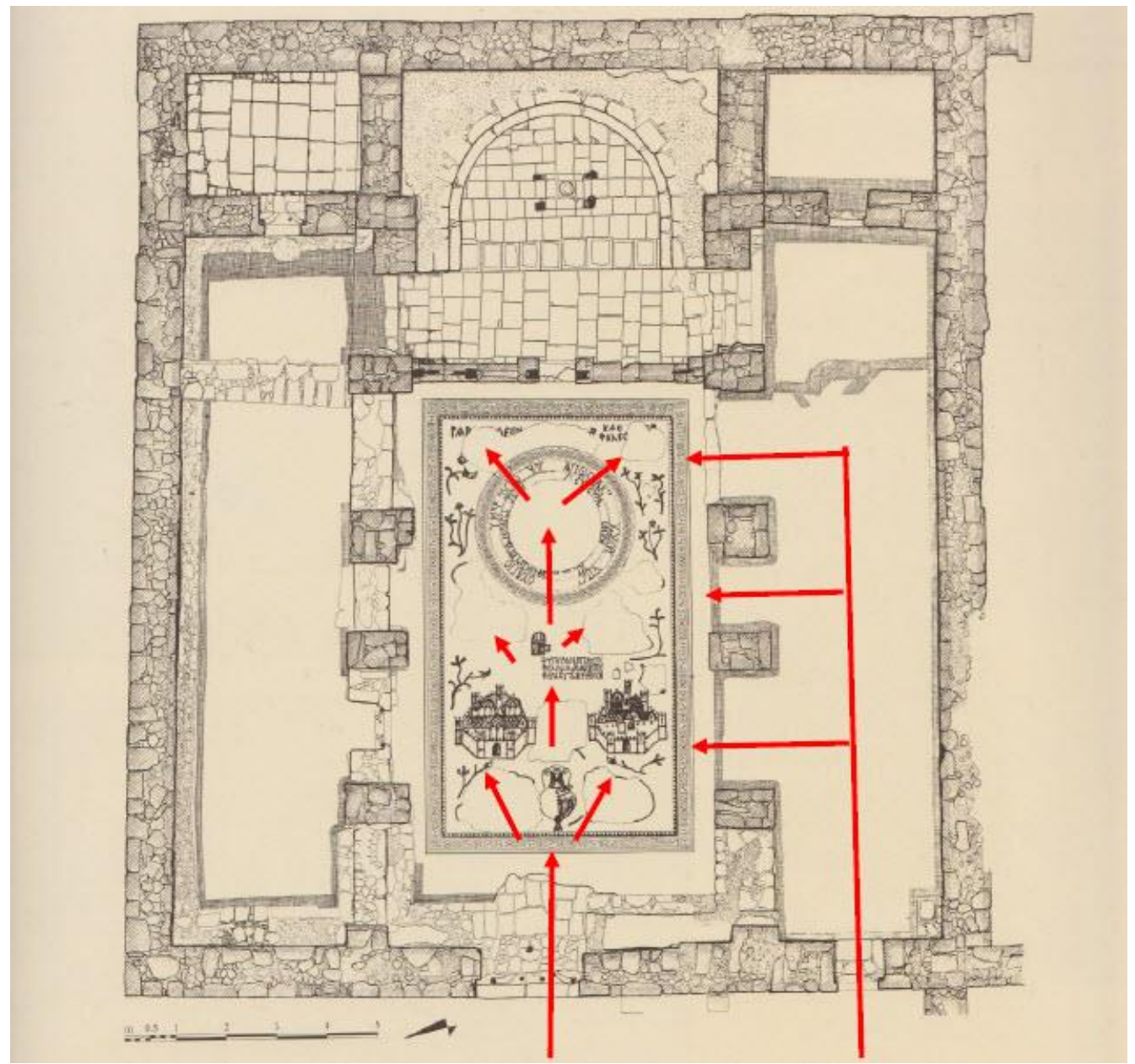

Figure 106: Patterns of Movement/Vision, Church of St. John, Khirbat al-Samra

Piccirillo, Mosaics of Jordan, 05. Modified by the Author. 


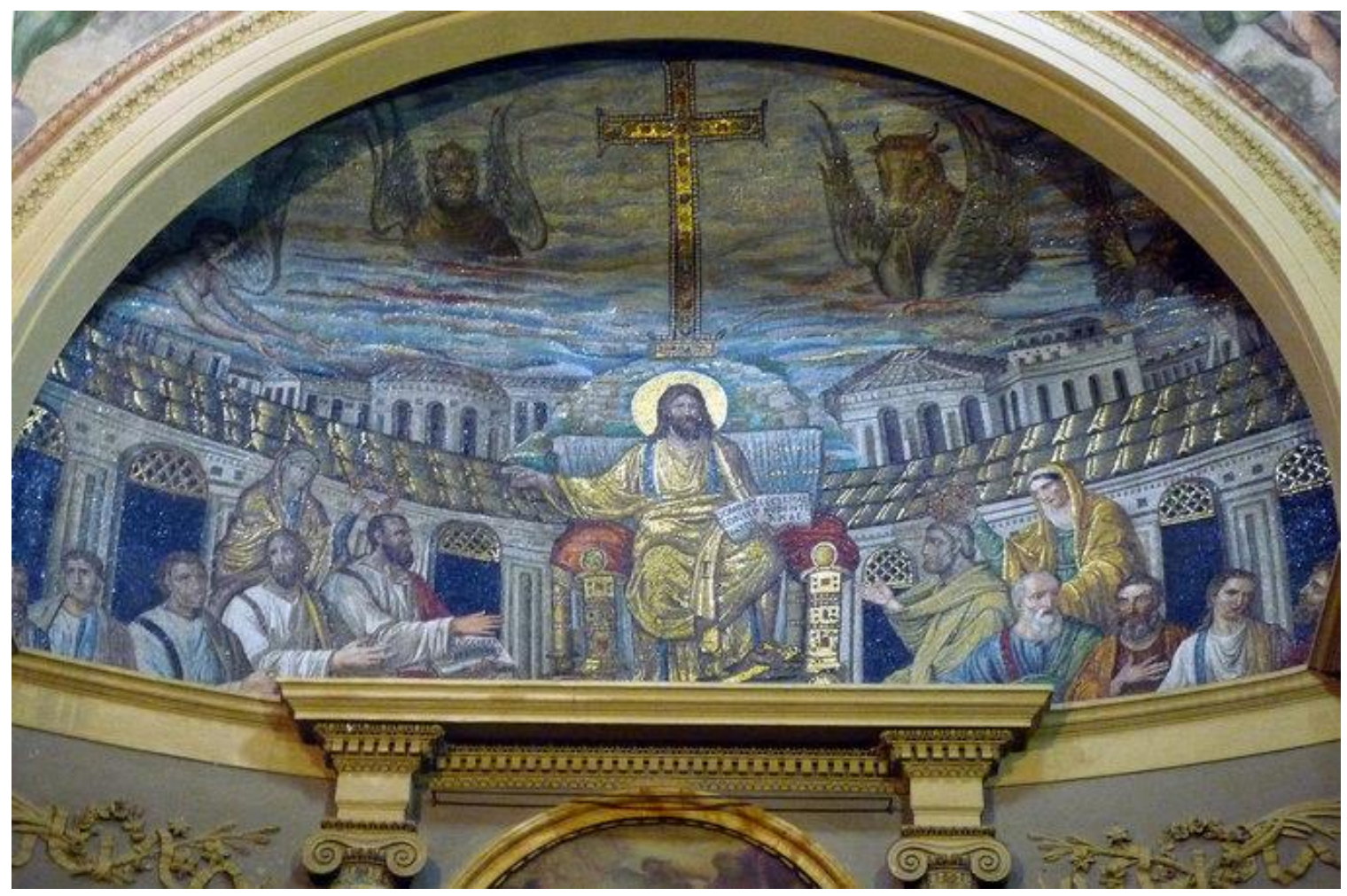

Figure 107: Heavenly Jerusalem, Apse Mosaic, Santa Pudenziana, Rome, Late Fourth Century

Author's Photograph.

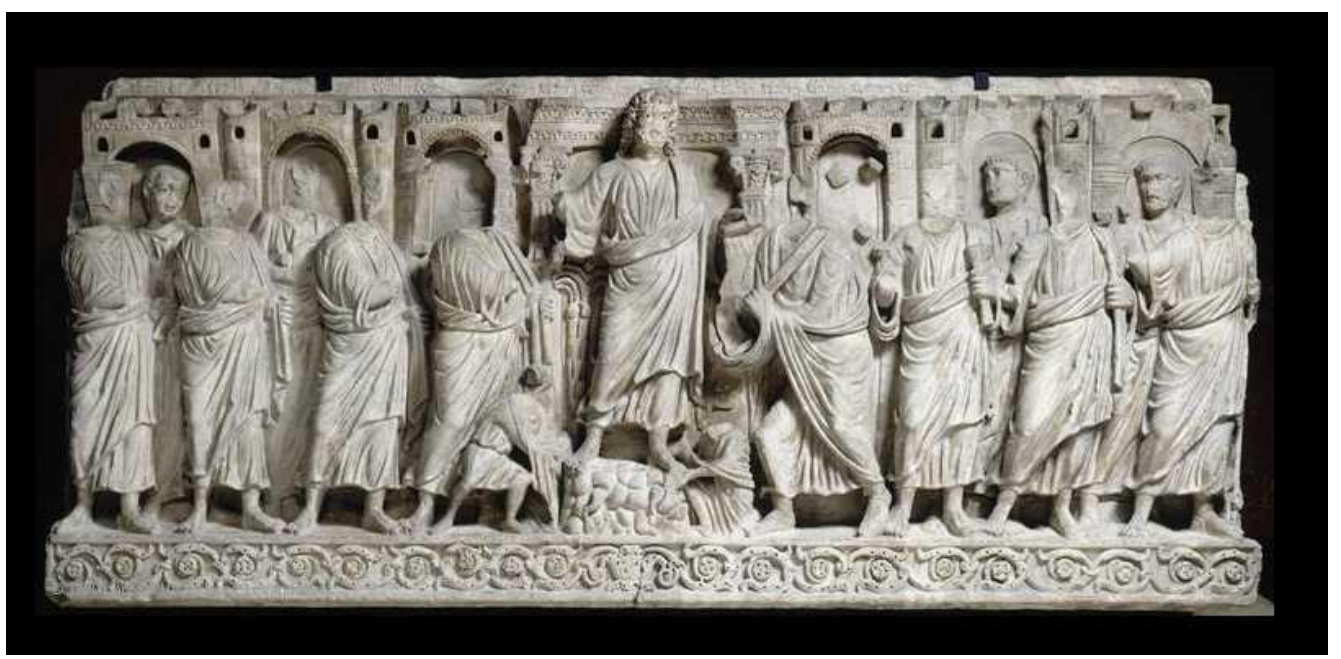

Figure 108: “City Gates” Sarcophagus, Late Fourth Century (Louvre Museum)

Louvre Museum, “'City Gates'Sarcophagus,” accessed March 2, 20016, http://www.louvre.fr/en/oeuvrenotices/city-gates-sarcophagus. 


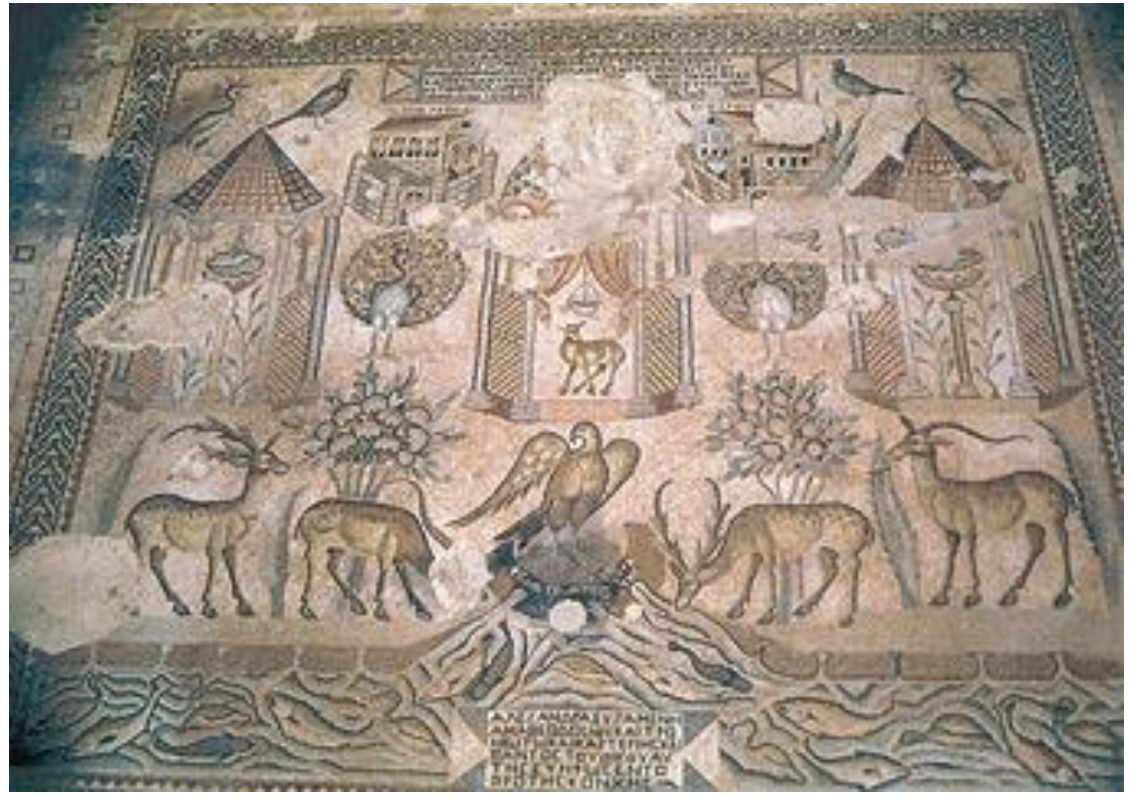

Figure 109: Mosaic with Jerusalem and Bethlehem, Church of the Holy Martyrs, Tayyibat al-Imam, Syria, 447

Abdul Zaqzuq and Michele Piccirillo, "The Mosaic Floor of the Church of the Holy Martyrs at Tayyibat alImam- Hamah, in Central Syria," Liber Annuus 49 (1999): 443-463. 


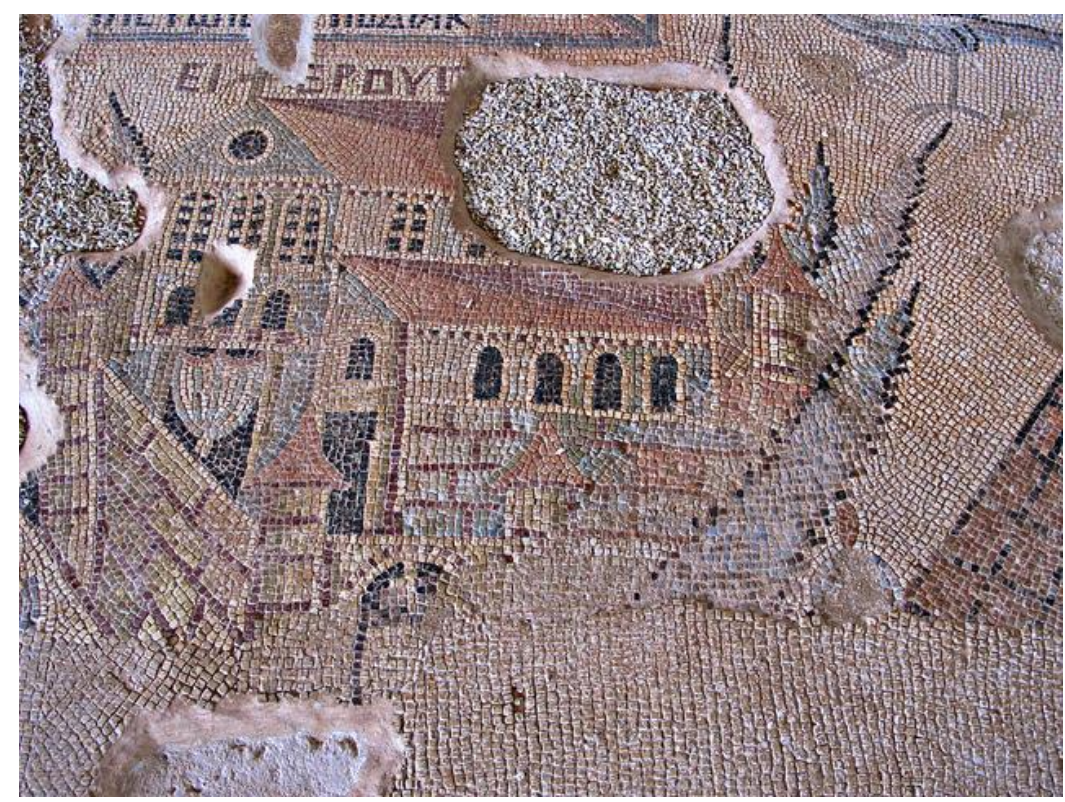

Figure 110a: Depiction of Jerusalem, Church of the Holy Martyrs, Tayyibat al-Imam, Syria

Zaqzuq and Piccirillo, "Mosaic Floor," Plate 1.

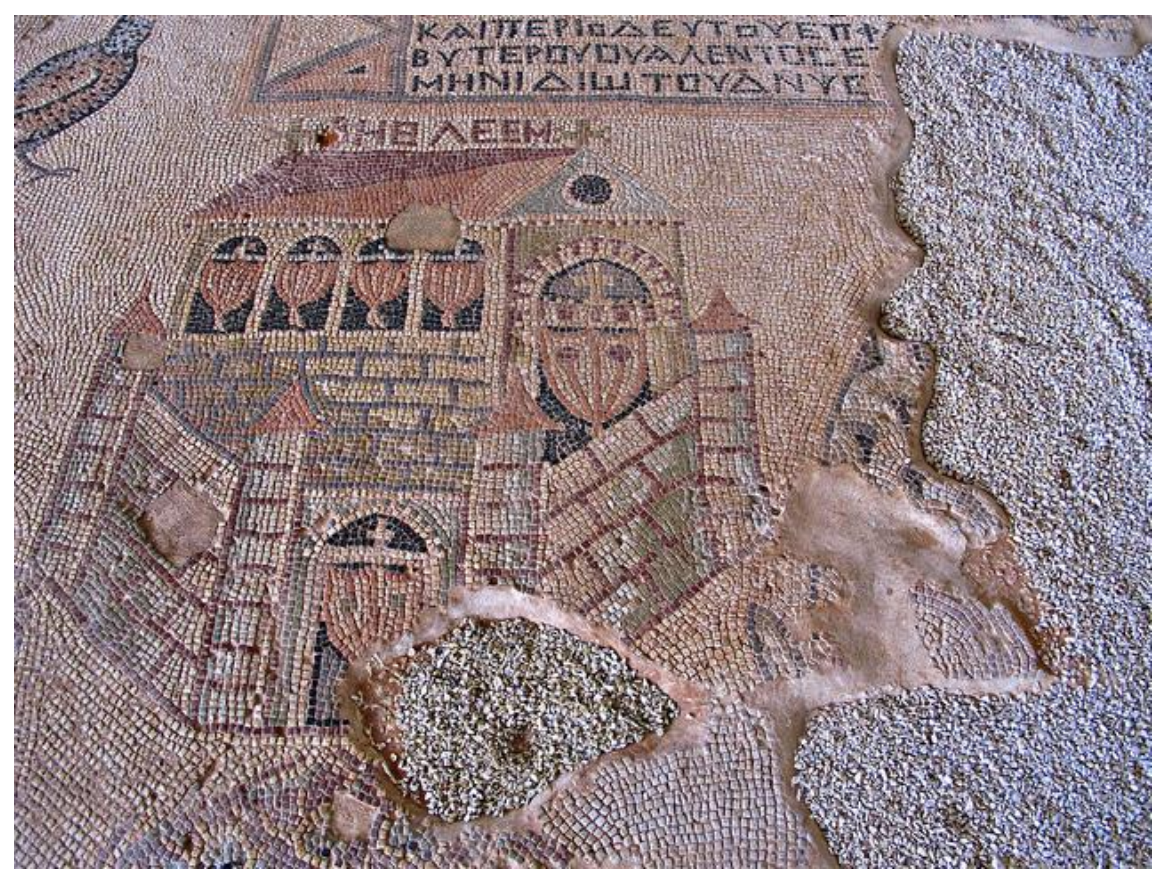

Figure 110b: Depiction of Bethlehem, Church of the Holy Martyrs, Tayyibat al-Imam, Syria

Zaqzuq and Piccirillo, "Mosaic Floor," Plate II. 


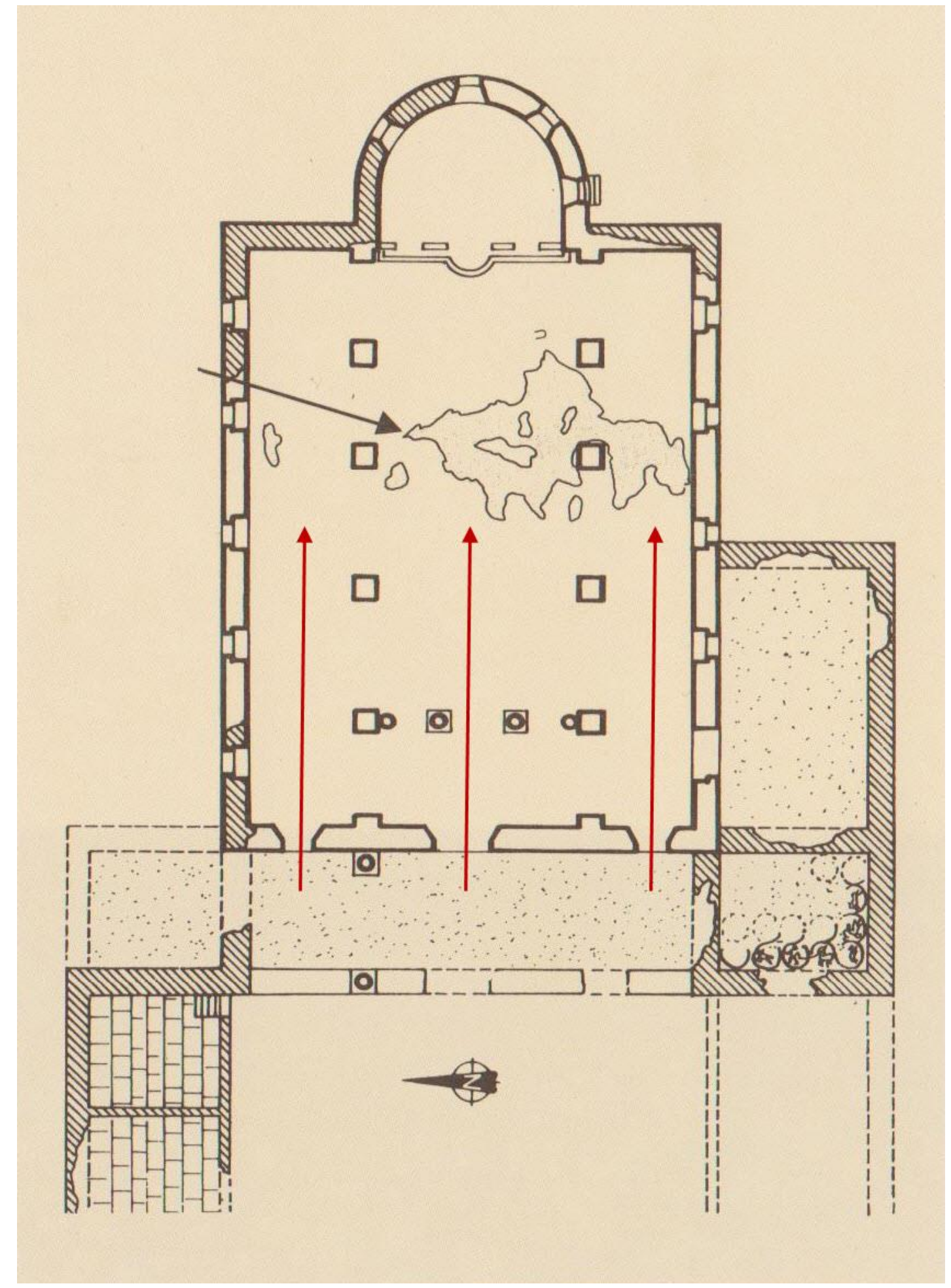

Figure 111: Patterns of Movement/Vision, Church of the Map, Madaba

Piccirillo, Mosaics of Jordan, 94. Modified by the Author. 


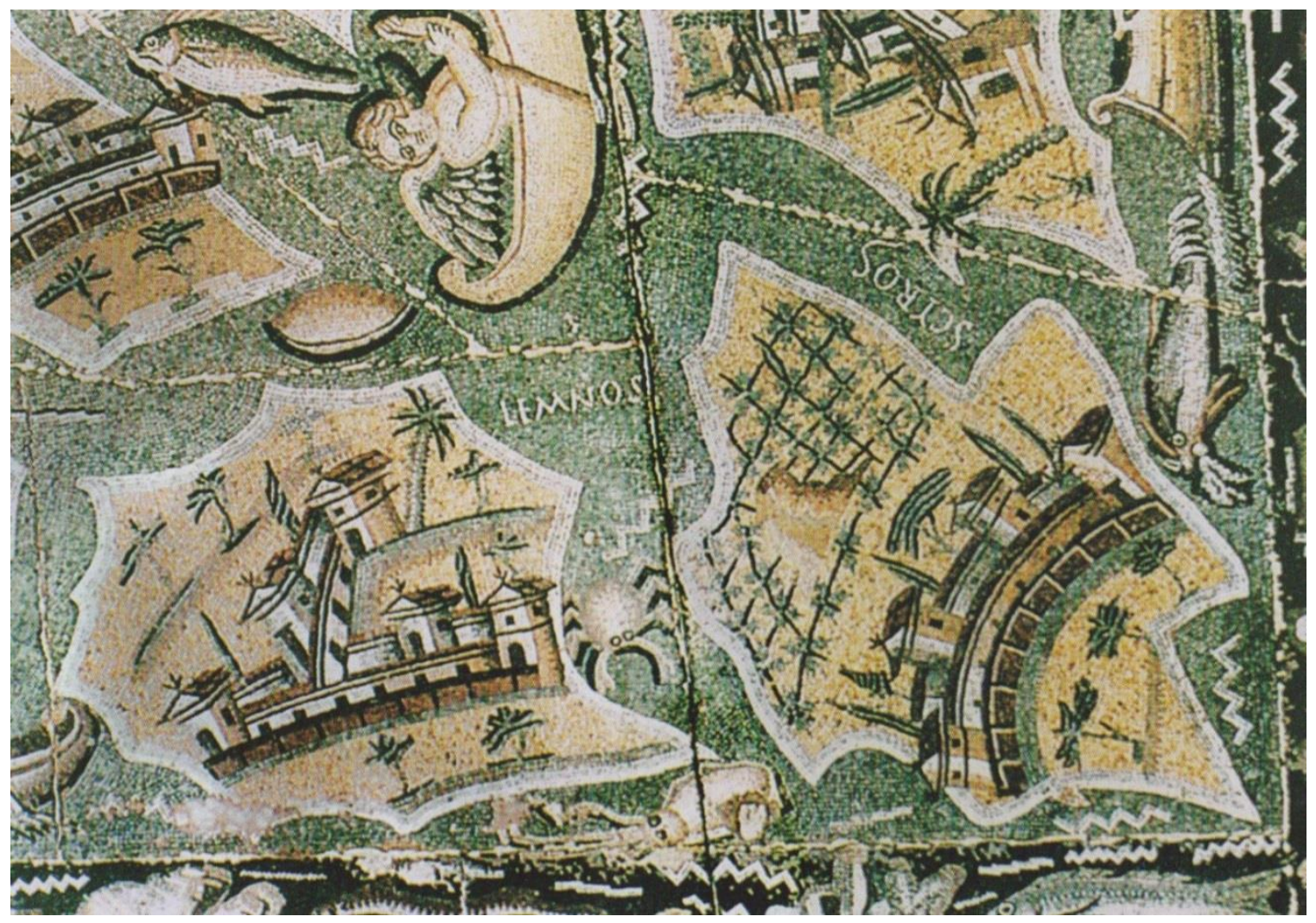

Figure 112: Mediterranean Sea Mosaic, Ammaedara (Haïdra), Tunisia, Late Third or Early Fourth Century

Chet van Druzer and Ilya Dines, Apocalyptic Cartography: Thematic Maps and the End of the World (Leiden: Brill, 2016), Figure 41. 


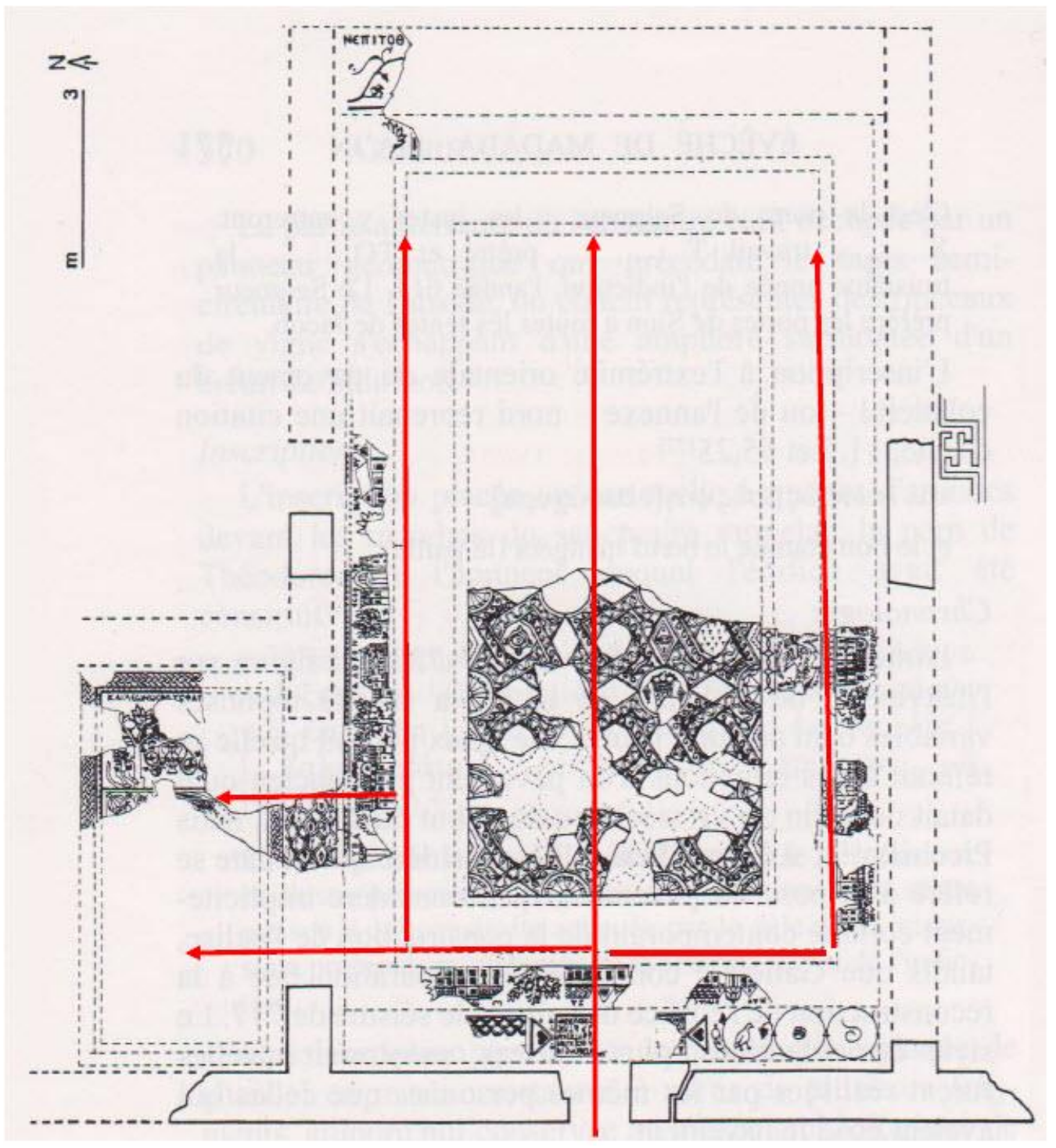

Figure 113: Patterns of Movement/Vision, Church of the Acropolis, Ma'in Michel, Les églises, 372. Modified by the Author. 


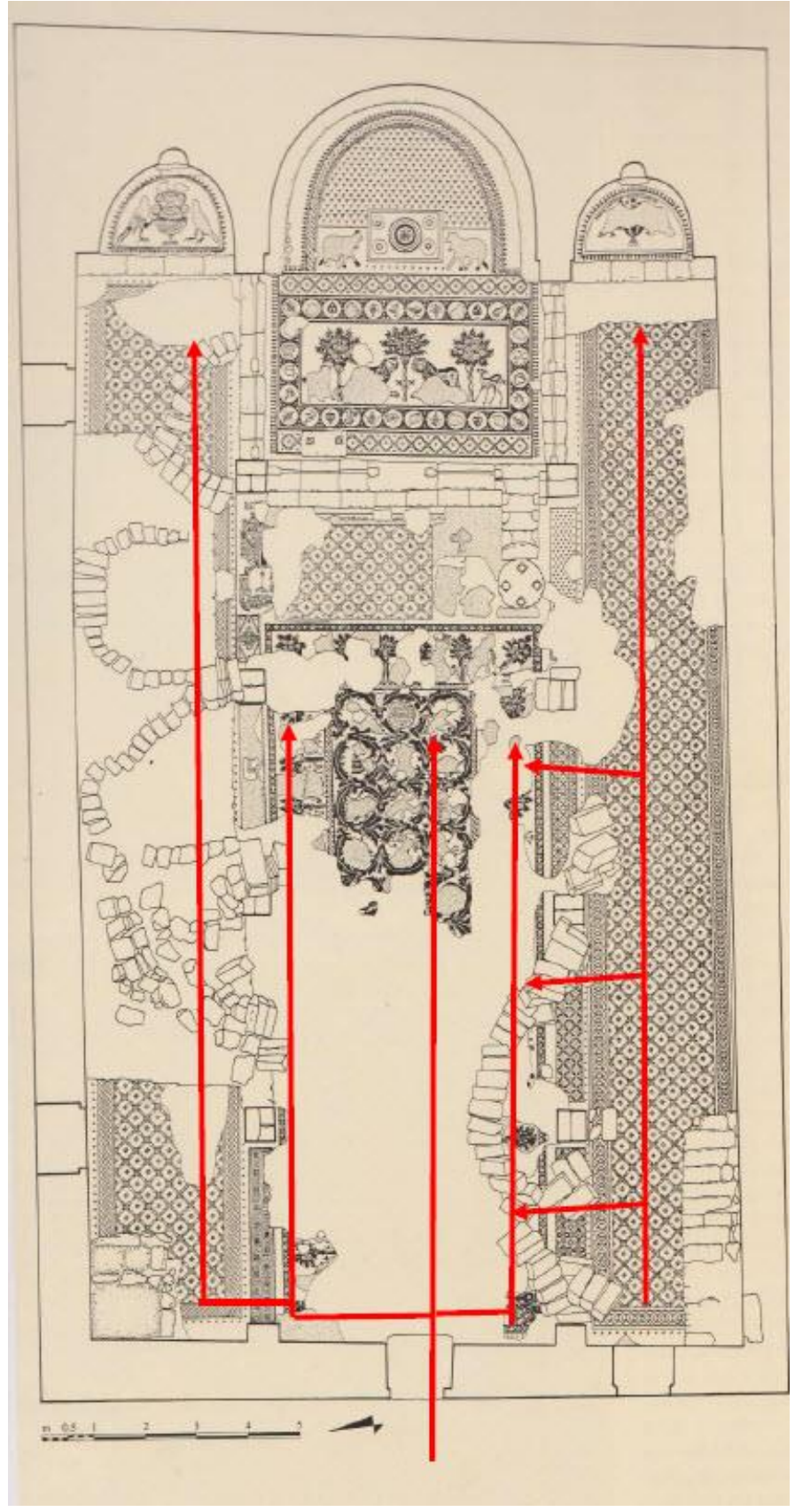

Figure 114: Patterns of Movement/Vision, Church of the Lions, Umm al-Rasas

Piccirillo, Mosaics of Jordan, 237. Modified by the Author. 


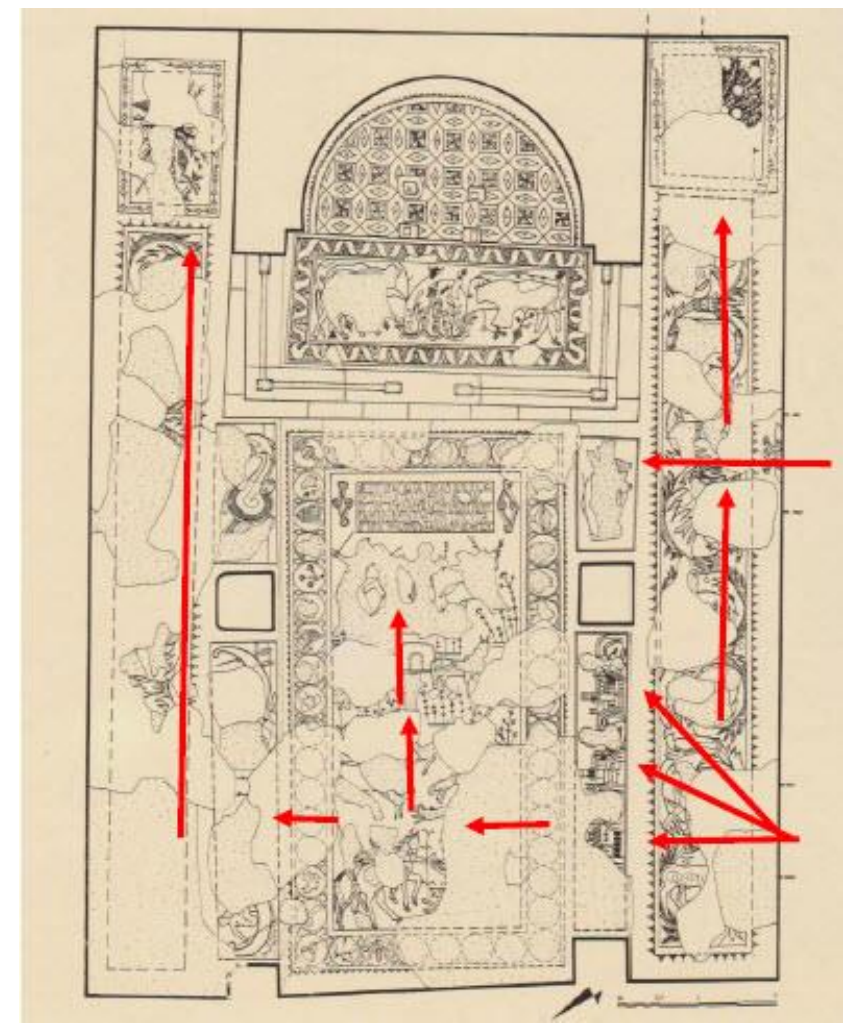

Figure 115: Patterns of Movement/Vision, Church of the Priest Wa'il, Umm al-Rasas

Piccirillo, Mosaics of Jordan, 242. Modified by the Author. 


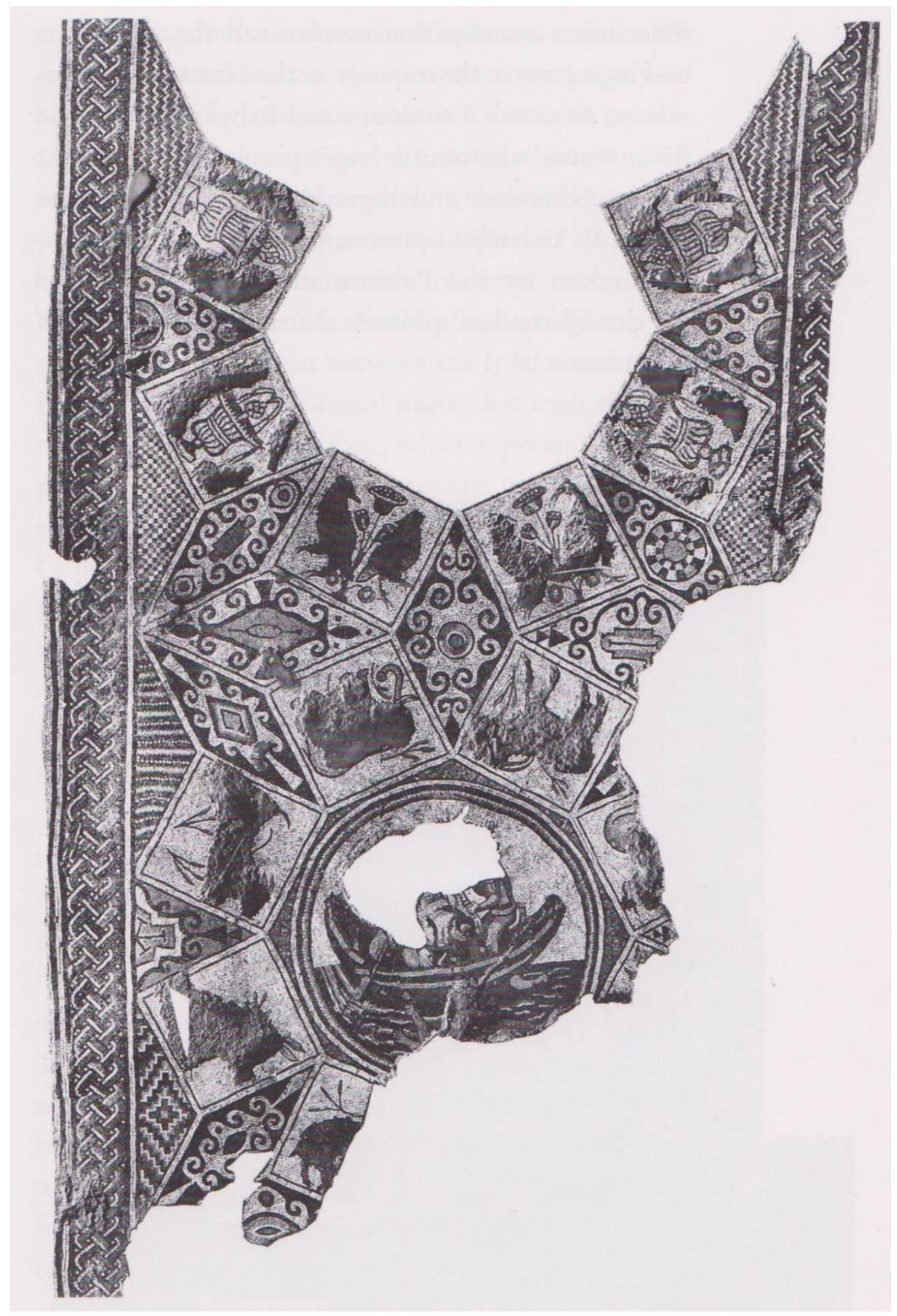

Figure 116: Depiction of Jonah, Beth Guvrin, Israel, Mid-sixth Century

Talgam, Mosaics of Faith, 245. 


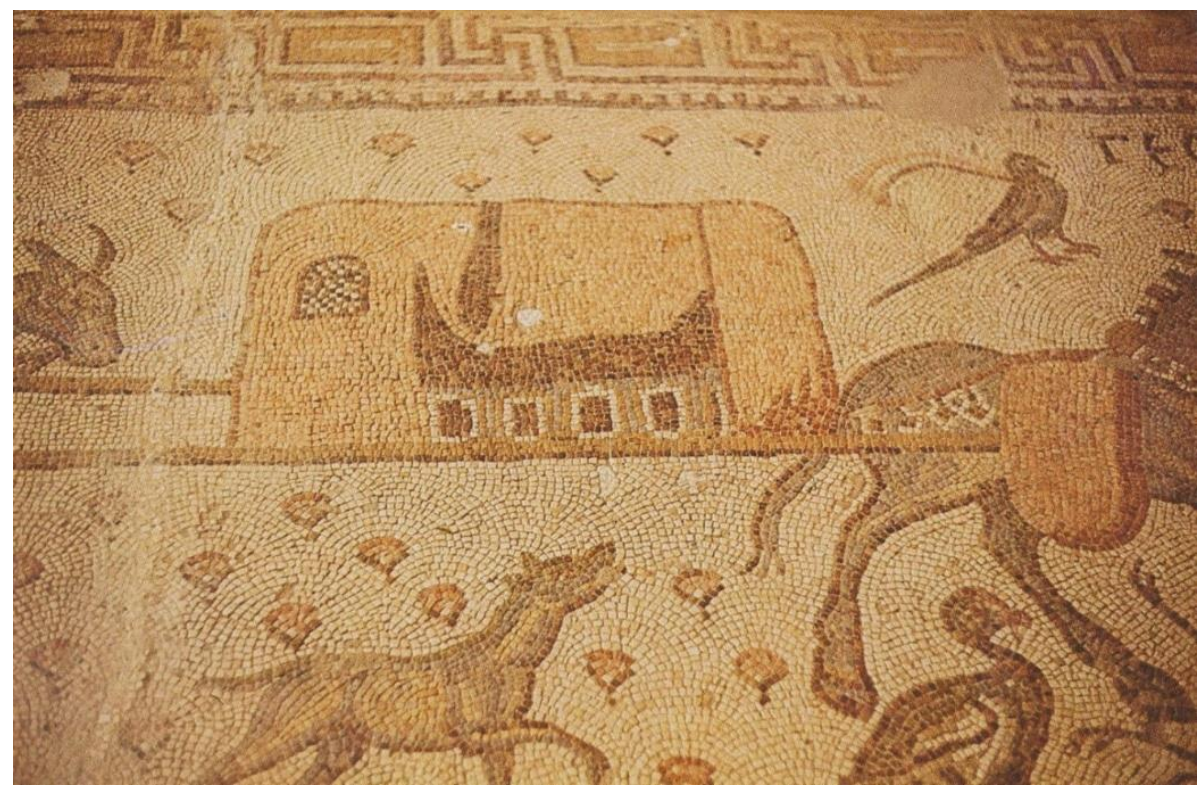

Figure 117: Depiction of a Horse Transporting Relics, North Church, Huarte, Syria, Late Fifth/Early Sixth Century

Pauline Donceel- Voûte, Les pavements des églises Byzantine de Syrie et du Liban: décor, archéologie, et liturgie (Louvain-la-Neuve, Belgium: Publications d'Archéologie et d'Histoire de l'Art de l'Université Catholique de Louvain, 1988), Figure 73.

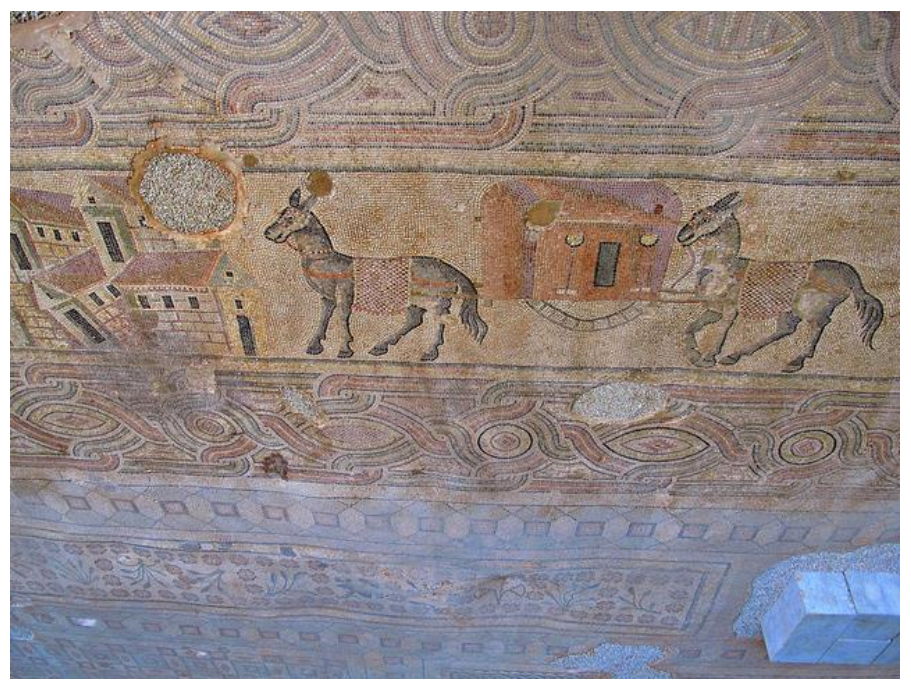

Figure: 118: Depiction of Horses Transporting Relics, Church of the Holy Martyrs, Tayyibat al-Imam, Syria, 447 (Also formerly Figure 127a)

Zaqzuq and Piccirillo, "Mosaic Floor," Plate X. 


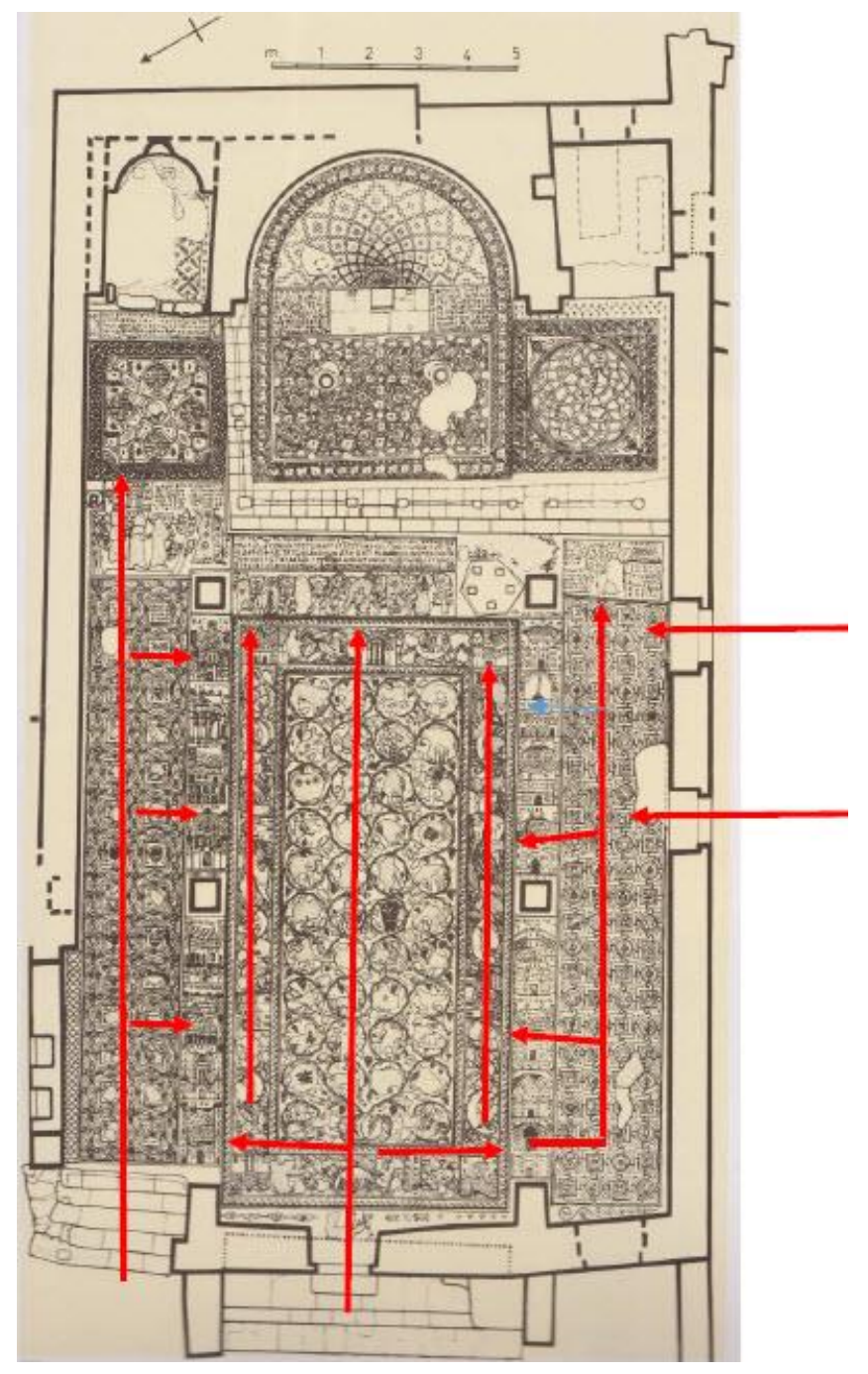

Figure 119: Patterns of Movement/Vision, Church of St. Stephen, Umm al-Rasas

Piccirillo, Mosaics of Jordan, 239. Modified by the Author. 


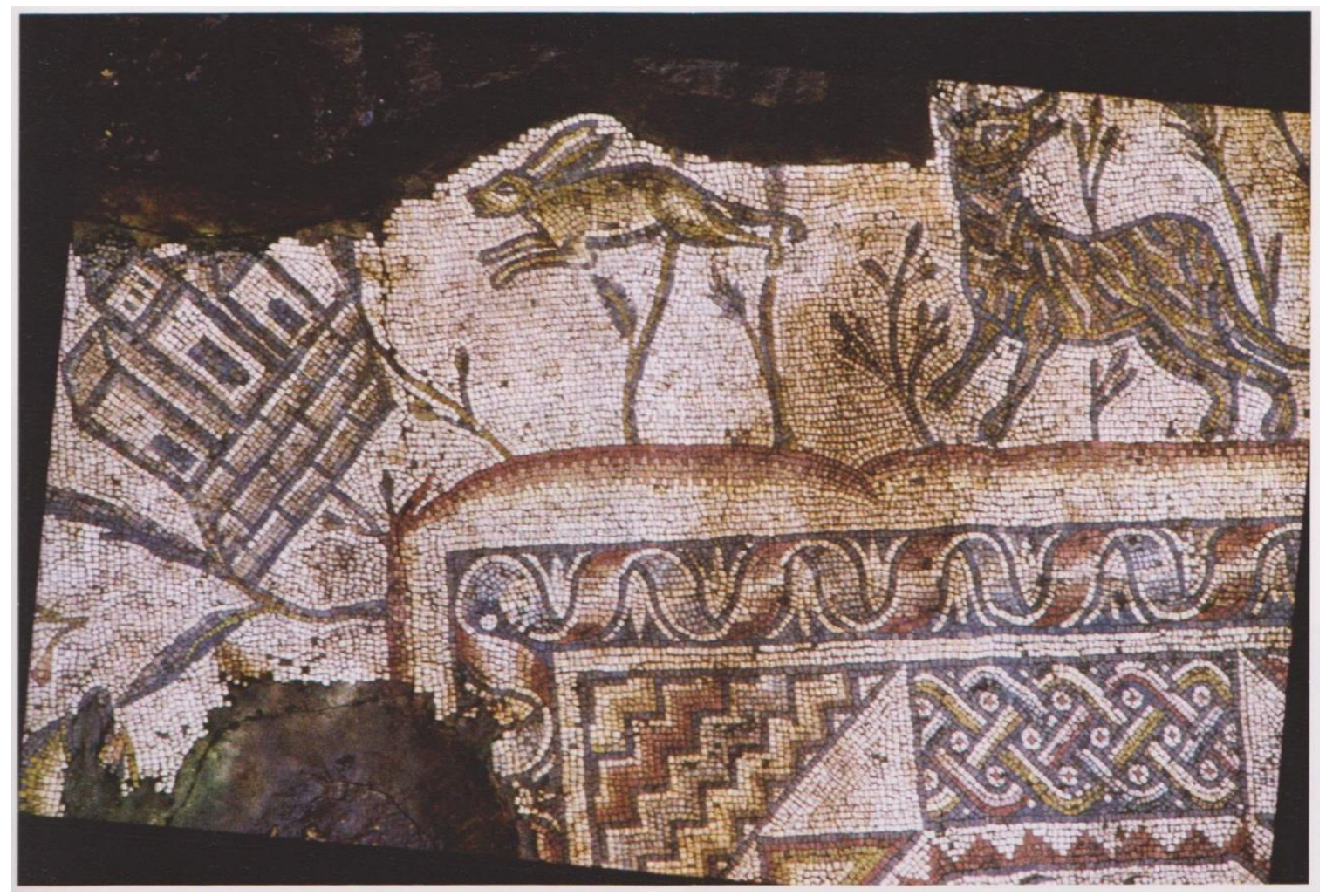

Figure 120: Detail of a Border Mosaic from a Villa, Beth Guvrin, Israel (Fifth Century?)

Talgam, Mosaics of Faith, 125. 


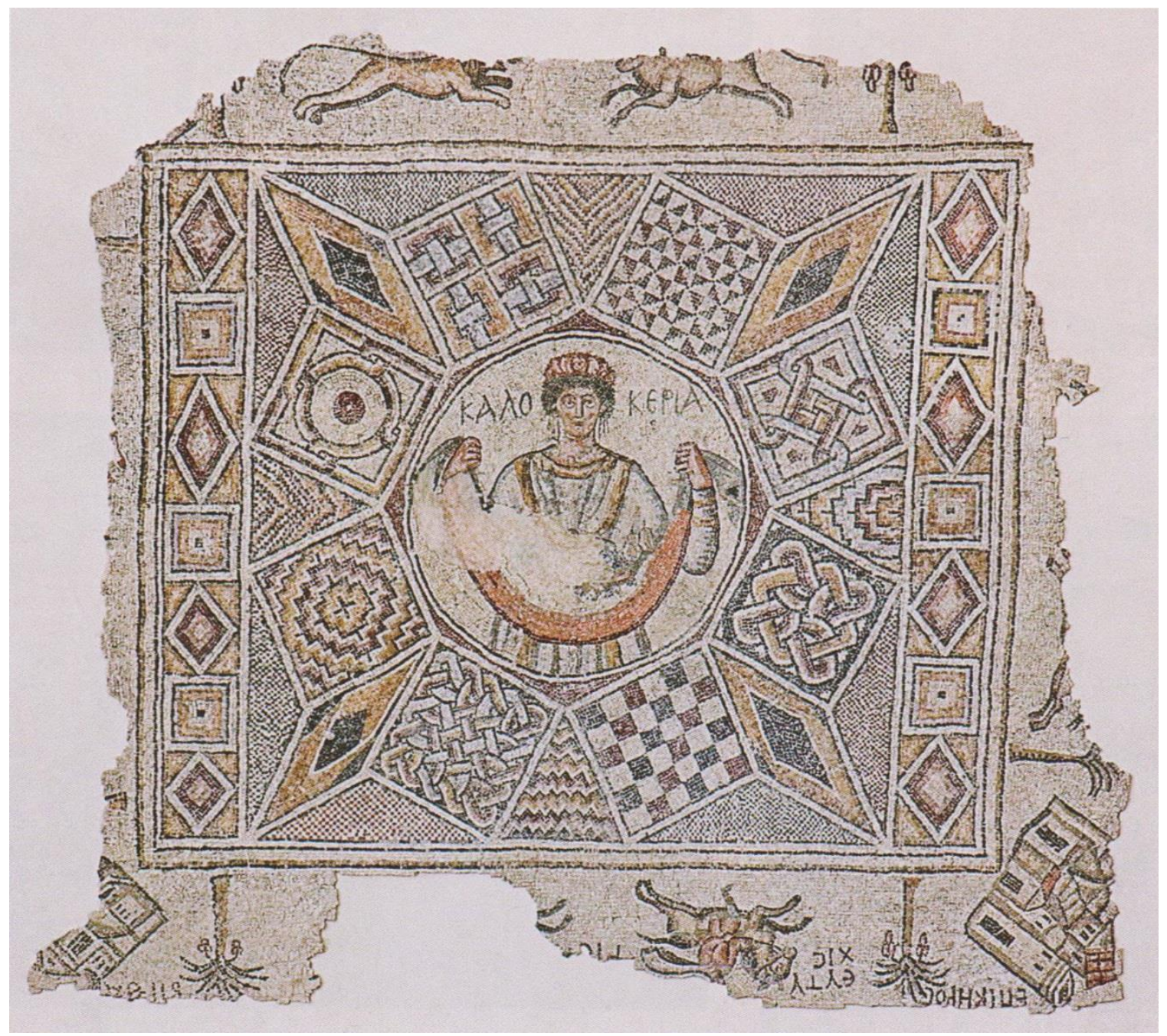

Figure 121: Kalo Keria Mosaic, Winter Bathhouse, Caesarea Maritima, Israel, (Fifth Century?)

Talgam, Mosaics of Faith, 348. 


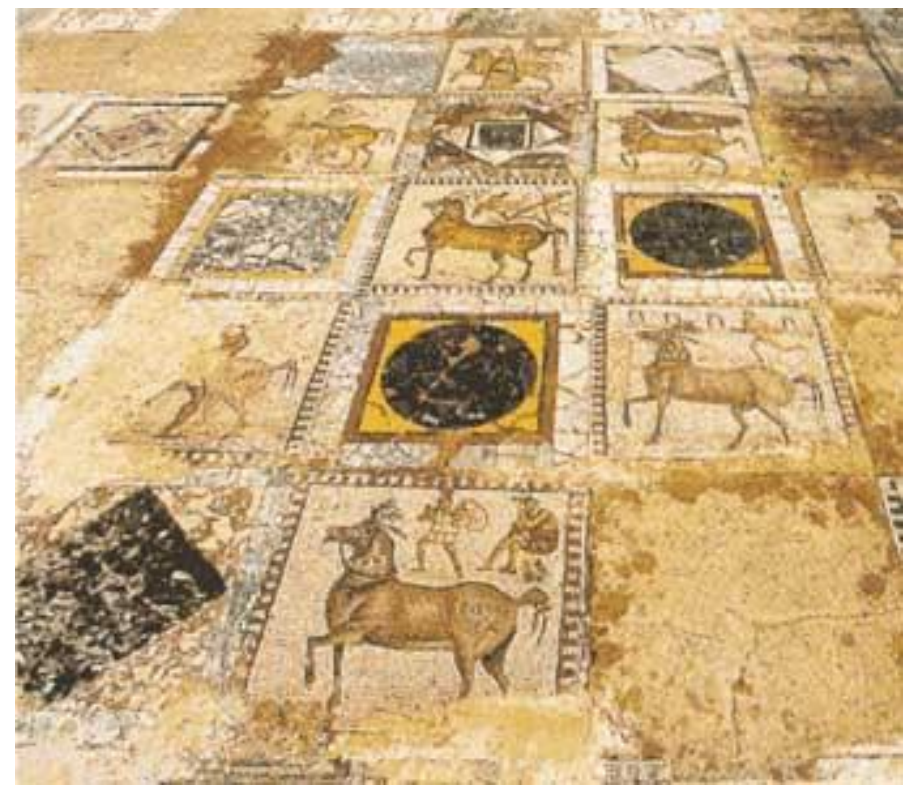

Figure 122: Depictions of Named Horses, Maison des Chevaux, Carthage, Tunisia, (Fourth or Fifth Century)

Author's Photograph.

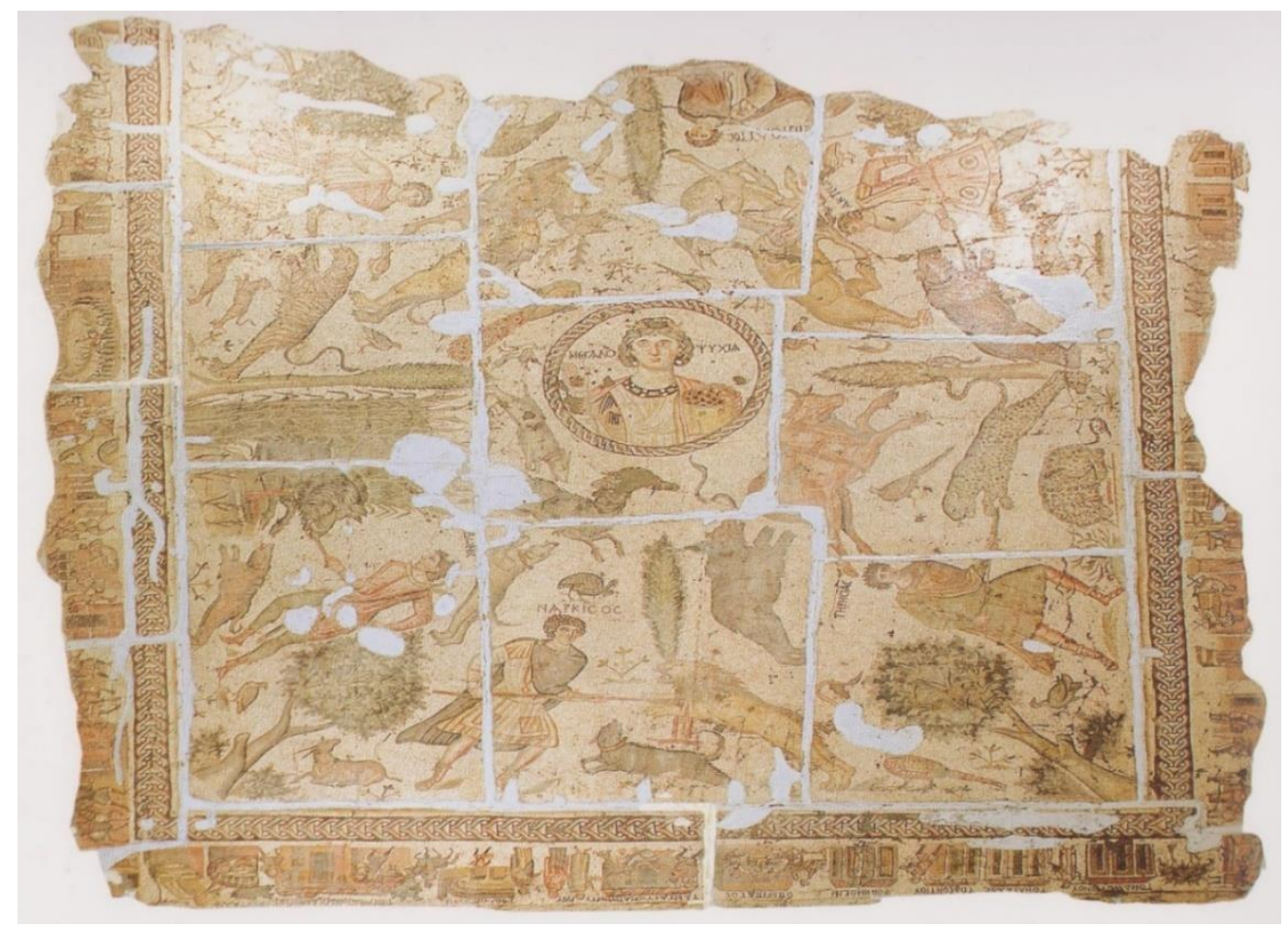

Figure 123: Megalopsychia Mosaic, Yakto Complex, Daphne, Syria (Mid-fifth Century)

Christine Kondoleon, Antioch: The Lost Ancient City (Princeton, NJ: Princeton University Press, 2000), 8. 


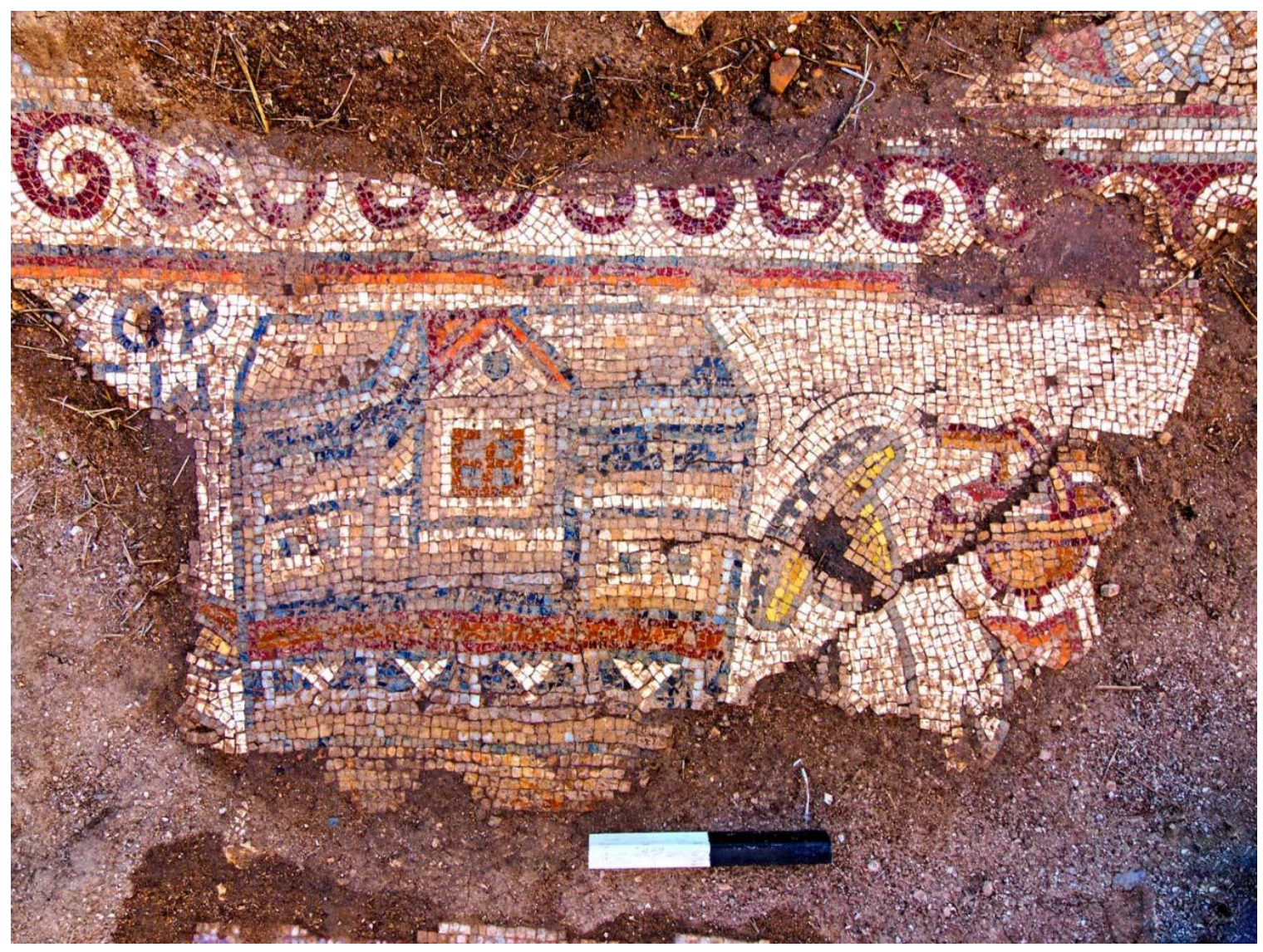

Figure 124: Depiction of Chortaso, Kiryat Gat, Israel (Sixth Century)

Science News, "Byzantine-Period Mosaic Map of an Ancient City Uncovered in Israel," October 1, 2015, accessed November 10, 2015,

http://www.sci-news.com/archaeology/science-mosaic-map-chortaso-ancient-egyptian-city-03293.html. 


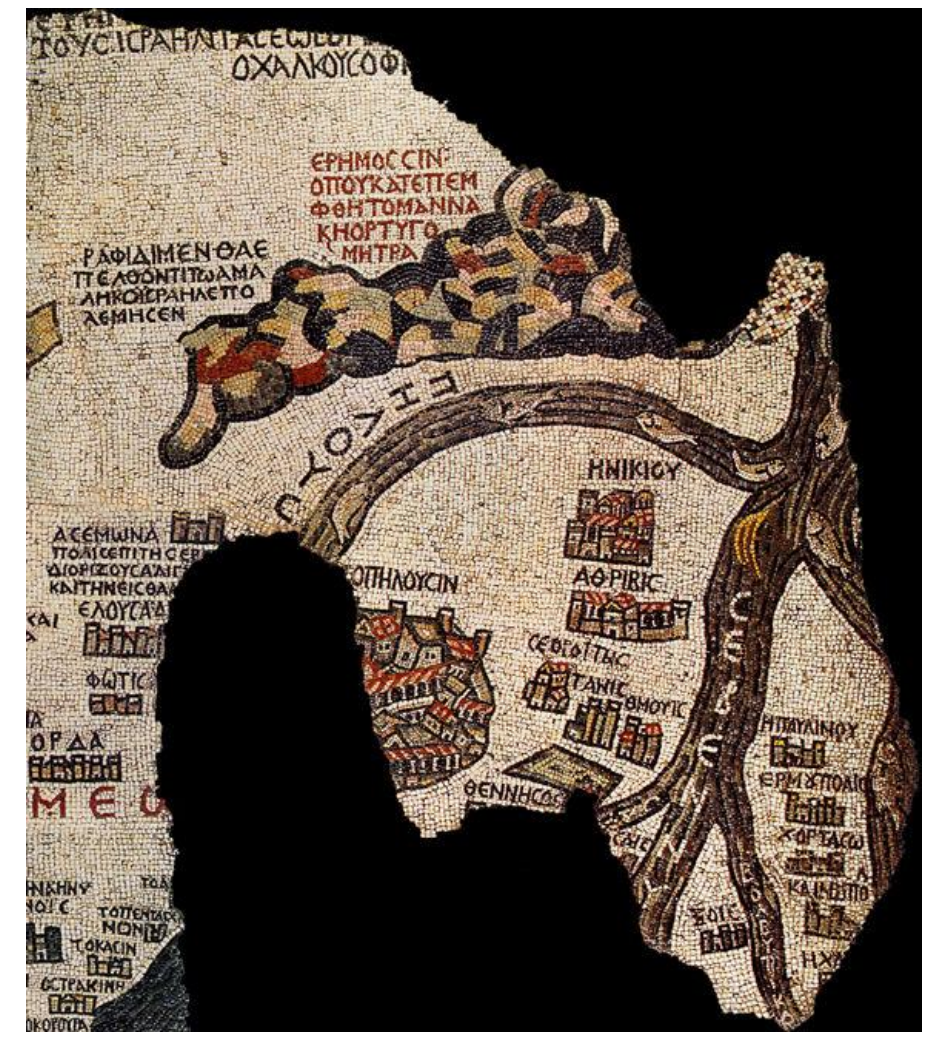

Figure 125: Depiction of Egyptian Sites in Lower Egypt, Madaba Mosaic

Franciscan Archaeological Institute, The Madaba Mosaic Map, "The Sinai Desert and Egypt," accessed February 1, 2016, http://www.christusrex.org/www1/ofm/mad/sections/section10.html.

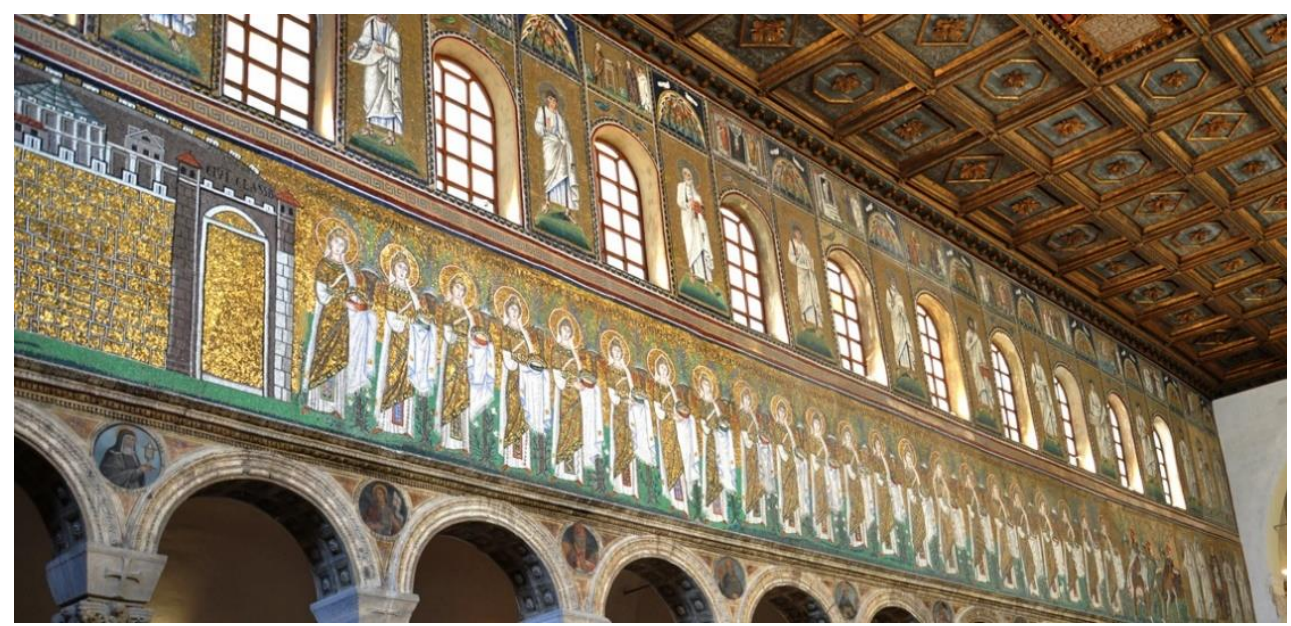

Figure 126a: Mosaics of the North Aisle Wall, Sant'Apollinare Nuovo, Ravenna, Italy (c. 504)

Author's Photograph. 


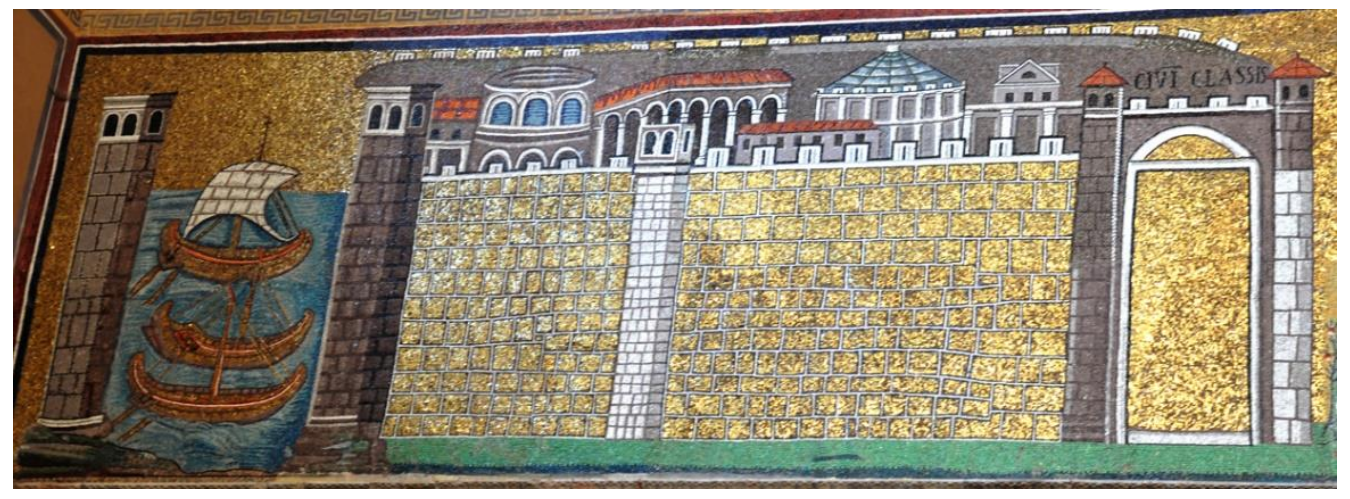

Figure 126b: Depiction of Classe on the North Aisle Wall, Sant'Apollinare Nuovo, Ravenna, Italy (c. 504)

Author's Photograph.

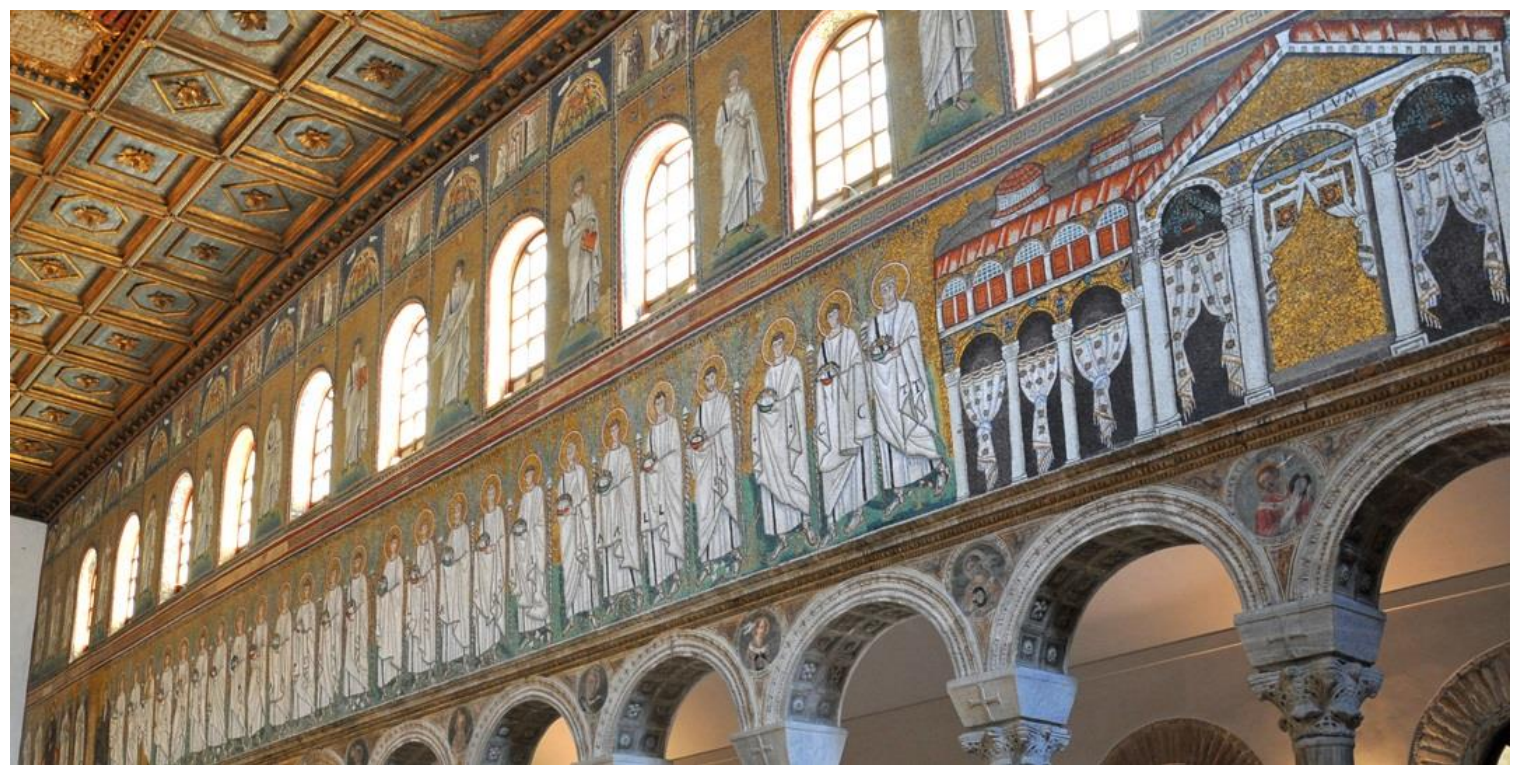

Figure 127a: Mosaics of the South Aisle Wall, Sant'Apollinare Nuovo, Ravenna, Italy (c. 504, revised c. 561)

Author's Photograph. 


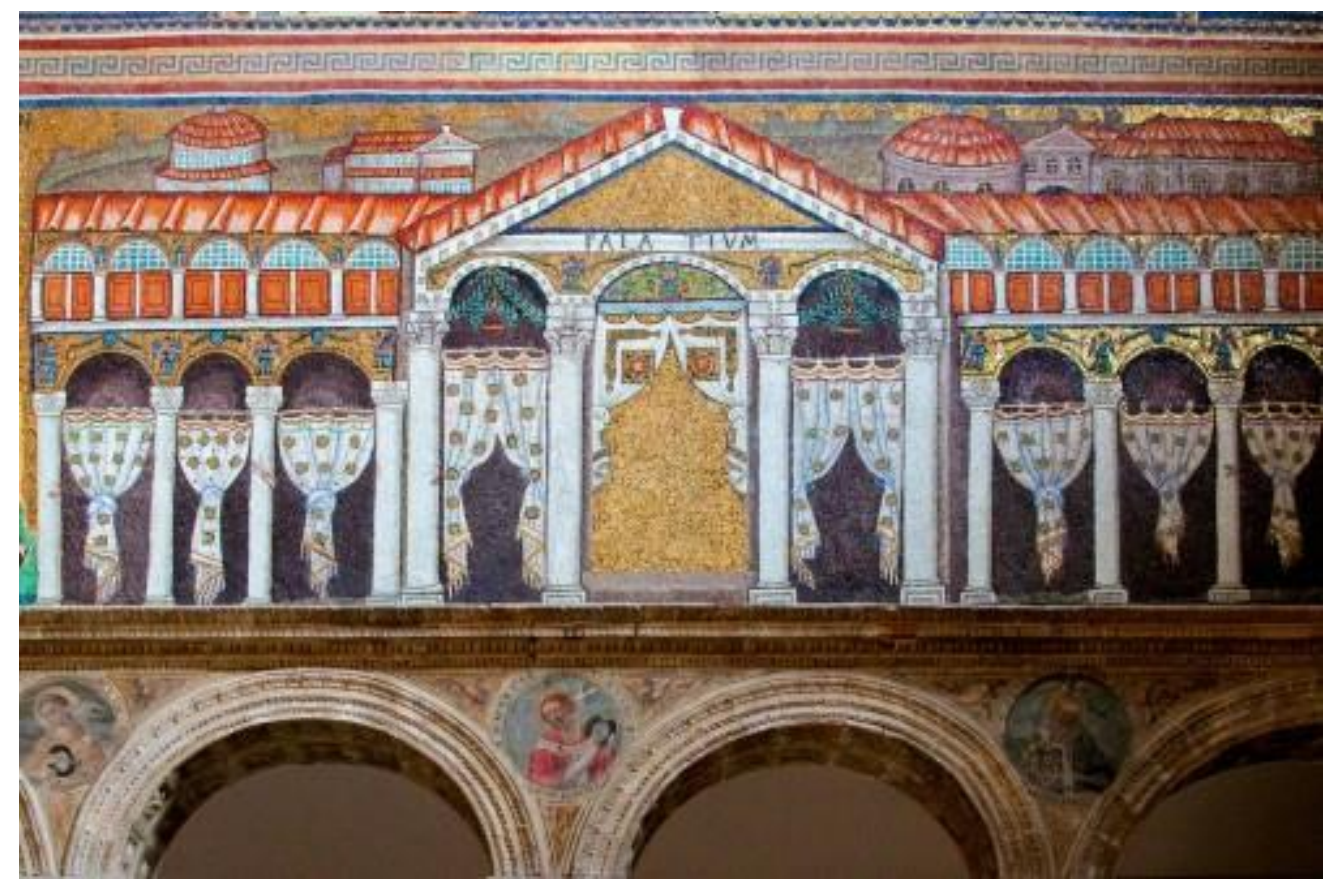

Figure 127b: Depiction of Ravenna and the Palace on the South Aisle Wall, Sant'Apollinare Nuovo, Ravenna, Italy (c. 504, revised c. 561)

Author's Photograph.

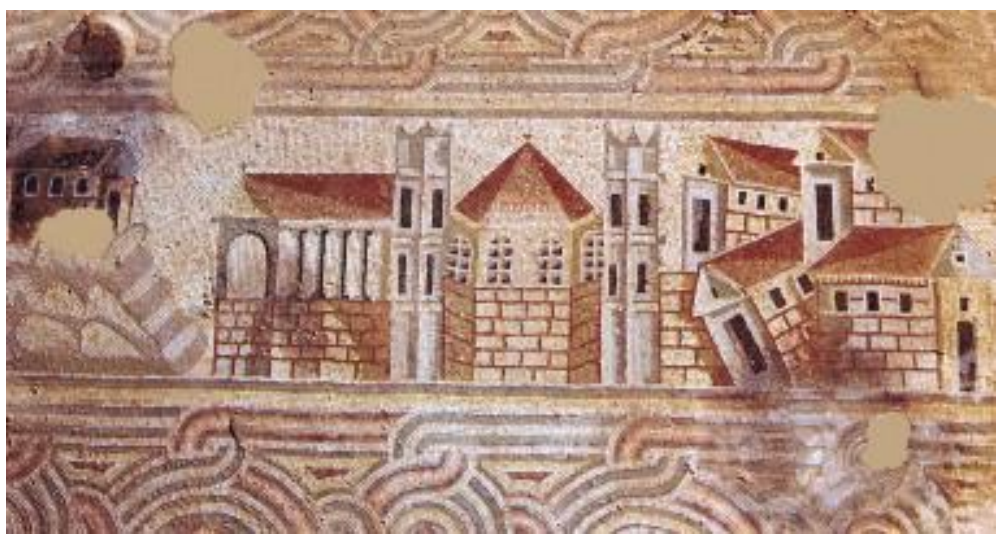

Figure 128: Depiction of a City, Church of the Holy Martyrs, Tayyibat al-Imam, Syria (447)

Zaqzuq and Piccirillo, "Mosaic Floor," Plate XIV. 


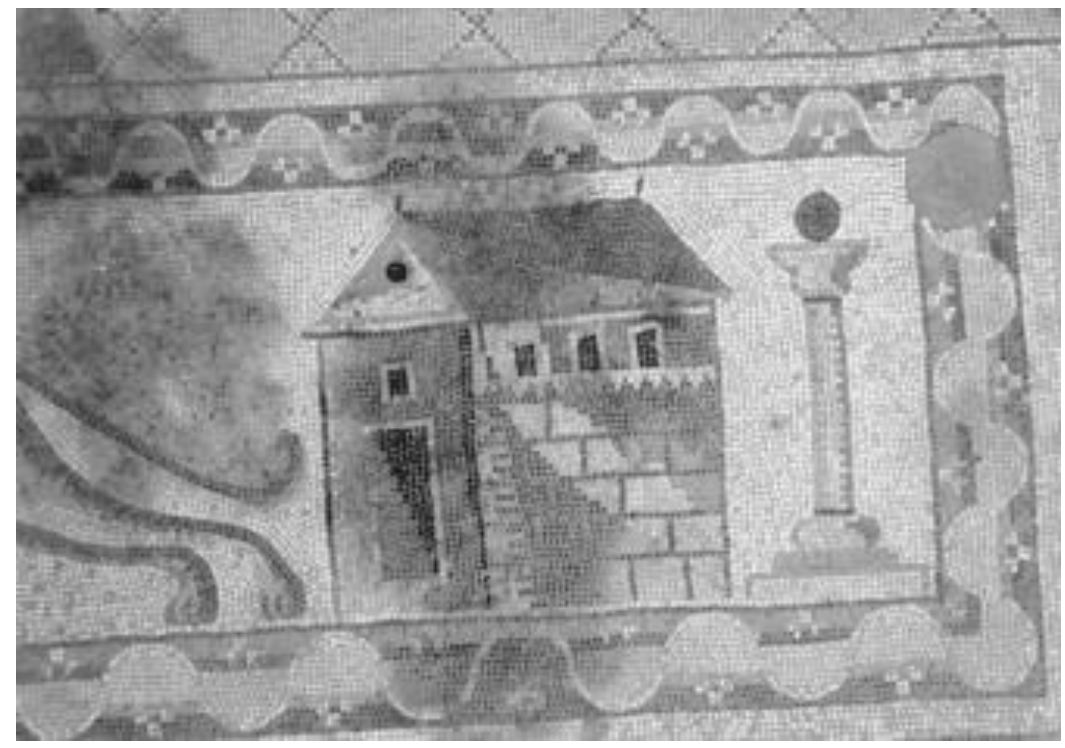

Figure 129: Depiction of a Building with a Stylite (?) Tower, Church of the Holy Martyrs, Tayyibat al-Imam, Syria (447)

Zaqzuq and Piccirillo, "Mosaic Floor," Figure 19.

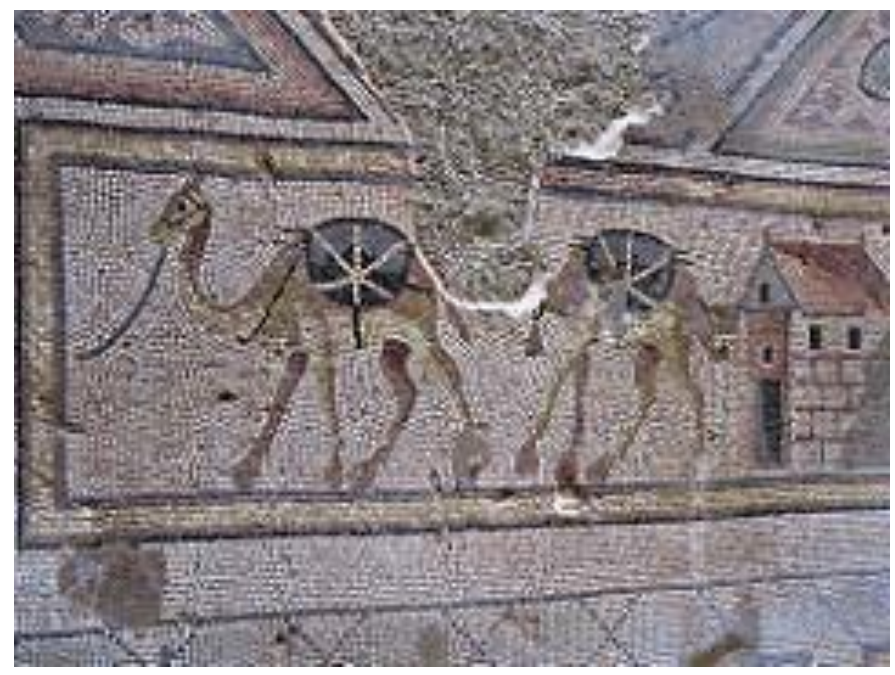

Figure 130: Depiction of Camels Leaving a City, Church of the Holy Martyrs, Tayyibat al-Imam, Syria (447)

Zaqzuq and Piccirillo, "Mosaic Floor,” Plate IX. 


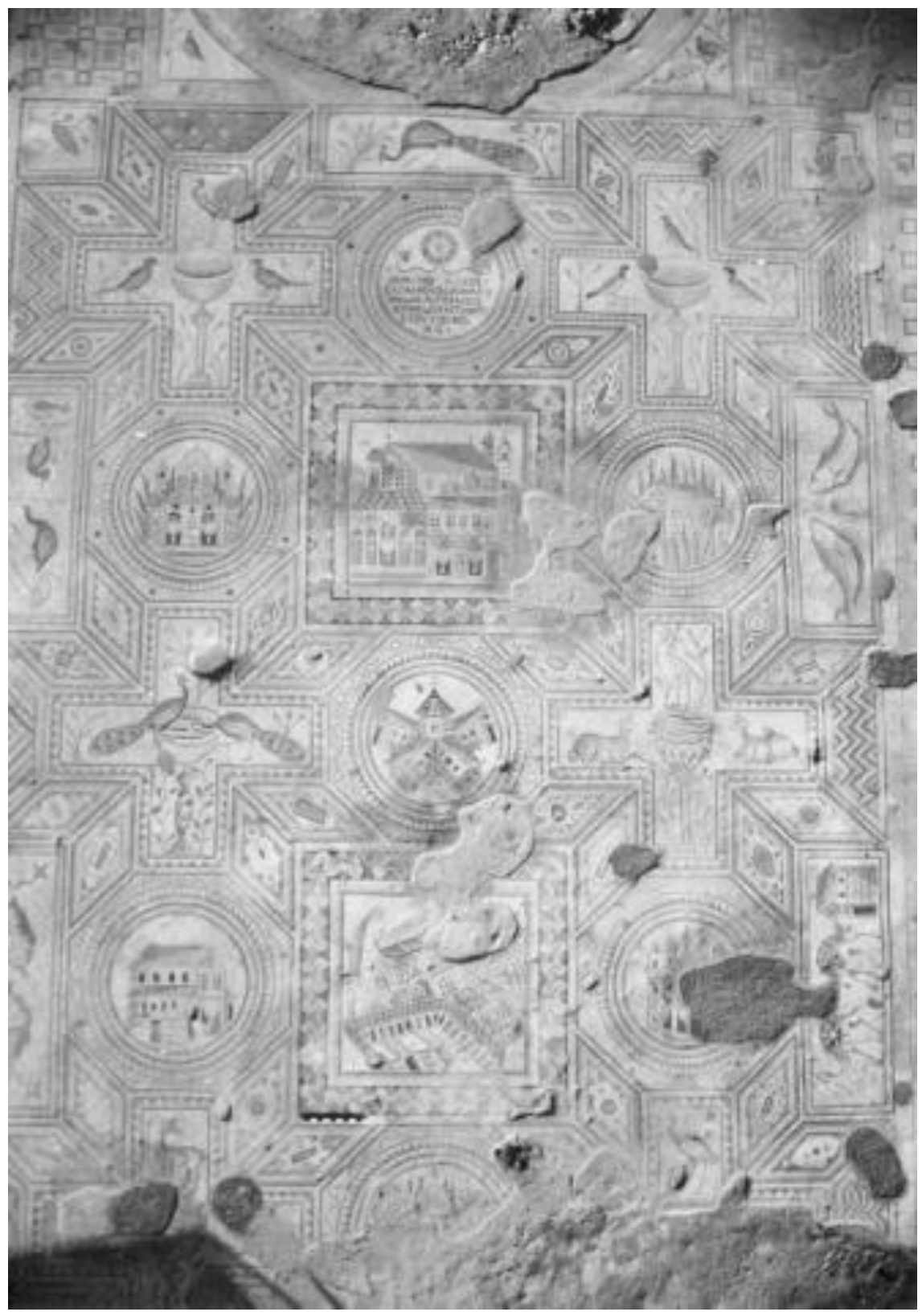

Figure 131: Geometric Panel with Architectonic Motifs, Church of the Holy Martyrs, Tayyibat al-Imam, Syria (447)

Zaqzuq and Piccirillo, "Mosaic Floor," Figure 10. 


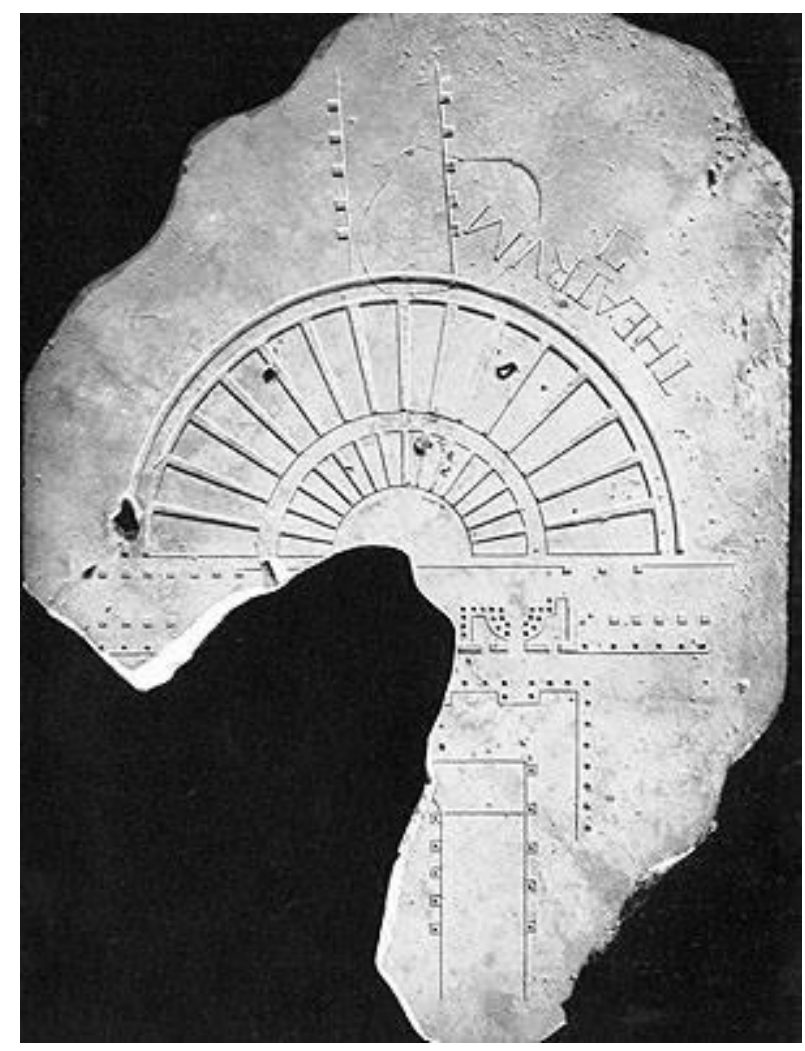

Figure 132: Fragment of the Forma Urbis Romae, Rome, Early Third Century

University of Munich: "Projekte Kunstgeschichte- Architecture," accessed January 12, 2016, http://www.projekte.kunstgeschichte.uni-muenchen.de/arch_complete_vers/40-ren-barockarchitektur/studieneinheiten/lektion_2/II_1_07p.htm.

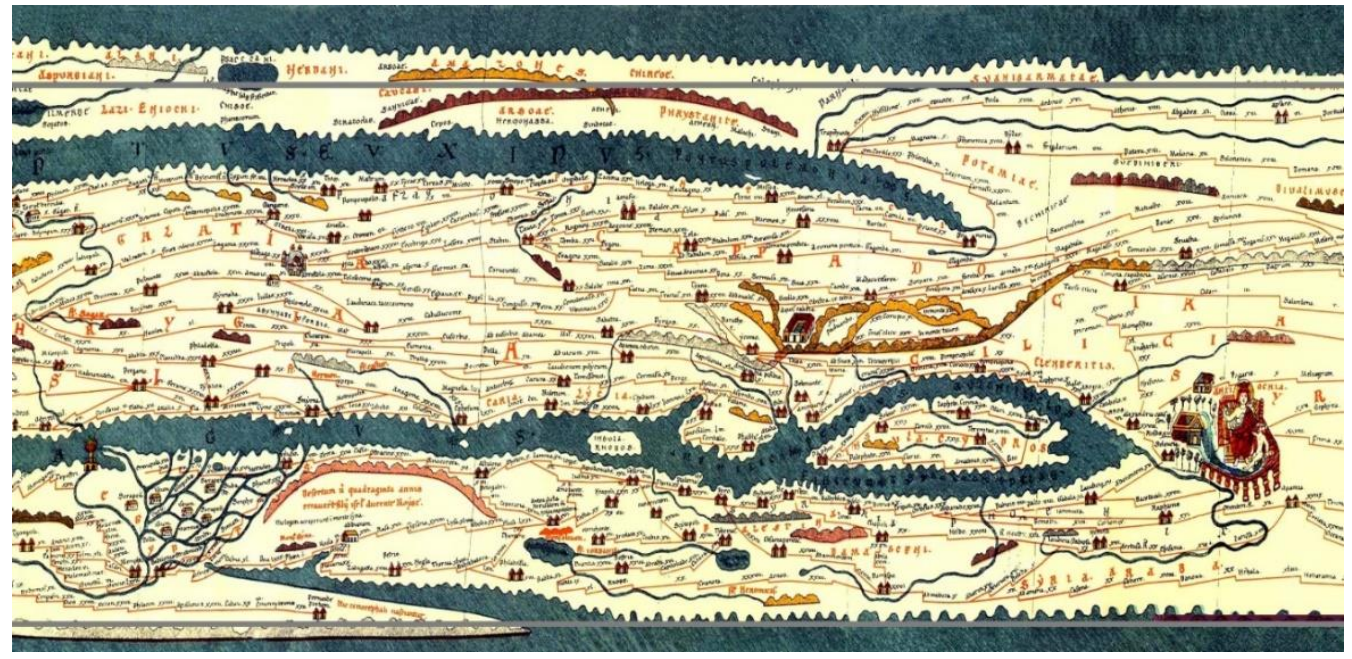

Figure 133: Reproduction of the Peutinger Table, Fourth Century (?)

Cartes Anciennes, "La Table de Peutinger," accessed January 6, 2016, http://www.valleedudropt.com/cartancin.htm. 


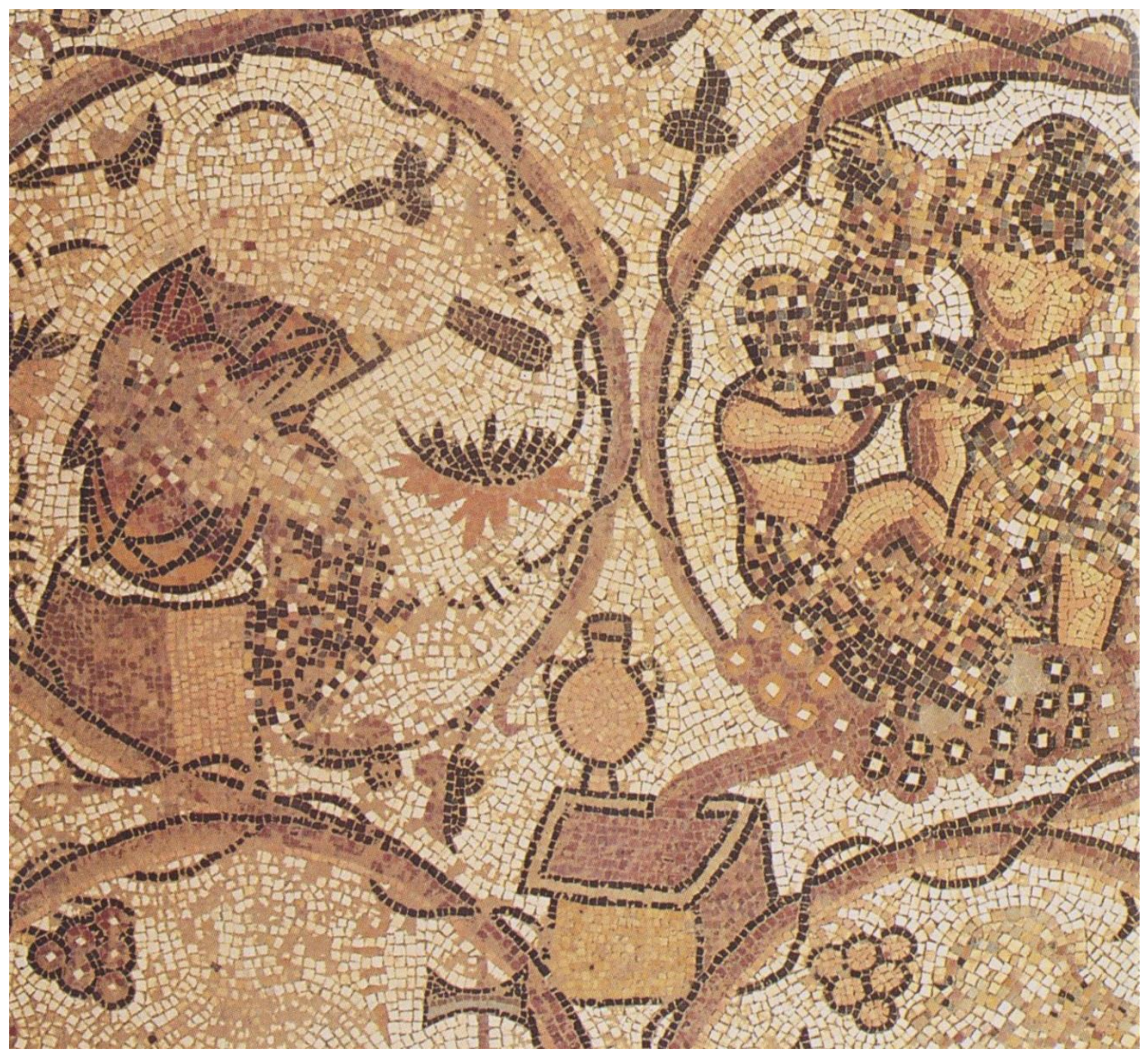

Figure 134: Vintaging Scene, Nave Mosaic, St. Stephen, Umm-al Rasas

Piccirillo, Mosaics of Jordan, 238. 


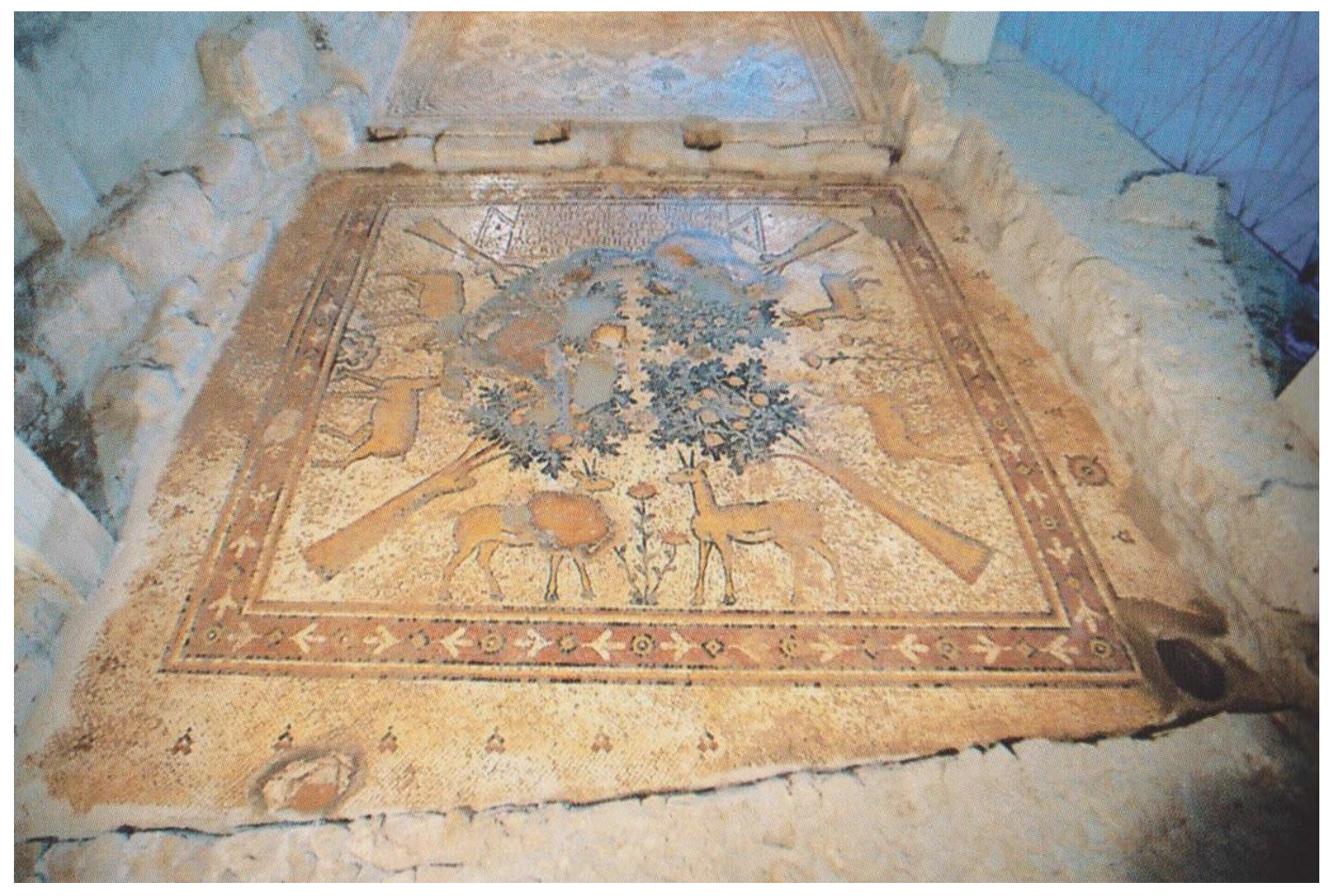

Figure 135: Depiction of Fruit Trees and Facing Animals, Church of the Apostles, Madaba (578)

Author's Photograph.

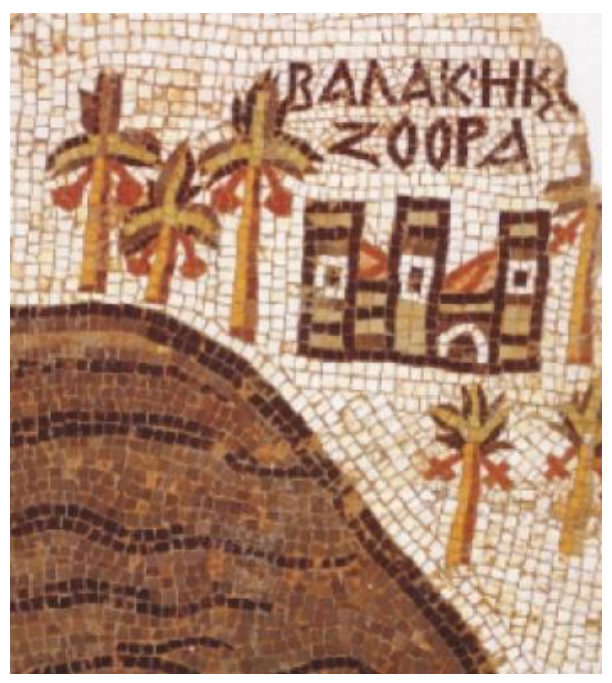

Figure 136: Depiction of Zoara, Madaba Mosaic

Franciscan Archaeological Institute, "The Madaba Mosaic Map: Zoara," accessed March 10, 2016, http://www.christusrex.org/www1/ofm/mad/discussion/024discuss.html. 


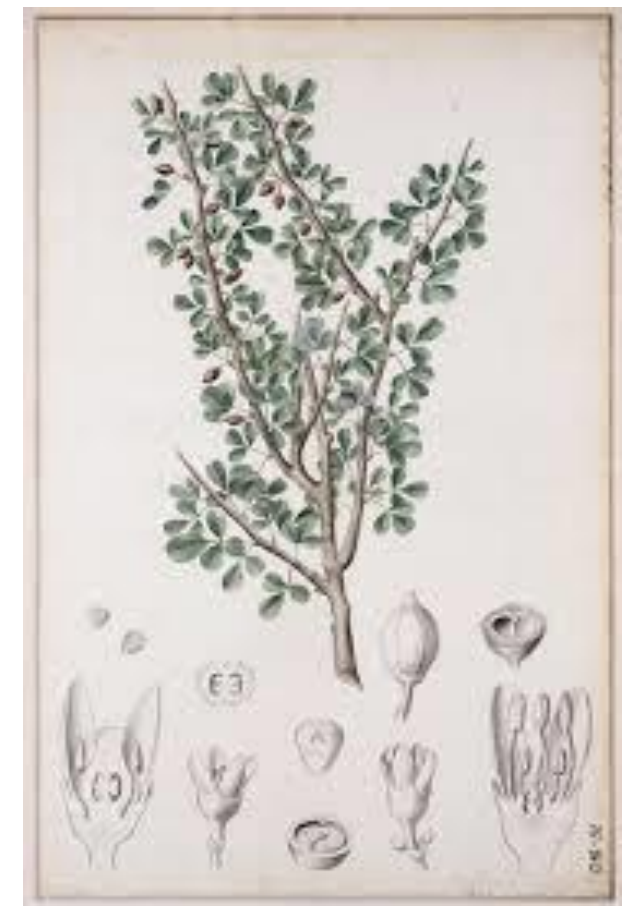

Figure 137: Drawing of Commiphora gileadensis (Gilead Balm or Gilead Balsam)

Drawing by Petronella J.M. Pas, University of Amsterdam (Public Domain)

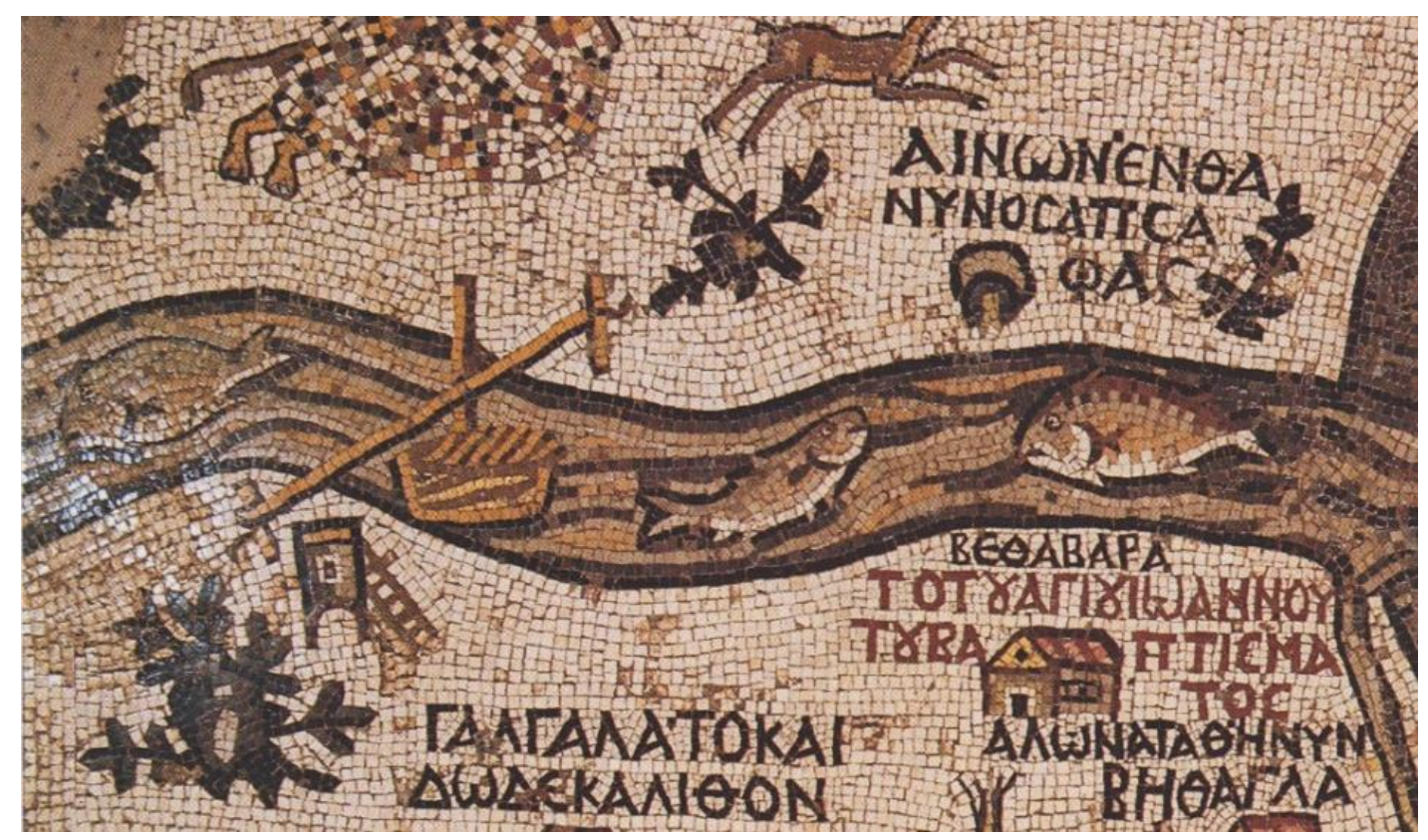

Figure 138: Depiction of Fish and Opobalsam Plants, Madaba Mosaic

Piccirillo, Mosaics of Jordan, 82. 


\section{CURRICULUM VITA}

NAME:

ADDRESS:

DOB:

EDUCATION

\& TRAINING:
Tracey Elizabeth Eckersley

Department of Fine Arts (Art History)

136 Lutz Hall

University of Louisville

Louisville, KY 40292

North York, Ontario, Canada- December 14, 1970

B.A., Classical and Near Eastern Archaeology

Wilfrid Laurier University

1989-1993

M.A., Classical Studies

McMaster University

1993-1996

M.M.St., Museum Studies

University of Toronto

1997-1999

Ph.D., Art History

University of Louisville

2006-2016

AWARDS:

$\mathrm{O} \Delta \mathrm{K}$ Scholarship

Omicron Delta Kappa National Leadership Honor Society

Burton MacDonald and Rosemarie Sampson Fellowship American Center of Oriental Research, Amman, Jordan 2014

Allen R Hite Scholarship

Department of Fine Arts, University of Louisville 2013 
Frederic Lindley Morgan Architectural History Scholarship Department of Fine Arts, University of Louisville 2012

Frederic Lindley Morgan Travel Scholarship Department of Fine Arts, University of Louisville 2012

Cressman Scholarship Department of Fine Arts, University of Louisville 2011

Don Payton Graduate Award

Department of Fine Arts, University of Louisville 2010, 2011

Faculty Favorite Teaching Award

University of Louisville 2007

Graduate Teaching Assistantship Department of Fine Arts, University of Louisville 2006-2010

University of Toronto Open Scholarship 1997-1999

McMaster University Teaching Assistantship 1993-1995

McMaster University Entrance Scholarship 1993

PROFESSIONAL SOCIETIES:
American Alliance of Museums

American Institute of Archaeology, Kentucky Chapter

American School of Oriental Research

Association Internationale pour l'Étude de la Mosaïque Antique, North American Chapter

Byzantine Studies Association of North America

Canadian Museums Association

College Art Association

International Center of Medieval Art 
Southeastern College Art Conference Association

PUBLICATIONS

AND

PRESENTATIONS:

NATIONAL

MEETING

PRESENTATIONS: "Mapping Meaning: The Topographic Mosaics of Ma'in and Umm al-Rasas in their Architectural and Cultural Contexts," Annual Byzantine Studies Conference, Yale University New Haven, CT

(November, 2013)

“The Postman Always Looks Twice: 'Outsider' Envelope Art from the Collection of Allan Weiss," Southeastern College Art Conference, Mobile, AL (November, 2009)

REFEREED

JOURNALS:

"The Musée National de Carthage: Colonial Thinking in a PostColonial World." Parnassus (Spring 2008): 18-23.

BOOKS AND

SYMPOSIA:

"Putting Christians on the Map: Topographic Mosaics from Late Antique Jordan as Representations of Authority and Status," University of Louisville Graduate Research Symposium (April, 2014)

Symposium Chair (Taking the "S" Out of Craft, February 23, 2013) Aegis (University of Louisville Association of Graduate Students, Department of Fine Arts)

Symposium Chair (Imaging Desire, February 14, 2009)

Aegis (University of Louisville Association of Graduate Students, Department of Fine Arts)

"The Musée National de Carthage: Colonial Thinking in a PostColonial World," Aegis Biennial Symposium on Art History and Visual Culture, University of Louisville, Louisville, KY (February, 2007)

INVITED

SPEAKER: "Reimagining the Religious Landscape: An Investigation of the Madaba 'Map' Mosaic in its Socio-Cultural Contexts," American School of Oriental Research, Amman, Jordan (August, 2014) 
"Mosaic Treasures from Turkey," Jefferson Community \& Technical College's Faculty Professional Development Day, Louisville, KY (November, 2013)

"Putting Christians on the Map: Topographic Mosaics from Late Antique Jordan as Representations of Authority and Status," Workshop for the University of Louisville's Medieval and Renaissance Society (April, 2013) 